\title{
Bewijsmotivering in strafzaken
}

Citation for published version (APA):

Dreissen, W. H. B. (2007). Bewijsmotivering in strafzaken. [Doctoral Thesis, Maastricht University]. Boom Juridisch. https://doi.org/10.26481/dis.20070906wd

Document status and date:

Published: 01/01/2007

DOI:

10.26481/dis.20070906wd

Document Version:

Publisher's PDF, also known as Version of record

\section{Please check the document version of this publication:}

- A submitted manuscript is the version of the article upon submission and before peer-review. There can be important differences between the submitted version and the official published version of record.

People interested in the research are advised to contact the author for the final version of the publication, or visit the DOI to the publisher's website.

- The final author version and the galley proof are versions of the publication after peer review.

- The final published version features the final layout of the paper including the volume, issue and page numbers.

Link to publication

\footnotetext{
General rights rights.

- You may freely distribute the URL identifying the publication in the public portal. please follow below link for the End User Agreement:

www.umlib.nl/taverne-license

Take down policy

If you believe that this document breaches copyright please contact us at:

repository@maastrichtuniversity.nl

providing details and we will investigate your claim.
}

Copyright and moral rights for the publications made accessible in the public portal are retained by the authors and/or other copyright owners and it is a condition of accessing publications that users recognise and abide by the legal requirements associated with these

- Users may download and print one copy of any publication from the public portal for the purpose of private study or research.

- You may not further distribute the material or use it for any profit-making activity or commercial gain

If the publication is distributed under the terms of Article $25 \mathrm{fa}$ of the Dutch Copyright Act, indicated by the "Taverne" license above, 
Bewijsmotivering in strafzaken 



\title{
Bewijsmotivering in strafzaken
}

\author{
PROEFSCHRIFT
}

ter verkrijging van de graad van doctor aan de Universiteit Maastricht, op gezag van de Rector Magnificus prof. mr. G.P.M.F. Mols volgens het besluit van het College van Decanen, in het openbaar te verdedigen op donderdag 6 september 2007 om 16.00 uur

door

Wilhelmina Hubertina Bernardina Dreissen 
Promotor:

Prof. mr. E. Prakken

\section{Copromotor:}

Dr. mr. D.M.H.R. Garé

\section{Beoordelingscommissie:}

Prof. mr. A.H. Klip (voorzitter)

Dr. P.L. Bal

Prof. dr. H.F.M. Crombag

Prof. mr. J.M. Reijntjes (Universiteit van de Nederlandse Antillen)

Dr. J. Wöretshofer (rechtbank Maastricht)

Dit promotieonderzoek is mede mogelijk gemaakt door een door NWO verstrekte subsidie ten behoeve van verblijf in Berlijn en Karlsruhe (Duitsland).

Opmaak binnenwerk: Boekopmaak Nettie Litjens Maastricht, www.boekopmaak.nl Ontwerp omslag: Iris de Graaf

Van dit proefschrift verschijnt een handelseditie bij Boom Juridische uitgevers, Den Haag, onder ISBN 978-90-5454-919-2. 
'Auch der Beschränkte, Unwissende, Unbesonnene faßt leicht und lebhaft eine subjektive Überzeugung. Aber je leichter er sie faßt, desto mehr hat man Ursache, ihr zu mißtrauen. Die Gewähr für die Wahrheit des Urteils über die Tatfrage is darin zu suchen, daß der Urteilende neben dem unerschütterlichen Willen, der Wahrheit die Ehre zu geben, die erforderlichen Kenntnisse und Fähigkeiten besitze und daß er davon in besonnener Reflexion wirklich Gebrauch macht.'

Friedrich Karl von Savigny 1858, p. 476 



\section{Inhoudsopgave}

Inleiding en probleemstelling 1

$1.1 \quad$ Achtergrond 1

1.2 Belang van motivering 1

1.3 Probleemstelling 3

$1.4 \quad$ Behandelplan 3

1.5 Datum afronding van het onderzoek 5

$2 \quad$ Het bewijsrecht en de motiveringsplicht vanaf 1838

$2.1 \quad$ Inleiding 7

2.2 De ontwikkeling van het strafrechtelijke bewijsrecht

2.2.1 Naar het eerste nationale Wetboek van Strafvordering 9

2.2.2 Het Wetboek van Strafvordering van $1838 \quad 13$

2.2.2.1 De wettige bewijsmiddelen 13

2.2.2.2 De bewijsminima 16

$\begin{array}{ll}\text { 2.2.2.3 De overtuiging van de rechter } & 17\end{array}$

2.2.2.4 Blote vermoedens 18

$\begin{array}{lll}2.2 .2 .5 & \text { Tussenconclusie } & 19\end{array}$

2.2.3 De periode tussen 1838 en $1910 \quad 20$

2.2.3.1 Het ontwerp Godefroi 21

2.2.3.2 De Nederlandse Juristenvergadering $1882 \quad 24$

2.2.3.3 De aanloop naar het Wetboek van $1926 \quad 27$

2.2.4 Het Ontwerp Wetboek van Strafvordering van de

2.2.4.1 Bewijsminima en motivering 31

2.2.4.2 De afschaffing van het bewijsmiddel der aanwijzingen en de
motivering

2.2.5 Het Wetboek van Strafvordering van $1926 \quad 36$

$\begin{array}{lll}2.2 .6 & \text { Slot } & 37\end{array}$

2.3 De ontwikkeling van de motiveringsplicht vanaf $1813 \quad 38$

2.3.1 Het Wetboek van Strafvordering 1838 en $1886 \quad 39$

2.3.1.1 Met redenen omkleed 40

2.3.1.2 Gevolgen voor de praktijk 42

$2.4 \quad$ Het Wetboek van Strafvordering van $1926 \quad 44$

2.4.1 De inhoud van de bewijsmiddelen 45

2.4.1.1 Het aanwijzen van de redengevende feiten en omstandigheden 46

2.4.1.2 Bijzondere motiveringsplicht in geval van 'onbekwame' getuigen 
2.4.1.3 Met redenen omkleed 51

2.5 Conclusie 53

$3 \quad$ Het Nederlandse bewijsrecht vanaf 1926

3.1 Inleiding 55

3.2 Onmiddellijke mondelinge bewijsvoering 55

3.2.1 Het de-auditu-arrest en zijn gevolgen $\quad 59$

3.2.2 Het ondervragingsrecht van de verdediging 62

3.2.2.1 Anoniem bewijs 66

3.2.2.2 Grenzen aan het 'gewone' getuigenbewijs 70

3.3 De wettige bewijsmiddelen 75

3.3.1 De eigen waarneming van de rechter 76

$\begin{array}{lll}\text { 3.3.2 Waarnemingen van derden } & 81\end{array}$

$\begin{array}{lll}\text { 3.3.3 } & \text { Bewijs door middel van deskundigen } & 84\end{array}$

$\begin{array}{lll}3.4 & \text { Bewijsverboden } & 88\end{array}$

$\begin{array}{lll}3.5 & \text { De bewijsminima } & 90\end{array}$

$\begin{array}{lll}\text { 3.5.1 De oorspronkelijke bewijsminima } & 91\end{array}$

3.5.2 De nieuwe bewijsminima 95

3.5.2.1 Anoniem bewijs 95

$\begin{array}{lll}\text { 3.5.2.2 Niet gehoorde getuigen } & 97\end{array}$

$\begin{array}{lll}3.6 & \text { Conclusie } & 100\end{array}$

4 De weergave van de inhoud van de bewijsmiddelen 103

$4.1 \quad$ Inleiding 103

Het belang van de vermelding van de inhoud van de
bewijsmiddelen

$\begin{array}{lll}4.3 & \text { Nadere bewijsoverwegingen } & 105\end{array}$

4.3.1 Onderdeel van de bewijsconstructie? 106

4.3.2 Vermelding van de bron 109

4.3.3 De inhoud van de nadere bewijsoverweging 110

$\begin{array}{ll}4.4 & \text { Uitzonderingen op het vermelden van de inhoud van de } \\ \text { bewijsmiddelen in het vonnis } & 112\end{array}$

4.4.1 Het mondelinge vonnis 114

$\begin{array}{ll}\text { 4.4.1.1 Het stempelvonnis en de aantekening in het proces-verbaal } & \\ \text { van de zitting } & 115\end{array}$

4.4.1.2 Verwijzing naar de bewijsmiddelen 117

$\begin{array}{lll}4.4 .2 & \text { Het verkorte vonnis } & 120\end{array}$

$\begin{array}{lll}\text { 4.4.2.1 De kop-staartpraktijk } & 121\end{array}$

$\begin{array}{lll}\text { 4.4.2.2 De eerste poging tot codificatie van de kop-staartpraktijk } & 122\end{array}$

4.4.2.3 De huidige regeling 124

4.4.2.4 Inhoud van het verkorte vonnis 126

$\begin{array}{lll}\text { 4.4.2.4.1 Weerlegging van bewijsverweren in het verkorte vonnis } 127 & 137\end{array}$

$\begin{array}{ll}\text { 4.4.2.5 Aanvulling van het verkorte vonnis } & 130\end{array}$

viii 
4.4.2.5.1 Termijn waarbinnen het verkorte vonnis moet worden aangevuld

De inhoud van de aanvulling Het verkorte vonnis bezien in het licht van art. 6 EVRM 133 Art. 6 lid 1 EVRM

Het oproepen van getuigen in hoger beroep en het verkorte vonnis

Het voortbouwend hoger beroep en het verkorte vonnis

4.4.3.1 Bekentenis van het bewezenverklaarde feit $\quad 149$

4.4.3.2 Een gehele of gedeeltelijke bekentenis 150

4.4.3.3 Bekentenissen uit het vooronderzoek 152

4.4.3.4 Bekennende verdachten en het negatief-wettelijk bewijsstelsel 154

$\begin{array}{lll}\text { 4.4.3.5 Efficiency } & 155\end{array}$

4.4.4 Geen aanvulling van het vonnis in eerste aanleg 157

4.4.5 Het vermelden van de inhoud van de bewijsmiddelen in het project Promis $\quad 159$

4.5 Conclusie 163

Redengevendheid van het bewijsmateriaal

Aspecten van relevantie

Motiveringsplicht met betrekking tot het bewijsobject

5.2.2.1 Motivering van de uitleg van het bewijsmateriaal 179

$\begin{array}{lll}\text { 5.2.2.2 Denaturering } & 181\end{array}$

5.2.3 Verband tussen bewijsobject en bewijsmateriaal 184

5.2.3.1 Statistisch bewijs en de eis van relevantie 186

5.2.3.2 Motivering van het logische verband 188

$\begin{array}{ll}\text { 5.2.3.3 Invulling van de eis van redengevendheid } & 189\end{array}$

5.2.3.4 Uitleg van art. 359 lid 3 Sv door de Hoge Raad 190

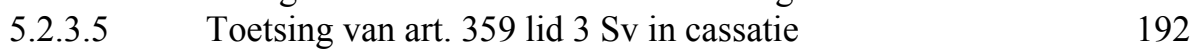

5.2.3.5.1 Redengevendheid op onderdelen 193

5.2.3.5.2 Toereikendheid van het bewijsmateriaal 195

5.2.4 Nadere motiveringseisen ten aanzien van de redengevendheid 198

5.2.4.1 De kennelijk leugenachtige verklaring van de verdachte 198

5.2.4.2 Het zwijgen van de verdachte 203

$\begin{array}{lll}\text { 5.2.4.3 Schakelbewijs } & 206\end{array}$

$\begin{array}{lll}\text { 5.2.4.3.1 De zaak Scheper } & 207\end{array}$ 
5.2.4.3.2 De zaak Lucia de B. 209

5.2.4.4 Meer en Vaartverweren 212

5.3 Conclusie 215

6 Bijzondere motiveringseisen aangaande de $\begin{array}{ll}\text { betrouwbaarheid } & 217\end{array}$

$\begin{array}{lll}6.1 & \text { Inleiding } & 217\end{array}$

$6.2 \quad$ Nadere motiveringsplichten ingevolge art. $360 \mathrm{~Sv} \quad 217$

6.2.1 Onbeëdigde getuigen 218

6.2.2 Anoniem bewijs $\quad 219$

6.2.3 Kroongetuige 222

6.2.4 Afgeschermde getuige 226

6.2.5 Tussenconclusie 230

6.3 Met redenen omkleed 232

6.3.1 Motivering van de vrijspraak 233

6.3.1.1 Toetsing van een vrijspraak in cassatie 233

6.3.1.2 Is het stellen van nadere motiveringseisen aan een vrijspraak gewenst? 236

6.3.2 Motivering van de bewezenverklaring 237

6.3.2.1 De uitleg van de Hoge Raad van het tweede lid 238

6.3.3 De responsieplicht op verweren 240

6.3.3.1 Betrouwbaarheidsverweren 243

6.3.3.1.1 Dubieuze getuigen 245

6.3.3.1.2 Dubieuze deskundigen 246

6.3.3.1.3 Dubieus onderzoek 249

6.3.3.2 Tussenconclusie 254

6.3.3.3 Eisen te stellen aan het verweer 255

6.3.4 De wet van 10 november 2004: een algemene responsieplicht 259

6.3.4.1 Totstandkoming 260

6.3.4.2 Uitleg van de Hoge Raad 263

6.3.4.2.1 De reikwijdte 263

6.3.4.2.2 Uitdrukkelijk onderbouwde standpunten. 265

6.3.4.2.3 De omvang van de motiveringsplicht 268

6.3.4.2.3.1 In de uitspraak zelf ligt reeds een nadere motivering besloten 269

6.3.4.2.3.2 Geen afbreuk aan begrijpelijkheid van de motivering 271

6.3.4.2.3.3 Van ondergeschikt belang 272

$\begin{array}{lll}\text { 6.3.4.3 Toegevoegde waarde van de responsieplicht } & \\ & \text { ex art. 359 lid 2 Sv }\end{array}$

6.3.5 Promis 276

6.4 Conclusie 278

$7 \quad$ Bewijs en bewijsmotivering in Duitsland 281

$\begin{array}{lll}7.1 & \text { Inleiding } 281\end{array}$

7.2 Het formele onmiddellijkheidsbeginsel 283 
7.3 Het 'Strengbeweisverfahren' 285

7.3.1 De wettigheid van het bewijs 286

7.3.2 Het beginsel van mondelinge procesvoering 288

7.3.3 Het materiële onmiddellijkheidsbeginsel 290

7.3.4 Het beginsel van materiële waarheidsvinding 295

7.3.4.1 De historie van $§ 244$ Abs. 2 StPO 295

7.3.4.2 Volledige feitenvaststelling 298

$\begin{array}{lll}7.4 & \text { Tussenconclusie } & 301\end{array}$

$\begin{array}{lll}7.5 & \text { De bewijswaardering } & 302\end{array}$

7.5.1 De ontstaansgeschiedenis van $\S 261$ StPO 303

$\begin{array}{lll}\text { 7.5.2 Het begrip 'overtuiging' } & 306\end{array}$

7.5.3 De motivering van het bewijsoordeel 311

$\begin{array}{lll}\text { 7.5.3.1 Bewijswaarderingsfouten } & 313\end{array}$

7.5.3.2 Bewijswaardering bevat onduidelijkheden of leemtes 315

7.5.3.3 Onvolledige bewijswaardering in geval van een

$\begin{array}{ll}\text { 7.5.3.4 Bijzondere bewijsconstructies } & 320\end{array}$

$\begin{array}{lll}\text { 7.5.3.4.1 De enkele verklaring van de verdachte } & 320\end{array}$

$\begin{array}{lll}\text { 7.5.3.4.2 Het zwijgen van de verdachte } & 321\end{array}$

7.5.3.4.3 Het liegen van de verdachte $\quad 322$

7.5.3.4.4 Aussage gegen Aussage 323

$\begin{array}{lll}\text { 7.5.3.4.5 } & \text { Verklaring van horen zeggen } & 328\end{array}$

$\begin{array}{lll}7.6 & 330\end{array}$

8 Waarheidsvinding: Duitsland en Nederland vergeleken 335

$\begin{array}{lll}8.1 & \text { Inleiding } & 335\end{array}$

$\begin{array}{lll}8.2 & \text { Materiële waarheidsvinding } & 337\end{array}$

8.2.1 De bewijsstandaard in strafzaken 337

$\begin{array}{lll}\text { 8.2.2 De onderzoeksplicht van de rechter } & 338\end{array}$

8.3 Begrenzing van de materiële waarheidsvinding 340

8.3.1 Beperkingen met het oog op een behoorlijke waarheidsvinding 341

8.3.2 Rechterlijke afhankelijkheid bij de waarheidsvinding 345

8.3.2.1 Afhankelijkheid in verband met de omvang van het onderzoek 345

8.3.2.2 Afhankelijkheid in verband met de aard van het onderzoek. 347

$\begin{array}{lll}8.4 & \text { Waarborgen voor een deugdelijke waarheidsvinding } & 349\end{array}$

8.4.1 De beslissing tot vervolging 349

8.4.2 De behandeling ter terechtzitting 351

8.4.2.1 Het onmiddellijkheidsbeginsel 352

8.4.2.2 De rechterlijke onderzoeksplicht 355

8.4.3 De waardering van het bewijsmateriaal 358

$\begin{array}{lll}8.5 & \text { Tussenconclusie } 359\end{array}$

8.6 Motivering als sluitstuk van de waarheidsvinding in strafzaken 360

8.6.1 De formele motiveringsplicht in Nederland 360

8.6.2 De formele motiveringsplicht in Duitsland 362

8.6.3 Materiële motiveringsplicht in Nederland 364 
8.6.4 Materiële motiveringsplicht in Duitsland 366

8.7 Het hoger beroep 367

$\begin{array}{lll}8.8 & \text { Conclusie } & 370\end{array}$

9 Het belang van de motivering 375

$9.1 \quad$ Inleiding 375

9.2 De legitimering van het rechterlijk oordeel 375

9.2.1 Legitimering van het bewijsoordeel 377

9.3 Vormen van legitimering 379

$\begin{array}{lll}\text { 9.3.1 De rechter } & 379\end{array}$

9.3.2 Binding aan het recht 383

$\begin{array}{lll}\text { 9.3.3 Procedurele eisen } & 384\end{array}$

9.3.3.1 Tegenspraak 385

9.3.3.2 Externe openbaarheid 389

9.3.4 Motivering 390

9.4 Functies van de motivering van de bewijsbeslissing 392

9.4.1 De controlefunctie 392

9.4.1.1 Controle in hoger beroep 394

9.4.1.2 Controle in cassatie 394

9.4.2 De inscherpingsfunctie 395

9.4.3 De explicatiefunctie 398

$\begin{array}{lll}9.5 & \text { De verhouding tussen de verschillende motiveringsfuncties } & 402\end{array}$

9.6 Lessen uit Duitsland 404

$\begin{array}{lll}9.7 & \text { Conclusie } & 407\end{array}$

Bijlage: voorbeeld Duits strafvonnis $\quad 409$

$\begin{array}{ll}\text { Samenvatting } & 423\end{array}$

$\begin{array}{ll}\text { Summary } & 431\end{array}$

$\begin{array}{ll}\text { Literatuur } & 441\end{array}$

$\begin{array}{ll}\text { Jurisprudentie } & 467\end{array}$

$\begin{array}{ll}\text { Dankwoord } & 475\end{array}$

$\begin{array}{ll}\text { Curriculum Vitae } & 477\end{array}$ 


\section{Lijst van afkortingen}

$\begin{array}{ll}\text { Abs. } & \text { Absatz } \\ \text { art. } & \text { artikel } \\ \text { BGB1 } & \text { Bundesgesetzblatt } \\ \text { BGH } & \text { Bundesgerichtshof } \\ \text { BGHR } & \text { BGH-Rechtsprechung Strafsachen } \\ \text { BGHSt } & \text { Enstscheidungen des Bundesgerichtshofes in Strafzaken } \\ \text { ECRM } & \text { Europese Commissie voor de rechten van de mens } \\ \text { EHRM } & \text { Europees Hof voor de rechten van de mens } \\ \text { HR } & \text { Hoge Raad } \\ \text { LJN } & \text { landelijk jurisprudentienummer } \\ \text { m.nt. } & \text { met noot } \\ \text { MDR } & \text { Monatschrift für deutsches Recht } \\ \text { MvT } & \text { memorie van toelichting } \\ \text { NbSr } & \text { Nieuwsbrief Strafrecht } \\ \text { NJ } & \text { Nederlandse Jurisprudentie } \\ \text { NJV } & \text { Nederlandse Juristenvereniging } \\ \text { NJW } & \text { Neue Juristische Wochenschrift } \\ \text { OM } & \text { Openbaar Ministerie } \\ \text { NOvA } & \text { Nederlandse Orde van Advocaten } \\ \text { NStZ } & \text { Neue Zeitschrift für Strafrecht } \\ \text { NVvR } & \text { Nederlandse Vereniging voor Rechtspraak } \\ \text { Rb. } & \text { rechtbank } \\ \text { RG } & \text { Reichsgericht } \\ \text { RGSt. } & \text { Entscheidungen des Reichsgericht in Strafsachen } \\ \text { Sr } & \text { Wetboek van Strafrecht } \\ \text { Stb. } & \text { Staatsblad } \\ \text { Stcrt. } & \text { Staatscourant } \\ \text { StR } & \text { Strafsenat van het Bundesgerichtshof } \\ \text { StGB } & \text { Strafgesetzbuch } \\ \text { StPO } & \text { Strafprozessordnung } \\ \text { StV } & \text { Strafverteidiger } \\ \text { Sv } & \text { Wetboek van Strafvordering } \\ & \end{array}$





\section{$1 \quad$ Inleiding en probleemstelling}

\subsection{Achtergrond}

De plicht tot het motiveren van rechterlijke oordelen is neergelegd in artikel 121 Grondwet: vonnissen dienen de gronden te bevatten waarop zij rusten. Deze motiveringseis is voor strafrechtelijke vonnissen uitgewerkt in de artikelen 359 en $360 \mathrm{~Sv}$. Waar het gaat om de motivering van de bewijsbeslissing zijn maar liefst vijf voorschriften van toepassing. Het vonnis dient in geval van een bewezenverklaring de inhoud van de bewijsmiddelen te bevatten waarop die beslissing rust (art. 359 lid 3, eerste volzin, Sv), de inhoud van die bewijsmiddelen moet redengevend zijn voor die beslissing (art. 359 lid 3, eerste volzin, Sv), het gebruik van bepaalde bewijsmiddelen moet nader worden gemotiveerd (art. 360 lid 1 en $2 \mathrm{~Sv}$ ), en uitdrukkelijk ingenomen en onderbouwde standpunten van partijen moeten - indien de rechter deze niet volgt - worden weerlegd (art. 359 lid 2 , tweede volzin, Sv). Bovendien dient de rechter de - positieve dan wel negatieve bewijsbeslissing met redenen te omkleden (art. 359 lid 2, eerste volzin, Sv).

Wie al deze bepalingen leest, verkeert in de veronderstelling dat aan het Nederlandse strafvonnis hoge eisen worden gesteld aan de verantwoording van het bewijsoordeel. Niets is minder waar. In tegenstelling tot hetgeen op basis van de wettekst en daaraan ten grondslag liggende toelichting zou mogen worden verwacht, zijn strafvonnissen in Nederland zeer summier als het gaat om de motivering van de beslissing of de verdachte het hem tenlastegelegde feit heeft begaan. In het merendeel van de gevallen bevatten vonnissen enkel de conclusie; de verdachte heeft het hem tenlastegelegde feit begaan, dan wel het tenlastegelegde feit is niet wettig en overtuigend bewezen. Dat dit onvoldoende is, werd ook door de Raad voor de Rechtspraak beaamd. Hij startte in 2004 een project met als inzet te bezien of het mogelijk is - met gelijkblijvende financiële middelen - te komen tot betere vonnissen onder andere op het punt van de bewijsmotivering. Conclusie was dat, ondanks het feit dat motivering van vonnissen meer tijd en dus ook meer geld kostte, een verbetering mogelijk en noodzakelijk was.

\subsection{Belang van motivering}

Hoewel de noodzaak tot verbetering door de Raad van de Rechtspraak niet nadrukkelijk wordt toegelicht, is die evident. Het in sommige gevallen volledig uitblijven van een onderbouwing van een bewezenverklaring of vrijspraak is niet alleen niet in overeenstemming met hetgeen de wetgever van 1926 beoogde, maar 
is ook in maatschappelijke zin niet aanvaardbaar. De vraag of de verdachte het hem verweten feit heeft begaan, is de meest wezenlijke die door de rechter dient te worden beantwoord. Alleen als deze vraag in positieve zin en met een aan zekerheid grenzende waarschijnlijkheid kan worden beantwoord, kan sanctionerend worden opgetreden door de overheid. Blijft er twijfel bestaan, dan dient de rechter vrij te spreken. De legitimatie van de inzet van het strafrecht is dus in grote mate afhankelijk van de waarborgen waarmee het bewijsoordeel in strafzaken is omgeven. Eén van die waarborgen is gelegen in de plicht van de rechter om de bewijsbeslissing te motiveren. Daarnaast kan gewezen worden op de wijze waarop bewijsvoering - de presentatie van het bewijs ter zitting - is gereguleerd en de wettelijke en jurisprudentiële bewijsregels die in acht moeten worden genomen. Motivering en de normering van de bewijsvoering en bewijswaardering zijn onlosmakelijk met elkaar verbonden. Enerzijds dient uit de motivering te blijken dat de regels die de bewijsbeslissing betreffen zijn nageleefd. In de literatuur wordt dit aspect van de motivering wel aangeduid als de controlefunctie van de motivering. Anderzijds is het onmogelijk om de bewijsbeslissing vooraf zodanig te normeren, dat in alle gevallen de toepassing van deze regels zou leiden tot een 'juiste' uitkomst, in die zin dat met een aan zekerheid grenzende waarschijnlijkheid vaststaat dat de verdachte het bewezenverklaarde feit ook inderdaad heeft begaan. Uitgaande van de onmogelijkheid om een dergelijke set van a priori geldige en sluitende regels op te stellen, houdt de rechter een grote mate van beoordelingsvrijheid met betrekking tot de vraag of in het concrete geval het bewijs geleverd wordt. Of de rechter deze aan hem toekomende beoordelingsvrijheid, in artikel $338 \mathrm{~Sv}$ tot uitdrukking komend in het begrip 'overtuiging', op juiste wijze heeft gebruikt, kan alleen worden getoetst indien de rechter bereid, dan wel verplicht is te verantwoorden op welke gronden hij tot zijn oordeel is gekomen. De motivering vormt in die zin dus een aanvulling op de normering van het bewijsoordeel. Dit aspect wordt in de literatuur wel aangeduid als de inscherpingsfunctie van de motivering.

Los van de bewijsproblematiek wordt aan de motivering nog een derde functie toegekend, te weten: de explicatiefunctie. Door te motiveren licht de rechter het publiek, maar ook procespartijen, in over de gronden die hij voor zijn beslissing aanvoert. Het belang van de motivering in dit verband is gelegen in het feit dat in en buiten de rechtszaal het oordeel van de onafhankelijke en onpartijdige rechter kenbaar wordt en kritisch kan worden beoordeeld. Deze functie verwijst niet alleen naar de motivering van de bewijsbeslissing, maar ook naar andere aspecten van de uitspraak zoals de straftoemeting. Als de nadruk wordt gelegd op de explicatiefunctie, dan dient de motivering de openbaarheid van de rechtspraak. 


\subsection{Probleemstelling}

In dit onderzoek wordt bezien in hoeverre de motiveringseisen ten aanzien van de bewijsbeslissing zoals die in het Wetboek van Strafvordering zijn opgenomen en zoals zij in de jurisprudentie zijn uitgelegd, tegemoetkomen aan de drie functies die de motivering worden toegedicht. Omdat de twee eerstgenoemde functies (de controlefunctie en de inscherpingsfunctie) in nauw verband staan met de wijze waarop het bewijsoordeel in strafzaken is genormeerd, is een analyse van de motiveringseisen niet mogelijk zonder eveneens in te gaan op het bewijsrechtelijke kader dat in acht moet worden genomen bij de totstandkoming van die beslissing. Evident is immers dat de controlefunctie afhankelijk is van de mate waarin er regels zijn die het bewijsoordeel reguleren. Naarmate er echter minder regels zijn of deze minder strikt worden uitgelegd, komt aan de inscherpingsfunctie van de motivering meer belang toe. In dat verband is er voor gekozen om in het onderzoek ook de motivering van bewijsbeslissingen zoals die in Duitsland plaatsvindt te betrekken. Het Duitse bewijsstelsel wordt als 'vrij' gekenschetst. Dit betekent dat de rechter in principe vrij is in de waardering van het hem gepresenteerde bewijs. Het Duitse bewijsrecht bevat geen (algemene) bepalingen die de rechter op dit punt binden. Nederland daarentegen kent van oorsprong een negatief-wettelijk bewijsstelsel. Het wettelijke element bestaat daaruit dat de rechter is gebonden aan de in de wet genoemde bewijsmiddelen en met betrekking tot het gebruik van die bewijsmiddelen geformuleerde voorwaarden waaronder de bewijsminima. Het 'negatief' in negatief-wettelijk bewijsstelsel slaat op de overtuiging van de rechter die eveneens vereist is voor een bewezenverklaring. Het rechtsvergelijkende onderzoek zal moeten uitwijzen in hoeverre de binding van de rechter aan wettelijke bewijsregels ook zijn uitwerking heeft op de omvang van de rechterlijke motiveringsplicht.

\subsection{Behandelplan}

Het onderzoek start met een rechtshistorische verkenning van het Nederlandse bewijsrecht en de ten aanzien van de bewijsbeslissing geldende motiveringsplicht. Daarbij is het jaar 1813 als beginpunt gekozen, omdat dat het jaar is waarin in Nederland de juryrechtspraak werd afgeschaft. Eén van de argumenten om tot afschaffing van de 'ons' door de Fransen opgedrongen jury over te gaan, was gelegen in het feit dat de jury niet kon worden gebonden aan wettelijke bewijsregels en men ook anderszins geen nadere motivering van hun oordeel kon verlangen. De noodzaak van een eigen bewijsregeling en een daaraan gekoppelde motiveringsplicht was vanaf dat moment geboren. Dat beide - bewijsregeling en motivering - binnen de Nederlandse context onlosmakelijk met elkaar verbonden 
zijn, blijkt duidelijk uit de totstandkoming van het Wetboek van Strafvordering van 1926.

In het nieuwe Wetboek van Strafvordering 1926 werd het negatief-wettelijk bewijsstelsel gehandhaafd, maar op belangrijke punten aangepast. In hoofdstuk 3 wordt de ontwikkeling van het Nederlandse bewijsrecht vanaf 1926 in vogelvlucht doorgenomen. Doel daarvan is om te bezien in welke mate het bewijsoordeel in strafzaken in wettelijke zin nader is genormeerd en hoe deze bewijsregels in de jurisprudentie zijn uitgelegd.

In hoofdstuk 4, 5 en 6 wordt vervolgens ingegaan op de verschillende motiveringsbepalingen en de wijze waarop daaraan vanaf 1926 inhoud is gegeven. In hoofdstuk 4 staat de vermelding van de inhoud van de gebezigde bewijsmiddelen in het vonnis centraal. Hoewel deze verplichting blijkens de memorie van toelichting bij het Wetboek van Strafvordering van 1926 eigenlijk niet werd beschouwd als een motiveringseis vormde zij lange tijd de ruggengraat van de Nederlandse bewijsmotivering. Aan de hand van de inhoud van de bewijsmiddelen kan immers worden gecontroleerd of de rechter de beperkingen die in de wet werden gesteld aan het bewijsoordeel en die inherent zijn aan het negatiefwettelijk bewijsstelsel in acht heeft genomen. Op de plicht tot het opnemen van de inhoud van de bewijsmiddelen zijn echter zeer vergaande uitzonderingen geformuleerd.

De twee meest wezenlijke eisen die aan het bewijs in strafzaken kunnen worden gesteld betreffen de relevantie en de betrouwbaarheid van het gebezigde bewijsmateriaal. Beide eisen zijn niet expliciet in het materiële bewijsrecht opgenomen, maar met betrekking tot zowel de relevantie als de betrouwbaarheid van het door de rechter gebezigde bewijsmateriaal gelden specifieke motiveringseisen. De eis van relevantie komt in het Wetboek van Strafvordering terug in artikel 359 lid 3: het door de rechter gebezigde bewijsmateriaal dient redengevend te zijn. De wijze waarop de Hoge Raad invulling heeft gegeven aan deze motiveringseis staat centraal in hoofdstuk 5. In hoofdstuk 6 komen de overige motiveringsbepalingen aan bod, te weten artikel 359 lid 2 en 360 lid 1 en 2 Sv. Voor zover de Hoge Raad op grond daarvan een nadere motivering verlangt van de feitenrechter ziet dat in bijna alle gevallen op de betrouwbaarheid van het bewijs.

In hoofdstuk 7 wordt het Duitse bewijsrecht en de daaraan gekoppelde motiveringsplicht belicht. Zoals hiervoor vermeld, verschilt het Duitse bewijsrecht wezenlijk van het Nederlandse, omdat het noch een limitatieve opsomming van de bewijsmiddelen, noch enige andere regel kent die de rechter bindt bij de waardering van het bewijs. Wel kent het Duitse bewijsrecht meer strikte regels aangaande de presentatie van het bewijs ter zitting. Ten aanzien van de motiveringsplicht geldt een gelijke situatie als ten aanzien van de bewijswaarderingsregels. Waar in het Nederlandse Wetboek van Strafvordering maar liefst vijf bepalingen zijn opgenomen waarin de rechter verplicht wordt tot motivering, 
kent de Duitse Strafprozessordnung er geen. Ondanks dat heeft het Bundesgerichtshof gemeend dat in bepaalde gevallen van de rechter mag worden verwacht dat hij de selectie en waardering van het bewijsmateriaal nader toelicht. De redenen waarom en de gevallen waarin een nadere motivering van de Duitse feitenrechter worden verlangd, komen in hoofdstuk 7 aan de orde.

In hoofdstuk 8 wordt stilgestaan bij de karakteristieke eigenschappen van het bewijsoordeel in strafzaken en de wijze waarop dat in juridische zin is genormeerd. Die normering kan op verschillende wijze vorm krijgen, hetgeen wordt geïllustreerd aan de hand van de verschillen tussen het Duitse en het Nederlandse (bewijs)recht en de gevolgen daarvan voor de eisen die in beide landen worden gesteld aan het feitenoordeel van de strafrechter.

Het onderzoek wordt afgesloten met een hoofdstuk over het belang van motivering. De aan de motivering verbonden functies worden in een meer algemeen kader geplaatst, te weten de noodzaak tot legitimering van het rechterlijke oordeel, meer specifiek het bewijsoordeel. Binnen dat kader wordt ook de verhouding tussen de verschillende functies aan de orde gesteld. Aan de hand daarvan zal worden bezien aan welke van de eerder genoemde functies meer waarde toekomt en in hoeverre dat overeenstemt met de wijze waarop thans invulling wordt gegeven aan de verschillende motiveringsplichten aangaande de bewijsbeslissing in strafzaken.

\subsection{Datum afronding van het onderzoek}

Het onderzoek is afgerond op 1 maart 2007. Na die tijd verschenen rechtspraak en regelgeving is niet meer opgenomen. Hierop is één uitzondering gemaakt, te weten de uitspraken van de Hoge Raad d.d. 15 mei 2007 inzake de rechtsgeldigheid van de zogeheten promis-vonnissen. 



\section{Het bewijsrecht en de motiveringsplicht vanaf 1838}

\section{$2.1 \quad$ Inleiding}

Sinds 1926 kent het Wetboek van Strafvordering vier bepalingen die rechtstreeks op de motivering van de bewijsbeslissing betrekking hebben. Kort samengevat houden deze in dat het vonnis in geval van een bewezenverklaring de inhoud van de bewijsmiddelen moet bevatten (art. 359 lid $1 \mathrm{~Sv}$ 1926) ${ }^{1}$ en dat de daaruit voortvloeiende redengevende feiten en omstandigheden moeten worden aangewezen (art. 359 lid 3 Sv 1926). In geval de bewezenverklaring steunt op de verklaring van een niet beëdigde getuige moet de rechter het gebruik daarvan nader motiveren (art. 360 lid 1 Sv 1926). Zowel de vrijspraak als de bewezenverklaring moeten met redenen zijn omkleed (art. 359 lid 2 Sv 1926).

De inhoud van deze voorschriften is in principe vanaf 1926 ongewijzigd gebleven. Wel is artikel $360 \mathrm{~Sv}$ sindsdien uitgebreid met een aantal andere gevallen waarin van de rechter een nadere motivering wordt geëist. Bovendien is vanaf 1 januari 2005 artikel $359 \mathrm{~Sv}$ met betrekking tot de motivering van de bewezenverklaring gewijzigd in die zin dat in geval van een bekennende verdachte minder strenge eisen daaraan worden gesteld. Bovendien is toen een algemene responsieplicht ten aanzien van de bewijsverweren opgenomen. Op deze wijzigingen van de wettekst na 1926 zal in dit hoofdstuk nog niet worden ingegaan.

In dit hoofdstuk staat de ontstaansgeschiedenis van de oorspronkelijk in het Wetboek van Strafvordering van 1926 opgenomen motiveringsvoorschriften centraal. Daarbij zal worden betoogd dat de motiveringsplichten zoals die vanaf 1926 uit de artikelen 359 en 360 Sv 1926 voortvloeien niet los kunnen worden gezien van de keuzes die de wetgever heeft gemaakt met betrekking tot de inhoud van het bewijsrecht. Alvorens in paragraaf 2.3 op de motiveringsvoorschriften zelf in te gaan, zal daarom eerst de ontwikkeling van het Nederlandse strafrechtelijke bewijsrecht worden besproken.

1 Per 1 januari 2005 is deze bepaling verplaatst naar het derde lid van art. 359 Sv. Zie de Wet van 10 november 2004 (aanpassing eisen motivering bewezenverklaring bekennende verdachte), Stb. 2004, 580 (inwerkingtreding 1 januari 2005, Stb. 2004, 641). 


\subsection{De ontwikkeling van het strafrechtelijke bewijsrecht vanaf 1795 tot en met 1926}

De ontwikkeling van het strafrechtelijke bewijsrecht in Nederland heeft altijd in het teken gestaan van de vraag in hoeverre de rechter vrij was in de beoordeling van de bewijskracht en bewijswaarde van het ter zitting gepresenteerde bewijsmateriaal. Van oudsher wordt ter beantwoording van die vraag onderscheid gemaakt tussen zogeheten wettelijke en vrije bewijsstelsels.

In een wettelijk bewijsstelsel wordt de vrijheid van de strafrechter beperkt door de in de wet opgenomen bewijsregels. Deze regels kunnen van dien aard zijn dat aan de rechter in principe geen enkele vrijheid wordt gegund. De toepassing van de wettelijke bewijsregels leidt ertoe dat het antwoord op de vraag of de verdachte het strafbare feit al dan niet heeft begaan 'automatisch' daaruit voortvloeit. In dat geval spreekt men van een positief-wettelijk bewijsstelsel.

In het negatief-wettelijk bewijsstelsel bevat de wet geen sluitend systeem van bewijsregels. De wet bevat slechts regels die bij toepassing ertoe kunnen leiden dat de strafrechter niet tot een bewezenverklaring mag komen, en dus moet vrijspreken. In tegenstelling tot de positieve variant wordt in een negatief-wettelijk bewijsstelsel de rechter niet gedwongen om een bewezenverklaring uit te spreken. De beoordeling van de vraag of op basis van het ter zitting gepresenteerde bewijsmateriaal, mits dit voldoet aan de in de wet gestelde minimumeisen, een bewezenverklaring kan worden uitgesproken, is overgelaten aan de rechter. Hij moet in geval van een bewezenverklaring daartoe de overtuiging hebben.

In de zogeheten vrije bewijsstelsels wordt de waardering van de feiten zoals die ter zitting zijn gebleken niet in de wet gereguleerd. De waardering van het bewijsmateriaal wordt overgelaten aan de rechter. Hij moet zonder wettelijke belemmeringen zijn mening kunnen vormen over de vraag of de verdachte het hem verweten feit heeft begaan. De bewijsvraag in deze stelsels kan gelijk gesteld worden met de vraag of de rechter al dan niet overtuigd is. Daarbij moet echter worden aangetekend dat het begrip 'overtuiging' niet altijd eenzelfde betekenis heeft. Onderscheid kan worden gemaakt tussen die stelsels waarin het overtuigingsbegrip subjectief wordt ingevuld (het stelsel der conviction intime) en stelsels waarin aan dit begrip een geobjectiveerde betekenis wordt toegekend (het stelsel der conviction raisonnée). In het stelsel van de conviction intime worden buiten de subjectieve overtuiging geen verdere eisen aan het bewijsoordeel gesteld. In het stelsel van de conviction raisonnée wordt daarentegen de rechter geacht zijn overtuiging (mede) te vormen aan de hand van algemeen aanvaarde wetenschappelijke en ervaringsregels, en wordt van hem verlangd dat hij dit ook in het vonnis kenbaar maakt door zijn bewijsoordeel te motiveren. 
De hierboven geschetste indeling in bewijsstelsels is niet volledig ${ }^{2}$ en bovendien is het verschil tussen de diverse stelsels in de praktijk niet zo strikt als beschreven. Zo zal een zuiver positief-wettelijk bewijsstelsel nooit bestaan, omdat het nu eenmaal niet mogelijk is in de wet a priori een sluitende bewijsregeling voor alle mogelijke gevallen op te nemen. ${ }^{3}$ Bovendien, uitgaande van de hypothetische situatie dat dit wel mogelijk is, houdt de strafrechter toch altijd enige beoordelingsvrijheid bij de toepassing van die bewijsregels. Ook een volledig vrij bewijsstelsel bestaat in de praktijk niet; in die landen waar een vrij stelsel wordt toegepast, is wel degelijk een aantal regels met betrekking tot het bewijs in de wet opgenomen. ${ }^{4}$ Te denken valt dan vooral aan bewijsvoeringsregels, zoals de eis dat het bewijs ter zitting gepresenteerd moet worden, dat getuigen alleen onder ede mogen verklaren, en het recht van de verdediging om getuigen te ondervragen. In de praktijk zal men dus enkel kunnen spreken van meer of minder vrije bewijsstelsels, afhankelijk van de vraag in hoeverre het oordeel over de bewijsvraag in de wet is gereguleerd, en hoe het overtuigingsbegrip wordt geïnterpreteerd.

Toch is het theoretische onderscheid tussen de diverse bewijsstelsels van belang om inzicht te krijgen in de wijze waarop het Nederlandse bewijsrecht zich vanaf 1795 heeft ontwikkeld. Immers, vanaf dat moment wordt in Nederland een levendige discussie gevoerd over de vraag welk bewijsstelsel aan de nationale wetgeving ten grondslag zou moeten liggen. Bij de vormgeving van het nationale bewijsrecht speelt ook - zeker vanaf het midden van de $19^{\mathrm{e}}$ eeuw - de betekenis en inhoud van de motivering van het bewijsoordeel een belangrijke rol.

\subsubsection{Naar het eerste nationale Wetboek van Strafvordering}

Als in 1795 voor het eerst een nationale eenheidsstaat - de Bataafse republiek wordt uitgeroepen, ontstaat de noodzaak van een eigen nationale wetgeving. Tot dat moment bestond er in de diverse provinciën en zelfs in verschillende steden een grote diversiteit aan regels ten aanzien van de wijze van procederen en de wijze waarop het bewijs in strafzaken moest worden beoordeeld.

2 De indeling in wettelijke en vrije bewijsstelsels is een typisch juridische indeling en bovendien wordt in deze indeling over het hoofd gezien dat het bewijsoordeel nader genormeerd wordt door hetgeen in de jurisprudentie ten aanzien van het bewijs wordt bepaald. In verband met dat laatste kan bijvoorbeeld worden gewezen op de ontwikkeling van het leerstuk van onrechtmatig verkregen bewijs in de Nederlandse rechtspraak. Zie over nadere indelingen met betrekking tot bewijsstelsels Nijboer 2000a, p. 56-61.

3 Aldus Nijboer 2000a, p. 48 en reeds in 1865 De Bosch Kemper, p. 185: 'De groote fout, waaraan deze theorie zich schuldig maakt, is, dat zij niet in aanmerking neemt noch kan nemen het eigenaardig karakter van elk bewijsmiddel in ieder bijzonder geval.'

4 In gelijke zin: Nijboer 2000a, p. 49 en Reijntjes 1980, p. 13. 
Weliswaar had Philips II een poging tot uniformering gedaan door de invoering van de Criminele Ordonnantiën in 1570, maar deze poging had weinig effect. Alleen in de provincie Holland lieten de Criminele Ordonnantiën van Philips II hun sporen na, en wel in die zin dat men daar de mening was toegedaan dat in strafzaken veroordeling alleen kon plaatsvinden op basis van een bekentenis. Deze bekentenis werd vaak afgedwongen door het gebruik van de pijnbank. ${ }^{5}$ Dit idee was gebaseerd op een verkeerde interpretatie van de Criminele Ordonnantiën ${ }^{6}$ en werd gevoed door het besluit om in geval van een bekentenis geen hoger beroep toe te laten. In de overige provinciën werden de Criminele Ordonnantiën niet toegepast ${ }^{7}$ en werd veelal teruggevallen op eigen oude vormen van strafvordering waarbij een veroordeling in strafzaken ook mogelijk was indien de rechter de overtuiging had dat de verdachte het hem verweten feit had begaan zonder dat deze het feit had bekend. ${ }^{8}$

Om een einde te maken aan deze diversiteit op het gebied van de strafvordering en het bewijs in strafzaken wordt op 28 september 1798 de 'Commissie tot het vervaardigen van een Civiel en Crimineel Wetboek' benoemd. Zij krijgt de opdracht één nationaal wetboek voor het procederen in burgerlijke en strafzaken te ontwerpen. In het vierde deel van dit Wetboek zou dan de regeling over het bewijs worden opgenomen. De eerste aanzet tot een dergelijk algemene bewijsregeling verschijnt in 1804, te weten het 'Ontwerp van Wetten omtrent het Bewijs'. Dit Ontwerp bevat maar liefst 398 bepalingen, maar heeft ondanks zijn uitgebreidheid en gedetailleerdheid niet de strekking het bewijsoordeel van de rechter volledig aan de wettelijke regels te binden. In artikel 24 van het eerste hoofdstuk staat namelijk te lezen:

$5 \quad$ Het afschaffen van de pijnbank in 1798 leidde dan ook in de provincie Holland tot grote problemen. Immers, daarmee kwam het middel om de noodzakelijke bekentenis te krijgen te vervallen. Teneinde te voorkomen dat vele schuldigen vrij moesten worden gesproken, werd op 10 oktober 1798 een provisioneel reglement voor Holland afgekondigd. In het eerste lid van artikel 1 van dit Reglement werd de pijnbank volledig afgeschaft, maar in het tweede lid werd de rechter de bevoegdheid gegeven om 'door zoodanige middelen, als hij gepast zoude oordelen, den beklaagde tot antwoorden te noodzaken'. De Bosch Kemper concludeert dan ook dat daarmee feitelijk een gewijzigde pijnbank werd ingevoerd. Zie De Bosch Kemper 1838-1840, Eerste deel, p. CXXXVI.

6 Zie De Bosch Kemper 1838-1840, Eerste deel, p. CXXIV: 'Men zocht dit streven, om confessie te verlangen, te regtvaardigen, met het voorgeven, dat alleen op confessie konde worden veroordeeld, niettegenstaande het gemeene regt en de ordonnantiën van Philips uitdrukkelijk veroordeeling op convictie toelieten.'

7 De Bosch Kemper 1838-1840, Eerste deel, p. XCVII.

8 Zie voor een overzicht van de tot 1795 in de verschillende provinciën voorkomende vormen en regels met betrekking tot de strafprocedure De Bosch Kemper 1838-1840, Eerste deel, p. XCVIII-CXXXIV. 
'Daar het niet mogelijk is, zonder uitzondering te bepalen welke bewijzen in elk geval genoegzaam zijn, moet de regter, door de algemene regels van het regt voorgelicht, in gemoede beoordelen, wat hem als waar of waarschijnlijk voorkomt. ${ }^{99}$

In principe ligt hierin de eerste versie van ons huidige negatief-wettelijk bewijsstelsel besloten. De strafrechter is aldus het Ontwerp gebonden aan de wettelijke bepalingen, maar moet bovendien naar zijn eigen overtuiging beoordelen of de voorgelegde feiten hem waar of niet waar voorkomen. De 398 bepalingen hebben echter nooit een wettelijke status verkregen. De reden hiervoor is dat men inmiddels de idee van een algemene regeling voor procederen in burgerlijke én strafzaken liet varen. Ten aanzien van het strafrechtelijke bewijsrecht bestond er vervolgens nog onenigheid over de vraag of dit dan bij het procesrecht of bij het materiële recht moest worden ondergebracht. ${ }^{10}$

In eerste instantie wordt het bewijsrecht ondergebracht in het Crimineel Wetboek voor het Koninkrijk Holland ${ }^{11}$ onder de titel 'Van het bewijs der misdaden'. 12 Van de 398 bepalingen uit het 'Ontwerp van Wetten omtrent het Bewijs' worden slechts de algemene bepalingen (in totaal 14) overgenomen. ${ }^{13}$ Het Crimineel Wetboek voor het Koninkrijk Holland werd afgekondigd op 14 juli 1809, en krijgt kracht van wet op 1 februari 1809. Daarmee wordt volgens Van de Vrugt een mijlpaal bereikt in de geschiedenis van ons strafrecht:

'De veelheid van oude rechtsbronnen, alsmede het Romeinse recht zijn afgeschaft. Daarvoor in de plaats komt een algemeen in het rijk geldend in heldere en beknopte stijl gesteld wetboek, dat een nuchtere afweging in zich draagt van de revolutionaire idealen en de eigengeaardheid van de oud Nederlandse rechtsopvattingen en rechtsinstelling., 14

Het Crimineel Wetboek is echter maar een korte levenstijd gegund. Als gevolg van de inlijving van het Koninkrijk door Frankrijk op 9 juli 1810 wordt in Nederland de Franse wetgeving van kracht. Zo treedt op 1 januari 1811 ook de Franse Code d'Instruction Criminelle van 1808 in het Koninkrijk in werking. Wat betreft het bewijsrecht betekent dit dat het oordeel in strafzaken vanaf dan is opgedragen aan een jury, die puur op zijn gemoedelijke overtuiging (conviction intime) moet oordelen. De jury is niet gebonden aan wettelijke bewijsregels, zoals ook blijkt uit artikel 342 van de Code d'Instruction Criminelle:

9 De Bosch Kemper 1838-1840, Derde deel, p. 485.

10 De Bosch Kemper 1838-1840, Derde deel, p. 486.

11 Zie daarover uitgebreid Van Binsbergen 1949.

12 Titel 29, artikelen 359-375.

13 Modderman 1867, p. 152.

14 Van de Vrugt 1982, p. 53. 
'dat de wet aan de gezworenen geene regelen voorschrijft, waarvan zij de al of niet genoegzaamheid der bewijzen zullen moeten doen afhangen; dat zij alleen verlangt, dat de gezworenen in stilte en afgetrokkenheid naar de opregtheid van hun geweten onderzoeken, welken invloed op hun gemoed hebben gehad de te berde gebragte bewijsen, en de verdediging van den aangeklaagde. ${ }^{, 15}$

Als in 1813 een einde komt aan de Franse overheersing blijven in principe de Franse regels met betrekking tot de strafvordering van kracht. Slechts op één punt wordt hiervan afgeweken en wel de beoordeling in strafzaken door de jury. Bij het zogeheten Souverein Besluit van 1813 wordt de juryrechtspraak afgeschaft. ${ }^{16}$ Eén van de belangrijkste redenen om het oordeel niet aan een jury op te dragen, is de gedachte dat de waarheidsvinding in strafzaken wel degelijk aan algemene regels moet en kan worden gebonden. Aangezien men van gezworenen niet mag verwachten dat zij deze regels kunnen toepassen, wordt de rechtspleging in strafzaken opgedragen aan beroepsrechters. Bovendien wordt de jury direct in verband gebracht met de periode van Franse overheersing waaraan men liever niet wil terugdenken, zoals blijkt uit de woorden van een Kamerlid destijds:

'en iedereen was blijde toen, dadelijk na de gelukkige omwenteling, dit uitheemsche geschenk der dwingelandij hetwelk wij voor eene inbreuk op onze vrije regterlijke instellingen aanzagen, met verachting naar den grond, van waar het oorspronkelijk was, werd terugverwezen. ${ }^{17}$

Echter bij gebrek aan eigen nationale bewijsregels ontstaat in Nederland vervolgens wel de situatie waarbij in strafzaken de rechters puur op hun eigen subjectieve gevoelens konden oordelen. Uit de vele ontwerpen ${ }^{18}$ die dan worden ingediend om tot een nationaal Wetboek van Strafvordering te komen, blijkt echter dat men wilde breken met het stelsel der conviction intime. De waarborg voor de zekerheid van het bewijs wordt in elk van deze ontwerpen niet gevonden in de blote innerlijke overtuiging van de rechter, maar in de gronden waarop de rechter die overtuiging heeft verkregen. Met betrekking tot de vraag of de wetgever regels moet stellen waaruit voorvloeit welke die gronden moesten zijn, wordt een middenweg bewandeld. In alle ontwerpen die aan het wetboek van 1838 vooraf gingen, wordt telkens weer aangehaakt bij het reeds in het Crimineel Wetboek van 1809 geformuleerde uitgangspunt:

15 Vertaling is overgenomen uit: Asser 1827, p.111-112.

16 Besluit van 11 december 1813 houdende bepalingen ten aanzien van de Lijfstraffelijke Regtsoefening in de Vereenigde Nederlanden, Stb. 1813, 10. Art. 16 luidt: 'De Hoven van Assisen zullen voortaan worden gehouden zonder Jury en de Regters in dezelve zullen, zoowel met opzigt tot de misdaad als tot de applicatie der wet, uitspraak doen.'

17 Noordziek 1887, p. 103 en meer uitgebreid Bossers 1987, p. 91 e.v.

18 Aan het Wetboek van Strafvordering van 1838 gaat een groot aantal ontwerpen vooraf. Het eerste ontwerp stamt uit 1815. Vervolgens zijn in 1819, 1828, 1829, 1830 en 1836 telkens nieuwe ontwerpen ingediend. Zie voor een uitgebreide bespreking en vindplaatsen van deze ontwerpen Voorduin 1839, deel I, p. I-XL. 
'dat de Wetgever voorts wel kon voorschrijven eenige algemeene regelen, die men moest in acht nemen bij het beoordeelen der bewijsmiddelen, even als een bepaald verbod, om eenige bewijsmiddelen, welker bedrieglijkheid de ondervinding had aangetoond, als wettig en voldoende aan te nemen; maar dat er geene mogelijkheid bestond, om, zonder dwaling te veroorzaken, de bewijskracht voor te schrijven, welke elk bewijsmiddel in elk bijzonder geval zoude moeten hebben. ${ }^{, 19}$

\subsubsection{Het Wetboek van Strafvordering van 1838}

In het uiteindelijk op 1 oktober 1838 in werking getreden Wetboek van Strafvordering wordt in titel 27 'Van het bewijs der misdrijven' een negatief-wettelijk bewijsstelsel opgenomen. ${ }^{20}$ Dit komt tot uitdrukking in artikel $427 \mathrm{~Sv}$ (1838):

'1. Niemand kan wegens misdrijf veroordeeld worden, ten zij de regter, door wettige bewijsmiddelen, de overtuiging hebbe bekomen, dat eene strafbare daad werkelijk heeft plaats gehad, en dat de beklaagde daaraan schuldig is.

2. Op bloote vermoedens of onvolkomen bewijs mag niemand veroordeeld worden.'

Voor een bewezenverklaring is vereist dat er sprake is van zogeheten 'volkomen bewijs.' Hieruit vloeit een tweetal eisen voort, te weten: het bewijs moet wettig zijn en de rechter moet persoonlijk overtuigd zijn van het feit dat de verdachte de hem verweten gedraging heeft begaan. De eis van wettigheid is tweeledig. Enerzijds mag de rechter de bewezenverklaring alleen doen steunen op wettige bewijsmiddelen. Anderzijds dient hij de in de wet genoemde bewijsminima in acht te nemen. De in het tweede lid genoemde voorwaarde dat een bewezenverklaring niet mag steunen op blote vermoedens bevat een duidelijke afwijzing van het stelsel van de conviction intime. In de praktijk betekent dat echter niet meer dan dat de bewezenverklaring op wettig bewijs moet steunen. Op deze verschillende aspecten van het bewijsstelsel zoals dat in het Wetboek van 1838 vorm kreeg, zal hieronder nader worden ingegaan.

\subsubsection{De wettige bewijsmiddelen}

Op grond van artikel $428 \mathrm{~Sv} 1838$ worden als wettige bewijsmiddelen toegelaten: het bewijs door getuigen, schriftelijke bescheiden, de bekentenis en de aanwijzingen. Ten aanzien van elk van deze bewijsmiddelen worden in afzonderlijke

19 De Bosch Kemper 1838-1840, Derde deel, p. 490.

20 Het is echter niet zo dat de vraag welk bewijsstelsel aan het Wetboek ten grondslag moest liggen geen punt van discussie was. Uit de totstandkoming van het Wetboek van Strafvordering van 1838 blijkt dat bij de behandeling van de diverse ontwerpen in de zogeheten Afdelingen, diverse leden de voorgestelde regeling van het bewijs veel te uitgebreid vonden. Voorduin 1840, deel II, p. 620. Ook buiten het parlement leefde de vraag op welke wijze het bewijsrecht moet worden vormgegeven. Een fervent voorstander van een wettelijke bewijstheorie is Weiland 1826, p. 28 e.v. 
bepalingen nadere regels geformuleerd. Met betrekking tot het getuigenbewijs wordt bijvoorbeeld bepaald wie tot het geven van een getuigenverklaring bevoegd is (art. $433 \mathrm{~Sv}$ 1838), waarover de getuigen kunnen verklaren (art. $434 \mathrm{~Sv} 1838$ ), ${ }^{21}$ en welke aspecten een rol spelen bij de beoordeling van de geloofwaardigheid van de verklaring. Ten aanzien van dit laatste bepaalt artikel 435 Sv 1838:

'In de beoordeling der waarde van de getuigenis, moet de regter bijzonder acht geven op de onderlinge overeenstemming der getuigen; op de overeenstemming der getuigenissen met hetgeen van elders aangaande de zaak en het geding bekend is; op de beweegredenen welke de getuigen kunnen hebben gehad om de zaak op deze of gene wijze voor de dragen; op de levenswijze, de zeden en den stand der getuigen; en, in het algemeen, op alles wat op derzelver meerdere of mindere geloofwaardigheid invloed zou kunnen hebben. ${ }^{22}$

Hoewel dat niet zo uitdrukkelijk in de wet wordt gesteld, blijkt uit de samenhang van de diverse bepalingen, dat een getuigenverklaring alleen als wettig bewijs kan dienen indien zij ter terechtzitting is afgelegd. Met betrekking tot de vorm wordt uitdrukkelijk bepaald dat een getuige alleen onder ede (art. 183 lid $2 \mathrm{~Sv}$ 1838) en mondeling (183 lid 4 Sv 1838) mag verklaren.

Opvallend in het lijstje van wettige bewijsmiddelen is het bewijsmiddel der aanwijzingen. In het huidige Wetboek van Strafvordering komt dit niet meer voor. Onder aanwijzingen in de zin van het Wetboek van Strafvordering 1838 worden verstaan:

'daadzaken, gebeurtenissen of omstandigheden, welker bestaan en overeenstemming, zoo onderling, als met het misdrijf zelf, klaarblijkelijk aantoonen dat er een misdrijf gepleegd is, en wie hetzelve bedreven heeft. ${ }^{23}$

Aanwijzingen zijn aldus feiten die weliswaar het tenlastegelegde feit niet direct bewijzen, maar die met dat tenlastegelegde feit in een zodanig verband staan dat het plaatsvinden van dit delict en de betrokkenheid van de verdachte daarbij daaruit met een bepaalde mate van waarschijnlijkheid kunnen worden afgeleid. ${ }^{24}$ Het gaat om bijkomende omstandigheden die door middel van redenering het tenlastegelegde feit en de betrokkenheid van de verdachte daarbij aantonen. Als voorbeeld van een aanwijzing noemt De Bosch Kemper het feit dat de verdachte na de moord is gevlucht. Het vluchten van de verdachte kort na het plegen van een misdrijf duidt op betrokkenheid bij het delict, indien die vlucht uit niets

21 De getuige mag enkel verklaren over feiten welke hij zelf gehoord, gezien of ondervonden heeft.

22 Simons 1899, p. 285 merkt met betrekking tot deze bepaling op: 'De breede bepaling, welke art. 399 (Sv 1886) geeft, is niet anders dan eene aanwijzing voor den rechter zonder eenige verbindende kracht.' 'Is dus dit artikel (...) zonder bezwaar, het is ook zonder eenig nut, en kan gerust uit onze wetgeving verdwijnen. De wetgever behoort te gebieden of te verbieden; het uitdeelen van goeden raad kan hij aan anderen overlaten.'

23 Art. $442 \mathrm{~Sv} 1838$

24 Uytwerf Sterling 1829, p. 423. 
anders dan uit het bewustzijn van het plegen van het misdrijf kan worden verklaard. ${ }^{25}$ Uitgaande van de juistheid van deze stelling en het feit dat uit andere bewijsmiddelen volgt dat de verdachte is gevlucht, ${ }^{26}$ mag de rechter concluderen dat de verdachte schuldig is aan het misdrijf.

De in artikel $428 \mathrm{~Sv} 1838$ opgenomen limitatieve opsomming van de bewijsmiddelen is door velen bekritiseerd. Deze kritiek wordt in de eerste plaats gevoed door een inconsequentie in de wet zelf. In artikel 445 Sv 1838 is namelijk bepaald dat ook verklaringen van onbevoegde getuigen voor het bewijs kunnen worden gebezigd, mits de inhoud van deze verklaringen door andere aan de rechter bekend geworden feiten en omstandigheden wordt bevestigd. ${ }^{27}$ Zo kan de verklaring van een niet-beëdigde 15-jarige (een niet wettig bewijsmiddel) in combinatie met de verklaring van een medeverdachte (eveneens een niet wettig bewijsmiddel) wel voor het bewijs gebezigd worden. ${ }^{28}$

Een tweede punt van kritiek op de in de wet opgenomen bewijsmiddelen betreft het bewijsmiddel der aanwijzingen. Een aanwijzing kan alleen voor het bewijs worden gebruikt indien het bestaan van deze aanwijzing werd bewezen door getuigen, schriftelijke bescheiden, de eigen waarneming van de rechter of de verklaring van de verdachte in of buiten rechte. Opvallend is dat aldus de eigen waarneming van de rechter ter zitting en de verklaring van een verdachte afgelegd in het vooronderzoek op zichzelf beschouwd geen wettige bewijsmiddelen zijn, maar enkel kunnen dienen om het bestaan van een aanwijzing te bewijzen. Ten aanzien van de overige bronnen waaruit het bestaan van de aanwijzing kan worden afgeleid, doet zich de vreemde situatie voor dat uit het ene bewijsmiddel (bijvoorbeeld een getuigenverklaring) een ander bewijsmiddel, de aanwijzing, voortvloeit. Eén verklaring kan op deze wijze verschillende bewijsmiddelen

25 De Bosch Kemper 1838-1840, Derde deel, p. 577.

26 Het bestaan der feiten die een aanwijzing voor de juistheid van het tenlastegelegde vormen moet volgens art. 443 Sv 1838 blijken uit de daar genoemde 'bewijsmiddelen'. Consequentie van deze regel is dat de rechter geen aanwijzingen uit aanwijzingen mag afleiden. Hierop wordt nader ingegaan in paragraaf 2.2.4.2.

27 Modderman 1867, p. 153 zegt hierover: 'het tevens een grote fout is niet wettelijke bewijsmiddelen toe te laten, want deze kunnen, eens toegelaten, evenzeer tot 's regters overtuiging meewerken'. Pols 1882, p. 384 spreekt in dit verband van 'eene ongerijmde bepaling'. In gelijke zin: Simons 1899, p. 266.

28 In gelijke zin: J. de Bosch Kemper 1840 II, p. 600, die eveneens van mening is dat in art. 445 een inbreuk wordt gemaakt op het uitgangspunt dat de rechter enkel op de in art. $428 \mathrm{~Sv} 1838$ genoemde wettige bewijsmiddelen een bewezenverklaring mag baseren. Hij meent echter dat de opsomming van de wettige bewijsmiddelen in $428 \mathrm{~Sv}$ (1838) niet volledig limitatief is. Zij is slechts limitatief voor zover de aldaar genoemde bewijsmiddelen ieder afzonderlijk voor het bewijs gebezigd worden. De niet in artikel $428 \mathrm{~Sv}$ (1838) genoemde bewijsmiddelen worden dus niet volledig uitgesloten. Zij mogen wel aan de bewezenverklaring ten grondslag worden gelegd, voor zover de inhoud daarvan wordt bevestigd door andere de rechter bekend geworden feiten en omstandigheden. 
omvatten. ${ }^{29}$ Pols wijt dit aan het dubbelzinnige gebruik van de term 'bewijsmiddel'. Enerzijds wordt deze term gebezigd om daarmee de bron te omschrijven waaruit het bewijs mag worden geput. Anderzijds wordt deze term gehanteerd om niet de bron, maar de feiten die daaruit blijken aan te duiden, zoals het geval is bij de aanwijzing. ${ }^{30}$ De aanwijzing is in zoverre dus een bijzonder vreemde eend in de bijt der bewijsmiddelen. De Pinto meent zelfs dat binnen een wettelijk bewijsstelsel het gebruik van aanwijzingen voor het bewijs onbestaanbaar is:

'dat het bewijs door aanwijzingen, hoe gevaarlijk en hoe onzeker het somtijds zijn moge, inderdaad niet kan gemist worden; maar ik houd het voor niet minder waar, dat hetzelve met een waarachtig stelsel van wettig bewijs inderdaad en niet in naam, volstrekt onbestaanbaar is, en dat het elk denkbeeld van wettig bewijs vernietigt, omdat het de beslissing over het bewezene of onbewezene der schuld van de wet overbrengt bij den regter, en dus ten slotte alles tot de zoo luide afgekeurde intime convictie der Franschen terug brengt.' 31

\subsubsection{De bewijsminima}

De eis van wettigheid van het bewijs zoals die in het Wetboek van Strafvordering van 1838 is opgenomen, ziet niet alleen op de limitatieve opsomming van de toegestane bewijsmiddelen, maar ook op de hoeveelheid bewijs die vereist is voor een bewezenverklaring. Behalve een omschrijving van de wettige bewijsmiddelen en het stellen van nadere voorwaarden aan deze bewijsmiddelen zijn in de titel over het bewijs van het Wetboek van Strafvordering van 1838 verschillende bewijsminima opgenomen. Zo geldt de afzonderlijke getuigenis van een enkele getuige niet als wettig bewijs (art. $433 \mathrm{~Sv} 1838$ ), en bepaalt artikel $439 \mathrm{~Sv} 1838$ dat de bekentenis van de verdachte die niet wordt bevestigd door andere omstandigheden evenmin wettig bewijs kan opleveren.

Ten aanzien van de toepassing van de unus testis regel zoals die in artikel $433 \mathrm{~Sv}$ 1838 is opgenomen, valt op dat deze niet zo strikt is als op het eerste gezicht lijkt. Er is slechts sprake van een afzonderlijke getuigenis, indien de juistheid - beter gezegd: de betrouwbaarheid - van die verklaring door geen enkele andere omstandigheid wordt bevestigd. Zo beschouwde de Hoge Raad de verklaring van het slachtoffer in een verkrachtingszaak niet als een afzonderlijke getuigenverklaring, nu deze verklaring werd bevestigd door de grote ontsteltenis van de getuige bij thuiskomst, het feit dat zij het gebeurde direct had kenbaar gemaakt

29 Zie onder andere Pols 1882, p. 375: 'En als wij art. 428 en 443 Sv [1838, WD] vergelijken, dan komen wij tot het bevreemdende resultaat, dat onze wetgever een bewijsmiddel noemt iets dat door bewijsmiddelen wordt bewezen.'

30 Pols 1882, p. 375

31 De Pinto 1843, p. 175. 
aan haar vader, haar zedelijkheid zoals ook bevestigd door derden, en de kras in het gezicht waaraan zij de dader had herkend. ${ }^{32}$

Hetzelfde geldt in principe ook ten aanzien van de bekentenis van de verdachte. Op de enkele bekentenis van de verdachte kan geen bewezenverklaring steunen, maar voldoende is indien er omstandigheden zijn gebleken waaruit de geloofwaardigheid van die bekentenis blijkt. Niet nodig is dat die omstandigheden blijken uit een wettig bewijsmiddel. Zo kan de bekentenis van een verdachte worden bevestigd door de verklaring van een onbevoegde getuige. ${ }^{33}$

\subsubsection{De overtuiging van de rechter}

Een wezenlijk onderdeel van het negatief-wettelijk bewijsstelsel, zoals dat in het Wetboek van Strafvordering van 1838 is gecodificeerd, vormt de overtuiging van de rechter. Slechts indien de rechter de persoonlijke overtuiging heeft dat de verdachte het hem tenlastegelegde feit heeft begaan, kan hij overgaan tot een bewezenverklaring. Dit uitgangspunt blijkt niet alleen uit artikel 427 Sv 1838, maar is tevens expliciet opgenomen in artikel $431 \mathrm{~Sv} 1838$ :

'Geenerlei bewijsmiddel zal ter veroordeeling van eenen beklaagde of beschuldigde verpligtend zijn, wanneer de regter niet volkomen overtuigd is dat deze het hem ten laste gelegde misdrijf waarlijk heeft begaan of daaraan medepligtig is.'

De tekst van de bepaling maakt duidelijk dat men zich afkeert van een stelsel waarin de rechter gedwongen wordt bij een bepaalde hoeveelheid bewijs een bewezenverklaring uit te spreken. Een dergelijk - positief wettelijk - stelsel gaat er van uit dat de objectieve waarheid kan worden gevonden door het bewijsoordeel aan algemeen geldende bewijsregels te binden. Uit deze regels volgt niet alleen welke bewijsmiddelen zijn toegelaten, maar bovendien wordt daarin van te voren de waarde van elk bewijsmiddel bepaald, zodat de rechter bij een bepaald kwantum aan bewijs de bewezenverklaring moet uitspreken. ${ }^{34}$ Toepassing van die regels leidt in alle gevallen tot een juridisch juist oordeel met betrekking tot het tenlastegelegde feit. In het Wetboek van 1838 wordt echter nadrukkelijk afstand genomen van dit uitgangspunt. Niet alleen ziet men in dat het onmogelijk is om een volledig stelsel van regels in de wet op te nemen dat naar het waarheidsoordeel in elke concrete zaak zou kunnen leiden, maar bovendien is men inmiddels ook doordrongen van het feit dat een volstrekt objectieve waarheidsvinding onmogelijk is. De rechter zal immers niet in staat zijn om geheel buiten zichzelf om het hem gepresenteerde bewijsmateriaal te waarderen. Dit is treffend verwoord door De Bosch Kemper:

\footnotetext{
J. de Bosch Kemper, 1840 II, p. 534-535.

J. de Bosch Kemper, 1840 II, p. 569.

Feith 1910, p. 3.
} 
'Er is geene theorie van bewijs denkbaar, zonder dat de slotsom der bewijsgronden aan het subjectief gevoel van de regter worde overgelaten; overal waar iemand oordeelen moet, is het een mensch die het oordeel velt, en moge de bepalingen omtrent de bewijskracht der afzonderlijke middelen eng of naauw beperken, het is altijd een subjectief gevoel, hetgene over het al of niet bestaan dier beperkingen moet uitspraak doen. ${ }^{35}$

\subsubsection{Blote vermoedens}

De reikwijdte van de in het tweede lid van artikel 427 Sv 1838 opgenomen regel - de bewezenverklaring mag niet steunen op blote vermoedens - is niet altijd duidelijk geweest. De Bosch Kemper ziet hierin een bevestiging van zijn idee dat voor een veroordeling niet alleen de gemoedelijke overtuiging van de rechter vereist is, maar dat bovendien die subjectieve overtuiging moet voortvloeien uit een rationele afweging van de bewijsgronden die uit de bewijsmiddelen blijken. In die zin wijkt zijns inziens de in het Wetboek van Strafvordering van 1838 vereiste overtuiging af van het overtuigingsbegrip zoals dat ten tijde van de Franse overheersing werd gehanteerd. ${ }^{36}$ Enerzijds wordt van de rechter verlangd dat hij zijn overtuiging baseert op wettige bewijsmiddelen; een beperking die aan de juryleden niet werd opgelegd. Anderzijds dient het bewijsoordeel in strafzaken in tegenstelling tot dat oordeel in het stelsel van de conviction intime een rationele grondslag te krijgen. Uit het gebruik van de term 'blote vermoedens' leidt De Bosch Kemper af dat de rechter in zijn oordeel tot uitdrukking moet brengen op welke gronden hij het bewijs van het tenlastegelegde feit aanneemt. De rechter is daarbij volgens hem gebonden aan de algemene ervaringsregels, die - indien juist toegepast - ertoe leiden dat zij de schuld van de verdachte zodanig aanwijzen, dat de onschuld onaannemelijk wordt. ${ }^{37}$ Het criterium 'blote vermoedens' biedt volgens De Bosch Kemper een maatstaf voor de beoordeling van de mate van waarschijnlijkheid waarin de door de rechter bewezen feiten moeten komen vast te staan. Dit kan vervolgens in cassatie worden getoetst:

'Dat de vraag: Wat regterlijke zekerheid of volkomen bewijs is? eene rechtsvraag daarstelt, schijnt mij het noodzakelijke gevolg van het opnemen van regelen omtrent het bewijs in de Wetgeving. Indien toch aan den regter geheel wordt overgelaten,

35 J. de Bosch Kemper 1840 II, p. 523. In gelijke zin: Uytwerf Sterling e.a.1829, p. 417: 'Men is het er algemeen over eens, dat het niet doenlijk is, om de regelen omtrent het bewijs zoodanig zamen te stellen, dat niet eindelijk de subjective overtuiging des Regters den eigenlijken grond tot veroordeeling oplevere.' Ook Modderman 1867, p. 51 erkent dat met betrekking tot het bewijsoordeel 'oneindig veel moet worden overgelaten aan het gezonde oordeel, onpartijdigheid, menschenkennis, nauwgezette overweging en rijke ervaring van het oordeelend subject'.

36 J. de Bosch Kemper 1840 II, p. 524

37 J. de Bosch Kemper 1840 II, p. 511. 
welke trap van waarschijnlijkheid een volkomen bewijs vormt, belet niets, dat op bloote vermoedens iemand veroordeeld worde. ${ }^{38}$

De door De Bosch Kemper gewenste uitleg van de tweede volzin van artikel 427 Sv 1838 is echter nooit door de Hoge Raad gevolgd. In tal van uitspraken geeft hij te kennen dat in cassatie niet over de bewijswaarde van het door de feitenrechter gebezigde bewijs kan worden geklaagd. De jurisprudentie ziet vooral op gevallen waarin van de zijde van de verdediging de door feitenrechter getrokken gevolgtrekking uit bepaalde feiten (aanwijzingen) ter discussie wordt gesteld, omdat deze conclusie slechts een bloot vermoeden zou zijn. De Hoge Raad wijst dergelijke klachten echter stelselmatig af:

'dat (...) volgens art. $442 \mathrm{~W}$. v Strafv., alle met inachtneming van art. 443 W.v.Sv. bewezene daadzaken, gebeurtenissen of omstandigheden zonder eenige wettelijke beperking als aanwijzing kunnen in aanmerking komen; terwijl de beantwoording der vraag, of zij in onderling verband het bewijs van misdrijf en schuld opleveren, of m.a.w. de kracht der aanwijzingen in elke zaak aan des rechters oordeel blijft overgelaten; dat dus de gevolgtrekking uit een wettig bewezen feit nimmer is een bloot vermoeden of gissing, door art. $427 \mathrm{~b}$ als bewijsmiddel gewraakt, en dat de meerdere of mindere juistheid, het min of meer afdoende van zoodanige gevolgtrekking, geen onderwerp van onderzoek in cassatie kan uitmaken. ${ }^{39}$

De waarde van de bepaling dat de rechter zijn oordeel niet op blote vermoedens mag baseren is in de praktijk beperkt. Van schending is slechts sprake indien de rechter zijn oordeel baseert op feiten die niet uit wettige bewijsmiddelen blijken.

\subsubsection{Tussenconclusie}

Het bewijsstelsel zoals dat in 1838 in het Wetboek van Strafvordering tot uitdrukking kwam kan worden gekwalificeerd als negatief-wettelijk. Daarbij moet echter voor ogen worden gehouden dat de in het Wetboek opgenomen regeling vooral tot doel heeft te voorkomen dat de rechter alleen op basis van zijn subjectieve overtuiging oordeelt. De afkeer van het Franse stelsel - de conviction intime - is zodanig dat de wetgever het noodzakelijk acht de rechter te binden aan enkele in de praktijk heersende en in de wetenschap erkende regels. De wetgever heeft daarbij gekozen voor een stelsel waarin de rechter in principe is gebonden aan wettige bewijsmiddelen en aan bepaalde bewijsminima. De concrete vormgeving van het stelsel in het Wetboek is echter alles behalve doorzichtig. Enerzijds wordt de aanwijzing als bewijsmiddel genoemd, terwijl dit in het stelsel van de wet eigenlijk geen bewijsmiddel is. Anderzijds is de opsomming niet limitatief. Uit het stelsel blijkt dat in principe de eigen waarneming van de rechter,

38 J. de Bosch Kemper 1840 II, p. 505.

39 HR 16 februari 1885, Weekblad van het Regt, nr. 5142. Zie voor een uitgebreid overzicht van de jurisprudentie op dit punt Prins 1892, p. 21 e.v. 
de verklaring van de verdachte uit het vooronderzoek en de verklaring van de onbevoegde getuige niet als wettig bewijsmiddel worden erkend, terwijl deze toch aan de bewezenverklaring ten grondslag mogen worden gelegd. ${ }^{40}$ Aan de in het Wetboek opgenomen bewijsminima worden bovendien niet al te hoge eisen gesteld.

Ten aanzien van de voor een bewezenverklaring vereiste 'overtuiging' geldt dat deze haar grondslag moet vinden in de wettige bewijsmiddelen. Bovendien moet de overtuiging meer zijn dan een bloot vermoeden. Maar deze eis wordt door de Hoge Raad alleen in verband gebracht met de eis dat het bewijs van het tenlastegelegde feit uit wettige bewijsmiddelen moet blijken. In die zin biedt het tweede lid van artikel $427 \mathrm{~Sv}$ geen verdergaande garantie dan hetgeen reeds in het eerste lid is bepaald. Voor zover daaruit al de door De Bosch Kemper voorgestane opvatting volgt dat uit het vonnis moet blijken dat de onschuld van de verdachte onaannemelijk is, kan dit in cassatie niet worden getoetst.

\subsubsection{De periode tussen 1838 en 1910}

Met de vaststelling van het Wetboek van Strafvordering 1838 is de discussie over de inhoud van het Nederlandse bewijsrecht nog lang niet afgesloten. Voor een deel wordt deze discussie gevoed door het niet consistente stelsel van bewijsregels zoals opgenomen in het Wetboek van Strafvordering 1838. Maar behalve commentaar op specifieke onderdelen van de bewijsregeling, is er ook meer fundamentele kritiek. Zo wordt in twijfel getrokken of in de wet wel regels met betrekking tot het bewijs in strafzaken moeten worden opgenomen. ${ }^{41}$

De strijd gaat dan vooral tussen de voorstanders van een wettige bewijstheorie en zij die weliswaar een bewijstheorie erkennen, maar deze niet in de wet opgenomen willen zien. Slechts enkelen, meestal ook voorstander van juryrechtspraak, zijn van mening dat het oordeel in strafzaken in zijn geheel niet aan regels gebonden moet worden, dus noch aan wettige noch aan wetenschappelijke regels. Zij menen dat het bewijsoordeel in strafzaken altijd neerkomt op de subjectieve overtuiging van de rechter dan wel de juryleden:

'regelen voorschrijven, waarnaar die overtuiging zich zal moeten gedragen, is eene onmogelijkheid. Zij [de rechters, WD] vinden in hun geweten den toetssteen waaraan zij de feiten beoordeelen zullen: daar óók alleen vindt de beschuldigde den waarborg voor een eerlijke beoordeeling der geïncrimineerde feiten, ${ }^{42}$

40 Pols 1882, p. 336-337.

41 Pols 1882, p. 368 merkt dienaangaande op: 'De tegenstanders van wettelijke bewijsvoorschriften vinden echter in de wijze waarop de bewijsleer in ons recht geregeld is, rijke stof bij hunne bestrijding.'

42 Tripels 1882 , p. 151 en p. 150. 
Met name Modderman heeft zich krachtig verzet tegen het stelsel van de conviction intime:

'Zegt iemand, ik ben overtuigd, dan geeft mij dat geen den minsten waarborg voor de juistheid dier overtuiging; dien waarborg krijg ik eerst dan, wanneer hij mij den weg aanwijst, langs welken hij zijn doel bereikt heeft. ${ }^{43}$

Hoewel de voorstanders van de conviction intime tijdens de Nederlandse Juristenvergadering in 1886 nog een meerderheid vormden, is hun standpunt nooit overgenomen in een van de voorgestelde wijzigingen van het Wetboek van Strafvordering. In hetgeen hierna wordt beschreven zal daarom slechts zijdelings op dit standpunt worden ingegaan. De aandacht richt zich met name op het debat tussen de voorstanders van een wettelijk bewijsstelsel en degenen die een vrij bewijsstelsel in de zin van conviction raisonnée voorstaan. Het verschil tussen beide opvattingen betreft niet zozeer de vraag of er regels zijn die van belang zijn voor het bewijsoordeel in strafzaken, maar vooral de vraag of die regels in de wet moeten worden opgenomen. Deze strijd laait telkens op als een wijziging van het Wetboek van Strafvordering wordt voorgesteld.

\subsubsection{Het ontwerp Godefroi}

Het eerste voorstel tot wijziging van het Wetboek van Strafvordering komt van de hand van minister Godefroi. ${ }^{44}$ Dit voorstel breekt volledig met het negatiefwettelijk bewijsstelsel zoals opgenomen in het Wetboek van 1838. Artikel 75 van titel VII 'Van het rechtsgeding in eersten aanleg' van het Ontwerp luidde:

'De regtbank beraadslaagt naar aanleiding van de dagvaarding en van het onderzoek op de teregtzitting over de navolgende punten:

$1^{\mathrm{e}}$. of overtuigend is gebleken dat het ten laste gelegde feit is gepleegd en dat het is gepleegd door den beklaagde; (...).'

In artikel 90 van diezelfde titel wordt vervolgens de rechter opgedragen om in het vonnis de middelen aan te wijzen waardoor de rechter tot de overtuiging is gekomen. In het ontwerp ontbreekt een opsomming van bewijsmiddelen en evenmin zijn bewijsminima opgenomen. In de memorie van toelichting bij dit ontwerp wordt overwogen dat de vrees voor lichtvaardige veroordelingen, die bij de voorstanders van een negatief-wettelijk bewijsstelsel bestaat, niet terecht is. Immers, de rechter mag de bewezenverklaring alleen doen steunen op feiten en omstandigheden die hem tijdens het onderzoek ter terechtzitting ter kennis zijn gekomen en bovendien moet hij in het vonnis verantwoording afleggen over de

43 Modderman 1867, p. 45, 160 en 166.

44 Het ontwerp was tot stand gekomen onder de Minister van Jusitite Godefroi. Het werd echter voor de eerste keer bij de Tweede Kamer ingediend door zijn opvolger, Olivier, op 10 november 1863, Kamerstukken II 1863-1864, B. 665. 
wijze waarop hij tot zijn overtuiging is gekomen. Tot slot biedt de mogelijkheid van hoger beroep een belangrijke waarborg tegen lichtvaardige veroordelingen.

Het voorstel tot afschaffing van het negatief-wettelijk bewijsstelsel is aanleiding voor het provinciaal Utrechtsche genootschap van Kunsten en Wetenschappen om een prijsvraag uit te schrijven met de titel 'Zijn er gegronde bezwaren tegen eene wettelijke bewijsleer in strafzaken'. De inzendingen van Jongstra ${ }^{45}$ voorstander van de wettelijke bewijsleer, en Modderman, ${ }^{46}$ voorvechter van de vrije bewijsleer, en ook hun later gepubliceerde reacties op elkaar ${ }^{47}$ zijn illustratief voor de opvattingen over het bewijsrecht die op dat moment binnen Nederland leven. Jongstra beschouwt in het bijzonder de eis dat de rechter is gebonden aan een bepaald minimum aan bewijs als een waarborg tegen menselijke dwaling en willekeur. Het schrappen van dergelijke bewijsregels uit de wet zoals voorgesteld in het Ontwerp-Godefroi betreurt hij zeer, te meer daar het Wetboek van Strafvordering van 1838 geen verdere garanties biedt voor een onpartijdige rechtspraak. Hij wijst in dat verband onder andere op de benoeming van rechters voor onbepaalde tijd en zonder invloed van het volk, op het ontbreken van het vereiste van eenstemmigheid voor een veroordeling, op het feit dat wraking van rechters alleen mogelijk is op zeer beperkte gronden, alsmede op het geheim der raadkamer. ${ }^{48}$ De wettelijke bewijstheorie is zijn inziens het product van eeuwenlange ervaring en de rede waaruit voor de rechter regels voorvloeien die hem beperken in de vrije waardering van het bewijs. In vergelijking daarmee valt de ervaring en het verstand van één mens, van de rechter alleen, in het niet. Zijns inziens moeten deze regels in de wet worden vastgelegd, omdat de wetgever over meer mogelijkheden en tijd beschikt om een deugdelijk systeem van bewijsregels te construeren. ${ }^{49}$ Indien men het overlaat aan de rechter in de concrete zaak om te beoordelen welke de toepasselijke regels zijn met betrekking tot het bewijs, bestaat immers het gevaar dat hij zich laat leiden door andere zaken, die niet relevant zijn voor de waarheidsvinding:

'bijgeloof, kerkgenootschappelijke onverdraagzaamheid en haat, staatkundige drijverij en vele andere hartstochten en vooroordeelen, de zucht om te straffen, de vooral bij vaste regters heerschende weerzin tegen vrijspraak en hunne neiging, om in elken beschuldigde eenen schuldige te zien; voorts eigenbelang, familiebelang en coteriebelang, om niet te spreken van persoonlijke vijandschap, die daar, waar geen regt van

45 Jongstra 1868a. Eerder had Jongstra zich al kritisch uitgelaten over het Ontwerp Godefroi. Zie Jongstra 1863.

46 Modderman 1867.

47 Jongstra 1868 b en Modderman 1868.

48 Jongstra 1863 , p. 579-580.

49 Jongstra 1868a, p. 202: 'Vooreerst is het wel niet te betwisten, dat de som der kennis van al degenen, die medewerken tot het maken een wet, grooter is dan die van hen, welke een regterlijke uitspraak tot stand brengen.' 
wraking zonder opgave van bepaalde redenen bestaat, niet zelden de gelegenheid vindt, om zich, onder begunstiging van den nacht der raadkamer, te doen gelden. ${ }^{, 50}$

Modderman keert zich in zijn beantwoording van de prijsvraag tegen het door Jongstra ingenomen standpunt. Zijn voornaamste bezwaar is dat in de wettige bewijstheorie noodzakelijkerwijs algemene regels worden geformuleerd die bij toepassing op de concrete gevallen tot onware uitkomsten kunnen leiden. Waar bijvoorbeeld de verklaring van een onbeëdigde getuige volledig wordt uitgesloten van het bewijs, wordt in principe door de wetgever een algemene uitspraak gedaan over het waarheidsgehalte van die verklaring. In het concrete geval dat ter berechting aan de rechter wordt voorgelegd, kan echter uit overige omstandigheden blijken dat deze verklaring wél op waarheid berust. De wettelijke bewijstheorie doet aldus Modderman geweld aan het beginsel van materiële waarheidsvinding, omdat de rechter wordt gedwongen om bepaald bewijsmateriaal, dat mogelijk wel juiste feiten en omstandigheden bevat, buiten beschouwing te laten. In de woorden van Modderman:

'De theorie [de wettelijke, WD] doet meer dan luim en willekeur uitsluiten, zij dwingt tevens 's regters overtuiging. ${ }^{, 51}$

Zo brengt de wettelijke bewijstheorie met zich dat ten onrechte schuldigen worden vrijgesproken. Omgekeerd kan zij er ook toe leiden dat onschuldigen te snel worden veroordeeld. Immers, in hoeverre kan de wet voorkomen dat de rechter genoegen neemt met het in de wet voorgeschreven bewijsminimum? Is hier eenmaal aan voldaan, dan is immers het oordeel van de rechter op dit punt onaantastbaar.

In de optiek van Modderman mag de wet wel regels stellen met betrekking tot de vorm waarin het bewijsmateriaal aan de rechter wordt gepresenteerd voor zover die de echtheid van het bewijsmiddel garandeert, ${ }^{52}$ maar deze regels mogen er nooit toe leiden dat bij voorbaat bepaald materiaal wordt uitgesloten. Evenmin mogen voorschriften in de wet worden opgenomen die bepaald bewijsmateriaal uitsluiten op grond van het vermoeden van ongeloofwaardigheid, bijvoorbeeld verklaringen van medeverdachten of verklaringen van verwanten. ${ }^{53}$ Tot slot moeten volgens Modderman bepalingen over de kracht van het bewijs uit het Wetboek van Strafvordering verbannen worden. Dit laatste geldt zowel ten aanzien van positieve bepalingen waaruit volgt dat de rechter wordt gedwongen om tot een bewezenverklaring te komen, als ten aanzien van negatieve bepalingen die

50 Jongstra 1863, p. 613-614 en Jongstra 1868a, p. 200.

51 Modderman 1867, p. 180.

52 Modderman 1867, p. 172 denkt in dit verband aan ondertekening van schriftelijke stukken, beëdiging van getuigen en verzegeling van stukken van overtuiging.

53 Modderman 1867, p. 173. 
hem dwingen de verdachte vrij te spreken indien niet is voldaan aan een bepaald minimum aan bewijsmateriaal. ${ }^{54}$

Waarborgen voor een juiste oordeelsvelling ziet Modderman in eerste instantie in het verbeteren van de kwaliteit van de rechterlijke macht en het garanderen van de onpartijdigheid van de rechter. Met betrekking tot dit laatste merkt hij op dat rechters geen bemoeienis mogen hebben met de beslissing om al dan niet te vervolgen, en op geen enkele wijze betrokken moeten zijn bij de bewijsverkrijging in het vooronderzoek, noch bij de bewijsvoering tijdens het onderzoek ter terechtzitting. ${ }^{55}$ Bovendien hecht hij veel belang aan de openbaarheid van het onderzoek ter terechtzitting, het beginsel van mondelinge procesvoering en onmiddellijkheid, en de mogelijkheden van de verdediging om het bewijs ter zitting te toetsen. ${ }^{56}$ Tot slot wijst Modderman op het belang van de motivering van het vonnis. In een wettelijke bewijstheorie omvat de motivering niet meer dan een aanwijzing dat het door de wet gevorderde bewijs aanwezig is. Zijn de bewijsregels eenmaal afgeschaft, dan is de motivering een feitelijke toelichting der schuldigverklaring waarin valt te lezen op welke feiten die conclusie is gebaseerd en waarom aan die feiten bewijskracht toekomt. ${ }^{57}$ In hoger beroep kan de volledigheid van de motivering worden getoetst. ${ }^{58}$

Modderman's betoog voor afschaffing van het negatief-wettelijk bewijsstelsel had tot doel het ontwerp voor een Wetboek van Strafvordering te ondersteunen zoals dat door Godefroi was opgesteld. Het ontwerp heeft echter nooit een wettelijke status gekregen. Ondanks het feit dat het tot zes keer toe is ingediend, is het uiteindelijk in 1870 definitief ingetrokken.

\subsubsection{De Nederlandse Juristenvergadering 1882}

In 1875 wordt wederom een herziening van het Wetboek van Strafvordering overwogen. Deze herziening heeft in principe enkel tot doel het Wetboek van Strafvordering in overeenstemming te brengen met het te wijzigen Wetboek van Strafrecht. Velen zien in de aangekondigde herziening echter een kans om het bewijsstelsel zoals het in het Wetboek van 1838 was neergelegd wederom ter discussie te stellen.

In 1882 staat het thema onder andere op de agenda van de vergadering van de Nederlandse Juristenvergadering. De beide pre-adviseurs Willeumier en Tripels keren zich tegen de negatief-wettelijke bewijsleer ten faveure van een vrij bewijs-

54 Modderman 1867, p. 175-176.

55 Modderman 1867, p. 280-281.

56 Modderman 1867, p. 281. In gelijke zin: De Jong van Beek en Donk 1866, p. 356.

57 Modderman 1867, p. 286.

58 Modderman 1867, p. 286. Voor toetsing van de motivering in cassatie ziet hij geen mogelijkheid. 
stelsel. Deze eenzijdige benadering is voor Pols aanleiding om in een zeer uitgebreid artikel in Themis het belang van een wettelijke bewijsleer aan te tonen.

Het preadvies van Tripels is alleen al opvallend omdat de schrijver zich als een van de weinigen nog voorstander toont van jury-rechtspraak. Hij baseert zich daarbij op ervaringen die hij als Maastrichtse advocaat regelmatig opdoet in België. Hij meent dat het oordeel in strafzaken kan worden overgelaten aan het gezond verstand van de juryleden, die op grond van het onderzoek ter terechtzitting een volledige indruk krijgen van alle voor hun oordeel relevante feiten en omstandigheden. In principe wenst hij dus een terugkeer naar het stelsel van de conviction intime waarbij enkel de subjectieve overtuiging van de juryleden doorslaggevend is voor het feitelijke oordeel in strafzaken. Een eerste aanzet in de richting van de juryrechtspraak ziet hij in het afschaffen van alle bewijsregels. ${ }^{59}$ In die zin kiest hij evenals Willeumier voor een vrij bewijsstelsel. Tripels wijst echter het door Willeumier voorgestane stelsel van de conviction raisonnée af en ontkent dat in de in dat stelsel verankerde plicht tot motivering een waarborg tegen rechterlijke willekeur is gelegen. Deze plicht leidt zijns inziens alleen tot het veelvuldig gebruik van vaststaande modellen voor die motivering ${ }^{60}$ en bovendien heeft die motivering geen toegevoegde waarde aangezien die niet door een hogere rechter kan worden gecontroleerd. ${ }^{61}$

Willeumier is in tegenstelling tot Tripels bepaald geen voorstander van juryrechtspraak. Bovendien merkt hij op dat in geval van rechtspraak door een jury de behoefte aan wettelijke bewijsregels groter zal zijn dan in een stelsel van vaste rechters. Bij deze laatsten gaat het immers om

'juridisch gevormde mannen, tot hun ambt opgeleid in de school van het recht, waar zij ook de leer omtrent het bewijs hebben hooren ontvouwen. ${ }^{62}$

Willeumier bouwt in zijn betoog voor een vrije bewijsleer in principe voort op de argumenten die Modderman vijftien jaar daarvoor reeds had beschreven. Hij wijst - evenals Modderman in 1867 - op het risico dat de wettelijke bewijstheorie in zich draagt, namelijk het gevaar van formalisme: daar waar de vorm goed is,

59 Tripels 1886, p. 147-148: 'Is het mogelijk dat de wetgever in een zij het nog zoo omslagtige wet alle omstandigheden en gebeurtenissen tot opheldering van de aanklagt kan definieren, de duizend gevallen die zich kunnen voordoen zal voorzien? Is het denkbaar dat aan de overtuiging (...) de weg wordt aangewezen langs welken zij zich mag bewegen? Zoolang de gedachte niet aan kluister kan gelegd worden, behoort de wetgever deze niet te vervaardigen'.

60 Tijdens de vergadering van de NJV in 1882 sprak Tripels in dit verband de volgende veelzeggende woorden: 'Weet gij, Mijne Heeren, wie in de meeste gevallen de belangrijkste rol vervult bij de motiveering van een vonnis? Ik zal het u zeggen: de drukker. Tot bewijs hiervan toon $\mathrm{ik} u$ hier verscheidene modellen van gemotiveerde vonnissen wegens bedelarij, mishandeling, belastingzaken enz. enz., men heeft die slechts met de namen van de veroordeelden in te vullen!' Handelingen NJV II 1882, p. 197.

61 Handelingen NJV II 1882, p. 198.

62 Willeumier 1882, p. 103. 
wordt ook de inhoud verondersteld juist te zijn. ${ }^{63}$ Als belangrijkste waarborg tegen rechterlijke willekeur wijst Willeumier op de plicht van de rechter om zijn oordeel te motiveren. De strafrechter moet de bewijsmiddelen opgeven waaruit hij de gronden van zijn overtuiging heeft geput, maar de bewijsmiddelen die hem die gronden kunnen bijbrengen, moeten niet beperkt zijn. ${ }^{64}$

Het is vervolgens Pols die zich genoodzaakt ziet om enig tegenwicht te bieden tegen de beide pre-adviseurs. Hij schrijft naar aanleiding van de beide preadviezen een uitgebreid artikel waarin hij zich keert tegen het vrije bewijsstelsel, en wijst op de waarborgen die verbonden zijn aan een negatief-wettelijk bewijsstelsel. De door Tripels voorgestelde terugkeer naar het stelsel der conviction intime - met of zonder jury-rechtspraak - acht hij een gepasseerd station. Een dergelijk stelsel veronderstelt volgens Pols dat de waarheidsvinding in strafzaken kan worden overgelaten aan de 'werking van het quasi-natuurlijke waarheidsinstinct ${ }^{65}$ van mensen. Pols meent daarentegen dat het oordeel in strafzaken een grotere mate van zekerheid dient te bevatten dan enkel een overtuiging gebaseerd op geloof of routine. Weliswaar kan deze subjectieve overtuiging volledig waar zijn, maar zij is veel te feilbaar en veel te gevaarlijk om er een veroordeling tot straf op te bouwen. ${ }^{66}$ In strafzaken is volgens Pols een 'juridieke' of 'rechterlijke' zekerheid vereist. ${ }^{67}$ Die zekerheid kan worden verkregen door de wijze van onderzoek in strafzaken te reguleren en het oordeel zelf te binden aan bewijsregels die door de wetenschap en ervaring als juist zijn erkend. Daarmee is weliswaar geen absolute zekerheid gegarandeerd, maar deze 'rechterlijke overtuiging' biedt in ieder geval meer houvast dan de enkele subjectieve overtuiging waarmee Tripels genoegen lijkt te nemen.

De vraag of de regels die uit de wetenschap en ervaring volgen ook in de wet moeten worden vastgelegd, beantwoordt Pols in tegenstelling tot Willeumier bevestigend. Immers, wat heeft het voor zin om - zoals de voorstanders van een vrije bewijstheorie doen - enerzijds te veronderstellen dat er bewijsregels zijn, en anderzijds die regels niet algemeen verbindend te achten. Door de rechter niet aan die regels te binden, verwordt de vrije bewijsleer immers vanzelf tot een stelsel waarin niet voorkomen kan worden dat de rechter zijn oordeel baseert op

63 In gelijke zin: Stuffken 1866, p. 82: 'dat de rechter, in plaats van alleen dan het bestaan der schuld voor zeker te houden, wanneer zijne overtuiging het hem zegt, licht tot veroordeeling overgaat, zoo spoedig hij gelooft, het minimum der bij de wet gevorderde bewijzen gevonden te hebben, - ohne der gesetzlichen Vorschrift entsprechend die Zweifel an der Schuld genügend zu würdigen.'

64 Willeumier 1882 , p. 108

65 Pols 1882, p. 344.

66 Pols 1882, p. 371

67 Pols 1882, p. 339-340. 
enkel zijn subjectieve overtuiging. ${ }^{68}$ Bovendien loert in een dergelijk stelsel het gevaar van rechtsongelijkheid:

'niet belet kan worden dat de eene rechter, naar rechterlijke zekerheid zoekende, die bewijsmiddelen wraakt, de ander, zich met de gemoedelijke of moreele zekerheid vergenoegend ze toelaat. ${ }^{69}$

Binnen de vrije bewijsleer is - aldus Pols - geen taak voor de cassatierechter weggelegd. Toetsing van de juistheid van het bewijsoordeel in cassatie is immers bij gebrek aan regels waaraan getoetst kan worden niet mogelijk. ${ }^{70}$ Overigens erkent Pols dat het negatief-wettelijk bewijsstelsel zoals dat in het Wetboek van 1838 is neergelegd verre van ideaal is. Hij geeft dan ook toe dat de gebrekkige regeling de voorstanders van een vrije bewijsleer argumenten biedt om het negatief-wettelijk bewijsstelsel te bestrijden. ${ }^{71} \mathrm{Zijns}$ inziens zou echter een vervolmaking van die wettelijke regels meer voor de hand liggen dan een volledige afschaffing van de bestaande regels.

Bij de behandeling van de preadviezen van Tripels en Willeumier in de vergadering van de Nederlandse Juristenvereniging wordt ook expliciet op het standpunt van Pols ingegaan. Desondanks wijst de vergadering bij de stemming het negatief-wettelijk bewijsstelsel af. ${ }^{72}$ Dit had echter geen enkele consequentie voor de wetgeving. Bij de uiteindelijke herziening van het Wetboek van Strafvordering in 1886 wordt het bewijsrecht slechts op een beperkt aantal - ondergeschikte - punten gewijzigd. Het uitgangspunt dat de rechter gebonden is aan de in de wet neergelegde bewijsregels blijft gehandhaafd.

\subsubsection{De aanloop naar het Wetboek van 1926}

Als aan het begin van de $20^{\mathrm{e}}$ eeuw een algemene herziening van het Wetboek van Strafvordering wordt aangekondigd, komt noodzakelijkerwijs ook de vraag 'welke bewijstheorie aan het Wetboek van Strafvordering ten grondslag moet liggen' weer aan de orde. Wederom staat het onderwerp op de agenda van de Juristen-Vereniging. Feith, die ditmaal optreedt als preadviseur, is voorstander van een negatief-wettelijk bewijsstelsel, maar meent wel dat de regels met betrekking tot het bewijs zoals zij in het Wetboek van 1838 zijn opgenomen op tal van punten moeten worden gewijzigd. ${ }^{73}$

\footnotetext{
Pols 1882, p. 367. In gelijke zin: De Ridder 1900, p. 286.

Pols 1882, p. 353.

Pols 1882, p. 355.

Pols 1882, p. 368

72 De vraag 'Moeten bij eene herbezinning van het Wetboek van Strafvordering de beginselen, nedergelegd in de artikelen 427 en 431, worden behouden?' wordt met 36 tegen 24 stemmen ontkennend beantwoord.

73 Feith 1910, p. 92-95.
} 
Opvallend is dat tijdens de vergadering van de Nederlandse Juristenvereniging de vraag of het negatief-wettelijk bewijsstelsel moet worden gehandhaafd nadrukkelijk in verband wordt gebracht met de motivering van de bewijsbeslissing. Feith meent dat handhaving van de wettelijke bewijsregels in ieder geval de rechter dwingt om de inhoud van de bewijsmiddelen in het vonnis op te nemen, zodat daaruit blijkt dat op wettig bewijs recht is gedaan. Bij het vervallen van de wettelijke bewijsregels zal zijns inziens ook de noodzaak om de inhoud van de bewijsmiddelen in het vonnis op te nemen verdwijnen.

'De verleiding wordt dan wel heel sterk voor den rechter om zich maar met een paar algemeene phrasen van de zaak af te maken. ${ }^{, 74}$

Voorstanders van het vrije bewijsstelsel menen daarentegen dat, indien de rechter is gebonden aan wettelijke bewijsregels, de motivering beperkt zal blijven tot 'iets stijfs, iets hoekigs, iets schablonenmässigs' ${ }^{75} \mathrm{Zij}$ wijzen daarbij op de bestaande praktijk waarin rechters een zogeheten 'proces-verbaal-vonnis' wijzen. In een dergelijk vonnis wordt alleen de inhoud van de relevante verklaringen opgenomen, afgesloten met de standaardzin dat uit deze verklaringen en de daaruit voortvloeiende aanwijzingen in onderling verband is gebleken, dat verdachte het feit heeft begaan. De werkelijke redenering, hoe de rechter tot zijn oordeel is gekomen, blijkt uit deze vonnissen niet. Vooral die tekstuele constructie van het bewijs in het vonnis beschouwen zij als een van de belangrijkste waarborgen voor een behoorlijke rechtspraak. ${ }^{76}$

Ook Simons heeft moeite met de wijze waarop vonnissen worden geredigeerd. ${ }^{77}$ Hij meent dat dit vooral te wijten is aan het standpunt van de Hoge Raad in deze. Ten onrechte koppelt de Hoge Raad de eisen van de motivering aan het negatiefwettelijk bewijsstelsel. Zijns inziens moet de motivering worden beschouwd als een zelfstandige grondwettelijke eis waaraan elk vonnis dient te voldoen. In tegenstelling tot vele andere sprekers koppelt hij dus de motiveringsplicht los van het gekozen bewijsstelsel. Ten aanzien van de vraag welk bewijsstelsel ten grondslag moet liggen aan het nieuw te ontwerpen Wetboek van Strafvordering kiest hij een middenweg:

'Vrije en wettelijke bewijsleer zijn beginselen van veel te algemeene strekking om door ééne uitspraak te worden beoordeeld. Voor iederen regel, voor ieder voorschrift moet de quaestie afzonderlijk worden onderzocht en afzonderlijk worden beslist. ${ }^{78}$

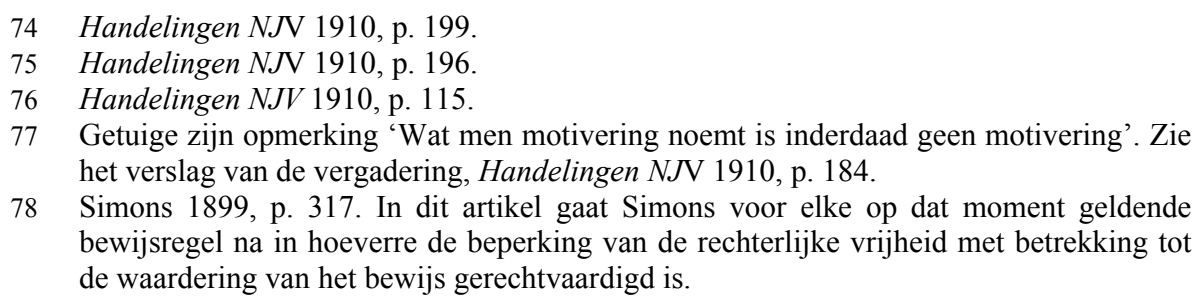

78 Simons 1899 , p. 317. In dit artikel gaat Simons voor elke op dat moment geldende bewijsregel na in hoeverre de beperking van de rechterlijke vrijheid met betrekking tot de waardering van het bewijs gerechtvaardigd is. 
Bij de stemming spreekt de vergadering van de Nederlandse Juristenvereniging zich uit voor het behoud van het negatief-wettelijk bewijsstelsel. ${ }^{79}$ Diezelfde meerderheid vindt echter ook dat de rechter in het vonnis zich meer dan tot dan toe het geval was rekenschap moet geven van de wijze waarop hij zijn overtuiging heeft gevestigd. In tegenstelling tot de vergadering in 1886 wordt dus 24 jaar later het negatief-wettelijk bewijsstelsel wel aanvaard door de Nederlandse Juristenvereniging.

\subsubsection{Het Ontwerp Wetboek van Strafvordering van de Commissie Ort}

Rond de eeuwwisseling wordt, zoals gezegd, aangedrongen op een nieuw Wetboek van Strafvordering. Het Wetboek van Strafvordering 1838 bevat talloze punten die in de praktijk niet voldoen en bovendien is de heersende gedachte dat de positie van de verdachte in het voor- en eindonderzoek moet worden versterkt. In het inquistoire strafproces zouden meer accusatoire elementen moeten worden ingebouwd. ${ }^{80}$ Op 8 april 1910 wordt de 'Staatscommissie voor de herziening van het Wetboek van Strafvordering' officieel ingesteld. ${ }^{81}$

De commissie staat onder leiding van Ort, wiens eigen ontwerp de leidraad vormt voor de besprekingen van de commissie. Het door Ort vervaardigde ontwerp steunt grotendeels op het Ontwerp-Godefroi uit 1863. Met betrekking tot het bewijsrecht wijkt het echter op een wezenlijk punt daarvan af. Immers, in tegenstelling tot het voorstel van Godefroi, bevat het Ontwerp-Ort wel een opsomming van wettelijke bewijsmiddelen. Als wettige bewijsmiddelen worden gekwalificeerd de verklaring van de getuige, de verklaring van de verdachte, de deskundigenverklaring, schriftelijke bescheiden en de eigen waarneming van de rechter. Ort acht een nadere omschrijving van de bewijsmiddelen noodzakelijk:

'ten einde te weren het gebruik van middelen wier betrouwbaarheid door hunnen oorsprong wordt uitgesloten, gelijk bijv. het testimonium de auditu en de verklaringen van medebeklaagden, ${ }^{82}$

79 Het vraagpunt luidt: 'Moet de grondslag van het bewijs van strafzaken blijven het beginsel dat voor een veroordeelend vonnis de overtuiging van den rechter omtrent de schuld van den beklaagde gevormd moet zijn met inachtneming van wettelijke regelen: a. omtrent de wijze van bewijslevering; b. omtrent de te bezigen bewijsmiddelen; c. omtrent den inhoud van sommige als bewijsmiddel te bezigen verklaringen (bijvoorbeeld verbod van getuigenis van hooren zeggen of van meeningen en gissingen); d. omtrent bewijsminima; met dien verstande dat de rechter in zijn uitspraak rekenschap geeft van de wijze waarop hij, in verband met de in verband met de wettelijke bepalingen onder c en d zijn overtuiging heeft gevestigd?'. Deze vraag wordt zonder hoofdelijke stemming door een grote meerderheid bevestigend beantwoord.

80 Zie nader over de invulling van de termen 'inquisitoir' en 'accusatoir': Nederburgh 1919.

81 Koninklijk Besluit van 8 april 1910, nr. 17.

82 Toelichting op het Ontwerp van een Wetboek van Strafvordering van B. Ort, p. 28, opgenomen in Lindenberg 2002, p. 65. 
Nieuw in de opsomming van de bewijsmiddelen zijn de eigen waarneming van de rechter ${ }^{83}$ en de verklaring van de deskundige.$^{84}$ Uit de lijst van toegestane bewijsmiddelen is het bewijsmiddel der aanwijzingen geschrapt. In tegenstelling tot het Wetboek van Strafvordering van 1838 zijn in het Ontwerp-Ort geen bewijsminimumregels opgenomen:

'... het ligt voor de hand dat het onmogelijk is bij de wet te voren de bewijskracht te bepalen; de vooraf vastgestelde waarde is toch niet te vereenigen met het feit dat het middel door de wet als deugdelijk wordt toegelaten. De bepaling eener mate van deugdelijkheid ontneemt aan het middel zijn eigenlijk wezen. ${ }^{85}$

Zo bezien houdt het Ontwerp-Ort dus het midden tussen het negatief-wettelijk bewijsstelsel, zoals het in het Wetboek van 1838 is opgenomen, en een vrij bewijsstelsel. Enerzijds worden de bronnen waaruit de rechter het bewijs mag putten beperkt door een nadere definiëring van die bewijsmiddelen, anderzijds worden alle regels met betrekking tot de waardering van het ter zitting gepresenteerde bewijsmateriaal verbannen. Ten aanzien van de vorm van het door de rechter te bezigen bewijsmateriaal worden eisen gesteld, maar is eenmaal aan deze eisen voldaan, dan is de waardering van de bewijzende kracht van de inhoud van het bewijsmateriaal aan de rechter overgelaten. ${ }^{86}$

De behandeling van het ontwerp-Ort in de Staatscommissie-Ort leidde waar het de inrichting van het materiële bewijsrecht betreft tot felle discussies. ${ }^{87}$ In het kader van deze studie zijn met name de discussies relevant betreffende het al dan niet opnemen van bewijsminima en de afschaffing van de aanwijzingen als bewijsmiddel, een en ander tegen de achtergrond van de verplichting tot motivering van de bewijsbeslissing.

83 In het Wetboek van Strafvordering 1838 en 1886 kwam de eigen waarneming van de rechter als bewijsmiddel wel voor, maar kon daaruit slechts het bestaan van een aanwijzing worden bewezen. Zie art. Sv 1838 en art. 407 Sv 1886.

84 In het Wetboek van Strafvordering 1838 kon de verklaring van de deskundige, voor zover het zijn wetenschappelijke gevoelen betrof, alleen voor het bewijs meewerken indien de rechter zich daarmee kon verenigen. Simons 1925, p. 166.

85 Toelichting op het Ontwerp van een Wetboek van Strafvordering van B. Ort, p. 27-28, opgenomen in Lindenberg 2002, p. 64-65.

86 Toelichting op het Ontwerp van een Wetboek van Strafvordering van B. Ort, p. 25, opgenomen in Lindenberg 2002, p. 64.

87 Dat was gezien de samenstelling van de commissie niet vreemd. Een aantal leden, te weten Feith, Van Hamel en Simons had immers tijdens de NJV-vergadering in juni 1910 duidelijk stelling genomen met betrekking tot de vraag of het negatief-wetttelijke bewijsstelsel moest worden gehandhaafd. Feith had zich in zijn preadvies ontpopt als voorvechter van het negatief-wettelijk bewijsstelsel; Van Hamel als duidelijk tegenstander en Simons had een gematigd standpunt ingenomen, maar was evenals Van Hamel overtuigd van de noodzaak van een betere motivering van vonnissen. 


\subsubsection{Bewijsminima en motivering}

In het ontwerp-Ort zijn geen regels opgenomen die de waardering van het door de rechter gebezigde bewijsmateriaal nader reguleren. Wel is dienaangaande een bijzondere motiveringsplicht opgenomen, te weten:

'In het geval dat het bewijs der daadsaken uitsluitend wordt gevonden in de verklaring hetzij van één getuige, hetzij van één of meer getuigen, aangeduid bij artikel 347, hetzij van den beklaagde, vermeldt het vonnis de beweegredenen die tot het aannemen van dat bewijs hebben geleid. ${ }^{, 8}$

Vooral Feith, voorstander van een negatief-wettelijk bewijsstelsel, dringt in de Commissie aan op het alsnog in het Ontwerp opnemen van bewijsminima. De in het Ontwerp-Ort opgenomen motiveringsplicht acht hij een onvoldoende waarborg. Ort en Van Hamel achten de bewijsminimumregels niet gewenst en niet nodig. Niet gewenst omdat zij voorstander zijn van een vrij bewijsstelsel en dus de rechter niet willen binden aan wettelijke bewijsregels. Niet nodig omdat de deugdelijkheid van het oordeel ook kan worden gegarandeerd door daaraan specifieke motiveringseisen te stellen. ${ }^{89}$ Aldus komt ook in de Staatscommissie de klassieke tegenstelling tussen de voor- en tegenstanders van het negatief-wettelijk bewijsstelsel tot uitdrukking. Bovendien speelt in de discussie over de vraag 'of het wettelijke bewijsrecht bewijsminima dient te bevatten' de kwestie met betrekking tot de bewijskracht van het proces-verbaal van een opsporingsambtenaar een rol. ${ }^{90}$ Simons, die voorstander is van het opnemen van de unus testis regel, meent dat deze regel ook van toepassing moet zijn op de enkele verklaring van de opsporingsambtenaar. Naar zijn mening valt niet in te zien waarom de opsporingsambtenaar als getuige beter gekwalificeerd is dan de 'gewone' getuige. ${ }^{91}$ Opvallend is dat de Commissie bij de bespreking van het ontwerp-Ort zich in eerste instantie uitspreekt vóór het alsnog opnemen van een bepaling, inhoudende dat een bewezenverklaring niet uitsluitend mag steunen op de verklaring van een ander dan de verdachte. ${ }^{92}$ Op grond van deze bepaling is de enkele verklaring

88 Artikel 408, derde volzin, in het Ontwerp-Ort, opgenomen in Lindenberg 2002, p. 39.

89 In de $4^{\mathrm{e}}, 5^{\mathrm{e}}$ en $6^{\mathrm{e}}$ vergadering van de Staatscommissie staat de bespreking van de beginselen van het bewijs centraal. Notulen van de Staatscommissie voor de herziening van het Wetboek van Strafvordering; het verslag van $4^{\mathrm{e}}$ en $5^{\mathrm{e}}$ vergadering, opgenomen in Lindenberg 2002, p. 157-171.

90 Zie daarover uitgebreid Polak 1927.

91 Notulen van de Staatscommissie voor de herziening van het Wetboek van Strafvordering; het verslag van $40^{\mathrm{e}}$ vergadering. p. 5, opgenomen in Lindenberg 2002, p. 329. In gelijke zin: Simons 1899, p. 304: 'De bijzondere bewijskracht van het verbaal schijnt mij op zich zelf eene volkomen onverdedigbare uitzondering op den in art. 397 [Sv 1886, WD] gestelden regel, eene uitzondering die slechts als een noodzakelijk kwaad kan worden aanvaard omdat de behoefte der practijk het gebiedend vordert'.

92 Notulen van de Staatscommissie voor de herziening van het Wetboek van Strafvordering; het verslag van $41^{\mathrm{e}}$ vergadering, opgenomen in Lindenberg 2002, p. 330-332. Daarvoor 
van de verdachte wel voldoende, maar die van een getuige dan wel een opsporingsambtenaar onvoldoende om tot een bewezenverklaring te geraken. Maar als dit punt in de $57^{\mathrm{e}}$ vergadering van de Commissie door de voorzitter ${ }^{93}$ weer ter discussie wordt gesteld, beslist een krappe meerderheid dat deze bepaling alsnog geschrapt moet worden. De minderheid - voorstanders van het behoud van de bewijsminima - dringt dan vervolgens aan op nadere bewijsmotiveringsvoorschriften; van de rechter moet op zijn minst verlangd worden dat hij zijn oordeel nader motiveert indien dit gebaseerd is op de verklaring van één getuige. Ten aanzien van het proces-verbaal van de opsporingsambtenaar meent men dat ook daar een nadere motivering van de rechter moet worden geëist in die gevallen waarin de verbalisant in het proces-verbaal verklaart over feiten die jegens hem zijn begaan.

Uit het grillige verloop van de discussie in de Commissie blijkt eens te meer dat de inhoud van het materiële bewijsrecht en de eisen die men stelt aan de motivering van het bewijsoordeel communicerende vaten zijn. Het bestaan van wettelijke regels met betrekking tot de waardering van het bewijs doet de noodzaak van een nadere motivering afnemen. Andersom geldt evenzeer dat het ontbreken van dergelijke regels logischerwijze moet leiden tot een correctie van de rechterlijke oordeelsvrijheid en die correctie wordt gevonden in de plicht tot nadere motivering. In het uiteindelijk in 1913 door de Commissie aangeboden Ontwerp tot herziening van het Wetboek van Strafvordering is geen enkele bewijsminimumregel opgenomen. In de toelichting valt te lezen dat de binding van de rechter aan dergelijke regels er toe zou kunnen leiden dat hij tegen zijn overtuiging in moet vrijspreken. Bovendien is de Commissie van mening dat - als men al een minimum aan bewijs eist - dit minimum niet moet worden gevonden in het aantal bewijsmiddelen, maar in de bewijsgronden. Aan dit standpunt ligt de idee ten grondslag dat niet de bewijsmiddelen bewijzen, maar de daarin opgenomen feiten en omstandigheden - de bewijsgronden - het bewijs van het tenlastegelegde feit kunnen opleveren. Eén bewijsmiddel kan daarom zeer vele bewijsgronden bevatten en om die reden voldoende zijn voor een bewezenverklaring. Tevens wordt gewezen op het beperkte belang van de bestaande bewijsminimumregels. De enige regel die wellicht enig gewicht heeft, is de 'unus testis, nullus testis'regel. Maar aangezien in de rechtspraak niet wordt geëist dat elk onderdeel van het tenlastegelegde feit door meer dan één getuige moet worden bevestigd, heeft ook deze regel in de praktijk een geringe waarde. Bovendien wordt in de toelichting van het Ontwerp gewezen op de inconsequentie die de unus testis-regel

was al een bepaling opgenomen die alleen betrekking had op de getuige, echter onder andere Simons had aangedrongen op het uitbreiden van deze bepaling tot alle andere informanten in het strafproces met uitzondering van de verdachte.

93 Ort beschouwt de ingevoegde bepaling 'als een vlekje op de in het ontwerp aanvaarde bewijsleer'. Notulen van de Staatscommissie voor de herziening van het Wetboek van Strafvordering; het verslag van $57^{\mathrm{e}}$ vergadering. p. 7, opgenomen in Lindenberg 2002, p. 366. 
met zich brengt, namelijk dat een bewezenverklaring niet kan steunen op de verklaring van één getuige, terwijl een bewezenverklaring wel mogelijk is indien die verklaring afkomstig is van een opsporingsambtenaar. ${ }^{94}$

Het ontbreken van bewijsminima wordt gecompenseerd door het opnemen van een motiveringsplicht voor de strafrechter in die gevallen waarin de bewezenverklaring steunt op de verklaring van één getuige of op de enkele verklaring van de verdachte (artikel 353 van het Ontwerp). ${ }^{95}$ In de toelichting op het ontwerp van de staatscommissie Ort staat met betrekking tot de in artikel 353 opgenomen motiveringsplicht te lezen:

'De laatstbedoelde bepaling vervangt eenigermate de bestaande bewijsminima-voorschriften. (...) de rechter (is) bij de beoordeling der bewijskracht van de bijgebrachte bewijsmiddelen geheel vrijgelaten; hij mag het te laste gelegde feit dus zelfs bewezen verklaren, indien geen ander bewijsmiddel aanwezig is dan de verklaring van één getuige of van den verdachte zelf, zoo de omstandigheden waaronder het door die personen medegedeelde werd waargenomen van dien aard zijn dat daarin op zich zelf reeds eene aanleiding is gelegen om die waarneming als juist en die mededeeling voor waar te houden. Het schijnt dan echter een eisch van goede justitie die omstandigheden te noemen; ook in dat geval is dus de eisch gesteld eener redengeving, waarom aan het uit den aard zwakke bewijsmiddel niettemin bewijskracht toekomt.,96

Opvallend is dat in het uiteindelijke Ontwerp van de Staatscommissie ${ }^{97}$ de bijzondere motiveringsplicht ten aanzien van het proces-verbaal van een opsporingsambtenaar niet is opgenomen, ondanks het feit dat een meerderheid van de Commissie zich voor een dergelijke motiveringsplicht had uitgesproken. Wellicht kan de verklaring hiervoor worden gevonden in het feit dat het 'Bureau' dat belast was met de begeleiding van de commissie en verantwoordelijk was voor de uiteindelijke redactie van het Ontwerp reeds eerder bij monde van de voorzitter had laten weten dat zij het nut van een dergelijke bepaling niet zag. Het zou aldus het Bureau 'neerkomen op een phrase waarin de rechter zijn vertrouwen in de betrouwbaarheid van den verbalisant zou uitspreken. ${ }^{, 98}$

94 Toelichting bij het ontwerp tot vaststelling van een Wetboek van Strafvordering, Kamerstukken 1912-1913, p. 277, opgenomen in Lindenberg 2002, p. 489.

95 Zie art. 353 van het Ontwerp. Op grond van diezelfde bepaling wordt van de rechter ook een nadere redengeving verlangd indien het bewijs onder andere wordt aangenomen op de verklaring van een getuige die niet onder ede heeft verklaard, maar enkel is gemaand de waarheid te zeggen. Het betreft dan getuigen die de leeftijd van 16 jaar nog niet hebben bereikt of getuigen die als gevolg van een storing of gebrekkige ontwikkeling van de geestesvermogens de betekenis van de eed niet voldoende beseffen.

96 Toelichting bij het ontwerp tot vaststelling van een Wetboek van Strafvordering, Kamerstukken 1912-1913, p. 302, opgenomen in Lindenberg 2002, p. 495.

97 Het ontwerp werd op 17 mei 1913 aan de Koningin aangeboden.

98 Notulen van de Staatscommissie voor de herziening van het Wetboek van Strafvordering; het verslag van $57^{\mathrm{e}}$ vergadering. p. 6, opgenomen in Lindenberg 2002, p. 366. 


\subsubsection{De afschaffing van het bewijsmiddel der aanwijzingen en de motivering}

Nog op een tweede punt houden de voorgestelde wijzigingen met betrekking tot het materiële bewijsrecht rechtstreeks verband met de motivering van de bewezenverklaring. Het betreft dan de afschaffing van het bewijsmiddel der aanwijzingen. Inmiddels is de opvatting dat aanwijzingen niet langer als bewijsmiddel gekwalificeerd kunnen worden reeds algemeen geaccepteerd.

'Eene aanwijzing is toch niets anders dan hetgeen door een bewijsmiddel blijkt, mitsdien een bewijsgrond. Een bewijsgrond nu kan dienen om een zeker feit rechtstreeks of bij gevolgtrekking te bewijzen. (...) Evenals hetgeen de rechter rechtstreeks uit een bekend geworden daadzaak afleidt, is echter ook het bij gevolgtrekking afgeleide, een ten processe vaststaand feit, door een bewijsmiddel bekend geworden, dus zelf geen middel. ${ }^{99}$

Het schrappen van dit bewijsmiddel is dan ook bij de totstandkoming van het Wetboek van Strafvordering geen punt van discussie. Wel wordt bij de behandeling van het Ontwerp-Ort de vraag aan de orde gesteld of niet expliciet in het Wetboek moet worden opgenomen dat de rechter het bewijs van het tenlastegelegde zowel rechtstreeks als indirect uit de inhoud van de bewijsmiddelen mag afleiden. De meerderheid van de commissie acht echter een expliciete vermelding van de mogelijkheid van indirect bewijs niet nodig. ${ }^{100}$

Met het afschaffen van het bewijsmiddel 'aanwijzing' verdwijnt ook het verbod van het bewijs van aanwijzingen door aanwijzingen. Dit verbod was gebaseerd op artikel 443 van het Wetboek van Strafvordering van $1838 .{ }^{101}$ Die bepaling hield in dat het bestaan van de aanwijzing slechts kon worden bewezen door getuigen, schriftelijke bescheiden, persoonlijk onderzoek of bezichtiging door de rechter, en door de (buitengerechtelijke) bekentenis van den beklaagde. De opsomming van de bewijsmiddelen waaruit het bestaan van een aanwijzing kon worden afgeleid was limitatief. ${ }^{102}$ Uit de memorie van toelichting behorende bij het ontwerp van het Wetboek uit 1829 blijkt dat men het verbod als:

'een waarborg van der burgeren veiligheid had geoordeeld, dat de daadzaken, die als aanwijzingen worden aangemerkt, op de gewone wijze moesten bewezen worden, met andere woorden dat indiciën niet door indiciën konden worden bewezen.'

99 Toelichting bij het Ontwerp van een Wetboek van Strafvordering door B. Ort, p. 30, opgenomen in K. Lindenberg 2002, p. 65. In gelijke zin: Domela Nieuwenhuis 1911, p. 45, Karsten 1910, p. 370, Kirberger 1914, p. 444 en Bruijn 1885, p. 74: 'Dat een groot gedeelte van de moeilijkheden, die aan de toepassing der thans geldende bewijsvoorschriften zijn verbonden, aan de opneming der aanwijzingen onder de bewijsmiddelen is toe te schrijven.'

100 Notulen van de Staatscommissie voor de herziening van het Wetboek van Strafvordering; het verslag van 52e vergadering, p. 3, opgenomen in Lindenberg 2002, p. 353.

101 In het Wetboek van Strafvordering van 1886 was de bepaling opgenomen in art. 407.

102 Simons 1886, p. 208. 
Het verbod om aanwijzingen uit aanwijzingen af te leiden, betekende dat de rechter beperkt was in zijn mogelijkheden om door middel van gevolgtrekking feiten vast te stellen. Hij mocht wel uit de feiten die bleken uit de bewijsmiddelen een nieuw feit afleiden, maar het was niet toegestaan om uit dat beredeneerde feit nogmaals een nieuw feit af te leiden. De rechter mocht dus niet uit een aaneenschakeling van gevolgtrekkingen het bewijs opbouwen. ${ }^{103}$ De Hoge Raad hield onder het Wetboek van Strafvordering van 1838 en 1886 vast aan dit verbod om aanwijzingen uit aanwijzingen af te leiden. De handhaving hiervan was echter onmogelijk. Zo werd onder andere door Feith de afschaffing van deze wettelijke bepaling bepleit, omdat zij er enkel toe leidde dat de rechter in zijn vonnis gedachtesprongen maakte. Feith refereerde daarbij aan hetgeen tot die tijd regel was met betrekking tot het bewijs door aanwijzingen; niet de gehele redenering van feiten en omstandigheden tot gevolgtrekking en tot een nieuwe gevolgtrekking werd in het vonnis opgenomen; dit zou namelijk in strijd zijn met art $407 \mathrm{~Sv}$ (1886). In plaats daarvan werd van de aanwijzing direct naar de eindconclusie gesprongen. ${ }^{104}$ Deze praktijk kon niet door de Hoge Raad worden tegengehouden, omdat de feitenrechter vrij was om te bepalen welke bewijskracht hij toekende aan de door hem als anwijzing gekwalificeerde feiten. ${ }^{105}$ Terecht concludeerde Karsten dan ook dat het verbod om aanwijzingen uit aanwijzingen af te leiden tot een ijdele vormkwestie is gemaakt. ${ }^{106} \mathrm{Bij}$ de behandeling van het Ontwerp-Ort zijn het Feith en Simons die zich keren tegen deze dan gangbare praktijk waarbij:

'het aan den lezer wordt overgelaten te trachten den gedachtengang die den rechter tot zijne beslissing heeft geleid te reconstrueren'.

Simons stelt dan ook voor om in die gevallen waarin de bewezenverklaring niet rechtstreeks voortvloeit uit de in het vonnis vermelde bewijsmiddelen, van de rechter te eisen dat hij de omstandigheden waaruit hij het bewijs afleidt en de bewijsmiddelen waaruit die omstandigheden zijn gebleken in het vonnis vermeldt. Dit voorstel wordt uiteindelijk door de Commissie overgenomen, met dien verstande dat geen onderscheid wordt gemaakt tussen die gevallen waarin de bewijsbeslissing rechtstreeks uit de bewijsmiddelen volgt en die gevallen waarin sprake is van een indirecte bewijsconstructie. In het ontwerp wordt aan artikel 354 toegevoegd:

103 Karsten 1910, p. 371.

104 In gelijke zin: Kirberger 1914, p. 443: 'In het bijzonder bemoeilijkt de vrees voor een bewijs van aanwijzingen door aanwijzingen - somtijds niet te vermijden! - de vrije motiveering, juist zij is het, die den rechter belemmert in het houden van een misschien niet strikt noodzakelijk, maar overtuigend betoog' en Plantenga 1911, p. 320.

105 Art. 444 Sv 1838 bepaalde: 'De beoordeling der kracht van bewijs, welke aanwijzingen in elk bijzonder geval hebben, wordt aan de bescheidenheid des regters overgelaten.'

106 Karsten 1910, p. 373. 
'De beslissing moet steunen op daartoe redengevende feiten of omstandigheden.'

Met deze toevoeging in het Ontwerp-Ort worden de bezwaren die bestonden tegen het bewijsmiddel der aanwijzingen ondervangen. Niet langer wordt de aanwijzing als bewijsmiddel beschouwd, terwijl wel wordt onderkend dat voor de feitenvaststelling in strafzaken het gebruik van aanwijzingen onmisbaar is zeker in die gevallen waarin geen direct bewijs beschikbaar is. Ook is het niet langer verboden om aanwijzingen uit aanwijzingen af te leiden. Bovendien wordt het gevaar dat aan het bewijs door middel van aanwijzingen is verbonden, namelijk dat de rechter te snel algemene conclusies verbindt aan het bestaan van bepaalde feiten (de aanwijzingen), beperkt door een nieuw motiveringsvoorschrift. Van de rechter wordt verlangd dat hij in geval van een bewezenverklaring de feiten die hij afleidt uit de bewijsmiddelen en waarop zijn overtuiging steunt in het vonnis noemt. Op deze wijze wordt de gedachtegang van de rechter inzichtelijk en voor controle in hoger beroep en cassatie vatbaar.

\subsubsection{Het Wetboek van Strafvordering van 1926}

Het Ontwerp van de Commissie-Ort wordt op 8 juli 1913 bij de Raad van State aanhangig gemaakt. In zijn advies spreekt de Raad van State zich in positieve zin uit over het behoud van het negatief-wettelijk bewijsstelsel. Daarmee is waarschijnlijk bedoeld dat het Ontwerp-Ort evenals het dan geldende Wetboek een limitatieve opsomming van de bewijsmiddelen kent. Beduidend minder enthousiast is de Raad over het loslaten van het bewijsminimumstelsel:

' $\mathrm{Nu}$ geeft de Raad gaarne toe dat de rechter op grond van de op zichzelf staande bekentenis of verklaring de schuld niet licht zal aannemen; doch het komt hem toch veiliger voor de mogelijkheid daarvan bij de wet uit te sluiten. De bepaling van art. 353 [de bijzondere motiveringsplicht; WD] kan 's Raads bedenking niet wegnemen. Kan nu al uit den aard der zaak om velerlei redenen dezelfde eisch niet worden gesteld ten aanzien van ambtelijke processen-verbaal, dit kan geen aanleiding zijn om een grooten waarborg voor goede berechting in het algemeen te doen vervallen. ${ }^{10}$

De Raad adviseert dan ook de bewijsminima weer in het Ontwerp op te nemen. Het Ontwerp wordt vervolgens op 7 april 1914 aan de Tweede Kamer aangeboden. Uit het verslag van de Commissie van Voorbereiding blijkt dat een groot deel van haar leden zich aansluit bij de kritiek van de Raad van State. ${ }^{108}$ Daarop besluit de Minister van Justitie (wederom Ort) het Ontwerp conform het voorstel van de Raad van State aan te passen. Daarmee zijn de bewijsminima terug van weg-

107 Advies van de Raad van State uitgebracht d.d. 23 december 1913, p. 8, opgenomen in Lindenberg 2002, p. 525 e.v.

108 Kamerstukken II 1917-1918, 77, nr. 1 (Verslag van de Commissie van Voorbereiding), p. 61: 'Zij vreesden dat, als de verklaring van één getuige als volledig bewijs zou kunnen gelden, de veroordeling van onschuldigen daarvan het gevolg zou kunnen zijn.' 
geweest. Artikel 353 wordt in overeenkomstige zin aangepast; de daarin opgenomen nadere motiveringsplicht is overbodig en wordt geschrapt, aangezien een bewezenverklaring niet langer op de enkele verklaring van de verdachte of getuige kan steunen. Bovendien wordt ten aanzien van de processen-verbaal van opsporingsambtenaren bepaald dat het bewijs enkel daarop kan worden aangenomen.

Het schrappen van het bewijsmiddel der aanwijzingen en de daarvoor in de plaats tredende motiveringsplicht kan wel op de goedkeuring van zowel Tweede als Eerste Kamer rekenen.

'Zeer terecht zijn de aanwijzingen uit de opsomming der wettige bewijsmiddelen weggelaten. Doch de redengevende feiten of omstandigheden, waarop de beslissing dat het feit door den verdachte is begaan, cq. moet steunen, daaronder dus begrepen wat thans heet aanwijzingen, kunnen, naar het ontwerp, worden afgeleid uit den inhoud der wettige bewijsmiddelen. Praktisch verschil met den bestaande wettelijken toestand bestaat hier niet, behalve dan in zoover, daar voortaan aanwijzingen ook op aanwijzingen zullen kunnen steunen., ${ }^{109}$

\subsubsection{Slot}

Uit de bovengeschetste ontwikkeling blijkt dat de inhoud van het materiële bewijsrecht voor een deel parallel loopt aan de opvattingen met betrekking tot de motivering van de bewijsbeslissing. Voor de aanhangers van een negatief-wettelijk bewijsstelsel betekent dit dat zij de voorkeur geven aan wettelijke bewijsregels, omdat zij vrezen dat bij gebrek aan bewijsregels de rechter het oordeel enkel op zijn subjectieve overtuiging zal baseren. Zij menen dat de vrijheid van de rechter bij de waardering van het hem gepresenteerde bewijsmateriaal moet worden beperkt en nemen daarbij op de koop toe, dat die beperkingen met zich brengen dat in bepaalde strafzaken mogelijk een schuldige moet worden vrijgesproken. De voorstanders van een vrije bewijsleer daarentegen wijzen dit laatste af. $\mathrm{Zij}$ menen dat het a priori in de wet vastleggen van bewijsregels kan leiden tot bewijsoordelen die niet in overeenstemming zijn met de idee dat in strafzaken zoveel mogelijk de waarheid moet worden gevonden. Zij zien in de motivering een belangrijke waarborg voor een deugdelijke feitenvaststelling.

Bij de totstandkoming van het Wetboek van Strafvordering van 1926 wordt deze controverse zeer duidelijk. Enerzijds is daar de discussie over de bewijsminima; moeten deze worden gehandhaafd, of moet in geval de bewezenverklaring slechts op één verklaring steunt een bijzondere motiveringsplicht gelden. Uiteindelijk kiest men voor het handhaven van bepaalde bewijsminima en wordt de door de Staatscommissie-Ort voorgestelde uitgebreide motiveringsplicht geschrapt. Anderzijds wordt dit dilemma ook duidelijk met betrekking tot het bewijsmiddel 'aanwijzing'. Gebleken was dat rechters het voorschrift waarin was bepaald dat

109 Kamerstukken II 1919-1920, 18 (Eindverslag), p. 65. 
het bewijs van aanwijzingen niet uit andere aanwijzingen mocht worden afgeleid, stelselmatig ontdoken, en dat dit leidde tot verwrongen - weinig inzichtelijke bewijsconstructies in het vonnis. Dit inzicht leidt ertoe dat in het nieuwe Wetboek van Strafvordering de aanwijzingen niet langer als wettig bewijsmiddel worden gekwalificeerd en dat daarvoor in de plaats treedt het motiveringsvoorschrift zoals thans vastgelegd in artikel 359 lid 3 Sv: de rechter dient de redengevende feiten en omstandigheden aan te wijzen.

Ten aanzien van beide punten - de bewijsminima en het bewijs door middel van aanwijzingen - blijkt dat de mate waarin de rechter aan wettelijke bewijsregels wordt gebonden en de eisen die worden gesteld aan de motivering van het bewijsoordeel werken als communicerende vaten. Het schrappen van bepaalde bewijsregels wordt gecompenseerd door een nadere motiveringsplicht. Aan de andere kant werd verondersteld dat het bestaan van wettelijke bewijsregels een nadere motiveringsplicht overbodig maakt.

Een van de punten die bij de discussie over de vormgeving van het bewijsrecht een belangrijke rol speelt, is de vraag wat de inhoud van de motivering zal zijn indien men geen bewijsregels in de wet zou opnemen. Voorstanders van het behoud van bewijsregels meenden dat bij gebrek aan regels de motivering beperkt zou blijven tot een holle frase, temeer daar in cassatie bij gebrek aan wettelijke regels op dit punt geen controle kon worden uitgeoefend. Tegenstanders meenden dat juist het opnemen van wettelijke bewijsregels ertoe zou leiden dat de rechter zich niet geroepen zou voelen om zijn oordeel nader te verantwoorden. De motivering zou beperkt blijven tot de constatering dat het gebezigde bewijs wettig was. $\mathrm{Zij}$ baseerden zich daarbij op wat tot dan toe gangbaar was bij de vormgeving van het vonnis. In de volgende paragraaf zal meer specifiek op de ontwikkeling van de motiveringseisen vanaf 1813 worden ingegaan.

\subsection{De ontwikkeling van de motiveringsplicht vanaf 1813}

Uit de bovengeschetste ontwikkeling van het bewijsrecht zou de indruk kunnen ontstaan dat de motivering van het vonnis altijd (mede) in het teken heeft gestaan van het waarborgen van een deugdelijke waarheidsvinding. Dat is echter niet waar. In de eerste periode na de Franse overheersing kent het Nederlandse recht in het geheel geen bepaling waarin rechters worden verplicht hun vonnissen te motiveren. In het Souverein Besluit 1813 was weliswaar de juryrechtspraak opgeheven en was het oordeel in strafzaken aan rechters opgedragen, maar in dat besluit werd van de rechters geen nadere verantwoording van hun oordeel verlangd. Dit is bevreemdend, omdat een van de argumenten voor afschaffing van de jury-rechtspraak was dat men van een jury niet kon verwachten dat zij rekenschap zou 
afleggen over de gronden waarop het oordeel steunde. Kennelijk verwachtte men dit wel van rechters.

Deze omissie wordt hersteld in de Grondwet van 1815. Artikel 172 bepaalde:

'In alle criminele vonnissen, ten laste van een beschuldigde gewezen, moet de misdaad worden uitgedrukt en omschreven, met aanhaling van de artikelen der wet, waarop de uitspraak is gegrond. ${ }^{110}$

Aan dit grondwetsartikel is echter nooit enige consequentie verbonden met betrekking tot de motivering van de bewijsbeslissing. Het had slechts tot doel de veroordeelde inzicht te geven in de feiten waarvoor hij was veroordeeld. ${ }^{111}$ Dit betekende dat strafrechtelijke vonnissen in die tijd een zeer uitvoerige beschrijving van de feiten bevatten. De vraag daarentegen waaruit die feiten bleken, werd meestal afgedaan met de opmerking 'dat zulks was gebleken bij confessie of andersints'. ${ }^{112}$

\subsubsection{Het Wetboek van Strafvordering 1838 en 1886}

De specifieke uitwerking van het artikel 172 van de Grondwet volgt in het Wetboek van Strafvordering van 1838. Het daarin opgenomen artikel 211 luidt:

'Het arrest wordt door den president met opene deuren uitgesproken, in tegenwoordigheid van al de raadsheren, die over de zaak gezeten hebben, en van den procureurgeneraal; het moet met redenen bekleed zijn, en het misdrijf uitdrukken met alle omstandigheden, die volgens de wet tot verzwaring of verligting van straf aanleiding geven, en voorts inhouden 's hofs beslissing over de punten bij artikel 206 vermeld, mitsgaders ingeval van veroordeeling, den tekst der wet welke wordt toegepast en de straf waarin de beschuldigde wordt veroordeeld; alles op straffe van nietigheid. ${ }^{113}$

110 In 1848 wordt deze bepaling gewijzigd. Artikel 156 Gw 1848 houdt dan in: 'Alle vonnissen moeten de gronden, waarop zij rusten, en in strafzaken de artikelen der wet waarop de veroordeling rust, vermelden en met open deuren worden uitgesproken'.

111 Simons 1898, p. 327: 'De gevorderde motivering had alleen tot doel te voorkomen dat de rechter straf oplegde zonder dat uit het vonnis bleek voor welk feit die straf werd opgelegd'.

112 Waaldijk 1963, p. 15.

113 De tekst van deze bepaling is echter niet zonder discussie vastgesteld. In de ontwerpen vóór 1828 werd enkel als eis ten aanzien van het vonnis gesteld dat in het vonnis de misdaad moet worden uitgedrukt. In het ontwerp van 1828 bepaalt art. 28 ten aanzien van het vonnis dat het moest 'inhouden de daadzaken aan den beschuldigde ten laste gelegd'. In het ontwerp van 1829 worden voor het eerst de woorden 'met redenen bekleed' ingevoegd: 'Het arrest moet met redenen zijn bekleed en het misdrijf uitdrukken en omschrijven'. In het ontwerp van 1830 wordt uiteindelijke de volgende tekst (van art. 166) vastgesteld: 'Het arrest moet met redenen zijn bekleed, en het misdrijf met alle omstandigheden uitdrukken.' In de uiteindelijke tekst is dit laatste gewijzigd in die zin dat enkel die omstandigheden die leiden tot strafverzwaring dan wel verlichting in het vonnis tot uitdrukking moeten komen. 
Bij de wijziging van het Wetboek in 1886 wordt artikel 211 slechts tekstueel enigszins aangepast en vernummerd tot artikel $221 \mathrm{~Sv} 1886 .{ }^{114}$ De inhoud van de bepaling is in principe gelijk aan die onder het oude Wetboek. Volgens De Pinto is dat ook wenselijk; hij wijst in dat verband op de jurisprudentie ten aanzien van artikel 211:

'dat juist in verband met die rijke en in menig opzicht gevestigde jurisprudentie veel er voor pleitte hier zoomin mogelijk af te wijken van de bestaande voorschriften die - wat de hoofdzaak - de noodige wettelijke waarborgen geven voor eene goede motivering der vonnissen., 115

Slechts op één punt wijkt artikel 221 duidelijk af van zijn voorganger. Met verwijzing naar artikel 156 van de Grondwet van 1848 wordt enkel nog de vermelding van de wetsartikelen waarop de veroordeling rust nodig geacht. Dit in tegenstelling tot artikel 211 (1838) waarin werd bepaald dat het vonnis de tekst van de wetsartikelen moest inhouden. ${ }^{116}$ De wijziging op dit punt werd wenselijk geacht, omdat overname van de tekst van de wetsbepalingen slechts leidde tot 'noodelozen omslag en schrijverij'. ${ }^{117}$

\subsubsection{Met redenen omkleed}

De vraag is welke betekenis moet worden toegekend aan de woorden 'met redenen bekleed', zoals die zowel in artikel 211 Sv 1838 als in artikel 221 Sv 1886 zijn opgenomen. Van Heusden ${ }^{118}$ is de mening toegedaan, dat de wetgever anno 1838 niet de bedoeling heeft gehad van de rechter te eisen dat hij de redenen die ten grondslag liggen aan zijn overtuiging in het vonnis opneemt. Hij komt tot deze conclusie door een vergelijking van de Franse wetteksten met de nieuwe Nederlandse wetteksten. Artikel 162 van de Code d'Instruction Criminelle, luidde:

'tout jugements définitif de condemnation sera motivé, et les termes de la loi appliqueé y seront insérés, á peine de nullité.'

114 Art. 221 Sv 1886 luidde: 'Het vonnis moet met redenen omkleed zijn en het strafbare feit uitdrukken met alle omstandigheden, die volgens de wet tot verzwaring of verlichting van de straf aanleiding geven. Het moet wijders inhouden de beslissing der regtbank over de punten bij art. 211 vermeld, mitsgaders, ingeval van veroordeling, de artikelen der wet welke worden toegepast en de straf waartoe de beklaagde wordt veroordeeld.'

115 De Pinto 1888, p. 258.

116 De Pinto wijst in dit verband op een foutje in de redactie van het artikel. Zijns inziens had er niet moeten staan dat het vonnis de artikelen der wet waarop de veroordeling steunt moest inhouden, maar dat deze artikelen in het vonnis moesten worden vermeld. Dit laatste is kennelijk wel de bedoeling van de wetgever geweest, maar het woord 'inhouden' zou ook op het letterlijk weergeven van de tekst van de wet kunnen duiden. Zie De Pinto 1888, p. 260.

117 Bok 1893, p. 21 en 24.

118 Van Heusden 1840. 
Onder de Franse wetgeving werd van de rechter enkel geëist dat het vonnis melding maakte van de feiten die hij voor bewezen hield, en dat uit het vonnis bleek welk volgens de wet strafbaar feit deze feiten inhielden. Uit de totstandkomingsgeschiedenis van het Wetboek van 1838 blijkt volgens Van Heusden dat men zoveel mogelijk de Code d'Instruction Criminelle als leidraad heeft willen nemen, en enkel verbetering heeft willen aanbrengen waar nodig. Van Heusden is van mening dat daar waar nergens uit de wetsgeschiedenis expliciet blijkt dat men heeft willen breken met de Franse praktijk, dit dus kennelijk ook niet de bedoeling is geweest. De woorden 'met redenen bekleed' moeten dus worden uitgelegd conform 'sera motivé' in de Franse rechtspleging: het vonnis dient de bewezenverklaring en de kwalificatie te omvatten.

De Bosch Kemper kent een ruimere betekenis aan artikel 211 Sv 1838 toe. Hij legt met betrekking tot de eisen die moeten worden gesteld aan de motivering van het vonnis een verband met het negatief-wettelijk bewijsstelsel zoals dat in het Wetboek van 1838 is opgenomen:

'dat de wil des Nederlandschen Wetgevers is, dat het arrest volledig al datgene bevatte, waaruit kan worden geoordeeld, of de Wet juist is toegepast; maar daarentegen niets behoeft te behelzen van hetgeen de Wetgever aan het geweten des regters heeft overgelaten. 119

Hij leidt dit af uit de wijziging van het ontwerp van 1836 waarin niet langer wordt gesproken van alle omstandigheden, maar enkel nog van die omstandigheden die volgens de wet tot strafvermindering of vermeerdering kunnen leiden. In zijn visie moet een vonnis, wil het voldoende gemotiveerd zijn, aan twee eisen voldoen. Ten eerste moeten daarin de bewijsmiddelen nauwkeurig worden vermeld. Ten tweede moet in het arrest een juiste omschrijving van de feiten worden gegeven. Een op deze wijze vormgegeven arrest stelt de Hoge Raad in staat de wettigheid van het bewijs te controleren én te oordelen over juiste toepassing van de strafwet:

'De beweegredenen der arresten (moeten) slechts beschouwd worden als een waarborg; dat volgens de Wet is geoordeeld, en niet als waarborg, dat er juist is geoordeeld. ${ }^{120}$

Vrij snel na de inwerkingtreding van het Wetboek van Strafvordering, op 18 december 1838, wordt de Hoge Raad de vraag voorgelegd aan welke eisen het vonnis moet voldoen wil het voldoende gemotiveerd zijn. In zijn arrest legt de Hoge Raad evenals De Bosch Kemper een duidelijke verbinding tussen de motiveringsplicht van de rechter en het negatief-wettelijk bewijsstelsel zoals dat in het Wetboek van 1838 is vormgegeven:

119 De Bosch Kemper 1838-1840, Tweede deel, p. 578

120 De Bosch Kemper 1838-1840, Tweede deel, p. 579. 
'dat mitsdien, bij de bestaande wetgeving, de schuldigverklaring enkel op innerlijke overtuiging niet meer toegelaten zij, 's Regters convictie moet voortkomen uit, en gegrond zijn op de bewijsmiddelen, welke bij de 22ste Titel van het Wetboek van Strafvordering zijn voorgeschreven, en waaromtrent artikel 427 uitdrukkelijk bepaalt, dat niemand wegens misdrijf kan worden veroordeeld, tenzij de Regter door wettige bewijsmiddelen, de overtuiging hebbe bekomen, dat eene strafbare daad werkelijk heeft plaats gehad, en dat de beklaagde daaraan schuldig is; dat uit deze bepaling, in verband met die, welke het motiveren der vonnissen in strafzaken voorschrijft, ontwijfelbaar volgt, dat uit de vermelding der redenen moet blijken dat de voorschriften omtrent het bewijs niet zijn veronachtzaamd, opdat de beklaagde daarin eenen waarborg vinde tegen willekeurige veroordeling, enkel op innerlijke overtuiging gegrond'. ${ }^{121}$

Daarmee wordt de motivering nadrukkelijk in verband gebracht met het geldende bewijsrecht, maar wordt de omvang van de motivering ook daartoe beperkt. Uit het vonnis moet blijken dat de wettelijke bewijsregels in acht zijn genomen. Dit betekent dat vonnissen vanaf 1838 , ondanks het feit dat de wet die eis niet nadrukkelijk bevat, de inhoud van de bewijsmiddelen moeten bevatten. ${ }^{122}$ Van de rechter wordt echter niet geëist dat hij toelicht in hoeverre de bewijsmiddelen hem betrouwbaar voorkomen en in hoeverre het geheel der bewijsmiddelen toereikend is om daarop de overtuiging te baseren:

'dat tot de zaken, waarvan de beoordeeling aan den regter in cassatie is opgelegd, wél behoort het onderzoek omtrent de wettigheid der bewijsmiddelen, door welke de regterlijke overtuiging is teweeg gebracht, doch dat dat onderzoek zich niet mag uitstrekken tot de waardeering der bewijsmiddelen in zich zelve, noch tot de vraag of, en in hoeverre zij, ofschoon van aard wettig en aannemelijk, in regten kunnen geacht worden als elementen ter bewerking van regterlijke overtuiging toereikend te zijn geweest, aangezien de daadzaken in een arr. of vonnis, waarvan beroep in Cassatie vermeld, volgens art. 105 R.O. als bestaande moeten beschouwd en aangenomen worden, en dat overzulks, het inroepen van art. 433 [Sv 1838; WD] ten deze geene toepassing kan vinden'. ${ }^{123}$

\subsubsection{Gevolgen voor de praktijk}

De betekenis die de Hoge Raad aan artikel 211 Sv 1838 (en later artikel 221 Sv 1886) geeft, heeft vergaande gevolgen voor de praktijk. De verplichting om de inhoud van de bewijsmiddelen op te nemen, leidt ertoe dat vonnissen veel uitgebreider zijn dan tot dan toe gebruikelijk. Men kan immers niet langer volstaan met de enkele overweging dat het tenlastegelegde feit en de schuld van de verdachte blijkt uit de bekentenis van de verdachte en/of de verklaringen van diverse getuigen. De jurisprudentie van de Hoge Raad aangaande artikel 211 Sv

121 HR 24 december 1838, Rechtskundig Bijblad 1839, p. 44-50. Zie voor de conclusie van advocaat-generaal Van Maanen, Nederlandsche Jaarboeken voor regtsgeleerdheid en wetgeving 1839, p. 68-83.

122 Redactie Regtsgeleerd Bijblad 1839, p. 295.

123 HR 4 juni 1839, aangehaald door Gompertz 1885, p. 21. 
1838 wordt zodanig uitgelegd dat in het vonnis de door de strafrechter gebezigde verklaringen van getuigen en van de verdachte in extenso moeten worden opgenomen. ${ }^{124}$

Het opnemen van de inhoud van het gebezigde bewijsmateriaal vereist echter een grote mate van alertheid van de strafrechter. Immers, hij mag geen zaken opnemen die niet voldoen aan de wettelijke eisen. Doet hij dit toch, dan wordt het vonnis in zijn geheel in cassatie vernietigd. Iets wat in deze periode veelvuldig voorkomt, omdat volgens de redactie van het Rechtsgeleerd Bijblad rechters niet gewend zijn om op enige wijze het bewijsoordeel te motiveren:

'Nadat gedurende bijna 30 jaren door den Regter alleen het schuldig of niet-schuldig, zonder opgave van redenen, is uitgesproken, is het iets ongewoons, die beweeggronden te moeten vermelden; en juist in die ongewoonheid is de groote moeijelijkheid gelegen. Hierbij komt, dat het voor de Regters, die onder de vorige Wetgeving reeds in functie zijn geweest, iets vreemds is, de gronden hunner overtuiging aan de voorschriften der Wet te moeten toetsen. ${ }^{125}$

Met name het bewijsmiddel der aanwijzingen levert in dit verband problemen op. Zoals reeds in paragraaf 2.2.4.2 beschreven, mag de strafrechter geen aanwijzingen uit aanwijzingen afleiden. Hij mag dus uit feiten die uit de toegestane bewijsmiddelen blijken wel door middel van redenering nieuwe feiten afleiden, maar het is niet toegestaan om uit deze afgeleide feiten wederom nieuwe feiten te destilleren. Voor zover uit het vonnis blijkt dat de rechter wel het bestaan van aanwijzingen uit aanwijzingen heeft afgeleid, wordt het in cassatie vernietigd. Dat leidt ertoe dat rechters niet langer in hun vonnissen de feiten waaruit zij het bewijs indirect afleiden nadrukkelijk noemen. Zij volstaan in het vonnis met het weergeven van de inhoud van de relevante verklaringen gevolgd door de overweging dat uit deze verklaringen en de daaruit voortvloeiende aanwijzingen in onderling verband is gebleken dat de verdachte het feit heeft begaan. ${ }^{126}$ Door het vonnis op deze wijze vorm te geven, kan het in cassatie alleen worden vernietigd indien uit die verklaringen het bewezenverklaarde niet direct dan wel indirect kan volgen. Deze praktijk wordt door de Hoge Raad toegestaan. Hij eist namelijk niet dat de feitenrechter in een veroordelend vonnis vermeldt welke verklaringen of delen daarvan door hem als rechtstreekse bewijsmiddelen dan wel als anwijzingen zijn gebezigd. ${ }^{127}$ Aldus ontstaat een algemene praktijk van vonnis wijzen

124 Jolles 1874, p. 465 bestrijdt deze uitleg van de jurisprudentie van de Hoge Raad: 'De Hoge Raad verlangde alleen, dat zou worden aangewezen, wat uit de bekentenis, of de verklaring der getuigen, of het proces-verbaal gebleken was.'

125 Redactie Regtsgeleerd Bijblad 1839, p. 304.

126 Taverne 1924, p. 306-307: 'Zoo is ten slotte door de aanwijzingen-door-aanwijzingenjammer de toestand ontstaan dat de rechter de bewijsconstructie zoo min mogelijk motiveert, omdat, wat dat punt betreft, het best gemotiveerde vonnis de meeste vernietigingskansen bevat.'

127 Waaldijk 1963, p. 58. 
waarin niet zozeer de inhoud van de motivering, maar enkel de vorm doorslaggevend is, of in de woorden van Simons:

'het (was) niet meer de vraag óf de rechter in zijn vonnis rekenschap moest geven van de door hem gevolgde bewijsvoering, maar hoe die bewijsvoering moest zijn ingericht om te voldoen aan art. 211 en aan cassatie te ontsnappen. ${ }^{128}$

De oorzaak hiervan wordt door Simons in verband gebracht met het in 1838 geïntroduceerde negatief-wettelijk bewijsstelsel, en het feit dat de Hoge Raad de motiveringsplicht enkel daarmee in verband bracht. De conclusie van de tegenstanders van een negatief-wettelijk bewijsstelsel, dat een dergelijk stelsel ertoe leidt dat de motivering iets verwrongens, iets sjabloonmatigs krijgt, was dus niet helemaal uit de lucht gegrepen. Daarbij moet echter worden aangetekend dat vooral ook de wijze waarop de Hoge Raad inhoud gaf aan de woorden 'met redenen omkleed', zoals opgenomen in artikel $211 \mathrm{~Sv} 1838$ en artikel $221 \mathrm{~Sv}$ 1886, eraan heeft bijgedragen dat geen sprake was van een daadwerkelijke motivering van het bewijsoordeel in strafzaken.

\subsection{Het Wetboek van Strafvordering van 1926}

In het uiteindelijk in 1926 in werking getreden Wetboek van Strafvordering wordt aan het negatief-wettelijk bewijsstelsel in grote lijnen vastgehouden. Wel blijkt uit de totstandkoming van het Wetboek van Strafvordering van 1926 dat men met de praktijk van motiveren die onder het vorige Wetboek gebruikelijk was, wilde breken:

'Het veroordelend vonnis behelst in de meeste gevallen niet meer dan eenen opsomming van hetgeen door de getuigen en den verdachte is verklaard voor zoover deze verklaringen ten bezware van laatstgenoemde strekken, (en) de overweging dat door die verklaringen of de daarin gelegen aanwijzingen het wettig en overtuigende bewijs van het te laste gelegde geleverd wordt geacht (...). Welke de aanwijzingen zijn, waarom de rechter aan de bijgebrachte bewijsgronden bewijskracht toekent, (...), wordt in den regel niet medegedeeld., ${ }^{129}$

De opstellers van het Wetboek achten het dus mogelijk de motivering meer inhoud te geven met behoud van de wettelijke bewijsregels. Daartoe wordt een viertal motiveringsvoorschriften in het Wetboek opgenomen, te weten 1) het vonnis bevat de inhoud van de bewijsmiddelen, 2) de redengevende feiten en omstandigheden

128 Simons 1898, p. 329; In gelijke zin: Gompertz 1885, p. 30: 'Welke is dan de waarborg der verplichte motiveering in ons recht? Van een algemeen vereischte, een grondwettig beginsel, beperkt haar de Jurisprudentie tot de uiteenzetting van het wettelijk bewijs. En ook daar nog is hij zuiver formeel. Slechts gelden de voorschriften der quantiteit, terwijl uitdrukkelijk is uitgemaakt dat op de qualiteit niet mag gelet worden. Daardoor werkt zij eerder belemmerend, dan dat zij tot waarborg strekt'.

129 Kamerstukken II 1913-1914, 286, nr. 3 (MvT), p. 179. 
moeten worden aangewezen, 3) het gebruik van getuigen als bedoeld in artikel $216 \mathrm{~Sv}$ moet nader worden gemotiveerd, en 4) de beslissing over de vraag of de verdachte het feit heeft begaan, is met redenen omkleed. Deze motiveringseisen moeten er toe leiden dat de bestaande praktijk van motivering een halt wordt toegeroepen:

'Een vonnis, eenvoudig achtereenvolgens de gebezigde bewijsmiddelen opsommend met de bijvoeging dat uit die bewijsmiddelen en de daaruit voorvloeiende aanwijzingen, alles in onderling verband en samenhang, het bewijs is geleverd, zooals de Hoge Raad onder het vroegere recht was toegelaten, niet meer geoorloofd is. ${ }^{, 130}$

\subsubsection{De inhoud van de bewijsmiddelen}

Op grond van het eerste lid van artikel $359 \mathrm{~Sv} 1926$ moeten in het vonnis de tenlastelegging en de inhoud van de bewijsmiddelen worden vermeld. Het eerste lid luidt:

Het vonnis bevat het ten laste gelegde alsmede de inhoud van de bewijsmiddelen, voor zover deze tot het bewijs daarvan geldt.

In het Ontwerp-Ort kwam de bewuste bepaling niet voor. Artikel 408 van dat ontwerp eiste slechts dat het vonnis de bewijsmiddelen moest vermelden waaruit de feiten bleken waarop de overtuiging van de rechter steunde. Het weergeven van de inhoud van de bewijsmiddelen in het vonnis was niet noodzakelijk. Echter, op voorstel van Dresselhuys wordt alsnog besloten nadrukkelijk in de wettekst vast te leggen dat de inhoud van de bewijsmiddelen in het vonnis moet worden opgenomen. Het voorstel van Dresselhuys is echter niet meer dan een codificatie van de bestaande jurisprudentie. De Hoge Raad had die eis reeds in 1838 uit artikel $211 \mathrm{~Sv}$ (1838) afgeleid. Uit de memorie van toelichting bij het Ontwerp van de Staatscommissie blijkt eveneens dat men die jurisprudentie een wettelijke grondslag wilde geven. Het voorschrift beoogt te garanderen dat slechts wettige bewijsmiddelen tot de constructie van het bewijs zullen medewerken. ${ }^{131}$

Het feit dat deze eis reeds op grond van de vorige wetboeken gold, is er misschien debet aan dat de wetgever dit niet, althans niet als een nieuw, motiveringsvoorschrift beschouwde. In de memorie van toelichting wordt een vijftal eisen met betrekking tot de motivering genoemd; het weergeven van de inhoud van de bewijsmiddelen komt in deze opsomming niet voor. ${ }^{132}$

Een andere reden voor het niet beschouwen van het opnemen van de inhoud van de bewijsmiddelen als onderdeel van de motivering kan worden gevonden in het

130 Simons 1925, p. 238.

131 Kamerstukken II 1913-1914, 286, nr. 3 (MvT), p. 179.

132 Kamerstukken II 1913-1914, 286, nr. 3 (MvT), p. 179-181. In gelijke zin: Knigge 1980, p. 141. 
aan het ontwerp ten grondslag liggende onderscheid tussen bewijsmiddelen en bewijsgronden. Bewijsmiddelen worden beschouwd als de trechter waarlangs de feiten die voor de bewezenverklaring mogelijk relevant zijn ter kennis van de rechter komen. De bewijsgronden zijn in deze optiek de feiten zelf. Zo is de getuigenverklaring een bewijsmiddel en de daarin genoemde feiten kunnen als bewijsgrond dienen. De daadwerkelijke motivering van de bewezenverklaring bestond volgens de toelichting op het ontwerp in het aanwijzen van de (bewijs) gronden voor dat oordeel. Daarmee wordt bedoeld dat de rechter de feiten en omstandigheden in het vonnis moet noemen waaruit hij het bewijs van het tenlastegelegde feit afleidt, opdat controle kan worden uitgeoefend 'op datgene wat men veilig zou kunnen noemen den logischen gedachtengang der vonnissen'. ${ }^{133}$ Deze inhoudelijke motiveringseis komt tot uitdrukking in het derde lid van artikel 359 Sv 1926 waarin van de rechter wordt verwacht dat hij de redengevende feiten en omstandigheden, dus de bewijsgronden, aanwijst. De eis dat deze feiten ook via een wettig bewijsmiddel ter kennis van de rechter moeten komen is niet beschouwd als een onderdeel van de eigenlijke motivering. Het is een logische consequentie van het in de wet opnemen van bewijsregels, maar ziet niet op de inhoudelijke verantwoording van het bewijsoordeel. De wettigheid van (de inhoud van) het gebezigde bewijsmateriaal is een bijkomende eis, die wellicht oorspronkelijk in de optiek van de opsteller van het ontwerp Wetboek van Strafvordering, Ort, niet aan de hand van het vonnis, maar op basis van het proces-verbaal van de zitting kan worden gecontroleerd. ${ }^{134}$ Bij de behandeling van dit ontwerp komt de commissie-Ort daarop terug. De commissie acht de enkele vermelding van de bewijsmiddelen in het vonnis onvoldoende en eist alsnog dat ook de inhoud daarvan in het vonnis wordt opgenomen.

Overigens is het door Ort en ook door de commissie-Ort voorgestane onderscheid tussen bewijsmiddelen en bewijsgronden door velen betwist. Bij de uiteindelijke behandeling van het ontwerp Wetboek van Strafvordering moet ook Ort, toen Minister van Justitie, erkennen dat het onderscheid niet altijd goed was doorgevoerd. ${ }^{135}$

\subsubsection{Het aanwijzen van de redengevende feiten en omstandigheden}

In het derde lid van artikel $359 \mathrm{~Sv} 1926$ wordt de eis opgenomen dat in het vonnis de redengevende feiten en omstandigheden moeten worden aangewezen. Lid 3 luidt:

133 Kamerstukken II 1913-1914, 286, nr. 3 (MvT), p. 180.

134 In gelijke zin: Knigge 1980, p. 142.

135 Kamerstukken II 1917-1918, 77, nr. 1 (verslag van de Commissie van Voorbereiding en het antwoord van de Minister), p. 59. 
De beslissing dat het feit door de verdachte is begaan, moet steunen op daartoe redengevende feiten of omstandigheden, als zodanig in het vonnis aangewezen.

Zoals hiervoor beschreven komt dit specifiek op de bewezenverklaring betrekking hebbende motiveringsvoorschrift voort uit de problemen die het bewijsmiddel der aanwijzing zoals dat in het Wetboek van 1838 en 1886 was opgenomen met zich bracht. De kwalificatie van de aanwijzing als bewijsmiddel en de toepassing van het daaraan gekoppelde verbod om aanwijzingen uit aanwijzingen af te leiden, hadden uiteindelijk als consequentie dat vonnissen weinig inzichtelijk waren en vaak niet meer omvatten dan een opsomming van de verklaringen waaruit het bewezenverklaarde kon worden afgeleid:

'Bij de geldende wijze van motiveering wordt het aan den lezer van het vonnis overgelaten te trachten, den gedachtengang, die den regter tot zijne beslissing heeft geleid te reconstrueren. 136

Het schrappen van de aanwijzing als wettig bewijsmiddel in het Wetboek van Strafvordering in 1926 betekent echter niet dat de aanwijzing niet meer voor het bewijs kan worden gebezigd. In die gevallen waarin geen direct bewijs van de betrokkenheid of de schuld van de verdachte aanwezig is, kan de rechter uit het bestaan van bepaalde feiten en omstandigheden eveneens de conclusie trekken dat de verdachte bij het hem tenlastegelegde feit is betrokken dan wel daaraan schuld heeft. Ook mag de rechter in zijn bewijsconstructie gebruik maken van een aaneenschakeling van gevolgtrekkingen. Dit laatste was onder het oude Wetboek van Strafvordering verboden, maar wordt nu toelaatbaar geacht.

Om te voorkomen dat de rechter zijn gevolgtrekkingen niet expliciteert - zoals onder het oude Wetboek gebruikelijk was - wordt in het derde lid van artikel 359 Sv 1926 geëist dat de rechter de feiten in het vonnis aanwijst waarop hij zijn (tussen)conclusie baseert. Aldus wordt de feitenrechter door het op schrift stellen van de argumenten die hem logisch tot zijn conclusie hebben geleid, verplicht zich nauwkeurig rekenschap te geven van de waarde van het materiaal waaruit hij zijn conclusie opbouwt. ${ }^{137}$ Bovendien kan de naleving van het voorschrift worden gegarandeerd, immers:

'Zoowel de rechter in hooger beroep als die in cassatie zal derhalve voortaan controle moeten uitoefenen op datgene, wat men veilig zou kunnen noemen, den logischen gedachtengang der vonnissen [cursivering: WD]. ${ }^{138}$

Bij de totstandkoming van deze bepaling is onder andere punt van debat geweest in hoeverre deze bepaling ook geldt indien de bewezenverklaring steunt op direct bewijs. In een dergelijk geval is er immers geen sprake van een gevolgtrekking,

136 Notulen van de Staatscommissie voor de herziening van het Wetboek van Strafvordering; het verslag van $52^{\mathrm{e}}$ vergadering. p. 4, opgenomen in Lindenberg 2002, p. 353.

137 Kamerstukken II 1913-1914, 286, nr. 3 (MvT), p. 180

138 Kamerstukken II 1913-1914, 286, nr. 3 (MvT), p. 180. 
maar zijn de feiten en omstandigheden die bijvoorbeeld een getuige heeft waargenomen en waarover hij verklaart direct relevant voor de bewezenverklaring. Het aanwijzen van de redengevende feiten en omstandigheden zou dan overeenkomen met het vermelden van de inhoud van de bewijsmiddelen, en die eis wordt al gesteld in het eerste lid van artikel $359 \mathrm{~Sv} 1926 .{ }^{139}$ Tijdens de beraadslagingen van de Staatscommissie-Ort is dit punt uitdrukkelijk aan de orde geweest. Simons, van wie het voorstel tot het aanwijzen van de redengevende feiten en omstandigheden in het vonnis komt, meent dat de noodzaak tot het aanwijzen van de redengevende feiten en omstandigheden alleen bestaat in geval van indirect bewijs. Het uiteindelijke standpunt van de commissie is echter dat ook in geval van rechtstreeks of direct bewijs de eis kan worden gehandhaafd. Dit hoeft volgens de Commissie niet te leiden tot breedvoerige uiteenzettingen in het vonnis. Ingeval van direct bewijs kan na de vermelding van de inhoud van de bewijsmiddelen bijvoorbeeld worden volstaan met de overweging 'dat de getuigen A en B de verdachte het hem tenlastegelegde feit hebben zien plegen'. ${ }^{140}$

Een tweede punt waarover binnen de Commissie-Ort met betrekking tot artikel 359 lid 3 Sv 1926 onduidelijkheid bestond, betreft de vraag welke feiten in het vonnis moeten worden aangewezen. Moeten dit de feiten zijn waaruit wordt afgeleid, en dus de feiten zoals die uit de bewijsmiddelen naar voren komen? Of moeten de daaruit afgeleide feiten in het vonnis worden opgenomen? Deze vragen zijn alleen relevant voor zover de bewezenverklaring niet rechtstreeks, dus indirect, uit de bewijsmiddelen voortvloeit. Zoals gezegd worden in geval van een directe bewijsconstructie geen feiten uit andere feiten afgeleid en kan er dus geen sprake zijn van het vermelden van afgeleide feiten. Met betrekking tot indirecte bewijsconstructies blijft deze kwestie onduidelijk. Uit de verslaglegging van de Commissie kan worden opgemaakt dat men het oog had op de 'afgeleide' feiten. ${ }^{141}$ Beziet men echter het modelvonnis, dat bij wijze van voorbeeld in de memorie van toelichting is opgenomen, dan valt op dat daarin geen afgeleide feiten worden

139 Aldus Blok \& Besier 1925, p. 205: 'Doch dan is de eisch, dat de redengevende feiten in het vonnis zullen worden opgenomen, bij rechtstreeksche bewijsvoering overbodig, daar het eerste lid van art. 359 reeds het opnemen van de inhoud der bewijsmiddelen in het vonnis vordert.'

140 Notulen van de Staatscommissie voor de herziening van het Wetboek van Strafvordering; het verslag van $52^{\mathrm{e}}$ vergadering, p. 4-5, opgenomen in Lindenberg 2002, p. 353.

141 In het verslag van $52^{\mathrm{e}}$ vergadering van de Staatscommissie voor de herziening van het Wetboek van Strafvordering, opgenomen in Lindenberg 2002, p. 353, staat op p. 5 te lezen: 'Ingeval van indirect bewijs zullen b.v. eerst kunnen worden opgesomd de verschillende feiten en omstandigheden, die den rechter tot zijne overtuiging hebben gebracht, waarna zal kunnen volgen: 'zijnde omstandigheid A, blijkens hunne ter terechtzitting afgelegde verklaring, waargenomen door de getuigen B en C,' enz. Ook kan intusschen eerst de inhoud der bewijsmiddelen worden vermeld en daarna worden opgegeven, welke feiten en omstandigheden daaruit werden afgeleid.' 
benoemd. ${ }^{142}$ Ook Zijlstra komt tot de conclusie dat men in het modelvonnis tevergeefs zoekt naar de verwachte 'tussenschakels' tussen de bewijsmiddelen en het bewezenverklaarde. ${ }^{143}$

Beide punten, de vraag in hoeverre het aanwijzen van de redengevende feiten ook geldt in geval van een directe bewijsconstructie en de vraag wat onder een redengevend feit moet worden verstaan, hangen nauw met elkaar samen. Wordt onder een redengevend feit verstaan het feit waaruit wordt afgeleid, dan is ook het aanwijzen van redengevende feiten in geval van een directe bewijsconstructie mogelijk, zij het dat dit niets toevoegt, aangezien in het eerste lid van artikel 359 Sv 1926 al wordt geëist dat de inhoud van de bewijsmiddelen in het vonnis wordt vermeld. Wordt daarentegen van de feitenrechter verlangd dat hij alleen de afgeleide feiten in het vonnis vermeldt, dan is dit in geval van een directe bewijsconstructie onmogelijk. Vooruitlopend op hetgeen in hoofdstuk vijf aan de orde zal worden gesteld, kan reeds nu worden gezegd dat de betrekkelijke waarde die uiteindelijk het aanwijzen van de redengevende feiten in het vonnis voor de rechtspraktijk zal hebben, kan worden toegeschreven aan de ondoordachte keuzes die de wetgever op dit punt heeft gemaakt.

\subsubsection{Bijzondere motiveringsplicht in geval van 'onbekwame' getuigen}

Een van de grote manco's van de bewijsregeling zoals opgenomen in het Wetboek van Strafvordering van 1838 betrof de uitsluiting van verklaringen van onbevoegde getuigen. Zoals hiervoor uiteengezet, werd als wettig bewijsmiddel alleen de verklaring van een bevoegde getuige erkend. Verklaringen van onbevoegde getuigen, zoals minderjarigen en onder curatele gestelden, mochten in principe niet voor het bewijs gebruikt worden (art. $433 \mathrm{~Sv} 1838$ en Sv 1886). ${ }^{144}$ Hierop maakte de wetgever van 1838 echter wel een uitzondering. In die gevallen waarin een onbevoegde getuige ter zitting was gehoord, mocht zijn verklaring wel als toelichting op de bewezenverklaring gelden (art. $445 \mathrm{~Sv} 1838$ en art. $409 \mathrm{~Sv}$ 1886). De onbevoegdheid van de getuige had niet tot consequentie dat ook verklaringen van deze personen ter zitting werden geweerd. De artikelen 188 en $190 \mathrm{~Sv}$

142 Taverne spreekt in dit verband van zogheten 'tusschenfeiten' en komt eveneens tot de conclusie dat het modelvonnis die niet noemt. In het modelvonnis is slechts de inhoud van de bewijsmiddelen opgenomen. Taverne 1927, p. 247.

143 Zijlstra 1926, p. 8. In gelijke zin: J.E. Simons 1926, p. 8.

144 In art. 433 Sv 1838 worden als onbevoegd aangemerkt getuigen zoals genoemd in de artikelen 188 en 190 van dat wetboek. Art. 188 noemt de (ex-)echtgenoot, verschillende bloed- en aanverwanten van de beschuldigde, en de aanbrengers, wier aangiften door de wet met geld beloond worden. Art. 190 verklaart kinderen tot zestien jaar, personen die bij gebrek aan verstandelijke vermogens onder curatele zijn gesteld en tot een onterende straf veroordeelde personen niet bevoegd. In het Wetboek van 1886 worden deze bepalingen enigszins gewijzigd. Degenen die aangifte van een strafbaar feit hebben gedaan worden niet langer als onbevoegd aangemerkt. Zie art. 162, 164 en 165 Sv 1886. 
1838 bepaalden dat ook de onbevoegde getuige ter informatie van de rechter kon worden gehoord. In dat geval werd echter niet de eed afgenomen. Hoewel niet geheel duidelijk was welke waarde nu eigenlijk aan dergelijke onbeëdigde verklaringen kon worden gegeven, ${ }^{145}$ merkte Feith ${ }^{146}$ terecht op dat praktisch gezien de rechter zijn overtuiging evengoed op verklaringen van bevoegde en beëdigde, als op onbevoegde en niet beëdigde getuigen mocht vestigen. Daarmee wordt het stelsel van een limitatieve opsomming van de wettelijke toegestane bewijsmiddelen ondergraven. ${ }^{147}$

Bovendien was er veel kritiek op het in het Wetboek van 1838 en 1886 gemaakte onderscheid met betrekking tot getuigen. Velen waren van mening dat niet viel in te zien waarom per definitie aan de verklaring van een 15-jarige minder gewicht moet worden toegekend dan aan de verklaring van een 17 -jarige. ${ }^{148}$ En ook ten aanzien van een persoon die onder curatele was gesteld, wilde men geen absolute uitsluiting van zijn verklaring voor het bewijs in strafzaken.

'Sluit men om redenen van algemeenen aard dezen of genen van het afleggen van getuigenis uit, men berooft den rechter van eene bron van kennis, die voor de ontdekking der waarheid van groot nut zou kunnen geweest zijn en onthoudt hem een getuige, die wellicht alle waarborgen van geloofwaardigheid zou hebben gegeven. ${ }^{, 149}$

Anderen daarentegen meenden dat in ieder geval moest worden vastgehouden aan de eis van beëdiging. In geval de getuige niet in staat was de eed af te leggen, omdat hij of zij onvoldoende besef had van het 'gewicht der waarheid in het strafgeding', moest ook zijn verklaring worden uitgesloten van het bewijs. ${ }^{150}$

In het Wetboek van Strafvordering van 1926 wordt aan de bestaande kritiek op dit punt tegemoet gekomen. Niet langer wordt onderscheid gemaakt tussen bevoegde en niet-bevoegde getuigen. In principe is elke getuige in staat om een verklaring af te leggen. Wel wordt onderscheid gemaakt tussen de beëdigde en niet-beëdigde getuige. Aan de eis dat elke getuige een verklaring onder ede moet afleggen, wordt vastgehouden. Men beschouwt dit als een waarborg voor de juistheid van die verklaring. De getuige die een niet waarheidsgetrouwe verklaring aflegt, loopt immers het risico dat hij ter zake van meineed zal worden vervolgd.

145 Zie voor een korte schets van de diverse opvattingen: Simons 1899, p. 265-266.

146 Feith 1910, p. 65-66.

147 Zie Simons 1899, p. 266: 'Art. 409 [1886, WD] is in ons bewijssysteem eene inconsequentie maar dit belet niet dat de wetgever die bepaling aldus kan hebben gewild, haar als een min of meer erkende uitzondering op zijn algemeen beginsel kan hebben bedoeld.' Zie ook: Pols 1882, p. 384.

148 Gratama 1854, p. 227.

149 Simons 1899 , p. 271.

150 Pols 1882, p. 385; In gelijke zin: Feith 1910, p. 69: 'Het wil er bij mij niet in, dat verklaringen van personen, die niet ontwikkeld genoegd zijn om een eed af te leggen, toch van zoodanig belang zijn, dat de rechter er zijne overtuiging op zou kunnen bouwen.' 
Een uitzondering op de regel dat elke getuige de eed dan wel de belofte moet afleggen, wordt gecreëerd voor personen die de betekenis van de eed of belofte niet voldoende beseffen. Zij worden slechts gemaand conform de waarheid te verklaren. ${ }^{151}$ Het gaat dan om personen die de leeftijd van zestien nog niet hebben bereikt of personen met een gebrekkige ontwikkeling van hun geestesvermogens. Deze kunnen wel als getuigen worden gehoord en hun verklaringen kunnen ook voor het bewijs worden gebezigd, maar van de rechter wordt verlangd dat hij, voor zover hij de bewezenverklaring onder andere op een dergelijke verklaring doet steunen, in het vonnis uiteenzet waarom hij ondanks het ontbreken van de eed dan wel belofte daaraan toch waarde hecht.

Deze bijzondere motiveringsplicht is neergelegd in artikel 360 lid 1 Sv 1926:

Van het gebruik als bewijsmiddel van de verklaring van de getuige bedoeld in artikel 216, tweede lid, geeft het vonnis in het bijzonder reden.

Wat deze nadere motiveringsplicht zou moeten inhouden, wordt noch in de memorie van toelichting noch in de eerdere stukken die aan de basis lagen van het Wetboek van Strafvordering van 1926 verduidelijkt. Blok en Besier vinden de bijzondere redenen in de omstandigheden welke voor de rechter aanleiding zijn om ondanks het aan de getuige eigen gebrek toch vertrouwen te schenken aan zijn verklaring.

'Die omstandigheden kunnen b.v. zijn de zeer eenvoudige aard van het verklaarde, de den rechter gebleken ontwikkeling van het vermogen van den getuige om waar te nemen en waarnemingen weer te geven en dergelijke. Van die omstandigheden moet hij [de rechter; WD] dan in het vonnis rekenschap geven. ${ }^{152}$

\subsubsection{Met redenen omkleed}

De laatste eis met betrekking tot de motivering van het eindoordeel van de feitenrechter is opgenomen in het tweede lid van artikel $359 \mathrm{~Sv}$ 1926:

De beslissingen vermeld in de artikelen 349, eerste lid, en 358, tweede en derde lid, zijn met redenen omkleed.

Relevant voor de bewijsbeslissing is de verwijzing naar artikel 358 lid 2 Sv 1926. Dit betekent dat de beslissingen vermeld in artikel 350 Sv 1926 waaronder die met betrekking tot de vraag of de verdachte het hem tenlastegelegde feit heeft begaan, met redenen moeten zijn omkleed. Deze eis geldt dus zowel ten aanzien van een vrijspraak als voor het geval waarin de rechter komt tot een bewezenverklaring.

151 Het huidige art. 216 tweede lid Sv.

152 Blok \& Besier 1925, p. 214. 
In het ontwerp Wetboek van Strafvordering van de Commissie-Ort was de verplichting van de rechter om ook de bewijsbeslissing met redenen te omkleden niet opgenomen. Sterker nog: uit het ontwerp van de Staatscommissie blijkt dat men slechts een motivering van de rechter eiste ten aanzien van zijn beslissing met betrekking tot de zogeheten voorvragen. ${ }^{153}$ Ten aanzien van de hoofdvragen, met uitzondering van die met betrekking tot de bewijsvraag, werd slechts een nadere redengeving verlangd indien een 'te dien aanzien door den verdachte uitdrukkelijk voorgedragen verweer' niet was gehonoreerd. ${ }^{154}$ Een algemene motiveringsplicht ten aanzien van de materiële of hoofdvragen werd dus door de Commissie-Ort niet beoogd. Een verplichte motivering van een vrijspraak werd in het geheel niet wenselijk geacht. Gewezen werd onder andere op het gevaar dat aldus twee categorieën vrijgesprokenen zouden ontstaan, te weten zij die eervol en zij die oneervol worden vrijgesproken. ${ }^{155}$

'Wel is waar is het ook hierbij voor den officier van justitie en den verdachte vaak van belang te weten, welk punt der aanklacht door den rechter niet bewezen wordt geacht, en zou motiveering somtijds haar nut hebben, doch in de meeste gevallen is zulks onverschillig en is het voor den verdachte ook beter, indien niet wordt onderscheiden tusschen hen, die worden vrijgesproken omdat de rechter hunne onschuld als gebleken aanneemt, en hen die niet worden veroordeeld, omdat het bewijs van het te laste gelegde niet ten volle is geleverd. ${ }^{156}$

Waarom in de uiteindelijk in 1920 vastgestelde tekst de eis dat de rechter zijn beslissingen moest motiveren ook is uitgebreid tot de feitelijke beslissing wordt uit de parlementaire stukken niet duidelijk. ${ }^{157}$ Waarschijnlijk is dat men ten aanzien van de kwalificatiebeslissing, de beslissing over de strafbaarheid van het feit en de dader, en de bepaling van de straf ook in geval er geen verweer werd gevoerd toch van de rechter een nadere verantwoording wilde. ${ }^{158}$ Wellicht is vervolgens abusievelijk door de verwijzing naar artikel 350 Sv 1926 ook de bewijsbeslissing

153 Deze verplichting geldt ongeacht of er een verweer op dit punt is gevoerd of niet. Artikel 342 lid 1 jo. 351 lid 1 jo. 351 lid 3 jo. 352 lid 2 van het Ontwerp Wetboek van Strafvordering. Anders Knigge 1980, p. 60, die meent dat in de ogen van de concept-wetgever er ten aanzien van de formele of voorvragen alleen een verplichting tot verantwoording bestond indien ter zake door de verdachte verweer was gevoerd.

154 Art. 351, derde volzin, Ontwerp van de Staatscommissie, opgenomen in Lindenberg 2002, p. 404.

155 Notulen van de Staatscommissie voor de herziening van het Wetboek van Strafvordering; het verslag van $42^{\mathrm{e}}$ vergadering. p. 9-10, opgenomen in Lindenberg 2002, p. 334.

156 Kamerstukken II 1913-1914, 286, nr. 3 (MvT), p. 180.

157 Aldus ook Taverne 1927, p. 216: 'Het merkwaardige van deze aanvulling van art. 359 tweede lid is wel dat uit niets blijkt waarom zij tot stand is gebracht. Men treft haar aan in het gewijzigde ontwerp (TK 1917-1918, 77, nr. 2) zonder dat iemand er om gevraagd heeft, terwijl de regering evenmin kenbaar maakt, waarom zij het artikel aanvulde.'

158 Blok \& Besier 1925, p. 207 vermoeden dat de wetgever deze wijziging noodzakelijk achtte in verband met art. 161 Grondwet (thans art. 121 Grondwet), dat bepaalde dat vonnissen met redenen omkleed waren. Zij achten het echter twijfelachtig of deze bepaling met zich bracht dat elke beslissing in het vonnis een opgave van de gronden vereiste. 
meegenomen als één van de beslissingen die met redenen omkleed moest worden, daarbij vergetende dat ten aanzien van de bewezenverklaring al drie motiveringsvoorschriften bestonden. ${ }^{159}$ Een andere verklaring is dat de verwijzing naar artikel $350 \mathrm{~Sv}$ met inbegrip van de bewijsbeslissing niet op een vergissing berust, maar dat dit bewust is gebeurd, omdat men het toch wenselijk achtte dat de rechter ook de vrijspraak nader zou motiveren. ${ }^{160}$

Hoewel dus niet geheel duidelijk is wat de achtergrond van de wijziging in het ontwerp-Ort is geweest, is het effect ervan dat in geval van een bewezenverklaring naast de andere in artikel 359 en 360 genoemde specifieke motiveringseisen, ook de algemene eis geldt dat deze beslissing met redenen omkleed moest zijn. In feite is er dus sprake van een verdubbeling van de motiveringseis op dit punt. ${ }^{161}$ Wat de algemene eis in concreto zal moeten inhouden wordt nergens geëxpliciteerd. Het is dan ook niet vreemd dat na de inwerkingtreding van het Wetboek in 1926 velen deze eis als overbodig beschouwen en daaraan geen enkele betekenis toekennen. ${ }^{162}$

\subsection{Conclusie}

De ontwikkeling van de motiveringsvoorschriften vanaf het begin van de $19^{\mathrm{e}}$ eeuw tot aan de inwerkingtreding van het Wetboek van Strafvordering 1926 kan niet los worden gezien van de ontwikkeling van het materiële bewijsrecht. Aan het begin van de $19^{\mathrm{e}}$ eeuw wil men duidelijk afstand nemen van het stelsel van de conviction intime waarin het bewijsoordeel is overgelaten aan de subjectieve overtuiging van de rechter.

Het Wetboek van Strafvordering van 1838 bindt de rechter aan de daarin opgenomen bewijsregels en daarmee tracht men het bewijsoordeel in strafzaken in zekere mate te objectiveren. De in het Wetboek van 1838 opgenomen bewijsregeling is echter alles behalve consequent en leidt in de praktijk tot onoverkomelijke bezwaren. De in artikel $211 \mathrm{~Sv} 1838$ opgenomen eis van motivering van de vonnissen wordt door de Hoge Raad zeer beperkt uitgelegd. Voldoende is dat uit het vonnis blijkt dat het door de rechter gebezigde bewijsmateriaal voldoet aan de wettelijke eisen. Praktisch gezien betekent dit dat een vonnis waarin de inhoud van het gebezigde bewijsmateriaal is opgenomen voldoende is. Deze praktijk leidt in het tweede deel van de $19^{\mathrm{e}}$ eeuw en het begin van de $20^{\mathrm{e}}$ eeuw tot fundamentele discussie over de vraag in hoeverre in de wet wel bewijsregels moeten worden opgenomen. Een van de wezenlijke punten in het debat

159 Taverne 1927, p. 216.

160 J. Simons 1926, p. 8.

161 Waaldijk 1963, p. 93.

162 Taverne 1927, p. 240. Taverne acht overigens ook het eerste lid van artikel 359 Sv overbodig. 
tussen de aanhangers van de wettelijke bewijstheorie en de voorstanders van een vrije bewijsleer betreft de waarde die men toekent aan de motivering van het bewijsoordeel. De laatstgenoemden menen dat de motivering essentieel is voor een deugdelijke waarheidsvinding. Alleen uit de motivering kan blijken dat het oordeel van de rechter niet enkel op zijn subjectieve overtuiging steunt. Zij menen bovendien dat in een wettelijk bewijsstelsel de motivering beperkt zal blijven tot een zeer formele, inhoudende dat het gebezigde bewijsmateriaal voldoet aan de wettelijke eisen. Zij beroepen zich daarbij op de gangbare praktijk. Voorstanders van een wettelijke bewijstheorie menen echter dat een vrije bewijsleer onvermijdelijk zal leiden tot een terugkeer naar het stelsel der conviction intime. Immers, bij gebrek aan wettelijke regels vervalt ook de mogelijkheid om in cassatie de bewijsbeslissing te toetsen, en dientengevolge krijgt de feitenrechter de vrijheid om op grond van zijn subjectieve overtuiging te oordelen.

De discussie over het bewijsstelsel en de omvang van de rechterlijke motiveringsplicht heeft ook zijn weerslag gehad op de inhoud van het Wetboek van Strafvordering 1926. De uiteindelijk vastgestelde bewijsregeling kan noch als een wettelijk noch als een vrij bewijsstelsel worden gekwalificeerd. Het is in principe een mix van beide waarbij er tussen de bewijsregels enerzijds en de eisen te stellen aan de motivering anderzijds een direct verband bestaat. Hoe stringenter de bewijsregels, des te minder eisen worden gesteld aan de rechterlijke verantwoording. Het behoud van de bewijsminima in het Wetboek van 1926 is daarvan een mooi voorbeeld. Andersom geldt evenzeer dat hoe meer vrijheid de rechter wordt gelaten, hoe groter de noodzaak is om door middel van een motiveringseis toch enige grip te houden op de 'juistheid' van het bewijsoordeel. In dat verband kan worden gewezen op het afschaffen van het bewijsmiddel 'aanwijzing' en de daarvoor in de plaats tredende plicht om in het vonnis de redengevende feiten en omstandigheden aan te wijzen. Ook de in artikel 360, eerste lid, Sv 1926 opgenomen motiveringsplicht ten aanzien van het gebruik van niet-beëdigde getuigenverklaringen bevestigt de idee dat bewijsregels en motiveringseisen functioneren als communicerende vaten.

In de komende hoofdstukken zal worden bezien in hoeverre de idee dat bewijsrecht en bewijsmotivering elkaar aanvullen ook in de verdere ontwikkeling van de diverse bepalingen naar voren komt. Daartoe zal in hoofdstuk 3 nader in worden gegaan op de ontwikkeling van het bewijsrecht na 1926. In hoofdstuk 4, 5 en 6 zal worden bezien hoe de verschillende in 1926 opgenomen motiveringsplichten in de praktijk uitwerkten. 


\section{Het Nederlandse bewijsrecht vanaf 1926}

\subsection{Inleiding}

Zoals in het vorige hoofdstuk bleek, is bij de invoering van het Wetboek van Strafvordering 1926 het negatief-wettelijk bewijsstelsel gehandhaafd. De rechter dient in gevolge artikel $338 \mathrm{~Sv}$ naar aanleiding van het onderzoek ter terechtzitting een bewijsbeslissing te nemen. In geval van een bewezenverklaring dient deze te steunen op wettige bewijsmiddelen. In artikel $339 \mathrm{~Sv}$ worden de bewijsmiddelen limitatief opgesomd en in de daarop volgende artikelen wordt elk van deze bewijsmiddelen nader omschreven en soms voorzien van een bewijsminimum. Bovendien wordt in het wetboek een bewijsverbod opgenomen: verklaringen van medeverdachten mogen niet voor het bewijs gebruikt worden. Oude zeer specifieke bewijsregels zijn verdwenen en vervangen door nadere motiveringsplichten. Dit geldt voor het bewijsmiddel der aanwijzing, dat werd vervangen door de plicht om de redengevende feiten en omstandigheden aan te wijzen. Ook de specifieke eisen met betrekking tot verklaring van jonge getuigen of getuigen met een gebrekkige geestelijke ontwikkeling werden vervangen door een nadere motiveringsplicht.

In de hoofdstukken 3, 4 en 5 zal specifiek worden ingegaan op de diverse motiveringsverplichtingen. In dit hoofdstuk staat het bewijsrecht centraal en meer specifiek op welke wijze inhoud is gegeven aan de eisen die aan de verschillende bewijsmiddelen worden gesteld vanaf 1926. Typerend is dat direct vanaf de inwerkingtreding van het Wetboek van Strafvordering de bewijsrechtelijke beperkingen die zijn gesteld aan het feitenoordeel van de strafrechter door de Hoge Raad niet al te strikt worden uitgelegd. Dat geldt niet alleen voor de materiële eisen die aan het door de rechter te gebruiken bewijsmateriaal worden gesteld, maar ook voor de procedurele eis dat het bewijs in mondelinge vorm ter zitting moet worden gepresenteerd. Achtereenvolgens zal op de onmiddellijke bewijsvoering, de wettige bewijsmiddelen, de bewijsverboden en bewijsminima worden ingegaan.

\subsection{Onmiddellijke mondelinge bewijsvoering}

De hele bewijsregeling zoals die in 1926 is vastgesteld, stoelt op de idee dat het onderzoek ter terechtzitting de centrale plaats is waar het bewijs in mondelinge vorm moet worden gepresenteerd. ${ }^{1}$ Hierin liggen twee eisen ten aanzien van de

1 In gelijke zin: Hoge Raad 1 juli 1985, NJ 1986, 161: 'Vooropgesteld moet worden dat 
presentatie van het bewijs besloten. Ten eerste dient zij in mondelinge vorm te geschieden. Ten tweede moet het bewijs ter terechtzitting gepresenteerd worden. Mondelinge presentatie van het bewijs heeft tot doel de communicatie ter zitting te optimaliseren. Het gesproken woord als vorm van communicatie is rijker aan spontane expressie dan het geschreven woord. ${ }^{2}$ Bovendien heeft mondelinge interactie ter zitting ook een toegevoegde waarde waar het de openbaarheid van de rechtspleging betreft. Niet alleen procespartijen, maar ook het publiek kan hetgeen ter zitting aan de orde wordt gesteld gemakkelijk volgen. De presentatie van het bewijs in een mondelinge vorm onderstreept aldus het openbare karakter van de zitting en daarmee het openbare karakter van de strafrechtspleging in zijn geheel. In die zin hangen de eis van mondelinge procesvoering en de eis dat al het bewijs op de zitting moet worden gepresenteerd - het onmiddellijkheidsbeginsel - onlosmakelijk met elkaar samen. ${ }^{3}$

De idee van mondelinge procesvoering is in het Nederlandse recht nergens nadrukkelijk verwoord, maar kan - waar het de bewijsvoering betreft - worden afgeleid uit de nadere omschrijving van elk van de bewijsmiddelen. Voor zover het bewijsmiddel uit een verklaring bestaat, moet deze in mondelinge vorm worden afgelegd. De enige uitzondering daarop vormen de schriftelijke bescheiden. Voor zover daarin verklaringen van personen zijn opgenomen, te denken valt vooral aan verklaringen van opsporingsambtenaren, kunnen deze ondanks het feit dat zij enkel in schriftelijke vorm de rechter bereiken voor het bewijs meewerken. ${ }^{4}$ Deze uitzondering op de mondelinge presentatie komt voort uit praktische redenen. Men zou onmogelijk kunnen verlangen dat in strafzaken telkens de opsporingsambtenaar ter zitting dient te verschijnen, teneinde daar hetgeen door hem met betrekking tot het strafbare feit is waargenomen mondeling te verklaren. ${ }^{5}$ Bovendien acht men de betrouwbaarheid van de inhoud van die processen-verbaal mede gegarandeerd

het behoort tot de in het Wetboek van Strafvordering neergelegde fundamentele regels van het strafproces, dat het bewijs dat de verdachte het hem ten laste gelegde heeft begaan door de rechter slechts mag worden aangenomen, indien hij daarvan uit het onderzoek op de terechtzitting door de inhoud van wettige bewijsmiddelen de overtuiging heeft verkregen. In het voorschrift dat de rechter beraadslaagt en beslist naar aanleiding van het onderzoek op de terechtzitting wordt het ook door art. 6 Europees Verdrag mensenrechten gewaarborgde onmiddellijkheidsbeginsel tot uitdrukking gebracht.'

2 Garé 1994, p. 54

3 In die zin ook Garé 1994, p. 54: 'Uit het beginsel der mondelinge procesvoering vloeit weliswaar geen onmiddellijkheid voor(t), het onmiddellijkheidsbeginsel daarentegen eist wel dat het proces mondeling gevoerd wordt.'

4 Ook voor deskundigen maakte men in art. 344 lid 1 onder 4 Sv een uitzondering. De reden om ten aanzien van hen niet altijd een mondelinge presentatie ter zitting te verlangen zijn tweeërlei. Enerzijds wenste men niet van dit bewijs af te zien als de deskundige mogelijk niet ter zitting kon verschijnen; anderzijds besefte men dat het onderzoek van de deskundige soms zo omvangrijk en ingewikkeld dan wel technisch kon zijn dat een schriftelijke rapportage meer voor de hand lag. Zie Hielkema 1996, p. 197.

$5 \quad$ Kamerstukken II 1913-1914, 286, nr. 3 (MvT), p. 166. 
door de persoon die ze opmaakt, te weten de opsporingsambtenaar. ${ }^{6}$ Wel wordt ten aanzien van alle schriftelijke bescheiden geëist dat de inhoud daarvan ter zitting de verdachte wordt geacht te zijn voorgelezen. ${ }^{7}$ Daarmee wordt alsnog voldaan aan de eis dat al het bewijs in mondelinge vorm ter zitting moet worden gepresenteerd.

Direct samenhangend met de eis dat de procesvoering mondeling dient te geschieden is de eis dat de bewijsvoering ter terechtzitting moet plaatsvinden. Dit blijkt expliciet uit artikel $338 \mathrm{~Sv}$ :

'Het bewijs dat de verdachte het telastegelegde feit heeft begaan, kan door de rechter slechts worden aangenomen indien hij daarvan uit het onderzoek ter terechtzitting [cursivering WD] door den inhoud van de bewijsmiddelen de overtuiging heeft bekomen.'

Aldus ligt in artikel $338 \mathrm{~Sv}$ de formele kant van het onmiddellijkheidsbeginsel besloten. Het belang van dit beginsel is gelegen in het feit dat hiermee een contradictoire behandeling van de strafzaak wordt gegarandeerd. Procespartijen kunnen naar aanleiding van het ter zitting gepresenteerde bewijsmateriaal direct reageren en waar nodig de relevantie en betrouwbaarheid betwisten. ${ }^{8}$ Bewijsmateriaal dat niet ter zitting is gepresenteerd, mag de rechter niet in zijn oordeelsvorming meenemen. Bovendien garandeert het aanvaarden van het onderzoek ter terechtzitting als enige informatiebron, dat de rechter zich altijd zelfstandig een oordeel kan vormen over het ter zitting geopenbaarde materiaal. ${ }^{9}$

Daarmee is echter niets gezegd over de inhoudelijke eisen die worden gesteld aan het bewijsmateriaal dat ter zitting wordt gepresenteerd. Deels vloeien deze eisen voort uit het negatief-wettelijk bewijsstelsel waarin ten aanzien van het gebruik van elk bewijsmiddel nadere voorwaarden zijn opgenomen. Deze voorwaarden komen specifiek in paragraaf 3.3 aan de orde. Buiten deze eisen kan echter de vraag worden gesteld in hoeverre in strafzaken niet ook eisen moeten worden gesteld aan de mate van authenticiteit van het bewijsmateriaal. Met andere woorden: staat in strafzaken elke bron voor de rechter open of moet hij zich beperken tot de meest originele bron. Deze laatste idee ligt ten grondslag aan het materiële onmiddellijkheidsbeginsel: ${ }^{10}$

$6 \quad$ Kamerstukken II 1913-1914, 286, nr. 3 (MvT), p. 171.

7 Zie art. $301 \mathrm{~Sv}$. Overigens kan op grond van het derde lid met toestemming van partijen worden volstaan met het verkort voorhouden van de inhoud van het bewijsmateriaal.

8 Deze idee ligt ook ten grondslag aan art. $301 \mathrm{~Sv}$ : 'Strekking van het artikel is in de eerste plaats, te voorkomen dat een verdachte wordt veroordeeld op stukken die hem onbekend zijn en waarover hij zich niet heeft kunnen uitlaten. Daarnaast dient het voorschrift ook de uitwendige openbaarheid', aldus advocaat-generaal Keijzer in zijn conclusie voorafgaand aan HR 6 oktober 1998, NJ 1998, 881.

$9 \quad$ S.A.M. Stolwijk 1976, p. 4.

10 Nijboer 2000a, p. 76 maakt geen onderscheid tussen mondelinge procesvoering, formele en materiële onmiddellijkheid. Hij vat al deze aspecten onder het onmiddellijkheidsbeginsel: 'Het geheel van regels en beginselen dat ertoe strekt dat de oordelende rechter 
'So gesehen verlangt die Idee materieller Unmittelbarkeit nach richterlicher Kenntnisnahme der Beweise gewissermaßen "im Original”. Anders ausgedrückt: Die Beweisführung durch abgeleitetes Beweis (= Beweissurrogate) ist begrifflich-abstrakt immer eine Verletzung der materiellen Unmittelbarkeit., ${ }^{11}$

Uit de totstandkoming van het Wetboek van Strafvordering van 1926 blijkt dat de wetgever een voorkeur had voor presentatie ter zitting van het bewijsmateriaal in zijn meest originele vorm. In ieder geval blijkt uit de letterlijke tekst van het wettelijke bewijsrecht dat verdachten, getuigen en deskundigen zelf ter zitting moeten verschijnen om aldaar hun verklaring ten overstaan van de rechter af te leggen. ${ }^{12}$ De wetgever creëerde echter zelf een aantal uitzonderingen. Zo mag ingevolge het tweede lid van artikel 341 lid 2 Sv de verklaring van de verdachte uit het vooronderzoek voor het bewijs worden gebruikt indien de inhoud daarvan blijkt uit een ander bewijsmiddel, bijvoorbeeld de schriftelijke verklaring van de rechter-commissaris of een opsporingsambtenaar. Ook de verklaring van de getuige afgelegd bij de rechter-commissaris wordt niet uitgesloten van het bewijs (art. $298 \mathrm{~Sv}$ oud). Ook voor de verklaring van de deskundige is expliciet de mogelijkheid opgenomen om deze in schriftelijke vorm ter kennis van de rechter te laten komen (art. 344 lid 1 onder $4 \mathrm{~Sv}$ ). Deze expliciet in de wet neergelegde uitzonderingen doen vermoeden dat de wetgever in alle andere gevallen niet wilde weten van een indirecte bewijsvoering waarin verklaringen van getuigen door tussenkomst van andere personen ter kennis van de rechter kwamen. ${ }^{13}$ Hij was op dit punt echter niet geheel eenduidig. Enerzijds lezen wij in de memorie van toelichting:

'De uitsluiting van het testimonium de auditu blijft dus (...) gehandhaafd, zodat de uitgebreide jurisprudentie van de Hoge Raad op art. 398 W.v.Sv van toepassing kan blijven. $^{14}$

Anderzijds komen we in diezelfde memorie van toelichting de volgende passage tegen:

'Intusschen belet ook hier niets den rechter in bijzondere gevallen het behoorlijke gestaafde feit, dat een getuige een ander iets heeft hooren zeggen, roepen of verklaren, als bewijsgrond tegen de verdachte te bezigen. ${ }^{, 15}$

Hoewel het laatste citaat ziet op het gebruik van de verklaring van horen zeggen als aanwijzing (een bewijsmiddel dat niet meer in het wetboek is opgenomen) en

zelf zoveel als mogelijk authentieke bronnen van informatie bezigt; die alle ter terechtzitting zijn aan de orde gesteld en getoetst - op tegenspraak -, waarbij wat betreft personen (verdachte, getuige, deskundige) de orale vorm - de persoon is aanwezig en legt een mondelinge verklaring af - prevaleert boven de schriftelijke (verslag, proces-verbaal etcetera), vat men samen onder de uitdrukking onmiddellijkheidsbeginsel.'

11 Geppert 1979, p. 166.

12 In gelijke zin: Rozemond 2000, p. 217.

13 Garé \& Mevis 2000, p. 27.

14 Kamerstukken II 1913-1914, 286, nr. 3, p. 170.

15 Kamerstukken II 1913-1914, 286, nr. 3, p. 170. 
dus niet als verklaring van de getuige zelf, wordt deze passage vaak aangegrepen om aan te tonen dat de wetgever kennelijk niet beoogde de verklaringen van horen zeggen geheel voor het bewijs uit te sluiten. ${ }^{16}$

\subsubsection{Het de-auditu-arrest en zijn gevolgen}

De halfslachtigheid van de wetgever op dit punt maakte het mogelijk dat de Hoge Raad reeds in hetzelfde jaar waarin het wetboek in werking trad een vergaande beperking kon doorvoeren. De Hoge $\operatorname{Raad}^{17}$ oordeelde dat het bepaalde in artikel 342 lid $1 \mathrm{~Sv}$ er niet aan in de weg staat een getuigenverklaring voor het bewijs te gebruiken die niet door de getuige zelf ter zitting wordt afgelegd, maar bij monde van een andere persoon ter kennis van de zittingsrechter komt. Die andere persoon kan dan een getuige ter zitting of een opsporingsambtenaar zijn. De eerste geeft ten overstaan van de rechter weer wat hij de oorspronkelijke getuige heeft horen verklaren; de opsporingsambtenaar doet in het proces-verbaal verslag van hetgeen hij van de getuige heeft gehoord.

Deze uitspraak had tot gevolg dat de positie van het onderzoek ter terechtzitting als de centrale plaats waar al het bewijsmateriaal mondeling aan de orde wordt gesteld in belangrijke mate werd aangetast. Het was immers vanaf dat moment mogelijk om alle informatie over het tenlastegelegde feit door middel van een proces-verbaal ter kennis van de rechter te brengen. Verklaringen van getuigen worden opgenomen door opsporingsambtenaren en zij geven de inhoud van die verklaringen - veelal in hun eigen bewoordingen - weer in het proces-verbaal. De rechter hoeft ter zitting slechts nog de processen-verbaal voor te houden, en het horen van getuigen wordt tot een minimum beperkt. Zo ook Van Dijck:

'De rechter zal voortaan uitsluitend recht kunnen doen op stukken, de dagvaarding van getuigen is voor het bewijs niet langer onmisbaar. ${ }^{, 18}$

Wat als uitzondering op de mondelinge bewijsvoering was bedoeld, wordt na het de-auditu-arrest de standaardmethode; in het proces-verbaal mag alles worden opgenomen dat opsporingsambtenaren op een of andere wijze direct of indirect hebben vernomen en dit mag ook aan de bewezenverklaring ten grondslag worden gelegd. En aldus verwordt het Nederlandse strafproces al gauw tot een procedure waarin de in het vooronderzoek vergaarde en schriftelijk vastgelegde informatie

16 Rozemond 1999b, p. 146 neemt aan dat niet de vraag of de de-auditu-verklaring voor het bewijs mag worden gebruikt relevant is, maar de vraag op welke wijze die voor het bewijs mag worden gebruikt. Dient zij slechts ter onderbouwing van de betrouwbaarheid van een andere verklaring of kan zij zelfstandig aan de bewezenverklaring ten grondslag worden gelegd?

17 HR 20 december 1926, NJ 1927, 85.

18 Van Dijk 1927, p. 52. In gelijke zin: Nijboer 2000a, p. 78. 
alleen nog maar ter zitting wordt geverifieerd. ${ }^{19}$ Het mondelinge en openbare karakter van het onderzoek ter zitting komt grotendeels te vervallen. Voor het publiek zal in het merendeel van de strafzaken niet duidelijk zijn dat er tijdens de zitting bewijsmateriaal wordt gepresenteerd en wat de inhoud daarvan dan is. Volstaan kan immers worden met het mededelen van de korte inhoud van de stukken. ${ }^{20}$ Slechts indien de verdediging hiertoe een gerechtvaardigd verzoek doet of de rechter het horen van de oorspronkelijke getuige zelf noodzakelijk acht, worden getuigen ter zitting gehoord. ${ }^{21}$

Bovendien heeft het toelaten van het testimonium de auditu ook directe consequenties voor het bewijsrecht zelf. De eis van beëdiging van de getuige en de deskundige komt voor zover hun verklaringen in een proces-verbaal worden neergelegd te vervallen. De preventieve functie van de eedsaflegging wordt gemist. ${ }^{22}$ Ten aanzien van de inhoud van de overgebrachte verklaring stelde de Hoge Raad in eerste instantie geen inhoudelijke eisen ${ }^{23}$ aangezien dit niet de verklaring is die voor het bewijs wordt gebruikt. ${ }^{24}$ Later is hij daar op teruggekomen en wordt niet alleen ten aanzien van de overbrengende verklaring, maar ook ten aanzien van de overgebrachte verklaring geëist dat deze geen gissingen en meningen mag bevatten. ${ }^{25}$ Door de toelating van het testimonium de auditu ontstaat bovendien

19 Over de vergaande consequenties van dit arrest schreef Pompe 1959, p. 15: 'Men zou kunnen zeggen, dat dit arrest voor het strafprocesrecht meer betekenis heeft dan het hele wetboek. Langs deze weg kan immers, wat de wet betreft, het hele onderzoek ter terechtzitting tot een louter formaliteit vervallen.'

20 Art. 301 lid 3 Sv

21 Art. 264 jo. $288 \mathrm{~Sv}$ vermeldt de criteria op grond waarvan een verzoek van de verdediging tot het oproepen van een getuige kan worden geweigerd. Bij Wet van 10 november 2004 (horen van getuigen), Stb. 2004, 579 (inwerkingtreding 1 januari 2005, Stb. 2004, 640) zijn beide artikelen gewijzigd in die zin dat de officier van justitie resp. de rechter een verzoek tot het horen van een getuige onder andere kan afwijzen indien de gezondheid of het welzijn van de getuige in gevaar komt door de verschijning ter zitting. Voorheen gold de eis dat de gezondheidstoestand van de getuige ernstig in gevaar komt. In art. $315 \mathrm{~Sv}$ is de ambtshalve bevoegdheid van de rechtbank opgenomen tot het oproepen van getuigen. Daarbij geldt het zogeheten noodzakelijkheidscriterium. Op basis van art. $328 \mathrm{~Sv}$ jo $331 \mathrm{~Sv}$ kan de verdediging de rechtbank verzoeken om gebruik te maken van haar ambtshalve bevoegdheid tot het oproepen van getuigen.

22 Corstens 2005a, p. 655.

23 HR 14 november 1935, NJ 1936, 102 en HR 16 april 1946, NJ 1946, 328.

24 Thans zien we deze denktrant nog terug bij de vraag of er sprake is van anoniem bewijs. Verklaart een niet-anonieme getuige ter zitting wat hij van een andere anonieme persoon heeft gehoord, dan is dit in de ogen van de Hoge Raad geen verklaring van een persoon wiens identiteit niet blijkt. Immers, voor het bewijs wordt de verklaring van de getuige ter zitting gebruikt en diens identiteit is wel bekend. Hierover nader in paragraaf 3.5.2.1.

25 Zie HR 20 december 1955, NJ 1956, 202. Evenmin mag door middel van een verklaring van horen zeggen de verklaring van een medeverdachte in het proces worden ingevoerd. Zie HR 14 juni 1961, NJ 1962, 26 en HR 22 september 1987, NJ 1988, 380. Deze correctie op de de-auditu-jurisprudentie heeft echter in de praktijk nauwelijks enige betekenis nu de Hoge Raad het begrip 'medeverdachte' zeer beperkt uitlegt. Zie daarover paragraaf 3.4 . 
in bewijsrechtelijke zin ongelijkheid tussen verklaringen afgelegd ten overstaan van de rechter-commissaris en verklaringen afgelegd bij de politie. Ten aanzien van de eerste geldt wel de eis van beëdiging voor zover duidelijk is dat de getuige niet ter zitting zal kunnen verklaren (art. $298 \mathrm{~Sv}$ oud); ten aanzien van de tweede geldt zij niet. De eerste werd beschouwd als afgelegd ter zitting en gold dus als een getuigenverklaring in de zin van artikel 342 lid 1 Sv. De verklaring van de getuige afgelegd tegenover de politie daarentegen werd als schriftelijk bescheid in de zin van artikel 344 lid 1 onder $2 \mathrm{~Sv}$ gekwalificeerd. Aan deze inconsequentie is met ingang van 1 augustus $2003^{26}$ een einde gemaakt, toen artikel $298 \mathrm{~Sv}$ kwam te vervallen. ${ }^{27}$ Thans wordt de verklaring van de getuige afgelegd ten overstaan van de rechter-commissaris gekwalificeerd als een proces-verbaal van een opsporingsambtenaar.

De meest wezenlijke consequentie van het toelaten van de verklaring van horen zeggen is evenwel dat daarmee het aan het materiële onmiddellijkheidsbeginsel ten grondslag liggende belang van de materiële waarheidsvinding in het gedrang komt. De mogelijkheden voor de rechter en de procespartijen om de betrouwbaarheid van de oorspronkelijke verklaring te toetsen worden immers in vergaande mate beperkt. ${ }^{28}$ Waar de getuige ter zitting niet verschijnt en dit in bewijsrechtelijke zin ook niet langer nodig is, krijgen procesdeelnemers geen eigen indruk van de getuige, hebben zij niet langer de mogelijkheid de getuige te confronteren met ander bewijsmateriaal en kunnen zij hem niet vragen leemtes of onduidelijkheden in zijn eerdere verklaringen aan te vullen of op te helderen. Dat geldt in versterkte mate voor anonieme verklaringen die op deze manier in het strafproces hun intrede kunnen doen. Zonder te weten van wie de verklaring afkomstig is en of deze persoon op een of andere wijze belang heeft bij het afleggen van een belastende verklaring, is toetsing van de betrouwbaarheid van diens op schrift gestelde verklaring ter zitting een redelijk zinloze exercitie.

De toelating van de verklaring van horen zeggen heeft aldus een zware wissel getrokken op het Nederlandse strafproces. Niet alleen werd daardoor het mondelinge karakter van de bewijsvoering in zijn essentie aangetast, maar bovendien werden daarmee de mogelijkheden om het bewijs ter zitting op zijn deugdelijkheid te toetsen beperkt. Pas onder invloed van het EVRM zijn enkele correcties op de de-auditu-praktijk tot stand gekomen. Die correcties zien niet alleen op het gebruik van anoniem bewijs dat gezien zijn aard altijd door middel van een de-

26 Wet van 3 april 2003, Stb. 2003, 143 (inwerkingtreding 1 juli 2003, Stb. 2003, 260).

27 Corstens 2005a, p. 653 merkt hierover op dat daarmee ook op wetgevingsniveau definitief de de-auditu-praktijk is aanvaard.

28 Het belang van de confrontatie ter zitting met de meest originele vorm van het bewijsmateriaal is door Garé 1994, p. 71 e.v. uitvoerig beschreven. 
auditu-verklaring ter kennis van de rechter komt, maar ook op de 'gewone' deauditu-verklaringen.

\subsubsection{Het ondervragingsrecht van de verdediging}

Op grond van artikel 6 lid 3 EVRM heeft de verdediging het recht om getuigen à charge te ondervragen. Dit recht is een uitwerking van het in artikel 6 EVRM aan de verdachte toekomende recht op een 'fair trial'. Het ondervragingsrecht wordt door het Europese Hof voor de rechten van de mens beschouwd als de mogelijkheid van de verdediging om het bewijs te kunnen toetsen en waar mogelijk de geloofwaardigheid van de getuige of de betrouwbaarheid van zijn verklaring in twijfel te trekken of te betwisten.

In constante rechtspraak houdt het Europese Hof voor de rechten van de mens als hoofdregel aan dat getuigen op de openbare terechtzitting ten overstaan van alle procesdeelnemers met het oog op een contradictoire procedure moeten worden gehoord. ${ }^{29}$ Uitzonderingen op deze hoofdregel zijn toegestaan, maar in dat geval moet de verdediging in enige fase van het geding de mogelijkheid hebben gehad om de getuige te ondervragen. Dat betekent echter niet dat in alle gevallen waarin het ondervragingsrecht van de verdediging buiten de zittingszaal is gerealiseerd, het gebruik van de bewuste getuigenverklaring niet in strijd is met artikel 6 EVRM. Er moeten, aldus het Europese Hof voor de rechten van de mens, goede redenen zijn waarom de getuige niet ter zitting kan worden gehoord en die redenen moeten ook kenbaar worden gemaakt. Redenen om tot het niet horen van de getuige ter zitting over te gaan, kunnen zijn gelegen in de belangen van de getuige. Zo kan een directe confrontatie van de getuige met de verdachte te belastend zijn voor het welzijn van de getuige, ${ }^{30}$ of kan angst voor represailles van de zijde van de verdachte een goede grond zijn om de getuige anoniem en buiten de rechtszaal te horen. ${ }^{31}$ Een geheel andere grond om niet tot het horen van de getuige ter

29 Onder andere: EHRM 20 november 1989, NJ 1990, 245 m.nt. EAA (Kostovski t. Nederland): '41. In principle, all evidence must be produced in the presence of the accused at a public hearing with a view to adversarial argument.'

30 Onder andere: EHRM 2 juli 2002, NJ 2003, 671 m.nt. Sch onder HR 20 mei 2003, NJ 2003, 672 (S.N. t. Zweden): ' 47 . The Court has had regard to the special features of criminal proceedings concerning sexual offences. Such proceedings are often conceived of as an ordeal by the victim, in particular when the latter is unwillingly confronted with the defendant. These features are even more prominent in a case involving a minor. In the assessment of the question whether or not in such proceedings an accused received a fair trial, account must be taken of the right to respect for the private life of the perceived victim. Therefore, the Court accepts that in criminal proceedings concerning sexual abuse certain measures may be taken for the purpose of protecting the victim, provided that such measures can be reconciled with an adequate and effective exercise of the rights of the defence.'

31 Onder andere: EHRM 26 maart 1996, NJ 1996, 741 m.nt. Kn (Doorson t. Nederland): 
zitting over te gaan, is als blijkt dat de getuige niet ter zitting zal verschijnen of mogelijk wel verschijnt, maar aldaar geen vragen beantwoordt met een beroep op zijn verschoningsrecht. ${ }^{32}$ In dat geval kan het ondervragingsrecht ter zitting niet worden gerealiseerd en moet men wel terugvallen op de verklaring van deze getuige uit het vooronderzoek.

Het Europese Hof voor de rechten van de mens stelt dus het horen van de getuige ter zitting voorop, maar sluit niet uit dat in bijzondere gevallen het horen van getuigen ter zitting niet mogelijk is, dan wel dat de bijzondere belangen van de getuigen prevaleren boven het recht van de verdediging. Echter voor zover de getuigen niet kunnen of hoeven te worden gehoord ter zitting, dient de verdediging in een aan de zitting voorafgaande fase de mogelijkheid te hebben om haar ondervragingsrecht te kunnen effectueren. ${ }^{33}$ In uitzonderlijke gevallen wijkt het Europese Hof voor de rechten van de mens ook af van de eis dat de verdediging een directe ondervragingsmogelijkheid moet worden gegund. In geval van minderjarige slachtoffers van zedendelicten kan in plaats van een directe cross examination de mogelijkheid voor de verdediging om de betrouwbaarheid van deze getuige te onderzoeken anders worden vormgegeven. ${ }^{34}$ Gedacht kan dan worden aan het opnemen van het verhoor van het kind op videoband, het laten analyseren van het verhoor

'70. It is true that Article 6 does not explicitly require the interests of witnesses in general, and those of victims called upon to testify in particular, to be taken into consideration. However, their life, liberty or security of person may be at stake, as may interests coming generally within the ambit of Article 8 of the Convention. Such interests of witnesses and victims are in principle protected by other, substantive provisions of the Convention, which imply that Contracting States should organise their criminal proceedings in such a way that those interests are not unjustifiably imperilled. Against this background, principles of fair trial also require that in appropriate cases the interests of the defence are balanced against those of witnesses or victims called upon to testify.'

32 EHRM 24 november 1986, NJ 1988, 745 m.nt. EAA (Unterpertinger t. Oostenrijk).

33 Zie bijvoorbeeld EHRM 4 juli 2000, NJ 2001, 401 m.nt. Kn (Kok t. Nederland): '54. However, if the anonymity of prosecution witnesses is maintained, the defence will be faced with difficulties which criminal proceedings should not normally involve. Accordingly, the Court has recognised that in such cases Article $6 \S 1$ taken together with Article $6 \S 3$ (d) of the Convention requires that the handicaps under which the defence labours be sufficiently counterbalanced by the procedures followed by the judicial authorities (ibid., p. 471, § 72).'

34 Zo achtte het EHRM in de zaak S.N. t. Zweden de geboden mogelijkheid tot toetsing van het getuigenbewijs wel voldoende, mede gezien het optreden van de verdediging. De verdediging had weliswaar geen mogelijkheid gehad om de getuige direct te ondervragen, maar daar stond tegenover dat de ter zitting genomen maatregelen klager voldoende in de gelegenheid stelden om de verklaringen van het slachtoffer en diens geloofwaardigheid te betwisten. Zie EHRM 2 juli 2002, NJ 2003, 671 m.nt. Sch onder $N J$ 2003, 672. In de zaak Bocos-Cuesta t. Nederland achtte het EHRM daarentegen de geboden toetsingsmogelijkheden voor de verdediging onvoldoende: 'In these circumstances, the Court finds that the applicant cannot be regarded as having had a proper and adequate opportunity to challenge the witness statements which were of a decisive importance for his conviction and, consequently, he did not have a fair trial.' EHRM 10 november 2005, NJ 2006, 239 m.nt. Sch. 
door een deskundige, het stellen van aanvullende vragen door een derde ten behoeve van de verdediging en het afspelen van de videoband ter zitting. Wil het Europese Hof voor de rechten van de mens een dergelijke indirecte toetsing van de betrouwbaarheid van de getuige accepteren, dan dient wel duidelijk gemotiveerd te zijn dat directe toetsing door middel van een rechtstreekse ondervraging door de verdediging niet mogelijk is, omdat dit zou leiden tot secundaire victimisatie. Bovendien eist de Straatsburgse rechter in dergelijke gevallen dat de rechter met grote behoedzaamheid de verklaring hanteert. Daarbij kunnen allerlei factoren een rol spelen die duiden op de betrouwbaarheid van de getuige en diens verklaring. ${ }^{35}$ Heeft de verdediging de mogelijkheid gehad om de getuige te ondervragen, of in bijzondere gevallen de mogelijkheid gehad om op andere wijze de betrouwbaarheid van de getuige en diens verklaring te toetsen, dan staat artikel 6 EVRM aan het gebruik van die verklaring voor het bewijs niet in de weg.

Hoewel op basis van het bovenstaande wellicht de indruk kan ontstaan dat alle getuigen op een of andere manier door de verdediging moeten kunnen worden gehoord of anderszins de betrouwbaarheid van hun verklaring moet kunnen worden getoetst, heeft het Europese Hof voor de rechten van de mens een dergelijk omvangrijk recht niet erkend. Het gemis van het ondervragingsrecht leidt in Straatsburg slechts tot consequenties indien de bewezenverklaring alleen of in beslissende mate berust op de verklaring van een niet door de verdediging gehoorde getuige. ${ }^{36}$ Daarmee introduceert het Europese Hof voor de rechten van de mens een nieuw soort bewijsminimum. Door Van Zeben ${ }^{37}$ is er overigens terecht op gewezen dat het door het Europese Hof voor de rechten van de mens gestelde bewijsminimum niet gelijk kan worden gesteld met vergelijkbare bepalingen in de Nederlandse wetgeving, zoals artikel 342 lid $2 \mathrm{~Sv}$. Bij de behandeling van de bewijsminima in paragraaf $3.5 \mathrm{zal}$ ook meer specifiek op het door het Europese Hof voor de rechten van de mens geïntroduceerde bewijsminimum worden ingegaan.

Niet geheel duidelijk is in hoeverre het Europese Hof voor de rechten van de mens ook het optreden van procespartijen betrekt bij zijn oordeel of het ondervragingsrecht voldoende tot zijn recht is gekomen. Enerzijds lijkt van de verdediging verwacht te worden dat zij ook zelf actief is om haar rechten te realiseren. ${ }^{38}$

35 Deze factoren moeten echter niet worden verward met het 'bewijsminimum' dat het EHRM stelt ten aanzien van het gebruik van niet gehoorde getuigen.

36 Het geheel afwezig zijn van enig steunbewijs leidt in de ogen van het EHRM tot schending van art. 6 lid 3 onder d EVRM. EHRM 27 februari 2001, NJ 2002, 101 m.nt. Sch (Luca t. Italië): 'Where a conviction is based solely or to a decisive degree on depositions that have been made by a person whom the accused has had no opportunity to examine or to have examined, whether during the investigation or at the trial, the rights of the defence are restricted to an extent that is incompatible with the guarantees provided by Article 6.' Het betrof in dat geval het gebruik van anoniem bewijs.

37 Van Zeben 2006, p. 8.

38 In de zaak S.N. neemt het EHRM onder andere geen schending aan omdat de verdediging berustte in de afwezigheid bij het verhoor van de getuige en het niet nodig achtte om 
Anderzijds neemt het Europese Hof voor de rechten van de mens niet snel aan dat de verdediging afstand van haar ondervragingsrecht heeft gedaan. ${ }^{39}$ Met betrekking tot het handelen van het Openbaar Ministerie en de rechter geldt dat wordt verwacht dat zij zoveel mogelijk de verdediging behulpzaam zijn bij het effectueren van haar ondervragingsrecht. Het Openbaar Ministerie mag niet te snel aannemen dat een getuige onvindbaar is ${ }^{40}$ en zou, indien duidelijk is dat de getuige niet ter zitting kan worden gehoord, de verdediging in een vroeg stadium moeten betrekken bij politieverhoren. ${ }^{41}$ Van de rechter wordt in ieder geval verwacht dat hij daadwerkelijk onderzoek doet naar het bestaan van redenen die zijns inziens het horen van de getuige ter zitting onmogelijk of onwenselijk maken. ${ }^{42}$

aanvullende vragen te stellen. EHRM 2 juli 2002, NJ 2003, 671 m.nt. Sch onder NJ 2003, 672 (r.o. 49-51).

39 Zie EHRM 10 november 2005, NJ 2006, 239 m.nt. T.M. Schalken (Bocos-Cuesta t. Nederland): ' 65 . As regards the question whether the applicant or his lawyer had dropped the request to hear the four children at the closure of the trial proceedings before the Court of Appeal, the Court reiterates that the waiver of a right guaranteed by the Convention - in so far as such a waiver is permissible - must be established in an unequivocal manner (see, among other authorities, Colozza v. Italy, judgment of 12 February 1985, Series A 89, $\S 26)$. 66. The Court notes in the present case that, throughout the entire trial proceedings, the applicant clearly and repeatedly requested the courts to allow the defence to question the four children. (...) The Court, therefore, finds that the applicant cannot be regarded as having waived his rights under Article 6 as to the hearing of these witnesses.'

40 Het EHRM eist dat de nationale vervolgende autoriteiten zich voldoende maar tevergeefse moeite hebben getroost om de getuigen op zitting te krijgen. Daaraan was voldaan in de zaak Scheper t. Nederland: 'However, it has not been argued and neither has it appeared that the judicial authorities have been negligent in their efforts to bring these three witnesses before the Court of Appeal or the investigating judge. In view of these efforts, their failure to appear did not make it necessary to discontinue the prosecution (see Artner v. Austria, judgment of 28 August 1992, Series A 242-A, p. 10, § 21).' EHRM 5 april 2005, NJ 2005, 551 m.nt. Sch.

41 Van Zeben 2006, p. 7.

42 Zo achtte het EHRM de noodzaak van anonimiteit in de zaak Visser t. Nederland onvoldoende toegelicht: 'Neither did the Court of Appeal carry out such an examination into the seriousness and well-foundedness of the reasons for the anonymity of the witness when it decided to use the statement made before the investigating judge in evidence against the applicant. In these circumstances the Court is not satisfied that the interest of the witness in remaining anonymous could justify limiting the rights of the defence to the extent that they were limited.' EHRM 14 februari 2002, NJ 2002, 378 m.nt. Sch. en in vergelijkbare zin EHRM 23 april 1997, NJ 1997, 635 m.nt. Kn (Van Mechelen e.a. t. Nederland): '59. In the present case, the police officers in question were in a separate room with the investigating judge, from which the accused and even their counsel were excluded. All communication was via a sound link. The defence was thus not only unaware of the identity of the police witnesses but were also prevented from observing their demeanour under direct questioning, and thus from testing their reliability (see the above-mentioned Kostovski judgment, p. $20, \S 42$ in fine). 60 . It has not been explained to the Court's satisfaction why it was necessary to resort to such extreme limitations on the right of the accused to have the evidence against them given in their presence, or why less far-reaching measures were not considered. In the absence of any further information, the Court cannot find that the operational needs of the police provide sufficient justification.' 
Daarmee is de jurisprudentie van het Europese Hof voor de rechten van de mens op hoofdlijnen samengevat. ${ }^{43}$ Een dergelijke korte samenvatting is echter per definitie niet volledig. Het casuïstische karakter van de uitspraken van het Europese Hof voor de rechten van de mens is daaraan onder meer debet. Binnen het kader van dit onderzoek kan hiermee vooralsnog worden volstaan. Evident is immers dat op basis van de uitspraken van het Straatsburgse hof de de-auditu-praktijk in Nederland zwaar onder druk komt te staan. Waar Straatsburg als uitgangspunt neemt dat het getuigenbewijs ter zitting door middel van cross examination door de verdediging moet kunnen worden getoetst, heeft in Nederland als gevolg van het de-auditu-arrest lange tijd het tegenovergestelde uitgangspunt gegolden, te weten: het horen van getuigen ter zitting is niet noodzakelijk. Het in artikel 6 EVRM gestelde ondervragingsrecht levert niet alleen ten aanzien van het gebruik van anoniem bewijs problemen op, maar ook met betrekking tot het horen van wel bij naam bekende getuigen. De wijze waarop in Nederland is gepoogd de strafrechtspleging op dit punt in overeenstemming te brengen met de eisen die vanuit Straatsburg worden opgelegd, komt in de twee volgende paragrafen aan de orde. Het door het Europese Hof gecreëerde bewijsminimum wordt slechts zijdelings aangestipt en zal hierna bij de bespreking van de overige bewijsminima uitgebreid aan bod komen.

\subsubsection{Anoniem bewijs}

De aanvaarding voor het bewijs van de verklaring van horen zeggen maakt het mogelijk dat ook anonieme verklaringen hun weg vinden in het strafproces. De rechtvaardiging voor het gebruik van dergelijke verklaringen ligt meestal in de angst voor represailles. Daarnaast speelt vaak ook het opsporingsbelang een rol. Teneinde informanten en infiltranten te kunnen blijven inzetten in het criminele milieu is het noodzakelijk dat binnen dat milieu de identiteit van deze personen niet bekend wordt. ${ }^{44}$ Om deze en mogelijk nog andere redenen werden vanaf de jaren tachtig van de vorige eeuw getuigen wier identiteit verborgen moest blijven, gehoord door de rechter-commissaris. De rechter-commissaris gaf in een procesverbaal weer wat hij van de niet met naam genoemde getuige had vernomen. De Hoge Raad keurde deze praktijk goed, zij het met de kanttekening dat de in het proces-verbaal opgenomen anonieme verklaring met de nodige behoedzaamheid moest worden gebruikt. ${ }^{45}$

43 Meer uitgebreid hierover Alink \& Van Zeben 2006.

44 Sinds kort worden ook belangen in het kader van de nationale veiligheid beschouwd als redenen om getuigen niet langer ter zitting te horen. Zie de Wet van 28 september 2006 (afgeschermde getuigen), Stb. 2006, 460 (inwerkingtreding 1 november 2006, Stb. 2006, 461).

45 HR 4 mei 1981, NJ 1982, 268 m.nt. ThWvV. 
Het Europese Hof voor de rechten van de mens achtte deze praktijk echter in strijd met artikel 6 EVRM, zoals bleek uit zijn uitspraak in de zaak Kostovski. ${ }^{46}$ De rechtspraak van het Europese Hof voor de rechten van de mens dwong de Hoge Raad tot het stellen van strengere eisen: de verklaring van de anonymus moest voortaan door een rechter worden afgenomen, die in zijn proces-verbaal onder andere kenbaar diende te maken op welke gronden hij de getuige betrouwbaar acht. Bovendien moest de verdediging op enigerlei wijze in de gelegenheid worden gesteld om tijdens het verhoor vragen te stellen of te doen stellen. ${ }^{47}$

In 1993 is vervolgens een regeling met betrekking tot het anonieme bewijs in het Wetboek van Strafvordering opgenomen. ${ }^{48}$ De bewijsrechtelijke poot van deze regeling maakt onderscheid tussen de mondelinge verklaring van de bedreigde getuige, afgelegd ten overstaan van de rechter-commissaris en de anonieme verklaring neergelegd in een schriftelijk bescheid. In dat laatste geval kan gedacht worden aan de verklaring van een anonieme angever of informant. ${ }^{49}$ Ten anzien van beide vormen van anoniem bewijs geldt het algemene bewijsminimum dat de beslissing dat de verdachte het hem tenlastegelegde heeft begaan niet uitsluitend op grond van anoniem bewijsmateriaal mag worden aangenomen (art. 344a lid $1 \mathrm{~Sv}) .{ }^{50}$ Bovendien moet de verdediging de gelegenheid worden geboden om de getuige te ondervragen. Bij de bedreigde getuige is dit gerealiseerd door de verdediging het recht te geven tijdens het verhoor door de rechter-commissaris van deze getuige vragen te stellen of te doen stellen. Bij andere - schriftelijke vormen van anoniem bewijs kan de verdediging de bruikbaarheid van dit bewijs blokkeren door een verzoek in te dienen om deze getuige te horen. Laat zij dit achterwege, dan kan alsnog de op schrift gestelde anonieme verklaring voor het bewijs gebruikt worden, zonder dat daarvoor de bijzondere procedure van de bedreigde getuige moet worden doorlopen. Wel dient in dat geval de betrokkenheid van de verdachte in belangrijke mate steun te vinden in andersoortig bewijsmateriaal (art. 344a lid $3 \mathrm{~Sv}$ ).

In de wettelijke regeling met betrekking tot het gebruik van verklaringen van bedreigde getuigen wordt het gebrek aan directe confrontatie met de persoon van wie de verklaring afkomstig is, gecompenseerd door het verhoor te laten plaatsvinden door een rechter in het vooronderzoek. De verdediging houdt haar ondervragingsrecht, zij het dat dit nooit op gelijke wijze kan worden uitgeoefend als op de zitting. Belangrijkste handicap is gebrek aan kennis over de achtergrond van de getuige en het niet kunnen aanschouwen van de reactie van de getuige op vragen van de verdediging. Bovendien kunnen vragen die bij beantwoording mogelijk

46 EHRM 20 november 1989, NJ 1990, 245 m.nt. EAA (Kostovski t. Nederland).

47 HR 2 juli 1990, NJ 1990, 692 m.nt. ThWvV.

48 Wet van 11 november 1993 (getuigenbescherming), Stb. 1993, 603 (inwerkingtreding 1 februari 1994).

49 HR 14 maart 2006, NJ 2006, 209.

$50 \quad$ HR 30 juni 1998, NJ 1999, 88 m.nt. JR. 
de identiteit van de getuige onthullen door de rechter-commissaris worden geweigerd. ${ }^{51}$ Met dit weliswaar beperkte ondervragingsrecht is enigszins tegemoet gekomen aan het nadeel dat de verdediging ondervindt bij het gebruik van anoniem bewijs. De zittingsrechter zal het echter zonder eigen indruk van de getuige moeten stellen. De beoordeling van de betrouwbaarheid van de verklaring moet (deels) plaatsvinden aan de hand van het proces-verbaal van de rechter-commissaris. De specifieke bewijsminima waken ervoor dat de rechter alleen op basis van het anonieme bewijsmateriaal tot de conclusie komt dat de verdachte het feit heeft begaan. Bovendien is in artikel 360 lid $1 \mathrm{~Sv}$ een nadere motiveringsplicht opgenomen. De rechter moet het gebruik van het anonieme bewijsmateriaal nader verantwoorden. ${ }^{52}$ Ten aanzien van anoniem bewijsmateriaal dat niet in de vorm van de verklaring van de bedreigde getuige tot de zittingsrechter komt, is niet voorzien in een rechterlijke toets van de betrouwbaarheid. Voor zover de verdediging niet verzoekt om het horen van de bron, ${ }^{53}$ kan de rechter de op schrift gestelde verklaring van de anonieme persoon gebruiken met in achtneming van de in de wet gestelde bewijsminima. Bovendien dient hij ook in dit geval het gebruik van het anonieme bewijsmateriaal nader te verantwoorden. ${ }^{54}$

De Hoge Raad neemt echter niet snel aan dat er sprake is van een anonieme verklaring. Blijkt uit de schriftelijke stukken dat een persoon op een bepaalde plaats werkzaam is en is het dus aan de hand daarvan mogelijk om hem - indien gewenst - op te roepen als getuige, dan is er in de optiek van de Hoge Raad geen sprake van een 'persoon wiens identiteit niet blijkt'. Het gaat immers in de woorden van de Hoge Raad om personen die kunnen worden geïndividualiseerd zodat de verdediging in beginsel hun verhoor als getuige door de rechter-commissaris of ter terechtzitting kan verzoeken. ${ }^{55}$ Dit geldt bijvoorbeeld voor opsporingsambtenaren die om tactische redenen hun naam niet in het proces-verbaal willen opnemen. Als uit een aanvullend proces-verbaal volgt dat zij werkzaam zijn bij een bepaald onderdeel van de politie en van hogerhand hun opsporingsbevoegdheid wordt bevestigd, dan wordt de verklaring niet beschouwd als een verklaring van

51 Franken 2006b, p. 273 acht de waarde van dergelijke verhoren mede gezien het feit dat beantwoording van door de verdediging gestelde vragen kan worden belet in de praktijk gering: 'Het ondervragingsrecht van bijzondere getuigen bestaat in theorie, maar kan moeilijk als een effectief recht worden aangemerkt.'

52 Op de inhoud van die verantwoording wordt in hoofdstuk 6 nader ingegaan.

53 Niet te snel mag worden aangenomen dat de verdediging afstand doet van haar ondervragingsrecht. Zie HR 14 maart 2006, NJ 2006, 209: 'Weliswaar is niet uitdrukkelijk verzocht om de anonieme getuige te horen maar hetgeen door de verdediging is aangevoerd met betrekking tot die getuige en haar verklaring, kan bezwaarlijk anders worden verstaan dan als het te kennen geven van de wens om haar te ondervragen of te doen ondervragen. Gelet daarop stond art. 344a, derde lid, Sv in de weg aan het gebruik van het bedoelde proces-verbaal voor het bewijs.'

54 Art. 360 lid $1 \mathrm{~Sv}$.

55 HR 29 april 1997, $N J$ 1997, 666 m.nt. 'tH onder 29 april 1997, NJ 1997, 667 en HR 18 mei 1999, NJ 2000, 106 m.nt. Sch. 
een anoniem persoon. ${ }^{56}$ In dergelijke gevallen is artikel 344a lid $3 \mathrm{~Sv}$ niet van toepassing en blokkeert het verzoek van de verdediging om de getuige te ondervragen het gebruik van zijn verklaring niet. Evenmin gelden de bewijsminima en is de rechter verplicht het gebruik van het bewijsmateriaal nader te verantwoorden. ${ }^{57}$ Ook de verklaring van een met name genoemde getuige waarin hij weergeeft wat hij van een ander niet met naam genoemde persoon heeft gehoord wordt niet als een verklaring in de zin van artikel 344a lid $3 \mathrm{~Sv}$ beschouwd. ${ }^{58}$ De identiteit van de zegspersoon is bekend en desgewenst kan deze ter zitting worden gehoord. Het ontbreken van de identiteit van de persoon waaraan deze getuige zijn kennis ontleent, staat niet aan het gebruik van diens verklaring in de weg. Op deze wijze werkt de de-auditu-praktijk nog steeds door. Enige verschil is dat in dergelijke gevallen de overbrengende verklaring wel op haar betrouwbaarheid kan worden getoetst.

Uit het voorgaande blijkt dat de regeling met betrekking tot het gebruik van het anonieme bewijsmateriaal duidelijk is geënt op de rechtspraak van het Europese Hof voor de rechten van de mens met betrekking tot artikel 6 lid 3 EVRM. Daar ligt echter ook een probleem omdat het Europese Hof niet zozeer de waarheidsvinding als wel een fair trial centraal stelt. Voor het hof staat de contradictoire procesvoering centraal; de verdediging moet op enig moment in de procedure in de gelegenheid worden gesteld verklaringen van getuigen à charge op hun betrouwbaarheid te toetsen. De inhoud van het bewijsoordeel laat het Europese Hof voor de rechten van de mens in grote mate ongemoeid. Dat roept de vraag op of in landen zoals Nederland waarin de verantwoordelijkheid voor de waarheidsvinding grotendeels is opgedragen aan de zittingsrechter, de inpassing van de rechten die voortvloeien uit artikel 6 EVRM wel mogelijk is, zonder dat dit afbreuk doet aan die rechterlijke verantwoordelijkheid. Prakken en Spronken spreken in dit verband van het zoeken naar de kwadratuur van een cirkel. ${ }^{59}$

Dit dilemma wordt overduidelijk in de regeling van het anonieme bewijs. Enerzijds wordt de verdediging in de gelegenheid gesteld haar ondervragingsrecht te realiseren. Echter van een effectief ondervragingsrecht kan nooit sprake zijn. Het beschermen van de anonimiteit van de getuige verzet zich daartegen en meer algemeen heeft de verdediging in deze fase van het onderzoek vaak niet de beschikking over alle relevante informatie. Anderzijds gaat het verschuiven van

56 De uitzondering is overigens niet beperkt tot opsporingsambtenaren. Bijvoorbeeld: HR 4 juni 2002, NJ 2002, 416, waarin de verklaring van een medewerker van een autoverhuurbedrijf een rol speelde. Zijn identiteit was weliswaar niet in het proces-verbaal van de opsporingsambtenaren opgenomen, maar was wel bij hen bekend. Voor zover gewenst kon deze dus worden opgeroepen.

57 Over de bewijsminima meer in paragraaf 3.5. Over de motiveringsplicht nader in hoofdstuk 6.

58 HR 14 december 2004, NJ 2005, 383 m.nt. YB.

59 Prakken \& Spronken 2001, p. 73. 
het ondervragingsrecht naar het vooronderzoek ten koste van de eigen verantwoordelijkheid van de zittingsrechter. Hij moet afgaan op dat wat in het vooronderzoek is vastgesteld en ontbeert de mogelijkheid om zelf onderzoek te doen naar de betrouwbaarheid van de anonieme verklaringen. In geval van een bedreigde getuige is hem zelfs die mogelijkheid ontzegd. ${ }^{60}$

De compensatie voor het verlies van zelfstandige onderzoeksmogelijkheden voor de zittingsrechter en het beperkte ondervragingsrecht van de verdediging wordt gevonden in een aanvullende regeling van het bewijsrecht. Bewijsminima en motiveringsplichten moeten garanderen dat het bewijsoordeel een minimum aan betrouwbaarheid bevat. De vraag of dat kan is onder andere afhankelijk van de eisen die vervolgens worden gesteld aan het andere bewijs en de inhoud van de motivering. Beide aspecten worden later in dit onderzoek uitgebreid aan de orde gesteld. Hier kan echter wel al worden opgemerkt dat de bewijsminima weinig betekenis hebben, onder andere omdat de Hoge Raad niet snel aanneemt dat er sprake is van een 'anonieme' verklaring. Om diezelfde reden is ook de motiveringsplicht beperkt. Bovendien zijn omvang en kwaliteit van de motivering in sterke mate afhankelijk van de mogelijkheden van de rechter om zelfstandig onderzoek te doen. In geval van anonieme getuigenverklaringen zijn de mogelijkheden van de rechter evenals van de verdediging tot het doen van nader onderzoek gelimiteerd. ${ }^{61}$

\subsubsection{Grenzen aan het 'gewone' getuigenbewijs}

Niet alleen ten aanzien van het gebruik van anoniem bewijs heeft het EVRM een stempel gedrukt op de Nederlandse strafvordering. Het ondervragingsrecht zoals dat in artikel 6 lid 3 onder d EVRM is verwoord, heeft ook gevolgen gehad voor het 'gewone' getuigenbewijs.

Volgens vaste jurisprudentie van het Europese Hof voor de rechten van de mens dient het bewijsmateriaal in principe ter zitting te worden gepresenteerd. De in Nederland gangbare praktijk om te volstaan met de schriftelijke vastlegging van getuigenverklaringen uit het vooronderzoek, lijkt regelrecht in strijd te zijn met het recht van de verdediging om getuigen te ondervragen. Waar de verdediging tijdens het opsporingsonderzoek meestal niet eens op de hoogte is van het bestaan van de getuige, is van aanwezig zijn bij én de mogelijkheid om vragen te stellen tijdens het verhoor van de getuige door de politie in die fase meestal geen sprake. Het ondervragingsrecht zal dus in een latere fase moeten worden gerealiseerd.

60 HR 20 april 1999, NJ 1999, 677 m.nt. 'tH.

61 Dat geldt eens te meer voor de (anonieme) afgeschermde getuige. Deze nieuwe getuige is in het Wetboek van Strafvordering geïntroduceerd met ingang van 1 november 2006. Wet van 28 september 2006 (afgeschermde getuigen), Stb. 2006, 460 (inwerkingtreding 1 november 2006, $S t b$. 2006, 461). Meer uitgebreid daarover in paragraaf 6.2.4. 
In het arrest 'Grenzen getuigenbewijs' heeft de Hoge Raad aangegeven in welke gevallen het ontbreken van de mogelijkheid om de getuige te kunnen ondervragen, bewijsrechtelijke consequenties heeft. ${ }^{62}$ Voor zover de verdediging niet heeft verzocht om het ondervragen van de getuige heeft dit in het geheel geen gevolgen. Het initiatief ligt dus in principe bij de verdediging. ${ }^{63}$ Dit uitgangspunt wordt slechts verlaten in die gevallen waarin de getuige zowel door de politie als door een rechter is gehoord en zijn verklaring ten overstaan van de rechter op wezenlijke punten afwijkt van de belastende verklaring bij de politie. In dat geval dient de rechter ambtshalve de getuige ter zitting op te roepen, teneinde de discrepanties tussen de beide verklaringen ter zitting aan de orde te stellen. Uit deze rechtspraak komt nog een stukje van de rechterlijke verantwoordelijkheid voor de volledigheid van het onderzoek naar voren. Blijkt uit het dossier dat de getuige ten overstaan van een rechter (meestal de rechter-commissaris) en in het bijzijn van de verdediging op een eerdere verklaring terugkomt, dan moet de zittingsrechter een poging doen om te achterhalen welke van beide verklaringen meer waarde toekomt. ${ }^{64}$ Daartoe moet hij - zo mogelijk - de getuige zelf kunnen zien en vragen kunnen stellen. Heeft oproeping van de getuige echter geen resultaat, dan staat het de rechter vrij - ook zonder dat hij de getuige zelf heeft gezien en heeft kunnen ondervragen - om de belastende politieverklaring voor het bewijs te gebruiken. ${ }^{65}$ Laat hij de oproeping van de getuige in zijn geheel achterwege, dan wordt daarmee de belastende 'politieverklaring' onbruikbaar voor het bewijs. ${ }^{66}$ Dit is slechts anders indien er voldoende steunbewijs is.

Blijkt daarentegen uit het dossier niet dat de getuige is teruggekomen op zijn eerdere verklaring of dit wel heeft gedaan maar niet ten overstaan van een rechter, dan ligt het initiatief tot oproepen van de getuige in principe bij de verdediging. De Hoge Raad eist op dit punt dat de raadsman daarbij de wettelijk voorgeschreven procedures ingevolge artikel $263 \mathrm{~Sv}$ (verzoek aan het Openbaar Ministerie) en artikel $328 \mathrm{~Sv}$ (verzoek aan zittingsrechter) volgt. Ontbreekt een dergelijk duidelijk en stellig verzoek, dan kan het oproepen van de getuige achterwege blijven. ${ }^{67}$ Ook

62 HR 1 februari 1994, NJ 1994, 427 m.nt. C.

63 Nijboer en Van Hoorn 2001, p. 569 spreken in dit verband van 'onmiddellijkheid op bestelling'.

64 In gelijke zin: HR 12 september 2006, NbSr 2006, 393.

65 Een daadwerkelijke directe toetsing van de eerder door de getuige afgelegde verklaringen door de getuige daarover zelf te horen is derhalve niet nodig. Voldoende is dat de rechter een poging heeft ondernomen een contradictoire behandeling te realiseren. Slaagt hij daar niet in, omdat de getuige niet verschijnt, dan is daarmee in de ogen van de Hoge Raad voldaan aan de eisen die art. 6 EVRM op dit punt stelt.

66 Bijvoorbeeld: HR 15 maart 2005, LJN AS4681.

67 HR 21 mei 1996, NJ 1996, 611 en HR 15 maart 2005, LJN AR3260: '3.3. Kennelijk heeft het Hof het hiervoor onder 3.2.1 weergegeven betoog van de raadsman niet opgevat als tevens behelzende een voldoende stellig verzoek - in de zin van art. 328 in verbinding met art. 331, eerste lid, Sv - tot de oproeping als getuige van de desbetreffende personen 
indien door of namens de verdachte wel degelijk een stellig verzoek tot het oproepen van de getuige is gedaan, hoeft dit niet altijd voldoende te zijn. Zo wordt ten aanzien van de oproeping van een opsporingsambtenaar geëist dat duidelijk uit het verzoek naar voren komt, waarom getwijfeld zou moeten worden aan de betrouwbaarheid van diens schriftelijke verklaring. Daarbij neemt het Hoge Raad als uitgangspunt dat uit artikel 344, tweede lid, Sv volgt dat de wetgever een bijzonder vertrouwen heeft gesteld in de betrouwbaarheid van een dergelijk procesverbaal. Met andere woorden: zonder duidelijke argumenten die mogelijk die betrouwbaarheid in een ander daglicht plaatsen, is er geen noodzaak tot nader onderzoek. In de woorden van de Hoge Raad:

'Van een verdachte die de betrouwbaarheid wenst te toetsen en/of aan te vechten van een in een proces-verbaal van politie opgenomen verklaring van een verbalisant omtrent hetgeen deze zelf heeft waargenomen en ondervonden, (mag) worden gevergd niet alleen dat hij tijdig gebruik maakt van de mogelijkheden die de wet hem biedt tot het (doen) ondervragen van de desbetreffende opsporingsambtenaar, maar ook dat hij zijn daartoe strekkend verzoek behoorlijk motiveert., ${ }^{68}$

Ontbreekt een dergelijke onderbouwing, dan staat het niet-horen van deze getuige niet aan het gebruik van diens schriftelijke verklaring in de weg, ook al berust de bewezenverklaring alleen op deze verklaring. Door het stellen van dergelijke hoge eisen aan het initiatief van de verdediging kan in vele gevallen alsnog worden afgezien van het horen van getuigen ter zitting. Mols merkt naar aanleiding van dit arrest terecht op dat hiermee de bekeuringen uitdelende opsporingsambtenaar boven kritiek en controle verheven dreigt te worden, terwijl de ervaring leert dat ook opsporingsambtenaren fouten maken. ${ }^{69}$ Bovendien ben ik met Fokkens van mening dat de Hoge Raad hier niet in de pas loopt met de jurisprudentie van het Europese Hof voor de rechten van de mens. ${ }^{70}$ Op basis van de uitspraak van het Europese Hof voor de rechten van de mens in de zaak Saïdi kan immers worden geconcludeerd dat het oproepen van getuigen alleen dan niet nodig is als uit de opstelling van de verdediging blijkt dat zij geen prijs stelt op het uitoefenen van het ondervragingsrecht. ${ }^{71}$ Bovendien kan worden betwijfeld of de formalistische benadering van de Hoge Raad wel recht doet aan de idee van materiële waarheidsvinding. Waar in Nederland de uiteindelijke verantwoordelijkheid voor het bewijsoordeel ligt bij zittingsrechter, wijst het stellen van hoge eisen aan het verzoek van de verdediging tot het oproepen van getuigen op het afschuiven van die ver-

teneinde ter terechtzitting in hoger beroep ten verzoeke van de verdediging als getuigen te worden gehoord. Mede in aanmerking genomen dat het hier gaat om uitlatingen van een rechtsgeleerd raadsman, is 's Hofs uitleg niet onbegrijpelijk en moet deze in cassatie worden geëerbiedigd.'

68 HR 10 februari 2004, NJ 2004, 452 m.nt. Kn.

69 Mols 2004, p. 373-374.

70 Fokkens 2004, p. 153.

71 EHRM 20 september 1993, NJ 1994, 358 m.nt. Kn (Saïdi t. Frankrijk). 
antwoordelijkheid. ${ }^{72}$ Dat vermoeden wordt bevestigd als evident is dat de onderliggende strekking van het betoog van de verdediging is, het kunnen toetsen van de bewijswaarde van het zich in het dossier bevindende bewijsmateriaal. In dergelijke gevallen zou meer aandacht moeten worden besteed aan de inhoud van het betoog, dan aan de formele inkleding daarvan. ${ }^{73}$

De formele benadering van de Hoge Raad blijkt nog op een ander punt. De Hoge Raad neemt genoegen met de oproeping en verschijning van de getuige ter zitting. Niet vereist is dat het ondervragingsrecht ook daadwerkelijk gerealiseerd wordt. Voor het gebruik van de verklaring van de getuige afgelegd ten overstaan van de politie is enkel vereist dat de getuige ter zitting verschijnt. Weigert hij daar antwoord te geven op de hem gestelde vragen, dan staat dit niet aan het gebruik van de politieverklaring voor het bewijs in de weg. ${ }^{74}$ Van een effectieve toetsing van de betrouwbaarheid is echter in een dergelijke situatie geen sprake.

Naast de vraag bij wie de verantwoordelijkheid ligt voor het realiseren van het ondervragingsrecht, is voor de beoordeling van de bruikbaarheid van de niet gehoorde getuigen voor het bewijs tevens de betekenis van dit bewijsmateriaal voor de uiteindelijke bewezenverklaring van belang. Zoals uit de rechtspraak van het Europese Hof voor de rechten van de mens blijkt, is het niet kunnen ondervragen van getuigen alleen problematisch indien de bewezenverklaring alleen of in belangrijke mate is gebaseerd op de verklaring van de niet-gehoorde getuige. De Hoge Raad heeft dit voor de Nederlandse situatie vertaald in die zin dat het oproepen van de getuige achterwege kan blijven indien zijn verklaring in belangrijke mate steun vindt in andere bewijsmiddelen. ${ }^{75}$ Naderhand heeft hij dit criterium teruggebracht tot 'in voldoende mate' ${ }^{76}$ Evenals bij het anonieme bewijs wordt het gebrek aan directe confrontatie met het bewijsmateriaal ter zitting gecompen-

72 In gelijke zin: Nijboer 2000c, p. 101.

73 In gelijke zin: Knigge in zijn annotatie bij HR 10 februari 2004, NJ 2004, 452: 'De vraag daarbij is wat een verdachte nog moet aanvoeren als zijn belang bij het horen van de verbalisant evident is, bijvoorbeeld als hij - zoals in casu - ontkent en de verbalisant de enige witness against him is. Moet de verdachte dan redenen opgeven die de presumptie van betrouwbaarheid die de Hoge Raad in art. 344 lid 2 Sv leest, ondergraven?'

74 HR 1 februari 1994, NJ 1994, 427 m.nt. C: 'De enkele omstandigheid dat een getuige die voor een rechter is opgeroepen en aldaar is verschenen, weigert een verklaring af te leggen, brengt niet mee dat inbreuk wordt gemaakt op het door art. 6, lid 3, aanhef en onder d. EVRM gewaarborgde recht. Dat de rechter geen gijzeling van die getuige heeft bevolen, doet daaraan niet af.' In gelijke zin: HR 6 juni 2006, NJ 2006, 332.

75 HR 1 februari 1994, NJ 1994, 427 m.nt. C.

76 HR 14 april 1998, NJ 1999, 73 m.nt. Kn onder HR 29 sept. 1998, NJ 1999, 74: 'In het licht van meer recente jurisprudentie van het Europese Hof voor de rechten van de mens (EHRM) (zoals EHRM 26 maart 1996, NJ 1996, 741 en vergelijk ook EHRM 7 augustus 1996, $N J$ 1998, 185) moet de kwalificatie "in belangrijke mate" aldus worden begrepen dat reeds voldoende is als de betrokkenheid van de verdachte bij het hem tenlastegelegde feit bevestigd wordt door ander bewijsmateriaal. Als die betrokkenheid dus in voldoende mate steun vindt in andere bewijsmiddelen, staat art. 6 EVRM niet in de weg aan het gebruik tot het bewijs van zo'n - de verdachte belastende - verklaring.' 
seerd door een bewijsrechtelijke oplossing in de vorm van een bewijsminimum. Het bewijsminimum bij de niet ondervraagde, niet anonieme getuige is echter minder streng. De betrokkenheid van de verdachte bij het feit moet in voldoende mate - en dus niet in belangrijke mate - steun vinden in ander bewijsmateriaal. ${ }^{77}$ Afgezien van de minder strikte eisen ten aanzien van het minimum aan bewijs, is een tweede onderscheid met de anonieme verklaringen gelegen in het gemis van een nadere motiveringsplicht voor de rechter. Noch in het geval dat de politieverklaring de enige beschikbare verklaring van deze getuige is, noch indien ter zitting de getuige alsnog verschijnt en daar een verklaring aflegt die van zijn eerdere verklaring afwijkt, hoeft de rechter te verantwoorden waarom hij de politieverklaring aan de bewezenverklaring ten grondslag legt. Dat geldt overigens ook voor het geval de getuige bij de politie al op zijn eerdere verklaringen terugkomt. Ook dan is de rechter vrij die verklaring of onderdelen daarvan eruit te pikken die zijns inziens het meest betrouwbaar zijn.

Het ongeclausuleerde gebruik van de-auditu-verklaringen is dus weliswaar onder invloed van het EVRM enigszins teruggebracht, maar uit het arrest 'Grenzen getuigenbewijs' en daarop volgende jurisprudentie volgt dat er geen algemeen verbod ten aanzien van deze verklaringen geldt. Het gebrek aan de mogelijkheid om de betrouwbaarheid van deze verklaringen te toetsen wordt - in het licht van het EVRM - voornamelijk beschouwd als een handicap voor de verdediging. Waar dit strikt noodzakelijk is - bijvoorbeeld omdat anders een bewezenverklaring te zeer op los zand gebouwd zou zijn - moet het ondervragingsrecht van de verdediging worden gerealiseerd of moet een andere betrouwbaarheidstoets worden ingebouwd. De Hoge Raad is daarin echter zeer terughoudend. Efficiencyoverwegingen spelen een belangrijke rol, wat overduidelijk blijkt uit het feit dat schriftelijke verklaringen van opsporingsambtenaren in principe niet ter zitting hoeven te worden getoetst. Slechts een uitdrukkelijk en goed onderbouwd verzoek van de verdediging kan daarin verandering brengen.

Wat echter onderbelicht blijft, is dat binnen de Nederlandse strafvordering de waarheidsvinding in principe is opgedragen aan de zittingsrechter. Niet de verdediging, maar de rechter dient overtuigd te raken. Hij dient over een zodanige hoeveelheid informatie te beschikken dat hij rationeel gezien in staat is een verantwoorde beslissing te nemen over de vraag of de verdachte het hem tenlastegelegde feit heeft begaan. Een dergelijke verantwoorde beslissing veronderstelt dat de rechter inzicht heeft in de factoren die mogelijk de betrouwbaarheid van de getuigenverklaring beïnvloeden. Het verkrijgen van een eigen indruk van de getuige en het confronteren van deze getuige met mogelijke lacunes in zijn verklaring en discrepanties tussen zijn verklaring en ander

77 Daarover uitgebreid in paragraaf 3.5.2. 
bewijsmateriaal kunnen het inzicht van de rechter vergroten. Door in toenemende mate de verantwoordelijkheid voor de toetsing van de betrouwbaarheid van het getuigenbewijs bij de verdediging te leggen, wordt de eigen verantwoordelijkheid van de strafrechter op dit punt uit het oog verloren.

\subsection{De wettige bewijsmiddelen}

Het negatief-wettelijk bewijsstelsel zoals dat in het Wetboek van Strafvordering van 1926 werd gehandhaafd, wordt gekenmerkt door het feit dat enkel dat bewijsmateriaal mag worden gebezigd dat kan worden gekwalificeerd als een van de in de wet genoemde bewijsmiddelen. In artikel $339 \mathrm{~Sv}$ wordt een vijftal bewijsmiddelen genoemd dat voor het bewijs gebezigd mag worden. Dit zijn de eigen waarneming van de rechter, de verklaring van de verdachte, de verklaring van de getuige, de deskundigenverklaring en de schriftelijke bescheiden. Deze opsomming is nogal heterogeen van karakter; ${ }^{78}$ het bevat enerzijds zowel de waarneming van de rechter als de waarnemingen van andere informanten, anderzijds bevat het zowel schriftelijk als mondeling bewijsmateriaal. De opsomming is dus limitatief. Dat wil zeggen dat buiten de daar genoemde bewijsmiddelen geen ander bewijsmiddel door de rechter gebezigd mag worden. In de limitatieve opsomming van de bewijsmiddelen lag volgens de wetgever een garantie voor de deugdelijkheid van de waarheidsvinding:

'Eene opsomming der bewijsmiddelen is noodig om te voorkomen, dat de rechter hetzij op gevoelsindrukken, hetzij op op bewijsmiddelen wier betrouwbaarheid reeds door hun oorsprong wordt uitgesloten, zal rechtdoen. ${ }^{, 79}$

De uitputtende opsomming van de bewijsmiddelen is echter alleen een waarborg voor zover elk van de genoemde bewijsmiddelen restrictief wordt uitgelegd en er een strikte scheiding tussen de verschillende bewijsmiddelen bestaat. Vanaf 1926 heeft echter de Hoge Raad de vijf in artikel 339 Sv genoemde bewijsmiddelen ruim geïnterpreteerd. Dat blijkt reeds uit de in de vorige paragraaf beschreven deauditu-jurisprudentie waarin onder eigen waarneming van de getuige tevens werd verstaan het horen wat een ander had waargenomen. Maar ook op andere punten is de Hoge Raad vrij soepel met de wettelijke bewijsregels omgegaan. Het onderscheid tussen de verschillende bewijsmiddelen is evenmin altijd even strikt. Dat biedt de feitenrechter de mogelijkheid om het bewijsmateriaal zo te kwalificeren als het hem goed dunkt. In de volgende paragrafen komen de verschillende in artikel $339 \mathrm{~Sv}$ genoemde bewijsmiddelen aan bod.

78 Nijboer 2000a, p. 222-226. In gelijke zin: Nijboer 1982, aant. 3 bij art. 339 Sv.

79 Kamerstukken II 1913-1914, 286, nr. 3 (MvT), p. 164. 


\subsubsection{De eigen waarneming van de rechter}

In het Wetboek van Strafvordering van 1926 werd een strikte scheiding gemaakt tussen twee vormen van bewijsmiddelen, te weten verklaringen van anderen over door hen gedane waarnemingen en de eigen waarneming van de rechter. De eigen waarneming van de rechter is daarmee in de optiek van de wetgever het enige bewijsmiddel waarbij het bewijs rechtstreeks - dus zonder tussenkomst van andere personen - tot de rechter komt. ${ }^{80}$ De eigen waarneming van de rechter werd in 1926 als zelfstandig bewijsmiddel geïntroduceerd opdat ook het zelfstandige onderzoek van de strafrechter tot bruikbare bewijsresultaten zou kunnen leiden. Daarbij werd vooral gedacht aan

'het bezichtigen van overtuigingsstukken, de opneming eener bepaalde plaatselijke gesteldheid en de kennisneming van den inhoud van ter terechtzitting geproduceerde geschriften. ${ }^{, 81}$

Via de eigen waarneming kunnen aldus stukken van overtuiging voor het bewijs gebezigd worden. Te denken valt dan aan voorwerpen waarmee het delict is begaan of ten aanzien waarvan het delict is gepleegd. Ook kan door middel van een schouw de rechter de plaats van het delict in ogenschouw nemen en feiten en omstandigheden die hem daarbij blijken in de bewijsconstructie meenemen. De eigen waarneming kan ook betrekking hebben op personen. Zo kan de rechter waarnemen dat het uiterlijk van de verdachte overeenstemt met de beschrijving zoals een getuige die heeft gegeven. ${ }^{82}$ Naast fysieke kenmerken zou de rechter ook andere zaken ten aanzien van de personen ter zitting kunnen waarnemen, zoals bepaalde karaktertrekken, sociale klasse, iemands emotionele toestand of zijn houding en presentatie ter zitting. Met Van Woensel ben ik het eens dat terughoudendheid moet worden betracht bij het toekennen van bewijswaarde aan dergelijke waarnemingen van de rechter. De objectieve waarneembaarheid en de geldigheid van de uit een dergelijke incidentele waarneming getrokken conclusie is zeer twijfelachtig. ${ }^{83}$ Dat geldt overigens niet alleen ten aanzien van waar-

80 In het Wetboek van 1926 krijgt dit middel voor het eerst een zelfstandige status. Tot 1926 kon de eigen waarneming van de rechter alleen dienen als kenbron van aanwijzingen.

81 Kamerstukken II 1913-1914, 286, nr. 3 (MvT), p. 169.

82 HR 18 februari 1992, NJ 1993, 28 m.nt. Sch.

83 A.M. van Woensel, aant. 5.3 op art. 340 (suppl. 134, april 2003), in: Melai/Groenhuijsen e.a. In gelijke zin: Corstens 2005a, p. 638. Een mooi voorbeeld in deze is de betekenis die verschillende betrokkenen toekenden aan de houding ter terechtzitting van Kees B. in de Schiedammer parkmoord-zaak. Zo verklaarde de behandelend advocaat-generaal Renckens dat haar overtuiging dat Kees B. de dader was, werd versterkt door zijn gedrag ter zitting. De verdachte verliet volgens haar de zittingszaal als het hem te confronterend werd. Achteraf bleek Kees B. niet de dader en kan dus worden geconcludeerd dat zijn houding ter zitting in ieder geval niet voortkwam uit het besef van schuld. Dat is niet zoals De Roos 2005, p.1783 meent te wijten aan de valkuil van het onmiddellijkheidsbeginsel, maar heeft te maken met generalisaties of vooroordelen die niet worden 
nemingen van personen. Bij het afleiden van voor het bewijs relevante conclusies uit het aanschouwen van bepaalde zaken is de grens tussen waarneming en waardering van het waargenomene moeilijk te trekken. Dat geldt bijvoorbeeld indien de rechter dient te beoordelen of een afbeelding aanstotelijk voor de eerbaarheid is, of de vraag aan de orde is of op een pornografische foto een kind is te zien dat kennelijk de leeftijd van 16 jaren nog niet heeft bereikt. ${ }^{84}$ In dergelijke gevallen is het wenselijk dat de rechter zijn waarneming zo nauwkeurig mogelijk in het vonnis vastlegt, zonder daarin reeds vooruit te lopen op de kwalificatie. ${ }^{85}$ Het gebruik van de eigen waarneming van de rechter voor het bewijs is niet ongelimiteerd. Zo mag de rechter alleen zijn eigen waarnemingen gedaan tijdens het onderzoek ter zitting voor het bewijs bezigen. ${ }^{86}$ Alles wat hij buiten de zitting om te weten komt, is niet bruikbaar voor het bewijs. ${ }^{87}$ Enige uitzondering hierop zijn waarnemingen van de rechter die tevens als feiten van algemene bekendheid kunnen worden beschouwd. Ook al zijn dergelijke feiten niet nadrukkelijk ter zitting aan de orde geweest, dan nog kunnen deze zonder bezwaar aan de bewijsconstructie ten grondslag worden gelegd. Het is zelfs niet nodig deze feiten van algemene bekendheid te expliciteren. ${ }^{88}$ De waarneming dient bovendien betrekking te hebben op het onderzoek van de strafzaak die op dat moment wordt behandeld. De waarneming van de rechter bij de behandeling van de ene zaak, mag hij niet meenemen bij de behandeling van een andere zaak. ${ }^{89}$ Ook dient hij de waarnemingen zelf te hebben gedaan. Overgebrachte waarnemingen van

uitgesproken en dus ook niet kunnen worden getoetst op hun geldigheid

84 De Hoge Raad is op dit punt coulant. De eigen waarneming van het hof dat 'op grond van als algemeen bekend te veronderstellen criteria, aanstonds zonder meer duidelijk is dat zij afbeeldingen bevatten van kinderen die kennelijk beduidend jonger zijn dan 16 jaar' achtte de Hoge Raad toelaatbaar. Zie HR 8 mei 2001, NJ 2001, 479. Anderzijds achtte de Hoge Raad het niet mogelijk dat de feitenrechter had waargenomen dat een bepaald voorwerp een Nunchaku-wapen was. HR 10 december 1974, NJ 1975, 165.

85 In gelijke zin: Corstens 2005a, p. 638: 'Hij [de rechter, WD] moet daarbij voorzichtig zijn en aangeven waar de eigen waarneming eindigt en zijn conclusies beginnen.'

86 HR 1 juli 1985, $N J$ 1986, 161: 'Vooropgesteld moet worden dat het behoort tot de in het Wetboek van Strafvordering neergelegde fundamentele regels van het strafproces, dat het bewijs dat de verdachte het hem ten laste gelegde heeft begaan door de rechter slechts mag worden aangenomen, indien hij daarvan uit het onderzoek op de terechtzitting door de inhoud van wettige bewijsmiddelen de overtuiging heeft verkregen. In het voorschrift dat de rechter beraadslaagt en beslist naar aanleiding van het onderzoek op de terechtzitting wordt het ook door art. 6 Europees Verdrag mensenrechten gewaarborgde onmiddellijkheidsbeginsel tot uitdrukking gebracht.' In deze zaak had de rechtbank voorafgaand aan de zitting een bezoek gebracht aan een schietbaan. Dit bezoek was op uitnodiging van de behandelend officier van justitie. Mogelijk belastende informatie die uit dit bezoek kon vloeien mag niet aan de bewezenverklaring ten grondslag worden gelegd.

87 Wel kan hij ter gelegenheid van een schouw het onderzoek ter terechtzitting verplaatsen. Zie art. 318 Sv en HR 18 januari 1983, NJ 1983, 417.

88 Art. 339 lid 2 Sv.

89 HR 23 juni 1970, NJ 1971, 7. 
anderen zijn niet toelaatbaar; zij zijn immers niet gedaan tijdens het onderzoek ter terechtzitting. ${ }^{90}$

Een tweede beperking ten aanzien van het gebruik van de eigen waarneming van de rechter betreft feiten en omstandigheden die via een ander bewijsmiddel ter kennis van de rechter komen. Zij mogen niet gekwalificeerd worden als eigen waarneming van de rechter. Zou dit wel toegelaten zijn, dan zou daarmee de wettelijke regeling van de overige bewijsmiddelen overbodig zijn. Bovendien zouden dan de eisen, onder andere de bewijsminima, die worden gesteld aan die overige bewijsmiddelen gemakkelijk kunnen worden omzeild. Door bijvoorbeeld een verklaring niet als getuigenverklaring, maar als eigen waarneming van de rechter te kwalificeren, zou de rechter niet gebonden zijn aan het bepaalde in artikel 342 lid 1 en $2 \mathrm{~Sv}$. In een dergelijke opvatting zou ons negatief-wettelijk bewijsstelsel verworden tot een vrij bewijsstelsel. ${ }^{91}$ Evenmin is het toegelaten om mondelinge dan wel schriftelijke uitlatingen die om welke reden dan ook niet voldoen aan de wettelijke eisen, via de eigen waarneming van de rechter toch als bewijsmiddel te gebruiken. ${ }^{92}$

Waar de wetgever in 1926 vooral het oog had op sporen van het delict die via de eigen waarneming van de rechter aan de bewijsbeslissing zouden kunnen bijdragen, is thans de reikwijdte van het bewijsmiddel der eigen waarneming vergroot. Enerzijds is dit het gevolg van het gebruik van 'moderne' audiovisuele middelen. Foto's, computeruitdraaien, videobanden en geluidsopnamen kunnen ter zitting worden getoond dan wel worden afgespeeld, en via het bewijsmiddel van de eigen waarneming aan het bewijsoordeel ten grondslag worden gelegd. Daar is nauwelijks enig bezwaar tegen, omdat op deze wijze het bewijsmateriaal in zijn meest directe vorm ter zitting wordt gepresenteerd. Anderzijds zijn echter ook registraties onder het begrip 'eigen waarneming van de rechter' gebracht waarvan niet kan worden gezegd dat het gaat om persoonlijke waarnemingen van de rechter. Reijntjes spreekt in dit verband van 'oneigenlijke eigen waarneming'.

In de eerste plaats kan dan gedacht worden aan situatietekeningen van de plaats van het delict. ${ }^{94}$ Dergelijke tekeningen zijn meestal gemaakt aan de hand van waarnemingen van anderen. Zo zal bij verkeersongelukken een dergelijke teke-

90 Dat speelt bijvoorbeeld in die gevallen waarin de samenstelling van de rechtbank gedurende de behandeling van de strafzaak is gewijzigd. Dan wordt de waarneming van de eerdere rechter niet tevens geacht te zijn gedaan door de latere, vervangende rechter. Zie voor het omgekeerde geval: HR 9 januari 2001, NJ 2001, 125. In die zaak was ten onrechte het onderzoek ter terechtzitting opnieuw aangevangen. De voor de hernieuwde aanvang van het onderzoek gedane waarneming van de afgespeelde videoband mocht voor het bewijs gebezigd worden, aangezien de samenstelling van de rechtbank ongewijzigd was gebleven.

91 A.M. van Woensel, aant. 3.1 op de art. 340 (suppl.134 april 2003), in Melai/Groenhuijsen e.a.

92 In gelijke zin: Nijboer 2000a, p. 229.

93 Reijntjes 2006a, paragraaf 3.4.3.8.

94 Zie bijvoorbeeld HR 8 april 1975, NJ 1975, 281 m.nt. ThWvV. 
ning worden gemaakt door de ter plekke verschenen opsporingsambtenaren. Ook het gebruik van leugenachtige verklaringen van de verdachte wordt door menigeen onder het bewijsmiddel 'eigen waarneming' gerubriceerd. ${ }^{95}$ Dit is strikt genomen onjuist omdat de rechter die leugenachtigheid niet kan waarnemen. ${ }^{96}$ Maar het limitatieve stelsel der bewijsmiddelen dwingt daartoe. Hetzelfde geldt voor het toekennen van bewijswaarde aan het zwijgen van de verdachte. Hoewel aan het zwijgen zelf geen directe bewijsrechtelijke consequenties mogen worden verbonden, mag de rechter daaruit wel conclusies trekken met betrekking tot de bewijswaarde van ander redengevend bewijsmateriaal. ${ }^{97}$

De uitbreiding van de categorie 'eigen waarneming van de rechter' heeft tot gevolg dat het onderscheid met de andere bewijsmiddelen niet altijd even duidelijk is. Dit geldt vooral voor de afgrenzing van de eigen waarneming ten opzichte van de schriftelijke bescheiden. Reeds bij de introductie van de eigen waarneming in 1926 bestond onduidelijkheid op dit punt. Moet het vervalste geschrift nu worden aangemerkt als een schriftelijk bescheid of kan dit via de eigen waarneming van de rechter aan de bewijsbeslissing ten grondslag worden gelegd? Deze vraag is niet slechts academisch, maar heeft ook praktische consequenties. Ten aanzien van de eigen waarneming van de rechter gelden immers niet de bewijsrechtelijke beperkingen zoals die wel voor de schriftelijke bescheiden (art. 344 lid $1 \mathrm{~Sv}$ ), en in het bijzonder voor de overige schriftelijke bescheiden (art. 344 lid 1 onder $5 \mathrm{~Sv}$ ) gelden. Bovendien moeten schriftelijke bewijsstukken op grond van artikel 301 $\mathrm{Sv}$ de verdachte worden voorgelezen. Artikel $301 \mathrm{~Sv}$ is niet van toepassing op de eigen waarneming van de rechter, voor zover dit stukken betreft die niet voor voorlezing vatbaar zijn. Daarvoor geldt het bepaalde in artikel $309 \mathrm{~Sv}$; de stukken van overtuiging moeten de verdachte worden getoond. Het niet naleven van dit voorschrift leidt - in tegenstelling tot het bepaalde van artikel $301 \mathrm{~Sv}$ - niet tot uitsluiting van het bewijsmateriaal. Het verschil op dit punt vloeit waarschijnlijk voort uit de gedachte dat alle procesdeelnemers hetzelfde kunnen waarnemen als de rechter en het derhalve niet noodzakelijk is dit nog nader te expliciteren. Dat geldt zeker voor audio- en video-opnamen die ter zitting worden afgespeeld. Reijntjes heeft er echter terecht op gewezen dat in geval van situatietekeningen of foto's de waarneming van de rechter niet altijd zo expliciet geschiedt. ${ }^{98}$ In dergelijke gevallen zou het wenselijk zijn als de wet op straffe van nietigheid zou eisen dat de rechter zijn eigen waarneming ter zitting expliciteert. Het zou de

95 Zie Van Veen in zijn noot onder HR 22 september 1992, NJ 1993, 55. In paragraaf 5.2.4.1 wordt nader op de kennelijk leugenachtige verklaring van de verdachte ingegaan.

96 In gelijke zin: A.M. van Woensel, aant. 5.4 op de art. 340 (suppl.134 april 2003), in Melai/Groenhuijsen e.a.

97 Bijvoorbeeld: HR 3 juni 1997, NJ 1997, 584. In paragraaf 5.2.4.2 wordt nader op het gebruik van het zwijgen van de verdachte voor het bewijs ingegaan.

98 Reijntjes 1980, p. 201. 
openbaarheid van de zitting ${ }^{99}$ en de mogelijkheid van tegenspraak voor de verdediging vergroten. ${ }^{100}$ Deze wettelijke inconsequenties heeft de Hoge Raad er echter niet van weerhouden om schriftelijk bewijsmateriaal ook voor het bewijs te accepteren in de vorm van de eigen waarneming van de rechter, voor zover dat materiaal tevens als stuk van overtuiging - voorwerp waarmee of waaraan het delict is begaan - kan worden aangemerkt. ${ }^{101}$

Ten aanzien van de meer moderne vormen van rechterlijke waarneming - die waarbij audiovisuele middelen kunnen worden ingezet - doet zich eigenlijk een omgekeerde situatie voor. Hier wordt vaak met een schriftelijke reproductie volstaan in plaats van het rechtstreeks tonen van bewijs ter zitting. In veel gevallen is het afspelen van video- en geluidsbanden ter zitting niet nodig, omdat de inhoud daarvan reeds in een proces-verbaal van opsporingsambtenaren is opgenomen. ${ }^{102}$ De vraag is echter of in dergelijke gevallen de eigen waarneming van de rechter niet de meest geëigende weg is om dergelijke registraties voor het bewijs te bezigen. Weergave van het audiovisueel materiaal in schriftelijke vorm leidt immers in veel gevallen tot verlies van de oorspronkelijkheid. Ten aanzien van geluidsbanden zal een selectie worden gemaakt en wordt de inhoud soms enkel zakelijk weergegeven. Ten aanzien van beeldmateriaal doet zich het probleem voor dat het vertalen van die beelden een kwestie van interpretatie is. Bovendien wordt door het gebruik van het proces-verbaal waarin de inhoud van dergelijke banden is opgenomen, de bewijswaarde in formele zin verhoogd. Ten aanzien van een procesverbaal geldt immers geen bewijsminimum; sterker nog de bewezenverklaring kan berusten op enkel een proces-verbaal van een opsporingsambtenaar (art. 344 $\operatorname{lid} 2 \mathrm{~Sv}$ ).

Uit de jurisprudentie van de Hoge Raad komt naar voren dat de eigen waarneming van de rechter wordt beschouwd als een vangnet voor al het bewijsmateriaal dat niet op de een of andere manier onder een van de andere bewijsmiddelen kan worden vervat. Daarmee is voor een groot deel de waarde van de limitatieve opsomming van de bewijsmiddelen zoals die in artikel 339 is vervat, komen te vervallen. De wetgever in 1926 had de illusie dat hij alle mogelijke toelaatbare vormen van bewijs kon vatten in de vijf in artikel 339 Sv genoemde categorieën.

99 In gelijke zin: Corstens 2005a, p. 638: 'Ook al zijn die in beslag genomen geschriften (tevens corpora of instrumenta delicti) voor partijen kenbaar, de uitwendige openbaarheid wordt tekortgedaan, indien zij niet aan genoemde regime worden onderworpen.'

100 In gelijke zin: Nijboer 2000a, p. 231.

101 A.M. van Woensel, aant. 5.2 bij art. 340 Sv (suppl. 134 april 2003), in: Melai/Groenhuijsen e.a. Voor zover overigens het bewijsmateriaal voor voorlezing vatbaar is, zal het ter zitting moeten worden voorgelezen of de inhoud daarvan kort moeten worden medegedeeld (art. 301 lid $4 \mathrm{~Sv}$ ).

102 Bijvoorbeeld: HR 8 juni 2004, NJ 2004, 413 voor het gebruik van foto's die waren opgenomen in het proces-verbaal van de opsporingsambtenaren. 
Nieuwe technische ontwikkeling op het gebied van audiovisuele registratie had hij echter niet voorzien. De Hoge Raad heeft er goed aan gedaan dergelijke registraties onder het bewijsmiddel 'eigen waarneming van de rechter' te laten vallen. Dat geldt in mindere mate voor het gebruik van tekeningen, tabellen en grafieken opgesteld door derden. In principe dienen deze vormen van bewijs niet beschouwd te worden als eigen waarneming van de rechter, omdat zij geen zelfstandige waarneming van de rechter bevatten. Daarmee is niet gezegd dat deze vormen van bewijs moeten worden uitgesloten. Het geeft slechts aan dat de intentie van de wetgever om alle mogelijke vormen van bewijs te vatten in vijf categorieën niet geslaagd is. Ook het vatten van de leugenachtige verklaring van de verdachte en diens zwijgen onder de eigen waarneming is gekunsteld. Het betreft hier geen waarneming, maar veel meer een redenering. Bij gebrek aan het vroegere bewijsmiddel der aanwijzingen moeten echter ook deze vormen van bewijs binnen een negatief-wettelijk bewijsstelsel een plaats krijgen en zo worden noodgedwongen de grenzen van de eigen waarneming van de rechter opgerekt.

Het oprekken van het begrip 'eigen waarneming' heeft mede tot gevolg dat de afbakening met andere bewijsmiddelen minder strikt is. Dit geldt vooral ten aanzien van het bewijsmiddel 'schriftelijke bescheiden'. Het feit dat de rechter in bepaalde gevallen de mogelijkheid heeft om bewijsmateriaal ofwel in de vorm van eigen waarneming, ofwel als schriftelijk bescheid te bezigen, doet afbreuk aan het in de wet neergelegde stelsel van bewijsvoering en bewijswaardering. De rechter kan naar gelang hem dat beter uitkomt, zijn keuze bepalen. Daarbij spelen vaak proceseconomische overwegingen - zoals het strakke zittingsschema - een prominentere rol dan overwegingen die verband houden met een behoorlijke en deugdelijke waarheidsvinding.

\subsubsection{Waarnemingen van derden}

In vrijwel alle strafzaken is de rechter voor het bewijs afhankelijk van de zintuiglijke waarnemingen van derden. In de opsomming van de wettige bewijsmiddelen komt dit ook tot uitdrukking. Drie van de vijf genoemde bewijsmiddelen zien voornamelijk op verklaringen van derden over wat zij in relatie tot het tenlastegelegde feit hebben gezien, gehoord of anderszins hebben waargenomen of ondervonden. Het gaat dan om verklaringen van de verdachte (art. $341 \mathrm{~Sv}$ ), van getuigen (art. $342 \mathrm{~Sv}$ ) en van opsporingsambtenaren (344 lid 1 onder $2 \mathrm{~Sv}$ ). De verklaring van een opsporingsambtenaar kan qua inhoud worden gelijkgesteld met een getuigenverklaring. Met betrekking tot de vorm wijkt zij echter af; de opsporingsambtenaar mag als enige schriftelijk verklaren over hetgeen hij heeft waargenomen. Bovendien komt aan zijn verklaring een grotere waarde toe; op grond van het tweede lid van artikel $344 \mathrm{~Sv}$ kan een bewezenverklaring enkel gebaseerd zijn op de verklaring van een opsporingsambtenaar. 
Aan de inhoud van de verklaringen van verdachten, getuigen en opsporingsambtenaren wordt in de wet steeds dezelfde eis gesteld; zij mogen slechts mededelingen bevatten over feiten en omstandigheden die door hen zelf zijn waargenomen en ondervonden. Deze eis geldt ook indien de verklaring wordt overgebracht door een derde. In dat geval moet zowel de overbrengende als overgebrachte verklaring berusten op eigen waarneming en ondervinding. ${ }^{103}$ Ten aanzien van de verdachte vermeldt de wettekst dat hij alleen kan verklaren over feiten hem bekend uit eigen wetenschap, maar aan deze afwijkende terminologie komt geen betekenis toe. ${ }^{104}$ Uit de eis dat derden alleen kunnen verklaren over zaken die zij zelf hebben waargenomen of ondervonden vloeien drie grenzen voort ten aanzien van de inhoud van de verklaring.

Ten eerste mag niets verklaard worden wat het waarnemingsvermogen van de getuige te boven gaat. Dat betekent dat een getuige zich moet beperken tot het weergeven van 'blote feiten' en zich moet onthouden van het geven van meningen, conclusies en redeneringen over die feiten. Doet hij dat wel, dan begeeft de getuige zich op het terrein van de deskundige, en dat is niet toegestaan. Het onderscheid tussen getuigen en deskundigen is echter niet altijd even duidelijk. De Hoge Raad erkent dat de ene getuige op specifieke terreinen meer deskundig kan zijn dan de andere getuige. ${ }^{105}$ In geval van zo'n meer deskundige getuige kunnen eventuele gevolgtrekkingen dan ook door de beugel. ${ }^{106}$ In het bijzonder geldt dit voor opsporingsambtenaren. Op grond van zijn ervaring en kundigheid kan een verbalisant meer uit eigen waarneming verklaren dan een reguliere getuige. ${ }^{107} \mathrm{Zo}$ kan een opsporingsambtenaar verklaren over de snelheid waarmee een auto reed, zonder dat dit als een conclusie of mening wordt aangemerkt. ${ }^{108}$

Een tweede grens met betrekking tot de verklaringen van derden is gelegen in de afbakening van hun rol ten opzichte van de rechter. ${ }^{109}$ Getuigen mogen geen conclusies trekken die zijn voorbehouden aan de rechter. Dat betekent dat bijvoorbeeld een getuige wel mag verklaren dat een auto hard reed, maar niet dat hij te hard reed. ${ }^{110}$ Evenmin mag de getuige in zijn verklaring vooruitlopen op de juridische kwalificatie. Een verklaring inhoudende 'naar aanleiding van dit onderzoek werd duidelijk dat betrokkenen een duurzame gezamenlijke huishouding hebben gevoerd'

103 HR 20 december 1955, NJ 1956, 202 m.nt. BVAR.

104 Kamerstukken II 1913-1914, 286, nr. 3 (MvT), p. 170.

105 Garé onderscheidt op dit punt formeel en materieel gekwalificeerde getuigen. D.M.H.R. Garé, aant. 7 en 8 op art. 342 (nov. 1997, suppl. 107), in Melai/Groennhuijsen e.a.

106 Bijvoorbeeld: HR 20 september 1976, NJ 1977, 257; HR 15 mei 1990, NJ 1991, 10 m.nt. ThWvV en HR 25 juni 1991, NJ 1991, 808 m.nt. Sch.

107 Hierover kritisch: Hielkema 1991.

108 HR 1 oktober 1985, NJ 1986, 629. In gelijke zin: HR 18 november 1952, $N J$ 1953, 64; HR 25 juni 1985, NJ 1986, 109 m.nt. ThWvV en HR 12 november 1985, NJ 1986, 409.

109 Nijboer spreekt hier van de zogeheten 'ultimate issue'-regel. Zie Nijboer 2000a, p. 241

110 HR 25 november 1986, NJ 1987, 687. In gelijke zin: HR 30 mei 1972, NJ 1972, 381. 
is in die zin een ontoelaatbare conclusie. ${ }^{111}$ Zou zij wel toelaatbaar zijn, dan zou dat betekenen dat de feitelijke vaststelling volledig wordt overgelaten aan de getuige, in casu een opsporingsambtenaar, zonder dat de rechter daarop nog enige controle kan uitoefenen. Wat het onderzoek heeft ingehouden en welke feiten daarbij zijn vastgesteld, blijkt in zijn geheel niet. ${ }^{12}$ Desalniettemin meent de Hoge Raad dat het gebruik van dergelijke verklaringen niet altijd tot cassatie hoeft te leiden. Namelijk in die gevallen waarin de rechter op basis van ander beschikbaar bewijsmateriaal de gevolgtrekking van de getuige overneemt. ${ }^{113}$ De vraag blijft dan wel waarom de ontoelaatbare conclusie in het vonnis wordt opgenomen.

Tot slot volgt uit de eis van eigen waarneming en ondervinding dat de getuigenverklaring geen vermoedens, gissingen of andere veronderstellingen mag bevatten. ${ }^{114}$ Deze eis moet voorkomen dat speculatieve elementen de rechterlijke oordeelsvorming beïnvloeden. ${ }^{115}$ Op dit punt is de Hoge Raad echter bijzonder coulant. Het gebruik van een verklaring waarin de getuige verklaart dat 'hij dacht dat ...' of 'hij meende dat ...' wordt in cassatie zelden afgestraft. De Hoge Raad is bereid dergelijke verklaringen op een zodanige wijze te lezen dat zij wel voldoen aan de eis van eigen waarneming en ondervinding. ${ }^{116}$ Bevat de verklaring een gissing of vermoeden, dan is de Hoge Raad bereid een dergelijke verklaring zodanig te herformuleren dat hier niet langer sprake van is. Dit gebeurt dan door te overwegen dat de getuige door middel van deze verklaring tot uitdrukking heeft willen brengen welke gedachte of indruk bij hem opkwam. Een dergelijke gedachte of indruk kan de getuige wel waarnemen of - misschien in dit geval beter gezegd - ondervinden. Garé spreekt in dit verband van een 'objectiverende interpretatie'. ${ }^{117}$ Zo kan een verklaring inhoudende 'de man had de Turkse nationaliteit' worden opgevat als 'de getuige had de indruk dat de man er uitzag als iemand van Turkse afkomst'. ${ }^{118}$ De letterlijke tekst van de verklaring is niet doorslaggevend. Meer waarde komt toe aan de strekking van de verklaring. ${ }^{119}$ Voor zover die strekking niet direct blijkt uit de verklaring zelf is de Hoge Raad bereid een en ander in de verklaring in te lezen.

Uit de wijze waarop de Hoge Raad de eisen die worden gesteld aan waarnemingen van derden uitlegt, kan de algemene conclusie worden getrokken dat hij bereid is veel door de vingers te zien. In veel gevallen zal de jurisprudentie

111 HR 12 januari 1999, NJ 1999, 247. In gelijke zin: HR 12 mei 1992, NJ 1992, 658.

112 Zie over deze wijze van verbaliseren: advocaat-generaal Leijten in zijn conclusie bij HR 18 september 1989, $N J$ 1990, 166 en HR 12 mei 1992, NJ 1992, 658.

113 HR 16 maart 1993, NJ 1993, 719.

114 Zie bijvoorbeeld HR 4 juni 1996, NJ 1996, 633.

115 Borst 1980, aant. 4 bij art. 342 Sv, p. 137.

116 HR 2 juni 1987, NJ 1988, 178.

117 D.M.H.R. Garé, aant. 13 op art. 342 (suppl. 107, november 1997), in: Melai/Groenhuijsen e.a.

118 HR 11 februari 1992, NJ 1992, 516. Zie ook HR 4 juni 1991, NJ 1991, 790 m.nt. ThWvV.

119 In gelijke zin: Van Veen in zijn annotatie bij HR 4 juni 1991, NJ 1991, 790. 
wellicht zijn ingegeven door de idee dat een vonnis niet op een dergelijke 'technicality' moet stranden; zeker als duidelijk is dat de gissing, mening of conclusie wel kan worden gebaseerd op andere feiten of op veronderstelde deskundigheid van de verklarende persoon. Dit laat onverlet dat de rechtspraak van de Hoge Raad tot gevolg heeft dat de wettelijke eisen die worden gesteld aan de waarneming van derden in toenemende mate aan betekenis verliezen.

\subsubsection{Bewijs door middel van deskundigen}

Naast verklaring over waarnemingen van derden is in artikel 343 de verklaring van de deskundige als zelfstandig bewijsmiddel geformuleerd. De verklaring van de deskundige wordt omschreven als zijn bij het onderzoek ter terechtzitting medegedeelde gevoelen betreffende hetgeen zijn wetenschap hem leert omtrent datgene wat aan zijn oordeel is onderworpen. De deskundige heeft ook de mogelijkheid om schriftelijk te verklaren. ${ }^{120}$ In dat geval kan zijn verslag ex artikel 344 lid 1 onder $4 \mathrm{~Sv}$ voor het bewijs worden gebezigd. In het merendeel van de gevallen wordt een deskundige gedurende het vooronderzoek verzocht om zijn mening te geven. Hij zal dan schriftelijk rapporteren en - indien gewenst - zijn bevindingen ter zitting toelichten. Voor zover het aanwijzen van een deskundige door de rechter-commissaris gebeurt - op vordering van het Openbaar Ministerie of op verzoek van de verdediging - wordt in het Wetboek een specifieke procedure voorgeschreven. In toenemende mate worden deskundigen buiten de rechtercommissaris om door politie en justitie ingeschakeld. De meeste opdrachten voor onderzoek door het Nederlands Forensisch Instituut worden rechtstreeks door de politie gegeven. Ten aanzien hiervan geldt dus niet de procedure van artikel 227 e.v. Sv. In dergelijke gevallen kan de verdediging nauwelijks invloed uitoefenen noch op de beslissing wie als deskundige wordt benoemd, noch op het bepalen van de omvang van het onderzoek. De opdracht tot onderzoek en de omvang van dat onderzoek wordt dan door de politie eventueel in samenspraak met de officier van justitie bepaald. ${ }^{121}$

De in artikel 343 en 344 lid 1 onder 4 Sv gegeven omschrijving van een deskundigenverklaring is in hoge mate formeel. ${ }^{122}$ De wet geeft niet aan wie als

120 De meeste deskundigen rapporteren schriftelijk. Veelal worden daarvoor zogeheten vaste gerechtelijke deskundigen benaderd. De deskundigheid van deze vaste deskundigen wordt verondersteld. Teneinde dit te kunnen toetsen zou het wenselijk zijn dat deze deskundigen vaker ter zitting worden gehoord. Van Kampen 1998, p. 320.

121 Tijdens het opsporingsonderzoek worden vooral deskundigen ingeschakeld ten behoeve van het verkrijgen van criminalistische informatie en medisch-fysieke informatie over met name slachtoffers. Tijdens het gerechtelijk vooronderzoek ligt de nadruk op deskundigenonderzoek met betrekking tot de persoon van de verdachte. Hielkema 1996, p. 290.

122 In het Gewijzigd Ontwerp (GO) was een meer inhoudelijke definitie opgenomen, maar 
deskundige moet worden aangemerkt, evenmin wat onder wetenschap moet worden verstaan. Beide aspecten - deskundigheid en wetenschap - zijn onlosmakelijk met elkaar verbonden, wat blijkt uit de wijze waarop de Hoge Raad het begrip 'wetenschap' interpreteert. Onder het begrip 'wetenschap' valt elke bijzondere kennis die iemand bezit of geacht wordt te bezitten met betrekking tot een punt dat in het strafproces van belang is. ${ }^{123}$ Dat kan dus variëren van kennis op het gebied van de medische wetenschap tot kennis met betrekking tot de werking van zendmasten voor het mobiele telefoonverkeer. Degene die dergelijke kennis bezit of geacht wordt te bezitten kan als deskundige worden aangemerkt. Feitelijk kan dus een ieder met specifieke kennis op een bepaald gebied worden aangemerkt als deskundige en kan hetgeen hij verklaart naar aanleiding van het door hem gedane onderzoek als 'wetenschap' worden bestempeld. Of de verklaring uiteindelijk inderdaad afkomstig is van een deskundige, en of wat hij verklaart wetenschappelijk - in de ruime zin - is, is aan de feitenrechter om te beoordelen. Slechts op twee punten kan het gebruik van de deskundigenverklaring in cassatie getoetst worden.

Zoals de getuige niet als deskundige mag optreden, geldt ten aanzien van de deskundige dat hij niet als getuige mag optreden. Dit verschil komt ook tot uitdrukking in verschillende eedsformules voor de getuige en de deskundige. ${ }^{124} \mathrm{De}$ deskundigenverklaring mag derhalve geen elementen bevatten die thuis horen in een getuigenverklaring. In principe betekent dit dat de deskundige in zijn verslag of in zijn verklaring geen zintuiglijke waarnemingen zou mogen opnemen. Hij moet zich beperken tot wat zijn wetenschap hem leert. Dit veronderstelt echter dat de deskundige zijn taak zou kunnen volbrengen zonder dat daar enige waarneming aan te pas komt. Dat laatste is natuurlijk niet waar. De deskundige onderscheidt zich van de getuige doordat hij zijn onderzoek in opdracht van een ander verricht. Zijn specifieke expertise stelt hem in staat dat onderzoek uit te voeren. Uit het onderzoek kunnen 'nieuwe' door hem waargenomen feiten naar voren komen of kunnen reeds door anderen waargenomen feiten nader worden omschreven en geanalyseerd. Zo stelt de lijkschouwer bij zijn onderzoek officieel

daarin bleven bepaalde aspecten van de werkzaamheden van deskundigen onderbelicht. Om die reden is uiteindelijk gekozen voor een weinig inhoudelijke omschrijving van de deskundigenverklaring. In gelijke zin: Dubelaar 2006, p. 91: 'De bestaande regeling is erg uitwendig; inhoudelijke criteria voor de inschakeling van deskundige(n) ontbreken, evenals criteria voor de beoordeling van de deskundigenverklaringen voor het bewijs.'

123 Hielkema 1996, p. 213: 'Onder wetenschap moet worden verstaan: wetenschap in ruime (alledaagse) zin. (...) de deskundige verricht onderzoek of geeft voorlichting (...) op basis van bijzondere kennis of waardigheden die hij op grond van studie en ervaring heeft verkregen. Wetenschap in de zojuist gegeven context kan academische wetenschap zijn maar ook wetenschap over kunst, nijverheid, handel en dergelijke.'

124 De getuige dient te verklaren dat hij niets dan de waarheid zal zeggen (art. 290 lid $2 \mathrm{~Sv}$ ). De deskundige daarentegen dient ingevolge art. 299 Sv te verklaren dat hij zijn taak naar zijn geweten zal vervullen. 
de dood vast en wordt bij de daarop volgende sectie door de patholoog de doodsoorzaak onderzocht. Evenals de getuige zal ook de deskundige afhankelijk zijn van zintuiglijke waarneming, maar kan de deskundige door gebruik te maken van zijn expertise deze waarneming meer kracht bijzetten of nader expliciteren en mogelijk verklaringen aandragen voor de aldus waargenomen feiten. Iedere deskundigenverklaring zal dus een element van waarneming bevatten. ${ }^{125}$ Dit wordt door de Hoge Raad terecht toelaatbaar geacht. ${ }^{126}$ Alleen indien de deskundigenverklaring te veel het karakter van een getuigenverklaring heeft, zal dit tot cassatie leiden. Overigens wordt dit probleem in de praktijk vermeden door ter zitting gehoorde deskundigen als deskundige én als getuige te beëdigen. Op deze wijze kunnen eventuele delen van de verklaring die meer het karakter hebben van een getuigenverklaring ook als zodanig aan de bewezenverklaring ten grondslag worden gelegd. Voor schriftelijke deskundigenverslagen bestaat dit probleem niet, omdat daarvoor niet de eis van beëdiging geldt. ${ }^{127}$

Een tweede beperking is dat de deskundige in zijn verklaring of verslag niet mag vooruitlopen op het aan de rechter opgedragen oordeel. ${ }^{128}$ Door het stellen van deze eis wordt voorkomen dat de uiteindelijke vaststelling van de feiten volledig aan de deskundige wordt overgelaten. Hij mag als het ware niet op de stoel van de rechter gaan zitten. Prakken heeft erop gewezen dat in het ordeningsstrafrecht in toenemende mate strafbepalingen voorkomen waarbij het bewijs van de feiten voornamelijk afhankelijk is van het oordeel van deskundigen. ${ }^{129}$ Komt de deskundige, meestal een gespecialiseerde opsporingsambtenaar, aan de hand van het door hem ingestelde onderzoek tot de conclusie dat een bepaalde strafbare toestand bestaat of een strafbaar gevolg is ingetreden, dan is daarmee voor het overgrote deel de beslissing van de rechter al gegeven. De waarheidsvinding onttrekt zich in dergelijke zaken vaak volledig aan de rechter; de rechterlijke verantwoordelijkheid voor de feitenvaststelling is dan niet meer dan een formele. In materiële zin ligt die verantwoordelijkheid bij de deskundige/opsporingsambtenaar. In het klassieke strafrecht is een vergelijkbare ontwikkeling te bespeuren. Het toenemend gebruik van verschillende vormen van technisch bewijs, zoals DNAprofielen en geuridentificatieproeven, heeft ook hier tot consequentie dat een deel van de waarheidsvinding zich onttrekt aan de verantwoordelijkheid van de rechter. Hij kan immers geen verantwoordelijkheid nemen voor zaken die hij niet begrijpt. ${ }^{130}$ Tot welke dramatische gevolgen dat kan leiden, werd duidelijk bij de Schiedammer parkmoord; waar twee deskundigen verschilden van mening over de waarde die aan de uitslag van een DNA-analyse moest worden toegekend,

125 Nijboer 2000a, p. 256. In gelijke zin: Hielkema 1996, p. 216.

126 Hielkema 1996, p. 217 en de daar genoemde jurisprudentie.

127 HR 2 december 1935, NJ 1936, 136 en HR 21 februari 1978, NJ 1978, 663.

128 HR 21 november 2000, NJ 2001, 48.

129 Jessurun d'Oliveira-Prakken 1976, p. 29 e.v.

130 In gelijke zin: Jessurun d'Oliviera-Prakken 1976, p. 37. 
kreeg de rechter uiteindelijk slechts één versie te horen, te weten de voor de verdachte belastende versie. Achteraf bleek, nadat de werkelijke dader zich had gemeld, dat de andere versie de juiste was. Deze zaak maakt het belang van onafhankelijke deskundigen en een gedegen rechterlijke controle op hun werkzaamheden eens te meer duidelijk. Teneinde die rechterlijke controle mogelijk te maken, dienen deskundigen volledig te rapporteren en dient de rechter in ieder geval een solide basiskennis te hebben van de meest gangbare vormen van forensisch onderzoek. ${ }^{131}$

Concluderend kan worden gesteld dat in de wet ten aanzien van het deskundigenbewijs weinig materiële eisen worden gesteld. Tegelijkertijd neemt het belang van het deskundigenbewijs in strafzaken toe. Dat geldt zeker voor het ordeningsstrafrecht. Maar ook voor het bewijs van 'klassieke' delicten wordt in toenemende mate een beroep gedaan op expertise van anderen. De afwezigheid van concrete wettelijke normen ten aanzien van het gebruik van deskundigenverklaringen heeft tot gevolg dat de waardering van verklaringen van deskundigen volledig is overgelaten aan de strafrechter. Deze heeft echter op zijn beurt bij gebrek aan eigen expertise nauwelijks mogelijkheden om de deskundigheid en de inhoud van verklaring op zijn merites te beoordelen. Crombag spreekt in dat verband van een Catch $22 .{ }^{132}$ Van Koppen noemt het de paradoxale verhouding tussen rechter en deskundige. ${ }^{133}$ Deze kwestie ligt nog moeilijker zodra meer deskundigen worden geraadpleegd en zij tot verschillende conclusies komen. ${ }^{134}$ Hoe bepaalt de rechter dan zijn keuze, en dient hij dit dan niet op een of andere wijze te verantwoorden, ondanks het feit dat de wet op dit punt geen eisen stelt?

Voor een deel heeft de Hoge Raad dit probleem onderkend. Via de motivering worden thans wel materiële eisen aan het gebruik van het deskundigenbewijs gesteld. Indien de deskundigheid dan wel de betrouwbaarheid van de door de deskundige gehanteerde methode wordt betwist, dan mag de rechter aan een dergelijk verweer niet zonder meer voorbij gaan. Hij moet uitleggen waarom hij aan de verklaring van de deskundige waarde hecht, ondanks de door de verdediging aangevoerde argumenten. De rechter dient in zijn vonnis aan te geven waaruit hij de deskundigheid afleidt, of de deskundigheid zich uitstrekt tot het onderhavige onderzoek, welke methode de deskundige bij zijn onderzoek heeft toegepast,

131 Zie in dat verband ook: Crombag 2000 en Broeders 2003, p. 417: 'Waar rechter en advocaten niet altijd voldoende zijn opgeleid om de kwaliteit van technisch en wetenschappelijk bewijs te beoordelen, zulks niet direct tot hun taak rekenen of wellicht verkiezen te leven met de illusie dat ze dat wel kunnen, ligt de verantwoordelijkheid voor de kwaliteitsbewaking bij primair bij de individuele deskundigen en bij de laboratoria waar deze doorgaans werkzaam zijn.'

132 Crombag 2000, p. 1660.

133 Van Koppen 2004, p. 6.

134 Van Koppen 2004, p. 6. 
waarom de deskundige deze methode betrouwbaar acht, en of de deskundige in staat is deze methode goed toe te passen. ${ }^{135}$ Deze motiveringsplicht zal de taak van de strafrechter er niet makkelijker op maken, maar heeft tot gevolg dat de rechter niet klakkeloos het oordeel van een deskundige kan volgen. Hij dient zelfstandig onderzoek te doen naar de expertise en betrouwbaarheid van het door de deskundige verrichte onderzoek en de daaruit voortvloeiende onderzoeksresultaten. Van dat rechterlijk onderzoek - meestal het horen van de deskundige ter zitting moet hij in zijn vonnis laten blijken.

Waar ten aanzien van de waarnemingen van derden de Hoge Raad de materiële eisen terugbrengt, valt met betrekking tot het deskundigenbewijs een tegengestelde ontwikkeling te bespeuren. Bij gebrek aan duidelijke materiële eisen in de wet, worden alsnog via een motiveringsplicht nadere eisen aan deze vorm van bewijs gesteld. $^{136}$

\subsection{Bewijsverboden}

Uit de limitatieve opsomming van de bewijsmiddelen zoals die in artikel $339 \mathrm{~Sv}$ is opgenomen, volgt feitelijk het verbod om het bewijs van het tenlastegelegde feit op andere bronnen te baseren dan daar genoemd. De wijze waarop de Hoge Raad echter de diverse bewijsmiddelen heeft geïnterpreteerd, maakt het mogelijk alle informatie die bijdraagt tot de opheldering van het strafrechtelijke verwijt in één van de daar genoemde bewijsmiddelen te vervatten. De meest wezenlijke inbreuk op het limitatieve stelsel vond plaats in 1926. Uit het de-auditu-arrest volgt immers dat alle waarnemingen van derden via het proces-verbaal van een opsporingsambtenaar ter kennis van de rechter kunnen komen en niet langer vereist is dat deze personen ter zitting verklaren. Maar ook het bewijsmiddel 'eigen waarneming van de rechter' is gaan fungeren als een soort vangnet voor bewijsmateriaal dat niet onder een van de andere bewijsmiddelen kon worden ondergebracht. De vorm waarin het bewijsmateriaal is vervat - de bewijsmiddelen levert aldus nauwelijks nog een beletsel op om tot een bewezenverklaring te komen. Hooguit kan de inhoud van het bewijsmiddel in het specifieke geval zodanig zijn dat niet is voldaan aan de inhoudelijke eisen die ten aanzien van het bewijsmiddel gelden. Zo kan bijvoorbeeld het proces-verbaal een verklaring bevatten die ook in de ogen van de Hoge Raad als gissing moet worden aangemerkt. Dergelijke beperkingen zijn echter afhankelijk van de afzonderlijke strafzaak en het daarin gepresenteerde bewijsmateriaal.

Sluit het huidige bewijsrecht dan nog in algemene zin bepaalde vormen van bewijsmateriaal uit? Men kan in dat verband denken aan de verklaring van de

135 HR 27 januari 1998, NJ 1998, 404 m.nt. JR.

136 Nader hierover: hoofdstuk 6. 
medeverdachte. Artikel 341 lid $3 \mathrm{~Sv}$ bepaalt dat de verklaring van de verdachte alleen in zijn eigen zaak mag worden gebezigd. Het is dus op grond van deze bepaling uitgesloten om de verklaring van de ene verdachte tegen de andere verdachte te gebruiken. De wetgever meende dat aan het gebruik van dergelijke verklaringen uit betrouwbaarheidsoverwegingen een te groot risico kleefde; de medeverdachte zal immers geneigd zijn om de schuld af te schuiven op de ander, of in ieder geval zijn aandeel in het strafbare feit proberen te verkleinen of mooier voor te stellen. ${ }^{137}$

De Hoge Raad heeft echter het begrip 'medeverdachte' zeer beperkt uitgelegd. Medeverdachte is alleen diegene wiens zaak gevoegd is bij die van de verdachte. ${ }^{138}$ Dat betekent dat de verklaring van de medeverdachte die op een ander moment terechtstaat of die weliswaar gelijktijdig met de verdachte voor de rechter verschijnt, maar wiens zaak in formele zin is afgesplitst van die van de verdachte, wel degelijk voor het bewijs kan worden gebruikt. Dit kan de verklaring van de medeverdachte als zodanig afgelegd in het vooronderzoek of zijn getuigenverklaring ter terechtzitting in de zaak van de verdachte zijn. In het laatste geval wordt de medeverdachte onder ede gehoord en op zijn verschoningsrecht gewezen.

De wijze waarop de Hoge Raad uitleg heeft gegeven aan artikel 341 lid 3 Sv heeft tot gevolg dat in de praktijk zelden zaken van medeverdachten worden gevoegd. De voeging werpt immers in bewijsrechtelijke zin hindernissen op. Bovendien kan het voordeel van voeging - een meer proceseconomische behandeling van de zaken - ook worden verkregen door de zaken gelijktijdig te behandelen zonder tot een formele voeging van die zaken over te gaan. Ook bij een gelijktijdige behandeling hoeft het in het dossier aanwezige bewijsmateriaal slechts één keer te worden voorgehouden en wordt voorkomen dat getuigen en deskundigen verschillende keren moeten worden opgeroepen en gehoord. Met 'deze processuele foef ${ }^{139}$ wordt echter de bedoeling van de wetgever teniet gedaan; van een bewijsverbod kan nauwelijks nog worden gesproken.

Wel heeft de Hoge Raad zich categorisch uitgesproken tegen het gebruik van onder hypnose afgelegde belastende ${ }^{140}$ verklaringen. Hij overwoog dienaangaande:

137 Kamerstukken II 1913-1914, 286, nr. 3 (MvT), p 168.

138 HR 23 dec. 1929, NJ 1930, 229; HR 18 dec. 1933, NJ 1934, 324; HR 14 juni 1960, NJ 1960, 597 en HR 29 oktober 1974, NJ 1975, 108.

139 Corstens 2005a, p. 644.

140 Het acht slaan op onder hypnose afgelegde verklaringen ter ontlasting van de verdachte is de rechter niet verboden: HR 12 juni 1984, NJ 1985, 135 m.nt. ThWvV. In zijn noot onder $N J$ 1998, 798 acht Reijntjes dit inconsequent: 'Wie aanneemt dat de mogelijkheid om in een concreet geval tot een verantwoord oordeel te komen over het waarheidsgehalte van de afgelegde verklaring ten enen male ontbreekt, zal ook gebruik ten voordele van de verdachte niet kunnen toelaten.' 
'dat naar huidige wetenschappelijke inzichten geen zekerheid bestaat omtrent de objectieve betrouwbaarheid van onder hypnose afgelegde verklaringen, maar tevens dat in het algemeen aan de betrouwbaarheid van dergelijke verklaringen moet worden getwijfeld en dat de mogelijkheid om in een concreet geval tot een verantwoord oordeel te komen omtrent het waarheidsgehalte van een onder hypnose afgelegde verklaring ontbreekt. ${ }^{, 141}$

Hoewel een specifieke uitspraak van de Hoge Raad daaromtrent ontbreekt, mag worden aangenomen dat ook verklaringen die met behulp van een leugendetector of narcoanalyse tot stand komen, niet voor het bewijs mogen worden gebezigd. ${ }^{142}$ De deugdelijkheid van deze methoden is immers evenzeer omstreden. ${ }^{143}$ Overigens is het gebruik van dergelijke verklaringen ook uit behoorlijkheidsoverwegingen omstreden; de in artikel $29 \mathrm{~Sv}$ neergelegde verklaringsvrijheid van de verdachte komt in het gedrang.

Concluderend kan worden gesteld dat het Wetboek van Strafvordering zoals uitgelegd door de Hoge Raad geen bewijsverboden kent. De limitatieve opsomming van bewijsmiddelen leidt er niet toe dat op voorhand bepaalde vormen van bewijs zijn uitgesloten. Het enige in de wet neergelegde bewijsverbod - artikel 341 lid $3 \mathrm{~Sv}-$ is door de restrictieve interpretatie van het begrip 'medeverdachte' feitelijk buiten werking gesteld. Buiten het wetboek om heeft de Hoge Raad ten aanzien van het verhoor van getuigen onder hypnose bepaald, dat de resultaten van dat verhoor niet voor het bewijs gebezigd mogen worden. Daarmee is dat dan ook het enige bewijsverbod dat de Nederlandse strafvordering kent.

\subsection{De bewijsminima}

Het negatief-wettelijk bewijsstelsel zoals dat in 1926 vorm heeft gekregen beoogde minimumgaranties te bieden voor een deugdelijke feitenvaststelling. Daartoe werd de rechter gebonden aan wettige bewijsmiddelen en werden tevens bepaalde bewijsminima geformuleerd. De in 1926 in het wetboek opgenomen bewijsminima betreffen de verklaring van de verdachte, de verklaring van de getuige en de overige schriftelijke bescheiden. Naderhand zijn bij de Wet Getuigenbescherming specifieke minimumeisen ten aanzien van het gebruik van anoniem bewijs opgenomen. In de jurisprudentie zijn tenslotte nog bewijsminima geformuleerd ten aanzien van het gebruik van verklaringen van getuigen ten aanzien waarvan de verdediging niet de mogelijkheid heeft gehad om ze te ondervragen.

141 HR 17 maart 1998, NJ 1998, 798 m.nt. JR.

142 Het gebruik van de leugendetector, narco-analyse en andere onorthodoxe opsporingsmethoden in het opsporingsonderzoek is echter niet uitgesloten, hetgeen uit het bestaan van de Instructie onorthodoxe opsporingsmethoden van het College van ProcureursGeneraal kan worden afgeleid.

143 Merckelbach \& Boelhouwer 2002 en Horselenberg, Merckelbach, Crombag \& Van Koppen 2002. 


\subsubsection{De oorspronkelijke bewijsminima}

Zoals in hoofdstuk 2 vermeld, is tijdens de totstandkoming van het Wetboek van Strafvordering in 1926 onenigheid geweest over de vraag of in het Wetboek bewijsminimumregels moesten worden opgenomen. Uiteindelijk is het pleit beslist ten faveure van bepaalde bewijsminima. Voor de verklaring van de verdachte en de verklaring van de getuige zijn in artikel 341 lid 4 Sv respectievelijk artikel 342 lid $2 \mathrm{~Sv}$ zogeheten unus-regels opgenomen. ${ }^{144} \mathrm{Zij}$ houden in dat een bewezenverklaring niet enkel op de verklaring van de verdachte dan wel op de verklaring van één getuige mag worden gebaseerd. Door het opnemen van dergelijke regels gaf de wetgever blijk van een juist inzicht in de feilbaarheid van de mens. ${ }^{145}$ Het risico dat een onschuldige werd veroordeeld als de veroordeling enkel op één verklaring steunde, werd te groot geacht. Een dergelijke verklaring kan immers bewust of onbewust onjuiste informatie bevatten. Een derde bewijsminimum treffen we aan in artikel 344 lid 1 onder 5 Sv; de inhoud van een niet wettelijk gekwalificeerd schriftelijk stuk kan alleen in verband met de inhoud van andere bewijsmiddelen voor het bewijs worden gebruikt.

Opvallend is dat in de wet geen bewijsminimum is opgenomen ten aanzien van de verklaring van de deskundige en de eigen waarneming van de rechter. De reden daarvoor is waarschijnlijk dat ook de wetgever destijds geen situatie kon bedenken waarin enkel op basis van de verklaring van een deskundige, of de eigen waarneming van de rechter het aan de verdachte ten laste gelegde feit bewezen zou kunnen worden. Dat zou alleen mogelijk zijn indien de deskundige dan wel de rechter zelf getuige is van het strafbare feit. In geval van de rechter zou dit betekenen dat het strafbare feit zich op de zitting moet hebben voltrokken. De rechter mag echter niet zelf oordelen over hetgeen door hem zelf als getuige is waargenomen. Voor zover de deskundige ook als getuige waarnemingen zou hebben gedaan, is op basis van de wettekst niet uitgesloten dat zijn verklaring deels als getuigenverklaring en deels als deskundigenverklaring wordt beschouwd. ${ }^{146}$ In formele zin is er dan sprake van een tweede verklaring naast de getuigenverklaring. In materiële zin is echter de bron van het bewijs dan terug te voeren tot slechts één persoon. Nijboer meent dat een dergelijke bewijsconstructie niet toelaatbaar is. De deugdelijkheid van het onderzoek in strafzaken vereist, mede

144 Damaška beschouwt deze bewijsminimumregels als uitzonderlijk angezien na de Franse revolutie op het Europese continent het uitgangspunt van vrije bewijswaardering overal terrein won. Damaška 1997, p. 21: 'Highly atypical of Continental criminal justice is the Netherlands. In 1838, when the Dutch rejected the French procedural model, two mandatory corroboration rules found their way into the law: the court was prohibited from convicting the defendant on his confession alone or on the testimony of a single witness.'

145 Reijntjes in zijn annotatie van HR 28 september 2004, NJ 2005, 93.

146 In gelijke zin: advocaat-generaal Jörg in zijn conclusie bij HR 21 november 2000, NJ $2001,48$. 
gezien de subjectiviteit die inherent is aan verklaringen van mensen, dat het bewijs in strafzaken niet op één informant mag berusten. Er is aldus Nijboer een pluraliteit van informanten vereist om tot een bewezenverklaring te komen. ${ }^{147}$ De enige uitzondering hierop is artikel 344 lid 2 Sv. De hierin opgenomen regel, het bewijs van het tenlastegelegde feit kan enkel op het proces-verbaal van een opsporingsambtenaar worden aangenomen, is echter uit nood geboren. Bij gebrek daaraan zou het bewijs van strafbare feiten door een enkele opsporingsambtenaar geconstateerd, bij ontkennende verdachten niet te leveren zijn. ${ }^{148}$

Ten aanzien van alle andere informanten (verdachten en getuigen) geldt echter de regel dat een bewezenverklaring niet enkel op de verklaring van één van hen gebaseerd mag zijn. In de praktijk hebben de bestaande bewijsminima echter een zeer beperkte betekenis. Ten eerste zien ze op de gehele tenlastelegging en dat betekent volgens de Hoge Raad dat niet elk afzonderlijk onderdeel van de tenlastelegging een dubbele bevestiging behoeft. ${ }^{149}$ Zo kan het bewijs in een zaak waarin de verdachte terecht staat voor mishandeling bestaan uit de verklaring van het slachtoffer, aangevuld met de schriftelijke verklaring van een arts waaruit blijkt dat het slachtoffer pijn heeft ondervonden. De unus-verboden zijn aldus tot een blote vormkwestie geworden. ${ }^{150}$ Niet vereist is dat in materiële zin de door de rechter gebezigde bewijsmiddelen elkaar bevestigen of dat ten minste betrokkenheid van de verdachte uit meer dan één bewijsmiddel moet blijken. Dit ligt overigens anders bij uit artikel 6 EVRM voortvloeiende bewijsminima ten aanzien van anonieme en niet-gehoorde getuigen. Deze bewijsminima komen in de volgende paragraaf aan de orde.

147 Nijboer 2000a, p. 90.

148 In de memorie van toelichting bij het Wetboek van Strafvordering wordt gesproken van 'praktische redenen' die ertoe leiden dat de schriftelijke getuigenverklaring van de opsporingsambtenaar op één lijn moet worden gesteld met de mondelinge verklaring van de getuige ter zitting. Kamerstukken II, 1913-1914, 286, nr. 3, p. 173. Die 'praktische redenen' zijn terug te vinden in de notulen van de $40^{\mathrm{e}}$ vergadering van: 'Spreker [Dresselhuys: WD] zou de op den regel 'unus testis, nullus testis' geldende uitzondering voor den opsporingsambtenaar willen handhaven. Deze wordt geoefend en mede ter terechtzitting gecontroleerd op juistheid van de waarneming en is beëdigd. Bovendien is die uitzondering noodzakelijk, waar de omstandigheden niet toelaten de opsporingsambtenaren steeds in gemeenschap te doen optreden.'. Lindenberg 2002, p. 329.

149 HR 21 december 1976, NJ 1977, 162 m.nt. GEM: 'het voorschrift van art. 342, tweede lid, Sv betreft de telastelegging in haar geheel en niet een onderdeel daarvan'. In gelijke zin: HR 17 januari 1927, $N J$ 1927, 189; HR 14 januari 1935, NJ 1935, 494; HR 17 juni 1940, NJ 1940, 822; HR 12 januari 1942, NJ 1942, 373; HR 26 februari 1946, NJ 1946, 168; HR 8 november 1949, NJ 1950, 120; HR 15 oktober 1974, $N J$ 1975, 189 en HR 7 april 1981, NJ 1981, 399 m.nt. ThWvV.

150 Reijntjes in zijn noot onder HR 28 september 2004, NJ 2005, 93. Taverne in zijn noot bij HR 16 november 1931, NJ 1932, p. 282 spreekt van een 'geheel ontzield' voorschrift en Van Dijck in zijn noot bij HR 14 oktober 1929, NJ 1929, p. 1552 heeft het over een voorschrift dat nauwelijks nog een waarborg voor de verdachte is. 
Ten tweede lijkt de Hoge Raad in bepaalde zaken zelfs niet te eisen dat het tweede bewijsmiddel betrekking heeft op een deel van de tenlastelegging. Voldoende is als daaruit kan blijken dat bijvoorbeeld de verklaring van de 'kroongetuige' betrouwbaar is. Het tweede bewijsmiddel hoeft dus niet redengevend te zijn voor de bewezenverklaring, maar voldoende is indien het redengevend is voor de betrouwbaarheid van het ander bewijsmateriaal. Dat was bijvoorbeeld het geval in het arrest van de Hoge Raad d.d. 9 mei $2006 .{ }^{151}$ In die zaak was de verdachte veroordeeld ter zake van bedreiging met geweld. Het bewijs bestond uit de aangifte en nadere verklaring van het slachtoffer, zijn vrouw, en de verklaring van de huisarts dat hij letsel had geconstateerd bij het slachtoffer. Die laatste verklaring is echter niet redengevend voor de bedreiging. De verklaring van de arts bevestigde wel een deel van de verklaring van het slachtoffer en in zoverre was die dus redengevend voor de vaststelling van de betrouwbaarheid van die getuigenverklaring. De verzuchting van Nijboer dat er nogal wat zaken zijn waarop een veroordeling wordt uitgesproken op de getuigenverklaring van het slachtoffer plus een minieme hoeveelheid steunbewijs is dus waar. ${ }^{152}$

Bijzondere aandacht verdient het bewijsminimum dat is opgenomen in artikel 344 lid 1 onder $5 \mathrm{~Sv}$. Deze minimumregel betreft het bewijs door middel van schriftelijke bescheiden die niet onder een van de andere rubrieken vallen zoals genoemd in het eerste lid. Te denken valt aan kassabonnetjes, brieven geschreven door een getuige of het dagboek van de verdachte. In principe is de reikwijdte van deze regel beperkt tot schriftelijke stukken die niet afkomstig zijn van de officiële actoren zoals genoemd onder 1 tot en met 4 (rechterlijke instanties, opsporingsambtenaren, openbare colleges of deskundigen). De Hoge Raad staat echter toe dat bijvoorbeeld processen-verbaal die niet voldoen aan de eisen gesteld in artikel 344 lid 1 sub 2, wel als overig schriftelijk bescheid voor het bewijs worden gebezigd. ${ }^{153}$

Omdat de juistheid van de inhoud van deze schriftelijke stukken niet wordt gewaarborgd door de officiële kwaliteit van degene die het heeft opgesteld of die hoedanig-

151 HR 9 mei 2006, LJN AV0316.

152 Nijboer 2000a, p. 247.

153 Dat geldt voor niet-ondertekende processen-verbaal, niet gewaarmerkte kopieën, niet op ambtseed of ambtsbelofte opgemaakte processen-verbaal en voor processen-verbaal waaruit niet blijkt dat de daarin vermelde feiten en omstandigheden zijn waargenomen door de verbalisanten. Achtereenvolgens: HR 31 mei 1988, NJ 1989, 210; HR 10 maart 1987, NJ 1988, 25 en HR 22 juni 1982, NJ 1983, 90. Ook processen-verbaal van buitenlandse opsporingsambtenaren werden onder de categorie 'overige schriftelijke bescheiden gerangschikt: HR 25 februari 2003, NJ 2003, 571. Sinds 1 november 2006 kunnen deze processenverbaal als volwaardig schriftelijk bescheid worden aangemerkt, aangezien de in het eerste lid onder 3 genoemde categorie van art. $344 \mathrm{~Sv}$ is uitgebreid met 'geschriften, opgemaakt door een persoon in de openbare dienst van een vreemde staat of van een volkenrechtelijke organisatie'. Wet van 28 september 2006 (afgeschermde getuigen), Stb. 2006, 460 (inwerkingtreding 1 november 2006, Stb. 2006, 461). 
heid niet blijkt uit het bewijsmiddel zelf, stelt de wet de eis dat de inhoud van deze stukken slechts in verband met andere bewijsmiddelen voor het bewijs kan worden gebezigd. ${ }^{154}$ Oorspronkelijk meende men dat het in artikel 344 lid 1 onder 5 opgenomen bewijsvoorschrift tot doel had te bewerkstelligen dat duidelijkheid moest worden verkregen over de herkomst van het geschrift. Uit een ander bewijsmiddel zou dan moeten blijken wie de auteur van het niet gekwalificeerde geschrift is. ${ }^{155}$ Deze eis wordt echter niet door de Hoge Raad gesteld; voldoende is dat iets van de inhoud van het geschrift wordt bevestigd door een ander bewijsmiddel. ${ }^{156}$ Een tweede misvatting met betrekking tot de reikwijdte van dit bewijsminimum betreft de vraag welk ander bewijsmiddel in aanmerking komt om de inhoud van het overige geschrift te bevestigen. In de literatuur is wel de opvatting verkondigd dat de inhoud van het overige schriftelijke bewijs slechts in combinatie met een ander bewijsmiddel - dus niet overig schriftelijk bescheid - kon gelden als één bewijsmiddel. ${ }^{157}$ De Hoge Raad heeft deze visie echter afgewezen; de bevestiging van iets van de inhoud kan ook volgen uit een ander niet gekwalificeerd schriftelijk bescheid. ${ }^{158}$ Daarmee ontstaat de mogelijkheid dat een verdachte wordt veroordeeld op basis van twee of meer overige schriftelijke bescheiden. Elk van deze geschriften kan als 'volkomen' worden aangemerkt op basis van de inhoud van het andere geschrift en daarmee is in principe voldaan aan de eis dat de bewezenverklaring niet op één enkele verklaring is gebaseerd.

Deze uitleg van de Hoge Raad in combinatie met het feit hij niet eist dat de inhoud van het geschrift op specifieke punten moet worden bevestigd, maakt dat het bewijsminimum nauwelijks nog enige waarde heeft. De feitenrechter heeft de vrije keuze of hij aan het geschrift waarde hecht of niet. Is hij de mening toegedaan dat de inhoud bijdraagt aan zijn overtuiging, dan kan hij dit aan de bewezenverklaring ten grondslag leggen zonder dat hij nadrukkelijk hoeft te verantwoorden waaruit hem de authenticiteit van het geschrift is gebleken en in welk opzicht de inhoud van het geschrift wordt bevestigd door ander bewijsmateriaal. Voldoende is dat 'iets' van de inhoud ook blijkt uit ander bewijsmateriaal. Daarmee heeft het bewijsminimum zijn betekenis grotendeels verloren; immers het is nauwelijks voorstelbaar dat de rechter zijn overtuiging alleen op de inhoud van een dergelijk geschrift zal baseren zonder dat hem op een of andere manier is gebleken dat die inhoud als juist kan worden aangemerkt.

154 Kamerstukken II 1919-1920, 18 (Verslag van de Commissie van Voorbereiding), p. 60.

155 HR 9 januari 1928, NJ 1928, p. 212 m.nt. vD.

156 HR 19 maart 1974, NJ 1974, 241 m.nt. ThWvV en HR 14 december 1976, NJ 1977, 175 m.nt. ThWvV.

157 Borst 1985, p. 296: "Wij hebben hier (...) te maken met een "imperfect" bewijsmiddel: eerst door de combinatie met een "ander" bewijsmiddel ontstaat er een 'perfect' bewijsmiddel (...).'

158 HR 1 november 1988, NJ 1989, 574 m.nt. ALM en Hoge Raad 28 september 2004, NJ 2005, 93 m.nt. JR. 


\subsubsection{De nieuwe bewijsminima}

De in de vorige paragraaf als oorspronkelijk aangeduide bewijsminima zijn uitgebreid met een aantal nieuwe. Zo is in 2006 een bewijsminimum opgenomen met betrekking tot het gebruik van de verklaring van een 'kroongetuige'. Artikel 344a lid $4 \mathrm{~Sv}$ bepaalt dat het bewijs dat de verdachte het telastegelegde feit heeft begaan door de rechter niet uitsluitend kan worden aangenomen op grond van verklaringen van getuigen met wie op grond van artikel 226h, derde lid, of 226k een afspraak is gemaakt. ${ }^{159}$

Twee andere bewijsminima vloeien voort uit artikel 6 EVRM. Het betreft dan het gebruik van verklaringen van horen zeggen. De rechtspraak van het Europese Hof voor de rechten van de mens in tal van - ook Nederlandse - zaken op dit punt heeft onder andere geleid tot de introductie van een antal nieuwe bewijsminimumregels. Voor het gebruik van anoniem bewijs zijn die neergelegd in artikel 344a Sv. Voor verklaringen van getuigen die de verdediging niet heeft kunnen ondervragen, heeft de Hoge Raad in een 'regeling' voorzien.

\subsubsection{Anoniem bewijs}

Ten aanzien van het gebruik van anoniem bewijs kent de wet sinds 1994 twee bewijsminima. Deze zijn voortgekomen uit de jurisprudentie van het Europese Hof voor de rechten van de mens. Het Europese Hof acht het gebruik van anoniem bewijs niet op voorhand uitgesloten, maar stelt onder andere als voorwaarde dat het bewijs in strafzaken niet alleen of in beslissende mate op anoniem bewijsmateriaal mag steunen. ${ }^{160}$ Teneinde te voldoen aan de Straatsburgse criteria werd in artikel 344a Sv ${ }^{161}$ een nieuw bewijsminimum opgenomen, te weten:

'Het bewijs dat de verdachte het tenlastegelegde feit heeft begaan kan door de rechter niet uitsluitend worden aangenomen op grond van verklaringen van bedreigde getuigen of schriftelijke bescheiden houdende verklaringen van personen wier identiteit niet blijkt.'

Uit de tekst van deze bepaling volgt dat het bewijsminimum ziet op het daderschap van de verdachte en dus niet op de tenlastelegging als geheel. In tegenstelling tot

159 Wet van 12 mei 2005 (toezeggingen aan getuigen in strafzaken), Stb. 2005, 254 (inwerkingtreding 1 april 2006, Stb. 2006, 150).

160 EHRM 26 maart 1996, NJ 1996, 741 m.nt. Kn (Doorson t. Nederland): '76. Finally, it should be recalled that even when 'counterbalancing' procedures are found to compensate sufficiently the handicaps under which the defence labours, a conviction should not be based either solely or to a decisive extent on anonymous statements.'

161 Bij de inwerkingtreding van de Wet Bedreigde getuige was dat art. 344a Sv. Bij de Wet van 3 april 2003 (raadsheer-commissaris), Stb. 2003, 143 (inwerkingtreding 1 juli 2003, $S t b .2003,260)$ zijn de leden 2 en 3 toegevoegd, waardoor art. 344a werd vernummerd tot $344 \mathrm{a}$ lid $1 \mathrm{~Sv}$. 
het bewijsminimum in artikel 342 lid 2 moet dus de betrokkenheid van de verdachte blijken uit het andere - niet anoniem - materiaal. Een 'kale' aangifte van het strafbare feit is dus niet voldoende. ${ }^{162}$ Het Europese Hof voor de rechten van de mens eist immers niet alleen dat het bewijs niet uitsluitend, maar ook niet in beslissende mate op anonieme verklaringen mag berusten. De Hoge Raad heeft deze discrepantie onderkend en legt artikel 344a lid 1 thans uit conform de Straatsburgse jurisprudentie:

'Het bewijs dat de verdachte het tenlastegelegde heeft begaan, zal dus niet uitsluitend en - ingevolge de rechtspraak van het Europese Hof voor de rechten van de mens ook niet in beslissende mate mogen berusten op die [anonieme, WD] verklaringen., ${ }^{163}$

Inmiddels is ook op wetgevingsniveau een en ander doorgedrongen en is artikel 344a lid 1 aangepast in die zin dat het in overeenstemming is met de rechtspraak van het Europese Hof voor de rechten van de mens en de Hoge Raad. Artikel 344a luidt met ingang van 1 november 2006:

Het bewijs dat de verdachte het tenlastegelegde feit heeft begaan kan door de rechter niet uitsluitend of in beslissende mate worden gegrond op verklaringen van bedreigde getuigen of schriftelijke bescheiden houdende verklaringen van personen wier identiteit niet blijkt. ${ }^{164}$

Artikel 344a lid $1 \mathrm{~Sv}$ is van toepassing op alle anonieme verklaringen; dus zowel op verklaringen van bedreigde getuigen als op verklaringen van personen wier identiteit niet blijkt zonder dat zij als bedreigde getuigen zijn aangemerkt. Verschil tussen beide categorieën is dat ten aanzien van de eerste de wet voorziet in een counterbalancing procedure, terwijl daarin niet is voorzien ten aanzien van de overige anonieme getuigen. Logischerwijze worden ten aanzien van deze laatste groep ook hogere eisen gesteld aan het gebruik van hun verklaringen. Ten eerste geldt de eis dat de verdediging niet moet hebben verzocht om het horen van deze getuigen. Maakt de verdediging kenbaar gebruik te willen maken van haar ondervragingsrecht, dan zal moeten worden bezien op welke wijze daaraan uitvoering wordt gegeven. Ofwel wordt de getuige alsnog door de zittingsrechter of de rechter-commissaris gehoord waarbij hij zijn anonimiteit zal moeten prijsgeven; ofwel verzoekt de officier van justitie de rechter-commissaris de getuige alsnog als bedreigde getuige aan te merken, opdat deze in die hoedanigheid alsnog anoniem kan worden gehoord. De tweede eis betreft een nieuw bewijsminimum dat verder gaat dan de eis die in dat verband wordt gesteld aan bedreigde getuigen. Ten aanzien van de laatste geldt immers dat het bewijs niet in beslissende mate op zijn verklaring mag zijn gebaseerd; er moet dus 'steunbewijs' aanwezig zijn.

162 In gelijke zin: Corstens 2005a, p. 661.

163 HR 28 september 2004, NJ 2004, 611; In gelijke zin: HR 10 september 2002, NJ 2002, 519; HR 18 mei 1999, NJ 2000, 106 m.nt. Sch.

164 Art. 344a lid $1 \mathrm{~Sv}$ is gewijzigd bij de Wet van 28 september 2006 (afgeschermde getuigen), Stb. 2006, 460 (inwerkingtreding 1 november 2006, Stb. 2006, 461). 
De verklaring van de anonieme getuige niet zijnde een bedreigde getuige wordt daarentegen zelf als 'steunbewijs' beschouwd; de bewezenverklaring moet in belangrijke mate op ander bewijsmateriaal steunen. ${ }^{165}$

De waarde van dit bewijsminimum is echter grotendeels ondergraven doordat de Hoge Raad niet snel aanneemt dat er sprake is van een verklaring van een persoon wiens identiteit niet blijkt. In paragraaf 3.2.2.1 is uitvoerig aan de orde geweest dat de Hoge Raad enkel bewijsmateriaal als anoniem aanmerkt indien de persoon die heeft verklaard niet individualiseerbaar is. Daarnaast neemt de Hoge Raad aan dat een schriftelijke verklaring houdende een verklaring van een anonymus, niet gelijk kan worden gesteld met een verklaring van een persoon wiens identiteit niet blijkt.

\subsubsection{Niet gehoorde getuigen}

Zoals in paragraaf 3.2.2.2 bleek heeft artikel 6 lid 3 onder d EVRM ook consequenties voor het 'gewone' getuigenbewijs. Het Europese Hof voor de rechten van de mens legt het begrip 'getuige' op autonome wijze uit; niet beslissend is wat het nationale recht als verklaring van een getuige aanmerkt, maar of er de facto sprake is van een getuigenverklaring. Voor het recht om getuigen te ondervragen betekent dit dus dat niet bepalend is of deze verklaring ter zitting is afgelegd, dan wel vervat is in een schriftelijke of mondelinge verklaring van een andere persoon. Voor zover het een belastende verklaring betreft, moet de verdediging in de gelegenheid worden gesteld om deze getuigenverklaring door middel van het ondervragingsrecht op haar betrouwbaarheid te toetsen.

Dit betekent overigens in de ogen van het Europese Hof voor de rechten van de mens niet dat elke getuige op de zitting moet verschijnen opdat hij daar kan worden ondervraagd. Evenmin volgt uit de jurisprudentie dat buiten de zitting om altijd een recht op ondervraging bestaat. Eén van de criteria die het Europese Hof voor de rechten van de mens in dit verband bezigt betreft de bewijswaarde van de verklaring van een getuige. Is de vaststelling van de schuld van de verdachte alleen of in beslissende mate gebaseerd op de verklaring van de niet door de verdediging gehoorde getuige, dan is dit niet kunnen horen van de getuige in principe funest voor het gebruik van die verklaring voor het bewijs. Daarmee creëert het Europese Hof voor de rechten van de mens als het ware een nieuw bewijsminimum; de bewezenverklaring mag niet alleen, maar ook niet in beslissende mate, steunen op de verklaring van de niet-gehoorde getuige. ${ }^{166}$ Daarmee eist het Hof dat voor zover

165 In gelijke zin: Garé \& Mevis 2000, p. 111.

166 Bijvoorbeeld: EHRM 10 november 2005, NJ 2006, 239 m.nt. T.M. Schalken (BocosCuesta t. Nederland): 'the Court considers that the statements given by A., B., C. and D. to the police, which was the only direct evidence of the facts held against the applicant, must be regarded as having been of a decisive importance for the courts' finding of the 
het ondervragingsrecht van de verdediging niet of onvoldoende is gerealiseerd de betrokkenheid van de verdachte bij het tenlastegelegde feit tevens moet blijken uit ander (neutraal) bewijsmateriaal. ${ }^{167}$

De Hoge Raad heeft in het arrest Grenzen getuigenbewijs ${ }^{168}$ dit Straatsburgse bewijsminimum vertaald in de eis dat de getuigenverklaring in belangrijke mate steun moet vinden in andere bewijsmiddelen. Daarbij liet de Hoge Raad buiten beschouwing dat met name de betrokkenheid van de verdachte moest blijken uit ander bewijsmateriaal. In zijn arrest van 14 april $1998^{169}$ werd deze omissie hersteld, maar werd het bijbehorende criterium aangepast; de betrokkenheid van de verdachte moest niet langer in belangrijke mate, maar in voldoende mate blijken uit ander bewijsmateriaal. ${ }^{170}$ Terecht merkt Schalken met betrekking tot dit gedevalueerde criterium op dat bij voldoende ander bewijs niet kan worden uitgesloten dat de veroordeling niettemin in beslissende mate op de verklaring van de niet-ondervraagde getuige is gebaseerd. ${ }^{171}$ Daarmee zou het door de Hoge Raad gehanteerde criterium niet in alle gevallen overeen komen met de eis van het Europese Hof voor de rechten van de mens. Dat deed het in ieder geval niet in de zaak Bocos-Cuesta; het gerechtshof had in die zaak gemeend dat er voldoende steunbewijs was naast de verklaringen van de jeugdige niet ondervraagde slachtoffers. De Hoge Raad achtte dit oordeel van het hof niet onbegrijpelijk. ${ }^{172}$ Het Europese Hof voor de rechten van de mens meende evenwel dat artikel 6 EVRM was geschonden. ${ }^{173}$ Het feit dat de verdachte op de plaats van het delict was gezien achtte hij in tegenstelling tot de Hoge Raad onvoldoende ter bevestiging van de verklaringen van de slachtoffers.

In de zaak Scheper zaten de Hoge Raad en het Europese Hof voor de rechten van de mens wel op één lijn. Bij de behandeling van de zaak in Nederland bleek ondanks inspanningen van justitie ${ }^{174}$ het ondervragen van de slachtoffers door de verdediging niet mogelijk. De betrokkenheid van de verdachte zou echter volgens het gerechtshof niet alleen blijken uit de verklaringen van de slachtoffers afgelegd bij de politie, maar ook uit het feit dat alle drie de verkrachtingen op vergelijkbare wijze hadden plaatsgevonden. De verdachte had overigens niet betwist dat hij

applicant's guilt, whereas neither at the stage of the investigation nor during the trial was the applicant given the opportunity to examine or have these victims examined.'

167 Alink \& Van Zeben 2006, p. 42.

168 HR 1 februari 1994, NJ 1994, 427 m.nt. C.

169 HR 14 april 1998, NJ 1999, 73 m.nt. Kn onder HR 29 september 1998, NJ 1999, 74.

170 In zijn arrest d.d 12 oktober 1999, NJ 1999, 827 lijkt de Hoge Raad de eis van bevestiging alleen te stellen ten aanzien van die onderdelen in de getuigenverklaring die door de verdediging worden betwist.

171 Zie zijn annotatie bij EHRM 5 april 2005, NJ 2005, 551 (Scheper t. Nederland).

172 HR 12 oktober 1999, NJ 1999, 827.

173 EHRM 10 november 2005, NJ 2006, 239 m.nt. T.M. Schalken (Bocos-Cuesta t. Nederland).

174 Anders: Mols 2005, p. 1369: 'De vraag rijst of het hof niet meer moeite had moeten doen om haar als getuige te horen toen ze gewoon aanwezig was.' 
de slachtoffers had opgepikt en seks met hen had gehad. De Hoge Raad achtte de bewijsconstructie van het gerechtshof toelaatbaar. En ook het Europese Hof voor de rechten van de mens meende dat in dit geval voldoende steunbewijs voorhanden was:

'the Court observes that the applicant's conviction of the rape of Ms A., Ms B. and Ms C. did not rest solely on the statements made by them to the police. A number of leads, with which these witnesses had provided the police, had been followed up and had resulted in supporting evidence. Bearing in mind that it concerned three nearly identical incidents with a similar modus operandi by the perpetrator and which occurred within a relatively short time span in three different towns, and having regard to all the material used in evidence against the applicant, including his own statements made before the police and the trial courts, the Court holds that the applicant's conviction cannot be said to have been based only or to a decisive extent on the statements given by Ms A., Ms B. and Ms C. to the police (...). ${ }^{175}$

Naar aanleiding van deze zaak verzuchtte annotator Schalken:

'Minimaler bewijs dan in de zaken Verdam en Scheper is nauwelijks voor te stellen. Dat Straatsburg en Den Haag langzaam naar elkaar toe kruipen, stemt dus niet in alle opzichten tot grote vrolijkheid.' ${ }^{176}$

Daarmee is overigens ook de betrekkelijke waarde van bewijsminima aangegeven. $\mathrm{Al}$ ten aanzien van de klassieke bewijsminima kon worden geconcludeerd dat die in de praktijk veel van hun waarde hebben verloren. De waarde van de uit artikel 6 EVRM voortvloeiende bewijswaarderingsregel kan in voorkomende zaken ook beperkt zijn. Dat laat echter onverlet dat - hoe minimaal soms ook - het Straatsburgse Hof meer eisen stelt aan het bewijs dan onze eigen Hoge Raad. Waar tot voor enige jaren politieverklaringen van slachtoffers aangevuld met zijdelings - niet op het daderschap gericht - bewijs voldoende waren voor een veroordeling, dwingt Straatsburg de Nederlandse rechter thans óf tot het horen of laten horen van de getuige of tot het opnemen van (steun)bewijs met betrekking tot het daderschap van de verdachte. Dat is vanuit het oogpunt van waarheidsvinding in ieder geval vooruitgang. Dat de Hoge Raad angstvallig het de-auditu-bastion verdedigt door slechts mondjesmaat toe te geven aan de Straatsburgse eisen is vanuit het oogpunt van proceseconomie begrijpelijk. Dat speelt bijvoorbeeld in die gevallen waarin het bewijs tegen de verdachte alleen gebaseerd is op de waarnemingen van de opsporingsambtenaar. De Hoge Raad stelt zich in dergelijke gevallen op het standpunt dat dergelijke op schrift gestelde waarnemingen in principe als betrouwbaar moeten worden aangemerkt. Het horen van de verbalisant is niet nodig en evenmin geldt dan de eis dat het bewijs in voldoende mate moet blijken uit ander bewijsmateriaal. De vraag is of men ook in Straatsburg zo onder de indruk is van de vooronderstelde betrouwbaarheid van Nederlandse opsporingsambtenaren.

175 EHRM 10 november 2005, NJ 2006, 239 m.nt. T.M. Schalken (Bocos-Cuesta t. Nederland). 176 Schalken in zijn annotatie bij EHRM 5 april 2005, NJ 2005, 551 (Scheper t. Nederland). 


\subsection{Conclusie}

De wetgever van 1926 beoogde met de bewijsregeling willekeurige of volledig subjectieve beslissingen van de strafrechter tegen te gaan. De rechter werd geacht zijn bewijsbeslissing te nemen op basis van bewijsmateriaal dat in mondelinge vorm ter zitting werd gepresenteerd. Daarmee werd gegarandeerd dat procespartijen in de gelegenheid worden gesteld om hun visie op het bewijsmateriaal te geven en zonodig de inhoud daarvan ter discussie te stellen. Bovendien blijkt uit de wijze waarop de diverse bewijsmiddelen zijn geformuleerd dat de wetgever een duidelijke voorkeur had voor presentatie van het bewijs ter zitting zonder tussenkomst van andere personen. In materiële zin werd het bewijsoordeel nader genormeerd door de wettige bewijsmiddelen in artikel $339 \mathrm{~Sv}$ limitatief op te sommen en aan elk van deze bewijsmiddelen nadere eisen te stellen. Bovendien werd een bewijsverbod ten aanzien van het gebruik van verklaringen van medeverdachten opgenomen. Aldus werden de bronnen waaruit de rechter het bewijsmateriaal kon putten gelimiteerd en nader gedefinieerd. Ten aanzien van de waardering van het bewijs werd de rechter gebonden aan bewijsminima.

Van al deze waarborgen is echter weinig overgebleven. Met de aanvaarding van het testimonium de auditu als bewijsmiddel verwerd de presentatie van bewijsmateriaal ter zitting tot het herkauwen van de reeds in processen-verbaal opgenomen onderzoeksresultaten. De noodzaak om informanten ter zitting te horen, was immers niet meer aanwezig. Slechts onder invloed van de rechtspraak van het Europese Hof voor de rechten van de mens is de Hoge Raad noodgedwongen enigszins teruggekomen op zijn in 1926 ingenomen standpunt. Ook het materiële bewijsrecht is grotendeels uitgehold. Het niet in strikte zin naleven van de eisen die worden gesteld aan de diverse bewijsmiddelen werd door de Hoge Raad telkens getolereerd. Daardoor werd bovendien het onderscheid tussen de diverse bewijsmiddelen minder duidelijk. Ten aanzien van de in de wet opgenomen bewijsminima kan in zijn algemeenheid worden geconcludeerd, dat die zelden een obstakel vormen voor een bewezenverklaring. En in die gevallen waarin dat wel zo is, kan men zich in gemoede afvragen of de rechter überhaupt tot de vereiste overtuiging zou kunnen komen.

Daarmee is de toegevoegde waarde van het negatief-wettelijk bewijsstelsel grotendeels ondergraven en kan met Nijboer worden ingestemd als hij beweert dat het in Nederland gehanteerde bewijsstelsel een variant van het vrije bewijsstelsel is. ${ }^{177}$ De rechter is in principe vrij in de selectie en de waardering van het bewijsmateriaal; de wet stelt daaraan nauwelijks enige beperkingen noch in formele noch in materiële zin. Bij deze conclusie past een kanttekening. In 1926 werd gekozen voor handhaving van het negatief-wettelijk bewijsstelsel, omdat in de

177 Nijboer 2004, p. 493. 
ogen van de wetgever een vrij bewijsstelsel te veel ruimte liet aan de strafrechter. $\mathrm{Nu}$ blijkt dat het in Nederland ingevoerde bewijsstelsel feitelijk niet afwijkt van het vrije bewijsstelsel, roept dat de vraag op hoe die vrijheid van de rechter aangaande de beoordeling van de feiten moet worden genormeerd. Voorstanders van een vrij bewijsstelsel kenden in dit verband veel waarde toe aan de plicht van de rechter om zijn beslissing te motiveren. De aldus minder strikt gebonden overtuiging zou nader beredeneerd moeten worden. ${ }^{178}$ Derhalve zal bezien moeten worden in hoeverre de toename van motiveringseisen gelijke tred heeft gehouden met de afbraak van het negatief-wettelijk bewijsstelsel. In de komende drie hoofdstukken zullen de verschillende motiveringseisen die de wetgever stelde aan de bewijsbeslissing vanuit die optiek nader worden bekeken. In hoofdstuk 3 wordt ingegaan op de plicht van de feitenrechter om de inhoud van de bewijsmiddelen in het vonnis op te nemen. Hoewel de wetgever in 1926 de toen in het eerste lid van artikel 359 lid $1 \mathrm{~Sv}$ opgenomen eis met betrekking tot de inhoud van het vonnis zelf niet als motiveringseis zag, is dit in de praktijk een van de meest wezenlijke gebleken. In hoofdstuk 4 komt de eis van redengevendheid aan de orde. In hoofdstuk 5 zal tenslotte worden ingegaan op de eis van betrouwbaarheid van het bewijsmateriaal en de te dien aanzien geldende motiveringsverplichtingen zoals die volgen uit artikel 360 lid $1 \mathrm{~Sv}$ en artikel 359 lid $2 \mathrm{~Sv}$.

178 Fokkens 2006, p. 20. 



\section{De weergave van de inhoud van de bewijsmiddelen}

\subsection{Inleiding}

Op grond van het derde lid van artikel $359 \mathrm{~Sv}^{1}$ dient het vonnis de inhoud van de gebezigde bewijsmiddelen te bevatten. Deze bepaling vindt haar oorsprong in de jurisprudentie van de Hoge Raad. Reeds ver voor de inwerkingtreding van het Wetboek van Strafvordering van 1926 was de Hoge Raad van oordeel dat de invoering van het negatief-wettelijk bewijsstelsel in 1838 met zich bracht dat in cassatie de wettigheid van de gebezigde bewijsmiddelen diende te worden getoetst:

'dat uit de vermelding der redenen moet blijken dat de voorschriften omtrent het bewijs niet zijn veronachtzaamd, opdat de beklaagde daarin eenen waarborg vinde tegen willekeurige veroordeling, enkel op innerlijke overtuiging gegrond'.2

In het ontwerp-Ort is het vereiste over het opnemen van de bewijsmiddelen nog niet in de tekst opgenomen. Echter bij de bespreking van de motiveringsvoorschriften in de Commissie-Ort wordt aangedrongen op codificatie van de jurisprudentie op dit punt. $^{3}$

\subsection{Het belang van de vermelding van de inhoud van de bewijsmiddelen}

Uit de ontstaansgeschiedenis kan worden geconcludeerd dat de eis van het opnemen van de inhoud van de bewijsmiddelen voortvloeit uit het negatief-wettelijk bewijsstelsel. Door van de rechter te eisen dat hij het door hem gebruikte bewijsmateriaal in het vonnis opneemt, wordt immers de hogere rechter de gelegenheid geboden om aan de hand van het vonnis te toetsen of de wettelijke eisen die aan het bewijs worden gesteld in acht zijn genomen.

Allereerst kan aldus worden bezien of het gebezigde bewijsmateriaal terecht als wettig bewijsmiddel is gekwalificeerd. Dit betekent dat de voorwaarden die de

1 De verplichting tot het vermelden van de inhoud van de bewijsmiddelen stond oorspronkelijk vermeld in het eerste lid van art. 359 Sv. Per 1 januari 2005 is deze eis echter verplaatst naar het derde lid van art. 359 Sv. Zie de Wet van 10 november 2004 (aanpassing eisen motivering bewezenverklaring bekennende verdachte), Stb. 2004, 580 (inwerkingtreding 1 januari 2005, Stb. 2004, 641).

HR 24 december 1838, Rechtskundig Bijblad 1838, p. 44-50.

Notulen van de Staatscommissie voor de herziening van het Wetboek van Strafvordering het verslag van de $48 / 51^{\mathrm{e}}$ vergadering, opgenomen in Lindenberg 2002, p. 350-352. 
wet stelt aan bepaalde bewijsmiddelen kunnen worden getoetst. Zo kan bijvoorbeeld alleen op basis van de inhoud van de verklaring van een getuige worden geconcludeerd of deze getuige conform artikel 342 lid $1 \mathrm{~Sv}$ enkel verklaart over feiten en omstandigheden die door hem zelf zijn waargenomen of ondervonden. Voorts kan aldus worden getoetst of het bewijs genoegzaam is. Daarmee wordt niet alleen gedoeld op de vraag of de wettelijke bewijsminima in acht zijn genomen, maar ook op de vraag of het bewezenverklaarde uit de gebezigde bewijsmiddelen kan worden afgeleid. ${ }^{4}$ Ieder onderdeel van de bewezenverklaring moet immers zijn terug te voeren op de inhoud van één of meer bewijsmiddelen. Alleen ten aanzien van feiten van algemene bekendheid waarop de bewezenverklaring mogelijk steunt, geldt deze eis niet (art. 339 lid $2 \mathrm{~Sv}$ ). ${ }^{5}$

Tot slot kan aan de hand van de in het vonnis opgenomen inhoud van de bewijsmiddelen worden gecontroleerd of die inhoud redengevend is voor de bewezenverklaring. Deze eis wordt apart genoemd in het derde lid van artikel 359 Sv. Maar zoals verderop nog zal blijken, vallen de vermelding van de inhoud van de bewijsmiddelen en de eis van redengevendheid van het gebezigde bewijsmateriaal in de praktijk samen.

Ten aanzien van bovengenoemde eisen die aan het bewijsmateriaal worden gesteld, geldt dat deze alleen kunnen worden getoetst indien duidelijk is op welk bewijsmateriaal de rechter de bewezenverklaring heeft doen steunen. Waarom die inhoud van de bewijsmiddelen dan ook in het vonnis moet worden opgenomen, is daarmee echter nog niet verklaard. De inhoud van de bewijsmiddelen blijkt immers ook uit het procesdossier of uit het proces-verbaal van het onderzoek ter terechtzitting. Toch kan in het vonnis niet worden volstaan met een verwijzing naar deze stukken. Dit heeft verschillende redenen. Allereerst blijft met een algemene verwijzing naar die stukken onduidelijk welke onderdelen de rechter voor het bewijs heeft gebruikt en dus welke onderdelen aan de wettelijke eisen moeten voldoen. De tweede reden is van geheel andere aard. De Hoge Raad beschouwt het vermelden van de inhoud van de bewijsmiddelen in het vonnis niet alleen als een uitvloeisel van het wettelijke bewijsstelsel, maar ook als een waarborg voor de verdachte. De verdachte moet op eenvoudige wijze kennis kunnen nemen van het belastende bewijsmateriaal waarop de bewezenverklaring steunt. ${ }^{6}$ De meest aangewezen plaats daarvoor is het vonnis.

Het opnemen van de inhoud van de bewijsmiddelen in het vonnis houdt aldus enerzijds verband met het negatief-wettelijk bewijsstelsel en wordt anderzijds beschouwd als een waarborg voor de verdachte, die uit het vonnis moet kunnen

Knigge 1980, p. 152.

HR 30 oktober 1984, NJ 1985, 320.

Onder andere: HR 26 oktober 1971, NJ 1972, 194 en HR 14 mei 1985, NJ 1986, 9 m.nt. ThWvV. 
lezen waarop de bewezenverklaring steunt. Beide ideeën tezamen genomen maken dat het voorschrift zoals thans opgenomen in het derde lid van artikel $359 \mathrm{~Sv}$ van wezenlijk belang is voor de Nederlandse strafrechtspleging, hetgeen wordt onderstreept door het feit dat niet inachtneming ervan leidt tot nietigheid van het vonnis op grond van artikel 359 lid $8 \mathrm{~Sv}{ }^{7}$

Concreet betekent dit dat de rechter in het vonnis niet kan volstaan met een verwijzing naar de vindplaats van het bewijsmateriaal, zoals het proces-verbaal van de terechtzitting ${ }^{8}$ of (bijlagen bij) het proces-verbaal van opsporingsambtenaren. ${ }^{9}$ Een verwijzing naar de integrale inhoud van een proces-verbaal van opsporingsambtenaren met daarbij de toevoeging 'voor zover dit bewijsmiddel op eigen waarneming of wetenschap berust en voor zover het de telastelegging betreft en geen ontkenning daarvan inhoudt' is evenmin toegestaan. ${ }^{10}$ Ook de gevallen waarin het niet opnemen van het gebezigde bewijsmateriaal duidelijk het gevolg is van een vergissing en deze vergissing inmiddels hersteld is, kunnen niet op clementie van de Hoge Raad rekenen. ${ }^{11}$

\subsection{Nadere bewijsoverwegingen}

Veroordelende vonnissen in Nederland zijn waar het de bewezenverklaring betreft opgebouwd volgens een bepaald stramien. In principe worden de bewijsmiddelen met aanhaling van de gebezigde inhoud weergegeven. Dan volgt de bewezenverklaring zelf. De rechter overweegt dat op grond van de inhoud van de bewijsmiddelen, bevattende daartoe redengevende feiten en omstandigheden, hij wettig en overtuigend bewezen acht dat de verdachte het hem verweten feit heeft begaan. Het bewezenverklaarde feit wordt vervolgens in het vonnis opgenomen. Dat betekent dat de rechter die delen van de tenlastelegging die hij niet bewezen acht eruit laat en kennelijke verschrijvingen in de tenlastelegging herstelt. Dit deel van het vonnis zou men de eigenlijke bewezenverklaring kunnen noemen, grofweg bestaande uit de inhoud van de bewijsmiddelen en de overweging dat de rechter op grond daarvan het feit wettig en overtuigend bewezen acht.

Op grond van artikel 359 lid $3 \mathrm{~Sv}$ hoeft de rechter geen verdere toelichting te geven. Voor zover het bewijsoordeel nader moet worden onderbouwd, bijvoorbeeld op grond van artikel 360 lid 1 of $2 \mathrm{~Sv}$ of artikel 359 lid $2 \mathrm{~Sv}$ zal de rechter dit

7 Onder andere: HR 16 februari 1982, NJ 1982, 405 m.nt. ThWvV; HR 14 mei 1985, NJ 1986, 9 m.nt. ThWvV en HR 11 juni 1991, NJ 1991, 792.

8 Onder andere: HR 26 oktober 1971, NJ 1972, 194; HR 6 juni 1978, NJ 1979, 31; HR 13 mei 1986, NJ 1987, 81 en HR 3 december 1991, NJ 1992, 251 m.nt. ThWvV.

9 HR 6 juni 1978, NJ 1979, 31; HR 11 juni 1991, NJ 1991, 792 en HR 23 november 2004, LJN AR3280.

10 HR 28 september 1982, NJ 1983, 765. In gelijke zin: HR 30 mei 1972, NJ 1973, 456; HR 10 oktober 1972, NJ 1973, 457 en HR 10 oktober 1972, NJ 1973, 458 m.nt. ALM.

11 HR 17 februari 1987, NJ 1987, 920. 
doen in een zogeheten nadere bewijsoverweging. Ook is het niet ongebruikelijk om ook zonder een wettelijke verplichting daartoe in het vonnis zogeheten nadere bewijsoverwegingen op te nemen. De rechter kan dit doen als hij ondanks het ontbreken van een (goed onderbouwd) verweer toch de persoonlijke aandrang voelt om extra verantwoording af te leggen of gezien de aard van de zaak niet wenst te volstaan met motiveringsclichés. ${ }^{12}$

De nadere bewijsoverwegingen volgden vroeger na de eigenlijke bewezenverklaring. Tegenwoordig komen zij zowel voor als na de bewezenverklaring voor. Sinds 1 januari 2005 - het moment waarop een algemene responsieplicht in artikel 359 lid $2 \mathrm{~Sv}$ is opgenomen - is het gebruikelijk dat de strafrechter eerst op de bewijsverweren van de verdediging ingaat, alvorens hij zijn eigen bewijsconstructie in het vonnis opneemt.

Ten aanzien van deze nadere bewijsoverwegingen rijst de vraag of de daarin vermelde feiten en omstandigheden ook moeten blijken uit de in het vonnis opgenomen bewijsmiddelen. Met andere woorden: geldt de eis van artikel 359 lid $3 \mathrm{~Sv}$ ook ten aanzien van de feiten en omstandigheden die worden genoemd in de nadere bewijsoverwegingen? Deze vraag valt uiteen in drie deelvragen. De eerste is of hetgeen de rechter in de nadere bewijsoverweging noemt deel uitmaakt van de bewijsconstructie. Pas bij een bevestigend antwoord op deze vraag komt men toe aan de twee overige vragen, te weten: moet uit het vonnis blijken dat deze feiten aan een wettig bewijsmiddel zijn ontleend en moet vervolgens ook de inhoud van dat bewijsmiddel in het vonnis worden opgenomen?

\subsubsection{Onderdeel van de bewijsconstructie?}

Als de nadere bewijsoverweging deel uitmaakt van de bewijsconstructie heeft dit tot gevolg dat de feiten en omstandigheden die daarin worden genoemd aan een wettig bewijsmiddel moeten zijn ontleend waarvan de inhoud in het vonnis moet worden opgenomen.

Direct na de inwerkingtreding van het Wetboek van Strafvordering van 1926 was blijkens de jurisprudentie de plaats van de bewijsoverweging beslissend. Bevond de overweging zich onder de bewezenverklaring, dan makkte zij geen deel uit van de bewijsconstructie. ${ }^{13}$ Aan deze jurisprudentie heeft het leerstuk met betrekking tot de nadere bewijsoverweging ook zijn vroegere naam te danken, namelijk 'de bewijsoverweging onder de streep'. Tussen de bewezenverklaring en alles wat daarna in het vonnis was opgenomen, liep als het ware een streep en alles wat

$12 \quad$ Krikke 1977, p. 451.

13 In wezen was deze jurisprudentie een voortzetting van de jurisprudentie onder het oude Wetboek van Strafvordering van 1886. Bijvoorbeeld HR 19 juni 1916, Weekblad van het Recht nr. 9980, p. 2; HR 18 juni 1923, Weekblad van het Recht nr. 11097, p. 3 en HR 2 februari 1925, Weekblad van het Recht nr. 11342, p. 2. 
daaronder was opgenomen behoorde niet tot de bewijsvoering en was 'ten overvloede' opgenomen. ${ }^{14}$ Dat had tot gevolg dat alles wat 'onder de streep' was opgenomen, niet hoefde te voldoen aan de wettelijke eisen. Voor zover daarin feiten en omstandigheden werden genoemd ter 'nadere' onderbouwing van het bewijsoordeel hoefden die niet te blijken uit wettige bewijsmiddelen. Wel moesten deze feiten tijdens het onderzoek ter terechtzitting aan de orde zijn gesteld. ${ }^{15}$

In de latere jurisprudentie van de Hoge Raad is dit formele criterium losgelaten. Bepalend werd in hoeverre de inhoud van nadere bewijsoverweging redengevend is voor de bewezenverklaring. Zijn de in de bewijsoverweging genoemde feiten en omstandigheden relevant voor het bewijsoordeel, dan zijn ze onderdeel van de bewijsconstructie. ${ }^{16}$ Er wordt dus niet langer onderscheid gemaakt tussen

'motivering, aanvullende motivering, nadere precisering of ten overvloede aan de motivering toegevoegde overwegingen, omdat - wat er van al deze onderscheiding zij - een nadere precisering of overweging ten overvloede mede behoren tot een redengevend betoog, waarop de betrokken rechter in een concreet geval de bewezenverklaring bouwde. ${ }^{17}$

Het begrip 'redengevend' heeft echter een beperkte strekking. Het ziet niet op feiten die de rechter noemt om de betrouwbaarheid van het bewijsmateriaal te onderbouwen. ${ }^{18}$ Dit betekent bijvoorbeeld dat alle feiten die de rechter aanhaalt om daarmee aan te tonen dat het verweer van de verdachte dat een bepaalde verklaring onbetrouwbaar is, niet uit de in het vonnis opgenomen bewijsmiddelen hoeven te blijken. ${ }^{19}$ Evenmin redengevend zijn feiten die de rechter aanhaalt ter weerlegging van een onrechtmatig verkregen bewijsverweer ${ }^{20}$ of een beroep op

14 HR 19 oktober 1931, NJ 1932, 1290; HR 21 maart 1944, NJ 1944/45, 400; HR 26 februari 1946, $N J$ 1946, 173 en HR 19 juni 1956, NJ 1956, 516.

15 HR 12 juni 1956, NJ 1956, 389 m.nt. WP.

16 HR 16 maart 1965, NJ 1965, 275 m.nt. BVAR.; HR 18 juni 1968, NJ 1969, 68 m.nt. Enschedé, HR 8 juni 1971, NJ 1972, 231 m.nt. ALM; HR 7 december 1971, NJ 1972, 243; HR 28 mei 1974, NJ 1974, 331 m.nt. ThWvV; HR 19 november 1974, NJ 1975, 118 m.nt. ThWvV; HR 9 september 1980, NJ 1981, 53 m.nt. GEM; HR 12 oktober 1982, $N J$ 1984, 23 m.nt. GEM; HR 19 september 1988, NJ 1989, 478; HR 25 april 1989, NJ 1989, 866 en HR 23 september 2003, NJ 2004, 166.

17 Mulder, in zijn annotatie bij HR 8 juni 1971, NJ 1972, 231.

18 HR 18 mei 1976, NJ 1976, 539 m.nt. ThWvV, HR 1 februari 1977, NJ 1977, 230 m.nt. ThWvV, HR 22 januari 1980, NJ 1980, 293, HR 11 oktober 1983, NJ 1984, 585 m.nt. GEM, HR 4 februari 1992, NJ 1992, 530 m.nt. ThWvV.

19 Nijboer spreekt in dit verband van een aanvulling op de bewijsconstructie. De feitelijke grondslag van deze aanvulling hoeft niet gebaseerd te zijn op wettige bewijsmiddelen. Zie Nijboer 2000a, p. 303-304.

20 HR 8 december 1981, NJ 1982, 533 en HR 15 mei 2007, LJN AZ6101 (r.o. 3.4): 'Het middel berust op de opvatting dat de vaststelling van feiten die ten grondslag worden gelegd aan de verwerping van een verweer dat bewijsmateriaal onrechtmatig is verkregen, moet berusten op de in de uitspraak vermelde inhoud van wettige bewijsmiddelen. Die opvatting is niet juist.' 
afwezigheid van alle schuld. ${ }^{21}$ Wel moeten dergelijke feiten tijdens het onderzoek ter terechtzitting aan de orde zijn geweest, zodat procespartijen de gelegenheid hebben gehad om deze feiten te weerspreken. ${ }^{22}$ Behalve de bovengenoemde uitzonderingen wordt niet snel geconcludeerd dat de feiten die in een nadere bewijsoverweging zijn opgenomen niet voor de bewezenverklaring redengevend zijn geweest. Dit is op zich ook logisch aangezien anders de vraag kan worden gesteld waarom ze in het vonnis zijn opgenomen.

'Dat de rechter iets vermeldt, duidt er altijd op, dat hij dit redengevend heeft geacht, $\mathrm{al}$ is het in lichte mate. ${ }^{23}$

Naast het inhoudelijke criterium hanteerde de Hoge Raad lange tijd ook als richtsnoer de vraag of de overweging in zijn geheel beschouwd ten overvloede is gegeven. Kan het bewijsoordeel reeds volgen uit de feiten en omstandigheden zoals genoemd in de bewijsmiddelen, dan is de nadere bewijsoverweging kennelijk als een extra onderbouwing van dat oordeel gegeven. De daarin opgenomen feiten en omstandigheden maken dan geen deel uit van de eigenlijke bewijsvoering. Meestal blijkt dit ook uit de formulering van de bewijsoverweging: 'ten overvloede merkt het hof op, dat (...)'. ${ }^{24}$

In recente jurisprudentie komt men dit criterium 'overweging ten overvloede' als zodanig niet meer tegen. Wel een variant daarvan, namelijk dat niet zo zeer de overweging in zijn geheel ten overvloede is gegeven, maar dat sommige feiten die daarin zijn opgenomen overbodig zijn voor de bewijsconstructie en dus ten overvloede zijn opgenomen. De Hoge Raad reconstrueert dan als het ware de gedachtegang van het hof en komt vervolgens tot de conclusie dat de feiten in de nadere bewijsoverweging geen wezenlijke dan wel geen zelfstandige betekenis hebben binnen die gedachtegang. Zo oordeelde de Hoge Raad dat de overweging inhoudende dat de verdachte reeds voor een vergelijkbaar delict eerder was veroordeeld en dit delict had bekend, moest worden beschouwd als

'een de bewijsoverweging inleidende opmerking die niet van wezenlijke betekenis is voor de inhoud van de overweging en die daarom geen steun behoeft in de wettelijke bewijsmiddelen. ${ }^{25}$

In een ander geval had het hof bij het construeren van de voorbedachte rade van de verdachte onder andere betekenis toegekend aan het feit dat de verdachte van een meervoudige moord als eerste een vooraanstaand kickbokser met een kennelijk goed reactievermogen in de rug had geschoten. Uit de bewijsmiddelen bleek echter niet dat het slachtoffer kickbokser was noch dat hij een goed reactievermogen

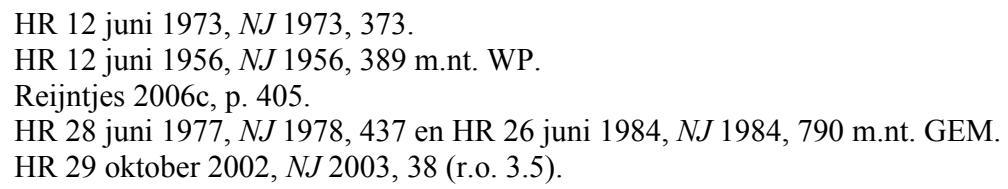


had. Het niet noemen van het bewijsmiddel waaraan het hof die feiten ontleende, vond in de ogen van de Hoge Raad genade, omdat aan die feiten geen zelfstandige betekenis toekwam. Weliswaar was het in strijd met artikel 359 lid $3 \mathrm{~Sv}$, maar dit hoefde vervolgens niet tot cassatie te leiden. ${ }^{26}$

De Hoge Raad gaat hier vrij ver om uitspraken voor cassatie te behoeden. Immers, eigenlijk zegt de Hoge Raad hier dat die feiten wel redengevend zijn, maar kennelijk niet redengevend genoeg om daarop het arrest te laten stranden. Deze handelwijze is in strijd met de taak van de Hoge Raad. Hij dient in cassatie uit te gaan van de feiten die het hof als relevant heeft aangemerkt en vervolgens te beoordelen in hoeverre de door het hof genoemde feiten zijn ontleend aan een in dat vonnis genoemd wettig bewijsmiddel. Indien de verwijzing naar het bewijsmiddel ontbreekt, is het niet aan de Hoge Raad om vervolgens te oordelen dat deze feiten kennelijk niet redengevend zijn geweest.

\subsubsection{Vermelding van de bron}

Uit het bovenstaande volgt dat de inhoud van een nadere bewijsoverweging wel degelijk deel uit kan maken van de bewijsconstructie, namelijk in die gevallen waarin de daarin opgenomen feiten en omstandigheden redengevend zijn voor de bewezenverklaring. In dat geval volgt uit artikel 359 lid $3 \mathrm{~Sv}$ dat de feiten moeten blijken uit een bewijsmiddel waarvan de inhoud in het vonnis is opgenomen. Op deze wijze kan uit het vonnis zelf volgen dat die feiten zijn ontleend aan een wettig bewijsmiddel. Niet nodig is dat de rechter het bewijsmiddel kwalificeert als wettig bewijsmiddel. Uit het vermelden van de bron en de inhoud daarvan kan worden afgeleid welk wettig bewijsmiddel de rechter op het oog heeft gehad. ${ }^{27}$

Om aan de eis van het derde lid van artikel 359 lid $3 \mathrm{~Sv}$ te voldoen, kan de rechter twee wegen bewandelen. Hij kan in de eigenlijke bewijsconstructie al het relevante bewijsmateriaal opnemen onder verwijzing naar de bron. Vervolgens kan hij in de nadere bewijsoverwegingen zijn redenering uit de doeken doen en voor de herkomst daarvan impliciet of expliciet verwijzen naar de in het vonnis opgenomen bewijsmiddelen. Deze methode was lange tijd gebruikelijk en kwam er op neer dat alle (redengevende) feiten uit de bewijsoverweging uit de in het vonnis opgenomen eigenlijke bewijsconstructie moesten blijken. Het gevaar bestaat echter bij een op zodanige wijze vormgegeven vonnis dat bij het formuleren van de nadere bewijsoverweging wordt vergeten te controleren of alle daarin genoemde feiten worden afgedekt door de eerder vermelde bewijsmiddelen. Of andersom:

26 HR 4 oktober 2005, LJN AT5759. In gelijke zin: HR 24 september 2002, NJ 2002, 570 en HR 18 april 2006, LJN AU9422.

27 HR 21 oktober 1980, NJ 1981, 69 m.nt. GEM. 
dat bij het uitwerken van het vonnis met de bewijsmiddelen geen acht wordt geslagen op de eerder in het verkorte vonnis geformuleerde bewijsoverwegingen. Een andere mogelijkheid die dit gevaar niet in zich draagt, is dat de rechter in de nadere bewijsoverweging zelf de bron noemt waaraan hij de daar genoemde feiten en omstandigheden ontleent. Zo kan bijvoorbeeld in een nadere bewijsoverweging het aanwezig zijn van voorwaardelijk opzet bij de verdachte blijken uit feiten die hij zelf heeft verklaard ter zitting. Door in deze overweging het bewijsmiddel te benoemen is de bron bekend en dat is volgens de Hoge Raad voldoende:

'Voor zover in het middel wordt betoogd dat de desbetreffende feiten in de vorm van afzonderlijke bewijsmiddelen, zoals die gebruikelijk voorafgaand aan de bewezenverklaring moeten worden weergegeven, stelt het een eis die het recht niet kent. ${ }^{28}$

Deze methode verdient in zekere zin zelfs de voorkeur, omdat op deze wijze de lezer van het vonnis direct weet aan welke bron de informatie is ontleend. Hij hoeft dan, afhankelijk van de plaats van de bewijsoverweging in het vonnis, niet vooruit of terug te bladeren om te controleren of de feiten zijn ontleend aan wettige bewijsmiddelen.

Het niet benoemen van de bron van de feiten in de nadere bewijsoverweging zonder dat blijkt aan welk wettig bewijsmiddel die feiten zijn ontleend, leidt in principe tot cassatie. ${ }^{29}$ Dat lijdt slechts in twee gevallen uitzondering. Ten eerste - zoals reeds in de vorige paragraaf bleek - voor zover de in de nadere bewijsoverweging genoemde feiten niet redengevend zijn, dan wel van ondergeschikte betekenis zijn voor de bewijsconstructie. Ten tweede, indien de feiten in de nadere overweging ook uit een ander wel in het vonnis genoemd bewijsmiddel blijken of kunnen worden afgeleid. ${ }^{30}$ In dat geval is gewaarborgd dat de feiten zijn ontleend aan een wettig bewijsmiddel. Dat de verdachte niet op eenvoudige wijze kan achterhalen waaraan de belastende informatie is ontleend, is dan kennelijk van minder belang.

\subsubsection{De inhoud van de nadere bewijsoverweging}

In de vorige paragraaf bleek dat feiten en omstandigheden die de rechter noemt in de nadere bewijsoverweging en die redengevend zijn voor de bewezenverklaring in principe moeten blijken uit wettige bewijsmiddelen. Niet alleen moet de bron waaraan de informatie is ontleend, maar ook de inhoud van die bewijsmiddelen in het vonnis worden opgenomen. De rechter kan dus niet volstaan met een enkele verwijzing naar de bron, maar moet de redengevende feiten en omstandigheden

28 HR 9 januari 2001, LJN AA9480. In gelijke zin: HR 12 november 1974, $N J$ 1975, 41 m.nt. ThWvV; HR 27 november 1984, NJ 1985, 379 m.nt. GEM en HR 7 november 2000, NJ 2001, 35.

29 HR 23 september 2003, NJ 2004, 166.

30 HR 15 mei 1990, NJ 1991, 10 m.nt. ThWvV. 
in het vonnis noemen. Evenals ten aanzien van de benoeming van de bron geldt dat de Hoge Raad geen eisen stelt aan de plaats waar die feiten en omstandigheden in het vonnis moeten worden vermeld. Dit kan dus geschieden in de nadere bewijsoverweging zelf. Het is echter ook toegestaan dat de bewijsoverweging alleen het bewijsmiddel noemt en voor de inhoud daarvan impliciet of expliciet wordt verwezen naar de eigenlijke bewijsconstructie waar de inhoud van de bewijsmiddelen is opgenomen. Kortom: het doet er niet toe waar het in het vonnis staat, als het er maar staat. ${ }^{31}$

Wel eist de Hoge Raad dat - voor zover de rechter zich beroept op gegevens die niet bij de bewijsmiddelen zijn opgenomen - deze in de bewijsoverweging met voldoende mate van nauwkeurigheid de feiten en omstandigheden moeten worden aangeduid:

'Indien het gaat om feiten of omstandigheden die door de rechter redengevend worden geacht voor de bewezenverklaring, dient de rechter die zich aldus - al dan niet in reactie op een bewijsverweer - beroept op bepaalde niet in de bewijsmiddelen vermelde gegevens, met voldoende mate van nauwkeurigheid in zijn overweging

a) die feiten of omstandigheden aan te duiden, en

b) het wettige bewijsmiddel aan te geven waaraan die feiten of omstandigheden zijn ontleend. ${ }^{32}$

Een letterlijke weergave van de inhoud van het bewijsmiddel in de nadere bewijsoverweging is echter niet nodig; een parafrasering van de inhoud is voldoende. ${ }^{33}$ En in sommige gevallen is ook het ontbreken van een dergelijke aanduiding geen reden voor cassatie:

'Ten onrechte heeft het Hof die bevindingen van de deskundige Chang niet omschreven in zijn nadere bewijsoverweging. De Hoge Raad leest die overweging met verbetering van die misslag, zodat dit verzuim niet tot cassatie kan leiden. ${ }^{34}$

Deze uitspraak roept de vraag op in hoeverre de Hoge Raad niet toch weer onderscheid maakt tussen de bewijsconstructie 'boven de streep' en die 'onder de streep'. Dit onderscheid werd vroeger gemaakt, waarbij de streep de scheidingslijn symboliseerde tussen de feiten die wel en die niet hun grondslag in de bewijsmiddelen moesten vinden. Alles onder de denkbeeldige streep behoefde niet uit wettige bewijsmiddelen te blijken. Thans is dit geen gangbaar criterium meer; alles dat redengevend is voor de bewezenverklaring moet zijn terug te leiden tot de inhoud van een wettige bewijsmiddel. Alleen lijkt de Hoge Raad nu weer aan te sluiten bij dit oude criterium als het gaat om de vraag op welke wijze de verwijzing naar het bewijsmiddel moet plaatsvinden. Immers, ten aanzien van

31 Nijboer 2000a, p. 304.

32 HR 24 juni 2003, NJ 2004, 165 m.nt. JR. Zie voor de wijze waarop een nadere bewijsoverweging dan vorm kan krijgen de conclusie van advocaat-generaal Bleichrodt bij HR 13 februari 2007, $L J N$ AZ5473.

33 In gelijke zin: Reijntjes in zijn annotatie bij HR 24 juni 2003, NJ 2004, 165.

34 HR 24 juni 2003, NJ 2004, 165 m.nt. JR. 
alles wat behoort tot de eigenlijke bewijsconstructie geldt dat de inhoud van het gebezigde bewijsmateriaal in het vonnis moet worden vermeld. Een verwijzing naar de inhoud is daar niet toegestaan. Wordt echter een deel van de bewijsconstructie uit de doeken gedaan in een nadere bewijsoverweging, dan geldt slechts een afgezwakte vorm hiervan; de feiten en omstandigheden moeten met een voldoende mate van nauwkeurigheid worden aangeduid. En bij gebreke daaraan is de Hoge Raad bereid de feiten en omstandigheden in te lezen.

Beziet men het arrest van de Hoge Raad waarin hij genoegen nam met een aanduiding van de feiten en omstandigheden nader, dan kan een verklaring van dit onderscheid gelegen zijn in de aard van de nadere bewijsoverweging. In die zaak had het hof ter weerlegging van het verweer van de verdachte verwezen naar de verklaring van een deskundige. Uit die verklaring bleek dat de alternatieve gang van zaken zoals die door de verdachte werd geschetst expliciet werd uitgesloten. Maar ook zonder die verklaring was de bewijsconstructie van het hof op zichzelf al sluitend. De bewijsoverweging kon in dat licht bezien, worden beschouwd als een aanvulling.

Heeft de nadere overweging tot doel de bewijsconstructie sluitend te maken, dan geldt waarschijnlijk de eis dat ook de inhoud van het bewijsmateriaal in het vonnis moet worden opgenomen. Is echter de nadere overweging een aanvulling op een uit zichzelf reeds sluitende bewijsconstructie - zoals in bovenvermelde zaak dan wordt genoegen genomen met een nauwkeurige aanduiding van de inhoud. Dat betekent dus niet - zoals vroeger wel werd betoogd - dat de overweging ten overvloede is gegeven, maar enkel dat minder strikte eisen worden gesteld aan de wijze waarop de inhoud van het bewijsmiddel in het vonnis moet worden opgenomen.

\subsection{Uitzonderingen op het vermelden van de inhoud van de bewijsmiddelen in het vonnis}

Eén van de eisen met betrekking tot de motivering van het bewijsoordeel die volgen uit het derde lid van artikel $359 \mathrm{~Sv}$ is dat uit het vonnis de herkomst en inhoud van de informatie waarop de bewezenverklaring steunt moet blijken. Daarbij maakt het geen verschil of de feiten en omstandigheden in de eigenlijke bewijsconstructie van het vonnis zijn opgenomen of in een bewijsoverweging worden genoemd. Deze wezenlijke en overigens ook typisch Nederlandse motiveringseis dient enerzijds om op die manier controle op de wettigheid en genoegzaamheid van het bewijs mogelijk te maken. Anderzijds kan op deze wijze de verdachte/veroordeelde op eenvoudige wijze kennis nemen van het gebezigde bewijsmateriaal. Op grond van het bovenstaande ontstaat wellicht de indruk dat in alle veroordelende strafvonnissen de inhoud van de gebruikte bewijsmiddelen, voor zover redengevend, is opgenomen. Deze veronderstelling is echter onjuist. Hoewel 
echter het vermelden van de inhoud van de gebruikte bewijsmiddelen een van de belangrijkste ijkpunten voor de juistheid van het bewijsoordeel is, zijn vonnissen waarin het gebezigde bewijsmateriaal is opgenomen eerder uitzondering dan regel. Daaraan liggen proceseconomische motieven ten grondslag.

Het opnemen van de inhoud van de bewijsmiddelen in het schriftelijke vonnis is immers een tijdrovend karwei. Het houdt in dat uit het procesdossier en uit het proces-verbaal van de zitting die feiten en omstandigheden worden overgenomen in het vonnis, die voor het bewijsoordeel relevant zijn en die het bewezenverklaarde feit volledig dekken. Daarbij moet worden voorkomen dat feiten en omstandigheden worden genoemd die niet relevant zijn of in strijd met de bewezenverklaring zijn. Fouten op dit punt kunnen ertoe leiden dat het vonnis in cassatie geen stand houdt. Vanuit de rechtspraktijk werd dan ook aangedrongen op versoepeling van de wetgeving op dit punt, opdat daarmee de rechtspleging efficiënter zou kunnen functioneren. De wetgever heeft hieraan toegegeven.

Zo werd allereerst de mogelijkheid geschapen om in eenvoudige zaken die worden behandeld door een alleensprekende rechter te volstaan met een mondeling vonnis. Van dit vonnis hoeft slechts een schriftelijke aantekening te worden gemaakt. In die aantekening hoeven de bewijsmiddelen niet te worden uitgeschreven.

Naderhand zijn ook de meervoudige kamers op dit punt ontlast. Zij moeten weliswaar nog steeds schriftelijke vonnissen wijzen, maar mogen volstaan met een verkorte vorm daarvan. De inhoud van de bewijsmiddelen mag in een zogeheten 'verkort vonnis' ontbreken. Slechts indien tegen het vonnis een rechtsmiddel wordt ingesteld, zijn de rechtbanken en hoven verplicht dit vonnis cq. arrest aan te vullen met de inhoud van de bewijsmiddelen.

Op de verplichting tot aanvulling van een dergelijk verkort vonnis zijn inmiddels ook weer uitzonderingen geformuleerd. De eerste is wederom van de hand van de wetgever. Sinds 1 januari $2005 \mathrm{kan}$ in geval de verdachte het hem tenlastegelegde feit heeft bekend, worden volstaan met een opgave van de bewijsmiddelen. ${ }^{35} \mathrm{De}$ tweede uitzondering lijkt zich te ontwikkelen in de rechtspraak. Bepaalde gerechtshoven nemen genoegen met verkorte vonnissen van rechtbanken. Als deze lijn wordt voorgezet vervalt daarmee in algemene zin de plicht tot het opnemen van inhoud van de bewijsmiddelen voor de rechtbanken. Artikel 359 lid 3 Sv zal dan alleen nog betekenis hebben voor arresten gewezen in hoger beroep, voor zover daartegen cassatie wordt ingesteld.

35 Wet van 10 november 2004 (aanpassing eisen motivering bewezenverklaring bekennende verdachte) $S t b$. 2004, 580 (inwerkingtreding 1 januari 2005, Stb. 2004, 641). 


\subsubsection{Het mondelinge vonnis}

In geval van een 'gewoon' schriftelijk vonnis moet zoals gezegd ingevolge artikel 359 lid $3 \mathrm{~Sv}$ in het veroordelende vonnis de inhoud van het gebezigde bewijsmateriaal worden opgenomen. Ten aanzien van alleensprekende rechters, zoals de (economische) politierechter, de kantonrechter, de kinderrechter en de unus iudex in appel, ${ }^{36}$ is in diverse bepalingen in het Wetboek van Strafvordering vastgesteld dat zij kunnen volstaan met een mondeling vonnis. ${ }^{37}$ Het mondelinge vonnis moet in principe voldoen aan dezelfde eisen die worden gesteld aan het schriftelijke vonnis. De rechter zal ter zitting moeten aangeven welke feiten hij bewezen acht en op grond van welk bewijsmateriaal hij tot die conclusie komt. Bij de introductie van het mondelinge vonnis van de politierechter in $1926^{38}$ kende de wetgever zelfs een meerwaarde toe aan het mondelinge vonnis ten opzichte van het schriftelijke:

'Immers dit is juist een belangrijk voordeel van het mondeling gegeven vonnis, dat daarbij de rechter door de aanwezigheid van den verdachte, die zich verdedigde, en van het publiek dat het rechtsgeding volgde, als van zelf zich genoopt zal gevoelen van zijne beslissing openlijk rekenschap te geven in die mate als de aard van het geval eischt. Meer nog allicht dan bij het op schrift stellen van een vonnis, dat hij later en voor een gansch ander publiek zal hebben uit te spreken, zal hij zich hier verplicht gevoelen, maar mede om bevrediging te schenken aan het rechtsgevoel van anderen en om vertrouwen te wekken in zijne rechtspraak. ${ }^{39}$

Uit onderzoek van Mevis blijkt echter dat de kwaliteit van het mondelinge vonnis sterk afhankelijk is van de individuele rechter en dat in geen enkele rechtbank het mondelinge vonnis van de politierechter voldoet aan alle eisen die daaraan

36 Ingevolge de Wet van 5 oktober 2006 (stroomlijnen hoger beroep), Stb. 2006, 470 (inwerkingtreding 1 maart/1 juli 2007, Stb. 2007, 70) wordt ook in appel een enkelvoudige kamer voor economische strafzaken ingericht. Kritisch daarover: Franken \& Prakken 2003, p. 111 en De Winter 2007, p. 130: 'Wie bij het hoger beroep in een economische strafzaak geen enkel probleem weet te ontwaren, kan er vanuit gaan dat hij de zaak onvoldoende heeft bestudeerd; er is eigenlijk altijd wel íets aan de hand.'

37 Art. 378 lid $1 \mathrm{~Sv}$ voor de politierechter; 395 lid $1 \mathrm{~Sv}$ voor de kantonrechter, art. 425 lid 3 Sv voor enkelvoudige kamer in hoger beroep, art. 499 lid 2 juncto 378 lid 1 Sv voor de kinderrechter en art. 48 lid 1 WED juncto 378 lid 1 Sv voor de economische politierechter. De alleensprekende rechters blijven bevoegd, eventueel op vordering van de officier van justitie of op verzoek van de verdediging, om een schriftelijk vonnis te wijzen. Zie de artikelen 379 Sv juncto 499 Sv en 48 WED, 396 Sv en 426, vijfde lid, Sv.

38 De mogelijkheid voor de kantonrechter om met een stempelvonnis te volstaan dateert uit 1935. Voor de economische politierechter is de mogelijkheid geïntroduceerd bij de Wet op de Economische Delicten in 1951. Op 1 januari 1976 werd een uniforme regeling ingevoerd die voor alle alleensprekende rechters in eerste aanleg gold. Zie de Wet van 26 juni 1975, Stb. 1975, 342 (inwerkingtreding 1 januari 1976, Stb. 1975, 694). Op 1 november 1996 werd deze regeling uitgebreid tot die gevallen waarin in hoger beroep door een enkelvoudige kamer vonnis werd gewezen. Zie de Wet van 26 september 1996, Stb. 1996, 487 (inwerkingtreding 1 november 1996, Stb. 1996, 521).

39 Kamerstukken II 1913-1914, 286, nr. 3 (MvT), p. 194. In gelijke zin: Blok en Besier 1925, deel II, p. 245. 
krachtens de artikelen 357 tot en met $359 \mathrm{~Sv}$ worden gesteld. ${ }^{40}$ Ten aanzien van de bewezenverklaring stelt hij vast dat sommige politierechters in geval van een ontkennende verdachte in hun mondelinge vonnis expliciet naar de bewijsmiddelen verwijzen. Anderen daarentegen volstaan er mee om in de loop van het onderzoek ter terechtzitting de diverse bewijsmiddelen ter sprake te brengen zonder daar in het mondelinge vonnis nog op terug te komen.

Waar in het mondelinge vonnis de kenbaarheid van de bewezenverklaring en het gebezigde bewijs niet altijd is gegarandeerd ${ }^{41}-$ en dat geldt zeker ten aanzien van verstekzaken - zou die kenbaarheid wel in de schriftelijke aantekening van dat mondelinge vonnis tot zijn recht moeten komen.

\subsubsection{Het stempelvonnis en de aantekening in het proces-verbaal van de zitting}

Het feit dat het vonnis mondeling wordt gegeven, betekent niet dat er in het geheel geen schriftelijke verslaglegging van het vonnis plaatsvindt. Dit geschiedt in het merendeel van de gevallen in een zogeheten 'aantekening mondeling vonnis'. ${ }^{42}$ In principe kan worden volstaan met een summiere aantekening, ook wel een stempelvonnis genoemd. ${ }^{43}$ Een dergelijk 'vonnis' bestaat uit één enkel A-viertje waarop een aantal bij ministeriële regeling vastgestelde gegevens ${ }^{44}$ zijn opgenomen. ${ }^{45}$ Met betrekking tot de bewijsbeslissing en het bewijsmateriaal waarop deze is gebaseerd treft men, behalve de kwalificatie van het bewezenverklaarde feit in geval van veroordeling, niets aan. Noch de inhoud van de bewijsmiddelen,

40 Mevis 1992, p. 90-91.

41 Mevis 1992, p. 83 komt tot de conclusie dat de wetgever duidelijkere regels met betrekking tot de invulling van het mondelinge vonnis zou moet stellen.

42 Officieel moet de aantekening van het mondeling vonnis aan het dubbel van de dagvaarding worden gehecht, echter dat voorschrift schijnt in de praktijk niet gevolgd te worden. Mevis 1992, p. 98.

43 Zie artikel 378a Sv voor de politierechter, art. 395a Sv voor de kantonrechter en art. 426 $\mathrm{Sv}$ voor de enkelvoudige kamer in hoger beroep. Voor de kinderrechter en de economische politierechter is artikel 378a Sv eveneens van toepassing ingevolge artikel 499, tweede lid, Sv respectievelijk artikel 48, eerste lid, WED.

44 Deze gegevens zijn: de naam van degene die het vonnis heeft gewezen, de dag van de uitspraak, de omstandigheid of het vonnis bij verstek dan wel op tegenspraak is gewezen, in geval van veroordeling de kwalificatie van het bewezenverklaarde feit, de toepasselijke wettelijke voorschriften, de opgelegde straf of maatregel, eventuele andere door de rechter genomen beslissingen en bijzondere strafmotiveringen, en de omstandigheid of al of niet ter zitting afstand is gedaan van hoger beroep.

45 Zie de Regeling aantekening mondeling vonnis door de politierechter, de kinderrechter, de economische politierechter, de kantonrechter en de enkelvoudige kamer voor de behandeling van strafzaken in hoger beroep d.d. 2 oktober 1996, Stcrt. 1996, nr. 197, p. 7. Overigens wordt in deze regeling nog verwezen naar artikel 426e Sv, dat per 1 februari 2002 is vervallen als gevolg van de inwerkingtreding van de Aanpassingswet modernisering rechterlijke organisatie (Stb. 2001, 584). 
noch de exacte bewoordingen van de bewezenverklaring zelf, hoeven in een dergelijk stempelvonnis te worden opgenomen. Bovendien is het niet nodig om het proces-verbaal van de terechtzitting uit te werken. In het dossier zal men hooguit de aantekeningen van de griffier over het verloop van de zitting aantreffen.

In een viertal gevallen kan met een dergelijk stempelvonnis niet worden volstaan. ${ }^{46}$ In die gevallen moet het proces-verbaal van de terechtzitting worden opgemaakt en moet het mondelinge vonnis daarin worden aangetekend. De meest voorkomende situatie waarin het stempelvonnis moet worden 'uitgewerkt' is die waarin tegen het vonnis binnen 3 maanden een gewoon rechtsmiddel wordt ingesteld. ${ }^{47}$ In dat geval vervalt de antekening van het mondelinge vonnis en treedt daarvoor het proces-verbaal van de terechtzitting in de plaats. Bovendien kunnen partijen zowel ter zitting als binnen 3 maanden na het wijzen van het mondelinge vonnis een vordering dan wel verzoek doen tot het uitwerken van het proces-verbaal. Tot slot geldt dat de alleensprekende rechter niet mag volstaan met een stempelvonnis indien het vonnis is gewezen bij verstek, de verdachte kennelijk niet op de hoogte was van het moment waarop de terechtzitting plaatsvond en op die zitting getuigen, dan wel deskundigen zijn gehoord of zich een benadeelde partij in het proces heeft gevoegd. In dat laatste geval heeft de verdachte geen enkele invloed op de feitenvaststelling kunnen uitoefenen. Indien dan met een aantekening van het mondelinge vonnis wordt volstaan, zou hij volledig onwetend blijven over de ter zitting vastgestelde feiten. Toch blijkt uit het eerder genoemde onderzoek van Mevis, dat in dergelijke bij verstek gewezen zaken meestal geen proces-verbaal wordt opgemaakt tenzij tegen het vonnis hoger beroep wordt ingesteld. ${ }^{48}$

46 Zie art. 378 lid $2 \mathrm{~Sv}$ voor de (economische) politierechter en de kinderrechter, art. 395 lid $2 \mathrm{~Sv}$ voor de kantonrechter en art. 425 lid $4 \mathrm{~Sv}$ voor de alleensprekende rechter in hoger beroep.

47 Voor de alleensprekende rechter in appel geldt de termijn van 3 maanden niet. Daarmee werd voorkomen dat de cassatierechter werd geconfronteerd met een stempelarrest Zie art. 425 lid 4 onder c Sv. Met ingang van 1 maart 2007 wordt dit lid vernummerd tot lid 3 ; lid 2 komt te vervallen ingevolge de Wet stroomlijnen hoger beroep. Eveneens op grond van dezelfde wetswijziging geldt de noodzaak tot uitwerking van het mondeling vonnis ook niet meer voor vonnissen in de zin van art. 410a, eerste lid, Sv. Dit zijn vonnissen waarbij een veroordeling is uitgesproken ter zake van overtredingen of misdrijven waarop een maximum gevangenisstraf is gesteld van 4 jaar en waarbij de opgelegde straf is beperkt tot een geldboete met een maximum van 500 Euro. Terzake van dergelijke mondelinge vonnissen geldt evenmin een uitwerkingsplicht indien de uitspraak is gedaan bij verstek. Zie de Wet van 5 oktober 2006 (stroomlijnen hoger beroep), Stb. 2006, 470 (inwerkingtreding vanaf 1 maart 2007, Stb. 2007; art. 410a Sv treedt pas op 1 juli 2007 in werking).

48 Mevis 1992, p. 93. 


\subsubsection{Verwijzing naar de bewijsmiddelen}

In de aantekening van het mondelinge vonnis in het proces-verbaal van de terechtzitting dient de rechter nadrukkelijk op de bewezenverklaring en de daarbij gehanteerde bewijsmiddelen in te gaan. In zoverre biedt de aantekening in het proces-verbaal (veel) meer dan het stempelvonnis. Aan de aantekening van het mondelinge vonnis in het proces-verbaal van de zitting worden echter niet dezelfde eisen gesteld als aan het schriftelijke vonnis. De meest in het oog springende afwijking betreft die met betrekking tot de vermelding van de inhoud van de bewijsmiddelen. ${ }^{49}$ In de aantekening van het mondelinge vonnis in het procesverbaal mag worden volstaan met een verwijzing naar het proces-verbaal van de zitting of naar andere processtukken die zich in het dossier bevinden. ${ }^{50}$

Voor zover wordt verwezen naar andere processtukken en niet de hele inhoud daarvan voor het bewijs wordt gebruikt, moet worden aangegeven welk deel wel is gebruikt. ${ }^{51}$ De verwijzing moet volgens de Hoge Raad dermate nauwkeurig zijn dat duidelijk is welke delen de rechter redengevend heeft geacht voor de bewezenverklaring. Daarmee sluit de Hoge Raad aan bij het criterium dat ook ten aanzien van de nadere bewijsoverwegingen geldt: de inhoud van de bewijsmiddelen moet worden vermeld voor zover die inhoud redengevend is voor de bewezenverklaring. In de aantekening van het mondelinge vonnis hoeft in tegenstelling tot het schriftelijke vonnis weliswaar niet de exacte inhoud van de bewijsmiddelen te worden vermeld, maar de verwijzing naar het gebruikte bewijsmateriaal mag niet dermate algemeen zijn dat ook evident niet redengevende feiten en omstandigheden daar onder vallen. Dit was bijvoorbeeld het geval in de zaak waarbij een groot aantal personen werd verdacht van overtreding van een samenscholingsverbod. Ten aanzien van elk van hen was in de aantekening mondeling vonnis

49 Andere afwijkingen ten opzichte van het schriftelijke vonnis zijn dat voor de inhoud van de tenlastelegging mag worden verwezen naar de dagvaarding. Voor de bewezenverklaring mag eveneens worden verwezen naar de dagvaarding, met aanduiding van eventuele beperking of uitlegging.

50 Regeling aantekening mondeling vonnis door politierechter, kinderrechter, economische politierechter, de kantonrechter en de enkelvoudige kamer voor behandeling van strafzaken in hoger beroep d.d. 2 oktober 1996, Stcrt. 1996, nr. 197, p. 7. Kennelijk is deze ministeriële regeling nog steeds van toepassing op de alleensprekende rechter in appel ondanks het feit dat het in de regeling genoemde artikel 426d, tweede lid, Sv bij de Aanpassingswet modernisering rechtspraak $(S t b .2001,584)$ is vervallen, en de mogelijkheid om te volstaan met de aantekening mondeling vonnis sindsdien is neergelegd in artikel 425 lid 4 Sv. Overigens wordt in de praktijk van deze mogelijkheid niet altijd gebruik gemaakt. Binnen de rechtbank Maastricht wordt in geval tegen een vonnis van de politierechter appel wordt aangetekend de inhoud van de bewijsmiddelen integraal weergegeven in het proces-verbaal van de terechtzitting.

51 Regeling aantekening mondeling vonnis door politierechter, kinderrechter, economische politierechter, de kantonrechter en de enkelvoudige kamer voor behandeling van strafzaken in hoger beroep d.d. 2 oktober 1996, Stcrt. 1996, nr. 197, p. 7. 
voor de bewezenverklaring verwezen naar een negental processen-verbaal. De Hoge Raad overwoog in de zaken van drie verdachten dat de door de rechtbank in deze zaak gebezigde algemene verwijzing ontoelaatbaar was:

'Immers de inhoud van die stukken, waarin verdachte niet wordt genoemd [cursivering WD], is niet redengevend voor het bewijs dat verdachte $(\ldots)$ het tenlastegelegde feit heeft begaan... ${ }^{52}$

Een verwijzing naar een volledig proces-verbaal onder de toevoeging 'alles voor zover op eigen waarneming en ondervinding berustende en het ten laste gelegde betreffend' is onvoldoende nauwkeurig. ${ }^{53}$ De Hoge Raad is echter niet altijd zo strikt. Zo oordeelde hij dat verwijzing naar een compleet proces-verbaal niet tot cassatie hoefde te leiden, ondanks het feit dat dit proces-verbaal een grote hoeveelheid feiten bevatte die voor de bewijsconstructie volstrekt onbelangrijk waren, en bovendien daarin de verklaring van de verdachte was opgenomen dat hij de auto niet had bestuurd (hij werd onder andere verdacht van onverzekerd rijden). ${ }^{54}$ Het bewijsmateriaal waarop het oordeel van de politierechter steunde bevatte aldus materiaal dat direct in strijd was met de bewezenverklaring en ander materiaal dat anderszins niet redengevend was. Reeds eerder had de Hoge Raad geoordeeld dat verwijzing naar een proces-verbaal van opsporingsambtenaren in een aantekening mondeling vonnis niet tot cassatie hoefde te leiden, hoewel het proces-verbaal delen bevatte die voor de bewijsconstructie nutteloos waren. ${ }^{55}$ Fokkens merkte daarover in zijn conclusie bij het arrest op:

'De delen van het proces-verbaal die niet redengevend kunnen zijn voor de bewezenverklaring hebben zo evident daarop geen betrekking dat er geen twijfel over kan bestaan dat die passages niet tot het bewijs zijn gebezigd.'

De vraag welke algemene verwijzing nu wel en welke niet toelaatbaar is, is op grond van bovengenoemde uitspraken niet duidelijk te beantwoorden. In het ene geval lijkt de Hoge Raad vrij strikt te zijn, in het andere geval is hij veel coulanter. Een duidelijk criterium wordt niet gegeven. De coulantie in de laatstgenoemde uitspraken kan wellicht verklaard worden uit het feit dat in beide gevallen in cassatie niet was geklaagd over de bewijsconstructie zoals die was opgenomen in de antekening van het mondelinge vonnis. Voor de verdachte was kennelijk duidelijk op welk bewijsmateriaal zijn veroordeling was gebaseerd. De Hoge Raad lijkt in dergelijke gevallen genoegen te nemen met een algemene verwijzing. Wordt in cassatie wel geklaagd over de bewijsconstructie omdat volgens de verdediging onduidelijk is welke delen van het aangehaalde bewijsmateriaal wel of niet

52 HR 28 mei 2002, LJN AE1490. Zie voor de uitspraken tegen de andere verdachten in dezelfde kwestie HR 28 mei 2002, LJN AE1494, en HR 28 mei 2002, LJN AE1511.

53 HR 17 maart 1987, NJ 1988, 28.

54 HR 5 maart 2002, LJN AD8883.

55 HR 19 juni 2001, NJ 2001, 482. 
redengevend zijn geweest voor de bewezenverklaring, dan kan dat aanleiding zijn om het vonnis te vernietigen.

Overigens wordt dit criterium niet gehanteerd in die gevallen waarin in appel wordt geklaagd over de gebrekkige aanduiding van het gebezigde bewijsmateriaal. Zelfs het volledig ontbreken van een proces-verbaal van de zitting met daarin opgenomen de aantekening van het mondeling vonnis, staat niet aan de behandeling in hoger beroep in de weg, ook niet indien de verdachte daartegen bezwaar heeft gemaakt. ${ }^{56}$

De waarborg die de Hoge Raad afleidde uit artikel 359 lid 1 Sv 1926 (thans lid 3), namelijk dat de verdachte op eenvoudige wijze moet kunnen kennisnemen van het tegen hem gebezigde bewijsmateriaal lijkt bij unusrechtspraak van minder belang. Of dat bewijsmateriaal bij het uitspreken van het mondelinge vonnis nadrukkelijk wordt genoemd, is aan de rechter zelf overgelaten. In de summiere aantekening van het mondelinge vonnis komt het geheel niet aan de orde. En voor zover het nodig is om het mondelinge vonnis in het proces-verbaal van de zitting aan te tekenen, kan de rechter volstaan met een verwijzing naar de processtukken. In dat laatste geval wordt kennelijk van de verdachte verwacht dat hij zelf het bewuste proces-verbaal achterhaalt en dat hij daaruit dan ook zelf maar moet afleiden welke delen wel en welke niet relevant zijn geweest voor de bewezenverklaring. Het is op zijn minst opmerkelijk te noemen dat waar het de kenbaarheid van de aan de bewezenverklaring ten grondslag liggende feiten betreft meer eisen worden gesteld aan de meervoudige kamers dan aan de enkelvoudige kamers. Men zou eigenlijk verwachten dat daar waar de rechtspraak is opgedragen aan een enkele persoon, deze eerder meer dan minder verantwoording over zijn oordeel zou moeten afleggen. Dat de alleensprekende rechter alleen eenvoudige zaken behandelt, is misschien een argument dat oorspronkelijk aan de invoering van mondelinge vonnissen van de kantonrechter ten grondslag heeft gelegen. ${ }^{57}$ Thans kan echter betwijfeld worden of dat argument nog opgaat. De bevoegdheid van de politierechter is zodanig uitgebreid dat daar ook ernstige feiten onder vallen, die niet altijd - ook qua bewijsaspecten - eenvoudig van aard te noemen zijn. ${ }^{58}$ De toegenomen werkdruk maakt bovendien dat politierechters niet gauw naar een meervoudige kamer zullen verwijzen.

56 HR 27 januari 1987, NJ 1987, 886 m.nt. ThWvV.

57 Kamerstukken II 1913-1914, 286, nr. 3 (MvT). p. 194: 'In de eenvoudige gevallen waarin het geven van een mondeling vonnis aangewezen is, zal eensdeels de beslissing zoo van zelf uit het ter terechtzitting verhandelde voortvloeien, en anderdeels de rechter zoo van zelf er toe gebracht worden om mondeling menige opmerking te maken waaruit zijne opvatting over onderscheden punten blijkt, dat een nadere ontleding daarvan in het genotuleerde vonnis zonder eenig bezwaar gemist kan worden.'

58 De in art. $369 \mathrm{~Sv}$ genoemde grens van zes maanden is verlegd tot 1 jaar bij Wet van 4 juli 2002 (verruiming bevoegdheid enkelvoudige kamers) Stb. 2002, 355; inwerkingtreding 12 juli 2002. Kritisch hierover: Mevis 2002. 
De uitbreiding van de unus-rechtspraak tot de fase van het appel is in dat opzicht ook opmerkelijk. Immers, daarmee ontstaat de mogelijkheid dat de verdachte in beide feitelijke instanties geen volledig vonnis krijgt, en dus geen inzicht krijgt in de exacte bewijsconstructie. Zowel in eerste aanleg als in appel kan immers in het vonnis worden volstaan met de verwijzing naar de bewijsmiddelen. Slechts door te verzoeken om een schriftelijk vonnis ex artikel $365 \mathrm{c} \mathrm{Sv}$, dan wel door het instellen van cassatie kan de verdachte bewerkstelligen dat hij de precieze inhoud van de ten laste van hem gebruikte bewijsmiddelen krijgt te zien. In hoeverre dit mogelijk strijd oplevert met artikel 6 EVRM zal aan de orde komen in de volgende paragraaf waarin het verkorte vonnis centraal staat en ten aanzien waarvan zich hetzelfde probleem voordoet.

\subsubsection{Het verkorte vonnis}

In tegenstelling tot de enkelvoudige kamers van de rechtbanken en hoven hebben de meervoudige kamers niet de mogelijkheid om te volstaan met een mondeling vonnis. Binnen veertien dagen na de sluiting van het onderzoek ter terechtzitting dienen zij uitspraak te doen en deze uitspraak moet tevens worden vervat in een schriftelijk vonnis. Dit laatste is nergens expliciet in het Wetboek van Strafvordering opgenomen, maar is kennelijk wel de bedoeling van de wetgever geweest. Dit kan - a contrario - uit de specifieke regeling van het mondelinge vonnis voor alleensprekende rechters worden afgeleid.

Het schriftelijke vonnis moet in principe voldoen aan alle eisen die daaraan worden gesteld in de titel 'Beraadslaging en uitspraak'. Dit betekent onder andere dat in het vonnis de inhoud van de bewijsmiddelen moet worden vermeld. Echter in het merendeel van de gevallen zal de verdachte na zijn veroordeling geen vonnis ontvangen waarin het tegen hem gebruikte bewijsmateriaal is opgenomen. Op grond van artikel $365 \mathrm{a} \mathrm{Sv}^{59}$ kan de rechtbank volstaan met een zogeheten verkort vonnis. In het verkorte vonnis ontbreken de bewijsmiddelen. ${ }^{60}$ Pas indien tegen het vonnis een gewoon rechtsmiddel is angewend, moet het worden aangevuld met de bewijsmiddelen. De mogelijkheid om een verkort vonnis te wijzen is gecreëerd bij de wet van 26 september $1996 .{ }^{61}$ Maar al lang daarvoor had het verkorte vonnis zijn intrede gedaan in de strafvorderlijke praktijk.

59 Artikel $365 \mathrm{a} \mathrm{Sv}$ is van overeenkomstige toepassing op het rechtsgeding in hoger beroep met dien verstande dat in afwijking van het tweede lid van artikel 365a aanvulling ook plaats vindt indien het cassatieberoep meer dan drie maanden na de dag van de uitspraak is ingesteld. Zie artikel $415 \mathrm{~Sv}$.

60 Artikel 138b Sv.

61 De Wet van 26 september 1996 tot wijziging van de bepalingen uit het Wetboek van Strafvordering betreffende het proces-verbaal van de terechtzitting en het vonnis (Stb. 


\subsubsection{De kop-staartpraktijk}

De noodzaak om binnen veertien dagen een schriftelijk vonnis te wijzen leidde reeds vanaf de jaren ' 50 tot onoverkomelijke problemen. Veel rechtbanken en hoven slaagden er niet in om binnen deze termijn een volledig - met bewijsmiddelen uitgewerkt - vonnis te redigeren. In de praktijk volstond men dan ook vaak met een onvolledig vonnis. Hoewel de wijze waarop een dergelijk onvolledig vonnis werd vormgegeven verschilde per arrondissement, hadden deze vonnissen één ding gemeen: de inhoud van de bewijsmiddelen ontbrak. ${ }^{62}$ In sommige gevallen bevatte het vonnis slechts een kop (de begingegevens) en een staart (de rechterlijke beslissingen in de zaak). ${ }^{63}$ Hieraan dankten zij dan ook hun naam: kop-staartvonnissen.

In het algemeen werden de kop-staartvonnissen aangevuld op het moment dat door het Openbaar Ministerie of de verdachte een rechtsmiddel was ingesteld. Echter ook op dit punt ontstonden tussen de gerechten grote verschillen. In bepaalde gevallen werd zelfs het kop-staartvonnis in het geheel niet aangevuld. De zegswijze 'van uitstel komt afstel' was meer dan eens van toepassing. Dit had als consequentie dat tegen de tijd dat de behandeling van het hoger beroep of het cassatieberoep diende geen volledig uitgewerkt vonnis beschikbaar was.

De Hoge Raad accepteerde de kop-staartpraktijk van rechtbanken. Het starten van de behandeling in hoger beroep zonder dat een uitgewerkt vonnis in eerste aanleg beschikbaar was, hoefde niet tot cassatie te leiden. ${ }^{64}$ Op grond van het tweede lid van artikel $423 \mathrm{~Sv}$ hoeft het hof immers alleen de zaak terug te verwijzen naar de rechtbank indien de rechtbank niet aan de beoordeling van de hoofdzaak was toegekomen, dan wel daaraan niet had mogen toekomen. ${ }^{65}$ Indien de rechtbank een vonnis aflevert zonder vermelding van de inhoud van de bewijsmiddelen, wil dat niet zeggen dat er geen behandeling van de hoofdzaak heeft plaatsgevonden. Er is wat dat betreft - in de woorden van Fokkens - geen verschil tussen een gebrekkig gemotiveerde bewezenverklaring en een niet-gemotiveerde bewezenverklaring. ${ }^{66}$

Was de Hoge Raad coulant met betrekking tot kop-staartvonnissen gewezen in eerste aanleg, niet volledig uitgewerkte arresten van hoven werden niet getolereerd. Ten aanzien van een door het Hof Arnhem gewezen arrest waarin slechts naar de inhoud van de bewijsmiddelen werd verwezen, oordeelde de Hoge Raad:

1996, 487); inwerkingtreding 1 november 1996 (Stb. 1996, 521).

62 Een uitgebreide inventarisatie van de kop-staartpraktijk is te vinden bij: Mevis 1992.

63 P.A.M. Mevis, aant. 5 op art. 365a Sv (suppl. 123, augustus 2001), in: Melai/Groenhuijsen e.a.

64 HR 17 september 1990, NJ 1991, 12.

65 Art. $423 \mathrm{~Sv}$ is met ingang van 1 maart 2007 gewijzigd bij de Wet van 5 oktober 2006 (stroomlijnen hoger beroep), Stb. 2006, 470 (inwerkingtreding 1 maart/1 juli 2007, Stb. 2007, 70).

66 Advocaat-generaal Fokkens in zijn conclusie bij HR 17 september 1990, NJ 1991, 12. 
'dat het hof, (...) op grond van het eerste lid [thans het derde lid: WD] van art. 359 Sv, in hoger beroep van toepassing krachtens art. $415 \mathrm{~Sv}$, gehouden [is: WD] om in zijn arrest de inhoud van de bewijsmiddelen weer te geven, waarop de bewezenverklaring steunt; de in eerstgenoemde bepaling gelegen waarborg, dat de veroordeelde op eenvoudige wijze kennis kan nemen van de inhoud van de te zijnen laste gebezigde bewijsmiddelen, is door de wetgever van zodanig gewicht geacht dat hij de nietinachtneming daarvan in het laatste lid van art. 359 Sv met nietigheid heeft bedreigd. ${ }^{67}$

Van Veen concludeerde dat deze uitspraak van de Hoge Raad het einde van de kop-staartpraktijk betekende. Teneinde de daarmee toenemende werklast van rechtbanken en hoven te compenseren, zag hij twee mogelijkheden. De eerste is een aanzienlijke uitbreiding van de rechterlijke macht en het personeel van de griffies. De tweede is wijziging van de wet, door voor alle rechterlijke colleges het wijzen van mondelinge vonnissen toe te staan. Maar:

'Wat niet zou moeten kunnen is dat de hoven en rechtbanken dit arrest naast zich neerleggen en dat de Minister van Justitie in die situatie berust. ${ }^{68}$

\subsubsection{De eerste poging tot codificatie van de kop-staartpraktijk}

De Minister van Justitie berustte inderdaad niet: op 14 april 1986 werd een wetsvoorstel tot wijziging van het Wetboek van Strafvordering bij de Tweede Kamer ingediend. ${ }^{69}$ In dit voorstel wordt de suggestie van Van Veen niet gevolgd. In plaats van meer rechterlijke colleges de mogelijkheid te geven om enkel mondeling vonnis te wijzen, wordt gekozen voor een andere oplossing: in het geval de verdachte de bewezenverklaring niet weerspreekt mag in het vonnis de inhoud van de bewijsmiddelen ontbreken. In het wetsvoorstel wordt aan artikel 359, eerste lid, Sv een nieuwe zin toegevoegd, luidende:

'Vermelding van de inhoud van de bewijsmiddelen kan echter achterwege blijven, indien de verdachte ter terechtzitting, dan wel indien hij niet op de terechtzitting verschenen is tijdens het vooronderzoek, niet heeft weersproken dat het bewezenverklaarde feit door hem is begaan en evenmin heeft weersproken dat het feit of hijzelf strafbaar is.'

In geval van een 'niet-weersprekende' verdachte zou op grond van het wetsvoorstel kunnen worden volstaan met de opsomming van de gebezigde bewijsmiddelen. ${ }^{70}$

67 HR 14 mei 1985, NJ 1986, 9 m.nt. ThWvV.

68 Van Veen in zijn annotatie bij HR 14 mei 1985, NJ 1986, 9.

69 Kamerstukken II 1985-1986, 19488, nrs. 1-3.

70 De eerste zin van artikel 359 Sv zou volgens het wetsvoorstel luiden: 'Het vonnis bevat het ten laste gelegde alsmede de gebezigde bewijsmiddelen en de inhoud van deze bewijsmiddelen voor zover deze tot het bewijs van het ten laste gelegde gelden.' Nog los van de taalkundige onjuistheden (zie daarover nader Van Veen 1986, p. 993) wordt in deze redactie van het eerste lid uitgegaan van een onderscheid tussen de gebezigde bewijsmiddelen en de inhoud van de bewijsmiddelen. Dit onderscheid is alleen te begrijpen indien bedoeld is een opsomming van de gebezigde bewijsmiddelen. 
Dit voorstel kon echter op weinig bijval rekenen, onder andere omdat onduidelijk was wat de minister bedoelde met 'een verdachte die niet heeft weersproken dat het bewezenverklaarde feit door hem is begaan'. ${ }^{71}$ Allereerst bevat de voorgestelde tekst een inconsequentie. De verdachte kan hooguit het tenlastegelegde feit weerspreken, maar niet het bewezenverklaarde feit. Bovendien is onduidelijk in hoeverre de zwijgende verdachte kan worden aangemerkt als een niet-weersprekende verdachte. Als het zwijgen gelijk wordt gesteld met het niet-weerspreken, betekent dat een uitholling van het zwijgrecht van de verdachte. ${ }^{72}$ Eenzelfde probleem doet zich voor met betrekking tot de verdachte die gedurende het vooronderzoek gebruik heeft gemaakt van zijn zwijgrecht en die tijdens het onderzoek ter terechtzitting verstek laat gaan. De bij verstek veroordeelde verdachte kan noch een bewezenverklaring noch een tenlastelegging weerspreken. Immers, in het vooronderzoek heeft hij vaak geen weet van de feiten die hem uiteindelijk ten laste worden gelegd. ${ }^{73}$ Borst wijst bovendien op de consequenties van het voorstel voor het negatief-wettelijk bewijsstelsel:

'Het negatief-wettelijk bewijsstelsel van de art. 338-344 wordt (behoudens bij ontkennende verdachten) vrijwel gedegradeerd tot een vrijblijvend advies of een beleefd verzoek aan de rechter. (...) heel het wettelijk bewijsstelsel berust op de vooronderstelling dat de rechter de bewijsvoering schriftelijk moet verantwoorden - en van die verplichting wordt hij nu juist ontslagen. ${ }^{, 74}$

Werd aan de ene kant beweerd dat het voorstel van de minister veel te ver gaat, aan de andere kant werden er bezwaren geuit die erop neerkomen dat het voorstel in onvoldoende mate tegemoet kwam aan de capaciteitsproblemen binnen de rechterlijke macht. Het voorstel hield immers in dat in zaken waarin de verdachte het tenlastegelegde wel had weersproken, binnen veertien dagen een volledig schriftelijk vonnis gereed moest zijn. In de gevallen waarin geen rechtsmiddel tegen het vonnis wordt ingesteld, werd dit als werken voor het archief beschouwd. Bovendien leidde het wetsvoorstel alleen maar tot een taakverzwaring ten opzichte van de bestaande praktijk. ${ }^{75}$ Immers, de bestaande praktijk was dat enkel in die gevallen waarin een rechtsmiddel werd ingesteld een vonnis volledig moest worden uitgewerkt. Van een daadwerkelijke legalisering van de kop-staartpraktijk was dus geen sprake. ${ }^{76}$

71 In gelijke zin: de Raad van State in zijn advies d.d. 29 januari 1986, Kamerstukken II 1985-1986, 19488, nr. A

72 Van Veen 1986, p. 994.

73 Van Veen 1986, p. 994.

74 Borst 1987, p. 666.

75 Corstens 1993, p. 106.

76 Van Almelo, Cohen en Wiewel 1992, p. 508. 
De kritiek op het voorstel was voor de Minister van Justitie reden om de commissie-Moons ${ }^{77}$ te vragen het wetsvoorstel 19488 te beoordelen. Het advies van deze commissie was negatief. Daarop werd op 19 oktober 1993 wetsvoorstel 19488 ingetrokken. ${ }^{78}$ Korte tijd later - op 16 november van datzelfde jaar - werd een nieuw voorstel tot wijziging van de bepalingen uit het Wetboek van Strafvordering betreffende het proces-verbaal van de terechtzitting en het vonnis bij de Tweede Kamer ingediend. ${ }^{79}$ Dit voorstel was gebaseerd op het door de Commissie-Moons geformuleerde concept-wetsvoorstel en werd na enige inhoudelijke wijzigingen en toevoegingen goedgekeurd. De wet trad in werking op 1 november 1996 en daarmee was de kop-staartpraktijk uiteindelijk van een wettelijke grondslag voorzien. ${ }^{80}$ Alleen spreekt de wet niet langer van een kop-staartvonnis, maar van een zogeheten verkort vonnis.

\subsubsection{De huidige regeling}

In de huidige regeling is een definitie van het verkorte vonnis neergelegd in artikel $138 \mathrm{~b}$ Sv. Het verkorte vonnis is een gewoon schriftelijk vonnis waarin slechts de inhoud van de bewijsmiddelen, dan wel in geval van een bekennende verdachte de opgave van de bewijsmiddelen mag ontbreken. ${ }^{81}$ Bij de wet van 26 september 1996 is niet alleen geregeld dat het vonnis mag worden verkort, maar ook het proces-verbaal van de terechtzitting hoeft niet volledig uitgewerkt te worden. In artikel 327a Sv is namelijk bepaald dat tevens een verkort proces-verbaal wordt opgemaakt indien een verkort vonnis wordt gewezen. Het verkort proces-verbaal bevat ingevolge artikel 138c Sv enkel de beslissingen van de rechter waarvan de

77 De officiële benaming van deze commissie is: de Commissie herijking Wetboek van Strafvordering.

78 Kamerstukken II 1993-1994, 19488, nr. 9.

79 Kamerstukken II 1994-1995, 23989, nrs. 1-3.

80 Wet van 26 september 1996, Stb. 1996, 487 (inwerkingtreding 1 november 1996, Stb. 1996, 521).

81 Art. 138b Sv is gewijzigd bij de Wet van 10 november 2004 (aanpassing eisen motivering bewezenverklaring bekennende verdachte), Stb. 2004, 580 (inwerkingtreding 1 januari 2005 Stb. 2004, 641). Deze wijziging vloeide voort uit de aangepaste tekst van art. 359 lid $3 \mathrm{~Sv}$. Op grond van deze gewijzigde bepaling hoeven de redengevende feiten en omstandigheden niet langer expliciet te worden aangewezen. Voor 1 januari 2005 was dit wel vereist voor het volledige, maar ingevolge het oude art. 138b Sv niet voor het verkorte vonnis. Voldoende is thans dat in het schriftelijke vonnis de inhoud van de bewijsmiddelen wordt vermeld 'inhoudende de redengevende feiten en omstandigheden'. Als gevolg van deze wijziging is dus ook het expliciet vrijstellen van de rechter tot het aanwijzen van de redengevende feiten en omstandigheden in het verkort vonnis overbodig geworden. Bovendien werd bij diezelfde wetswijziging in het derde lid van art. $359 \mathrm{~Sv}$ de mogelijkheid gecreëerd om in geval van een bekennende verdachte te volstaan met een opgave van de bewijsmiddelen. Het vermelden van de inhoud van het gebezigde bewijsmateriaal is dan niet meer nodig. 
wet eist dat ze worden vastgelegd en die niet reeds in het verkorte vonnis zijn opgenomen. Moet het verkorte vonnis worden aangevuld, dan moet ook het procesverbaal zodanig worden gecompleteerd dat het aan alle wettelijke eisen voldoet. ${ }^{82}$

In artikel $365 \mathrm{a} \mathrm{Sv}$ is bepaald dat met een verkort vonnis kan worden volstaan zolang er geen gewoon rechtsmiddel tegen is aangewend. Aanvulling is alleen niet nodig indien hoger beroep wordt ingesteld nadat drie maanden zijn verstreken sinds de uitspraak (art. 365a, tweede lid, Sv). Volgens de Commissie-Moons, wier voorstel op dit punt is gevolgd, wordt naarmate er meer tijd verstrijkt sinds de uitspraak, het steeds lastiger om het proces-verbaal en vonnis uit te werken. De zaak ligt niet meer zo in het geheugen en de kans dat de griffier en rechters die op de zaak hebben gezeten nog in eenzelfde positie werkzaam zijn neemt af. ${ }^{83}$ Met de inwerkingtreding van het wetsvoorstel 'stroomlijning hoger beroep' zal ook van aanvulling van het verkorte vonnis kunnen worden afgezien, indien een vonnis in de zin van het toekomstige artikel 410a, eerste lid, Sv is gewezen. Van een dergelijk vonnis is sprake indien de verdachte is veroordeeld terzake van één of meer misdrijven of overtredingen waarop naar wettelijke omschrijving niet meer dan vier jaar gevangenisstraf is gesteld en waar de rechter heeft volstaan met het opleggen van een geldboete die het bedrag van 500 Euro niet overschrijdt. ${ }^{84}$ Ten aanzien van deze feiten is een verlofstelsel gecreëerd. Ook indien het verlof tot hoger beroep wordt verleend, is de rechter in eerste aanleg niet verplicht tot aanvulling van het vonnis en het proces-verbaal van de zitting. In dergelijke gevallen is geen noodzaak tot 'voortbouwen'. 85

Is een verkort vonnis gewezen, dan kunnen de verdediging en het Openbaar Ministerie om aanvulling verzoeken, respectievelijk deze vorderen. Artikel 365c Sv maakt het mogelijk om ook in het bezit van een volledig uitgewerkt vonnis te komen zonder een rechtsmiddel in te stellen. Het volledige vonnis zou van nut kunnen zijn voor een civielrechtelijke procedure die verband houdt met het strafbare feit of voor een verzoek tot gratie of herziening. ${ }^{86}$ Weliswaar kan de aanvulling ook worden afgedwongen door een rechtsmiddel in te stellen, maar hieraan zijn twee nadelen verbonden. Enerzijds zou dan het instellen van een rechtsmiddel worden gebruikt voor een ander doel dan waarvoor het is gegeven. Anderzijds loopt de procespartij die het rechtsmiddel instelt het risico dat de andere partij meeappelleert, en dat daarmee het intrekken van het rechtsmiddel zinloos wordt. Voor de verdediging geldt bovendien in geval van mee-appelleren van het Openbaar Ministerie het bezwaar dat artikel 424 lid $2 \mathrm{~Sv}^{87}$ dan niet langer van toepassing

82 Zie artikel 327a, derde lid, Sv.

83 Corstens 1993, p. 112.

84 Het bij de Wet van 5 oktober 2006 (stroomlijnen hoger beroep), Stb. 2006, 470 (inwerkingtreding 1 maart/1 juli 2007, Stb. 2007, 70). gewijzigde art. 365a Sv.

85 Van Woensel 2007, p. 13.

86 P.A.M. Mevis, aant. 5 op art. 365c (suppl. 123, augustus 2001), in: Melai/Groenhuijsen e.a.

87 Art 424 lid 2 Sv zoals dat tot 1 maart 2007 geldt, luidt: 'Indien alleen de verdachte in 
is en dat zij het risico loopt dat de straf hoger uit zal vallen dan in eerste aanleg. Per 1 maart 2007 is echter artikel 424 Sv vervallen en bestaat dus het risico van een hogere straf in appel ongeacht wie het hoger beroep heeft ingesteld. ${ }^{88}$ Voor het verzoek dan wel de vordering tot aanvulling van het verkorte vonnis geldt een termijn van 3 maanden, die aanvangt vanaf het moment van de uitspraak. Dit betekent voor degene die eerst na drie maanden appel instelt en dus op grond van artikel 365a, tweede lid, Sv geen aanvulling meer krijgt, dat zijn verzoek tot aanvulling op grond van artikel $365 \mathrm{c} \mathrm{Sv}$ eveneens kan worden geweigerd. Is wel binnen drie maanden na de uitspraak om aanvulling van het vonnis verzocht, dan zal dit verzoek moeten worden gehonoreerd. ${ }^{89}$ Dit ligt anders indien de benadeelde partij een verzoek tot aanvulling van het vonnis doet. Een verzoek van die zijde kan worden afgewezen indien daarmee geen redelijk belang is gediend. Dit zal bijvoorbeeld het geval zijn indien in het verkorte vonnis eventueel in samenhang met het verkorte proces-verbaal alle voor de benadeelde partij relevante gegevens zijn opgenomen. ${ }^{90}$

\subsubsection{Inhoud van het verkorte vonnis}

Zoals gezegd, definieert artikel $138 \mathrm{~b}$ Sv het verkorte vonnis als een vonnis waarin de bewijsmiddelen bedoeld in artikel 359, derde lid, niet zijn opgenomen. Het weergeven van de (redengevende) inhoud van de bewijsmiddelen die aan de bewezenverklaring ten grondslag liggen, kan dus achterwege blijven. In geval van een bekennende verdachte hoeft het verkorte vonnis evenmin een verwijzing naar of opgave van die bewijsmiddelen te bevatten. Dat betekent dat de feitelijke grondslag voor de bewezenverklaring in het verkorte vonnis volledig ontbreekt. In de praktijk is het verkorte vonnis een normaal schriftelijk vonnis, maar daar waar de inhoud van de bewijsmiddelen wordt vermeld, verschijnen in het verkorte vonnis de letters 'PM' (pro memorie).

Artikel 138b Sv stelt de strafrechter alleen vrij van de verplichting om de inhoud van de bewijsmiddelen in het vonnis op te nemen. Dit betekent dat hij de overige bepalingen met betrekking tot de bewijsmotivering wel in acht moet nemen. In het verkorte vonnis zou dus wel expliciet op standpunten van partijen moeten worden ingegaan, voor zover de rechter die niet overneemt (art. 359 lid $2 \mathrm{~Sv}$ ). Evenzeer

hooger beroep is gekomen, kan hij ter zake van hetgeen in eersten aanleg te zijnen laste bewezen is verklaard, slechts met eenparigheid van stemmen tot een zwaardere straf worden veroordeeld, dan hem bij het vonnis is opgelegd.'

88 Art. 424 Sv vervalt bij Wet van 5 oktober 2006 (stroomlijnen hoger beroep), Stb. 2006, 470 (inwerkingtreding vanaf 1 maart/1 juli 2007, Stb. 2007, 70).

89 Kamerstukken II 1994-1995, 23989, nr. 3, p. 8.

90 Kamerstukken II 1994-1995, 23989, nr. 6, p. 5. 
zou de bijzondere motiveringsplichten opgenomen in artikel 360 lid 1 en $2 \mathrm{~Sv}$ in het verkorte vonnis tot uitdrukking moeten komen. ${ }^{91}$

\subsection{Weerlegging van bewijsverweren in het verkorte vonnis}

Tot 1 januari 2005 gold op basis van de jurisprudentie van de Hoge Raad dat de strafrechter in zijn vonnis expliciet op bepaalde verweren van de verdediging moest ingaan. Dit laatste overigens alleen indien hij die verweren verwierp. Vanaf 1 januari 2005 is de Wet tot aanpassing van de eisen te stellen aan de motivering van de bewezenverklaring bij een bekennende verdachte in werking getreden. ${ }^{92}$ In tegenstelling tot wat de titel doet vermoeden heeft deze wet ook gevolgen voor de motivering van de bewezenverklaring in zaken waarin de verdachte niet heeft bekend. Bij amendement is de responsieplicht van de strafrechter op verweren vergaand uitgebreid. Op grond van het gewijzigde lid 2 van artikel $359 \mathrm{~Sv}$ dient de rechter uitdrukkelijk ingenomen en onderbouwde standpunten van het Openbaar Ministerie en de verdediging, voor zover hij ze niet tot de zijne maakt, gemotiveerd in zijn vonnis te weerleggen. Op de achtergrond en reikwijdte van deze bepaling wordt in paragraaf 6.3.4 nader ingegaan. De wijziging heeft echter ook gevolgen voor de inhoud van het verkorte vonnis.

Tot 1 januari 2005 moest voor de beantwoording van de vraag of al in het verkorte vonnis de verwerping van bewijsverweren dient te geschieden, onderscheid worden gemaakt tussen die verweren waarvan de Hoge Raad eist dat de verwerping gemotiveerd geschiedt en die verweren waarvoor een dergelijke eis niet geldt. Ten aanzien van de laatste categorie, en die omvatte het grootste deel van de bewijsverweren, gold simpelweg dat de feitenrechter niet verplicht was op deze verweren te reageren. Waar een dergelijke motiveringsplicht ontbrak ten aanzien van het schriftelijke vonnis, gold zij evenmin ten aanzien van het verkorte vonnis. Dit liet overigens onverlet dat de feitenrechter wel degelijk in zijn verkort vonnis op deze verweren mocht ingaan. In de praktijk gebeurde dat echter zelden.

Anders lag het bij bewijsverweren waarvan de Hoge Raad stelde dat zij wel gemotiveerd moesten worden weerlegd, indien zij door de feitenrechter werden verworpen. Het betrof dan de zogeheten Meer en Vaartverweren, dakdekkersverweren, onrechtmatig verkregen bewijsverweren en bepaalde betrouwbaarheids-

91 Ten aanzien van de overige verweren, niet zijnde bewijsverweren, geldt dat zij reeds conform artikel 358 lid 3 in samenhang met artikel 359 lid $2 \mathrm{~Sv}$ in het verkorte vonnis moeten worden weerlegd. Zie bijvoorbeeld HR 13 juni 2000, NJ 2000, 523 en HR 9 november 1999, NJ 2000, 71.

92 Wet van 10 november 2004 (aanpassing eisen motivering bewezenverklaring bekennende verdachte), Stb. 2004, 580 (inwerkingtreding 1 januari 2005, Stb. 2004, 641). 
verweren. ${ }^{93}$ Door Brouns is beweerd dat de grondslag voor deze motiveringsplicht in artikel 359 lid $2 \mathrm{~Sv}$ was gelegen. ${ }^{94}$ Op grond van deze bepaling - in samenhang met artikel 358 lid $2 \mathrm{~Sv}$ - diende het bewijsoordeel met redenen te zijn omkleed. Dit zou betekenen dat weerlegging van deze verweren steeds in het verkorte vonnis diende te geschieden, aangezien de feitenrechter ten aanzien van het verkorte vonnis niet was vrijgesteld van het bepaalde in het tweede lid van artikel $359 \mathrm{~Sv}$. De Hoge Raad oordeelde echter anders:

'Ook ten aanzien van die verweren, verdient het de voorkeur dat een beslissing daaromtrent reeds in het verkorte vonnis of arrest is opgenomen. Anderzijds houden bewijsverweren veelal zozeer verband met de bewijsvoering in engere zin, dat redelijke uitleg van het voorschrift dat het verkorte vonnis of arrest wordt aangevuld met bewijsmiddelen als bedoeld in art. 359, eerste lid [thans het derde lid: WD], en de redengevende feiten als bedoeld in art. 359, derde lid, Sv meebrengt dat nadere overwegingen omtrent het bewijs, zoals de onderhavige verwerping van een verweer met betrekking tot de rechtmatigheid van de bewijsgaring, ook voor het eerst kunnen worden opgenomen in de aanvulling op het verkorte vonnis of arrest. ${ }^{95}$

De Hoge Raad ging in dit arrest uitdrukkelijk in op het belang van een gemotiveerd vonnis. Dit kon echter niet verhelen dat hij uiteindelijk dit belang opofferde aan de proceseconomie. Eigenlijk oordeelde de Hoge Raad immers dat het voor de verdachte en diens raadsman weliswaar wenselijk is dat zij direct antwoord krijgen op hun verweer, maar dat dit antwoord in vele gevallen slechts kan worden gegeven indien de inhoud van de bewijsmiddelen in het vonnis wordt opgenomen. ${ }^{96} \mathrm{Als}$ de feitenrechter ervoor kiest om te volstaan met een verkort vonnis, dan moet de verdediging - wil zij de redenen weten waarom haar verweer niet is geaccepteerd wachten tot het moment waarop het verkorte vonnis wordt aangevuld met de bewijsmiddelen. De Hoge Raad repte met geen woord over de wettelijke grondslag van de motiveringsplicht. Zonder onderscheid te maken naar het soort verweer meende hij dat de rechter pas in de aanvulling van het verkorte vonnis op bewijsverweren hoeft te responderen. ${ }^{97}$ Kennelijk leidde de Hoge Raad deze responsieplicht dus niet af uit het tweede lid van artikel $359 \mathrm{~Sv}$.

93 Daarover meer in hoofdstuk 6.

94 Brouns 2001, p. 196.

95 HR 18 april 2000, NJ 2001, 352 m.nt. Kn. In gelijke zin: HR 5 juni 2001, NJ 2001, 500.

96 Mevis spreekt met betrekking tot de door de Hoge Raad wenselijk geachte responsie in het verkort vonnis in zijn annotatie onder HR 24 mei 2005, NJ 2006, 433 van 'een aandoenlijke naïviteit'. Die opmerking is terecht; er zijn weinig rechtbanken en hoven die zonder noodzaak een volledig vonnis zullen wijzen. Sterker nog: zelfs de grenzen van de huidige regeling worden opgezocht, zoals blijkt uit het arrest waarop de annotatie van Mevis betrekking heeft

97 Anders: P.A.M. Mevis, aant. 8 op art. 138b Sv (suppl. 123, augustus 2001), in: Melai/ Groenhuijsen e.a. Hij meent dat enkel reacties op Meer en Vaart- en betrouwbaarheidsverweren in het verkort vonnis kunnen ontbreken. 
Vanaf 1 januari 2005 is de responsieplicht echter uitdrukkelijk opgenomen in artikel $359 \mathrm{~Sv}$, en wel in het tweede lid. Zij is bovendien aanmerkelijk uitgebreid. Uit de tekst van het tweede lid volgt dat zij betrekking heeft op alle verweren, en bovendien geldt zij ook indien verweren van de zijde van de verdediging door de rechter worden overgenomen, maar het Openbaar Ministerie zich daar op zijn beurt uitdrukkelijk tegen heeft verzet. Artikel 138b Sv stelt de strafrechter alleen vrij van de verplichting om de inhoud van de bewijsmiddelen in het vonnis op te nemen. Dit betekent dat hij de overige bepalingen met betrekking tot de bewijsmotivering waaronder het bepaalde in artikel 359 lid $2 \mathrm{~Sv}$ wel in acht moet nemen. De vraag is of deze wetswijziging inderdaad betekent dat de Hoge Raad afstand neemt van zijn uitspraak van 18 april 2001. Helaas: in zijn standaardarrest aangaande de betekenis en de reikwijdte van het nieuwe lid 2 van artikel $359 \mathrm{~Sv}$ was de Hoge Raad zeer duidelijk op dit punt:

'Bij het voorgaande past de kanttekening dat in het geval dat wordt volstaan met een verkorte uitspraak in de zin van art. 365a, eerste lid, Sv, de vereiste nadere motivering daarin behoort te worden opgenomen. Dit is evenwel anders indien het 'uitdrukkelijk onderbouwde standpunt' betrekking heeft op de bewijsbeslissing, waaronder mede begrepen de bewijsvoering. De weerlegging daarvan mag worden opgenomen in de aanvulling als bedoeld in art. 365a, tweede lid, Sv (vgl. HR 18 april 2000, NJ 2001, 352). ${ }^{98}$

De Hoge Raad houdt derhalve vast aan zijn oude jurisprudentie, terwijl dit toch in strijd is met de bewoordingen van artikel $138 \mathrm{~b}$ Sv. Daarenboven lijkt deze uitspraak in strijd met de bedoeling van de wetswijziging van 1 januari 2005: motivering op maat. Daar waar partijen geen behoefte hebben aan nadere uitleg kan die achterwege blijven en daar waar partijen dat wel hebben wordt het vonnis nader geëxpliciteerd. In geval van een uitdrukkelijk ingenomen en goed onderbouwd standpunt lijkt mij dat partijen wel degelijk belang hebben bij een nadere uitleg van de rechter waarom hij dat standpunt niet volgt. Een uitleg die niet pas na het instellen van een rechtsmiddel moet worden gegeven, omdat het dan vaak als 'mosterd na de maaltijd' wordt ervaren en hooguit de hogere rechter tijdig inzicht biedt.

Bovendien doet zich de vraag voor of het niet in het verkorte vonnis uitdrukkelijk reageren op standpunten van de verdediging - zeker gezien het wetsvoorstel 'stroomlijning hoger beroep' - niet tot strijd met artikel 6 EVRM leidt. Daarop zal hierna nog nader worden ingegaan. ${ }^{99}$

98 HR 11 april 2006, NJ 2006, 393 m.nt. Y. Buruma (overweging 3.8.3).

99 Paragraaf 4.4.2.11. 


\subsubsection{Aanvulling van het verkorte vonnis}

Kan in eerste instantie worden volstaan met een verkort vonnis, op het moment dat door een van de procespartijen een gewoon rechtsmiddel ${ }^{100}$ wordt ingesteld, moet het verkorte vonnis worden aangevuld met de inhoud van de bewijsmiddelen. Tevens zal in de aanvulling - indien dat niet al in het verkorte vonnis is gedaan - op bewijsverweren moeten worden gerespondeerd. Aanvulling van het verkorte vonnis gewezen door de rechtbank is niet nodig indien het rechtsmiddel meer dan drie maanden na de uitspraak is aangewend. ${ }^{101}$ Is een verkort arrest gewezen door het gerechtshof, dan zal het moeten worden aangevuld. Dit is ook logisch aangezien anders in cassatie geen controle op de bewezenverklaring kan plaatsvinden. ${ }^{102}$

\subsection{Termijn waarbinnen het verkorte vonnis moet worden aangevuld}

In artikel $365 \mathrm{a}$, derde lid, $\mathrm{Sv}$ is een termijn voor aanvulling van het verkorte vonnis opgenomen. ${ }^{103}$ Bevindt de verdachte zich in voorlopige hechtenis ter zake van het ter terechtzitting onderzochte feit, dan moet aanvulling van het verkorte vonnis binnen drie maanden na het instellen van het rechtsmiddel geschieden. ${ }^{104}$ Is de verdachte op vrije voeten, of is hij voorlopig gehecht ter zake van een ander strafbaar feit, dan geldt een termijn van 4 maanden. Op niet naleving van deze termijn is echter in de wet geen sanctie gesteld. Volgens de memorie van toelichting is een sanctie op overschrijding van deze termijn in de vorm van vernietiging van het vonnis bewust achterwege gelaten, omdat in de praktijk een strafzaak ook niet in hoger beroep of cassatie zal worden behandeld zolang het uitgewerkte vonnis niet beschikbaar is. Op deze manier is gegarandeerd dat ten tijde van de behandeling in hoger beroep of cassatie een volledig vonnis beschikbaar is. ${ }^{105}$ Conform de bedoelingen van de wetgever heeft de Hoge Raad geoordeeld dat overschrijding van de in artikel 365a Sv genoemde termijn niet tot nietigheid van het vonnis leidt. ${ }^{106}$ Wel kan overschrijding van de termijn van artikel $365 \mathrm{a}$ $\mathrm{Sv}$ in extreme gevallen leiden tot overschrijding van de redelijke termijn als bedoeld in artikel 6 lid 1 EVRM. ${ }^{107}$

100 Onder een gewoon rechtsmiddel wordt begrepen verzet, hoger beroep en beroep in cassatie.

101 Artikel 365a, tweede lid, Sv.

102 Artikel 415 Sv.

103 Deze termijn is als gevolg van art. $415 \mathrm{~Sv}$ ook van toepassing indien naar aanleiding van het hoger beroep cassatie is ingesteld.

104 Op dit punt wijkt de wet wel af van het voorstel van de Commissie-Moons; deze had immers voor gedetineerden een termijn van 1 maand en voor niet-gedetineerden een termijn van 3 maanden voorgesteld; zie Corstens 1993, p. 110.

105 Kamerstukken II 1995-1996, 23989, nr. 3, p. 8.

106 HR 24 maart 1998, NJ 1998, 557 en HR 23 juni 1998, NJ 1998, 860.

107 HR 21 september 1999, NJ 1999, 786. 
De vraag wat dient te geschieden indien ten tijde van de behandeling van de strafzaak in hoger beroep of cassatie geen aanvulling van het verkorte vonnis of arrest aanwezig is, komt verderop aan de orde.

\subsection{De inhoud van de aanvulling}

Moet het verkorte vonnis worden aangevuld omdat in de bewuste strafzaak een rechtsmiddel is ingesteld, dan moeten aan het vonnis de gebezigde bewijsmiddelen worden toegevoegd. Aan dit vereiste houdt de Hoge Raad - waar het arresten van de hoven betreft - streng de hand. Het volstaan met een 'uittreksel' van de uitspraak (kennelijk iets anders dan een verkort arrest) is niet acceptabel; zelfs niet als tegen de tijd dat de behandeling bij de Hoge Raad dient een volledig uitgewerkt, dus aangevuld vonnis beschikbaar is. De Hoge Raad oordeelde:

'Hofs verzuim een arrest op te maken dat voldeed aan de hier ingevolge art. $415 \mathrm{~Sv}$ toepasselijke wettelijke eisen, in het bijzonder die van art. 365a in verbinding met art. $138 \mathrm{~b} \mathrm{~Sv}$, heeft betrekking op een wezenlijke vorm van het strafproces zodat het nietigheid van de bestreden uitspraak oplevert, ook al is deze niet met zoveel woorden in de wet bedreigd. De omstandigheid dat zich bij de op de voet van art. 434, eerste lid, Sv aan de Hoge Raad gezonden stukken ook een kennelijk later opgemaakt - volledig uitgewerkt - arrest van het Hof bevindt dat beantwoordt aan de wettelijke voorschriften inzake de vormgeving van rechterlijke uitspraken als de onderhavige, dwingt niet tot een ander oordeel. ${ }^{108}$

Het is ook terecht dat de Hoge Raad op dit punt aan de letter van de wet vasthoudt; de regeling van het verkorte vonnis is nog geen tien jaar oud en rechters zoeken kennelijk nu al wegen om met minder dan een verkort vonnis te volstaan of om de verplichting tot aanvulling te omzeilen. ${ }^{109}$ Dat doet niet alleen afbreuk aan de motivering van vonnissen, maar eerst en vooral is hier sprake van een duidelijk negeren van de wensen van de wetgever. In de woorden van Mevis:

'Als rechters (of het $\mathrm{OM}$ of de politie) zich op hun eigen professionaliteit gaan beroepen (of nog erger: op werklast) ter legitimering van een handelwijze die evident van de wet afwijkt, komen elementaire grenzen in zicht. En dat gebeurt in pragmatisch Nederland veel te vaak. ${ }^{110}$

Het ontbreken van een volledig uitgewerkt arrest was overigens wel acceptabel in de zaak waarin de verdediging alsnog de mogelijkheid kreeg om een aanvulling van de cassatieschriftuur in te dienen. Ten tijde van het indienen van de cassatieschriftuur bevond de aanvulling van het verkorte arrest zich niet in het dossier. Het feit dat het hier om een misverstand ging (dus niet om een moedwillige actie

108 HR 24 mei 2005, NJ 2006, 433 m.nt. P.A.M. Mevis. In gelijke zin: HR 6 december 2005, LJN AT5754 en HR 28 maart 2006, LJN AV1620.

109 In gelijke zin: plaatsvervangend procureur-generaal Fokkens in zijn conclusie bij HR 24 mei 2005, NJ 2006, 433.

110 Mevis in zijn annotatie bij HR 24 mei 2005, NJ 2006, 433. 
van het hof) en dat de verdediging in de gelegenheid werd gesteld om alsnog in een aanvullende schriftuur op de aanvulling in te gaan, vond in de ogen van Hoge Raad genade. ${ }^{111}$

\subsection{Discrepanties tussen het verkorte vonnis en de aanvulling}

De aanvulling van het verkorte vonnis of arrest kan geschieden door middel van een bijlage of door middel van het met tekstverwerkende apparatuur invoegen van de weergave van de bewijsmiddelen. Deze werkwijze impliceert dat de tekst van alle overige onderdelen al bij het wijzen van het verkorte vonnis definitief vastligt en wijziging dus niet meer toegelaten is. Dit werd ook zo bij de totstandkoming van de regeling van het verkorte vonnis in de memorie van toelichting overwogen. ${ }^{112}$ De aanvulling is volgens de wetgever ook daadwerkelijk als aanvulling bedoeld. Er mogen dus tussen het verkorte vonnis en de aanvulling geen discrepanties ontstaan.

De Hoge Raad is op dit punt echter minder strikt dan men op grond van de totstandkomingsgeschiedenis zou mogen verwachten. In zijn jurisprudentie maakt de Hoge Raad onderscheid tussen onderdelen die verplicht in het verkorte vonnis moeten worden opgenomen en onderdelen waarvoor een dergelijke plicht niet geldt. Zijn in het verkorte vonnis zaken opgenomen die daar strikt genomen nog niet in hoeven te staan, dan kan bij de aanvulling van dat vonnis hiervan nog worden afgeweken. Dat betekent dat voor zover in het verkorte vonnis in een bewijsoverweging wordt ingegaan op de redengevendheid van het bewijsmateriaal, dit als een onverplicht onderdeel van het verkorte vonnis kan worden beschouwd. De redengevendheid van het bewijsmateriaal volgt immers uit de inhoud van de bewijsmiddelen en dat deel hoeft niet in het verkorte vonnis te worden opgenomen.

'Redelijke wetsuitleg brengt mee dat indien een dergelijke opgave in de zin van art. 359 , derde lid, Sv reeds in het verkorte arrest is opgenomen, deze in de aanvulling van dat arrest mag worden verbeterd. ${ }^{113}$

In dezelfde zin oordeelt de Hoge Raad in die gevallen waarin de feitenrechter reeds in het verkorte vonnis ingaat op verweren van de zijde van de verdediging. In de ogen van de cassatierechter is de reactie op bewijsverweren of standpunten van partijen geen verplicht onderdeel van het verkorte vonnis. Een aanvulling of verbetering van dergelijke overwegingen in de aanvulling van het verkorte vonnis is derhalve toegestaan. ${ }^{114}$ Wat echter in het verkorte arrest reeds verplicht moet worden opgenomen, kan niet in de aanvulling worden verbeterd. ${ }^{115}$ Dit betekent

111 HR 7 november 2006, LJN AY6787.

112 Kamerstukken II 1994-1995, 23989, nr. 3, p. 7.

113 HR 16 maart 1999, NJ 1999, 387. In gelijke zin: HR 1 oktober 2002, LJN AE5663.

114 HR 24 september 2002, NJ 2002, 629.

115 In de aanvulling op het verkorte arrest mogen de kwalificatie en de aangehaalde wettelijke 
onder andere dat de bewezenverklaring zelf niet in de aanvulling mag worden gewijzigd, zoals het geval was in de uitspraak van de Hoge Raad d.d. 2 december 2003. ${ }^{116}$ Daar was door het Gerechtshof Arnhem in het verkorte arrest bewezen verklaard dat de verdachte opzettelijk mishandelend een persoon had geduwd en op of tegen het lichaam van deze persoon had geschopt. In de aanvulling op het verkorte arrest overwoog het hof: 'dat door een kennelijke vergissing in de bewezenverklaring de zinsnede "waardoor deze pijn heeft ondervonden" was doorgestreept'. De Hoge Raad is op dit punt heel streng:

'Het staat de rechter niet vrij in de aanvulling op het verkorte arrest alsnog onderdelen van de tenlastelegging bewezen te verklaren waarvan in het verkorte arrest is vrijgesproken., ${ }^{117}$

Dat laat onverlet dat een wijziging in de bewezenverklaring soms gebaseerd kan zijn op een kennelijke vergissing. In dat geval is de Hoge Raad bereid om die vergissing 'verbeterd te lezen'. ${ }^{118}$

\subsubsection{Het verkorte vonnis bezien in het licht van art. 6 EVRM}

Zoals hierboven uiteengezet kan in een verkort vonnis de volledige feitelijke grondslag voor de bewezenverklaring ontbreken. De rechter is niet verplicht om de inhoud van de bewijsmiddelen te vermelden in het verkorte vonnis. Evenmin eist de Hoge Raad dat in het verkorte vonnis al wordt ingegaan op de door de verdediging gevoerde bewijsverweren. Het gebrek aan inzicht in de bewijsconstructie kan voor de verdediging een ernstige handicap opleveren. Zij moet op basis van een onvolledig vonnis beslissen of het instellen van hoger beroep of cassatie een zinvolle exercitie is. $\mathrm{Zij}$ moet die beslissing nemen zonder wetenschap over de gronden waarop de bewezenverklaring rust, en zonder inzicht in de redenen waarom eerdere bewijsverweren niet werden gehonoreerd. Bovendien wordt vanaf 1 januari 2005 van de verdediging verwacht dat zij binnen twee weken na het instellen van het hoger beroep in de appelschriftuur aangeeft welke getuigen zij wenst te horen. ${ }^{119}$ Weliswaar is het indienen van een appelschriftuur niet verplicht, ${ }^{120}$ dat

voorschriften niet verbeterd worden: HR 28 januari 2002, NJ 2003, 168. Evenmin kan de afwijzing van een aanbod tot het verrichten van onbetaalde arbeid ten algemenen nutte conform. art. 359 lid 8 (oud) Sv eerst bij aanvulling op het verkorte arrest geschieden: HR 18 december 2001, NJ 2002, 350.

116 HR 2 december 2003, NJ 2004, 119. In gelijke zin: HR 27 juni 2000, NJ 2000, 548.

117 Dit leidde overigens niet tot cassatie, aangezien de HR op een ander punt de zaak redde; de bewezenverklaring kon alsnog als mishandeling worden gekwalificeerd. In gelijke zin: HR 27 juni 2000, NJ 2000, 548.

118 HR 26 maart 2002, NJ 2004, 351 m.nt. D.H. de Jong en HR 24 januari 2006, LJN AU6786.

119 Art. 410, derde lid, Sv. Deze bepaling is ingevoerd bij de Wet van 10 november 2004 (horen van getuigen), Stb. 579 (inwerkingtreding 1 januari 2005, Stb. 2004, 640). 
neemt niet weg dat het niet indienen van een schriftuur met daarbij een opgave van de te horen getuigen nadelige consequenties heeft voor de verdediging. Laat zij dit namelijk achterwege, dan geldt voor latere verzoeken tot het horen van getuigen dat zij moeten voldoen aan het zwaardere criterium dat oproeping noodzakelijk is. ${ }^{121}$ Het is de vraag hoe de verdediging aan deze impliciete plicht om reeds bij appelschriftuur getuigen op te geven kan voldoen op basis van een verkort vonnis. Onduidelijk is immers in geval van een verkort vonnis welke getuigenverklaringen een rol hebben gespeeld bij de oordeelsvorming in eerste aanleg en in hoeverre het dus voor de beoordeling in hoger beroep van belang is om deze getuigen in appel (opnieuw) te horen. ${ }^{122}$ De achtergestelde positie van de verdediging in dit verband roept de vraag op in hoeverre het wijzen van een verkort vonnis wel in overstemming is met het uitgangspunt van een 'fair trial' zoals neergelegd in artikel 6 EVRM.

De onbekendheid met de door de rechter gehanteerde bewijsconstructie kan op twee manieren in verband met artikel 6 EVRM worden gebracht. Allereerst kan het ontbreken van een motivering in zijn algemeenheid als een inbreuk op het in artikel 6 lid 1 EVRM neergelegde beginsel van 'fair trial' worden beschouwd. Bovendien kan het ontbreken van de bewijsconstructie in het vonnis de mogelijkheden voor de verdachte om zijn verdediging voor te bereiden in negatieve zin worden beïnvloed. Bij gebrek aan wetenschap over de bewijsconstructie in eerste aanleg wordt het de verdediging bemoeilijkt om haar kansen in hoger beroep in te schatten. Dat zou in strijd kunnen zijn met artikel 6 lid 3 onder b EVRM.

\subsubsection{Art. 6 lid 1 EVRM}

In verschillende uitspraken heeft het Europese Hof voor de rechten van de mens overwogen dat uit artikel 6 lid 1 EVRM de verplichting voor rechterlijke auto-

120 Bij de Wet Stroomlijnen hoger beroep is wel een verplichting tot het indienen van een appelschriftuur ingevoerd voor vonnissen als bedoeld in het nieuwe art. 410a Sv. Het betreft dan vonnissen waarbij de verdachte is veroordeeld terzake van een of meer misdrijven dan wel overtredingen waarop een maximum gevangenisstraf is gesteld van 4 jaar en de veroordeling is beperkt tot oplegging van een geldboete van niet hoger dan 500 Euro. Zie Wet van 5 oktober 2006 (stroomlijnen hoger beroep), Stb. 2006, 470 (inwerkingtreding 1 maart / 1 juli 2007, Stb. 2007, 70).

121 Art 414, tweede lid, Sv en art. 418, derde lid, Sv. Beide bepalingen ingevoerd bij de Wet van 10 november 2004 (aanpassing eisen motivering bewezenverklaring bekennende verdachte), Stb. 579 (inwerkingtreding 1 januari 2005, Stb. 2004, 640).

122 Reeds bij de eerste introductie van deze voorstellen door de Raad van de Rechtspraak werd op dit punt gewezen door Prakken 2003, p. 835: 'Zelfs wordt geopperd het indienen van een getuigenlijst op het moment van instellen van beroep verplicht te stellen: zonder dat hij weet hoe de bewijsmiddelen zijn gekozen moet de verdachte dus opgave van getuigen doen en grieven indienen. Dit kan nauwelijks serieus gemeend zijn. Het betekent dat het vonnis nog minder dan nu al het geval is gemotiveerd hoeft te zijn, maar dat de verdachte wel zijn beroep moet motiveren en zich daar in een vroeg stadium op moet vastleggen.' 
riteiten voorvloeit om hun beslissingen te onderbouwen. Daar voegt het echter ook telkens aan toe dat artikel 6 lid 1 EVRM:

'cannot be understood as requiring a detailed answer to every argument. The extent to which this duty to give reasons applies may vary according to the nature of the decision. It is moreover necessary to take into account, inter alia, the diversity of the submissions that a litigant may bring before the courts and the differences existing in the Contracting States with regard to statutory provisions, customary rules, legal opinion and the presentation and drafting of judgments. That is why the question whether a court has failed to fulfill the obligation to state reasons, deriving from Article 6 (art. 6) of the Convention, can only be determined in the light of the circumstances of the case. ${ }^{123}$

Uit de jurisprudentie van het Europese Hof blijkt dat de motivering van beslissingen moet worden gezien in het licht van het garanderen van een behoorlijke rechtspleging (proper administration of justice). De motivering dient ertoe de beslissing te legitimeren. Door het geven van argumenten worden niet alleen partijen, maar meer in het algemeen het publiek in staat gesteld de beslissing op haar waarde te toetsen. Dit komt het gezag van de beslissing ten goede:

'The Court notes that, even though a domestic court has a certain margin of appreciation when choosing arguments in a particular case and admitting evidence in support of the parties' submissions, an authority is obliged to justify its activities by giving reasons for its decisions. ${ }^{124}$

Bovendien moet uit de motivering van de beslissing blijken dat partijen en de door hen aangedragen argumenten zijn gehoord:

'The Court emphasizes that a further function of a reasoned decision is to demonstrate to the parties that they have been heard. Moreover, a reasoned decision affords a party the possibility to appeal against it, as well as the possibility of having the decision reviewed by an appellate body., 125

Het volledig ontbreken van een motivering leidt tot schending van artikel 6 lid 1 EVRM, vooral in die gevallen waarin klager wel degelijk relevant bewijsmateriaal of relevante argumenten heeft aangevoerd ter ondersteuning van zijn standpunt. ${ }^{126}$ Het uitblijven van een reactie wekt de indruk dat zijn argumenten in het geheel niet zijn betrokken in de besluitvorming. ${ }^{127}$ Ook het geven van een algemene

123 EHRM 9 december 1994, 18064/91 (Hiro Balani t. Spanje) (r.o. 27). In gelijke zin: EHRM 19 april 1994, 16034/90 (Van de Hurk t. Nederland).

124 EHRM 1 juli 2003, 37801/97 (Suominen t. Finland).

125 EHRM 1 juli 2003, 37801/97 (Suominen t. Finland).

126 Voor zover de klager niet in de gelegenheid is gesteld zijn standpunt toe te lichten, leidt dit eveneens tot schending van art. 6 lid 1 EVRM: EHRM 21 maart 2002, 53478/99 (Sajtos t. Griekenland).

127 EHRM 9 december 1994, 18064/91 (Hiro Balani t. Spanje) en EHRM 9 december 1994, 18390/91 (Ruiz Torija t. Spanje). 
motivering, zonder dat het daarin genoemde criterium wordt getoetst aan de feiten van de zaak is niet toelaatbaar. ${ }^{128}$

Bij de beoordeling van de vraag in hoeverre artikel 6 lid 1 EVRM is geschonden, neemt het Hof de hele rechtsgang in beschouwing. Dat heeft twee consequenties. Ten eerste hoeft de bevestiging van een vonnis in eerste aanleg in hoger beroep met overneming van de gronden geen schending van artikel 6 lid 1 EVRM op te leveren. Dit laatste voor zover natuurlijk het vonnis in eerste aanleg wel op voldoende wijze de aan de beslissing ten grondslag liggende redenen expliciteert en uit de behandeling in hoger beroep blijkt dat daar alle relevante aspecten onder ogen zijn gezien. ${ }^{129}$ Ten tweede betekent het feit dat het Europese Hof voor de rechten van de mens de volledige procedure in acht neemt soms dat hogere eisen worden gesteld aan de motivering. Zo zal bijvoorbeeld in het geval dat een en dezelfde zaak twee keer op basis van hetzelfde bewijsmateriaal wordt beoordeeld én de uitkomsten in die zaken wezenlijk van elkaar verschillen in het latere vonnis expliciet aandacht moeten worden besteed aan de redenen voor het afwijkende oordeel. ${ }^{130}$

Daarnaast veronderstelt het bestaan van een beroepsmogelijkheid dat het vonnis zodanig gemotiveerd moet worden dat betrokkenen op een effectieve manier gebruik kunnen maken van de voor hen openstaande beroepsmogelijkheden:

'Thus, in dismissing an appeal, an appellate court may, in principle, simply endorse the reasons for the lower court's decision. A lower court or authority in turn must give such reasons as to enable the parties to make effective use of any [cursivering: WD] existing right of appeal. ${ }^{131}$

De Europese Commissie voor de rechten van de mens heeft eenmaal het Nederlandse kop-staartvonnis in het licht van het eerste lid van artikel 6 EVRM beoordeeld. In de betreffende zaak was zowel in eerste aanleg als in hoger beroep aanvankelijk een vonnis afgegeven zonder vermelding van de bewijsmiddelen. Echter op het moment dat het hoger beroep respectievelijk het beroep in cassatie diende, beschikte de verdediging over een volledig vonnis. De Commissie achtte het wenselijk dat het vonnis op het moment dat moet worden beslist over het al

128 EHRM 29 mei 1997, 21522/93 (Georgiadis t. Griekenland) en EHRM 29 september 2005, 2507/02 (Kurti t. Griekenland).

129 EHRM 30 november 2004, 26890/95 (Kukkola t. Finland); EHRM 19 december 1997, 20772/92 (Helle/Finland) en EHRM 21 mei 2002, 28856/95 (Jokela t. Finland).

130 EHRM 6 september 2005, 65518/01 (Salov t. Oekraïne). In gelijke zin: EHRM 22 april 1992, 12351/86 (Vidal t. Belgium). In die zaak was het verzoek van de verdediging tot het horen van een viertal getuigen stilzwijgend afgewezen. Op basis van het gelijke bewijsmateriaal komt de appelrechter naar terugverwijzing door de cassatierechter tot een beduidend zwaardere straf. Het EHRM oordeelt dat in een dergelijk geval het verzoek tot het horen van de getuigen niet impliciet mag worden afgewezen.

131 EHRM 27 september 2001, 49684/99 (Hirvisaari t. Finland) (r.o. 30). 
dan niet instellen van een rechtsmiddel volledig is, maar achtte desalniettemin de klacht niet-ontvankelijk.

'Moreover, the applicant became acquainted with the Regional Court's and the Court of Appeal's complete judgments at a time when he could still present supplementary grounds of appeal, or grounds of cassation respectively. It cannot be considered, therefore, that the procedure which was applied was prejudicial to his defence or otherwise made the proceedings unfair., 132

Uit deze uitspraak blijkt eens te meer dat in de Straatsburgse optiek de gehele rechtsgang moet worden bezien. Indien het onvolledige vonnis in een latere fase wordt aangevuld en dit de verdediging niet in een nadeligere positie brengt, is geen sprake van schending van het recht op 'fair trial'.

De beslissing van de Commissie dateert van 1995. Inmiddels zijn er echter nieuwe ontwikkelingen die maken dat het oordeel over de toelaatbaarheid van verkorte vonnissen thans anders zou kunnen uitpakken. In dit verband kan gewezen worden op de onlangs hernieuwde regeling van het oproepen van getuigen in hoger beroep en de wet 'stroomlijnen hoger beroep'. Daarop wordt verderop in de tekst specifiek ingegaan. ${ }^{133}$

\subsubsection{Art. 6 lid 1 juncto lid 3 onder b EVRM}

Behalve strijd met het eerste lid kan de onvolledigheid van het vonnis ook leiden tot schending van artikel 6 lid 3 onder b EVRM:

'Everyone charged with a criminal offence has the following minimum rights: (...)

(b) to have adequate time and facilities for the preparation of his defence; (...)'.

Het feit dat de verdediging geen inzicht heeft in de gronden waarop het oordeel in eerste aanleg is gebaseerd, kan tot gevolg hebben dat haar mogelijkheden om zich in voldoende mate voor te bereiden op de procedure in appel worden beperkt. Dit speelt bijvoorbeeld in die gevallen waarin partijen alleen een rechtsmiddel kunnen aanwenden met vermelding van de beroepsgronden. Laten zij dit achterwege of doen zij dit buiten de daarvoor geldende termijn, dan wordt het appel niet-ontvankelijk verklaard. Het Europese Hof voor de rechten van de mens achtte een dergelijke handelwijze in de zaak Hadjianastassiou in strijd met artikel 6 lid 1 juncto lid 3 onder b EVRM:

'The national courts must, however, indicate with sufficient clarity the grounds on which they based their decision. It is this, inter alia, which makes it possible for the accused to exercise usefully the rights of appeal available to him. ${ }^{, 134}$

132 ECRM 25 februari 1995, 22922/93 (Colak t. Nederland).

133 Paragraaf 4.4.2.10 en 4.4.2.11.

134 EHRM 16 december 1992, 12945/87 (Hadjianastassiou t. Griekenland). 
In minder directe zin kan het ontbreken van de bewijsconstructie in het vonnis invloed hebben op de beslissing om appel in te stellen. Immers, bij gebrek aan inzicht in de bewijsconstructie is het voor partijen moeilijk een goede inschatting te maken van de kans van slagen in hoger beroep. Dit laatste punt was de inzet van de zaak Zoon versus Nederland. Zoon was door de Rechtbank Rotterdam op 11 mei 1995 veroordeeld wegens valsheid in geschrift. In het vonnis waren conform de gangbare praktijk de bewijsmiddelen niet opgenomen. Onder het kopje 'bewijsmiddelen' was slechts de aanduiding 'PM' opgenomen, hetgeen betekende dat de bewijsmiddelen en de inhoud daarvan pas zouden worden aangevuld op het moment dat tegen het vonnis een rechtsmiddel zou worden ingesteld. Wel was in het vonnis de verwerping van diverse door hem gevoerde verweren opgenomen. Tegen dit vonnis werd door Zoon geen hoger beroep ingesteld. Wel diende hij op 16 juni 1995 een klacht in bij de toen nog bestaande Europese Commissie voor de rechten van de mens. Zoon meende dat het ontbreken van de bewijsmiddelen in het verkorte vonnis het voor hem onmogelijk maakte om een goede inschatting te maken van zijn kansen in hoger beroep. Weliswaar had hij een volledig (aangevuld) vonnis kunnen krijgen indien hij hoger beroep had ingesteld, maar hij meende dat dit een oneigenlijk gebruik van het instellen van het rechtsmiddel was. Bovendien liep hij dan het risico dat het Openbaar Ministerie met hem mee zou appelleren waardoor eventuele intrekking van het hoger beroep van zijn zijde zinloos zou worden. ${ }^{135}$

De Europese Commissie achtte deze klacht ontvankelijk. ${ }^{136}$ In haar rapport concludeerde zij - met een stemverhouding 17 voor en 7 tegen - dat artikel 6 lid 1 en lid 3 onder b. EVRM was geschonden, daartoe overwegende:

'Although the Commission notes that in Dutch criminal proceedings an appeal is considered to be directed against the charges brought against a person rather than against the first instance judgment, it considers it normal and prudent behaviour for an accused to want to acquaint himself with the complete judgment of the first instance court before deciding whether or not to lodge an appeal. 53. The Commission thus considers the fact that the applicant would receive a complete judgment only if and after he had lodged an appeal which exposed him to, however slight, a procedural risk, to be incompatible with the requirements of Article 6 paras. 1 and 3 (b) of the Convention. ${ }^{137}$

Het oordeel van het Europese Hof voor de rechten van de mens luidde echter geheel anders. Het Hof was van mening dat artikel 6 lid 1 en 3 onder b EVRM niet was geschonden, en daarmee werd de kop-staartpraktijk - die inmiddels in Nederland een wettelijke basis had gekregen - vooralsnog Straatsburg-proof. In tegenstelling tot de Commissie meende het Hof dat de aard van het Nederlandse hoger

135 Ingevolge art. $424 \mathrm{~Sv}$ welke bepaling per 1 maart 2007 is vervallen. Zie de Wet van 5 oktober 2006 (stroomlijnen hoger beroep), Stb. 2006, 470 (inwerkingtreding 1 maart / 1 juli 2007, Stb. 2007, 70).

136 ECRM 14 januari 1998, 29202/95 (Zoon t. Nederland).

137 ECRM 4 december 1998, 29202/95 (Zoon t. Nederland). 
beroep wel degelijk van belang was voor de vraag of de verdediging bij gebreke aan een volledig vonnis voldoende mogelijkheden had om een weloverwogen besluit te nemen over het al dan niet instellen van een rechtsmiddel. Niet het vonnis in eerste aanleg, maar het tenlastegelegde feit staat in hoger beroep in Nederlandse strafzaken centraal. In appel oordeelt het hof zelfstandig naar aanleiding van het onderzoek ter terechtzitting en op grondslag van de telastelegging. Voor de vaststelling van het oordeel in hoger beroep en dus ook voor de inschatting van de kansen van het hoger beroep is dus het vonnis in eerste aanleg niet beslissend:

'It is further noted that in Dutch criminal procedure an appeal is not directed against the judgment of the first-instance court but against the charge brought against the accused. An appeal procedure thus involves a completely new establishment of the facts and a reassessment of the applicable law. It follows, in the Court's opinion, that the applicant and his counsel would have been able to make an informed assessment of the possible outcome of any appeal in light of the judgment in abridged form and of the evidence contained in the case-file. ${ }^{138}$

Het argument van klager dat hij enkel in het bezit kon komen van het volledige vonnis indien hij een rechtsmiddel instelde en zo het risico liep van een behandeling in hoger beroep en mogelijk een hogere straf, achtte het Europese Hof voor de rechten van de mens niet overtuigend:

'The Court accepts that the prosecution's entitlement to lodge and maintain an appeal is an autonomous one, in no way dependent on whether the defence lodges an appeal. That being so the possibility that the prosecution might follow suit if the defence appealed cannot be of decisive importance. In the circumstances of the present case, therefore, it cannot be said that the applicant's defence rights were unduly affected by the absence of a complete judgment or by the absence of a detailed enumeration of the items of evidence relied on to ground his conviction from the judgment in abridged form. ${ }^{139}$

Bovendien achtte het Hof in de zaak Zoon het belang van het volledige vonnis afwezig, aangezien Zoon het tenlastegelegde feit had bekend. Voor zover er verweren waren gevoerd met betrekking tot het bewijs, waren deze in het verkorte vonnis gemotiveerd weerlegd. De enige kanttekening die het Europese Hof voor de rechten van de mens bij het verkorte vonnis in zijn algemeenheid maakte, is dat de veroordeling niet mag zijn gebaseerd op bewijsmateriaal dat zich noch in het dossier bevindt, noch tijdens het onderzoek ter terechtzitting behandeld is:

'Moreover, the applicant has not claimed, nor does it appear, that his conviction was based on evidence that was neither contained in the case-file nor presented at the hearing of the Regional Court. ${ }^{140}$

138 EHRM 7 december 2000, 29202/95, NJ 2001, 558 m.nt. PMe, r.o. 21 (Zoon t. Nederland).

139 EHRM 7 december 2000, 29202/95, NJ 2001, 558 m.nt. PMe, r.o. 22-23 (Zoon t. Nederland).

140 EHRM 7 december 2000, 29202/95, NJ 2001, 558 m.nt. PMe, r.o. 20 (Zoon t. Nederland). 
Dit laatste is een uiterst curieuze toevoeging. Hoe kan immers de verdachte beoordelen of de bewezenverklaring is gebaseerd op bewijsmateriaal dat niet ter zitting aan de orde is geweest, indien hij geen wetenschap heeft over het bewijsmateriaal dat aan die beslissing ten grondslag ligt?

\subsubsection{Reikwijdte van de zaak Zoon}

De uitspraak in de zaak Zoon leidde in Nederland tot de conclusie dat het wijzen van een verkort vonnis niet in strijd met artikel 6 EVRM zou zijn. Met name Myjer toonde zich daar verheugd over:

'Voor het overige kan ik niet bedenken wat er naar Straatsburgse maatstaven nog mis kan zijn aan de Nederlandse regeling van kop-staartvonnissen.' ${ }^{141}$

Het Straatsburg-proof zijn van de kop-staart-vonnissen is dan met name te danken aan het feit dat de behandeling in hoger beroep een geheel nieuwe feitelijke behandeling is. De verdachte kan zich daar wederom verweren tegen hetgeen hem in de tenlastelegging wordt verweten.

Toch kunnen bij de opgetogenheid van Myjer wel enige kanttekeningen worden geplaatst. Uit de jurisprudentie van het Europese Hof voor de rechten van de mens volgt dat het telkens vasthoudt aan het uitgangspunt dat uitspraken van rechters en andere autoriteiten gemotiveerd moeten worden. Dit uitgangspunt wordt steeds benadrukt. Daartoe voert het Hof enerzijds aan dat de motivering noodzakelijk is in het belang van een goede rechtspleging. Anderzijds wijst het op het belang van betrokkenen. Uit de uitspraak moet blijken dat hun argumenten zijn gehoord en in de besluitvorming zijn betrokken. Participatie in een procedure is van generlei waarde indien dit beperkt blijft tot het formeel horen. Uit het vonnis moet blijken dat de bijdrage van partijen bij de totstandkoming van het oordeel is betrokken. Bovendien kan het uitblijven van een gemotiveerde beslissing de effectiviteit van de mogelijkheid om daartegen beroep in te stellen nadelig beïnvloeden.

Het Europese Hof voor de rechten van de mens stelt geen absolute eis met betrekking tot de motivering van rechterlijke uitspraken. De vraag in hoeverre de rechterlijke autoriteit aan haar motiveringsverplichting heeft voldaan, is afhankelijk van de omstandigheden van de zaak en de nationale regels met betrekking tot de procedure en de invulling van het vonnis. Ten aanzien van het eerste - de omstandigheden van de zaak - speelt een belangrijke rol in hoeverre betrokkenen tijdens de behandeling van de zaak eigen gezichtspunten naar voren hebben gebracht en in hoeverre zij daarop een reactie hebben gekregen. Ten aanzien van het tweede punt - de nationale regelgeving - wijst het Europese Hof voor de rechten van de mens er telkens op dat de procedure in zijn geheel moet worden beschouwd.

141 Myjer 2001, p. 231. 
Uit de uitspraak van het Europese Hof voor de rechten van de mens in de zaak Zoon kan echter - gezien beide punten - geen al te vergaande conclusie worden getrokken met betrekking tot de vraag of het verkorte vonnis Straatsburg-proof is. Allereerst heeft de zaak Zoon betrekking op een bekennende verdachte. Voor zover hij al een bewijsverweer had gevoerd (in casu een onrechtmatig verkregen bewijsverweer) bevatte het verkorte vonnis een reactie op dat verweer. De Hoge Raad kent echter de feitenrechters de vrijheid toe om met een dergelijke reactie te wachten tot het moment waarop het verkorte vonnis moet worden aangevuld. Wordt in het verkorte vonnis geen reactie gegeven op de daar gevoerde bewijsverweren, dan zou dit wellicht in de ogen van het Europese Hof voor de rechten van de mens geen genade kunnen vinden. In diverse zaken heeft het Europese Hof voor de rechten van de mens aangegeven dat het belang van de motivering daarin is gelegen dat uit de motivering blijkt dat de verdachte is gehoord. Het niet reageren op verweren van de zijde van verdediging zou in strijd kunnen komen met het beginsel van 'fair trial' zoals vervat in het eerste lid van artikel 6 EVRM. Nog op een tweede punt is de zaak Zoon niet representatief. Zoon had enkel geklaagd over het feit dat hij op basis van het verkorte vonnis geen weloverwogen keuze kon maken over het al dan niet instellen van hoger beroep. Hij had dit - gezien het procesrisico dat aan het instellen van hoger beroep was verbonden uiteindelijk niet gedaan. Het Europese Hof voor de rechten van de mens geeft vervolgens in zijn uitspraak aan dat het procesrisico niet relevant was. Bovendien acht het voor het inschatten van de kansen in hoger beroep - gezien het Nederlandse stelsel van hoger beroep - de uitspraak in eerste aanleg niet alles bepalend is. Echter op dat punt is het Nederlandse stelsel van strafvordering aan verandering onderhevig.

Zoals eerder aangegeven zijn inmiddels met betrekking tot de behandeling van het hoger beroep de nodige wijzigingen doorgevoerd. Op 1 januari 2005 is de Wet Horen van getuigen in werking getreden. Dit voorstel heeft consequenties voor het oproepen van getuigen in hoger beroep. Op 24 oktober 2006 is de Wet Stroomlijnen hoger beroep vastgesteld. Daarbij zijn rigoureuze wijzingen doorgevoerd die de aard van het hoger beroep wezenlijk veranderen en die de vraag rechtvaardigen of ook na inwerkingtreding van deze wijzigingen Straatsburg op gelijke wijze blijft oordelen over de toelaatbaarheid van het verkorte vonnis.

\subsubsection{Het oproepen van getuigen in hoger beroep en het verkorte vonnis}

Op 1 januari 2005 is een viertal wetten ${ }^{142}$ in werking getreden die alle er op zijn gericht de behandeling van strafzaken te versnellen dan wel efficiënter te laten

142 Deze wetsvoorstellen vloeiden alle voort uit het zogeheten Veiligheidsprogramma. Zie Kamerstukken II, 2002-2003, 28684, nrs. 1-2. Het betreft de Wet van 10 november 2004 (inbeslagneming en doorzoeking door de rechter-commissaris), Stb. 2004, 577, de Wet 
verlopen. Eén daarvan betreft het oproepen van getuigen. In het voorstel zijn verschillende wijzigingen doorgevoerd. ${ }^{143}$ Relevant voor de toelaatbaarheid van het verkorte vonnis is de wijziging met betrekking tot het horen van getuigen in hoger beroep.

Vanaf 1 januari 2005 dient de verdediging ingevolge artikel 410 lid 3 Sv bij de appelmemorie getuigen die zij bij de behandeling van het hoger beroep wenst te horen, op te geven. Laat zij dat dan achterwege, dan kan het oproepen van getuigen op wens van de verdediging alleen nog geschieden indien het verzoek daartoe voldoet aan het noodzakelijkheidscriterium. Dit criterium gold al voor zover het verzoek tot het oproepen van getuigen ter zitting werd gedaan. Thans geldt het zoals blijkt uit het gewijzigde artikel 414 - ook indien voorafgaand aan de zitting een verzoek bij de advocaat-generaal wordt ingediend. Dit criterium is aanmerkelijk zwaarder. Getuigen die reeds bij appelmemorie ${ }^{144}$ zijn opgegeven, kunnen enkel worden geweigerd om redenen zoals genoemd in artikel 263 lid $2 \mathrm{~Sv} .{ }^{145}$

Van de verdediging wordt dus in principe verwacht dat zij bij appelmemorie de getuigen opgeeft. Het opgeven van de getuigen dient te geschieden binnen een termijn van twee weken vanaf het moment van het instellen van hoger beroep. De vraag is echter of de verdediging daartoe in staat is. Ten tijde van het instellen van het rechtsmiddel en het indienen van de appelmemorie is immers geen uitgewerkt proces-verbaal van de terechtzitting en ook geen vonnis beschikbaar. Dat betekent dat de verdediging getuigen dient op te geven op een moment dat zij geen inzicht heeft in de bewijsconstructie in eerste aanleg. Zij weet dus niet welke bewijsmiddelen wel en welke niet aan het oordeel van de rechtbank ten grondslag liggen. Evenmin heeft zij zicht op de wijze waarop de rechtbank verklaringen van getuigen en deskundigen heeft geïnterpreteerd en gewaardeerd en welke aspecten daarbij een rol hebben gespeeld. In het licht van de uitspraak van de Europese Commissie voor de rechten van de mens in de zaak Colak versus Nederland ${ }^{146}$ zou het vroegtijdig opgeven van getuigen wel degelijk een nadeel

van 10 november 2004 (wijzigingen in de regeling van voorlopige hechtenis), Stb. 2004, 578, de Wet van 10 november 2004 (horen van getuigen), Stb. 2004, 579 en de Wet van 10 november 2004 (aanpassing eisen motivering bewezenverklaring bekennende verdachte), Stb. 2004, 580 (inwerkingtreding 1 januari 2005, Stb. 2004, 638 tot en met 641).

143 Zie voor een kort overzicht van de inhoud van de wetswijziging: Nieuwsbrief Strafrecht 2005, p. 24-30.

144 Het indienen van een appelmemorie is thans alleen in de minder ernstige zaken verplicht. Vanaf 1 maart 2007 staat in geval van een veroordeling terzake van feiten waarbij een geldboete van maximaal 500 Euro is opgelegd hoger beroep niet langer automatisch open. Degenen die gebruik willen maken van het rechtsmiddel zullen de gronden daarvoor moeten kenbaar maken en aan de hand daarvan zal worden besloten of 'verlof' wordt verleend. De gronden dienen in een appelmemorie te worden neergelegd. Zie het gewijzigde art. 410, vierde lid, Sv in de Wet van 5 oktober 2006 (stroomlijnen hoger beroep), Stb. 2006, 470 (inwerkingtreding 1 maart/1 juli 2007, Stb. 2007, 70).

145 Meer uitgebreid over de wetswijziging: Brouwer 2005.

146 ECRM 25 februari 1995, 22922/93 (Colak t. Nederland). 
kunnen opleveren voor de verdediging. Dit nadeel kan de verdediging echter zelf compenseren; de verdediging zal alle mogelijk relevante getuigen reeds bij de appelmemorie moeten opgeven. Slechts op die manier voorkomt zij dat later opgegeven getuigen worden geweigerd op basis van het zwaardere noodzaakcriterium. Dat lijkt dan ook thans de praktijk te zijn. ${ }^{147}$ De wijziging van artikel 414, tweede lid, Sv leidt derhalve in combinatie met het wijzen van een verkort vonnis niet direct tot strijd met het recht op een fair trial zoals neergelegd in artikel 6 EVRM, maar het creëert voor de verdediging de noodzaak tot het doen oproepen van alle mogelijke getuigen, waar zij - indien zij in het bezit was geweest van het proces-verbaal van de zitting en het vonnis in eerste aanleg - wellicht van had afgezien. Zo meende ook de adviescommissie strafrecht van de Orde van Advocaten:

'Een te korte termijn leidt dan tot het opgeven van onnodig veel getuigen hetgeen niet in het belang van de staande en zittende magistratuur, en in veel gevallen evenmin in het belang van de verdediging (is). Art. 414 lid 2 Sv dwingt daartoe., ${ }^{148}$

\subsubsection{Het voortbouwend hoger beroep en het verkorte vonnis}

Met betrekking tot de behandeling van strafzaken in hoger beroep zijn de afgelopen jaren veel wijzigingen doorgevoerd. Al deze wijzigingen hebben een gemeenschappelijke noemer, te weten: een meer efficiënte afdoening van strafzaken in hoger beroep. Zo zijn er wijzigingen doorgevoerd met betrekking tot de oproepingsprocedure in appel, ${ }^{149}$ de verruiming van unusrechtpsraak in hoger beroep ${ }^{150}$ én zijn er tal van wijzigingen van kracht geworden die betrekking hebben op de bewijsvoering in de appelprocedure. ${ }^{151}$ De Wet 'oproepen van getuigen', zoals die in de vorige paragraaf aan de orde kwam, is er één van. Al deze wijzigingen zagen slechts op één facet van de procedure in hoger beroep. De Wet 'stroomlijnen hoger beroep' is echter qua opzet veel meer omvattend; in deze op

147 Reijntjes 2007, p. 29: 'De nieuwe regel brengt mee dat de raadsman gewoonlijk slechts veertien dagen tijd heeft om zich op zijn strategie te beraden, en dat hij dat bovendien moet doen op een moment dat hij het vonnis in eerste aanleg nog niet heeft. Dit wordt door veel raadslieden, maar ook door anderen, onredelijk geacht. Zelf vind ik het eerder onpraktisch, omdat het de raadsman uitnodigt, ja soms zelfs dwingt, om meer getuigen te laten oproepen dan hij eigenlijk nodig denkt te hebben.'

148 Adviescommissie Strafrecht van de Nederlandse Orde van Advocaten, Stroomlijnen hoger beroep, $<\mathrm{http}: / /$ www.advocatenorde.nl/wetenregelgeving/adviezen.asp $>$ preadvies nr. 419 aangeboden aan de Minister van Justitie d.d. 10 januari 2005.

149 Wet van 15 januari 1998 (de dagvaardingstermijn voor de politierechter, de oproeping in kantongerechtszaken en het instellen van hoger beroep), Stb. 1998, 31 (inwerkingtreding 1 februari 1998, Stb. 1998, 32).

150 Wet van 4 juli 2002 (verruiming bevoegdheid enkelvoudige kamers), Stb. 2002, 355 (inwerkingtreding 12 juli 2002).

151 Wet van 3 april 2003 (raadsheer-commissaris), Stb. 2003, 143 (inwerkingtreding 1 juli 2003, Stb. 2003, 260) en de Wet van 10 november 2004 (horen van getuigen), Stb. 2004, 579 (inwerkingtreding 1 januari 2005, Stb. 2004, 640). 
5 oktober 2006 vastgestelde wet werden zowel de toegang tot het hoger beroep als de omvang van het onderzoek in appel gewijzigd. ${ }^{152}$

De toegang wordt beperkt in die zin dat de drempel voor hoger beroep wordt opgetrokken van 50 Euro naar 100 Euro; wie veroordeeld is tot een geldboete van 100 Euro of minder heeft geen recht op een tweede feitelijke instantie. Daarbij is niet langer van belang of de verdachte bij verstek is veroordeeld of niet. Een tweede beperking van het aantal appelzaken wordt bewerkstelligd door het invoeren van een verlofsysteem. Is in eerste aanleg alleen een geldboete opgelegd die niet meer dan 500 Euro bedraagt, dan krijgt de veroordeelde niet automatische toegang tot het hoger beroep. Hij zal eerst verlof moeten vragen. Verlof wordt verleend indien dat 'in het belang van een goede rechtsbedeling is vereist'. ${ }^{153}$

Met betrekking tot de omvang van het onderzoek in appel vindt er een fundamentele wijziging plaats in die zin dat er niet - zoals nu nog het geval is - in appel per definitie een volledige nieuwe behandeling van de strafzaak plaatsvindt. Het nieuwe lid 2 van artikel $415 \mathrm{~Sv}$ luidt:

'Het gerechtshof richt het onderzoek ter terechtzitting op de bezwaren die door de verdachte en het openbaar ministerie worden ingebracht tegen het vonnis, in eerste aanleg gewezen, en op hetgeen overigens nodig is.'

De wijziging van het appel vindt zijn grondslag in de voorstellen van de onderzoeksgroep Strafvordering 2001. Zij opteerde voor een zogeheten voortbouwend appel. In een op deze wijze vormgegeven hoger beroep wordt als het ware voortgebouwd op het vonnis in eerste aanleg en op de bezwaren die daartegen door partijen worden ingebracht. De behandeling van de strafzaak in hoger beroep blijft beperkt tot die punten die door partijen ter discussie worden gesteld. Aldus Groenhuijsen en De Hullu:

'Het 'voortbouwend appel' zou de beslissing van de rechter in eerste aanleg tot vertrekpunt moeten nemen. De terechtzitting in hoger beroep dient inhoudelijk betrekking te hebben op die onderdelen van het beroepen vonnis waar de appelrechter ambtshalve voorlopig wezenlijk anders tegenaan kijkt en vooral op overwegingen en beslissingen waartegen door de verdediging of het OM bezwaar wordt gemaakt. Dat betekent praktisch gesproken dat het geding in appel wordt geconcentreerd rond die kwesties waar expliciet tegen wordt geopponeerd. Bezwaren kunnen blijken uit een schriftuur als bedoeld in het huidige art. $410 \mathrm{~Sv}$, uit een opgave aan het begin van de appelzitting volgens het huidige art. $416 \mathrm{~Sv}$, of uit de opstelling van de partijen tijdens het verloop van de terechtzitting in hoger beroep. De aandacht van de beroepsrechter dient te worden geconcentreerd op deze grieven.' 154

152 Daarnaast kent de wet nog talrijke andere wijzigingen. Een handzaam overzicht biedt Simmelink 2006, p. 122-124 en de bijdragen van diverse auteurs in P.G. Wiewel \& R.E. de Winter, Stroomlijning van het hoger beroep in strafzaken, Nijmegen: Ars Aequi Libri 2007.

153 Art. 410a Sv zoals opgenomen in de Wet van 5 oktober 2006 (stroomlijnen hoger beroep), Stb. 2006, 470 (inwerkingtreding 1 maart/1 juli 2007, Stb. 2007, 70).

154 Groenhuijsen \& De Hullu 2002, p. 387. 
Tegen deze wijziging van het karakter van het hoger beroep zijn veel bezwaren in te brengen. Zo wijst Mevis er onder andere op dat een dergelijke beperking van het hoger beroep alleen gerechtvaardigd is indien de kwaliteit van de behandeling in eerste aanleg is gegarandeerd. Hij is daarvan niet, althans niet in alle gevallen, overtuigd. ${ }^{155}$ Prakken en Franken hebben er op gewezen dat in het voorstel tot introductie van een voortbouwend hoger beroep ${ }^{156}$ de verantwoordelijkheid voor de kwaliteit van het onderzoek in appel en daarmee gepaard gaande lasten wel erg eenzijdig bij de verdediging worden gelegd. Zij betwijfelen of een voortbouwend appel kan leiden tot kwaliteitsverhoging. ${ }^{157}$

Bovendien roept introductie van het voortbouwend appel vragen op met betrekking tot de verenigbaarheid van een dergelijke invulling van de procedure in hoger beroep met het bestaan van het verkorte vonnis. Immers, indien het vonnis in eerste aanleg als vertrekpunt geldt voor het onderzoek in appel, ${ }^{158}$ dan dient dat vonnis ook zodanig te zijn uitgewerkt dat partijen daaruit kunnen afleiden welke redenering aan het oordeel ten grondslag heeft gelegen. In het verkorte vonnis ontbreekt een dergelijke redenering met betrekking tot het bewijsoordeel. Het oordeel van het Europese Hof voor de rechten van de mens in de zaak Zoon over de toelaatbaarheid van het verkorte vonnis was voor een belangrijk deel gebaseerd op het argument dat de behandeling in hoger beroep in Nederland niet is beperkt tot bezwaren tegen het vonnis in eerste aanleg, maar een tweede nieuwe feitelijke behandeling van het tenlastegelegde feit inhoudt. De onderzoeksgroep Strafvordering 2001 onderkende dit probleem en stelde ook voor om in geval van 'zware procedures' het verkort vonnis af te schaffen. ${ }^{159}$

In de wet 'stroomlijnen hoger beroep' is weliswaar gekozen voor het door de onderzoeksgroep Strafvordering 2001 geïntroduceerde begrip 'voortbouwend hoger

155 Mevis 2006, p. 9.

156 Het voortbouwend appel is geïntroduceerd door de Onderzoeksgroep Strafvordering 2001 in haar 3e interimrapport. Zie Groenhuijsen \& De Hullu 2002, p. 386-387.

157 Franken \& Prakken 2003, p. 113.

158 Kamerstukken II 2005-2006, 30320, nr. 3 , p. 7-8: 'In het «voortbouwend appèl» neemt de rechter in hoger beroep het vonnis inclusief de daaraan ten grondslag liggende behandeling als vertrekpunt. De terechtzitting heeft inhoudelijk betrekking op die onderdelen van het vonnis waar de appèlrechter voorlopig ambtshalve anders tegen aan kijkt en vooral [cursivering WD] op de overwegingen en beslissingen waartegen door de verdediging of het openbaar ministerie bezwaar wordt gemaakt.'

159 Simmelink 1999, p. 449: 'De huidige regeling van het verkorte vonnis in de art. 138b en $365 \mathrm{at} / \mathrm{m} 365 \mathrm{c} \mathrm{Sv}$ doet onrecht aan de aangegeven accenten betreffende de plicht tot motivering van het vonnis in eerste aanleg. In deze regeling wordt de motivering van de bewezen verklaring pas op schrift gesteld nadat hoger beroep is ingesteld. De functie van het vonnis en de daarin opgenomen overwegingen brengen mede dat bij de uitspraak, of zeer kort daarna, een uitgewerkt vonnis aan de partijen bij het geding (officier van justitie, verdachte en eventueel benadeelde partij) ter beschikking wordt gesteld. Deze verplichting voorkomt de ontwikkeling van praktijken waarin bij de uitspraak maar een zeer beperkt gedeelte van het vonnis (minder dan thans volgens de regeling van het verkort vonnis wordt geëist) op schrift wordt gesteld.' 
beroep', maar bij de uitwerking daarvan is niet gekozen voor een hele strikte variant daarvan in de vorm van een bindend grievenstelsel. In een dergelijk stelsel moeten partijen reeds bij appelmemorie hun bezwaren tegen het vonnis in eerste aanleg formuleren en deze grieven zijn bepalend voor de omvang van het onderzoek in hoger beroep. ${ }^{160}$ In bedoelde wet is ten aanzien van vonnissen waarbij een straf is opgelegd die is beperkt tot een geldboete van 500 Euro bepaald dat de verdachte verlof moet vragen om in appel te worden ontvangen. Wordt het verlof verleend, dan zijn niet alleen de eerder ingebrachte bezwaren bepalend voor de omvang van het onderzoek. In zoverre is er dus geen sprake van een 'strikt' grievenstelsel. Aan de inperking van het hoger beroep door middel van het vragen van verlof ligt de opvatting ten grondslag dat het hier gaat om lichte strafzaken die in beginsel door één instantie zouden kunnen worden afgedaan. ${ }^{161}$ Partijen moeten dus blij zijn dat ze überhaupt nog de mogelijkheid krijgen om de zaak aan een andere feitenrechter voor te leggen. Het feit dat verlof moet worden gevraagd zonder dat men de beschikking heeft over een volledig vonnis is gezien vanuit dat perspectief een overkomelijk probleem van geringe importantie. Het is de vraag of men er in Straatsburg ook zo over denkt. In het EVRM is weliswaar geen zelfstandig grondrecht op hoger beroep opgenomen, maar voor het Europese Hof geldt wel dat - voor zover een dergelijke rechtsgang is opengesteld - deze moet voldoen aan de eisen van een fair trial. ${ }^{162}$

Ten aanzien van de overige zaken waarvoor het verlofstelsel niet geldt, is evenmin gekozen voor een strikt grievenstelsel. De minister heeft daarvan afgezien om uiteenlopende reden. Een grievenstelsel zou niet te verenigen zijn met de ambtshalve onderzoeksplicht van de rechter. Bovendien geeft de minister aan dat het binden van de omvang van het onderzoek in appel aan de eerder geformuleerde bezwaren geen ruimte laat voor de ontwikkeling van nieuwe gezichtspunten mogelijk door een andere raadsman. ${ }^{163}$ Hoewel dit als een praktisch punt wordt neergezet en kennelijk minder van belang is, erkent de minister dat invoering van een strikt

160 In gelijke zin: Groenhuijsen \& De Hullu 2002, p. 357-358.

161 Kamerstukken II 2005-2006, 30320, nr. 3, p. 11.

162 Groenhuijsen \& De Hullu 2002, p. 358 met verwijzing naar EHRM 14 december 1999, 34791/97 (Khalfaoui t. Frankrijk). Buiten dit aspect wijst Haentjes 2007, p. 57 op mogelijke strijd met het EVRM, omdat in deze zaken niet alleen hoger beroep wordt uitgesloten, maar ook cassatie. Dit argument wordt versterkt door het gegeven dat het verlofstelsel niet alleen op bagatel-feiten ziet. Het enkele feit dat wordt volstaan met het opleggen van een geldboete als sanctie, betekent niet automatisch dat het om een gering strafbaar feit gaat.

163 Dit punt was reeds eerder door Franken \& Prakken 2003, p. 113 aan de orde gesteld: 'Een andere situatie die zich regelmatig voordoet is die waarin de verdachte, niet tevreden over zijn raadsman in eerste aanleg (...) besluit een andere raadsman te vragen hem in hoger beroep te verdedigen. Die moet dan wel de ruimte krijgen om een nieuwe verdedigingsstrategie vorm te geven en niet gebonden zijn aan de slecht bevallen strategie van zijn voorganger.' 
grievenstelsel ook problematisch zou zijn in combinatie met het bestaan van het verkorte vonnis. ${ }^{164}$

$\mathrm{Er}$ is derhalve gekozen voor een minder strikt grievenstelsel. Minder strikt in die zin dat enerzijds partijen die in hoger beroep gaan, niet gebonden zijn aan de door hen bij appelmemorie geuite grieven. Zij zijn ten eerste niet verplicht om een appelmemorie in te dienen en voor zover ze dat wel doen, kunnen zij bij aanvang van de behandeling in hoger beroep hierop nog terugkomen of nieuwe punten aandragen. Anderzijds is niet gekozen voor een stelsel waarbij de door partijen ingediende twistpunten alleen bepalend zijn voor de omvang van het onderzoek in appel. Er is, in overeenstemming met de Nederlandse traditie, ruimte gelaten voor de rechter om onderzoek te verrichten zonder dat hij daarbij beperkt is tot hetgeen door partijen als twistpunt is aangedragen.

Ervan uitgaande dat partijen voor aanvang van de behandeling in hoger beroep beschikken over een volledig uitgewerkt vonnis in eerste aanleg en dat zij naar aanleiding daarvan hun eerder ingediende grieven zouden kunnen aanvullen of wijzigen, hoeft het voortbouwend appel niet tot problemen in Straatsburg te leiden. Dat is anders in die zaken waarin het verkorte vonnis in zijn geheel niet wordt uitgewerkt. Een aantal hoven zag het ontbreken van een uitgewerkt vonnis in eerste aanleg niet als een beletsel om toch tot behandeling van de zaak over te gaan. Deze praktijk, die mijns inziens ook nu reeds contra legem is, ${ }^{165}$ kan onmogelijk worden gehandhaafd na inwerkingtreding van de wet 'stroomlijnen hoger beroep'. Het ontbreken van wetenschap over de bewijsconstructie in eerste aanleg en het feit dat de beoordeling in eerste aanleg wel als uitgangspunt dient voor de behandeling in hoger beroep gaan dan niet langer samen. Het enige dat hiertegen in zou kunnen worden gebracht, is dat partijen nog altijd de mogelijkheid hebben om zelf binnen drie maanden na de uitspraak in eerste aanleg te verzoeken om een uitgewerkt vonnis. ${ }^{166}$ Dat laat echter onverlet dat ook de rechter in hoger beroep moet oordelen naar aanleiding van het vonnis in eerste aanleg zonder dat hij op de hoogte is van de volledige inhoud. Wil men vasthouden aan de eigen verantwoordelijkheid van de rechter voor het onderzoek in strafzaken en dus ook voor het onderzoek in tweede instantie, dan ontkomt men er toch niet aan om deze te voorzien van een uitgewerkt vonnis. ${ }^{167}$ De verantwoordelijkheid voor het beschikbaar stellen van dat vonnis ten behoeve van de rechter kan niet bij partijen worden neergelegd. Doet men dat wel, dan is daarmee het Nederlandse strafproces

164 Kamerstukken II 2005-2006, 30320, nr. 3, p. 11: 'Los van de praktische eisen, die een grievenstelsel met zich brengt aangaande het beschikbaar komen van uitgewerkte vonnissen alvorens van een procespartij gevergd kan worden zijn grieven te formuleren, onderken ik ook het bezwaar, dat de eis vooraf schriftelijke grieven in te dienen die vervolgens een volledig bindend karakter hebben te ver zou kunnen voeren.'

165 Zie daarover uitgebreid paragraaf 4.4.4.

166 Art. 365c Sv.

167 In gelijke zin: Buruma 2003, p. 114-115. 
verworden tot een proces waarbij de waarheidsvinding in principe in handen is van procespartijen en de rol van de rechter met betrekking tot het feitenonderzoek is gemarginaliseerd. Dat is kennelijk niet de bedoeling van de wet 'stroomlijnen hoger beroep'. En dus moet het er voor worden gehouden dat na de inwerkingtreding van deze wet de illegale praktijk waarbij de behandeling in hoger beroep plaatsvond zonder uitgewerkt vonnis tot het verleden behoort.

\subsubsection{Geen aanvulling van de bewijsmiddelen bij bekennende verdachten $^{168}$}

Sinds 1 januari 2005 kent het Wetboek nog een uitzondering op de eis dat vonnissen de inhoud van de bewijsmiddelen moeten bevatten. Naast de mogelijkheid om te volstaan met een aantekening mondeling vonnis of een verkort vonnis, mag in geval van een bekennende verdachte ingevolge het nieuwe derde lid van artikel $359 \mathrm{~Sv}$ in het schriftelijke vonnis worden volstaan met een verwijzing naar de verklaringen en schriftelijke bescheiden. De tweede volzin van het derde lid luidt:

'Voor zover de verdachte het bewezen verklaarde heeft bekend, kan een opgave van bewijsmiddelen volstaan, tenzij hij nadien anders heeft verklaard dan wel hij of zijn raadsman vrijspraak heeft bepleit.'

Dit betekent dat niet langer de inhoud van de bewijsmiddelen in het vonnis hoeft te worden vermeld. Voldoende is dat in het vonnis de bron wordt aangeduid waaruit het belastende materiaal wordt geput. De nieuwe regeling is alleen van belang in die gevallen waarin de bekennende verdachte een rechtsmiddel tegen het vonnis instelt. Laat hij dat achterwege, dan kan met een verkort vonnis worden volstaan, waarin niet eens een opgave van de bewijsmiddelen hoeft te worden opgenomen.

De wetswijziging kwam voort uit het streven om de strafrechtspleging nog efficiënter te laten verlopen. Het volledig uitwerken van het vonnis is een tijdrovende kwestie en in geval van een bekennende verdachte is dat aldus de minister niet noodzakelijk:

'Indien de verdachte het tenlastegelegde feit ter terechtzitting bekent, is onderbouwing van de bewezenverklaring met uitgewerkte bewijsmiddelen gewoonlijk niet noodzakelijk om deze beslissing inzichtelijk te maken voor de verdachte, het openbaar ministerie, eventuele slachtoffers en de samenleving. De bewezenverklaring spreekt in dat geval min of meer vanzelf., 169

Het wetsvoorstel voorziet dus in een vereenvoudigde bewijsconstructie in geval van een zogeheten 'bekennende verdachte'. In de Nederlandse bewijsregeling is

168 De tekst van deze paragraaf is eerder in iets afwijkende vorm gepubliceerd onder de titel 'Het wetsvoorstel bewezenverklaring in geval van een bekennende verdachte' in Delikt \& Delinkwent 2004, p. 789-808.

169 Kamerstukken II 2003-2004, 29255, nr. 3, p. 4. 
het begrip 'bekentenis van de verdachte' echter niet nader omschreven. Artikel $341 \mathrm{~Sv}$ kent weliswaar de verklaring van de verdachte als bewijsmiddel, maar daarbij is geen onderscheid gemaakt tussen een bekennende en een niet bekennende verdachte. Elke verklaring van de verdachte die feiten en omstandigheden bevat die door de verdachte zelf zijn waargenomen of ondervonden, kan voor het bewijs van (een deel van) het tenlastegelegde feit dienen. De vraag die naar aanleiding van deze wijziging opkomt, is dan ook wat dient te worden verstaan onder een bekentenis van de verdachte.

\subsubsection{Bekentenis van het bewezenverklaarde feit}

Het derde lid van artikel $359 \mathrm{~Sv}$ bepaalt dat met een opgave van de bewijsmiddelen kan worden volstaan indien 'de verdachte het bewezen verklaarde heeft bekend'. Op het eerste gezicht lijkt deze tekst een tegenstrijdigheid te bevatten. Immers hoe kan de verdachte het bewezenverklaarde bekennen zonder dat er reeds sprake is van een bewezenverklaring. Ook door de Nederlandse Vereniging voor Rechtspraak $(\mathrm{NVvR})$ is op deze chronologische onmogelijkheid gewezen. ${ }^{170}$ In de memorie van toelichting wordt echter een voorstel van de NVvR en het Openbaar Ministeries tot wijziging van de tekst op dit punt afgewezen. Daartoe voert de minister aan dat de huidige tekst het voordeel heeft dat hij zeer beknopt is, en bovendien duidelijk moet zijn wat er is bedoeld, mede gezien de chronologische onmogelijkheid van een andere lezing. ${ }^{171}$

Toch zouden op dit punt problemen kunnen ontstaan. De minister veronderstelt dat de bekentenis van de verdachte qua inhoud en strekking overeenkomt met datgene dat bewezen wordt verklaard. Dit is echter gezien de grote mate van juridische gekunsteldheid van de in de tenlastelegging gebezigde taal niet altijd waarschijnlijk. Het is dus zeer goed mogelijk dat waar de verdachte denkt een strafbaar feit te bekennen, dit in juridische zin geen bekentenis van het bewezenverklaarde feit is. ${ }^{172}$ Wat te denken van het geval waarin de verdachte tegenover de politie een gave bekentenis aflegt met betrekking tot zijn betrokkenheid bij heling van bepaalde goederen. Zo verklaart hij onder andere: 'ik wist dat die fiets was gestolen'. Ter zitting ontstaat echter het vermoeden dat de verdachte deze wetenschap had, omdat hij zelf die fiets heeft gestolen. Voor zover de strafrechter toch van mening is dat de verdachte zich schuldig heeft gemaakt aan opzetheling, lijkt mij dat bovenstaande verklaring niet als een bekennende verklaring in de zin van het voorgestelde artikel 359 lid 3 kan worden beschouwd. Onduidelijk is namelijk wat de verdachte

170 Nederlandse Vereniging voor Rechtspraak, Advies inzake het wetsvoorstel inzake aanpassing van de eisen te stellen aan de motivering van de bewezenverklaring bij een bekennende verdachte, <http://www.verenigingvoorrechtspraak.nl/> advies nr. 248 d.d. 1 april 2003.

171 Kamerstukken II 2003-2004, 29255, nr. 3, p. 14.

172 Zie voor een mooi voorbeeld: Jörg 1993, p. 87. 
hier daadwerkelijk verklaart. Indien hij heeft bedoeld te zeggen dat hij wel wist dat die fiets gestolen was, omdat hij hem (alleen of samen met iemand anders) had gestolen, dan kan zijn verklaring onmogelijk als een bekentenis worden opgevat. De steler is immers geen heler. ${ }^{173}$ Is de strekking van zijn verklaring echter dat hij wist dat die fiets door een ander was gestolen, dan kan zijn verklaring wel als een (gedeeltelijke) bekentenis van het tenlastegelegde en bewezenverklaarde feit dienen. Zeker in die gevallen waarin de verdachte ter zitting niet verschijnt of wel verschijnt, maar zich beroept op zijn zwijgrecht, is het voor de strafrechter onmogelijk de strekking van de verklaring van de verdachte te achterhalen. In dat geval zal hij niet kunnen volstaan met een opgave van de bewijsmiddelen, maar zal hij het vonnis volledig moeten uitwerken. Een duidelijke bekentenis ontbreekt immers.

\subsubsection{Een gehele of gedeeltelijke bekentenis}

Op grond van het derde lid van artikel 359 lid $3 \mathrm{~Sv}$ is niet vereist dat de bekentenis van de verdachte een zogeheten 'gave' of volledige bekentenis is. Ook een verklaring van de verdachte waarin hij slechts een deel van het tenlastegelegde en het naderhand door de feitenrechter bewezenverklaarde feit bekent, kan er toe leiden dat op dat punt in het vonnis kan worden volstaan met een verwijzing naar de bewijsmiddelen. In de memorie van toelichting wordt het voorbeeld genoemd waarin de verdachte ter zitting in grote lijnen een diefstal bekent, maar betwist dat hij bepaalde in de tenlastelegging genoemde voorwerpen ook heeft gestolen. In dat geval kan de bewijsconstructie, aldus de minister, bestaan uit een opgave van de verklaring van verdachte ter zitting en de aangifte, alsmede een uitwerking van de aangifte op het punt van de betwiste voorwerpen, voor zover de diefstal daarvan bewezen wordt verklaard. ${ }^{174}$

Het voorbeeld van de minister is prachtig in zijn eenvoud. Maar te verwachten is dat niet in alle gevallen het zo simpel is. Wat in geval de verdachte erkent bepaalde handelingen te hebben verricht, maar nadrukkelijk ter terechtzitting betwist dat zijn opzet was gericht op het mogelijke gevolg van die handelingen? Logischerwijze zou dan met betrekking tot het bewijs van het opzet de bewijsconstructie volledig moeten worden uitgewerkt. Maar wat echter indien de handelingen die de verdachte erkent in wezen er al op wijzen dat hij het gevolg op de koop toe heeft genomen? Moet de verklaring van de verdachte nu worden gezien als een volledige bekentenis? Immers op grond van zijn verklaring zou men ook het opzet kunnen bewijzen. Of moet de expliciete ontkenning van de verdachte dat hij opzettelijk heeft gehandeld als uitgangspunt dienen. ${ }^{175}$ Mij lijkt het laatste, maar de tekst

173 HR 27 september 1994, NJ 1995, 65.

174 Kamerstukken II 2003-2004, 29255, nr. 3, p. 6-7.

175 Nog een voorbeeld: Aan de verdachte wordt medeplegen van moord tenlastegelegd. Ter zitting verklaart de verdachte: 'Ik heb het niet gedaan, de ander deed het; ik was er alleen 
van het huidige wetsontwerp geeft hierover geen uitsluitsel. In de memorie van toelichting wordt hierover opgemerkt: 'In beginsel is doorslaggevend of de rechter een bekennende verklaring van de verdachte aanwezig acht. ${ }^{, 176}$ Even verderop staat echter te lezen: 'Het komt niet wenselijk voor dat in dergelijke gevallen waarin het tenlastegelegde in de kern is ontkend, elke uitwerking van de bewijsmiddelen achterwege zou kunnen blijven. ${ }^{177}$

Het kon niet uitblijven dat na inwerkingtreding van de wet deze kwestie bij de Hoge Raad aan de orde zou worden gesteld. Het betrof een geval waarin het opzet werd betwist. De Hoge Raad eist voor toepassing van artikel 359 lid $3 \mathrm{~Sv}$ dat de verdachte 'het bewezenverklaarde duidelijk en ondubbelzinnig heeft bekend'. De vraag of daarvan in de concrete zaak sprake is, wordt echter aan de feitenrechter ter beoordeling overgelaten. ${ }^{178}$ Met aanhaling van de verklaring van de verdachte - iets dat het hof dus achterwege had gelaten - concludeert de Hoge Raad vervolgens dat naar het kennelijke oordeel van het Hof de verdachte het bewezenverklaarde duidelijk en ondubbelzinnig heeft bekend en dat dit geen blijk geeft van een onjuiste rechtsopvatting, terwijl het evenmin onbegrijpelijk is. Daarmee is evident dat de inhoud van de verklaring van de verdachte - voor zover daaruit feiten blijken waaruit de feitenrechter afleidt dat er sprake is geweest van opzet doorslaggevend is voor de vraag of er sprake is van een bekentenis. Irrelevant is de intentie van degene die de verklaring aflegt. Dat deze vervolgens in verbijstering achterblijft omdat zijn eigen verklaring waarin hij meende zich te verweren tegen de tegen hem geuite beschuldiging nu juist de reden is om geen nadere uitleg te geven, doet kennelijk niet ter zake. Met Schalken kan dus worden geconcludeerd dat het volstaan met de opgave van de bewijsmiddelen in geval van een bekennende verdachte aan de man werd gebracht als het promoten van een contradictoire procesvoering. ${ }^{179}$ In de praktijk is het gewoon een efficiencymaatregel.

Met betrekking tot die efficiency is overigens door het Openbaar Ministerie de vraag opgeworpen of bij dergelijke gedeeltelijke bekentenissen wel een werklastvermindering is te verwachten. In veel gevallen zal het immers minder tijd kosten om dan maar meteen de inhoud van alle bewijsmiddelen in het vonnis op te nemen. De minister onderkent dit en wijst erop dat het wetsvoorstel het mogelijk maakt om met een opgave van de bewijsmiddelen te volstaan, maar daartoe niet verplicht. Indien het efficiënter is om in het vonnis de bewijsmiddelen - ondanks een gedeeltelijke bekentenis van de verdachte - volledig uit te werken, dan ligt dat

maar bij en heb hem erheen gereden, het lijk afgevoerd en de auto bestuurd.' De verdachte denkt dat hij ontkent, maar onder de huidige stand van de deelnemingsjurisprudentie zal de rechter dit waarschijnlijk als bewijs van daderschap opvatten. Is er in dit geval sprake van een bekennende verklaring?

176 Kamerstukken II 2003-2004, 29255, nr. 3, p. 9.

177 Kamerstukken II 2003-2004, 29255, nr. 3, p. 10.

178 HR 26 september 2006, NJ 2006, 542.

179 Schalken in zijn annotatie bij HR 18 april 2006, NJ 2006, 645. 
in de rede. ${ }^{180}$ Het is echter te hopen dat in dergelijke gevallen niet naar een nog efficiëntere oplossing wordt gegrepen, namelijk slechts dat bewezen te verklaren wat niet door de verdachte wordt betwist. In het voorbeeld van de diefstallen zou men eenvoudig de door de verdachte betwiste gestolen voorwerpen uit de bewezenverklaring kunnen wegstrepen, en daarmee zou de noodzaak tot uitwerking van de bewijsmiddelen komen te vervallen. Voor eventuele civiele vorderingen in de strafzaak of daarbuiten zou dat echter problematisch kunnen zijn, nog afgezien van het feit dat het uitgangspunt van de materiële waarheidsvinding in strafzaken zich daartegen verzet.

\subsubsection{Bekentenissen uit het vooronderzoek}

Nog een ander aspect van de bekentenis verdient in dit verband de aandacht. De mogelijkheid om te volstaan met een verwijzing naar de bewijsmiddelen is niet beperkt tot de verdachte die ter zitting een bekennende verklaring aflegt. Ook indien tijdens het vooronderzoek een bekentenis is afgelegd, kan de strafrechter in het schriftelijk vonnis enkel een opgave van de bewijsmiddelen opnemen. Daarbij is wel de beperking opgenomen dat de verdachte niet nadien anders heeft verklaard dan wel hij of zijn raadsman vrijspraak heeft bepleit. ${ }^{181}$ In het conceptwetsvoorstel was deze beperking anders geformuleerd, namelijk 'tenzij de verdachte nadien ter terechtzitting anders heeft verklaard'. De minister achtte het gezien de adviezen die naar aanleiding van het conceptvoorstel waren ingediend wenselijk om op dit punt de tekst aan te scherpen. Op grond van de aangepaste tekst van het wetsvoorstel kan de verdachte ook al tijdens het vooronderzoek een eerder afgelegde bekennende verklaring 'intrekken' en hoeft hij daarmee dus niet te wachten tot het onderzoek ter terechtzitting. ${ }^{182}$ Bovendien zou op grond van de tekst van het conceptvoorstel aan de verdachte die ter terechtzitting zwijgt, op basis van zijn bekennende verklaring uit het vooronderzoek een uitgewerkt vonnis kunnen worden onthouden. Deze mogelijkheid is in artikel 359 lid 3 Sv nu uitgesloten, ervan uitgaande dat de verdachte die van zijn zwijgrecht gebruik maakt zelf, dan wel bij monde van zijn raadsman, vrijspraak zal bepleiten. ${ }^{183}$

180 Kamerstukken II 2003-2004, 29255, nr. 3, p. 4.

181 De feitenrechter hoeft niet in zijn vonnis te doen blijken dat aan deze eis - dat de verdachte niet nadien anders heeft verklaard dan wel hij of zijn raadsman vrijspraak heeft bepleit - is voldaan. HR 26 september 2006, NJ 2006, 542.

182 Het is overigens te hopen dat deze 'ingetrokken' verklaring niet als 'kennelijk leugenachtig' zal worden aangemerkt. Op grond van de jurisprudentie van de Hoge Raad mag de kennelijke leugenachtigheid van de verklaring van de verdachte niet zijn gebaseerd op een andere verklaring van de verdachte (HR 19 maart 2002, NJ 2002, 567) of op het zwijgen van de verdachte (HR 19 maart 1996, NJ 1996, 540 m.nt. Sch.). Dit laat echter onverlet dat er andere verklaringen in het dossier aanwezig zijn, die in tegenspraak kunnen zijn met de verklaring van de verdachte waarin hij het feit ontkent.

183 De Hoge Raad neemt dit vrij letterlijk; blijkt uit het proces-verbaal ter zitting dat de 
Weliswaar is zodoende een zekere waarborg ingebouwd om te voorkomen dat al te snel kan worden volstaan met een 'simpele' bewijsconstructie in het vonnis, maar helemaal bevredigend is dit niet. De verdachte die om welke reden dan ook ter zitting verstek heeft laten gaan, kan op grond van zijn bekennende verklaring uit het vooronderzoek een volledig uitgewerkt vonnis vergeten. Hij kan - ook indien hij appel instelt - slechts uit de in het vonnis opgenomen verwijzing naar de bewijsmiddelen opmaken, uit welke verklaringen de bewezenverklaring in eerste aanleg kan worden gedestilleerd. Echter, welke gedeeltes uit die verklaringen nu voor de rechter in eerste aanleg doorslaggevend waren, en welke delen buiten beschouwing zijn gelaten, blijft voor hem onduidelijk. Problematisch is bovendien dat niet is vereist dat alle feiten en omstandigheden die uit die bewijsmiddelen blijken, voldoen aan de wettige eisen. ${ }^{184}$ Zo mogen - indien bijvoorbeeld naar een proces-verbaal van aangifte en naar een bekennende verklaring van de verdachte wordt verwezen - in deze verklaringen feiten en omstandigheden blijven staan die niet door degene die de verklaring aflegt zelf zijn ondervonden of waargenomen (bijvoorbeeld: gissingen en conclusies). Eveneens mogen in deze verklaringen passages voorkomen waarin feiten en omstandigheden worden genoemd die voor de bewezenverklaring in zijn geheel niet relevant zijn of - sterker nog - daarmee in strijd zijn.

Een meer algemeen bezwaar tegen het niet uitwerken van het vonnis met de bewijsmiddelen in geval van een bekennende verklaring afgelegd tijdens het vooronderzoek, is gelegen in de nadruk die komt te liggen op de bekentenis. Al bij eerdere voorstellen om in geval van een bekennende verdachte de procedure aanmerkelijk te vereenvoudigen ${ }^{185}$ is gewezen op de problemen die in dat geval rijzen: wat heeft de verdachte bekend, betreft het een volledige bekentenis van het tenlastegelegde feit, op welke wijze is deze bekentenis tot stand gekomen, en wat is in zijn algemeenheid de diagnostische waarde van de bekentenis? ${ }^{186}$ Bovendien kan een dergelijke koppeling van procedurele vereenvoudiging aan

raadsman op enige wijze vrijspraak heeft bepleit, dan is toepassing van art. 359, derde lid, Sv uitgesloten. Zie HR 7 november 2006, NJ 2007, 108 m.nt. Y. Buruma en HR 18 april 2006, NJ 2006, 645 m.nt. T.M. Schalken. In deze laatste zaak had de verdachte een bekennende verklaring afgelegd. De raadsman had ter zitting vrijspraak bepleit van het primair tenlastegelegde omdat er zijns inziens geen sprake was van medeplegen, maar van medeplichtigheid. Het hof legde dit verweer naast zich neer en meende dat het ondanks dat verweer kon volstaan met een opgave van de bewijsmiddelen. De Hoge Raad achtte dit niet toelaatbaar.

184 Kamerstukken II 2003-2004, 29255, nr. 3, p. 14.

185 Het wetsvoorstel tot wijziging van het Wetboek van Strafvordering, Kamerstukken II 1985-1987, 19488. Dit voorstel werd ingetrokken op 19 oktober 1993, omdat door de Commissie Herijking Wetboek van Strafvordering (de commissie-Moons) een nieuw voorstel aangaande een vereenvoudigde procedure voor de bekennende verdachte was gedaan. Corstens 1993, p. 93 e.v.

186 De verschillende bijdragen in de bundel: M. Hildebrandt (red.), Een afzonderlijke procedure voor de bekennende verdachte?, Arnhem: Gouda Quint 1993. 
de bekentenis tot gevolg hebben dat het opsporingsonderzoek nog meer dan thans het geval is, gefocust is op het verkrijgen van een bekentenis van de verdachte, met alle gevolgen van dien. De Puttense moordzaak is in deze een 'mooi' voorbeeld: het verhoren van de verdachten met het oog op het verkrijgen van een bekennende verklaring had in die zaak een zodanige prioriteit dat het technisch onderzoek bijna volledig werd vergeten. ${ }^{187}$ Ook de Schiedammer parkmoord heeft aangetoond dat de gerichtheid op het verkrijgen van een bekentenis de kwaliteit van het totale opsporingsonderzoek ernstig aantast. In die zaak waren politie en justitie zo zeer overtuigd van de betrokkenheid van de verdachte dat men ontlastende feiten uit het oog verloor en vergat ook andere aanwijzingen die wezen op een andere verdachte nader te onderzoeken. In plaats daarvan richtte men zich volledig op het verhoor van de eerste verdachte, Kees B., die inderdaad tijdens twee van de vele verhoren bekende. Het verweer dat hij door de politie onder druk was gezet om te bekennen, werd niet serieus genomen. Achteraf bekende de werkelijke dader, Wik H., en daarmee was een gerechtelijke dwaling een feit. ${ }^{188}$

Beide zaken maken duidelijk dat het hechten van te veel belang aan de bekentenis kan leiden tot het gebruik van ongeoorloofde verhoormethodes. ${ }^{189}$ Dat kan vervolgens weer leiden tot een onvolledige en zelfs tot een onjuiste feitenvaststelling. Het is dan ook niet zonder reden dat sommigen zelfs bepleiten de bekentenis als bewijsmiddel te schrappen. ${ }^{190}$

\subsubsection{Bekennende verdachten en het negatief-wettelijk bewijsstelsel}

Tegen de in 2005 ingevoerde wijziging kan aldus worden ingebracht dat zij te weinig oog heeft voor de betrekkelijke waarde van een bekentenis. Daarenboven heeft de wijziging tot gevolg dat voor bekennende verdachten wordt gebroken met het in Nederland geldende negatief-wettelijk bewijsstelsel.

Weliswaar blijven ten aanzien van de bekennende verdachte formeel de bewijsrechtelijke minimumregels zoals die in ons negatief-wettelijk bewijsstelsel gelden van kracht, maar controle op de naleving van die regels is onmogelijk aangezien de feitenrechter niet langer de inhoud van de gebezigde bewijsmiddelen in het vonnis hoeft op te nemen. Een verwijzing is voldoende, en uit de memorie van toelichting blijkt dat het niet problematisch wordt geacht als in het bewijs-

187 Blaauw 2002, p. 309-310.

188 Zie voor een uitgebreide analyse van de fouten tijdens het onderzoek in deze zaak: F. Posthumus, Evaluatieonderzoek in de Schiedammer parkmoord, Amsterdam: aug. 2005 $<$ http://www.om.nl/schiedammer_parkmoord/ > . Reeds eerder in 2003 had Van Koppen gewezen op verschillende fouten in het opsporingsonderzoek. Zie Van Koppen 2003a.

189 In gelijke zin: Naeyé 1993, p. 54-55 : 'Het geeft (...) een nieuwe impuls aan het gevoel van de verhorende politieambtenaar dat de verdachte in beginsel behoort te bekennen, en als hij dat niet doet daarbij een handje geholpen mag worden.'

190 Wagenaar 2006, p. 219-220. 
materiaal waarnaar wordt verwezen ook passages voorkomen die niet aan de wettelijke eisen voldoen. ${ }^{191}$

Het is de vraag in hoeverre deze wetswijziging ertoe zal leiden dat in die gevallen waarin naar het oordeel van de strafrechter de verdachte bekend heeft, zijn aandacht voor de bewezenverklaring verslapt. Zal de strafrechter, die constant onder tijdsdruk werkt, niet in de verleiding komen om in zaken van bekennende verdachten de bewezenverklaring maar aan te nemen? En wordt die verleiding niet groter naar mate de mogelijkheden om in hoger beroep of cassatie dat oordeel inhoudelijk te toetsen verdergaand worden beperkt? De mogelijkheid om in cassatie de wettigheid, redengevendheid en genoegzaamheid van het bewijsmateriaal te toetsen, is zo goed als uitgesloten. Op welk bewijsmateriaal de feitenrechter zijn oordeel baseert, blijft immers onduidelijk, waardoor ook niet is na te gaan welke delen wel en welke delen niet aan de in de wet gestelde eisen moeten voldoen. Feitelijk betekent dit dat de in het Wetboek van Strafvordering gestelde eisen ten aanzien van het bewijs niet gelden voor bekennende verdachten. Daarmee is ten aanzien van deze groep verdachten als het ware een vrij bewijsstelsel gecreëerd. Eerdere wetsvoorstellen waarin voor bekennende verdachten een aparte procedure werd gecreëerd die tot dezelfde uitkomst leiden, waren niet aanvaardbaar. ${ }^{192}$ Inmiddels is echter in art 359 lid $3 \mathrm{~Sv}$ - weliswaar via een omweg - alsnog een aparte procedure voor de bekennende verdachte gecreëerd.

\subsubsection{Efficiency}

Zoals gezegd is de mogelijkheid om te volstaan met het opnemen van een summiere bewijsconstructie in het vonnis van de bekennende verdachte ingegeven door efficiencyoverwegingen. De vraag is echter of de doorgevoerde wijziging wel zo efficiënt is. Uit onderzoek van het WODC blijkt dat in 2001 in $42,3 \%$ van alle appelzaken hoger beroep is ingesteld door een bekennende verdachte. ${ }^{193}$ In al deze gevallen - 3700 zaken - hoeven dus de bewijsmiddelen niet door de rechtbank in eerste aanleg te worden uitgewerkt. Dat levert op zich een redelijke werkbesparing op. Echter, in deze berekening is een aantal belangrijke aspecten niet meegenomen.

Ten eerste zou de wijziging van artikel 359 lid $3 \mathrm{~Sv}$ wel eens mee kunnen brengen dat minder verdachten het feit bekennen, althans een eerdere belastende verklaring

191 Kamerstukken II 2003-2004, 29255, nr. 3, p. 14.

192 Zie aangehaalde voorstellen in noot 186.

193 M. Jacobs, Bekennen en ontkennen van verdachten; een onderzoek naar de proceshouding van verdachten naar aanleiding van het wetsvoorstel strekkende tot een vereenvoudigde bewijsmotivering bij bekennende verdachten, Den Haag: WODC 2004, <http://www. wodc.nl/>. Uit het onderzoek blijkt dat $6,6 \%$ van alle in eerste aanleg bekennende verdachten hoger beroep aantekent tegen het vonnis. 
intrekken. Het ligt voor de hand om te veronderstellen dat nog vaker dan nu, de verdachte zal worden aangeraden om alsnog te ontkennen (waarbij hij dan het risico loopt dat zijn verklaring als kennelijk leugenachtig wordt aangemerkt), of te zwijgen en vrijspraak te bepleiten, enkel om zo alsnog een uitgewerkt vonnis te verkrijgen. In dat geval zal geen tijdwinst worden geboekt en schiet het voorstel dus zijn primaire doel - een grotere efficiëntie van de strafprocedure - voorbij. In geval van een gedeeltelijke bekentenis is hierboven reeds erop gewezen dat de werkbesparing in eerste aanleg nogal dubieus is.

Ten tweede kan de mogelijk in eerste aanleg geboekte tijdwinst weer verloren gaan tijdens de behandeling in hoger beroep. In geval de verdachte of het Openbaar Ministerie hoger beroep instelt zal, zoals hierboven uiteengezet, uit het vonnis de exacte bewijsconstructie van de strafrechter in eerste aanleg niet te achterhalen zijn. Dit betekent dat ook het gerechtshof niet zal weten welke delen uit de opgegeven bewijsmiddelen de rechtbank voor ogen had, toen hij oordeelde dat het aan verdachte tenlastegelegde feit bewezen was. Voor het hof betekent dit een aanzienlijke taakverzwaring in die gevallen waarin de verdachte bij de behandeling van het hoger beroep zijn eerdere bekentenis weerspreekt. Immers het nieuwe artikel 359 lid $3 \mathrm{~Sv}$ is ingevolge art $415 \mathrm{~Sv}$ ook van toepassing op de behandeling in hoger beroep. Wordt door de verdachte in hoger beroep een niet bekennende verklaring afgelegd of wordt door hem of zijn raadsman vrijspraak bepleit, dan moet in het schriftelijke vonnis de bewijsconstructie worden uitgewerkt, en kan niet volstaan worden met een opgave van de bewijsmiddelen in de zin van het voorgestelde artikel 359 lid $3 \mathrm{~Sv}$. Evenmin kan met een opgave worden volstaan indien het hof in tegenstelling tot de rechtbank van mening is dat er van een bekennende verklaring van de verdachte in de zin van het voorgestelde artikel 359 lid $3 \mathrm{~Sv}$ geen sprake is. Waar de gerechtshoven nu het vonnis en het daarin opgenomen bewijsmateriaal als een soort spoorboekje voor de behandeling in hoger beroep kunnen gebruiken, wordt - indien het wetsvoorstel tot wet wordt verheven - van de hoven verwacht dat zij zelf het relevante en wettige bewijsmateriaal uitzoeken.

Tot slot kan er nog op worden gewezen dat de regeling zelf ook extra werk met zich kan brengen. Immers, de verdachte die meent dat zijn verklaring ten onrechte als bekentenis is aangemerkt, vindt daarin een grond om tegen het vonnis hoger beroep en/of cassatie in te stellen. Het aantal gevallen waarin de regeling tot cassatie zal leiden, achtte de minister in de memorie van toelichting klein. ${ }^{194}$ De kans dat een 'gaaf' bekennende verdachte in cassatie tegen de bewijsconstructie zal ageren is inderdaad niet groot, maar toch zeker niet uitgesloten. In geval van een gedeeltelijke bekentenis is echter de kans dat in cassatie door de verdachte wordt geklaagd over de bewijsconstructie bepaald niet ondenkbaar. Bijvoorbeeld

194 Kamerstukken II 2003-2004, 29255, nr. 3, p. 11. 
omdat hij van mening is dat ten onrechte een door hem afgelegde verklaring als bekennend is aangemerkt, of aan de verklaring een veel verdergaande strekking is toegekend, dan de verdachte zelf voor ogen stond op het moment dat hij de verklaring aflegde. Het enkele feit dat in dat geval is volstaan met een opgave van de bewijsmiddelen, kan dan reden zijn om in cassatie te gaan. De vraag is of al die kostbare tijd niet beter besteed kan worden aan het gewoon uitwerken van de bewijsmiddelen in plaats van aan gesteggel over de vraag of er al dan niet een bekennende verklaring ligt. Schalken heeft deze vraag bevestigend beantwoord:

'In deze tijd waarin het maatschappelijk belang van inzicht in rechterlijke overwegingen zo wordt benadrukt, is het bijna beschamend om te lezen hoe juristen zich druk maken over de vraag wat een verdachte in zo'n ernstige zaak nu precies heeft bekend, niet om op basis daarvan de bewijsconstructie zorgvuldig uit te werken, neen, integendeel, juist om te bereiken dat niet te hoeven doen., ${ }^{19}$

\subsubsection{Geen aanvulling van het vonnis in eerste aanleg}

Een volgende uitzondering op het bepaalde in artikel $359 \mathrm{lid} 3 \mathrm{~Sv}$ is niet het gevolg van activiteiten van de wetgever, maar wordt zichtbaar in de rechtspraak. Sommige feitenrechters menen dat ook in geval de verdachte hoger beroep heeft ingesteld tegen het vonnis in eerste aanleg, dit geen verplichting tot aanvulling van het verkorte vonnis met zich brengt. ${ }^{196} \mathrm{Zij}$ baseren zich daarbij op de uitspraak van het Europese Hof voor de rechten van de mens in de zaak Zoon en de op basis daarvan gewezen uitspraak van de Hoge Raad. Eén van de argumenten die het Europese Hof voor de rechten van de mens hanteerde om in de zaak Zoon geen schending van artikel 6 EVRM aan te nemen, was gelegen in het feit dat in Nederland de behandeling in hoger beroep een volledige nieuwe feitenbehandeling omvat. Voor het effectief gebruik kunnen maken van dit rechtsmiddel is dus niet noodzakelijk dat de verdachte beschikt over een volledig uitgewerkt vonnis in eerste aanleg. Niet het vonnis in eerste aanleg staat bij de behandeling in hoger beroep centraal, maar het aan de verdachte gemaakte verwijt ten aanzien waarvan in hoger beroep opnieuw zal moeten worden beoordeeld of dat - zowel in feitelijke als in juridische zin - terecht wordt gemaakt.

In een Antilliaanse zaak leidde de Hoge Raad uit dit standpunt van het Europese Hof voor de rechten van de mens af dat voor de behandeling in hoger beroep het bestaan van een goed gemotiveerd vonnis in eerste aanleg niet noodzakelijk was. Hij overwoog:

195 Annotatie van Schalken bij HR 18 april 2006, NJ 2006, 645.

196 Zie daarover uitgebreid $\S$ 4.4.4. 
'dat de behandeling in hoger beroep er mede toe strekt in eerste aanleg begane fouten en verzuimen te herstellen, zodat ook het eerste, vanuit een oogpunt van motivering gebrekkige, vonnis kan worden vernietigd en vervangen door een vonnis dat in dat opzicht wel aan de geldende motiveringseisen voldoet, terwijl voorts naar in het oordeel van het Hof besloten ligt, niet kan worden gezegd (...) dat voor wat betreft de behandeling in hoger beroep het enkele ontbreken van de bewijsmiddelen in het vonnis in eerste aanleg ertoe leidt dat geen sprake is van 'adequate time and facilities' voor de voorbereiding van de verdediging en van een 'fair trial' als bedoeld in art. 6 , eerste lid, EVRM., ${ }^{197}$

Het is waarschijnlijk deze uitspraak waarop Van Dijk en Croll doelen als zij beweren dat voor een rechtsgeldige bewijsconstructie niet noodzakelijk is dat de relevante passages van het gebruikte bewijs in het vonnis worden weergeven. ${ }^{198}$ Voldoende is volgens hen dat het vonnis in eerste aanleg verwijst naar die passages. Daarbij zien zij mijns inziens echter voorbij aan het feit dat het hier een Antilliaanse zaak betrof. In het Antilliaanse Wetboek van Strafvordering worden ten aanzien van het vonnis dezelfde eisen gesteld als ten aanzien van het Nederlandse. Ook daar dient de inhoud van de bewijsmiddelen in het vonnis te worden opgenomen. Maar in tegenstelling tot de Nederlandse strafvordering kent het Antilliaanse strafprocesrecht niet de mogelijkheid van een verkort vonnis. Waar in Nederland wel de mogelijkheid bestaat om in eerste instantie te volstaan met een vonnis waarin de bewijsmiddelen ontbreken, zou de tolerantie van de Hoge Raad in Nederlandse strafzaken wel eens minder kunnen zijn. In artikel 365a lid $2 \mathrm{~Sv}$ is immers expliciet bepaald dat in geval hoger beroep wordt ingesteld het vonnis moet worden aangevuld met de inhoud van de bewijsmiddelen.

Dat neemt niet weg dat inmiddels een aantal gerechtshoven de bovengenoemde uitspraak van de Hoge Raad veel ruimer interpreteert. Tot voor kort werd in geval het vonnis niet was uitgewerkt met de bewijsmiddelen de strafzaak niet geappointeerd. Uit verschillende uitspraken blijkt echter dat bepaalde gerechtshoven menen dat een onvolledig vonnis op dit punt niet langer meer aan de behandeling in hoger beroep in de weg staat. Het Hof Den Bosch vernietigt simpelweg uitspraken die niet voldoen aan de eis van artikel 359 lid $3 \mathrm{~Sv}$ en stelt daarvoor zijn eigen uitspraak in de plaats. ${ }^{199}$ Ook het Hof Arnhem lijkt zich - weliswaar met tegenzin - die richting uit te bewegen.

'In het algemeen is het zeker bij een ontkennende verdachte van wezenlijk belang dat het vonnis een bewijsconstructie bevat en dat dus de bewijsmiddelen worden aangevuld. Het hof acht het in de onderhavige complexe zaak die veel publiciteit heeft gehad onjuist dat er geen aanvulling met bewijsmiddelen is opgemaakt. Het

197 Hoge Raad 8 april 2003, NJ 2003, 433.

198 Van Dijk \& Croll 2003, p. 1864.

199 Hof Den Bosch 25 juni 2004, LJN AQ4440; Hof Den Bosch 23 juni 2004, LJN AP3696; Hof Den Bosch 18 juni 2004, LJN AP3706 en Hof Den Bosch 23 juni 2004, LJN AP3589. Hierover nader: Dreissen 2006a. 
hof komt echter, gelet op het hieronder staande, niet tot conclusie dat in dit stadium van het strafproces reeds schending van artikel 6 EVRM heeft plaatsgevonden.

Het hof constateert dat het vonnis van de rechtbank weliswaar de inhoud van de bewijsmiddelen niet bevat, maar dat in het vonnis wel een uitvoerige motivering is opgenomen met verwijzing naar de onderliggende bewijsmiddelen. Voorts is noch door de advocaat-generaal, noch zijdens de verdediging verzocht om de zaak aan te houden om de rechtbank alsnog in de gelegenheid te stellen de bewijsmiddelen aan te vullen. Gelet op het voorgaande kan naar het oordeel van het hof volstaan worden met vernietiging van het vonnis van de rechtbank. ${ }^{200}$

Indien deze opvatting door de Hoge Raad wordt overgenomen, betekent dit dat daarmee de waarborg voor de verdachte dat hij door middel van het vonnis op eenvoudige wijze kennis kan nemen van het belastende materiaal voorgoed aan de kant wordt gezet. Daarmee worden rechtbanken ontslagen van hun plicht om ambtshalve inzicht te geven in de bewijsconstructie. Slechts indien de verdachte erom vraagt, kan dit wellicht anders zijn. ${ }^{201}$ Bovendien heeft een dergelijke uitleg tot gevolg dat in die gevallen waarin de verdachte ook in hoger beroep wordt veroordeeld én hij geen cassatie instelt hij nooit zal weten op welk bewijsmateriaal de bewezenverklaring steunt.

Waar er reeds nu argumenten zijn om de door de hoven gehanteerde interpretatie als 'contra legem' aan te merken, zal, zoals hiervoor reeds gesteld, dat zeker het geval zijn zodra de wet 'stroomlijnen hoger beroep' in werking treedt. Uitgaande van het voortbouwende karakter van het hoger beroep dat in die wet is neergelegd, kan een behandeling in appel niet aanvangen zonder dat procespartijen en het hof op de hoogte zijn van het vonnis en de daaraan ten grondslag liggende overwegingen met betrekking tot het bewijs. In een voortbouwend appel is immers het vonnis in eerste aanleg het vertrekpunt voor de behandeling in hoger beroep.

\subsubsection{Het vermelden van de inhoud van de bewijsmiddelen in het project Promis}

In de jaren 2004 en 2005 liep in het ressort Arnhem het Project Motiveringsverbetering in strafvonnissen, beter bekend onder de afkorting Promis. Het doel van dit project was om met gelijkblijvende inzet van mensen en middelen te komen tot een verbetering van de kwaliteit van de vonnissen. ${ }^{202}$ De verbetering zou het gevolg moeten zijn van een meer toegespitste motivering van de bewijsbeslissing en de straftoemeting. Het project is in 2006 geëvalueerd en daarbij is tevens besloten dat het proefproject zal worden voortgezet en worden uitgebreid. De

200 Hof Arnhem 12 oktober 2005, LJN AU4229.

201 Van Dijk \& Croll 2003, p. 1864 menen zelfs dat los van de proceshouding van de verdachte er geen noodzaak bestaat tot het volledig uitwerken van een vonnis.

202 Promis evaluatierapport 2005, p. 3. 
tweede fase van het project staat bekend als Promis II en is in oktober 2006 van start gegaan.

In het project wordt uitgegaan van de idee van 'motivering op maat', hetgeen betekent dat beslissingen slechts gemotiveerd hoeven te worden als die punt van discussie waren tijdens de behandeling ter terechtzitting. Het sluit daarbij aan bij de uitgangspunten van de Onderzoeksgroep Strafvordering 2001, die ook ten grondslag liggen aan de wijziging van artikel $359 \mathrm{~Sv}$ waarin in geval van een bekennende verdachte kan worden volstaan met een opgave van de bewijsmiddelen.

In Promis-vonnissen is echter het achterwege laten van de inhoud van de bewijsmiddelen niet beperkt tot de gevallen waarin de verdachte bekent. In principe wordt in het kader van het project in geen enkel vonnis de inhoud van de bewijsmiddelen vermeld zoals dat thans gebruikelijk is. Afhankelijk van de opstelling van de procespartijen kan worden gedifferentieerd tussen een kale, een korte of een uitgebreide motivering. Een kale motivering kan volstaan in geval de verdachte bekent en geen verweer voert. In dergelijke gevallen bevat het vonnis niet meer dan een korte weergave van hetgeen bewezen wordt geacht en een korte vermelding van de bewijsmiddelen waaronder de bekentenis van de verdachte. In wezen sluit dit aan bij de eisen die thans ook op basis van artikel 359 lid $3 \mathrm{~Sv}$ worden gesteld aan een bewezenverklaring in geval van een bekennende verdachte. Een korte motivering is op zijn plaats indien de verdachte weliswaar ontkent, maar geen specifieke en onderbouwde verweren voert. De motivering van de bewezenverklaring bestaat dan uit een weergave van de door de rechtbank dan wel het hof vastgestelde feiten met een vermelding van de vindplaats van die feiten. ${ }^{203}$ Wordt evenwel het bewijs in de strafzaak betwist of zijn er andere redenen om meer nadrukkelijk op het bewijs in te gaan, dan volgt een uitgebreide motivering van de bewezenverklaring. In tegenstelling tot hetgeen thans gebruikelijk is, wordt die motivering reeds gegeven in het verkorte vonnis en wordt dus niet gewacht tot het moment dat een van de betrokken partijen een rechtsmiddel heeft ingesteld. De uitgebreide motivering bestaat uit de bewezenverklaring, een aanduiding van de bewijsmiddelen, een gemotiveerde bewezenverklaring met verwijzing naar de bewijsmiddelen en een nadere motivering naar aanleiding van hetgeen ter zitting is aangevoerd.

De gevallen waarin wordt geopteerd voor een uitgebreide motivering zijn divers. Ze sluiten deels aan bij de bestaande wettelijke en in de jurisprudentie erkende motiveringsplichten, maar zijn niet beperkt tot die gevallen waarin namens een van de partijen op dat punt een uitdrukkelijk en goed onderbouwd standpunt is ingenomen. ${ }^{204}$ De Promis-rechter zal in bepaalde gevallen ambtshalve tot een

203 Deze vorm is als zodanig in de voortzetting van het project (Promis II) niet meer terug te vinden.

204 Een nadere ambtshalve bewijsmotivering was in het eerste deel van het project vereist bij: het deels ontkennen (van het opzet) door de verdachte; het gebruik van voorwaardelijk 
uitgebreidere motivering van de bewezenverklaring moeten overgaan en ook indien bijvoorbeeld het verweer van de verdediging niet goed onderbouwd is, zal hij daarin aanleiding moeten zien om niet te volstaan met een korte bewijsmotivering. Op dat punt zal nog nader worden ingegaan in hoofdstuk 6.

Voor hetgeen in dit hoofdstuk centraal staat, te weten het vermelden van de inhoud van de bewijsmiddelen, is van belang dat in het kader van het project Promis bewust is gekozen voor een meer inhoudelijke motivering van de bewezenverklaring in plaats van het uitwerken van de bewijsmiddelen. Daarmee zijn promisvonnissen in strijd met de letterlijke bewoordingen van artikel 359 lid $3 \mathrm{~Sv}$. Artikel 359 lid $3 \mathrm{~Sv}$ stelt immers als eis dat in het vonnis de inhoud van de bewijsmiddelen wordt opgenomen voor zover de bewezenverklaring daarop steunt. Daar staat echter tegenover dat de uitgebreide promis-vonnissen altijd - ook indien geen rechtsmiddel wordt ingesteld - een gemotiveerde bewezenverklaring moeten bevatten, waarin een verwijzing naar de bewijsmiddelen is opgenomen. Dat betekent dat verdachten maar ook anderen veel vaker inzicht krijgen in de bewezenverklaring. Bovendien meent ook de toetsingscommissie van het project dat:

'de gedachtegang van de rechter ten aanzien van de bewijsconstructie in de PROMISvonnissen beter te volgen is dan in de huidige situatie het geval is. Dat geldt niet alleen ten opzichte van het huidige verkort vonnis, maar ook ten opzichte van het vonnis na uitwerking van de bewijsmiddelen. ${ }^{, 205}$

Dat neemt niet weg dat diezelfde toetsingcommissie ook opmerkte dat het niet uitwerken van de bewijsmiddelen in sommige gevallen ${ }^{206}$ als een gemis werd ervaren. Het ontbreken van de inhoud van de bewijsmiddelen leidde er soms toe dat men geen helder beeld kon krijgen van de bewijsconstructie. Dit punt kwam ook duidelijk naar voren in de evaluatie. $60 \%$ van de ondervraagde advocaten in wier zaak een promis-vonnis was gewezen, vond het bezwaarlijk dat de bewijsmiddelen niet werden uitgeschreven. Slechts $7 \%$ van de officieren van justitie dacht er net zo over. Deze bevindingen hebben ertoe geleid dat de suggestie van de toetsingscommissie om in geval van een uitgebreide motivering ook een samenvatting van de bewijsmiddelen in het vonnis op te nemen bij de voortzetting van het project is gevolgd.

Tegen het volstaan met een samenvatting van de bewijsmiddelen kan worden aangevoerd dat daarmee de exacte inhoud van de gebezigde bewijsmiddelen niet in het vonnis tot uitdrukking komt. Daarmee blijft onduidelijk of de inhoud

opzet, tegenstrijdigheden tussen verschillende verklaringen of innerlijke tegenstrijdigheid van een verklaring; de aanwezigheid van ontlastende verklaringen of ander ontlastend materiaal; het gebruik van ingetrokken (getuigen)verklaringen; bestrijding van de betrouwbaarheid van de getuigenverklaring; het gebruik maken van schakelbewijs en een uitgebreide discussie in raadkamer. Promis Evaluatierapport 2005, p. 22. Dit lijstje is bijna ongewijzigd overgenomen in het vervolgtraject. Zie Promis II projectplan 2006, bijlage V en I.

205 Promis Evaluatierapport 2005, p. 62.

206 In 13 vonnissen en 14 arresten. 
voldoet aan de eisen die de wet stelt. Is bijvoorbeeld hetgeen de getuige zegt gebaseerd op eigen waarneming of ondervinding? Bovendien kunnen tussen de verklaring zoals die ter zitting is afgelegd of is opgenomen in het proces-verbaal van politie en de wijze waarop die verklaring wordt gebezigd, discrepanties bestaan die nu niet in het vonnis zichtbaar worden. Denaturering van verklaringen en andere onderzoeksresultaten is minder zichtbaar, zowel voor degene die het vonnis opstelt als voor degene voor wie het vonnis bedoeld is.

Op 15 mei 2007 heeft de Hoge Raad de onduidelijke status van de zogeheten promis-vonnissen verhelderd. ${ }^{207}$ Dit gebeurde naar aanleiding van twee verzoeken tot cassatie in belang der wet ingediend door procureur-generaal Fokkens. Het volstaan met een verwijzing naar de wettelijke bewijsmiddelen in plaats van het opnemen van de redengevende inhoud van de bewijsmiddelen is naar het oordeel van de Hoge Raad niet in strijd met art. 359, derde lid, Sv. Een op die manier vormgegeven uitspraak kan de inzichtelijkheid van de door de rechter gevolgde gedachtengang (de explicatiefunctie) ten goede komen, terwijl niet op voorhand is uitgesloten dat aan de andere functie, te weten de controlefunctie, tekort wordt gedaan. Teneinde te kunnen garanderen dat het bewijsoordeel van de rechter steunt op redengevende feiten en omstandigheden die zijn ontleend aan wettige bewijsmiddelen, stelt de Hoge Raad twee nadere voorwaarden. Het volstaan met een verwijzing naar de bewijsmiddelen is niet toegestaan ingeval van indirecte bewijsconstructies en bovendien moet de verwijzing voldoende nauwkeurig zijn, opdat controle op de wettigheid van het bewijs kan plaatsvinden:

'Dat in die werkwijze de redengevende inhoud van een bewijsmiddel (...) zakelijk wordt samengevat, is op zichzelf niet onverenigbaar met genoemd motiveringsvoorschrift. Daarbij zal uiteraard de redengevend geachte inhoud van het bewijsmiddel geen geweld mogen worden aangedaan. Wel zullen de redengevende feiten en omstandigheden moeten worden onderscheiden van gevolgtrekkingen - geheel of ten dele van feitelijke aard - die de rechter aan die feiten en omstandigheden verbindt. Waar met een dergelijke gevolgtrekking wordt volstaan zonder dat de onderliggende redengevende feiten en omstandigheden worden opgenomen, is aan het wettelijk motiveringsvereiste niet voldaan. In dit verband moet ook worden benadrukt dat het bij deze werkwijze noodzakelijk is dat de verwijzing naar de wettige bewijsmiddelen waaraan de redengevende feiten en omstandigheden zijn ontleend, zo nauwkeurig is dat kan worden beoordeeld of de bewezenverklaring in toereikende mate steunt op de inhoud van wettige bewijsmiddelen en of de samenvatting geen ongeoorloofde conclusies of niet redengevende onderdelen inhoudt dan wel of het bewijsmiddel niet is gedenatureerd. ${ }^{208}$

In de eerste zaak waarin cassatie in het belang der wet was ingesteld, oordeelde de Hoge Raad dat het enkel samenvatten van de verklaringen van de getuigen

207 HR 15 mei 2007, LJN BA0424

208 HR 15 mei 2007, LJN BA0424 (r.o. 5.6.1) en HR 15 mei 2007, LJN BA0425 (r.o. 5.6). 
DE WEERGAVE VAN DE INHOUD VAN DE BEWIJSMIDDELEN

geen problemen opleverde. ${ }^{209}$ Ten aanzien van het bewijsmiddel waarbij dat op het eerste gezicht niet evident was - de verklaring van het slachtoffer - liet de Hoge Raad blijken dat hij wel degelijke de wettelijke eisen had gecontroleerd door de volledige inhoud van het bewijsmiddel alsnog in het arrest op te nemen. Daarmee deed de Hoge Raad feitelijk datgene wat op grond van de letterlijke tekst van artikel 359 lid $3 \mathrm{~Sv}$ het Hof had moeten doen. Dat roept de vraag op wat de toegevoegde waarde is van de werkwijze van het Hof, als vervolgens in cassatie de ontbrekende delen alnog worden aangevuld.

In de tweede zaak casseerde de Hoge Raad wel. ${ }^{210}$ De verwijzing naar de bewijsmiddelen was onvoldoende specifiek. In casus werd verwezen naar een procesverbaal bestaande uit een zevental pagina's, waaruit - ergens - zou moeten blijken dat de verdachten op de hoogte waren van de aanwezigheid van hennepplanten in een bepaalde woning.

Uit beide uitspraken zou kunnen worden afgeleid dat de Hoge Raad ruimte wilt geven aan het project Promis zonder tekort te doen aan de wettelijke eisen die aan het bewijs worden gesteld. Dat betekent dat het weergeven van de inhoud van de bewijsmiddelen kan bestaan uit het aanduiden van de essentie van de bewijsmiddelen met een verwijzing naar die bewijsmiddelen. Daarmee lijkt het pas sinds 1 januari 2005 opgenomen onderscheid tussen bekennende en niet bekennende verdachten te worden doorbroken. In beide gevallen kan immers worden volstaan met een verwijzing naar de bewijsmiddelen. Het enige verschil is dat in geval van een bekennende verdachte daarmee kan worden gewacht tot in het verkort vonnis, dus nadat appel is ingesteld. De niet-bekennende promis-verdachte heeft reeds zonder dat hij een rechtsmiddel heeft ingesteld recht op een verkorte weergave van de gebruikte bewijsmiddelen.

\subsection{Conclusie}

De thans in artikel 359 lid $3 \mathrm{~Sv}$ opgenomen motiveringseis, inhoudende dat in het vonnis de inhoud van de bewijsmiddelen moet worden opgenomen, had tot doel controle op de wettigheid van de gebezigde bewijsmiddelen en de redengevendheid en genoegzaamheid van de daarin opgenomen feiten mogelijk te maken. Bovendien biedt opneming van de inhoud van de bewijsmiddelen in het vonnis de verdachte de mogelijkheid om op eenvoudige wijze kennis te nemen van het hem belastende materiaal. De Hoge Raad achtte dat een wezenlijke waarborg, die bij niet inachtneming tot vernietiging van het vonnis moest leiden.

In het merendeel van de gevallen ziet de verdachte echter de tegen hem sprekende feiten niet in het vonnis terug. De waarborg die het derde lid van artikel $359 \mathrm{~Sv}$

209 HR 15 mei 2007, LJN BA0424.

210 HR 15 mei 2007, LJN BA0425. 
de verdachte beoogde te bieden, heeft het in veel gevallen af moeten leggen tegen efficiencyoverwegingen. De alleensprekende rechter kan volstaan met een mondeling vonnis waarvan hij slechts kort aantekening hoeft te maken. In die aantekening ontbreken de bewijsmiddelen. De meervoudige kamers kunnen in eerste instantie volstaan met een verkort vonnis waarin eveneens de bewijsmiddelen en bewijsoverwegingen mogen ontbreken. Slechts nadat tegen het vonnis een rechtsmiddel is ingesteld, moet het vonnis worden aangevuld. In geval van een (gedeeltelijk) bekennende verdachte mag in dat geval worden volstaan met een opgave van de bewijsmiddelen. En zelfs in zaken waarin verdachten de bewezenverklaring hebben betwist, wordt in de praktijk het verkorte vonnis niet altijd uitgewerkt, ondanks het feit dat een rechtsmiddel is ingesteld.

Ook in het project-Promis lijkt de waarde van het opnemen van de inhoud van de bewijsmiddelen in het veroordelende vonnis niet te worden onderkend. De rechter mag volstaan met een samenvatting van de inhoud. Een praktijk die ook de Hoge Raad onlangs heeft goedgekeurd.

Wat betekent dit nu? Uitgaande van de gegevens die beschikbaar zijn - te weten die over het jaar $1999^{211}$ - kan worden geconcludeerd dat in minder dan 3\% van de in eerste aanleg behandelde strafzaken in het vonnis de bewijsmiddelen moeten worden opgenomen. Van de 190.000 strafzaken werd slechts in 14.900 gevallen hoger beroep ingesteld. Slechts in die 14.900 zaken moet het verkorte vonnis of de aantekening van het mondelinge vonnis worden uitgewerkt. Echter, 5800 van die zaken zijn kantonrechterzaken. Ingeval van hoger beroep tegen een kantonrechtervonnis kan worden volstaan met een verwijzing naar de bewijsmiddelen in het proces-verbaal van de terechtzitting. Dat betekent dat in deze zaken de inhoud van de bewijsmiddelen ook na het instellen van het hoger beroep niet in het vonnis wordt opgenomen. Als men deze aftrekt van het totale aantal strafzaken waarin hoger beroep is ingesteld, dan resteren nog 9.100 strafzaken waarin in principe het vonnis moet worden uitgewerkt met de weergave van de bewijsmiddelen. Uit het onderzoek van het WODC $^{212}$ blijkt dat 3700 van deze zaken bekennende verdachten betreffen. Hierin kan dus worden volstaan met een opgave van de bewijsmiddelen. Resteren nog 5.400 zaken (minder dan 3\% van het totaal in eerste aanleg behandelde zaken). Een deel daarvan zijn vrijspraken waarop artikel 359 lid $3 \mathrm{~Sv}$ logischerwijze niet van toepassing is. Een ander deel ziet op uitspraken van enkelvoudige kamers die in principe kunnen volstaan met een verwijzing naar de bewijsmiddelen. En tot slot zijn in deze 5400 zaken ook zaken opgenomen waarin de rechtbank contra legem niet

211 Centraal Bureau Statistiek Voorburg/Heerlen, kerncijfers rechtspraak (23 januari 2007) $<$ http://statline.cbs.nl/StatWeb/table.asp?HDR=G1\&LA=n1\&DM=SLNL\&PA=70229ne $\mathrm{d} \& \mathrm{D} 1=\mathrm{a} \& \mathrm{D} 2=\mathrm{a} \& \mathrm{STB}>$.

212 M. Jacobs, Bekennen en ontkennen van verdachten; een onderzoek naar de proceshouding van verdachten naar aanleiding van het wetsvoorstel strekkende tot een vereenvoudigde bewijsmotivering bij bekennende verdachten, Den Haag: WODC 2004, <http://www.wodc.nl/>. 
voldoet aan de wettelijke eis van aanvulling van het verkorte vonnis. Het exacte aantal zaken waarin een vonnis wordt geproduceerd dat voldoet aan de eis van artikel 359 lid $3 \mathrm{~Sv}$ is bij gebrek aan - actuele en precieze - gegevens niet te bepalen. Wel kan worden geconcludeerd dat het aantal vonnissen waarin dus uiteindelijk de inhoud van de bewijsmiddelen wel wordt opgenomen zeer gering is in vergelijking tot die waarin of geen bewijsmiddelen of slechts een verwijzing naar de bewijsmiddelen hoeft te worden opgenomen.

Getalsmatig beschouwd heeft artikel 359 lid 3 dus een zeer beperkte betekenis. Deze door de Hoge Raad wezenlijk geachte waarborg voor de verdachte heeft dus in de praktijk weinig om het lijf en lijkt voor een belangrijk deel slechts een symbolische waarde te hebben. Daar moet tevens bij worden opgemerkt dat de eis die artikel 359 lid $3 \mathrm{~Sv}$ stelt en de wijze waarop daar gevolg aan wordt gegeven vaak de inzichtelijkheid in de bewijsconstructie niet vergroot. De inhoud van de bewijsmiddelen is immers een kwestie van knippen en plakken. Verbanden tussen de verschillende bewijsmiddelen worden niet verduidelijkt. Uit het project verbetering motivering strafvonnissen (Promis) blijkt dat de daar gegeven bewijsmotivering door $77 \%$ van de betrokken advocaten en officieren van justitie als een verbetering werd beschouwd ten opzichte van de gebruikelijke wijze van motivering. De verbetering is evident in vergelijking tot de verkorte vonnissen. Daarin treft men namelijk geen motivering aan met betrekking tot het bewijs. In hoeverre de respondenten hier ook in vergelijking met de uitgewerkte vonnissen een verbetering zagen is niet geheel duidelijk. 38\% gaf wel an het als een gemis te ervaren dat de bewijsmiddelen niet werden uitgeschreven. 



\section{Redengevendheid van het bewijsmateriaal}

\section{$5.1 \quad$ Inleiding}

Een van de inhoudelijke eisen die men aan het bewijs in strafzaken moet stellen, is dat het bewijsmateriaal dat wordt gebruikt relevant is voor die bewezenverklaring. ${ }^{1}$ Dat wil zeggen dat er een logisch verband bestaat tussen de feiten zoals die blijken uit het bewijsmateriaal en de feiten zoals die bewezen zijn. Acht bijvoorbeeld de rechter het opzettelijke handelen van de verdachte bewezen, dan dient hij het bestaan van dat opzet te hebben afgeleid uit feiten die in logische zin aan die vaststelling kunnen bijdragen. De verklaring van de verdachte inhoudende dat hij geen moment erbij heeft stilgestaan dat zijn handelen bij andere personen letsel te weeg zou brengen, kan ook zonder dat men weet heeft van de juridische uitleg van het begrip 'opzet' bij niemand de indruk wekken dat daaruit logisch volgt dat de verdachte het letsel opzettelijk teweeg heeft gebracht. Voor zover dat toch gebeurt, is de eis van relevantie van het bewijsmateriaal uit het oog verloren. ${ }^{2}$ Relevantie van het bewijsmateriaal ziet dus op de relatie tussen hetgeen bewezen moet worden en het daarvoor aangedragen bewijsmateriaal. Het begrip 'relevantie' kan echter ook ruimer worden opgevat. In dat geval kan de relevantie van het bewijsmateriaal ook reeds van belang zijn voor deelbeslissingen, zoals de beoordeling van de betrouwbaarheid van het aangeleverde bewijsmateriaal. Zo kan bijvoorbeeld een verklaring inhoudende dat de getuige geen belang heeft bij het afleggen van een belastende verklaring bijdragen aan de beoordeling van de betrouwbaarheid van die verklaring. Het ontbreken van enig eigen belang bij het afleggen van een belastende verklaring kan derhalve relevant zijn voor de beoordeling van de betrouwbaarheid van de verklaring. Deze ruime betekenis van het begrip 'relevantie' komt men bijvoorbeeld tegen in artikel 4.01 van de Amerikaanse Federal Rules of Evidence:

'Relevant evidence' means evidence having any tendency to make the existence of any fact that is of consequence of the determination of the action more probable or less probable than it would be without the evidence.'

Voor alle duidelijkheid: relevantie en betrouwbaarheid zijn twee verschillende eisen die aan bewijsmateriaal in strafzaken kunnen worden gesteld. Relevantie ziet op de relatie tussen bewijsmateriaal en het bewijsobject. Betrouwbaarheid ziet

1 In gelijke zin: Pradel 2000, p. 424. Hij formuleert een aantal algemene bewijsregels die alle Europese strafrechtssystemen gezamenlijk hebben. De tweede door hem geformuleerde regel betreft de relevantie van het bewijs.

2 HR 18 juni 1996, NJ 1996, 750. In vergelijkbare zin: HR 20 juni 2006, NJ 2006, 358. 
daarentegen op de relatie tussen degene die het bewijsmateriaal gebruikt en het bewijsmateriaal; de mate waarin hij of zij het bewijsmateriaal geloofwaardig acht. ${ }^{3}$ Zo bezien kan relevant bewijsmateriaal onbetrouwbaar zijn en betrouwbaar bewijsmateriaal irrelevant zijn. Het feit dat mijn buurvrouw op maandag mijn dochter in de stad zag, kan relevant zijn voor de vaststelling of mijn dochter die dag heeft gespijbeld van school; het zegt echter niets over de betrouwbaarheid van haar verklaring. Andersom kan het feit dat mijn buurvrouw op maandag mijn dochter in de stad heeft gezien uitermate betrouwbaar zijn, maar irrelevant voor de vraag of mijn dochter op dinsdag heeft gespijbeld. Dat laat onverlet dat voor de vraag of bepaald bewijsmateriaal betrouwbaar is, andere feiten en omstandigheden relevant kunnen zijn. Die feiten en omstandigheden zijn dan niet direct relevant voor het aantonen van het bewijsobject, maar voor de beoordeling van de betrouwbaarheid van het bewijsmateriaal.

In Nederlandse strafrecht komen wij het begrip 'relevantie' zoals opgenomen in de Federal Rules of Evidence niet tegen. Wel wordt in het derde lid van artikel $359 \mathrm{~Sv}$ de eis gesteld dat het door de rechter gebezigde bewijsmateriaal redengevend is voor de bewezenverklaring. Op twee manieren wijkt dit af van het Amerikaanse begrip 'relevancy'. Ten eerste geldt de eis van redengevendheid alleen ten aanzien van een positieve bewijsbeslissing. Alleen voor zover de rechter tot een bewezenverklaring komt, dient het bewijsmateriaal dat hij ten grondslag legt aan die beslissing redengevend te zijn. Komt hij echter tot een vrijspraak, dan hoeft hij dus niet aan te geven of en zo ja, op welke punten het bewijsmateriaal niet redengevend was.

Dit onderscheid vloeit als het ware voort uit het tweede onderscheid: de eis van redengevendheid is in de Nederlandse strafvordering opgenomen als motiveringsvoorschrift. In de Verenigde Staten daarentegen is het een eis die wordt gesteld aan de introductie van bewijsmateriaal ter zitting. Slechts voor zover het aangevoerde bewijs in belastende dan wel ontlastende zin relevant is voor de beoordeling van enige ter zitting te beoordelen kwesties kan het worden toegelaten. Dat betekent dat in de V.S. de relevantie van het bewijsmateriaal een preliminaire vraag is, en dus niet - zoals in Nederland - een kwestie is waarover achteraf enkel in geval van een bewezenverklaring verantwoording moet worden afgelegd. ${ }^{4}$ In tegenstelling tot de V.S. is in Nederland de mate waarin aan de eis van relevantie wordt voldaan sterk afhankelijk van de eisen die men stelt aan de motiveringsplicht van de rechter op dit punt.

In dit hoofdstuk zal worden betoogd dat in Nederland weliswaar de eis van relevantie van het bewijsmateriaal geldt, maar dat aan deze wezenlijke voorwaarde

Schum 1994, p. 66.

Uitgebreid over het verschil tussen bewijsregels als presentatieregels dan wel motiveringsregels: Nijboer 2000a, p. 60-61. 
voor de bewijsbeslissing weinig waarde toekomt, nu rechters op dit punt slechts in uitzonderlijke gevallen expliciet verantwoording hoeven af te leggen. Het gebrek aan verantwoordingsplicht heeft op zijn beurt weer het effect dat de relevantie van het bewijsmateriaal ten onrechte geen inhoudelijk leerstuk is binnen het Nederlandse bewijsrecht. Dit werd overduidelijk toen de Minister van Justitie in 2004 even dreigde de eis van redengevendheid in zijn geheel uit het Wetboek van Strafvordering te schrappen. ${ }^{5}$

\subsection{Aspecten van relevantie}

De eis van relevantie komt in de Nederlandse strafvordering zoals gezegd tot uiting in de motiveringseis zoals die is neergelegd in het derde lid van artikel $359 \mathrm{~Sv}$. Het door de rechter gebezigde bewijs dient redengevend te zijn. Deze eis is echter nergens in het Wetboek gepreciseerd. Uit de memorie van toelichting bij het Wetboek van Strafvordering van 1926 komt slechts de bedoeling van de wetsbepaling naar voren: door het aanwijzen van de redengevende feiten en omstandigheden zou de logische gedachtegang van de rechter in het vonnis tot uitdrukking moeten komen. ${ }^{6}$ Inmiddels is echter de eis van het aanwijzen van de redengevende feiten en omstandigheden geschrapt. De eerste volzin van het derde lid van artikel 359 Sv luidt thans:

'De beslissing dat het feit door de verdachte is begaan, moet steunen op de inhoud van in het vonnis opgenomen bewijsmiddelen, houdende daartoe redengevende feiten en omstandigheden.'

De eis dat de gebezigde bewijsmiddelen redengevende feiten en omstandigheden moeten bevatten, duidt er op dat er een logisch verband moet bestaan tussen het gebezigde bewijsmateriaal en het bewijsobject, de tenlastelegging. Op dit punt kan een drietal aspecten worden onderscheiden.

Ten eerste is het logische verband afhankelijk van de betekenis die wordt toegekend aan de diverse begrippen die in de tenlastelegging worden genoemd. Wordt in

5 De eerste volzin van artikel 359 lid $3 \mathrm{~Sv}$ in het wetsontwerp 'aanpassing eisen motivering bewezenverklaring bekennende verdachte' luidde oorspronkelijk: 'De beslissing dat het feit door de verdachte is begaan, moet steunen op de inhoud van in het vonnis opgenomen bewijsmiddelen.' Uit de memorie van toelichting, Kamerstukken II 2003-2004, 29255, nr. 3, p. 14, blijkt dat de Minister van Justitie inderdaad het belang van de eis van redengevendheid niet zag: 'Ten aanzien van die bewijsmiddelen zou niet langer de strikte eis worden gesteld dat ze slechts redengevende feiten en omstandigheden mogen bevatten. Bevestigd kan worden, dat in het vonnis geen redengevende feiten of omstandigheden meer behoeven te worden aangewezen; een voorschrift dat thans met een standaardformulering wordt nageleefd.' De minister schrapte echter niet alleen het voorschrift van het daadwerkelijk aanwijzen van de redengevende feiten, maar ook de eis van redengevendheid zelf. Naderhand - mede nadat Corstens 2003, p. 2237, daarop had gewezen - wordt deze 'fout' in een nota van wijzigingen (Kamerstukken II 2003-2004, 29255, nr. 6) hersteld.

$6 \quad$ Kamerstukken II 1913-1914, 286, nr. 3 (MvT), p. 180. 
de tenlastelegging bijvoorbeeld gesproken over 'ontuchtige handelingen' dan zal duidelijk moeten zijn wat onder dit begrip wordt verstaan, alvorens kan worden beoordeeld of dit deel van de tenlastelegging kan worden bewezen door het aangevoerde bewijsmateriaal. Voor de eis van redengevendheid is derhalve in eerste instantie vereist dat duidelijk is welke interpretatie men geeft aan hetgeen bewezen moet worden: het bewijsobject of probandum. ${ }^{7}$

Ten tweede zal de inhoud en betekenis van het aangevoerde bewijsmateriaal moeten vaststaan. De bewoordingen die bijvoorbeeld een getuige in zijn verklaring gebruikt, zijn niet altijd eenduidig. Alvorens het verband tussen deze verklaring en de tenlastelegging kan worden gelegd, dient duidelijkheid te bestaan over de exacte inhoud en bedoeling van deze verklaring.

Tot slot zal er een logisch verband tussen het geselecteerde bewijsmateriaal en het bewijsobject zelf moeten bestaan. ${ }^{8}$ In geval van het gebruik van schriftelijke of mondelinge verklaringen die rechtstreeks tot het bewijs van (onderdelen van) het tenlastegelegde kunnen dienen, zal dit zelden een probleem opleveren. Er is als het ware sprake van een één-op-één situatie die niet vraagt om een nadere toelichting. Bij indirecte bewijsconstructies bestaat een dergelijke één-op-één situatie niet. Tussen het bewijsmateriaal en de bewezenverklaring blijft een gat bestaan dat slechts door middel van afleiding kan worden gedicht. De vraag is in hoeverre hier de eis van redengevendheid van het bewijsmateriaal een nadere toelichting van de rechter op de bewijsconstructie vergt.

Op deze drie aspecten die van belang zijn voor de invulling van het begrip 'redengevendheid' - de interpretatie van het bewijsobject, de betekenis van het bewijsmateriaal en het verband tussen beide - zal in de volgende paragrafen nader worden ingegaan. Daarbij zal telkens ook worden bezien in hoeverre er ten aanzien van elk van deze aspecten van redengevendheid een motiveringsplicht geldt.

\subsubsection{Het bewijsobject}

Uit artikel $338 \mathrm{~Sv}$ volgt dat de strafrechter gebonden is aan de tenlastelegging als onderwerp van de bewezenverklaring. De rechter mag geen ander feit bewezen verklaren dan is tenlastegelegd. Wel kan hij van bepaalde onderdelen van de ten-

7 In de Angelsaksische literatuur wordt de eis als omschreven als 'materiality'. Twining 1985, p. 153: 'materiality concerns what has to be proved for the proponent to succeed (the facts in issue) and is governed by substantive law'.

8 Deze eis komt ook in Angelsaksische landen tot uitdrukking. Het daar gebruikte begrip relevancy ziet op twee aspecten. Ten eerste het eerder genoemde aspect van materiality. Het tweede aspect ziet op het logisch verband. Daarover Cleary 1984, p. 541-542: 'The second aspect of relevant is probative value, the tendency of evidence to establish the proposition that it is offered to prove. (...) Evidence that is probative often is said to have "logical relevance", while evidence lacking in probative value may be condemned as "remote" of "speculative".' 
lastelegging vrij spreken. Daarbij dient hij zowel juridische als feitelijke grenzen in acht te nemen; door partieel vrij te spreken mag het resterende (bewezenverklaarde) deel zowel in juridisch als in feitelijk opzicht niet wezenlijk afwijken van het tenlastegelegde. Gebeurt dat wel, dan is de tenlastelegging gedenatureerd. ${ }^{9}$ De gebondenheid aan de tenlastelegging brengt met zich dat de feitenrechter de in de tenlastelegging gebezigde terminologie zal moeten uitleggen conform de bedoelingen van degene die de tenlastelegging heeft opgesteld. In het merendeel van de gevallen leidt dit niet tot problemen, aangezien de in de tenlastelegging gebezigde begrippen voor een ieder duidelijk zijn of direct aansluiten op de in de wet genoemde begrippen en de uitleg van deze wettelijke termen binnen de juridische wereld algemeen aanvaard is. ${ }^{10}$ Is echter de inhoud van een in de tenlastelegging genoemd begrip niet evident of wordt deze ter zitting ter discussie gesteld, dan zal eerst omvang en reikwijdte van het begrip moeten worden verduidelijkt. Dat is niet alleen van belang voor de kwalificatievraag van het bewezenverklaarde, maar eerst en vooral voor de vraag of het gebezigde bewijsmateriaal relevant kan zijn voor het bewijs. ${ }^{11}$

Uit de jurisprudentie zijn tal van voorbeelden te geven waaruit blijkt dat het toekennen van enige bewijswaarde aan het bewijsmateriaal afhankelijk is van de betekenis die men geeft aan terminologie zoals die is opgenomen in de tenlastelegging. In NJ 1983, 402 speelde een dergelijk geval. ${ }^{12}$ Aan de verdachte was onder andere ten laste gelegd het ter aflevering in voorraad hebben van ongeregistreerde farmaceutische preparaten. De rechtbank had het ongeregistreerd zijn van de preparaten afgeleid uit de verklaring van de Inspecteur van de Volksgezondheid, inhoudende dat verdachte de bij hem aangetroffen en inbeslaggenomen preparaten niet had laten registreren. In cassatie voerde de verdachte aan dat uit het feit dat hij - als parallel-importeur - die preparaten niet had laten registeren niet kon worden afgeleid dat de preparaten niet geregistreerd waren. Sterker nog: uit het door de rechtbank gebezigde bewijsmateriaal bleek dat ze wel geregistreerd waren, niet door de importeur, maar wel door de fabrikant. De Hoge Raad meent evenwel dat de verklaring van de inspecteur wel degelijk redengevend was:

'voor zover daaruit door de $\mathrm{Rb}$. viel op te maken dat in ieder geval niet de verdachte als parallel-importeur heeft voldaan aan zijn verplichting tot het laten registreren van de in de bewezenverklaring genoemde farmaceutische specialites en preparaten., ${ }^{13}$

$9 \quad$ Van Dorst 2004, p. 181. Daarover nader in paragraaf 5.2.1.

10 Pelser 1995, p. 283.

11 In gelijke zin: Melai 1968, p. 126: 'Dit betekent dat het bewijsoordeel niet alleen afhangt van de ervaringsaspecten van het ten laste gelegde feit, maar mede van uiteenlopende interpretaties, die (...) kunnen verlopen van begrippen als 'oogmerk' 'opzet' of 'weg', via meer vloeiende begrippen als 'wegnemen' of 'goed' als bedoeld in art. $310 \mathrm{Sr}$, tot een begrip als 'eer' of 'aanstotelijk voor de eerbaarheid' als bedoeld in de artikelen 261 en 240 Sr.'

12 HR 1 februari 1983, NJ 1983, 402 m.nt. ThWvV.

13 HR 1 februari 1983, NJ 1983, 402 m.nt. ThWvV (r.o. 5). 
Uit deze uitspraak blijkt duidelijk dat de vraag naar de redengevendheid van het bewijsmateriaal afhankelijk is van het bewijsobject, en de wijze waarop dat wordt geïnterpreteerd. In deze zaak waren de preparaten wel degelijk geregistreerd, maar kennelijk moest het in de tenlastelegging opgenomen en bewezenverklaarde begrip 'ongeregistreerd' niet letterlijk worden opgevat, maar worden geïnterpreteerd als 'niet nader door de verdachte geregistreerd'.

Een soortgelijke kwestie speelt ook in de uitspraken van de Hoge Raad aangaande snelheidsmetingen. ${ }^{14}$ In al deze zaken is tenlastegelegd en bewezenverklaard dat met een bepaalde snelheid was gereden. Deze snelheid was vastgesteld met een daartoe geëigend zogeheten verkeersmeetmiddel en het resultaat van die meting was in een proces-verbaal vastgelegd. De vraag was echter hoe het in de tenlastelegging gebezigde begrip 'snelheid' moest worden opgevat. Onder dat begrip kan in de eerste plaats worden verstaan 'de gemeten snelheid' en in dat geval is het proces-verbaal waarin het meetresultaat wordt vermeld direct redengevend. Wordt echter, zoals de Hoge Raad deed, met 'snelheid' gedoeld op de werkelijk gereden snelheid, dan kan een dergelijk proces-verbaal niet, althans niet zonder meer, redengevend zijn voor de bewezenverklaring. ${ }^{15}$ Immers, bij snelheidsmetingen moet rekening worden gehouden met een foutmarge van 3\%, en slechts nadat deze foutmarge is toegepast op de gemeten snelheid wordt (in juridische zin) de werkelijke snelheid verkregen. ${ }^{16}$

De verhouding tussen de terminologie in de tenlastelegging en de relevantie van het bewijsmateriaal doet zich ook voor bij het bewijs van zogeheten 'innerlijke bestanddelen'. Met name het begrip 'opzet' heeft in dit verband de gemoederen bezig gehouden. ${ }^{17}$ Voor de laagste graad van opzet - het voorwaardelijke opzet - is vereist dat de verdachte de aanmerkelijke kans op het intreden van het strafbaar

14 HR 12 december 1995, $N J$ 1996, 397-399 m.nt. 'tH onder HR 23 januari 1996, $N J 1996$, 400; HR 12 maart 1996, NJ 1996, 511 m.nt. 'tH; HR 17 december 1996, NJ 1997, 473 m.nt. Sch; HR 17 juni 1997, NJ 1997, 735; HR 17 juni 1997, NJ 1997, 736 m.nt. JdH; HR 9 december 1997, NJ 1998, 855; HR 24 maart 1998, NJ 1998, 536 en HR 20 maart 2001, LJN AB0606.

15 In gelijke zin: HR 17 juni 1997, NJ 1997, 735 en 736 m.nt. JdH, waarin de Hoge Raad oordeelde dat de gemeten snelheid wel degelijk als redengevend voor de bewezenverklaring kan worden aangemerkt, indien uit ander bewijsmateriaal blijkt dat dit ook de daadwerkelijk gereden snelheid is. In NJ 1997, 736 was daarvan sprake, aangezien de verdachte met betrekking tot de gemeten snelheid had verklaard 'dat klopt'. Terecht merkt De Hullu in zijn annotatie bij het arrest op dat deze beslissing verrassend is in een stelsel waarin de werkelijke snelheid centraal staat. De verklaring van de verdachte is waarschijnlijk gebaseerd op hetgeen hij op zijn eigen kilometerteller heeft gezien en de accuraatheid van zowel die waarneming als de kilometerteller kan worden betwijfeld.

16 Deze juridische opvatting over de 'werkelijke snelheid' hoeft niet overeen te komen met die van wetenschappers uit andere disciplines. In gelijke zin: Broeders 2003, p. 29, en 't Hart 2001, p. 241: 'Wat (...) in het recht als werkelijkheid gelden mag, is op grond van de bijzondere normatieve aard van het recht de naar beneden bijgestelde werkelijkheid en niet het redelijke gemiddelde dat in het empirische metingsbegrip besloten ligt.'

17 Uitgebreid over het bewijs van opzet: Reijntjes 2004. 
gestelde gevolg op de koop heeft toegenomen. Uit recente jurisprudentie van de Hoge Raad volgt dat in dergelijke gevallen een aanmerkelijke kans op het intreden van het gevolg aanwezig moet zijn, ${ }^{18}$ dat de verdachte wist van het bestaan van een dergelijke kans, ${ }^{19}$ en dat hij die kans bewust heeft aanvaard. ${ }^{20}$ Ten aanzien van deze drie facetten van het voorwaardelijke opzet - aanmerkelijke kans, wetenschap en bewuste aanvaarding - moet bewijsmateriaal voorhanden zijn waaruit direct dan wel indirect de aanmerkelijke kans, de wetenschap bij verdachte en zijn bewuste aanvaarding van die kans kan worden afgeleid. Zo acht de Hoge Raad de kans op besmetting met het HIV-virus tijdens onbeschermd seksueel contact onvoldoende voor het aannemen van een aanmerkelijke kans op het overlijden van het slachtoffer. De deskundigenverklaring, inhoudende dat verdachte die besmet was met het HIV-virus, dit virus zou hebben kunnen overdragen op het slachtoffer en dat een dergelijke overdracht in een overgrote meerderheid van de gevallen bij het uitblijven van medische behandeling tot AIDS leidt, is dus niet redengevend voor het bewijs. Simpelweg, omdat daaruit niet kan blijken dat er een aanmerkelijke kans op AIDS bij het slachtoffer bestaat en - in nog verder weg staand verband - een aanmerkelijke kans op diens overlijden aanwezig is. ${ }^{21}$ Legt men echter het bestaan van de kans op het gevolg niet in kwantitatieve zin, maar meer in kwalititatieve (of zo men wil: normatieve) zin uit, dan had de HIVzaak een geheel andere uitkomst kunnen hebben. De Jong en Kessler hebben bijvoorbeeld bepleit dat aanmerkelijke kans moet worden beschouwd als de kans dat een maatschappelijke onaanvaardbaar gevolg $k a n$ intreden. ${ }^{22} \mathrm{Zij}$ menen derhalve dat de vraag of een kans als 'aanmerkelijk' kan worden beschouwd afhankelijk is van het gewicht dat men toekent aan het te beschermen rechtsbelang en onafhankelijk is van de statistische kans dat het kwalijke gevolg kan intreden. Bij een dergelijke uitleg van het begrip 'aanmerkelijke kans' had aan de deskundigenverklaring in de HIV-zaak wel degelijk redengevende kracht kunnen worden toegekend.

18 HR 25 maart 2003, NJ 2003, 552 m.nt. YB en HR 24 juni 2003, NJ 2003, 555.

19 HR 1 april 2003, NJ 2003, 553.

20 HR 8 april 2003, NJ 2003, 554 en HR 25 maart 2003, NJ 2003, 556.

21 HR 24 juni 2003, NJ 2003, 555 (r.o. 3.6.3).

22 De Jong \& Kessler 2002, p. 2233: 'Wij zijn er voorstanders van om van de zojuist beschreven normatieve benadering uit te gaan, en de 'aanmerkelijke kans' te verstaan als de onaanvaardbare kans. (...) Naar onze mening dwingen de HIV-zaken de rechter ertoe om kleur te bekennen in het debat over de feitelijke of de normatieve uitleg van de aanmerkelijke kans. Want de kans op besmetting met HIV, het ontwikkelen van AIDS en het daaraan overlijden is naar onze mening samengenomen zo klein dat deze niet van voldoende omvang is om in een uitsluitend kwantitatieve benadering in aanmerking te worden genomen. Wel kan dit kleine risico maatschappelijk onaanvaardbaar worden genoemd.' 


\subsubsection{Motiveringsplicht met betrekking tot het bewijsobject}

De vaststelling dat de relevantie of redengevendheid van het bewijsmateriaal in eerste instantie afhankelijk is van de wijze waarop hetgeen bewezen moet worden, het probandum, moet worden uitgelegd, roept de vraag op in hoeverre de rechter in zijn vonnis tot uitdrukking moet brengen op welke wijze hij het probandum heeft geïnterpreteerd.

In het in het Wetboek van Strafvordering van 1926 opgenomen stelsel van motiveringsplichten is niet voorzien in een motiveringsplicht aangaande de uitleg van de in de tenlastelegging bezigde begrippen. Wel dient in het vonnis de tenlastelegging te worden opgenomen en dient vervolgens ook de bewezenverklaring te worden opgenomen. Door te eisen dat zowel de tenlastelegging als de bewezenverklaring in het vonnis worden opgenomen, ontstaat de mogelijkheid om controle uit te oefenen op de overeenstemming tussen de tenlastelegging en bewezenverklaring. De rechter mag niet een wezenlijk ander feit bewezen verklaren dan door het Openbaar Ministerie is tenlastegelegd. Doet hij dat wel dan is er sprake van grondslagverlating en zal dit in cassatie tot vernietiging van het vonnis leiden. ${ }^{23}$ Echter niet elke afwijking op dit punt wordt gesanctioneerd. Zo mag de rechter van bepaalde delen van de tenlastelegging vrijspreken, mits daardoor het bewezenverklaarde feit niet een andere betekenis krijgt dan het tenlastegelegde feit, noch in juridische ${ }^{24}$ noch in feitelijke ${ }^{25}$ zin. Ook kennelijke schrijffouten ${ }^{26}$ in de tenlastelegging mogen door de rechter in de bewezenverklaring worden hersteld. Zelfs is de Hoge Raad bereid om in bepaalde gevallen waarin de bewezenverklaring afwijkt van de tenlastelegging de bewezenverklaring alsnog zelf verbeterd te lezen. ${ }^{27}$ Buiten deze uitzonderingen geldt echter de regel dat de rechter gebonden is

23 Uitgebreid over het leerstuk van grondslagverlating: Boksem 1996 en Van Dorst 2004, p. 181-189.

24 Bijvoorbeeld: HR 26 april 1988, NJ 1988, 933 (r.o. 7.2): 'Rb. en hof hebben het ten laste gelegde onder 1 subs. kennelijk aldus verstaan dat daarbij aan de verdachte is verweten dat zij, zo al niet het misdrijf voorzien bij art. $288 \mathrm{Sr}$, dan toch in elk geval het misdrijf voorzien bij art. $287 \mathrm{Sr}$ heeft gepleegd. In aanmerking genomen dat art. $288 \mathrm{Sr}$ betreft doodslag, gepleegd onder een of meer strafverzwarende omstandigheden, hebben Rb. en hof dat onderdeel van de telastelegging ook aldus kunnen verstaan. Hieruit vloeit voort dat Rb. en hof, door vrij te spreken van de ten laste gelegde strafverzwarende omstandigheden en het desbetreffende onderdeel van de telastelegging voor het overige bewezen te verklaren, de grondslag van de telastelegging niet hebben verlaten.'

25 Bijvoorbeeld: HR 25 juni 1996, NJ 1997, 106 m.nt. Sch onder HR 15 juli 1996, NJ 1997, 107 (r.o. 6.2): 'In aanmerking genomen a) dat de woorden 'voor hem links' voor de krachtens de artikelen 348 en $350 \mathrm{~Sv}$ door de rechter te dezen te geven beslissingen strafrechtelijk niet van belang zijn en b) dat niet kan worden gezegd dat het Hof door vrij te spreken van bedoeld onderdeel van de telastelegging iets anders heeft bewezenverklaard dan was telastegelegd, heeft het Hof, anders dan in het middel wordt betoogd, de grondslag der telastelegging niet verlaten.'

26 Bijvoorbeeld: HR 26 september 1995, NJ 1996, 93.

27 Bijvoorbeeld: HR 25 juni 2002, LJN AE1185 (r.o. 3.6): 'In aanmerking genomen dat de 
aan de tekst van de tenlastelegging en mag hij in de bewezenverklaring niet eigenmachtig afwijken van de bewoordingen van de tenlastelegging. ${ }^{28}$

Tussen de tenlastelegging en de bewezenverklaring dient er dus een grote mate van woordelijke overeenkomst te bestaan. Dit geldt echter niet voor de inhoud van de bewijsmiddelen en de bewezenverklaring. Verdachten en getuigen zullen zich vaak niet uitdrukken op een wijze die letterlijk overeenkomt met hetgeen in de tenlastelegging en de eventuele bewezenverklaring staat beschreven. Op dit punt kunnen incongruenties ontstaan en is het aan de rechter om te beoordelen of hetgeen uit het bewijsmiddel blijkt onder het ten laste gelegde en te bewijzen feit valt. Voor deze beoordeling dient enerzijds duidelijk te zijn wat de exacte inhoud en betekenis van de in het bewijsmiddel genoemde feiten en omstandigheden zijn. Anderzijds moet de rechter ook bepalen welke betekenis hij toekent aan de in de tenlastelegging opgenomen begrippen. Het eerste punt kwam in de paragraaf 4.2.2. aan de orde. Met betrekking tot het tweede punt - de inhoud van het bewijsobject - dient de rechter uit te gaan van de betekenis van het ten laste gelegde zoals die de opsteller van de tenlastelegging voor ogen stond. Voor zover er reeds in de tenlastelegging termen zijn opgenomen die rechtstreeks aan de wet zijn ontleend, dient de rechter deze uit te leggen conform de delictsomschrijving. De rechter hoeft echter in zijn vonnis de door hem gevolgde interpretatie niet tot uitdrukking te brengen. Wel dient hij op basis van het derde lid van artikel $359 \mathrm{~Sv}$ de inhoud van de bewijsmiddelen in het vonnis op te nemen. Door het opnemen van de inhoud van de bewijsmiddelen kan worden gecontroleerd of uit de inhoud van de bewijsmiddelen tevens de bewezenverklaring volgt en kunnen eventuele interpretaties van feitelijke en juridische termen door de rechter worden afgeleid en beoordeeld. Slechts in één geval dient de rechter in het vonnis expliciet aandacht te besteden aan de door hem aangenomen interpretatie van het bewijsobject. Dat is indien door de verdediging een zogeheten dakdekkersverweer is gevoerd.

\subsubsection{Dakdekkersverweren}

In geval van een dakdekkersverweer betwist de verdediging de bewezenverklaring niet op feitelijke, maar op juridische gronden. Dat doet zij door te stellen dat een

verdachte gelet op het vorenoverwogene daardoor niet in zijn verdediging is geschaad, leest de Hoge Raad de bewezenverklaring met verbetering van de in 3.3 vermelde misslag en derhalve zonder de daarin opgenomen woorden 'in de gemeente Venlo'. Dat brengt mee dat het middel feitelijke grondslag mist, zodat het niet tot cassatie kan leiden.'

28 Pelser 1995, p. 108. Overigens is het belang van deze regel zeer beperkt nu bij de Wet Vormverzuimen, Stb. 1995, 441 (inwerkingtreding 2 november 1996, Stb. 1996, 522) art. $313 \mathrm{~Sv}$ is gewijzigd in die zin dat het Openbaar Ministerie (binnen de grenzen van art. $68 \mathrm{Sr}$ ) op elk gewenst moment de tenlastelegging nog kan wijzigen. Voor zover van de zijde van de verdediging gewag wordt gemaakt van mogelijke fouten in de tenlastelegging zal dit voor de officier van justitie of de advocaat-generaal aanleiding zijn om het wijzigingsformulier in te vullen. 
reeds in de tenlastelegging opgenomen term uit de toepasselijke delictsomschrijving niet van toepassing is op het aan de rechter voorgelegde geval. Daarmee is het verweer in materiële zin een kwalificatieverweer, maar in formele zin een bewijsverweer. De verdachte ontkent immers het tenlastegelegde feit.

De dakdekkersverweren ontlenen hun naam aan het dakdekkersarrest van de Hoge Raad. ${ }^{29}$ In dat arrest was de verdachte tenlastegelegd dat hij als werknemer in de zin van artikel $2 \mathrm{WWV}$ werkzaamheden had verricht en daarvoor inkomsten had ontvangen en deze had verzwegen. De verdachte betwistte echter dat hij een werknemer in de zin van artikel $2 \mathrm{WWV}$ was. In het vonnis was de feitenrechter aan dat verweer voorbij gegaan, hetgeen op grond van de wet destijds - in 1982 - ook was toegestaan. Op basis van het toen geldende artikel 358 lid $3 \mathrm{~Sv}$ jo 359 lid $2 \mathrm{~Sv}$ konden bewijsverweren worden weerlegd zonder expliciete rechterlijke respons. De Hoge Raad meende evenwel dat de rechter niet aan dit verweer voorbij mocht gaan, nu het verweer niet van louter feitelijke aard was, maar daarin tevens een rechtsvraag aan de orde werd gesteld. ${ }^{30}$

Wordt echter de inhoud van bepaalde in de tenlastelegging opgenomen bewoordingen niet nadrukkelijk ter discussie gesteld, of gebeurt dit wel maar betreft het niet een aan de tenlastelegging ontleende term, ${ }^{31}$ dan bestaat er geen enkele noodzaak om de inhoud en de betekenis van bepaalde bewoordingen in de tenlastelegging en bewezenverklaring nader te expliciteren. ${ }^{32}$ Dit is echter voor de vraag of het tenlastegelegde bewezen kan worden door het door de feitenrechter aangehaalde bewijsmateriaal van wezenlijk belang. Immers, de vraag of het gebezigde bewijsmateriaal redengevend is voor de bewezenverklaring is in eerste instantie afhankelijk van het antwoord op de vraag wat er bewezen moet worden. Deze vraag wordt echter in de Nederlandse strafpraktijk zelden - met uitzondering van de hierboven genoemde dakdekkersverweren - expliciet beantwoord. Uit het in het vonnis opgenomen bewijsmateriaal en de bewezenverklaring moet worden afgeleid welke betekenis de rechter heeft toegekend aan in de tenlastelegging voorkomende termen. Voor zover daar een specifieke niet alledaagse interpretatie aan is gegeven,

29 HR 16 februari 1982, NJ 1982, 411.

30 Vanaf 1 januari 2005 geldt overigens voor alle bewijsverweren een responsieplicht, mits zij uitdrukkelijk en onderbouwd ter zitting aan de orde zijn gesteld. Daarover meer in paragraaf 6.3.4.

31 Zie voor een uitzondering hierop: HR 6 maart 2001, NJ 2001, 295. In die zaak betwistte de verdachte dat hij bepaalde personen in dienst had gehad en dus loonbelasting moest af te dragen. Dit aspect was niet in de tenlastelegging opgenomen, maar was wel relevant voor de strafbaarheid van de verdachte. Van een onjuiste belastingaangifte zou immers alleen kunnen worden gesproken indien in juridische zin een dienstbetrekking kon worden aangenomen. De Hoge Raad meende dat de feitenrechter in zijn vonnis nadrukkelijk had moeten ingaan op deze interpretatiekwestie. Nu dat niet was gebeurd, werd het vonnis vernietigd.

32 Reeds in 1918 schreef Taverne, p. 19: 'Een ontevreden advocaat heeft eens gezegd, dat het vonnis om de wetsuitlegging heen gaat als een kat om de heete brij en laten wij eerlijk zijn, daar is, zoolang de wet zoo blijft als ze is, heel veel van aan.' 
blijft die voor de lezer van het vonnis onduidelijk. Zo bleef ook de verdachte die aangevoerd had dat zijn werkplaats geen herstelinrichting voor motorvoertuigen (een garage dus) was, omdat hij daarin slechts kluste en dus geen bedrijfsmatige activiteiten verrichtte, onwetend over de vraag welke betekenis de rechter nu gaf aan het begrip 'herstelinrichting' of waaruit de rechter kennelijk had afgeleid dat er wel sprake was van bedrijfsmatige activiteiten. De Hoge Raad vernietigde de uitspraak van de politierechter waarbij werd overwogen dat:

'De woorden 'herstelinrichting voor motorvoertuigen' (...) in de telastelegging kennelijk [cursivering WD] in dezelfde betekenis (zijn) gebezigd als daaraan toekomt in het Besluit herstelinrichtingen voor motorvoertuigen milieubeheer. ${ }^{33}$

In het licht van deze betekenis werd het bewijsmateriaal niet redengevend geacht. Deze uitspraak maakt duidelijk dat er een direct verband is tussen de eis van redengevendheid en de dakdekkersverweren. De Hoge Raad had mijns inziens het vonnis van de politierechter ook kunnen vernietigen omdat de feitenrechter niet had gerespondeerd op het verweer. Feitelijk voerde de verdachte immers een dakdekkersverweer. In plaats daarvan kiest de Hoge Raad ervoor om de juiste interpretatie in het vonnis van de rechter in te lezen en vervolgens te concluderen dat er onvoldoende bewijs is. De uitkomst is hetzelfde. Belangrijk verschil is evenwel dat de betrokkenen maar ook anderen pas in cassatie uitsluitsel krijgen over de vraag welke betekenis moet worden toegekend aan het juridisch relevante begrip. Evenals Pelser ben ik van mening dat reeds van de feitenrechter mag worden verwacht dat hij zijn interpretatie van (juridisch) relevante begrippen in het vonnis kenbaar maakt en nader verantwoordt. ${ }^{34}$ Een dergelijke verantwoordingsplicht maakt dat de feitenrechter zich bewust is van zijn keuzes dienaangaande en bovendien kan zijn oordeel op dit punt worden gecontroleerd. Het impliciet laten van interpretatiekwesties leidt er tot slot toe dat vonnissen voor betrokkenen en het publiek weinig toegankelijk zijn. Waar de strafbaarheid van personen afhankelijk is van de uitleg van bepaalde begrippen doet de rechter er goed aan hieraan uitdrukkelijk in zijn vonnis aandacht te besteden en uit te leggen waarom hij een bepaalde interpretatie volgt. Slechts op die manier kan het vonnis overtuigende kracht hebben. Daarbij mag het geen verschil maken of de verdachte daartegen verweer heeft gevoerd of niet. De rechter zal immers reeds bij de beoordeling van de redengevendheid van het bewijsmateriaal zicht moeten hebben op de betekenis van het bewijsobject. Voor zover dat niet evident is, zal hij dat moeten expliciteren, omdat alleen op deze wijze de redengevendheid van het bewijsmateriaal inzichtelijk en toetsbaar wordt, hetgeen in de bovengenoemde zaak van de vermeende garagehouder niet het geval was. Bij gebrek aan uitleg over de betekenis van het begrip 'herstelinrichting' wordt de Hoge Raad

33 HR 25 juni 1996, NJ 1996, 751 (r.o. 5.2).

34 Pelser 1995, p. 282. 
feitelijk gedwongen om die dan maar in te lezen in de uitspraak. Of de door de Hoge Raad ingelezen interpretatie ook daadwerkelijk de interpretatie van de feitenrechter is geweest, blijft onbekend.

\subsubsection{Het bewijsmateriaal}

Voor de beoordeling van de redengevendheid van het bewijsmateriaal zal niet alleen duidelijk moeten zijn wat de inhoud en betekenis is van hetgeen bewezen moet worden, maar ook zal de inhoud en de betekenis van het aan de bewezenverklaring ten grondslag gelegde bewijsmateriaal niet voor verschillende uitleg vatbaar moeten zijn. Zoals in de vorige paragraaf al aan de orde kwam, zal de informatie die uit de bewijsmiddelen blijkt vaak niet vervat zijn in de terminologie van de tenlastelegging. Dat betekent dat de rechter zal moeten beoordelen of hetgeen bijvoorbeeld de getuige of de verdachte heeft verklaard, overeenstemt met hetgeen bewezen moet worden. ${ }^{35} \mathrm{Hij}$ zal als het ware een vertaalslag moeten maken. Verklaart de verdachte bijvoorbeeld ' $\mathrm{ik}$ heb haar tegen haar zin genaaid' dan zal de rechter dit vertalen in de strafrechtelijke relevante termen dat de verdachte tegen de zin van het slachtoffer geslachtsgemeenschap met haar heeft gehad. Heel vaak is echter een dergelijke vertaalslag reeds gemaakt. Opsporingsambtenaren nemen in hun processen-verbaal zelden de letterlijke verklaringen van verdachten en getuigen op. ${ }^{36}$ Meestal worden hun verklaringen samengevat en geparafraseerd op een zodanige manier dat de strafrechtelijke relevantie meer in het oog springt. Zo zullen er waarschijnlijk weinig mensen zijn die zeggen 'ik heb niemand toestemming gegeven om zich mijn fiets toe te eigenen', terwijl men zo een of vergelijkbare zinsnede veelvuldig terugvindt in processen-verbaal van aangifte. ${ }^{37} \mathrm{Nu}$ zal een dergelijke formulering vaak goed weergeven wat de getuige heeft bedoelen te zeggen en levert dit dus geen problemen op. Maar soms gaat het ook fout. Zoals bleek uit het zogeheten houtopstand-arrest van de Hoge Raad. ${ }^{38}$ De verdachte was ten laste gelegd dat hij zonder voorafgaande kennisgeving houtopstand had gerooid. Een handeling die op grond van de Boswet strafbaar is. Uit het proces-verbaal van de politie bleek dat de verdachte had

35 In gelijke zin: A.M. van Woensel, aant. 4 op art. 339 (suppl. 102 maart 1997), in Melai/ Groenhuijsen e.a.: 'Het nemen van die [bewijs-, WD] beslissing veronderstelt interpretatie door de rechter van de via de beschikbare bewijsmiddelen overgebrachte informatie.'

36 In gelijke zin: Wagenaar: 'Wellicht verdwijnt dan ook de gewoonte dat verklaringen van getuigen zodanig in processen-verbaal worden opgenomen, dat ze niet meer in de eigen bewoordingen van de getuige verschijnen, maar alleen in de bewoordingen van de verbalisant. Dat vind ik echt een gruwel, Je kunt dingen lezen waarvan je met zekerheid kunt stellen dat de getuige ze nooit heeft gezegd.'. Bockwinckel \& De Vries 1999, p. 29.

37 Rassin 2005, p. 103-104 spreekt in dit verband van politieproza: 'De lul sloeg mij op mijn bek' wordt dan snel: 'De verdachte bracht mij lichamelijk letsel toe, zonder dat ik daarvoor toestemming had gegeven.'

38 HR 20 juni 1978, NJ 1979, 41. 
erkend dat hij houtopstand had gerooid. Een verklaring die hij ook ter zitting herhaalde. Onduidelijk was echter wat onder houtopstand in algemene zin moet worden verstaan en wat de verdachte met die term had bedoeld. In het concrete geval was relevant of de verdachte bomen dan wel struiken had gekapt. De vraag die dan opdoemt, is of de verdachte dezelfde betekenis heeft gegeven aan deze term als voor het bewijs van het tenlastegelegde feit vereist is. Voor zover dat het geval is, is de verklaring redengevend voor het bewijs. Blijkt echter zoals het geval was in het arrest Houtopstand dat de verdachte bij het bezigen van de aan de delictsomschrijving ontleende term een andere betekenis - namelijk struiken voor ogen heeft, dan de betekenis die daaraan toekomt in de tenlastelegging - namelijk bomen - dan is die verklaring niet redengevend voor het bewijs. De verklaring dekt weliswaar woordelijk de inhoud van de in de tenlastelegging opgenomen wettelijke term, maar qua strekking stemt de inhoud van het bewijsmiddel niet overeen met hetgeen bewezen moet worden.

Het voorbeeld uit het houtopstandarrest ziet op de uitleg van het bewijsmateriaal dat direct relevant is voor de bewezenverklaring met als bijkomende bijzonderheid dat de in het bewijsmateriaal voorkomende term tevens van belang is voor de kwalificatie van het strafbare feit en in zoverre ook een juridische implicatie heeft. Maar de uitleg van het bewijsmateriaal kan ook enkel betrekking hebben op zijn feitelijke betekenis. Dit probleem speelde onder andere in een zedenzaak waarin het jeugdige slachtoffer verklaarde dat de verdachte zonder kleren was binnengekomen. Meestal zal men veronderstellen dat de verdachte dan naakt was binnengekomen, maar naar later bleek, had de jongen willen verklaren dat hij in zijn pyjama was binnengekomen en dus nog niet aangekleed was. ${ }^{39}$ Met name bij emotionele delicten als kindermisbruik is men geneigd slechts dat te horen wat men wil horen. Dat kan echter behoorlijk verschillen van hetgeen daadwerkelijk verklaard is of hetgeen de persoon heeft willen verklaren. Het zou daarom wellicht wenselijk zijn indien de rechter op dit punt zijn oordeel zou moeten onderbouwen.

\subsubsection{Motivering van de uitleg van het bewijsmateriaal}

Dient nu de rechter, in geval niet evident is wat met de inhoud van het bewijsmateriaal is bedoeld, in het vonnis tot uitdrukking te brengen hoe hij het een en ander heeft geïnterpreteerd? Het antwoord op deze vraag is in principe ontkennend. Binnen het Nederlandse bewijsrecht geldt als uitgangspunt dat de feitenrechter het bewijsmateriaal selecteert en waardeert. Hij mag dus delen van het aan hem

39 Het voorbeeld is ontleend aan een zaak waarin Crombag als deskundige optrad en tevens opgenomen in Rassin \& Van Koppen 2002, p. 512-513. Schrijvers wijzen op het beperkte taalbegrip van (jonge) kinderen en de daaraan gekoppelde gevaren voor het verhoor: 'de betekenis van allerlei woorden (mag) uiteraard niet zonder meer bekend worden verondersteld bij kinderen'. 
gepresenteerde bewijsmateriaal buiten beschouwing laten. Waarom hij die buiten beschouwing laat - bijvoorbeeld omdat die niet betrouwbaar of relevant zijn hoeft hij niet in het vonnis te vermelden. Evenmin hoeft hij in het vonnis tot uitdrukking te brengen waarom hij andere delen wel voor het bewijs bezigt. Dat betekent dat de motivering van de relevantie (en de betrouwbaarheid) van het bewijsmateriaal beperkt is tot het opnemen van het bewijsmateriaal in het vonnis. Uit het enkele feit dat de rechter dit bewijsmateriaal ten grondslag heeft gelegd aan de bewijsconstructie moet worden afgeleid dat de rechter dit relevant heeft geacht. Een nadere uitleg is in principe niet noodzakelijk. Ook niet indien het bewijsmateriaal mogelijk voor verschillende uitleg vatbaar is. Controle in cassatie op dit punt is dus logischerwijze beperkt. Waar de feitenrechter niets hoeft uit te leggen, kan de Hoge Raad ook niet beoordelen of die uitleg correct is geweest.

Bovendien is de Hoge Raad op dit punt zeer coulant; zelfs als bewijsmateriaal niet de inhoud van de tenlastelegging of een deel daarvan dekt, is hij bereid dat bewijsmateriaal zodanig uit te leggen dat het alsnog redengevend is. Zo werd een verklaring inhoudende 'zonder dat de identiteit van zijn auto kon worden vastgesteld' door de Hoge Raad verstaan als 'zonder dat hij behoorlijk gelegenheid had gegeven de identiteit van zijn auto vast te stellen'. ${ }^{40}$ In die casus bleek namelijk eveneens uit de bewijsmiddelen dat de identiteit van de auto wel degelijk door een getuige was vastgesteld; deze had namelijk het kenteken gezien en onthouden. Door het op deze wijze vertalen van de verklaring wordt bereikt dat bewijsmateriaal en bewijsobject alsnog goed op elkaar aansluiten.

In een ander geval meende de Hoge Raad ${ }^{41}$ dat de verklaring van de verdachte 'de valse factuur is opgemaakt door V. en A., maar ik heb de aanwijzingen daartoe gegeven' door het hof kon worden begrepen als een verklaring waarin tot uitdrukking kwam dat het initiatief tot en opdracht om de valse rekening uit te schrijven uitging van de verdachte. ${ }^{42}$

In beide genoemde gevallen meende de Hoge Raad dat aan de bewuste verklaringen een dergelijke betekenis kon worden toegekend, mede gezien in het licht van het overige bewijsmateriaal. Deze redenering is echter bijzonder vreemd. Voor de vraag of een bepaalde verklaring redengevend is voor de bewezenverklaring dient de inhoud van de verklaring duidelijk te zijn. De inhoud van deze verklaring kan niet worden afgeleid uit ander wel redengevend bewijsmateriaal. Doet men dit wel, dan ontstaat het gevaar dat men als het ware naar het resultaat (de redengevendheid) toe redeneert, zonder daarbij acht te slaan op die elementen in de verklaring die op het tegendeel zouden kunnen duiden. In het bovengenoemde

$40 \quad$ HR 3 maart 1987, NJ 1987, 1007.

41 HR 27 maart 1984, NJ 1984, 685.

42 In vergelijkbare zin: HR 15 januari 1980, NJ 1980, 274; HR 9 november 1982, NJ 1983 , 268 m.nt. 'tH; HR 29 november 1983, NJ 1984, 441; HR 19 februari 1985, NJ 1985, 633; HR 26 november 1985, NJ 1986, 389; HR 29 mei 2001, LJN AB1818 en HR 14 januari 2003, $N J$ 2003, 288 m.nt. YB. 
geval van de vervalste rekening lijkt mij dat uit de verklaring van de verdachte niet kan worden afgeleid dat de verdachte de opdracht tot het uitschrijven van de valse factuur gaf. Het feit dat hij elders een verklaring heeft afgelegd waarin hij wel erkende dat hij de opdracht tot vervalsing had gegeven, maakt niet dat men zijn eerdere verklaring overeenkomstig de latere, of omgekeerd zijn latere overeenkomstig zijn eerdere, kan uitleggen. Een dergelijke handelwijze maakt het recht van de verdachte om zijn verklaringen bij te stellen illusoir.

\subsubsection{Denaturering}

Door niet te eisen dat de feitenrechter in zijn vonnis uitlegt welke betekenis hij heeft gegeven aan het bewijsmateriaal geeft de Hoge Raad de feitenrechter alle ruimte om die uitleg te geven aan het bewijsmateriaal die hem goeddunkt. Bovendien is de Hoge Raad bereid om eventuele misslagen op dit punt te corrigeren. Slechts in zeer uitzonderlijke gevallen grijpt hij in; namelijk in die gevallen waarin evident is dat het bewijsmateriaal zoals dat in zijn oorspronkelijke vorm aan de feitenrechter is gepresenteerd qua strekking afwijkt van hetgeen in het vonnis is opgenomen. In dat geval is er sprake van denaturering van het bewijsmateriaal. Van denaturering van bewijsmateriaal kan worden gesproken indien de betekenis van de inhoud van het bewijsmateriaal zoals dat in het vonnis is opgenomen in wezenlijke zin afwijkt van de betekenis van het bewijsmateriaal in zijn oorspronkelijke vorm. Dat kan bijvoorbeeld gebeuren doordat de rechter slechts een deel van de verklaring van de verdachte of een getuige voor het bewijs bezigt. ${ }^{43}$ Voor zover de verdachte of getuige in het weggelaten stuk terugkomt op zijn eerdere uitlatingen of daarin een voorbehoud maakt, kan die verklaring een geheel andere strekking krijgen. ${ }^{44}$ De Hoge Raad neemt echter niet snel aan dat er sprake is van denaturering. Het weglaten van delen van een verklaring is toegestaan, indien de rechter van mening is dat die delen als niet geloofwaardig moeten worden aangemerkt. Zo mag de verklaring van de verdachte 'ik heb slechts 2 à 3 glazen sherry gedronken' worden teruggebracht tot 'ik heb sherry gedronken'. Voorwaarde is wel dat uit ander bewijsmateriaal blijkt dat de hoeveelheid alcohol die de verdachte heeft genuttigd meer is dan de toegestane hoeveelheid, en dus meer is dan 2 à 3 glazen sherry. Een dergelijke splitsing van de verklaring van de verdachte is toelaatbaar, mits - zoals Remmelink het destijds in zijn conclusie uitdrukte dat niet leidt tot vervalsing van die verklaring. ${ }^{45}$

43 Van Dorst 2004, p. 192 spreekt dan ook van 'splitsing van verklaringen'.

44 Bijvoorbeeld: HR 3 oktober 2006, NJ 2006, 550

45 HR 30 mei 1972, NJ 1972, 490 m.nt. CB. In gelijke zin: HR 23 oktober 1990, NJ 1991, 328; HR 9 oktober 1990, NJ 1991, 98. 
Van vervalsing was sprake in de zaak van de Hoge Raad d.d. 8 oktober $1991{ }^{46}$ De verdachte was door een politieagent gesommeerd zich te verwijderen. Hij had aan dat bevel geen gehoor gegeven. Dienaangaande verklaarde hij 'ik weet dat een politieambtenaar op die dagen telkens de aldaar op die weg aanwezige personen driemaal heeft gesommeerd zich te verwijderen. Ik heb die sommaties evenwel niet gehoord, doch als ik ze wel gehoord had dan had ik me toch niet verwijderd'. Voor het bewijs was enkel de eerste volzin van deze verklaring gebruikt. Dit was echter niet toelaatbaar. Het niet opvolgen van een bevel van een opsporingsambtenaar is alleen strafrechtelijk relevant indien de verdachte weet dat een dergelijke bevel is gegeven. De ogenschijnlijke redengevendheid van het eerste deel van de verklaring (ik weet van deze sommatie) wordt dus ontkracht door het tweede deel. Bij gebrek aan andere informatie waaruit zou kunnen blijken dat de verdachte wel degelijk de sommaties van de opsporingsambtenaar had gehoord, had de feitenrechter niet zomaar zijn verklaring mogen splitsen in een redengevend en een niet-redengevend deel. Dat laatste is slechts toegestaan voor zover uit ander bewijsmateriaal blijkt dat het niet-redengevende deel tevens niet betrouwbaar is.

In wezen is deze zaak vergelijkbaar met de casus in het zogeheten houtopstandarrest. De verdachte was tenlastegelegd dat hij houtopstand zonder voorafgaande kennisgeving had gerooid. De verdachte had ter zitting verklaard dat hij houtopstand had gerooid en deze verklaring was voor het bewijs gebezigd. Evenals de verklaring van de verbalisant inhoudende dat de verdachte houtopstand had geveld. Er was dus in bewijstechnische zin geen vuiltje aan de lucht. Uit het procesverbaal van de terechtzitting bleek evenwel dat de verdachte deze verklaring had toegelicht met de woorden 'de opstand op het perceel grond dat ik gerooid heb, laat zich het beste omschrijven als struiken'. De Hoge Raad meende dat in dit geval de toevoeging van de verdachte moest worden opgevat als:

'een betoog, naar zijn strekking inhoudende: Wat ik heb gerooid - en door mij kortheidshalve als "houtopstand" is aangeduid - is niet een houtopstand in de zin van art. 2 Boswet; dat tegenover voormeld verweer van req. het bewezen verklaarde, waarin het woord 'houtopstand" kennelijk is gebezigd in de betekenis welke aan dat woord toekomt in art. 2 Boswet, niet geacht kan worden naar de eis der wet met redenen te zijn omkleed. ${ }^{47}$

Hoewel de Hoge Raad deze uitspraak niet plaatst in de sleutel van het denatureringsleerstuk heeft zij er wel veel verwantschap mee. Ook annotator Van Veen meent dat in casu sprake is van denaturering van de verklaring van de verdachte door slechts het redengevende deel in de bewijsmiddelen op te nemen en het niet-redengevende deel zonder nadere toelichting buiten beschouwing te laten. Een in wezen ontkennende verklaring wordt aldus een bekennende verklaring.

46 HR 8 oktober 1991, NJ 1992, 156.

47 HR 20 juni 1978, NJ 1979, 41 m.nt. ThWvV. 
De reden waarom de Hoge Raad in dit arrest niet sprak over denaturering is wellicht gelegen in het tot voor kort gehanteerde uitgangspunt dat voor de bepaling van de inhoud van verklaringen afgelegd ter zitting alleen het vonnis doorslaggevend is, en dus niet het proces-verbaal ter terechtzitting. Klagen over verschillen tussen de inhoud van een verklaring zoals opgenomen in het procesverbaal en de inhoud zoals vastgelegd in de bewijsmiddelen in het vonnis had dus geen zin. In zijn arrest d.d. 22 november 2005 heeft de Hoge Raad ${ }^{48}$ officieel dit standpunt verlaten; thans is het proces-verbaal van de zitting niet alleen de enige kenbron voor het al dan niet gevoerd zijn van verweren, de inhoud van die verweren en het in acht genomen zijn van vormen, maar ook voor de inhoud van de aldaar afgelegde verklaringen. Voor zover die inhoud afwijkt van hetgeen in het vonnis onder de bewijsmiddelen is opgenomen kan in cassatie geklaagd worden over denaturering.

Dat hoeft overigens niet altijd succesvol te zijn. In de zaak die aanleiding gaf tot het 'omgaan' van de Hoge Raad bestond er een verdenking ter zake van diefstal van een fles wodka. De (mede)verdachte verklaarde dat hij de fles wodka uit het schap had gepakt nadat de winkelier de politie had gebeld. Voor het bewijs van de diefstal was enkel het deel 'ik heb een fles wodka gepakt' gebruikt. In cassatie werd geklaagd over denaturering van de verklaring van de verdachte; zijn verklaring over het pakken van de fles had immers betrekking op een moment dat na de beweerde diefstal lag. Van denaturering was echter volgens de Hoge Raad geen sprake. Het feit dat de verdachte de fles wodka pas achteraf uit het schap was genomen, werd immers weersproken door het overige bewijsmateriaal. De Hoge Raad hanteert hier weer de regel dat de feitenrechter wel degelijk een verklaring mag splitsen, als het deel dat hij buiten beschouwing laat en dat tevens niet-redengevend is als onbetrouwbaar kan worden aangemerkt.

Annotator Schalken merkt naar aanleiding van deze zaak op dat de Hoge Raad de feitenrechter wel erg in bescherming neemt. Zijns inziens werd in het onderhavige geval de bewijsconstructie van de rechter opnieuw door de Hoge Raad opgezet en vervolgens goed bevonden. Daarmee begeeft de Hoge Raad zich volgens Schalken op het terrein van de feitenrechter. De kritiek van Schalken is echter in dit geval onterecht. De bewijsconstructie van het hof blijft in stand. Het enige dat de Hoge Raad doet, is deze constructie verduidelijken door aan te geven waarom het afgesplitste deel van de verklaring van de verdachte buiten beschouwing kon blijven. Het was echter voor de begrijpelijkheid van de uitspraak van het hof beter geweest als het hof dat zelf had gedaan. Echter de wet noch de Hoge Raad eisen dat rechters hun uitspraken zodanig vorm geven dat duidelijk wordt hoe zij het bewijsmateriaal interpreteren, ook niet in die gevallen waarin de verdachte die denkt het feit te ontkennen naderhand tot zijn schrik ziet dat een deel van zijn

48 HR 22 november 2005, NJ 2006, 219 m.nt. T.M. Schalken. 
ontkennende verklaring alsnog voor het bewijs is gebezigd. Het probleem in dergelijke zaken is niet zoals Schalken meent dat de Hoge Raad een hernieuwde bewijswaardering doorvoert, maar dat bij gebrek aan uitleg over de bewijswaardering door de feitenrechter de Hoge Raad de ruimte krijgt en neemt om de bewijswaardering van de feitenrechter achteraf naar eigen inzicht in te vullen.

Het gevaar van, wat de Duitsers veel treffender hineininterpretieren noemen, kan in Nederland heel goed ontstaan, omdat van de feitenrechter niet wordt verlangd dat hij de wijze waarop hij verklaringen heeft geïnterpreteerd in zijn vonnis verantwoordt. Als dan achteraf blijkt dat de letterlijke bewoordingen van een dergelijke verklaring wellicht tot problemen kunnen leiden, komt de Hoge Raad in de verleiding om deze dan maar conform de bewezenverklaring te interpreteren waarbij het gevaar van denaturering van die verklaring op de loer ligt. Denaturering door de Hoge Raad is wellicht nog erger dan denaturering door de feitenrechter, omdat in cassatie voor verdediging en Openbaar Ministerie geen mogelijkheid meer openstaat om een eventuele andere betekenis of inhoud van de bewuste verklaring aan de orde te stellen.

Zou de feitenrechter evenwel worden gedwongen om zelf zijn interpretatie te verwoorden, dan leidt dit er toe dat deze interpretatie onderwerp van debat wordt in hoger beroep en cassatie. Bijkomend positief effect hiervan is, dat rechters zich bewuster worden van hun taak om het feitenmateriaal goed te screenen, en daar waar nodig ook ter zitting aanvullende vragen te stellen aan de getuige, verdachte of deskundigen met als gevolg dat deze exact kan verwoorden wat hij met de bewuste uitspraak heeft bedoeld, zonder dat de Hoge Raad daar achteraf zelf naar gaat gissen.

\subsubsection{Verband tussen bewijsobject en bewijsmateriaal}

Het laatste element dat naast de betekenis van het tenlastegelegde en de inhoud en strekking van het bewijsmateriaal van belang is voor de vaststelling van de relevantie van het bewijsmateriaal is het verband tussen het bewijsobject, de tenlastelegging en het bewijsmateriaal. In wezen is dit de daadwerkelijke eis van relevantie. Uitleg en interpretatie van het bewijsobject en het bewijsmateriaal zijn als het ware aan de relevantie-kwestie voorafgaande vragen.

In het merendeel van de strafzaken is de relevantie van het bewijsmateriaal gegeven. Voor zover er tussen het bewijsmateriaal en het bewijsobject geen verschil bestaat - er is als het ware sprake van een één-op-één-situatie - zal niemand de relevantie of de redengevendheid betwisten. Een dergelijke situatie doet zich voor bij direct bewijs. Uit het gepresenteerde bewijs kan zonder omwegen het bewijs van het tenlastegelegde feit of een deel daarvan volgen. Moet bijvoorbeeld bewezen worden dat de verdachte het slachtoffer sloeg, dan is de inhoud van de verklaring van de getuige dat hij zag dat de verdachte het slachtoffer met zijn 
rechtervuist in het gezicht sloeg direct relevant. Problemen met betrekking tot de relevantie van het bewijsmateriaal kunnen hier slechts ontstaan voor zover niet duidelijk is welke betekenis moet worden toegekend aan hetgeen moet worden bewezen of onduidelijkheden ontstaan met betrekking tot de interpretatie van de inhoud van de verklaring.

Bestaat er echter tussen het bewijsmateriaal en het bewijsobject geen één-op-éénsituatie, dan is de beoordeling van de relevantie van het bewijsmateriaal - nog afgezien van interpretatiekwesties - wel degelijk problematisch. Het te bewijzen feit moet dan als het ware uit het bewijsmateriaal worden afgeleid. Daarmee is overigens niet gezegd dat dit niet zou kunnen of mogen, ${ }^{49}$ of tot minder juiste conclusies zou moeten leiden. Aldus ook Mulder:

'De wet stelt niet de eis dat elk bestanddeel van een ten laste gelegd feit "direct" dus met het middel van een zelfstandige daarop rechtstreeks betrekking hebbende kenbron - zou moeten worden bewezen. Uit een door hem vastgestelde omstandigheid of handeling kan de rechter het bestaan of verricht zijn van een andere afleiden. De geldigheid van een dergelijke afleiding kan op een schaal van graden van waarschijnlijkheid tot de top van een dwingende conclusie hetzij op de ervaring (empirie) hetzij op de logica berusten: doorgaans op een vervlechting daarvan. ${ }^{50}$

De beoordeling van de relevantie bij indirecte bewijsconstructies is afhankelijk van de link die men kan leggen tussen het bewijsmateriaal aan de ene kant en hetgeen men wil bewijzen aan de andere kant. ${ }^{51}$ Die link komt tot uitdrukking in de algemene regel die men aan de hand van beide kan opstellen. Het formuleren van deze algemene regel geeft inzage in de mate van waarschijnlijkheid dat een bepaald feit of gegeven voorkomt in het geval dat men probeert aan te tonen. ${ }^{52}$

Stel: het vermoeden bestaat dat iemand is vermoord, echter het lijk heeft men niet aangetroffen. In dat geval kan het feit dat van die persoon vanaf een bepaald moment niets meer is vernomen een aanwijzing zijn voor het feit dat hij dood is. Het gegeven dat geen levensteken meer is waargenomen is in dat geval relevant voor het bewijs dat het slachtoffer dood is op basis van de algemene regel dat als van iemand niets meer is vernomen hij (waarschijnlijk) dood is. Het moge duidelijk zijn dat de link tussen beide niet erg sterk is en zeer afhankelijk is van de persoon van het slachtoffer, zijn gebruikelijke bezigheden etc. etc. Denkbaar is immers dat het vermeende slachtoffer met de noorderzon vertrokken is naar een voor derden onbekende bestemming. De rechter zal bij de beoordeling van de relevantie

49 HR 16 december 1929, NJ 1930, p. 313.

50 Mulder in zijn annotatie bij HR 13 december 1983, NJ 1984, 653.

51 Brouns spreekt in dit verband van 'de eis van de beperkte sprong'. Tegen die eis zou worden gezondigd indien de feitelijke inhoud van de bewijsmiddelen zodanig te kort schiet dat ze geen of een geringe waarborg voor de afgeleide bewezenverklaring is. Brouns 1987, p. 495.

52 Crombag, Van Koppen en Wagenaar 1992, p. 69 e.v. spreken in dit verband van 'verankering'. 
moeten bedenken of het ontbreken van enig levensteken waarschijnlijker is bij de dood van het slachtoffer, dan wel bij het nog in leven zijn van het vermoedelijke slachtoffer.

Relevantie kan zo bezien worden omschreven als de bewijskracht die men toekent aan feiten en omstandigheden waarbij een afweging wordt gemaakt tussen de kans dat die feiten en omstandigheden zich voordoen bij de te bewijzen situatie en de kans dat die feiten en omstandigheden ook in een andere situatie optreden. Naarmate meer feiten en omstandigheden worden aangevoerd die alle - onafhankelijk van elkaar - in de richting van het te bewijzen object wijzen, zal de gezamenlijke bewijskracht van die feiten en omstandigheden toenemen. De onderliggende generalisatie wordt immers specifieker en de kans dat de verschillende feiten en omstandigheden ook kunnen samenvallen met een alternatief scenario wordt steeds kleiner. ${ }^{53}$ Blijkt bijvoorbeeld dat het vermeende slachtoffer niet alleen niet meer is gezien of gehoord, maar ook dat hij sinds zijn verdwijning geen gebruik heeft gemaakt van zijn banktegoed en zijn mobiele telefoon, en tot slot zijn paspoort thuis heeft achtergelaten, dan vormen deze feiten en omstandigheden tezamen genomen een belangrijke aanwijzing voor het feit dat het slachtoffer dood is en wordt het scenario dat in die omstandigheden het slachtoffer nog in leven is minder waarschijnlijk.

Overduidelijk is dat bij het gebruik van indirect bewijs geen absolute zekerheid kan bestaan over het verband tussen de vastgestelde feiten en het te bewijzen feit. Het bestaan van alternatieve verklaringen kan niet worden uitgesloten. Voor zover de rechter het verband aanneemt, is dat oordeel dus een waarschijnlijkheidsoordeel. Het wijkt echter in dat opzicht niet af van andere deelbeslissingen van de rechter.

\subsubsection{Statistisch bewijs en de eis van relevantie}

De relevantie van het bewijsmateriaal kan ook in rekenkundige zin tot uitdrukking worden gebracht. In dat geval gaat het om een kansberekening waarbij de vraag aan de orde is hoe groot de kans is dat het bestaan van bepaalde feiten in een bepaalde context kan worden geweten aan toeval, dan wel wijst op een mogelijk verband met het tenlastegelegde feit. Naar mate de kans op een toevalstreffer kleiner is, des te waarschijnlijker is het dat het voorkomen van bepaalde feiten in relatie staat tot de het te bewijzen strafbare feit. Onder andere in de zaak Lucie de B. is het gebruik van statistische berekeningen aan de orde geweest. De wiskundige Elffers had berekend dat de kans dat de aanwezigheid van de Haagse verpleegster bij alle binnen een beperkte tijdspanne optredende niet medisch verklaarbare overlijdensgevallen enkel op toeval berustte 1 op de 342 miljoen was. De Recht-

53 Hierover meer uitgebreid: Bender \& Nack 1995 I, p. 209 e.v. en Dreissen 2004b. 
bank Den Haag had de verklaring van deze deskundige onder de bewijsmiddelen opgenomen. ${ }^{54}$ In hoger beroep werd echter voor de redengevendheid van de aanwezigheid van Lucia de B. bij een aantal van de overlijdensgevallen geen steun meer gezocht in de statistische berekening. ${ }^{55}$ Wellicht heeft daarbij een rol gespeeld dat over de waarde van dergelijke berekeningen voor de beoordelingen van concrete strafzaken én de wijze waarop een dergelijke kansberekening zou moeten worden uitgevoerd veel discussie bestaat. ${ }^{56}$

De Hoge Raad heeft ten aanzien van het gebruik van statistische berekeningen overwogen dat het gebruik daarvan beperkt dient te blijven tot die gevallen waarin:

'buiten redelijke twijfel zal moeten zijn dat voor het statistische verband tussen verdachte en de op de telastelegging genoemde incidenten, geen alternatieve verklaring bestaat. ${ }^{57}$

Het oordeel van de Hoge Raad betrof een vrijspraak van een crècheleidster door het Hof Amsterdam van 7 oktober 2003 ter zake van poging tot doodslag van een aantal aan haar zorg toevertrouwde kinderen in een kinderdagverblijf. ${ }^{58}$ De deskundige had berekend dat de kans dat iemand 11 of meer van 14 incidenten zou meemaken verwaarloosbaar klein is, namelijk 1 op de 50 miljoen en dat derhalve het meemaken van tenminste elf van de veertien incidenten door verdachte niet te rijmen valt met het toeval. Hij plaatste hierbij wel de kanttekening dat de conclusie op zichzelf niet aantoont dat verdachte de hand heeft gehad in de incidenten, aangezien het in principe denkbaar is dat andere verklaringen bestaan voor het zo veelvuldig voorkomen van incidenten wanneer verdachte de zorg over kinderen heeft. Deze kanttekening is door de Hoge Raad overgenomen in zijn hierboven weergegeven overweging. Dat betekent dat op basis van een statistische berekening ten aanzien van de aanwezigheid van de verdachte alleen geen daderschap kan worden afgeleid. Het betekent echter evenmin dat dergelijke kansberekeningen niet aan de bewijsconstructie ten grondslag kunnen worden gelegd. Voor zover dat gebeurt, zijn dergelijke berekeningen een numerieke invulling van de eis van redengevendheid van het bewijsmateriaal. Ten aanzien daarvan geldt evenzeer dat de onderliggende generalisatie voldoende specifiek moet zijn.

54 Rechtbank Den Haag 24 maart 2003, LJN AF6172.

55 Hof Den Haag 18 juni 2004, LJN AP2846.

56 In deze discussies staan de zogeheten klassieke statistici tegenover degenen die een bayesiaanse manier van redeneren aanhangen. Zie over de toepassing van statistisch bewijs in de rechtzaal onder andere: De Vos 2004 en 2006, Elffers 2003 en 2005 en Sjerps \& Coster van Voorhout 2005.

57 HR 26 oktober 2004, $L J N$ AR2190.

58 Hof Amsterdam 7 oktober 2003, LJN AL7736. Een bijna gelijkluidende overweging hanteert het Hof Den Haag 18 juni 2004, $L J N$ AP2846 bij de toepassing van het schakelbewijs in de zaak Lucia de B. Zie nader over het schakelbewijs paragraaf 5.2.4.3. 


\subsubsection{Motivering van het logische verband}

Het ligt voor de hand om te veronderstellen dat de wetgever, toen hij in 1926 de eis van redengevendheid als motiveringsvoorschrift opnam, verwachtte dat de rechter de relevantie van het bewijsmateriaal voor de bewezenverklaring onder ogen zou zien. Artikel 359 lid $3 \mathrm{~Sv}$ moest volgens de memorie van toelichting bij het wetboek bewerkstelligen dat:

'de lagere rechter door het verplicht op schrift stellen van de argumenten die hem logisch tot zijne conclusie leidden, genoopt zal worden zich zelf zeer nauwkeurig rekenschap te geven van de waarde van het materiaal, waaruit hij die conclusie opbouwt' ${ }^{59}$

Uit dit citaat volgt zonder twijfel dat de eis van relevantie een eis was die aan ons bewijsrecht ten grondslag zou moeten liggen. Dat kan ook worden afgeleid uit het feit dat het motiveringsvoorschrift werd opgenomen ter vervanging van het in het vorige wetboek opgenomen bewijsmiddel der aanwijzingen. Waar de rechter onder het oude Wetboek van Strafvordering de feiten waaruit hij het bewijs indirect afleidde als aanwijzingen moest kwalificeren, wordt dit bewijsmiddel in het Wetboek van Strafvordering 1926 geschrapt. ${ }^{60}$ Dit betekende echter niet dat indirecte bewijsconstructies onder het nieuwe wetboek niet toelaatbaar waren. Het afleiden van het bewijs van het tenlastegelegde feit of delen daarvan uit aanwijzingen is ook na 1926 nog steeds mogelijk. Dergelijke aanwijzingen kunnen immers blijken uit de overige bewijsmiddelen. Zij hoeven echter niet langer als aanwijzingen gekwalificeerd te worden en de beperkingen die op grond van het vorige wetboek golden ten aanzien van het bewijs door middel van aanwijzingen gelden niet meer. Wel dient de rechter dergelijke aanwijzingen of redengevende feiten en omstandigheden in het vonnis nadrukkelijk aan te wijzen. Uit de motivering van de uitspraak moet blijken welke feiten en omstandigheden volgens de rechter door de bewijsmiddelen vaststaan en hoe hij daaruit het bewijs van het tenlastegelegde afleidt. ${ }^{61}$ De eis van relevantie is zodoende niet langer een directe voorwaarde voor het gebruik van het bewijsmateriaal wil het als wettig gekwalificeerd worden, maar een indirecte die slechts in de motivering van het vonnis tot uitdrukking komt; daar moeten immers de relevante feiten en omstandigheden worden aangewezen. De mate waarin de relevantie van het bewijsmateriaal een wezenlijke voorwaarde voor het gebruik van dat bewijsmateriaal is, is dus vooral afhankelijk van de eisen die men op dit punt stelt aan de inrichting van het vonnis. Met andere woorden: hoe specifiek moet de rechter het verband tussen het bewijsmateriaal en het bewijsobject in het vonnis weergeven?

59 Kamerstukken II 1913-1914, 286, nr. 3 (MvT), p. 180.

60 Paragraaf 2.2.4.2.

61 Kamerstukken II 1913-1914, 286, nr. 3 (MvT), p. 180. 


\subsubsection{Invulling van de eis van redengevendheid}

Hoewel de strekking van het voorschrift uit de memorie van toelichting heel duidelijk naar voren komt - de rechter moet in het vonnis zijn logische gedachtegang kenbaar maken ${ }^{62}$ - leidde het derde lid van artikel $359 \mathrm{~Sv}$ al direct bij inwerkingtreding tot de nodige problemen. Zo was de bedoeling van de wetgever niet in overeenstemming met het door hem zelf verstrekte model-vonnis. Daarin werden wel allerlei redengevende feiten en omstandigheden opgesomd, maar een logische gedachtegang ontwaarde men daarin niet. ${ }^{63}$ Bovendien vreesde men dat het voorschrift tot een extra belasting van de rechterlijke macht zou leiden. ${ }^{64}$

Het meest wezenlijke probleem met betrekking tot het aanwijzen van de redengevende feiten en omstandigheden betrof evenwel de vraag welke feiten volgens de wetgever moesten worden aangewezen; ziet artikel 359 lid $3 \mathrm{~Sv}$ op de feiten waaruit wordt afgeleid of moeten de afgeleide feiten worden aangewezen? Deze vraag was in zoverre van belang omdat in het nieuwe motiveringsvoorschrift geen onderscheid werd gemaakt tussen gevallen waarin het bewijs direct uit de bewijsmiddelen volgde en gevallen waarin men slechts door afleiding tot een bewezenverklaring van het tenlastegelegde feit kon komen. In geval van direct bewijs volgt zonder verdere redenering de bewezenverklaring van de tenlastelegging of een deel daarvan uit het bewijsmateriaal. Hiervan is bijvoorbeeld sprake indien het tenlastegelegde is waargenomen of ondervonden door een getuige. Bij een directe bewijsvoering kunnen enkel de feiten waaruit het bewijs wordt afgeleid worden vermeld, simpelweg omdat er geen afgeleide feiten zijn. In geval van indirect bewijs bestaat er echter wel de mogelijkheid om afgeleide feiten aan te wijzen. Bij een indirecte bewijsvoering blijft er immers een gat bestaan tussen het feit zoals dat uit het bewijsmateriaal naar voren komt en het te bewijzen feit. Dit gat kan door middel van redenering of zogeheten 'tussenfeiten' worden opgevuld. Deze tussenfeiten vormen dan de afgeleide feiten en zouden op basis van artikel 359 lid 3 in het vonnis kunnen worden aangewezen. ${ }^{65}$ Het gebruiken van indirecte bewijsconstructies is vaak noodzakelijk omdat niet alle bestanddelen van het strafbare feit worden waargenomen of kunnen worden waargenomen. In dat laatste geval kan men denken aan het bewijs van opzet of schuld.

Het feit dat artikel 359 lid 3 geen onderscheid maakt tussen indirecte en directe bewijsconstructies, maar wel op beide van toepassing is, zou voedingsbodem zijn

62 Kamerstukken II 1913-1914, 286, nr. 3 (MvT), p. 182-183.

63 Taverne 1927, p. 233. In gelijke zin: J. Simons 1926, p. 8.

64 J.E. Simons 1926, p. 8, Taverne 1927, p. 228 en Sipkes 1926, p. 8: 'Wil men den rechter noodzaken, om na een uitvoerige opsomming van het bewijsmateriaal, van alles wat tot bewijs van het te laste gelegde dient, die verschillende daarin opgenomen feiten en omstandigheden nog een voor een tweede maal te gaan opnoemen? Doch dit zou toch een geheel onnut, zeer tijdrovend "monnikenwerk" zijn.'

65 Het begrip 'tusschenfeiten' is afkomstig van Taverne 1927, p. 234. 
voor de gedachte dat enkel de feiten waaruit het bewijs werd afgeleid moesten worden aangewezen in het vonnis. Deze gedachte wordt ondersteund door het modelvonnis, dat bij wijze van voorbeeld in de memorie van toelichting was opgenomen. Ook daarin treft men geen afgeleide feiten aan. Daar staat echter tegenover dat uit de totstandkoming van deze bepaling duidelijk blijkt dat men het oog had op het vermelden van de afgeleide feiten. In het verslag van de Commissie-Ort valt immers te lezen met betrekking tot de wijze waarop aan de verschillende motiveringseisen moet worden voldaan, dat de rechter eerst de inhoud van de bewijsmiddelen kan vermelden om vervolgens de daaruit afgeleide feiten en omstandigheden op te geven. ${ }^{66}$ Bovendien zou de toegevoegde waarde van artikel 359 lid 3 zeer beperkt zijn, indien deze bepaling alleen zag op het vermelden van de feiten waaruit werd afgeleid. ${ }^{67}$ Reeds op basis van het eerste lid van artikel $359 \mathrm{~Sv}$ moesten de inhoud van de bewijsmiddelen en dus ook de feiten waaruit het bewijs werd afgeleid, worden genoemd. Lid 1 en 3 van artikel $359 \mathrm{~Sv}$ zouden dan tot hetzelfde resultaat leiden, namelijk het vermelden van de inhoud van de gebezigde bewijsmiddelen. ${ }^{68}$ Een dergelijke resultaat zou haaks staan op de aan artikel 359 lid 3 ten grondslag liggende gedachte dat de rechter zijn logische gedachtegang in het vonnis zou moeten expliciteren en dus niet zou kunnen volstaan met enkel opsommen van het gebezigde bewijsmateriaal.

\subsubsection{Uitleg van art. 359 lid 3 Sv door de Hoge Raad}

Zoals uit de vorige paragraaf blijkt, was de strekking en reikwijdte van het nieuwe artikel 359 lid $3 \mathrm{~Sv}$ niet geheel duidelijk. Over het algemeen werd de bedoeling van de wetgever om tot inzichtelijkere vonnissen te komen wel onderschreven, maar twijfelde men er aan of de redactie van 359 lid $3 \mathrm{~Sv}$ op dit punt wel voldoende was doordacht. Taverne is heel stellig in zijn ideeën over artikel 359 lid $3 \mathrm{~Sv}$ : de bepaling zou wat hem betreft beter volledig kunnen verdwijnen. ${ }^{69}$ Het is dan ook niet vreemd dat de Hoge Raad, waar Taverne op dat moment deel van uitmaakte, nog in hetzelfde jaar waarin het Wetboek van Strafvordering in werking treedt een einde maakt aan de goede bedoelingen van de wetgever.

66 Het verslag van de 52e vergadering staat met betrekking tot de redactie van het vonnis op p. 5 te lezen: 'Ook kan (...) de inhoud der bewijsmiddelen worden vermeld en daarna worden opgegeven, welke feiten of omstandigheden daaruit werden afgeleid [cursivering WD]'.

67 Blok \& Besier II, p. 205.

68 Bovendien is door Taverne terecht opgemerkt dat in geval van een directe bewijsvoering het aanwijzen van de redengevende feiten en omstandigheden leidt tot een onlogische redenering, te weten voor het bewijs van feit A is redengevend het feit A. Dat kan natuurlijk niet juist zijn, omdat in dit ondermaansche geen feit reden kan geven voor zichzelf.' Taverne 1927, p. 254.

69 Taverne 1927, p. 262 
Hoewel het arrest aanvangt met een verwijzing naar de bedoeling van de wetgever, ${ }^{70}$ wordt vervolgens de eis van redengevendheid gelijk gesteld met de eis van de vermelding van de inhoud van de bewijsmiddelen. Doorslaggevend argument daarbij is inderdaad dat uit de redactie van het derde lid niet valt af te leiden wanneer wel en wanneer geen nadere redengeving mogelijk is en dat dientengevolge in cassatie vonnissen niet kunnen worden vernietigd indien de aanwijzing van de redengevende feiten en omstandigheden geschiedt door verwijzing naar de inhoud van de bewijsmiddelen. De Hoge Raad overweegt:

'1. dat artikel 359, derde lid, een zelfstandigen eisch stelt;

2. dat die eisch geheel algemeen en zonder onderscheid is gesteld;

3. dat ook bij indirect bewijs zich vele gevallen voordoen waarin een andere redengeving dan door den inhoud der bewijsmiddelen onmogelijk is;

4. dat de wet geen onderscheiding aan de hand doet om uit te maken, wanneer niet en wanneer wel een nadere redengeving mogelijk is;

5. dat de cassatierechter dus niet kan ingrijpen, als de rechter de inhoud der bewijsmiddelen voor de redengeving hanteert, en

6. dat de cassatierechter wel heeft na te gaan, of de feiten of omstandigheden - hetzij deze buiten of in den inhoud der bewijsmiddelen liggen - de redengeving kunnen opleveren., ${ }^{71}$

Deze uitspraak heeft grote consequenties voor de motivering van de bewezenverklaring en met name voor de eis dat de rechter de redengevende feiten en omstandigheden moet aanwijzen. Het specifiek aanwijzen van deze feiten en omstandigheden is volgens de Hoge Raad niet langer nodig; volstaan kan worden met een verwijzing naar de inhoud van de bewijsmiddelen. Deze verwijzing bestaat dan uit een sjabloonachtige zin opgenomen na de vermelding van de inhoud van de bewijsmiddelen, inhoudende dat deze bewijsmiddelen de feiten en omstandigheden bevatten waarop de bewezenverklaring steunt. Daarmee valt het motiveringsvereiste aangaande de redengevendheid van het bewijsmateriaal samen met de eis om de inhoud van de bewijsmiddelen op te nemen. Weliswaar geeft de Hoge Raad aan dat het wenselijk is dat - indien mogelijk - de feitenrechter zijn oordeel nader motiveert, maar bij gebrek aan een criterium in de wet waaruit zou kunnen worden afgeleid wanneer wel een nadere redengeving vereist is, kan de Hoge Raad de feitenrechter niet dwingen tot een nadere verantwoording van zijn bewijsoordeel. ${ }^{72}$ Hoewel de Hoge Raad het vereiste van 359 lid 3 Sv dus niet zodanig heeft uitgelegd dat op basis daarvan in geval van een indirecte bewijsconstructie expliciet de uit

70 'Het is de bedoeling der wet dat de rechter, zoo dit mogelijk is, de bewezenverklaring nog nader zal moeten motiveeren dan reeds door den inhoud der bewijsmiddelen is geschied.'

71 HR 29 november 1926, NJ 1927, 46 m.nt. Besier.

72 Zie expliciet daarover: HR 2 mei 1927, $N J$ 1927, 768. Ook in latere uitspraken wordt dit uitgangspunt gehandhaafd, zie onder andere: HR 10 december 1985, NJ 1986, 426 en HR 19 april 1983, NJ 1983, 574. In laatstgenoemde uitspraak oordeelde de Hoge Raad dat het ook niet nodig is om in geval van een bewezenverklaring ten aanzien van meerdere feiten in het vonnis aan te geven op welk van deze feiten het gebezigde bewijsmateriaal betrekking heeft. 
het bewijsmateriaal afgeleide feiten in het vonnis moeten worden vermeld, betekent dat niet dat aan artikel 359 lid $3 \mathrm{~Sv}$ geen enkele betekenis meer toekomt. Enerzijds hield de Hoge Raad vast aan het vereiste dat de feitenrechter in zijn vonnis nadrukkelijk de redengevende feiten en omstandigheden moest aanwijzen. Ontbreekt een dergelijke expliciete aanwijzing, dan wordt het vonnis in cassatie vernietigd. ${ }^{73}$ Daarmee dwong de Hoge Raad de feitenrechter als het ware tot het gebruik van toverformules in de trant van 'bevattende deze bewijsmiddelen de redengevende feiten en omstandigheden waarop de bewezenverklaring steunt'. Aan deze zinloze exercitie $^{74}$ is per 1 januari 2005 een einde gemaakt. Thans vereist het derde lid van artikel $359 \mathrm{~Sv}$ niet langer dat de feitenrechter de redengevende feiten en omstandigheden moet aanwijzen. Voldoende is het vermelden van de inhoud van de bewijsmiddelen waarbij als voorwaarde geldt dat die inhoud redengevend moet zijn.

Anderzijds biedt het vereiste van het derde lid van artikel $359 \mathrm{~Sv}$ - ondanks het feit dat de rechter niet expliciet op de redengevendheid van het bewijsmateriaal hoeft in te gaan - de cassatierechter een middel om te toetsen of het door de feitenrechter gebezigde materiaal relevant is voor het bewijs en in die zin heeft de eis van redengevendheid nog wel degelijk betekenis.

\subsubsection{Toetsing van art. 359 lid 3 Sv in cassatie}

Reeds uit de uitspraak van de Hoge Raad in 1926 bleek dat in cassatie de redengevendheid van het bewijsmateriaal wel getoetst kon worden. De Hoge Raad overwoog:

'dat de cassatierechter wel heeft na te gaan, of de feiten of omstandigheden - hetzij deze buiten of in den inhoud der bewijsmiddelen liggen - de redengeving kunnen opleveren'. ${ }^{, 75}$

Uit deze overweging komt echter ook naar voren dat de Hoge Raad de redengevendheid slechts op een zeer marginale wijze toetst. In cassatie wordt enkel bezien of de in de bewijsmiddelen genoemde feiten en omstandigheden redengevend voor de bewezenverklaring kunnen zijn. Deze afstandelijke toetsing is op zichzelf goed te begrijpen, aangezien de cassatierechter niet zelf nogmaals de feiten mag beoordelen. De cassatierechter kan slechts beoordelen of de feitenrechter met inachtneming van het recht en de vereiste vormen tot een bewezenverklaring heeft kunnen komen. Aangezien uit de wet geen concrete aanknopingspunten voor de vereiste motivering, behoudens het opnemen van de inhoud van de bewijsmiddelen, zijn te destilleren, kan in cassatie het oordeel van de feitenrechter alleen op zijn begrijpelijkheid worden getoetst.

73 HR 23 november 1965, NJ 1966, 227 en HR 12 juni 1979, NJ 1979, 584.

74 In gelijke zin: Jolles 1927: 'Ik zou in overweging willen geven, den eisch der redengevende feiten en omstandigheden geheel te doen vervallen want een formule heeft niet de minste waarde (...).'

75 HR 29 november 1926, NJ 1927, 46 m.nt. Besier. 
Deze begrijpelijkheidstoets valt uiteen in twee aspecten. Het eerste aspect ziet op de verschillende onderdelen van de bewijsconstructie; of het door de feitenrechter geselecteerde bewijsmateriaal enige betekenis heeft voor de bewezenverklaring. Het tweede punt ziet op de bewijsconstructie als geheel; het betreft de vraag of het bewijsmateriaal als geheel de bewezenverklaring dekt; of het met andere woorden toereikend is.

\subsection{Redengevendheid op onderdelen}

Zoals gezegd valt de motiveringseis aangaande de redengevendheid van het door de rechter gebezigde bewijs samen met de eis dat de rechter de inhoud van de bewijsmiddelen in het vonnis moet opnemen. Consequentie van het samenvallen van deze eisen is dat alles wat de rechter aan bewijsmateriaal in het vonnis opneemt per definitie moet worden aangemerkt als redengevend voor zijn bewijsbeslissing. ${ }^{76}$ Het opnemen van overbodige informatie is niet toegestaan, aangezien de bewezenverklaring hierdoor niet kan worden gemotiveerd. ${ }^{77}$

In cassatie kan vervolgens worden bezien of de inhoud van de bewijsmiddelen daadwerkelijk redengevend is. Daarbij laat de Hoge Raad - noodgedwongen de rechter veel ruimte. Bij gebrek aan uitleg op dit punt valt zoals gezegd niet veel te toetsen. In het merendeel van de gevallen leidt dit dan ook niet tot vernietiging. In dergelijke zaken volstaat de Hoge Raad meestal met de enkele constatering dat de feitenrechter het gebezigde bewijsmateriaal kennelijk redengevend heeft geacht en ook heeft kunnen achten waarbij eventueel nog expliciet wordt aangegeven voor welk deel van de tenlastelegging het bewijsmateriaal betekenis heeft. ${ }^{78}$

Alleen wanneer de in de bewijsmiddelen genoemde feiten en omstandigheden overduidelijk niet redengevend kunnen zijn voor de bewezenverklaring, gaat de Hoge Raad over tot vernietiging. Daarvan is in de eerste plaats sprake indien de feiten zoals die blijken uit de bewijsmiddelen direct in strijd zijn met de feiten die worden bewezen verklaard. Zo kan een bewijsmiddel inhoudende dat de verdachte ten tijde van het delict in Aken was, terwijl het delict is gepleegd in Tilburg niet redengevend zijn. ${ }^{79}$ In de tweede plaats wordt het bewijsmateriaal

76 In gelijke zin Knigge 1980, p. 155: 'Al hetgeen in het vonnis aan bewijs is aangedragen moet ook inderdaad tot het bewijs bijdragen'.

77 Corstens 2005a, p. 682.

78 Onder andere: HR 22 april 1969, NJ 1970, 125 m.nt. Enschedé; HR 3 januari 1978, NJ 1978, 627; HR 17 november 1981, NJ 1983, 84 m.nt. ThWvV, HR 18 mei 1982, NJ 1983, 49; HR 4 januari 1983, NJ 1983, 321 m.nt. ThWvV; HR 29 mei 1984, NJ 1985, 6 m.nt. ThWvV; HR 10 december 1985, NJ 1986, 426; HR 18 maart 1986, NJ 1986, 770; HR 10 juni 1986, NJ 1987, 61 m.nt. C; HR 4 november 1986, NJ 1987, 363 en HR 24 februari 1987, NJ 1988, 540.

79 HR 21 oktober 1975, NJ 1976, 178. In vergelijkbare zin: HR 20 december 1988, NJ 1989, 735; HR 18 juni 1996, NJ 1996, 750; HR 19 juni 2001, NJ 2001, 521; HR 2 november 2004, NJ 2005, 275 en HR 20 juni 2006, NJ 2006, 358. 
als niet redengevend beoordeeld als het bewezen verklaarde deel daaruit niet volgt of zonder nadere motivering daaruit niet volgt. ${ }^{80}$ Dit is bijvoorbeeld het geval indien de feitenrechter voorwaardelijk opzet heeft aangenomen zonder nadere toelichting. ${ }^{81}$ Het bestaan van de aanmerkelijke kans op het intreden van het gevolg, de wetenschap van de verdachte op het intreden van de kans en de aanvaarding van dat risico kunnen vaak niet zonder nadere toelichting worden afgeleid uit het bewijsmateriaal. ${ }^{82}$

Maar zelfs al is het bewijsmateriaal niet redengevend, dan nog wil dit niet zeggen dat dit altijd tot cassatie leidt. De Hoge Raad lijkt veelal bereid de nietigheid van het vonnis (art. 359 lid 3 jo lid $8 \mathrm{~Sv}$ ) op dit punt te relativeren. ${ }^{83}$ Het bezigen van niet redengevend bewijsmateriaal hoeft niet tot cassatie te leiden indien dit van ondergeschikt belang is en dus een behoorlijke motivering niet in de weg staat dat

'dit in het kader van de overige wel redengevende feiten en omstandigheden bevattende inhoud der gebezigde bewijsmiddelen van zodanig ondergeschikt belang is dat het niet gezegd kan worden een behoorlijke motivering van de bewezenverklaring in de weg te staan. $^{\text {, }}$

In andere gevallen oordeelt de Hoge Raad dat de passage waarvan in cassatie wordt beweerd dat zij niet redengevend is, dat ook niet is omdat zij door de feitenrechter enkel als inleiding op het wel redengevende deel van het gebezigde bewijsmiddel is gebezigd. ${ }^{85}$ En zelfs is de Hoge Raad bereid om delen van het bewijsmateriaal die evident niet redengevend kunnen zijn voor de bewezenverklaring geheel buiten beschouwing te laten, omdat het opnemen daarvan kennelijk berust op een vergissing.

'De door het middel gewraakte passage bevat niets wat bijdraagt aan het bewijs van hetgeen ten laste van de verdachte bewezen is verklaard en de bewezenverklaring kan volledig worden afgeleid uit het bewijsmiddel met weglating van die passage. Het moet er daarom voor worden gehouden dat het niet de bedoeling van de Politierechter is geweest om de meerbedoelde passage tot het bewijs te laten meewerken, zodat die passage bij vergissing in het bestreden vonnis is opgenomen. De Hoge Raad leest

80 Onder andere: HR 1 maart 1966, NJ 1966, 391 m.nt. van Berckel; HR 17 oktober 1968, NJ 1968, 79; HR 30 september 1975, NJ 1976, 70 m.nt. GEM; HR 8 januari 1980, NJ 1980, 201; HR 3 november 1981, NJ 1982, 160 en HR 1 juni 2004, NJ 2005, 252 m.nt. Kn.

81 In het project verbetering motivering strafvonnissen (Promis) geldt een nadere motiveringsplicht indien het opzet in zijn voorwaardelijke vorm wordt aangenomen. Promis Eindverslag 2005, p. 22.

82 Bijvoorbeeld ten aanzien van de wetenschap van de verdachte: HR 1 april 2003, $N J$ 2003, 553.

83 In gelijke zin: Fokkens 2006, p. 22-23.

84 HR 1 juni 1976, NJ 1977, 42. In gelijke zin: HR 17 februari 1981, $N J$ 1981, 536 m.nt. GEM; HR 19 mei 1987, NJ 1988, 218; HR 23 oktober 1990, NJ 1991, 171 m.nt. ThWvV; HR 6 oktober 1998, NJ 1998, 912; HR 22 januari 2002, LJN AD6244; HR 4 juni 2002, NJ 2002, 603 m.nt. PMe; HR 6 mei 2003, NJ 2003, 710 m.nt. Sch; HR 3 juni 2003, LJN AF5087, HR 18 januari 2005, NJ 2006, 12 en HR 20 juni 2006, LJN AW4479.

85 HR 23 oktober 1984, NJ 1985, 319. 
daarom het bestreden vonnis met verbetering van die vergissing en derhalve met weglating van de door het middel gewraakte passage. ${ }^{, 86}$

De betekenis van artikel 359 lid $3 \mathrm{~Sv}$ wordt door de bereidheid van de Hoge Raad om fouten van de feitenrechter op dat punt van ondergeschikt belang te achten of te herstellen nog verder teruggebracht. Ten onrechte, omdat ik met Reijntjes van mening ben dat de aanwezigheid van irrelevante onderdelen in de bewijsmotivering een indicatie is voor het feit dat de rechter een dwaalspoor heeft gevolgd. ${ }^{87}$ Ook Van Veen was kennelijk die mening toegedaan. In zijn annotatie bij het arrest van de Hoge Raad d.d. 23 oktober 1990 meende hij dat het opnemen van een irrelevante passage bij het bewijs een aanwijzing kan zijn voor de noodzaak van nader onderzoek. ${ }^{88}$ In casu was onder het bewijs een verklaring van een verbalisant opgenomen inhoudende dat de verdachte onvast ter been was. De verbalisant voegde daaraan toe dat dat het gevolg zou kunnen zijn van hetzij het alcoholgebruik, hetzij het ongeval dat hem daarvoor was overkomen, hetzij beide. Deze verklaring bevatte elementen die de conclusie dat de verdachte onder invloed heeft gereden niet steunen en zelfs daarmee in strijd zouden kunnen zijn. Desalniettemin achtte de Hoge Raad dit van zodanig ondergeschikt belang dat het een behoorlijke motivering van de bewezenverklaring niet in de weg stond. Mij lijkt dat het bezigen van deze verklaring voor het bewijs wel een behoorlijke motivering in de weg staat. Hoewel uit het arrest van de Hoge Raad niet blijkt welke de overige bewijsmiddelen waren die het hof had gebezigd, moet worden aangenomen dat het onvast ter been zijn van de verdachte voor het hof van wezenlijke betekenis was voor de bewezenverklaring. Wordt nota bene door een verbalisant een mogelijke andere oorzaak voor het onvast ter been zijn genoemd, dan dient het hof hiernaar onderzoek te doen en de uitkomst van dat onderzoek in het vonnis tot uitdrukking te brengen. Alleen dan is er sprake van een behoorlijke motivering en kan worden uitgesloten dat de feitenrechter een dwaalspoor heeft gevolgd.

\subsection{Toereikendheid van het bewijsmateriaal}

Geldt enerzijds voor al het in het vonnis opgenomen bewijsmateriaal dat het iets moet toevoegen aan de bewezenverklaring, anderzijds moet het geheel aan bewijsmiddelen de bewezenverklaring kunnen dragen. In de literatuur wordt de eis van toereikendheid of genoegzaamheid van het bewijs veelal omschreven als de voorwaarde dat elk onderdeel van de bewezenverklaring in één of meer bewijsmiddelen

86 HR 20 oktober 1998, NJ 1999, 49.

87 J.M. Reijntjes, Bewijs, paragraaf 34.3.5. (suppl. augustus 2006), in: G.J.M. Corstens e.a. (red.), Handboek Strafzaken, Deventer: Gouda Quint z.j.

88 HR 23 oktober 1990, NJ 1991, 171 m.nt. ThWvV. 
moet zijn terug te vinden. ${ }^{89}$ Slechts voor zover onderdelen van de bewezenverklaring feiten van algemene bekendheid zijn, behoeven zij geen bewijs.

Het onderscheid tussen beide aspecten - de redengevendheid van het bewijsmateriaal en de toereikende motivering van de bewezenverklaring - valt echter niet altijd goed te maken. Voor zover immers wordt vastgesteld dat één van de gebezigde bewijsmiddelen achteraf beoordeeld niet redengevend is, zal vaak het onderdeel van de bewezenverklaring waarop dat bewijsmiddel ziet niet blijken uit de bewijsmiddelen. De niet redengevendheid van het bewijsmateriaal leidt in dergelijke gevallen tevens tot een ontoereikende motivering van de bewezenverklaring. Teneinde verwarring van beide eisen te voorkomen, lijkt het daarom beter om slechts van een ontoereikende bewezenverklaring te spreken indien de in het vonnis opgenomen én redengevende bewijsmiddelen de bewezenverklaring niet dekken. De toetsing van de toereikendheid van het bewijs in cassatie bestaat in principe uit niet meer dan een vergelijking tussen de feiten die blijken uit de bewijsmiddelen en de bewezen verklaarde feiten. Van een niet toereikende bewijsmotivering is in de eerste plaats sprake indien feiten en omstandigheden zoals opgenomen in de bewezenverklaring niet kunnen worden teruggevonden in de bewijsmiddelen. De rechter is - simpel gezegd - vergeten om voor een bepaald onderdeel van de bewezenverklaring bewijsmateriaal in het vonnis op te nemen. Wordt daarover geklaagd in cassatie, dan zal dat tot vernietiging van het vonnis leiden. Is er daadwerkelijk sprake van 'vergeten', dan kan dat euvel alsnog door de feitenrechter worden hersteld. Blijkt echter dat voor het betreffende onderdeel geen bewijsmateriaal beschikbaar is, dan zal dat bij (terug)verwijzing tot vrijspraak moeten leiden. Dit speelde bijvoorbeeld in de zaak waarin de verdachte opzetheling was tenlastegelegd. In de tenlastelegging was opgenomen dat de verdachte wist dat het door hem verworven geld uit diefstal afkomstig was. Uit de bewijsmiddelen kon wel blijken dat de verdachte had moeten weten dat het geld 'stonk', maar nergens bleek dat de verdachte wist dat het geld de buit van een roofoverval was en dus uit diefstal afkomstig was. Aangezien dit wel was tenlastegelegd en dus bewezen moest worden, was de bewezenverklaring op dit punt ontoereikend. ${ }^{90}$ Vaak sneuvelen klachten over de ontoereikendheid van het bewijs in cassatie omdat weliswaar een deel van de bewezenverklaring niet blijkt uit de inhoud van de bewijsmiddelen, maar de Hoge Raad van mening is dat er sprake is van een feit van algemene bekendheid. Dergelijke feiten hoeven geen bewijs. Dit betekent ook dat de feitenrechter dergelijke feiten van algemene bekendheid niet in zijn vonnis hoeft op te nemen. Wordt bijvoorbeeld geklaagd over het feit dat uit de bewijsmiddelen niet blijkt dat de weg waarop het tenlastegelegde en bewezenverklaarde feit zou hebben plaatsgevonden openbaar was, dan kan dat in cassatie worden gepareerd door te overwegen dat het van algemene bekendheid is dat de

89 Van Dorst 2004, p. 196.

90 HR 30 november 1999, NJ 2000, 215 m.nt. JdH. 
bewuste weg voor het openbaar verkeer openstaat. ${ }^{91}$ Gezien de grote mate van verscheidenheid van feiten die als algemeen bekend verondersteld mogen worden, is niet uitgesloten dat de verdachte soms verrast wordt door dergelijke achteraf geformuleerde algemene bekendheden. Met name bij het bewijs van opzet wordt vaak een toevlucht genomen tot onuitgesproken feiten van algemene bekendheid, in de zin van algemene ervaringsregels. Zo wordt de bestuurder van een auto geacht te weten wat in zijn auto aanwezig is. Worden verdovende middelen aangetroffen in die auto, dan is daarmee ook het opzet op het aanwezig hebben, vervoeren of in- en uitvoeren van die middelen bewezen.

Het is dan ook beter wanneer de rechter dergelijke bekendheden vooraf ter sprake brengt, opdat de verdachte de mogelijkheid heeft ze te weerspreken. Voor zover ze worden weersproken, is het wenselijk dat de rechter dergelijke algemene bekendheden waarop hij zijn bewijsoordeel mede doet steunen in het vonnis verwoordt. Op die wijze kan zowel in hoger beroep als in cassatie dit oordeel worden getoetst en wordt voorkomen dat de rechter feiten van algemene bekendheid gebruikt om bewijsproblemen te omzeilen. ${ }^{92}$

De toereikendheid van het bewijs ziet niet alleen op de vraag of alle onderdelen van de bewezenverklaring worden gedekt door de in het vonnis opgenomen redengevende bewijsmiddelen, maar ook op de mate van waarschijnlijkheid dat de feitelijke gang van zaken zich heeft voorgedaan zoals die uit de bewezenverklaarde blijkt. Het Nederlandse bewijsrecht vereist niet dat met absolute zekerheid het bewezenverklaarde komt vast te staan. Voldoende is dat met een aan zekerheid grenzende waarschijnlijkheid de bewezenverklaarde feiten als 'waar' kunnen worden aangemerkt. Dat betekent dat de door de rechter gehanteerde bewijsmiddelen een andere feitelijke gang van zaken moeten uitsluiten. Deze andere feitelijke toedracht moet echter wel een reële mogelijkheid bevatten. Met louter fictieve scenario's waarvoor geen feitelijke grondslag is te vinden, hoeft de rechter geen rekening te houden. Zo hoefde de rechter geen rekening te houden met de door verdachte geopperde mogelijkheid dat het slachtoffer, een 74-jarige voetganger, een zebrapad was opgerend. Hij mocht deze mogelijkheid als irreëel terzijde schuiven en de dood van de bejaarde op het conto van de te hardrijdende en onder invloed van drugs verkerende verdachte schrijven. ${ }^{93}$ Voert de verdachte echter feiten aan die een andere feitelijke gang van zaken niet bij voorbaat uitsluiten, dan dient de rechter daarop in zijn vonnis nader in te gaan. In dergelijke gevallen is de redengevendheid van het bewijsmateriaal niet automatisch gegeven en rust er op de rechter een nadere motiveringsplicht.

$91 \quad$ HR 7 januari 1975, NJ 1975, 197.

92 In gelijke zin: Nijboer 2000a, p. 272.

93 HR 3 april 1973, NJ 1973, 283 m.nt. ThWvV. 


\subsubsection{Nadere motiveringseisen ten aanzien van de redengevendheid}

Uit het voorgaande is gebleken dat de motivering van de redengevendheid van het bewijsmateriaal samenvalt met de eis dat de feitenrechter de inhoud van de bewijsmiddelen moet opnemen. Van de rechter wordt in principe niet verlangd dat hij buiten de inhoud van de bewijsmiddelen aangeeft waaruit het verband tussen het bewijsmateriaal en de bewezenverklaring bestaat en waarom dit bewijsmateriaal toereikend is voor de bewezenverklaring. Op dit uitgangspunt is door de Hoge Raad een aantal uitzonderingen geformuleerd. Waar het gaat om de redengevendheid van het bewijsmateriaal bleek reeds dat de Hoge Raad in bepaalde uitspraken heeft aangegeven dat zonder nadere toelichting die redengevendheid in cassatie niet kan blijken. Daarmee draagt de cassatierechter de feitenrechter op om in die gevallen waarin het verband tussen bewijsmateriaal en bewijsobject niet evident is, dit nader toe te lichten. Ten aanzien van bepaalde bewijsconstructies wordt een dergelijke nadere motiveringsplicht standaard vereist. Het betreft dan het gebruik van een leugenachtige verklaring van de verdachte, het toekennen van bewijskracht aan het zwijgen van de verdachte en het gebruik van het zogeheten schakelbewijs. Waar het gaat om de toereikendheid van het bewijs wordt eveneens een nadere motiveringseis gesteld, namelijk in die gevallen waarin door of namens de verdachte een zogeheten Meer en Vaartverweer is gevoerd.

\subsubsection{De kennelijk leugenachtige verklaring van de verdachte}

Volgens vaste rechtspraak van de Hoge Raad mag de kennelijke leugenachtigheid van de verklaring van de verdachte meewerken aan het bewijs. ${ }^{94}$ In een dergelijke bewijsconstructie wordt dus niet de verklaring van de verdachte zelf voor het bewijs gebruikt. Dat is ook niet mogelijk, omdat deze verklaring een ontkenning inhoudt en als zodanig dus nooit redengevend kan zijn voor de bewezenverklaring. Wat wel voor het bewijs wordt gebruikt, is de vaststelling door de rechter dat deze verklaring leugenachtig is.

Op deze bewijsconstructie is veel kritiek. Prakken meent dat op deze wijze de vrijheid van de verdachte om niet aan zijn eigen veroordeling te hoeven meewerken geweld wordt aangedaan. ${ }^{95}$ Nijboer heeft gewezen op mogelijke strijd met artikel 6 lid 2 EVRM waarin het vermoeden van onschuld is opgenomen. ${ }^{96}$ Het Europees Hof van de rechten van de mens heeft echter geoordeeld dat het afleiden van belastende feiten uit liegen van de verdachte niet in strijd is met het nemo-

94 HR 29 juni 1971, NJ 1981, 417; HR 13 februari 1973, NJ 1973, 139, HR 19 maart 1974, NJ 1974, 241 m.nt. ThWvV, HR 12 november 1974, NJ 1975, 41 en HR 6 mei 1986, NJ 1987, 60 m.nt. ThWvV.

95 Jessurun d'Oliveira-Prakken 1976, p. 20.

96 Nijboer 2000a, p. 236. 
teneturbeginsel noch met het vermoeden van onschuld. ${ }^{97}$ Behalve processuele bezwaren zijn er ook bewijsrechtelijke problemen verbonden aan het gebruik van de leugenachtige verklaring van de verdachte. Ten eerste is de vraag op welke wijze dit 'bewijs' als bewijsmiddel gekwalificeerd kan worden. Voor zover de verklaring van de verdachte als zodanig onder de bewijsmiddelen wordt opgenomen, ontstaat immers het probleem dat de inhoud van die verklaring niet redengevend kan zijn voor het bewijs, aangezien het een (gedeeltelijke) ontkenning is. Volgens Corstens komt alleen de eigen waarneming van de rechter hiervoor in aanmerking. ${ }^{98}$ Hij laat hier echter meteen op volgen dat de leugenachtigheid van de verklaring niet door de rechter kan worden waargenomen. Het is immers geen waarneming, maar een conclusie die de rechter trekt uit de door de verdachte afgelegde verklaring en ander bewijsmateriaal waarmee die verklaring strijdig is. De Hoge Raad lijkt op dit punt een middenweg te bewandelen. Van belang is dat de inhoud van de leugenachtige verklaring in het vonnis wordt opgenomen. ${ }^{99}$ Daarbij maakt het niet uit of dat als verklaring van de verdachte onder de bewijsmiddelen gebeurt, dan wel die inhoud alleen vermeld wordt in een nadere bewijsoverweging. ${ }^{100}$ Voor zover de inhoud onder de bewijsmiddelen wordt opgenomen, moet in het vonnis wel kenbaar gemaakt worden dat niet de verklaring als zodanig, maar enkel de leugenachtigheid daarvan voor het bewijs wordt gebruikt. ${ }^{101}$

Een tweede probleem met betrekking tot het gebruik van de kennelijk leugenachtige verklaring betreft de vraag in hoeverre de vaststelling dat een verklaring van de verdachte kennelijk leugenachtig is redengevend is en zo ja, waarvoor. Corstens meent dat de kennelijke leugenachtigheid alleen kan dienen ter onderbouwing van de betrouwbaarheid van het bewijsmateriaal waarmee de verklaring van de verdachte in strijd is. ${ }^{102}$ De vaststelling dat de verklaring van de verdachte niet

97 EHRM 8 februari 1996, NJ 1996, 725 m.nt. Kn (John Murray t. Verenigd Koninkrijk): 'In the Court's opinion it follows (...) that the drawing of adverse inferences from a statement by an accused which is found to be untrue cannot be excluded (...).' In gelijke zin: EHRM 4 juli 2000, NJ 2001, 401 m.nt. Kn (Kok t. Nederland).

98 Corstens 2005a, p.639. In gelijke zin: Van Veen in zijn annotatie bij HR 22 september 1992, NJ 1993, 55: 'Het ligt enigszins voor de hand te veronderstellen, dat de HR zich gedwongen heeft gevoeld tot de genomen beslissing doordat art. 338 lid 1 Sv bepaalt dat de overtuiging van de rechter dat de verdachte schuldig is aan het begaan van een ten laste gelegd feit moet zijn gestoeld op wat aan wettige bewijsmiddelen ter zitting is gepresenteerd. Leugenachtigheid behoort daartoe niet. Dat hebben ook Blok en Besier onderkend. Zij vragen zich dan ook af of van de leugenachtigheid van een verklaring van de verdachte geen kennis wordt genomen door de eigen waarneming van de rechter ter zitting. Dat is wel een wettig bewijsmiddel (art. $340 \mathrm{~Sv}$ ). Dat zou wellicht in het geldende systeem het bewijsmiddel kunnen zijn om de leugenachtigheid van verklaringen van de verdachte, van verklaringen van de getuige en van voorgelezen schriftelijke stukken, te gebruiken voor de redengeving van de bewezenverklaring.'

99 HR 16 december 1986, NJ 1987, 746.

100 HR 12 november 1974, NJ 1975, 41 m.nt. ThWvV.

101 HR 13 februari 1973, NJ 1973, 139.

102 Corstens 2005a, p. 639. 
met dat andere wel als betrouwbaar aangemerkte bewijsmateriaal overeenstemt, dient dan enkel om in het vonnis tot uitdrukking te brengen dat de rechter meer waarde hecht aan het andere bewijsmateriaal. Dat oordeel wordt onderbouwd door te wijzen op evidente onjuistheden in de verklaring van de verdachte. De kennelijk leugenachtige verklaring is in die optiek niet redengevend voor de bewezenverklaring zelf, maar voor de betrouwbaarheid van het bewijsmateriaal dat qua inhoud haaks staat op de verklaring van de verdachte. Corstens hanteert hier het begrip 'redengevendheid' in ruime zin. ${ }^{103}$

Deze zienswijze stemt niet overeen met die van de Hoge Raad. De Hoge Raad acht de kennelijke leugenachtigheid zelf redengevend voor de bewezenverklaring, in die zin dat het feit dat de verdachte heeft gelogen duidt op betrokkenheid bij het tenlastegelegde feit. Deze interpretatie blijkt uit het feit dat de Hoge Raad voor het gebruik van de kennelijk leugenachtige verklaring eist dat dient vast te staan dat de verdachte de verklaring heeft afgelegd met het doel de waarheid te bemantelen. ${ }^{104}$ Met dit wat archaïsche taalgebruik bedoelt de Hoge Raad tot uitdrukking te brengen dat de reden van het liegen evident daarin moet hebben gelegen dat de verdachte heeft gepoogd de werkelijke gang van zaken te verdoezelen. In deze eis ligt in feite de redengevendheid van de leugenachtige verklaring. De achterliggende generalisatie is dat enkel een schuldige reden heeft om de zaken anders voor te stellen dan ze zijn. ${ }^{105}$ Hiertegen kan echter worden ingebracht dat de verdachte ook om andere redenen dan het verhullen van zijn betrokkenheid bij het delict kan liegen. Wellicht probeert hij enkel te voorkomen dat hij ten aanzien van het strafbare feit verdacht wordt en zodoende onderwerp van onderzoek wordt of probeert hij andere personen of andere zaken buiten het gezichtsveld van justitie te houden. Door desalniettemin de leugenachtige verklaring voor het bewijs toe te laten, wordt de verdachte gedwongen inzicht te geven in de redenen waarom hij een met het andere bewijsmateriaal strijdige verklaring heeft gegeven. Laat hij dat achterwege, dan wordt zijn liegen beschouwd als het verhullen van de betrokkenheid bij het delict.

Bovengenoemde bezwaren laten onverlet dat de Hoge Raad het gebruik van leugenachtige verklaringen van de verdachte toelaat. ${ }^{106}$ Kennelijke leugenachtige verklaringen van getuigen zijn overigens uitgesloten van het bewijs. Leugens van getuigen

103 In paragraaf 5.2.3.5 is het onderscheid tussen redengevendheid in enge en ruime zin aan de orde gesteld.

104 Zie onder andere: HR 6 december 2005, NJ 2006, 162.

105 In gelijke zin: Reijntjes 1980, p. 170: 'De rechter mag, de leugenachtigheid van de verklaring combinerend met de ervaringsregel dat men zelden zonder reden liegt, concluderen dat de leugen dient om de juistheid van het telastegelegde te verhullen.'

106 HR 29 juni 1971, NJ 1971, 417; HR 13 februari 1973, NJ 1973, 139, HR 19 maart 1974, NJ 1974, 241 m.nt. ThWvV, HR 12 november 1974, NJ 1975, 41 en HR 6 mei 1986, NJ 1987, 60 m.nt. ThWvV. 
passen volgens de Hoge Raad niet binnen het wettelijke bewijsstelsel en zijn niet redengevend. ${ }^{107}$ Verdachten daarentegen kunnen wel op een voor de bewijsbeslissing redengevende wijze liegen. Wil daarvan sprake zijn, dan dient wel aan een aantal voorwaarden te zijn voldaan. Zoals hiervoor al werd genoemd, dient de verklaring tot doel te hebben de waarheid te bemantelen. Daarnaast dient de leugenachtigheid kennelijk te zijn, hetgeen betekent dat de rechter uit ander bewijsmateriaal heeft kunnen afleiden dat hetgeen de verdachte verkondigt niet op waarheid berust. ${ }^{108}$ Dit andere bewijsmateriaal mag niet een eerdere of latere verklaring van de verdachte zijn. ${ }^{109}$ Ook niet als die verklaring van de verdachte in de vorm van een ander bewijsmiddel de rechter bereikt, bijvoorbeeld in een verklaring van een getuige waarin deze weergeeft wat hij de verdachte heeft horen zeggen ${ }^{110}$ of in een proces-verbaal waarin de inhoud van de door verdachte gevoerde telefoongesprekken is weergegeven. ${ }^{111}$ Evenmin mag de vaststelling van leugenachtigheid gebaseerd zijn op het zwijgen van de verdachte. ${ }^{112}$ Deze beperking vloeit voort uit het recht van de verdachte om niet te hoeven meewerken aan zijn eigen veroordeling. Hij mag met andere woorden zelf bepalen of hij verklaart en wat hij verklaart. Dit recht zou geen betekenis hebben indien bij wisselende verklaringen niet alleen de (deels) bekennende verklaring maar ook de ontkennende verklaring in de vorm van een kennelijk leugenachtige verklaring tegen hem gebruikt zouden kunnen worden. De Hoge Raad komt dus op dit punt tegemoet aan de eerder vermelde kritiek van Prakken.

De twee eisen die de Hoge Raad stelt aan het gebruik van leugenachtigheid van de verklaring van de verdachte dienen in het vonnis tot uitdrukking te komen. In zoverre geldt ten aanzien van deze bewijsconstructie een nadere motiveringsplicht. Enerzijds zal de feitenrechter in zijn vonnis tot uitdrukking moeten brengen uit welk bewijsmateriaal hij de leugenachtigheid afleidt; de bewijsmiddelen die in

107 HR 14 september 1992, NJ 1993, 54 m.nt. ThWvV: 'Aan een dergelijke verklaring - hetzij een verklaring van een getuige ter terechtzitting, hetzij een (hierna eveneens getuigenverklaring te noemen) verklaring van een ander dan de verdachte in enig schriftelijk bescheid als bedoeld in art. $344 \mathrm{~Sv}$ - kan in beginsel geen redengevende kracht worden toegekend. Het bezigen van een door de rechter als leugenachtig aangemerkte getuigenverklaring voor het bewijs strookt niet met het wettelijk bewijsstelsel, waarin ervan wordt uitgegaan dat een getuigenverklaring door de rechter slechts tot het bewijs kan worden gebezigd, wanneer deze naar zijn oordeel betrouwbaar en overeenkomstig de waarheid afgelegd is.' In vergelijkbare zin: HR 22 september 1992, NJ 1993, 55 m.nt. ThWvV.

108 HR 12 december 2006, LJN AZ2078: Het hof had de leugenachtigheid van de verklaring van de verdachte afgeleid uit de verklaring van een getuige. Echter beide verklaringen hoefden naar het oordeel van de Hoge Raad niet met elkaar in tegenspraak te zijn en aldus kon de leugenachtigheid van de verklaring van de verdachte niet uit de verklaring van de getuige worden afgeleid.

109 HR 19 maart 2002, NJ 2002, 567.

110 HR 24 mei 2005, NJ 2005, 396.

111 HR 6 december 2005, NJ 2006, 162.

112 HR 19 maart 1996, NJ 1996, 540 m.nt. Sch. 
strijd met de verklaring van de verdachte zijn, moeten worden vermeld. Anderzijds dient de rechter aan te geven dat daaruit de conclusie kan worden getrokken dat de verdachte de ware toedracht heeft willen verdoezelen. Werd vroeger genoegen genomen met de enkele constatering van de feitenrechter dat de verklaring kennelijk leugenachtig was en tot doel had de waarheid te bemantelen, thans lijkt de Hoge Raad meer eisen te stellen aan het oordeel van de feitenrechter op dit punt. In zijn arrest d.d. 24 mei 2005 trekt de Hoge Raad op beide punten de conclusie van de feitenrechter in twijfel. ${ }^{113}$ In de bewuste zaak was de verdachte ten laste gelegd dat zij op 22 mei opzettelijk meer dan drie kilo cocaïne had uitgevoerd. Het hof achtte dat bewezen en baseerde dit oordeel onder andere op de vaststelling dat haar verklaring leugenachtig was. Die verklaring hield onder andere in dat zij op zondag 18 mei in Punda een ticket had gekocht en dat zij voor haar vertrek op haar werk twee weken vrij van dienst had geregeld. Volgens het hof werd de juistheid van die verklaring weerlegd door 1) het feit dat het ticket niet op zondag kon zijn gekocht omdat het bewuste verkoopkantoor toen dicht was en zij zich bovendien vijf dagen later niet meer kon herinneren welke prijs zij daarvoor had betaald en 2) de datum op het retourticket; dit was 20 juni en deze datum was niet in overeenstemming met het feit dat verdachte slechts twee weken vrij had gekregen.

Op beide punten achtte de Hoge Raad het oordeel van het hof niet zonder meer begrijpelijk. Zonder nadere motivering viel volgens de Hoge Raad niet in te zien waarom ten aanzien van punt 2 die verklaring als leugenachtig kon worden aangemerkt, te meer daar uit de verklaring van de verdachte ook bleek dat zij reeds vakantie had gepland van 2 juni tot en met 26 juni. Mogelijkerwijs had de verdachte bedoeld dat zij naast haar reeds geplande vakantie twee weken vrij van dienst kon krijgen. Ook kon volgens de Hoge Raad de enkele omstandigheid dat in de verklaring van de verdachte datum en plaats van de aankoop van het ticket onjuist waren en dat zij zich niet herinnerde welk bedrag zij daarvoor heeft betaald (1) niet zondermeer - dus zonder nadere motivering - de conclusie dragen dat verdachte door aldus te verklaren de waarheid had willen bemantelen.

Met deze uitspraak lijkt de Hoge Raad het gebruik van de kennelijk leugenachtige verklaring van de verdachte te willen beperken. Daarvoor is ook alle reden. Want buiten de reeds genoemde bezwaren tegen het gebruik daarvan blijft toch het meest wezenlijke bezwaar dat het eigenlijk vreemd is dat men een verklaring die men in principe onbetrouwbaar acht, via deze constructie alsnog aan de bewezenverklaring ten grondslag legt. ${ }^{114}$ De wijze waarop het gebruik van de kennelijk leugenachtige verklaring aan banden wordt gelegd, is door een nadere motivering te verlangen in die gevallen waarin niet op het eerste gezicht evident is dat de

113 HR 24 mei 2005, NJ 2005, 396.

114 In gelijke zin: Nijboer 2000a, p. 235. Anders: advocaat-generaal Wortel in zijn conclusie bij HR 7 februari 2006, LJN AU8912. 
onderliggende ervaringsregel, te weten de schuldige probeert zijn straatje schoon te vegen, van toepassing is.

\subsubsection{Het zwijgen van de verdachte}

Vergelijkbaar met het liegen van de verdachte is de bewijsconstructie waarin het zwijgen van de verdachte meewerkt aan het bewijs. Ook hier geldt dat het zwijgen van de verdachte zelf of een beroep van de verdachte op zijn zwijgrecht niet als bewijsmiddel kan worden gekwalificeerd. Dit is ook nadrukkelijk zo door de Hoge Raad uitgemaakt. De verklaring van de verdachte dat hij een beroep doet op zijn zwijgrecht geldt niet als verklaring van de verdachte en mag dus niet als zodanig onder de bewijsmiddelen worden opgenomen. ${ }^{115}$ Ten eerste is een dergelijke verklaring op geen enkele wijze redengevend voor het bewijs van enig strafbaar feit. ${ }^{116}$ Ten tweede druist dit in tegen het op basis van artikel $29 \mathrm{~Sv}$ aan de verdachte toekomende recht om te zwijgen. ${ }^{117}$

Mag aldus de verklaring van de verdachte dat hij niet wenst te verklaren niet ten grondslag worden gelegd aan een bewezenverklaring, dat geldt niet voor de conclusies die de rechter uit het zwijgen van de verdachte trekt. De Hoge Raad overwoog:

'de omstandigheid dat een verdachte weigert een verklaring af te leggen of een bepaalde vraag te beantwoorden kan op zichzelf, mede gelet op het bepaalde in art. 29, eerste lid, Sv, niet tot het bewijs bijdragen. Dat brengt echter niet mee dat de rechter, indien een verdachte voor een omstandigheid, die op zichzelf of in samenhang met de verdere inhoud van de bewijsmiddelen beschouwd redengevend moet worden geacht voor het bewijs van het aan hem telastegelegde feit, geen redelijke, die redengevendheid ontzenuwende, verklaring heeft gegeven, zulks niet in zijn overwegingen omtrent het gebezigde bewijsmateriaal zou mogen betrekken. ${ }^{118}$

De overweging is ontleend aan het zogeheten Strippenkaart-arrest. De verdachte was tenlastegelegd dat hij een roofoverval had gepleegd in Hilversum. Verdachte ontkende op de dag van de overval in Hilversum te zijn geweest en beriep zich op zijn zwijgrecht toen hem werd gevraagd hoe hij de aanwezigheid van de strippenkaart in zijn jaszak kon verklaren. Op die strippenkaart stond een stempel waaruit bleek dat die kaart op de bewuste dag in Hilversum was gebruikt. Het hof had het zwijgen van de verdachte op dit punt in de bewijsconstructie opgenomen. De Hoge Raad achtte dat, zoals blijkt uit de hierboven opgenomen overweging, toelaatbaar, omdat het gebrek aan toelichting van de verdachte op dit punt de bewijskracht van de strippenkaart bevestigde.

115 HR 3 oktober 1995, NJ 1996, 109 en HR 1 juni 2004, NJ 2004, 366.

116 HR 31 maart 1987, NJ 1987, 868 m.nt. ThWvV en HR 8 november 1988, NJ 1989, 657 m.nt. 'tH.

117 HR 12 maart 1996, NJ 1996, 539 m.nt. Sch onder HR 19 maart 1996, NJ 1996, 540.

118 HR 3 juni 1997, NJ 1997, 584. 
De bewijsconstructie is feitelijk als volgt: Het feit dat de verdachte bij zijn aanhouding in het bezit is van de bewuste strippenkaart is een aanwijzing voor het feit dat hij die dag in Hilversum gebruik heeft gemaakt van de strippenkaart. Deze aanwijzing zou ontkracht kunnen worden, indien zou blijken dat niet de verdachte maar een ander die strippenkaart de bewuste dag zou hebben gebruikt. Waar echter de verdachte weigert enige toelichting te geven op dit punt kan de gevolgtrekking dat het bezit duidt op het feit dat de verdachte zelf gebruik heeft gemaakt van de strippenkaart worden gerechtvaardigd. Alternatieve verklaringen voor het bezit die mogelijk de conclusie van het hof zouden ondermijnen, worden immers niet gegeven. Had de verdachte verklaard dat hij die strippenkaart had gevonden, of dat die toebehoorde aan een ander, dan had het hof de strippenkaart alleen mogen bezigen voor het bewijs indien ofwel de verklaring van de verdachte op dit punt als niet aannemelijk kon worden aangemerkt, ofwel die verklaring kon worden weerlegd door ander bewijsmateriaal. Echter, bij gebrek aan enige verklaring van de verdachte mocht het hof ervan uitgaan dat het vinden van de strippenkaart in de jaszak redengevend was voor de vaststelling dat de verdachte zelf die dag in Hilversum gebruik had gemaakt van de strippenkaart.

De casus van de strippenkaart maakt twee dingen duidelijk. Ten eerste, dat het zwijgen van de verdachte niet direct redengevend is voor het bewijs van het tenlastegelegde feit. Het is slechts redengevend voor de vaststelling van de redengevendheid van een ander bewijsmiddel, in casu de strippenkaart. Ten tweede en in het verlengde hiervan, dat het gebruik van het zwijgen van de verdachte veel verwantschap vertoont met de hierna te bespreken Meer en Vaartverweren. Ook daar wordt gewezen op een mogelijk gat in de bewezenverklaring. Verschil is echter dat niet de verdachte een alternatieve verklaring voor de aanwezigheid van bepaald bewijsmateriaal geeft, maar de rechter daar zelf naar op zoek gaat. Blijkt vervolgens dat die zoektocht strandt op het zwijgen van de verdachte, die vaak als enige mogelijk ontlastende gegevens kan verstrekken, dan mag de rechter aannemen dat er geen alternatieve verklaringen voor de aanwezigheid van het bewijsmateriaal zijn.

Op het gebruik van het zwijgen van de verdachte voor het bewijs is veel kritiek. Aangevoerd wordt dat hierdoor het zwijgrecht van de verdachte illusoir wordt. De verdachte wordt immers gedwongen om te spreken en aldus mee te werken aan zijn eigen veroordeling. Weigert hij, dan kan de rechter daaruit voor de verdachte negatieve consequenties trekken voor de bewijsbeslissing. Op dit punt heeft echter het Europese Hof voor de rechten van de mens geoordeeld dat het trekken van conclusies uit het zwijgen van de verdachte niet per definitie in strijd is met artikel 6 EVRM en het daarin opgenomen recht van de verdachte om niet te hoeven meewerken aan zijn eigen veroordeling. Het Hof overwoog: 
'It is only if the evidence against the accused 'calls' for an explanation which the accused ought to be in a position to give that a failure to give any explanation 'may as a matter of common sense allow the drawing of an inference that there is no explanation and that the accused is guilty.' Conversely if the case presented by the prosecution had so little evidential value that it called for no answer, a failure to provide one could not justify an inference of guilt., 119

Het Europese Hof voor de rechten van de mens sluit derhalve het gebruik van het zwijgen van de verdachte voor het bewijs niet uit, maar stelt als voorwaarde dat er sprake moet zijn van een zodanige hoeveelheid belastend bewijs, dat dit als het ware vraagt om een verklaring van de verdachte. ${ }^{120}$ Waar de verdachte een dergelijke verklaring niet geeft én hij geacht mag worden die wel te kunnen geven, mag uit het zwijgen van de verdachte worden geconcludeerd dat er geen omstandigheden zijn die mogelijk op zijn onschuld zouden kunnen duiden.

Het gebruik van het zwijgen van de verdachte veronderstelt dat de rechter daarop expliciet ingaat. Het is immers niet mogelijk om het zwijgen zelf als bewijsmiddel in het vonnis op te nemen. De rechter zal in een nadere bewijsoverweging moeten toelichten naar aanleiding waarvan de verdachte zwijgt en welke conclusies hij (de rechter) daaruit trekt. Bovendien zal met het oog op de rechtspraak van het Europese Hof voor de rechten van de mens uit de uitspraak duidelijk moeten worden dat het gaat om een zaak die gezien het overige belastende bewijsmateriaal vraagt om een verklaring van de verdachte, die de verdachte indien hij onschuldig is ook geacht kan worden te geven.

In het merendeel van de gevallen bestaat een dergelijke overweging vaak uit een standaardoverweging, zoals:

'Daarbij betrekt de rechtbank dat de verdachten voor de hiervoor genoemde omstandigheden die in samenhang met de verdere inhoud van de bewijsmiddelen beschouwd redengevend moeten worden geacht voor het bewijs van door verdachten gepleegde feiten, geen redelijke, die redengevendheid ontzenuwende verklaring, hebben gegeven., ${ }^{121}$

119 EHRM 8 februari 1996, NJ 1996, 725 m.nt. Kn (John Murray t. Verenigd Koninkrijk). In gelijke zin: EHRM 4 juli 2000, NJ 2001, 401 m.nt. Kn (Kok t. Nederland) waarin het oordeel van het EHRM nogmaals wordt verwoord: 'The Court recognized that the privilege against self-incrimination is encompassed in the guarantees provided by Article 6 of the Convention. However, the Court also recognized that this immunity could not and should not prevent that the accused's silence, in situations which clearly called for an explanation from him, be taken into account in assessing the persuasiveness of the evidence adduced by the prosecution.'

120 Zie voor het ontbreken van een 'clear case': EHRM 20 maart 2001, 33501/96 (Telfner t. Oostenrijk): 'The Court cannot find that these elements of evidence, which were moreover not corroborated by evidence taken at the trial in an adversarial manner, constituted a case against the applicant which would have called for an explanation from his part.'

121 Rechtbank Rotterdam 27 maart 2003, LJN AF6787. 
Uit een dergelijke algemene overweging valt nauwelijks op te maken op welke punt de verdachte dan een nadere toelichting had moeten geven, of er sprake was van een 'clear case against him', of hij überhaupt een dergelijke verklaring had kunnen geven en waarom een eventueel door de verdachte gegeven verklaring van de feiten niet redelijk was. Wellicht dat een dergelijke overweging niet moet worden opgevat als een deel van de bewijsconstructie, maar enkel als een verwoording van de subjectieve overtuiging van de rechter. In bewijsrechtelijke zin heeft zij echter mijns inziens geen betekenis en kan zij beter achterwege blijven.

\subsubsection{Schakelbewijs}

Een derde bijzondere bewijsconstructie waarbij de redengevendheid van het bewijsmateriaal ter discussie staat, betreft het zogeheten schakel- of kettingbewijs. In geval van het bezigen van schakelbewijs wordt bewijsmateriaal dat dient ter onderbouwing van de bewijsbeslissing ter zake van feit A ook geacht bij te dragen aan het bewijs van feit B. Een dergelijke bewijsconstructie wordt gehanteerd indien de handelingen die aan de verschillende tenlastegelegde feiten ten grondslag liggen een dermate grote overeenkomst vertonen, dat - ook zonder dat ten aanzien van feit B afzonderlijk bewijs is voor een bepaald onderdeel van het tenlastegelegde feit - het bewijs daarvan mag worden afgeleid uit de mate van overeenkomst tussen de handelingen. In dat verband wordt de schakelbewijsconstructie wel beschouwd als een locomotief bestaande uit enkele sterke zaken die de bewijstechnisch wat zwakkere zaken moet trekken. ${ }^{122}$

Hoewel het schakelbewijs recentelijk in de belangstelling is komen te staan omdat het is toegepast in de zaak Lucia de B., komt men het gebruik van deze bewijsconstructie al tegen in het begin van de $20^{\mathrm{e}}$ eeuw. Reeds in 1930 oordeelde de Hoge Raad dat de verklaring van getuige over ontuchtige handelingen jegens haar gepleegd ook van belang kon zijn voor het bewijs van soortgelijke feiten jegens andere slachtoffers. ${ }^{123}$ Niet geheel duidelijk is of in die zaak de verklaringen over soortgelijke feiten dienden om het bewijs van betrokkenheid van de verdachte bij de aanranding te leveren of diende ter onderbouwing van de betrouwbaarheid van de enige getuigenverklaring in die zaak.

In de meer recente zaken dient het schakelbewijs er niet toe om de betrouwbaarheid van ander bewijsmateriaal te onderbouwen, maar om een gat in de bewijsconstructie te dichten. Dat gat kan betrekking hebben op een onderdeel van de tenlastelegging waarvoor geen direct bewijsmateriaal beschikbaar is. ${ }^{124}$ Er kan echter ook een gat in de bewijsconstructie ontstaan omdat het beschikbare bewijsmateriaal wel de gehele tenlastelegging dekt, maar in kwalitatieve zin niet aan de

122 Röttgering 2006, p. 37. Zij zelf spreekt in dit verband liever van een spooktrein.

123 HR 24 januari 1930, NJ 1913, 118-119.

124 Zoals in de hierna te bespreken zaak Lucia de B: HR 14 maart 2006, LJN AU5496. 
eisen voldoet. Dat speelt bij verklaringen van getuigen die niet door de verdediging konden worden gehoord. ${ }^{125}$ In dat geval dient er ander bewijsmateriaal te zijn waaruit eveneens de betrokkenheid van de verdacht bij het tenlastegelegde feit kan blijken. ${ }^{126}$

Het gebruik van het schakelbewijs is dubieus. In essentie komt het er immers op neer dat het bewijs van een bepaald onderdeel van de tenlastelegging wordt aangenomen, omdat het in andere soortgelijke gevallen wel kon worden bewezen. Betrokkenen zullen dit ervaren als toepassing van het gezegde 'eens een dief, altijd een dief'. Naarmate uit die andere wel bewezen gevallen een duidelijk en specifiek patroon van handelen blijkt en specifieke onderdelen van dat patroon ook in de nog te bewijzen zaak zijn vastgesteld, is er echter wel degelijk iets te zeggen voor het gebruik van schakelbewijs. De redengevendheid van het schakelbewijs is dan daarin gelegen dat de overeenkomst in de handeling, gegeven de bijzondere kenmerken van die handeling, het zeer waarschijnlijk maakt dat het nog te bewijzen feit zich op dezelfde wijze, dus volgens hetzelfde patroon, heeft voltrokken als de bewezen feiten. Het spreekt voor zich dat bij het gebruik van een schakelbewijsconstructie de rechter niet kan volstaan met het vermelden van de inhoud van de bewijsmiddelen. Hij zal in het vonnis moet expliciteren dat er sprake is van een bepaald patroon en dat dit patroon, omdat specifieke elementen daarvan kunnen worden geconstateerd, ook kan worden doorgetrokken naar andere feiten. ${ }^{127} \mathrm{Om}$ het enigszins te verduidelijken, zullen twee zaken waarin recentelijk het schakelbewijs een rol speelde nader worden besproken.

\subsection{De zaak Scheper}

In de zaak Scheper stond de verdachte terecht ter zake van drie gevallen van verkrachting. In bewijsrechtelijke zin ontstonden er problemen met betrekking tot de vraag of de verdachte dwang had gebruikt om de slachtoffers tot seks te bewegen; hij ontkende niet dat hij seks met de drie vrouwen had gehad, maar betwistte dat die seks had plaatsgevonden tegen de wil van de betrokken vrouwen. De verklaringen van de vrouwen op dit punt waren duidelijk; zij hadden vanaf een bepaald moment kenbaar gemaakt dat zij niet, althans niet zonder condoom, met verdachte verder seks wilden hebben. De verdediging had verzocht om het horen van de slachtoffers en dat bleek niet mogelijk. In dat geval moet - willen de verklaringen van de nietgehoorde getuigen voor het bewijs kunnen meewerken - de betrokkenheid van de

125 Zoals in de hierna te bespeken zaak Scheper: HR 11 juni 2002, NJ 2002, 459. Zie ook: HR 11 januari 2000, NJ 2000, 194.

126 Zie daarover uitgebreid paragraaf 3.5.2.

127 Het feit dat in het Project Motivering strafvonnissen (Promis) dit als een afzonderlijk geval wordt genoemd waarin de rechter ambtshalve zou moeten motiveren is dus weinig opzienbarend. Promis Evaluatierapport 2005, p. 22. 
verdachte bij het tenlastegelegde feit ook uit ander bewijsmateriaal blijken. ${ }^{128}$ Ten aanzien van twee van de drie tenlastegelegde verkrachtingen werd het verhaal van de aangeefsters bevestigd door ander bewijsmateriaal (een medische verklaring en de verklaring van de verdachte). Ten aanzien van de derde verkrachtingszaak ontbrak nader bewijs; het gerechtshof achtte ook ten aanzien van de derde verkrachting voldoende bewijs aanwezig en beriep zich daarbij op de grote mate van onderlinge gelijkenis van de drie feiten. De Hoge Raad acht deze constructie toelaatbaar:

'Gelet op de inhoud van de genoemde bewijsmiddelen, in samenhang met de overige bewijsmiddelen, moet worden geoordeeld dat de betrokkenheid van de verdachte bij de hem onder 1, 2 en 3 tenlastegelegde feiten, die voor wat betreft het patroon van handelen gelijksoortig zijn, zoals deze betrokkenheid blijkt uit de door de getuigen [het slachtoffer], [getuige 1] en [getuige 2] afgelegde verklaringen, in voldoende mate wordt bevestigd door ander bewijsmateriaal.

Het oordeel van de Hoge Raad was reden voor de verdachte om zijn zaak in Straatsburg aan de orde te stellen. Geklaagd werd over schending van artikel 6 lid 3 onder d EVRM: de verdachte had ten onrechte de getuigen niet kunnen horen, terwijl het bewijs in zijn zaak toch in belangrijke mate steunde op de verklaringen van deze getuigen. Maar het EHRM acht de klacht niet-ontvankelijk; weliswaar was het wenselijk geweest indien de verdachte de getuigen had kunnen horen, maar in casu leidt dat niet tot schending van artikel 6 EVRM onder andere omdat zijn veroordeling niet enkel was gebaseerd op de verklaringen van de niet gehoorde getuigen:

'Bearing in mind that it concerned three nearly identical incidents with a similar modus operandi by the perpetrator and which occurred within a relatively short time span in three different towns, and having regard to all the material used in evidence against the applicant, including his own statements made before the police and the trial courts, the Court holds that the applicant's conviction cannot be said to have been based only or to a decisive extent on the statements given by Ms A., Ms B. and Ms C. to the police.' 130

Het Europese Hof voor de rechten van de mens erkent in deze uitspraak het gebruik van schakelbewijs. Daarbij wijst het niet alleen op de gelijke modus operandi, maar ook op de beperkte tijdspanne waarin de verkrachtingen plaatsgevonden en het gegeven dat de verkrachtingen op verschillende plekken plaats hadden. Dat laatste is opvallend. Het duidt er wellicht op dat het hof genoegen neemt met bewijs dat op een of andere manier de betrouwbaarheid van de niet-gehoorde getuige bevestigt; het feit dat de getuigen los van elkaar met een gelijksoortige beschuldiging aan het adres van de verdachte komen, terwijl het gezien de geografische ligging van de plaatsen van het delict en de beperkte tijdspanne niet voor de hand ligt dat getuigen onderling contact hebben gehad, maakt het meer aannemelijk om de verklaringen als juist aan te merken.

128 Zie hierover uitgebreid paragraaf 3.5.2.2.

129 HR 11 juni 2002, NJ 2002, 459 (r.o. 3.6.2.).

130 EHRM 5 april 2005, NJ 2005, 551 m.nt. Sch (Scheper t. Nederland). 


\subsection{De zaak Lucia de B.}

Een tweede zaak waarin recentelijk het schakelbewijs een belangrijke rol heeft gespeeld, is de zaak van de Haagse verpleegster Lucia de B. Zij werd er onder andere van verdacht een aantal patiënten tijdens hun verblijf in het ziekenhuis om het leven te hebben gebracht door toediening van een overdosis medicijnen. Lucia de B. kwam als verdachte in beeld toen bleek dat een aantal medisch onverklaarbare overlijdensgevallen had plaatsgevonden op momenten waarop zij telkens dienst had. ${ }^{131}$

Direct bewijs van de betrokkenheid van de verdachte bij de verschillende gevallen van levensberoving of pogingen daartoe was er niet; de verdachte ontkende en bovendien was in een aantal gevallen zelfs moeilijk aan te tonen dat de slachtoffers waren overleden als gevolg van toediening van medicijnen. De verdenking van een mogelijk onnatuurlijke dood ontstond in de meeste gevallen enige tijd na het overlijden, waardoor obductie niet meer tot de mogelijkheden behoorde. Toch kwam het Hof Den Haag tot een bewezenverklaring van zeven gevallen van moord dan wel poging tot moord. ${ }^{132}$ In één van de zeven gevallen kwam het hof tot het oordeel dat bewezen kon worden dat er sprake was van een onnatuurlijke dood, dat die dood het gevolg was van toediening van een letale hoeveelheid digoxine en dat dat medicijn was toegediend door de verdachte. Een ander geval betrof een poging tot moord en ook daar achtte het hof bewezen dat er sprake was van een levensbedreigend incident als gevolg van toediening van een overdosis chloralhydraat door de verdachte. Ten aanzien van beide incidenten had de verdachte naar het oordeel van het hof leugenachtige verklaringen afgelegd.

De overige vijf tenlastegelegde feiten achtte het hof bewezen door toepassing van schakelbewijs. Daartoe stelde het eerst vast dat tussen de beide bewezen feiten een duidelijke overeenkomst bestond met betrekking tot de context waarin deze waren gepleegd - in een ziekenhuis - én de handelwijze van de verdachte: het toedienen van een letale dosis geneesmiddelen. Volgens het hof kon vervolgens ook worden aangenomen dat in de overige vijf gevallen de dood of het levensbedreigende incident was veroorzaakt door toediening van een overdosis medicijnen door de verdachte in aanmerking genomen dat in die vijf gevallen was vastgesteld dat het telkens ging om:

131 In eerste aanleg was dit gegeven eveneens onderdeel van de bewijsconstructie. De deskundige Elffers had een statistische berekening gemaakt van de kans dat het samenvallen van deze incidenten met de aanwezigheid van de verdachte op de afdeling enkel kon worden toegerekend aan het toeval. Deze kans kwam uit op 1 op 326 miljoen. Aan de hand daarvan concludeerde hij dat het in hoge mate waarschijnlijk was dat er een verband bestond tussen het werkzaam zijn van verdachte en het zich voordoen van bedoelde incidenten. Over de aard van het verband liet hij zich niet uit. Rechtbank Den Haag 24 maart 2003, LJN AF6172 (algemene bewijsoverwegingen 11 en 12).

132 Hof Den Haag 18 juni 2004, LJN AP2846 (algemene bewijsoverwegingen $5.53 \mathrm{t} / \mathrm{m}$ 5.59). 
- een plotseling en onverwacht overlijden dan wel levensbedreigend incident;

- een overlijden, dan wel levensbedreigend incident dat medisch niet verklaarbaar was, maar waar alle in aanmerking komende natuurlijke oorzaken boven iedere redelijke twijfel verheven uitgesloten waren, en

- het overlijden dan wel het incident moest hebben plaatsgevonden op het moment dat de verdachte op de afdeling van de betreffende patiënt aanwezig was.

Bovendien speelden alle incidenten zich af binnen een relatief kort tijdsbestek van iets meer dan één jaar en gaf de verdachte telkens alternatieve verklaringen voor het optreden van die incidenten die het Hof onjuist oordeelde.

De zeven bewezen feiten hebben dus als gemeenschappelijk kenmerk dat het telkens medisch onverklaarbare incidenten betreft die plotseling en onverwacht optreden op de afdeling van het ziekenhuis telkens als de verdachte daar ook dienst heeft en dat de verdachte verklaringen geeft voor die incidenten die niet juist zijn. $\mathrm{Nu}$ ten aanzien van twee van deze incidenten door het hof is vastgesteld dat zij zich hebben voorgedaan doordat de verdachte een letale dosis geneesmiddelen heeft toegediend, kan - aldus het hof - als zeer waarschijnlijk worden aangenomen dat ook in de overige 5 gevallen het incident heeft plaatsgevonden als gevolg van het handelen van de verdachte. Het ontbreken van bewijs ten aanzien van de doodsoorzaak én het handelen van de verdachte wordt met gebruikmaking van het bewijs in de andere twee zaken opgevuld.

In cassatie hield het oordeel van het hof op dit punt stand:

'Het Hof heeft aldus in zijn oordeel dat de verdachte de (...) feiten heeft begaan, mede betrokken dat de feitelijke gang van zaken ten aanzien van deze feiten, waaronder begrepen de context waarbinnen zij zich hebben toegedragen, de omstandigheden waarmee zij zijn omgeven en het desbetreffende handelen van de verdachte alsmede de verklaringen die de verdachte daarover heeft afgelegd, op essentiële punten belangrijke overeenkomsten vertoonde met de feitelijke gang van zaken ten aanzien het onder 1 en 5 bewezenverklaarde en de verklaringen van de verdachte dienaangaande. Dit heeft het Hof zonder schending van enige rechtsregel kunnen doen. ${ }^{133}$

De vaststelling van de Hoge Raad dat het gebruik van schakelbewijs mogelijk is zonder schending van enige rechtsregel is niet verrassend; er is immers geen regel zolang ook de Hoge Raad geen regel in deze aanneemt. Bij gebreke daarvan geldt de stelregel dat de selectie en waardering van het bewijsmateriaal aan de feitenrechter is overgelaten. Desalniettemin kan uit het arrest van de Hoge Raad toch een zekere afbakening ten aanzien van het gebruik van schakelbewijs worden afgeleid: de bewezen feiten en de nog te bewijzen feiten moeten op essentiële punten overeenkomen. Zoals te doen gebruikelijk is het aan de feitenrechter om te beoordelen of aan dit criterium is voldaan en grijpt de Hoge Raad slechts in, indien

133 HR 14 maart 2006, LJN AU5496 (r.o. 6.3.2). 
evident in strijd met dit criterium is gehandeld. Die kritische grens was in de zaak van de Haagse verpleegster kennelijk niet bereikt.

Daarmee is echter een feitenoordeel in stand gebleven, waarbij de grenzen van de redengevendheid van het bewijs zijn opgezocht en mijns inziens zijn overschreden. De betrokkenheid van de veroordeelde bij vijf van de zeven feiten is in wezen enkel afgeleid uit haar aanwezigheid op de afdeling ten tijde van het overlijden, haar proceshouding én het feit dat deze feiten verwantschap vertonen met twee andere feiten ten aanzien waarvan betrokkenheid van de veroordeelde ook enkel via afleiding is vastgesteld.

Elk van de onderliggende generalisaties is zwak en onvoldoende om het bewijsoordeel te kunnen dragen. De eerste ziet op haar aanwezigheid op de afdeling ten tijde van de verschillende incidenten. Haar aanwezigheid is weliswaar een noodzakelijke voorwaarde, maar kan andersom niet als voldoende voorwaarde voor haar betrokkenheid worden beschouwd. Ten aanzien van de tweede doet zich het probleem voor dat het niet consequent verklaren en mogelijk zelfs het in strijd met de waarheid verklaren niet altijd wijst op het verhullen van activiteiten waarvan men verdacht wordt. Het derde onderdeel van de bewijsconstructie is het meest zwakke. De kracht van de schakelbewijsconstructie is afhankelijk van de mate waarin ter zake van andere bewezenverklaarde feiten een duidelijk en specifiek patroon kan worden gedestilleerd en vervolgens de mate waarin specifieke elementen van dat patroon ook in andere gevallen terugkomt. Is het patroon meer specifiek en zijn de elementen die terugkeren in andere nog te bewijzen zaken zeer typerend voor dat patroon, dan komt meer waarde toe aan het schakelbewijs. In de zaak van Lucia de B. bestaat het patroon uit twee bewezen strafbare feiten, te weten een moord en een poging tot moord. Een patroon bestaande uit twee gevallen is zeer beperkt; zeker als men bedenkt dat op bepaalde punten de zaken niet met elkaar overeenkomen (in beide gevallen is een ander geneesmiddel gebruikt). De elementen van deze twee zaken die vervolgens ook bij de andere feiten worden vastgesteld, zijn nauwelijks typerend te noemen: onverwachte en onverklaarbare overlijdensgevallen op een afdeling waarop de verdachte werkzaam is en het afleggen van wisselende en mogelijk onjuiste verklaringen door de verdachte. Om vervolgens op basis daarvan te concluderen dat ook in de overige vijf gevallen de dood is ingetreden door toediening van een overdosis medicijnen door de verdachte is mijns inziens uit het oogpunt van redengevendheid van het bewijs een brug te ver. Het zou betekenen dat het waarschijnlijk is dat degene van wie je hebt vastgesteld dat hij betrokken is bij twee incidenten, ook de hand heeft gehad in andere overlijdensgevallen of levensbedreigende incidenten voor zover die - in ieder geval naar achteraf kan worden gereconstrueerd - medisch onverklaarbaar zijn, deze incidenten hebben plaatsgevonden op de afdeling ten tijde dat de verdachte daar werkzaam was en de verklaringen van de betrokken persoon ter bestrijding van haar betrokkenheid - in de ogen van de rechter - niet 
plausibel zijn. Dat komt akelig dicht bij toepassing van het spreekwoord: 'eens een dief, altijd een dief'.

Maarten 't Hart omschreef het schakelbewijs in deze zaak als volgt:

"“Als ik van twee klokken in huis bewezen heb dat ze gelijk lopen, heb ik van alle klokken in huis bewezen dat ze gelijk lopen." Ziedaar het kettingbewijs. "Als ik van twee katten uit het asiel heb bewezen dat ze zwart zijn, heb ik bewezen dat alle katten in het asiel zwart zijn." Ziedaar de schakelconstructie waar het hof zo trots op was. $^{134}$

Zijn omschrijving is wellicht iets te gechargeerd, maar geeft goed weer waar het probleem in de denktrant van het hof zit. Weliswaar heeft het hof door middel van het schakelbewijs een derde 'bewijsmiddel' gecreëerd, maar dat bewijs kan onmogelijk de ontbrekende stukjes met betrekking tot de wijze waarop de dood is ingetreden en degene die daarvoor eventueel verantwoordelijk is, opvullen. Daarvoor is enerzijds het gat in de bewijsconstructie te groot en anderzijds het aangeleverde stukje bewijs te weinig specifiek.

\subsubsection{Meer en Vaartverweren}

Zoals in paragraaf 5.2.3.5 aan de orde kwam, kan ten aanzien van de redengevendheid een onderscheid worden gemaakt tussen de redengevendheid van delen van het gebezigde bewijsmateriaal en de redengevendheid van het gehele bewijsmateriaal. Ten aanzien van het laatste gaat het om de vraag of het bewijsmateriaal toereikend is om de bewezenverklaring te dragen. Die toereikendheid ziet enerzijds op de vraag of het gebezigde bewijsmateriaal alle onderdelen van de bewezenverklaring dekt. Anderzijds ziet zij op de vraag of de toedracht zoals die uit de bewijsmiddelen blijkt met voldoende zekerheid kan worden aangenomen.

De toereikendheid van het bewijsmateriaal kan in principe worden afgeleid uit de inhoud van de bewijsmiddelen zoals die in het vonnis is opgenomen. Tot een nadere verantwoording is de feitenrechter niet gehouden. Slechts in één geval is in de jurisprudentie uitgemaakt dat de rechter expliciet op de toereikendheid van het bewijsmateriaal moet ingaan, namelijk in die gevallen waarin door de verdediging een zogeheten Meer en Vaartverweer is gevoerd.

134 Maarten 't Hart, Een hedendaags heksenproces; Pleidooi voor heropening van de zaakLucia de B., NRC Handelsblad 7 oktober 2006, p. 33. Meer uitgebreid en kritisch over de bewijsconstructie van het Hof Den Haag: T. Derksen 2006. Op basis van zijn analyse is een verzoek ingediend tot nader onderzoek door de commissie Evaluatie afgesloten strafzaken (beter bekend onder de naam: commissie-Posthumus II). Het verzoek is ontvankelijk verklaard en op dit moment wordt de zaak opnieuw bekeken. Het doel van commissie Evaluatie afgesloten strafzaken is via onderzoek 'na te gaan of zich in een specifieke strafzaak in de opsporing, vervolging en/of de presentatie van het bewijs ter terechtzitting ernstige manco's hebben voorgedaan die een evenwichtige beoordeling van de feiten door de rechter in de weg hebben gestaan'. 
In een Meer en Vaartverweer betwist de verdediging niet de inhoud van de bewijsmiddelen, maar stelt zij vragen bij de daaruit te trekken of getrokken conclusie met betrekking tot de toedracht van het feit. De mate van waarschijnlijkheid dat uit de vastgestelde feiten het te bewijzen feitencomplex volgt, wordt ter discussie gesteld. Daartoe wijst de verdediging op een andere mogelijke gang van zaken die niet met de bewijsmiddelen, maar wel met de bewezenverklaring in strijd is. Er wordt als het ware op een gat in de bewijsconstructie gewezen.

Een mooi voorbeeld in deze is het arrest 'Heroïne in de dakgoot'. Verdachte was het opzettelijk aanwezig hebben van heroïne ten laste gelegd. De heroïne was aangetroffen in de dakgoot die vanuit de door de verdachte bewoonde kamer bereikbaar was en die hij ook gebruikte als bewaarplaats. Verdachte voerde in hoger beroep het verweer dat niet alleen hij, maar ook zijn kamergenote toegang had tot die dakgoot en dat ook zij die dakgoot als bewaarplaats gebruikte. Het bewuste verweer zag dus op een gat in de bewijsconstructie; impliciet was er in die bewijsconstructie vanuit gegaan dat alleen verdachte toegang had tot de dakgoot en daarom moet hebben geweten van de aanwezigheid van de heroïne aldaar. ${ }^{135} \mathrm{De}$ verdachte wijst er echter op dat deze redenering niet sluitend is, omdat ook zijn huisgenote toegang had tot de bewuste dakgoot. De Hoge Raad overwoog:

' $\mathrm{Nu}$ het Hof de juistheid van dit met de inhoud der gebezigde bewijsmiddelen niet strijdige verweer in het midden heeft gelaten, is de met de bewezenverklaring onvernigbare mogelijkheid opengebleven dat de daarin bedoelde hoeveelheid heroïne door verdachtes kamergenote in de dakgoot van de door de verdachte bewoonde kamer is gelegd en het bewezen verklaarde opzet bij de verdachte heeft ontbroken. Derhalve is de bewezenverklaring niet naar de eis der wet met redenen omkleed ${ }^{136}$

Het arrest 'Heroïne in de dakgoot' is een schoolvoorbeeld van een puur feitelijk Meer en Vaartverweer. ${ }^{137}$ In veel gevallen heeft het verweer echter behalve een feitelijke component ook een juridische component bestaande uit de uitleg van een in de tenlastelegging voorkomende en vaak aan de delictsomschrijving ontleende term. In dergelijke gevallen is er eigenlijk sprake van een gecombineerd dakdekkers- en Meer en Vaartverweer. Van zo een combinatie was sprake in het zogeheten Meer en Vaartarrest, waar deze verweren hun naam aan ontlenen. ${ }^{138}$ In die zaak werd door de verdachte betwist dat hij geen voorrang had verleend op het kruisingsvlak tussen de twee verschillende rijbanen van de weg 'Meer en

135 In gelijke zin: Kortenhorst 1990, p. 83-89.

136 HR 5 februari 1980, NJ 1980, 342.

137 Andere voorbeelden zijn: HR 2 maart 1982, NJ 1982, 524 m.nt. ThWvV; HR 1 juli 1996, NJ 1996, 752; HR 24 januari 1989, NJ 1989, 600 en HR 9 december 1997, NJ 1998, 385 m.nt. JR.

138 HR 1 februari 1972, NJ 1974, 450 m.nt. ThWvV en AA 1973, p. 514 m.nt. GEM. Zie voor andere voorbeelden: HR 15 juni 1982, NJ 1983, 106; HR 24 januari 1989, NJ 1989, 600; HR 27 september 1994, NJ 1995, 65; HR 5 november 1996, NJ 1997, 138; HR 26 november 1996, NJ 1997, 210; HR 13 november 2001, NJ 2002, 220. 
Vaart'. Daartoe voerde hij aan dat het kruisingsvlak in dit geval beperkt moest worden uitgelegd en daartoe dus niet moest worden gerekend de middenberm tussen de beide rijbanen. $\mathrm{Nu}$ in het voor het bewijs gebezigde proces-verbaal enkel was opgenomen dat verdachte met zijn auto op het kruisingsvlak had gestaan en daaruit niet kon worden afgeleid in welke betekenis deze term was gehanteerd, ontstond de met de bewezenverklaring strijdige mogelijkheid dat verdachte met zijn auto op de middenberm had gestaan. De Hoge Raad casseerde omdat de bewezenverklaring niet behoorlijk met redenen was omkleed.

De Hoge Raad wijkt in deze Meer en Vaartjurisprudentie af van de tot voor kort geldende algemene regel dat op bewijsverweren geen nadrukkelijke reactie in het vonnis hoeft te worden opgenomen. Een dergelijke verplichting gold tot 1 januari $2005^{139}$ alleen voor verweren in de zin van artikel 358 lid 3 Sv. Ten aanzien van bewijsverweren was het uitgangspunt dat deze weerlegd worden door de inhoud van de bewijsmiddelen zoals die in het vonnis is opgenomen. De afwijking van deze regel is in het geval van een Meer en Vaartverweer zeer verklaarbaar; het verweer kan immers niet weerlegd worden door de inhoud van de bewijsmiddelen nu het daarmee niet in strijd is. Dat is nu juist de essentie van het verweer.

De nadere motiveringsplicht in geval van Meer en Vaartverweren is echter door de Hoge Raad sterk gerelativeerd. Zo wordt van de verdediging verwacht dat zij feiten aandraagt die duiden op een mogelijke alternatieve gang van zaken. Het enkel noemen van een theoretische mogelijkheid of een enkele niet nader gespecificeerde bewering is onvoldoende. ${ }^{140}$ In dergelijke gevallen is geen sprake van een verweer en geldt dus evenmin een nadere motiveringsplicht. ${ }^{141}$ Hetzelfde geldt indien de feiten die door de verdediging worden gesteld kennelijk door de feitenrechter als hoogst onwaarschijnlijk zijn gekwalificeerd. ${ }^{142}$ Ook in dat geval is er geen noodzaak om aan het verweer enige woorden te wijden in het vonnis. Zo achtte de Hoge Raad het niet nodig dat de feitenrechter inging op het verweer van de verdachte dat hij niet zelf de strikken voor konijnen had geplaatst, maar slechts een konijn in een strik had gevonden:

'de bewijsmiddelen (sluiten) weliswaar de mogelijkheid dat de verdachte en zijn mededader niets met de betreffende strikken te maken hadden niet uit (...), maar de $\mathrm{Rb}$. (heeft) die mogelijkheid, gelet op de inhoud der gebezigde bewijsmiddelen in

139 Vanaf 1 januari 2005 bepaalt het tweede lid van art. 359 Sv dat uitdrukkelijke en onderbouwde standpunten van verdediging en Openbaar Ministerie indien zij niet de door de feitenrechter worden gevolgd in het vonnis moeten worden weerlegd. Daaronder vallen dan ook de Meer en Vaartverweren. Zie paragraaf 6.3.4 over de wijze waarop deze responsieplicht wordt uitgelegd.

140 HR 17 november 1998, NJ 1999, 152.

141 Deze lijn in de jurisprudentie is ook terug te zien in jurisprudentie van de Hoge Raad met betrekking tot art. 359 lid $2 \mathrm{~Sv}$ aangaande de algemene responsieplicht bij bewijsverweren. Daarover meer in paragraaf 6.3.4.

142 HR 3 april 1973, NJ 1973, 283 m.nt. ThWvV; HR 6 januari 1987, NJ 1987, 916 en HR 30 januari 2001, NJ 2001, 242. 
onderling verband beschouwd, als zo onwaarschijnlijk (...) kunnen aanmerken, dat zij deze bij de bewijsvoering zonder meer terzijde mocht stellen., ${ }^{143}$

Betreft het verweer een andere niet hoogst onwaarschijnlijke lezing van de feiten, dan mag de feitenrechter dat niet passeren. Echter uit de jurisprudentie blijkt dat de Hoge Raad in dergelijke gevallen genoegen neemt met de enkele constatering dat de door de verdediging gestelde feiten niet aannemelijk zijn geworden. Een dergelijk oordeel is volgens de Hoge Raad niet onbegrijpelijk en kan in cassatie niet verder worden getoetst. ${ }^{144}$ Met Schalken kan worden ingestemd als hij naar aanleiding van deze uitspraak opmerkt dat de Hoge Raad daarmee de iets meer aangetrokken controle op de interpretatie van de feiten weer goeddeels uit handen geeft; alleen via de ultieme toets van onbegrijpelijkheid kan de Hoge Raad dan nog ingrijpen. ${ }^{145}$

\subsection{Conclusie}

De eis dat de bewezenverklaring op relevant bewijsmateriaal moet zijn gebaseerd, is opgenomen in ons huidige Wetboek van Strafvordering, en wel in het derde lid van artikel 359. Volgens de memorie van toelichting had deze bepaling tot doel de rechter er toe te brengen zijn (logische) gedachtegang in zijn vonnis tot uitdrukking te brengen. Hoewel de strekking van deze bepaling duidelijk was, heeft in de praktijk het derde lid van artikel 359 Sv nooit het effect gehad dat de wetgever voor ogen stond. De redenen hiervoor liggen in de onduidelijkheid die de wetgever schiep door in de memorie van toelichting een modelvonnis op te nemen dat zelf niet voldeed aan de doelstelling en in de onmogelijkheid om ten aanzien van direct bewijs aan het vereiste te voldoen.

Reeds vrij snel na de inwerkingtreding van het wetboek in 1926 kwam de Hoge Raad aan de genoemde bezwaren tegen artikel 359 lid 3 Sv tegemoet, en keurde hij de praktijk waarbij voor de redengevende feiten en omstandigheden werd verwezen naar de inhoud van de bewijsmiddelen goed. Vanaf dat moment is de beoordeling van de vraag of de redengevendheid van het bewijsmateriaal nader gemotiveerd moet worden aan de feitenrechter overgelaten. De Hoge Raad kan op dit punt niet casseren. Wel kan hij toetsen of het door de feitenrechter gebezigde bewijsmateriaal redengevend kan zijn, maar deze toetsing is noodgedwongen zeer marginaal. Bovendien blijkt de Hoge Raad geneigd veel met betrekking tot de redengevendheid van het bewijs in de vonnissen van de lagere rechters in te lezen en ook indien niet voldaan is aan de eis van artikel 359 lid $3 \mathrm{~Sv}$, dit met de mantel der liefde te

143 HR 22 december 1987, NJ 1988, 756

144 Onder andere: HR 25 april 1989, $N J$ 1989, 866 m.nt. 'tH; HR 26 juni 1990, NJ 1991, 172; HR 9 december 1997, NJ 1998, 385 m.nt. JR en HR 31 oktober 2000, NJ 2001, 238 m.nt. Sch.

145 Schalken in zijn annotatie bij HR 31 oktober 2000, NJ 2001, 238. 
bedekken. Slechts in enkele gevallen eist de Hoge Raad een nadere toelichting van de feitenrechter. Onder andere indien door de verdediging een gemotiveerd dakdekkersverweer dan wel een gemotiveerd Meer en Vaartverweer is gevoerd. Ook bewijsconstructies waarin het zwijgen dan wel het liegen van de verdachte voor het bewijs wordt gebezigd, vereisen een nadere toelichting. Hetzelfde geldt voor het gebruik van schakelbewijs. Het eisen van een nadere motivering in dergelijke gevallen ligt voor de hand; de genoemde verweren worden niet door de inhoud van de bewijsmiddelen weerlegd en de genoemde bewijsconstructies kunnen niet zonder nadere toelichting bij het in het vonnis opgenomen bewijsmateriaal blijken. Ondanks het feit dat in dergelijke gevallen de feitenrechter niet kan volstaan met het enkel vermelden van de inhoud van de bewijsmiddelen en dus zijn vonnis op dit punt nader moet inkleden, brengt dit niet met zich dat de Hoge Raad desgevraagd vervolgens ook uitgebreid op de inhoud van die motivering ingaat. In veel gevallen volstaat de feitenrechter met het opnemen van standaardformuleringen en worden deze door de Hoge Raad ongemoeid gelaten. Zoals: 'hetgeen door de verdachte is aangevoerd, is niet aannemelijk geworden' of 'dat de verdachte geen redelijke, die redengevendheid ontzenuwende verklaring, heeft gegeven'.

Concluderend kan gesteld worden dat voor zover de eis van relevantie van het bewijsmateriaal in artikel 359 lid $3 \mathrm{~Sv}$ is vervat, de Hoge Raad hier slechts in zeer beperkte mate controle op uitoefent en dat dientengevolge in de dagelijkse praktijk van de Nederlandse strafvonnissen de relevantie van het bewijsmateriaal nauwelijks een punt van aandacht is. 


\section{Bijzondere motiveringseisen aangaande de betrouwbaarheid}

\subsection{Inleiding}

In hoofdstuk 1 kwam al aan bod dat bij de totstandkoming van het Wetboek van Strafvordering een nadere motiveringsplicht aangaande de betrouwbaarheid van het gebezigde bewijsmateriaal het uiteindelijk moest afleggen tegen het opnemen van bewijsminima in het wetboek. Alleen het gebruik van onbeëdigde getuigenverklaringen moest ingevolge artikel 360 lid $1 \mathrm{~Sv}$ door de rechter nader in zijn vonnis worden toegelicht. Voor het overige meende de wetgever er goed aan te doen de rechter zoveel mogelijk vrijheid te laten bij de selectie en waardering van het bewijsmateriaal. Welke concrete betekenis men artikel 359 lid $2 \mathrm{~Sv}$ in het licht van de bewijsbeslissing toedichtte, valt niet uit de stukken te achterhalen. Evident is dat deze bepaling in de optiek van de wetgever niet met zich bracht dat de rechter de wijze waarop hij het bewijsmateriaal had gewaardeerd nader moest toelichten.

Net als ten aanzien van de plicht om de inhoud van de bewijsmiddelen in het vonnis op te nemen en de plicht om de redengevende feiten aan te wijzen, blijkt ook ten aanzien van de motiveringsplichten opgenomen in artikel 359 lid 2 en 360 lid 1 $\mathrm{Sv}$ dat de rechtspraak en de wetgever zich weinig gelegen lieten liggen aan de bedoelingen van de wetgever in 1926. Echter in tegenstelling tot hetgeen met betrekking tot de motiveringsplichten in de hoofdstukken 4 en 5 is geconcludeerd, betreft het hier niet een afkalving maar een verruiming van de verantwoordingsplicht. Ten eerste zijn de gevallen waarin op basis van artikel $360 \mathrm{~Sv}$ het gebruik van bepaald bewijsmateriaal nader moet worden gemotiveerd uitgebreid. Ten tweede heeft de Hoge Raad het tweede lid van artikel 359 Sv aangegrepen om van de strafrechter te eisen dat hij bepaalde verweren waaronder betrouwbaarheidsverweren, alleen gemotiveerd kan afwijzen. Deze jurisprudentie heeft op haar beurt aanleiding gegeven tot wijziging van artikel 359 Sv. Met ingang van 1 januari 2005 dient de rechter in zijn vonnis de gronden op te nemen waaruit blijkt waarom hij standpunten van partijen niet volgt. In dit hoofdstuk zal nader op de ontwikkeling van beide bepalingen, artikel 360 en 359 lid $2 \mathrm{~Sv}$, worden ingegaan.

\subsection{Nadere motiveringsplichten ingevolge art. $360 \mathrm{~Sv}$}

In artikel 360 , eerste en tweede lid, $\mathrm{Sv}$ is ten aanzien van een aantal bewijsmiddelen een bijzondere motiveringsplicht opgenomen. Voor zover de rechter een dergelijk 
bewijsmiddel aan de bewezenverklaring ten grondslag legt, dient hij het gebruik daarvan in het vonnis nader te motiveren. Bij de inwerkingtreding van het Wetboek van Strafvordering in 1926 zag de in artikel 360 Sv opgenomen nadere motiveringsplicht alleen op onbeëdigde getuigenverklaringen. Naderhand zijn hier nog drie verschillende vormen van getuigenverklaringen aan toegevoegd, te weten verklaringen van personen wier identiteit (deels) onbekend is, verklaringen van kroongetuigen en verklaringen van zogeheten afgeschermde getuigen. Gemeenschappelijk kenmerk van deze getuigenverklaringen is dat de betrouwbaarheid, dan wel de toetsing van de betrouwbaarheid problematisch is. De compensatie daarvoor wordt gevonden in een nadere motiveringsplicht van de rechter indien hij toch gebruik wenst te maken van deze 'dubieuze' verklaringen. In de volgende paragrafen zal op elk van deze vormen van bewijs en de daaraan gekoppelde verantwoordingsplicht nader worden ingegaan.

\subsubsection{Onbeëdigde getuigen}

In het Wetboek van Strafvordering van 1838 werd onderscheid gemaakt tussen bevoegde en niet bevoegde getuigen. Dit onderscheid werkte in de praktijk niet en in het wetboek van 1926 treft men het genoemde onderscheid ook niet meer aan. In plaats daarvan creëerde men het onderscheid tussen beëdigde en onbeëdigde verklaringen. Voor zover getuigen de leeftijd van 16 jaar nog niet hebben bereikt of de strekking van de eed niet begrijpen, hoeven zij de eed of de belofte niet af te leggen, maar worden zij door de rechter gemaand conform de waarheid te verklaren. ${ }^{1}$

Voor het gebruik van deze onbeëdigde verklaringen geldt vervolgens wel een nadere motiveringsplicht; de rechter zal in het vonnis tot uitdrukking moeten brengen waarom hij aan die verklaringen 'die niet onder den waarborg van den eed zijn afgelegd ${ }^{2}$ toch bewijskracht toekent. Blok en Besier menen dat die motivering moet bestaan uit het aangeven van de omstandigheden op grond waarvan de rechter van mening is dat aan de getuigenverklaring geloof kan worden gehecht:

'Die omstandigheden kunnen b.v. zijn de zeer eenvoudige aard van het verklaarde, de den rechter gebleken ontwikkeling van het vermogen van den getuige om waar te nemen en waarnemingen weer te geven en dergelijke. Van die omstandigheden moet hij [de rechter; WD] dan in het vonnis rekenschap geven., ${ }^{3}$

In de praktijk na de inwerkingtreding van het Wetboek in 1926 heeft deze nadere motiveringsplicht echter nauwelijks enige betekenis gehad. ${ }^{4}$ Meestal wordt volstaan

Art. 216, tweede lid, Sv en 290, tweede lid, Sv.

Kamerstukken II 1913-1914, 286, nr. 3 (MvT), p. 181.

Blok \& Besier 1925, p. 214.

Typerend is bijvoorbeeld dat in het hoofdstuk 'De bewijsmotivering in strafzaken' van Brouns 2001 in het boek 'Leerstukken van strafprocesrecht' art. 360 lid 1 Sv niet eens wordt genoemd onder de motiveringsplichten. 
met een standaardmotivering. Voldoende is een overweging waaruit blijkt dat er voor de rechter geen reden is om aan de betrouwbaarheid van de getuige te twijfelen. ${ }^{5}$ Soms wordt echter nadrukkelijk overwogen dat de getuige door zijn houding en antwoorden ter terechtzitting blijk heeft gegeven de gestelde vragen volkomen te hebben begrepen. ${ }^{6}$ Nog meer 'to the point' aldus Reijntjes ${ }^{7}$ is de overweging: 'dat de getuige blijk gaf de draagwijdte van het door hem verklaarde volkomen te hebben begrepen'. $\mathrm{Al}$ deze overwegingen zien op de kwaliteit van de getuige, die ondanks het feit dat hij kennelijk niet in staat is om de eed te begrijpen, wel in staat moet worden geacht te hebben begrepen welke impact zijn verklaring heeft. Het enkele feit dat de rechter meent dat de getuige betrouwbaar is, is voldoende. Op geen enkele wijze wordt de betrouwbaarheid van de inhoud van die verklaring nader gemotiveerd, bijvoorbeeld door te wijzen op het feit dat de getuige telkens consequent hetzelfde is blijven verklaren of de inhoud van zijn verklaring wordt bevestigd door ander bewijsmateriaal.

Nog los van het feit dat de rechter niet de betrouwbaarheid van de verklaring zelf hoeft te toetsen, is de betekenis van artikel $360 \mathrm{lid} 1 \mathrm{~Sv}$ goeddeels ondergraven door de beperkte reikwijdte ervan. Artikel $360 \mathrm{lid} 1 \mathrm{~Sv}$ is alleen van toepassing op verklaringen van niet-beëdigde en aangemaande getuigen afgelegd ten overstaan van de rechter-commissaris of de zittingsrechter. Dat betekent dat verklaringen van minderjarigen of geestelijk gehandicapten die door de politie zijn opgenomen niet onder de werking van artikel $360 \mathrm{~Sv}$ vallen. ${ }^{9}$ Dat geldt ook voor hun verklaringen afgelegd bij de rechter-commissaris zonder dat ze conform artikel 216 lid $2 \mathrm{~Sv}$ zijn gemaand. Met Reijntjes ben ik van mening dat dit allerminst consequent is. Of de Hoge Raad, zoals Reijntjes verwacht, in de toekomst de nadere motiveringsplicht van artikel 360 lid Sv op deze situaties analoog zal toepassen, acht ik twijfelachtig. ${ }^{10}$ Maar zelfs als dat zo zou zijn, lijkt daarmee niet veel gewonnen indien de feitenrechter kan volstaan met een van zijn toverspreuken.

\subsubsection{Anoniem bewijs}

Met de wet Getuigenbescherming ${ }^{11}$ werd in Nederland een wettelijke grondslag gegeven voor het gebruik van anoniem bewijs. Het gebruik van anoniem bewijs was al daarvoor in de Nederlandse rechtspraak geaccepteerd, maar de onmogelijkheid

\footnotetext{
HR 11 april 1927, NJ 1927, p. 596, W. 11672 en HR 27 nov. 1939, NJ 1940, 339 m.nt. T. HR 25 nov. 1929, NJ 1930, p. 102.

Reijntjes in zijn annotatie bij HR 20 mei 1997, NJ 1998, 22.

HR 20 okt. 1941, NJ 1942, 59 m.nt. T.

HR 21 november 2006, NJ 2006, 649.

10 Minkenhof/Reijntjes 2002, p. 380. In de nieuwe druk (Minkenhof's Nederlandse strafvordering 2006) is overigens deze verwachting niet meer opgenomen.

11 Wet van 11 november 1993 (getuigenbescherming), Stb. 1993, 603 (inwerkingtreding
} 1 februari 1994). 
of de beperkte mogelijkheid van de verdediging om de getuigen te ondervragen, stuitte in Straatsburg op problemen. ${ }^{12}$ Een nadere regeling van de voorwaarden waaronder het gebruik van bewijs waarvan de herkomst voor verdediging en zittingsrechter onbekend bleef, moest verdere debacles in Straatsburg voorkomen. In de wet Getuigenbescherming is de mogelijkheid gecreëerd om een bewezenverklaring mede te doen steunen op anoniem bewijs. Dat anonieme bewijs kan in verschillende vormen de zittingsrechter bereiken: in de vorm van een schriftelijk bescheid van de rechter-commissaris waarin deze verslag doet van zijn verhoor van de bedreigde getuige; in de vorm van enig ander schriftelijk bescheid waarin de verklaring van een niet met naam genoemde getuige wordt opgenomen (art. 344 lid $3 \mathrm{~Sv}$ ), of in de vorm van een mondelinge dan wel schriftelijke verklaring van een getuige wiens identiteit deels verborgen blijft (art. 190 tweede lid en art. 290 eerste lid Sv).

Behalve dat de wettelijke regeling voorziet in procedurele voorschriften ten aanzien van het verhoor van de bedreigde getuige, specifieke bewijsregels en bewijsminima, is in artikel 360 lid $1 \mathrm{~Sv}$ tevens een nadere motiveringsplicht opgenomen in geval de rechter van één van de genoemde vormen van bewijs gebruik maakt. Deze motiveringsplicht was al eerder, dus voor de inwerkingtreding van de wet Getuigenbescherming, in de jurisprudentie aangenomen:

'wanneer van processen-verbaal inhoudende verklaringen van niet met name genoemde personen voor het bewijs gebruik wordt gemaakt en de betrouwbaarheid van dat materiaal door of namens de verdachte ter terechtzitting wordt betwist, dient de rechter, als hij niettemin gebruik maakt van dat materiaal voor het bewijs daaromtrent verantwoording af te leggen. ${ }^{13}$

Verschil tussen de jurisprudentiële en wettelijke motiveringsplicht is, dat op grond van artikel $360 \mathrm{~Sv}$ de rechter nu ambtshalve de plicht tot motivering heeft en dus niet slechts indien de verdediging op dit punt een uitdrukkelijk verweer voert. Uit de memorie van toelichting blijkt dat dat een bewuste keuze is geweest:

'Het lijkt me gewenst de door de Hoge Raad geëiste extra motivering aangaande de betrouwbaarheid van de verklaring van een anoniem gebleven getuige, wanneer deze door of namens de verdachte wordt betwist, ook uit te strekken tot het geval waarin dat laatste niet is geschied, bij voorbeeld in een verstekzaak, of omdat de verdachte uit onwetendheid heeft gezwegen., ${ }^{14}$

De Hoge Raad heeft vervolgens op basis van de memorie van toelichting aan de nadere motiveringsplicht een tweeledig karakter gegeven. Enerzijds dient uit de motivering te blijken dat de bewijsrechtelijke eisen die aan het gebruik van het

12 Meer uitgebreid over de problematiek met betrekking tot het anonieme bewijs: paragraaf 2.2.2.1.

13 HR 1985, 426 m.nt. ThWvV. In gelijke zin: HR 25 september 1984, NJ 1985, 427 m.nt. ThWvV; HR 11 juni 1985, NJ 1986, 59, HR 12 november 1985, NJ 1986, 409; HR 29 oktober 1985, $N J$ 1986, 420.

14 Kamerstukken II 1991-1992, 22483, nr. 3, p. 38-39. 
anonieme bewijs zijn gesteld in acht zijn genomen. Anderzijds dient uitdrukkelijk te blijken dat de zittingsrechter de betrouwbaarheid van de anonieme verklaring zelfstandig heeft getoetst. Het is onvoldoende als uit de bewijsvoering de betrouwbaarheid kan blijken, bijvoorbeeld omdat de verklaring van de anonymus wordt bevestigd door wat in de overige bewijsmiddelen is vastgesteld. ${ }^{15}$ Eveneens onvoldoende is als de rechter voor de beoordeling van de betrouwbaarheid enkel verwijst naar hetgeen daaromtrent door de rechter-commissaris of een andere opsporingsambtenaar is overwogen. ${ }^{16}$ In dat laatste geval wordt immers de suggestie gewekt dat niet de zittingsrechter, maar degene die de anonieme bron heeft gehoord uiteindelijk beslist over de betrouwbaarheid van de verklaring. Problematisch aan het anonieme bewijs is immers dat de zittingsrechter, met mogelijke uitzondering voor de beperkt anonieme getuige, de getuige zelf niet kan zien of horen. In geval van een bedreigde getuige is hem zelfs de mogelijkheid tot het zelf horen van de getuige ontzegd ${ }^{17} \mathrm{Hij}$ is dus bij de beoordeling van de betrouwbaarheid van de door de anonymus gegeven verklaring in grote mate afhankelijk van hetgeen anderen daarover te zeggen hebben. Die afhankelijkheid verdraagt zich niet met het uitgangspunt dat de zittingsrechter uiteindelijk verantwoordelijk is voor de waarheidsvinding in de gegeven strafzaak. Teneinde die eigen verantwoordelijkheid een gezicht te geven, dient hij in het vonnis tot uitdrukking te brengen dat hij niet enkel op het oordeel van een ander is afgegaan. Dat laat onverlet dat hij wel degelijk het oordeel van die ander in zijn eigen oordeel mag betrekken. Daarnaast zal hij echter de afgelegde verklaringen in elk geval moeten toetsen aan ander door hem betrouwbaar geacht materiaal. De bewijsbeslissing moet dus niet alleen (in belangrijke mate) steunen op andere bewijsmiddelen dan de anonieme verklaring, maar (een deel van) dit materiaal moet ook die verklaring bevestigen, en wel in zoverre, dat een (positief) oordeel kan worden gevormd over de betrouwbaarheid ervan. ${ }^{18}$

De nadere motiveringsplicht betreffende het gebruik van anoniem bewijsmateriaal is niet in de eerste plaats ingegeven om betrokken partijen inzicht te geven in het beoordelingsproces van de rechter, maar veeleer om uitdrukking te geven aan het beginsel van materiële waarheidsvinding. Een beginsel dat in Nederland vooral is gekoppeld aan de positie van de zittingsrechter. Hij dient tot een eigen, onafhankelijk oordeel te komen over de feiten. Hij kan zich daarbij niet verschuilen achter andere functionarissen binnen het strafproces of achter het niet ageren van betrokken partijen. Ook voor zover de verdediging de betrouwbaarheid van het anonieme bewijsmateriaal niet heeft betwist, dient de rechter in zijn vonnis

15 HR 11 mei 1999, NJ 1999, 526; anders advocaat-generaal Fokkens in zijn conclusie bij dit arrest.

16 HR 20 mei 1997, NJ 1998, 22 m.nt. JR. In gelijke zin: HR 11 mei 1999, NJ 1999, 526 en HR 11 april 2000, NJ 2000, 546.

17 HR 30 juni 1988, NJ 1999, 88 m.nt. JR.

18 Reijntjes in zijn annotatie bij HR 20 mei 1997, NJ 1998, 22. 
expliciet tot uitdrukking te brengen dat hij zelfstandig de betrouwbaarheid van het bewijsmateriaal heeft getoetst. Laat hij dit achterwege, dan zal het vonnis in cassatie sneuvelen.

In de jurisprudentie van de Hoge Raad worden aldus hoge eisen gesteld aan de motiveringsplicht bij het gebruik van anoniem bewijsmateriaal. Helaas wordt dit weer voor een deel teniet gedaan doordat diezelfde Hoge Raad niet snel aanneemt dat er sprake is van anoniem bewijs. ${ }^{19}$ Voor zover immers de anonieme bron traceerbaar is - of 'individualiseerbaar' zoals de Hoge Raad dat noemt - kan niet worden gesproken van bewijsmateriaal houdende verklaringen van personen waarvan de identiteit niet blijkt. ${ }^{20}$ Ook niet-anonieme mondelinge verklaringen waarin wordt weergegeven wat een anonieme bron zou hebben gezegd, kunnen in de optiek van de Hoge Raad niet als zodanig gekwalificeerd worden. ${ }^{21}$ Dientengevolge is ook artikel $360 \mathrm{~Sv}$ niet van toepassing op dergelijke verklaringen en kunnen deze alsnog aan de bewezenverklaring ten grondslag worden gelegd zonder dat de feitenrechter gehouden is de toetsing van de betrouwbaarheid van die verklaringen zichtbaar te maken. Kennelijk geldt ten aanzien van dergelijke bewijsconstructies het beginsel van materiële waarheidsvinding in mindere mate of niet, terwijl toch ook hier niet evident is dat de zittingsrechter een eigen oordeel over de betrouwbaarheid heeft kunnen vormen.

\subsubsection{Kroongetuige}

Een derde categorie van getuigenverklaringen waarvoor ex artikel $360 \mathrm{~Sv}$ een nadere motiveringsplicht geldt, zijn verklaringen van getuigen die zijn afgelegd in ruil voor een toezegging van het Openbaar Ministerie om in hun strafzaak strafvermindering te bevorderen. ${ }^{22}$ Evenals bij het anonieme bewijs kent deze motiveringsplicht een voorloper in de jurisprudentie. Ten aanzien van een verklaring die in het kader van 'plea bargaining' was afgelegd, overwoog de Hoge Raad in 1995 reeds:

'Wel zal - in aanmerking genomen dat onder omstandigheden de betrouwbaarheid van zodanige verklaringen nadelig kan worden beïnvloed door datgene waartoe de betrokkene zich verplicht voelt of door wat hij in zijn belang acht gelet op de door hem met de betrokken autoriteiten gemaakte afspraken - de rechter indien de betrouwbaarheid van zodanige verklaring wordt aangevochten, blijk moeten geven van een onderzoek dienaangaande. ${ }^{, 23}$

19 Daarover meer uitgebreid: paragraaf 2.2.2.1.

20 HR 29 april 1997, NJ 1997, 666; HR 18 mei 1999, NJ 2000, 106 m.nt. Sch en HR 4 juni 2002, NJ 2002, 416.

21 HR 14 december 2004, NJ 2005, 383 m.nt. YB.

22 Art. 226g Sv juncto art. 44a Sr.

23 HR 23 mei 1995, NJ 1995, 683 m.nt. Sch (r.o 5.3.2). Meer algemeen over het fenomeen 'plea bargaining': Beijer 1994. 
De rechtsfiguur 'kroongetuige ${ }^{24}$ werd voor het eerst door de Hoge Raad ten principale beoordeeld in zijn arrest d.d. 30 juni $1998 .{ }^{25}$ Daarbij stelde de Hoge Raad voorop dat hij geen algemeen oordeel over de toelaatbaarheid van de kroongetuige in het Nederlandse strafproces wenste uit te spreken. De Hoge Raad meende dat de verstrekkendheid van de daarmee verband houdende gevolgen voor het Nederlandse strafproces met zich bracht dat een algemeen oordeel over de toelaatbaarheid van de kroongetuige aan de wetgever toekwam. ${ }^{26}$ Toch achtte de Hoge Raad in het gegeven geval het gebruik van verklaringen die waren verkregen na voorafgaande toezeggingen aan getuigen met betrekking tot hun eigen strafrechtelijke vervolging niet in strijd met artikel 6 EVRM. Daarbij werd de contradictoire behandeling ter terechtzitting als uitgangspunt genomen. Voor zover de betrouwbaarheid van de verklaringen van de kroongetuige worden betwist, dient:

'de getuige te worden ondervraagd door een rechter, bij voorkeur op de openbare terechtzitting waar de strafzaak wordt behandeld, waarbij ook de verdediging de gelegenheid krijgt tot het stellen van vragen aan de getuige. Bij gebreke van zodanige ondervraging is het gebruik tot het bewijs van het ambtsedige proces-verbaal van politie waarin de (betwiste) verklaringen van de getuige zijn opgenomen in beginsel ongeoorloofd. ${ }^{27}$

Bovendien achtte de Hoge Raad een nadere motiveringsplicht noodzakelijk omdat niet is uitgesloten dat de gemaakte afspraken de betrouwbaarheid van de gegeven verklaring nadelig kunnen beïnvloeden. Het risico bestaat dat de kroongetuige om de hem in het vooruitzicht gestelde reductie op zijn straf of om ander voordeel binnen te halen zijn eigen rol afzwakt en de rol van degene tegen wie hij een belastende verklaring aflegt zwaarder voorstelt dan die in werkelijkheid is. ${ }^{28}$ In de woorden van de Hoge Raad:

'In aanmerking genomen dat onder omstandigheden de betrouwbaarheid van verklaringen afgelegd door een verdachte nadat door hem en het Openbaar Ministerie afspraken zijn gemaakt waarbij toezeggingen zijn gedaan met betrekking tot strafvermindering of strafrechtelijke vervolging nadelig kan worden beïnvloed door datgene waartoe die

24 Nader over de betekenis van het onduidelijke begrip 'kroongetuige': Mols 2003, p. 314 e.v. 25 HR 30 juni 1998, NJ 1998, 799 m.nt. Sch.

26 Overweging 5.2.3 van de Hoge Raad luidt: 'Over de toelaatbaarheid van 'de kroongetuige' zal in dit arrest niet een algemeen oordeel worden gegeven en wel om de volgende redenen. Een op de desbetreffende problematiek toegesneden wettelijke regeling is niet voorhanden. Van een voldoende uitgekristalliseerde, algemeen aanvaarde rechtsopvatting omtrent dit vraagstuk in al zijn verschijningsvormen, kan evenmin worden gesproken. Er bestaat met name geen zekerheid over wat onder een 'kroongetuige' dient te worden verstaan en welke afgrenzing moet worden gegeven aan de toelaatbaarheid van een dergelijke getuige en van de inhoud van de met deze gemaakte afspraak. Een nadere bepaling en afgrenzing zal door de wetgever moeten worden gegeven. Een wettelijke regeling is in voorbereiding, maar de uitkomst daarvan is nog onzeker. Bij die stand van zaken gaat het de rechtsvormende taak van de rechter te buiten indien hij zich thans over het 'fenomeen van de kroongetuige' in algemene termen zou uitlaten.'

27 HR 30 juni 1998, NJ 1998, 799 m.nt. Sch (r.o. 7.12).

28 Corstens 2005a, p. 329. 
verdachte zich bij het afleggen van een getuigenverklaring waardoor een andere verdachte wordt belast verplicht voelt of door wat hij in zijn belang acht gelet op de gemaakte afspraken, zal de rechter, indien de betrouwbaarheid van zodanige verklaringen wordt aangevochten, blijk moeten geven van een onderzoek dienaangaande. ${ }^{, 29}$

De door de Hoge Raad geïntroduceerde nadere motiveringsplicht beperkte zich tot die gevallen waarin door of namens de verdachte de betrouwbaarheid van de verklaring van de kroongetuige in twijfel werd getrokken. In de gegeven casus achtte de Hoge Raad het arrest van het hof op dit punt voldoende. Het hof had naar het oordeel van de Hoge Raad ervan blijk gegeven de betrouwbaarheid van de bewuste verklaringen kritisch te hebben bekeken. Enerzijds had het hof aangegeven dat de verklaring van één van de kroongetuigen in hoge mate steun vond in ander gebezigd bewijsmateriaal. Anderzijds stemden de verklaringen van beide kroongetuigen in grote mate overeen en versterkten zij elkaar. Daarmee had het hof aan zijn motiveringsplicht voldaan.

Daarmee is niet gezegd dat volgens de Hoge Raad de verklaring van de kroongetuige inderdaad steun moet vinden in ander bewijsmateriaal. Voldoende is indien uit het vonnis blijkt dat de rechter zich bewust is geweest van het precaire karakter van de verklaring van een kroongetuige waar het de betrouwbaarheid betreft. Ook annotator Schalken stelt vragen bij de reikwijdte van de aldus gecreëerde responsieplicht naar aanleiding van het betrouwbaarheidsverweer:

'De motiveringsplicht beperkt zich - hoe belangrijk ook - tot toetsing van de betrouwbaarheid (horen door een rechter, ondervraging door de verdediging), maar is niet gericht op de beantwoording van materiële en nadere procedurele vragen in relatie tot de aard van de toezegging (subsidiariteit, proportionaliteit, rechtsgelijkheid, zorgvuldigheid, bij afspraak in acht te nemen waarborgen). (...) Bovendien is de vereiste toetsing van de betrouwbaarheid nogal relatief geformuleerd. De Hoge Raad beklemtoont weliswaar (in reeds eerder gebruikte bewoordingen) de mogelijkheid dat de waarheid door de OM-toezegging oneigenlijk kan worden beïnvloed (7.12 en 7.16), maar de wijze waarop vervolgens de betwisting van de betrouwbaarheid met waarborgen wordt omgeven valt niet al te streng uit.'

Zoals gezegd heeft inmiddels de wetgever van zich laten horen. De wet Toezeggingen aan getuigen ${ }^{30}$ is - na een lang en moeizaam wetgevingstraject - op 1 april 2006 in werking getreden. ${ }^{31}$ Naast de materiële en procedurele eisen die worden gesteld aan het doen van toezeggingen aan getuigen, is artikel $360 \mathrm{~Sv}$ uitgebreid met een nieuwe motiveringsplicht in geval gebruik wordt gemaakt van een verklaring die uit een dergelijke toezegging voortvloeit. Het tweede lid luidt thans:

29 HR 30 juni 1998, $N J$ 1998, 799 m.nt. Sch (r.o. 7.12). In gelijke zin: HR 6 april 1999, $N J$ 1999, 565 m.nt. Sch.

30 Wet van 12 mei 2005 (toezeggingen aan getuigen in strafzaken), Stb. 2005, 254 (inwerkingtreding 1 april 2006, Stb. 2005, 150).

31 Zie over de gang van zaken met betrekking tot de totstandkoming: Mols 2003, p. 318 e.v. en Abels 2005, p. 861-864. 
'Indien het bewijs mede wordt aangenomen op de verklaring van een getuige met wie op grond van artikel 226h, derde lid, of 226k door de officier van justitie een afspraak is gemaakt, geeft het vonnis daarvan in het bijzonder reden.'

Dit wijkt af van de motiveringseis die in de jurisprudentie werd gesteld, in die zin dat ook zonder dat de verdediging de betrouwbaarheid van de kroongetuige ter discussie heeft gesteld, de rechter het gebruik van diens verklaring met redenen dient te omkleden. In de wet zijn geen inhoudelijke criteria opgenomen waaraan die motivering moet beantwoorden. Uit de parlementaire stukken blijkt dat de minister dit ook niet nodig achtte:

'Het behoort echter van oudsher tot de moeilijke en delicate taak van de rechter te oordelen over de geloofwaardigheid van verschillende elkaar vaak tegensprekende getuigen en verdachten. In de memorie van toelichting noemde ik al de waardering van verklaringen van twee medeverdachten die elkaar de hoofdrol bij het plegen van het telastegelegde feit proberen toe te dichten, zonder dat sprake is van enige afspraak met de officier van justitie. Ook aan de noodzaak tot waardering van verklaringen van getuigen à charge en à decharge die haaks op elkaar staan, kan de rechter zich niet onttrekken. Bij het nemen van de bewijsbeslissing komt het er uiteindelijk op aan dat de rechter aan de ene verklaring wel en aan de andere geen geloof hecht. Nadere regulering is op dit terrein niet te geven. Wel is in mijn hiervoor reeds aangekondigde nota van wijziging een handreiking voor de zittingsrechter opgenomen, die ertoe strekt dat hij bij zijn oordeelsvorming het oordeel van de rechter-commissaris over de betrouwbaarheid van de criminele getuige kan betrekken. ${ }^{32}$

Daarmee lijkt de motiveringsplicht inzake het gebruik van verklaringen van kroongetuigen af te wijken van de wijze waarop die wordt ingevuld bij het gebruik van anoniem bewijs. Uit de motivering in geval van het gebruik van het anonieme bewijs moet immers blijken dat de bewijsrechtelijke eisen die aan het gebruik van het anonieme bewijs zijn gesteld in acht zijn genomen en dat de zittingsrechter de betrouwbaarheid van de anonieme verklaring zelfstandig heeft getoetst. De minister trekt die lijn niet door voor het kroongetuigenbewijs, omdat zijns inziens de beoordeling van de kroongetuige niet in wezenlijke zin afwijkt van die van iedere andere getuige. Daarmee gaat hij echter voorbij aan de bijzonder precaire positie van de kroongetuige, die in het licht van de gemaakte afspraak zich ofwel gedwongen voelt tot ofwel baat heeft bij het verstrekken van belastende informatie. De dwang die van de afspraak uitgaat dan wel het belang dat de getuige heeft bij het nakomen van die afspraak zouden wellicht ten koste kunnen gaan van de juistheid van de verstrekte informatie. Het is wenselijk dat de Hoge Raad te zijner tijd de motiveringsplicht zoals die in het nieuwe tweede lid is opgenomen niet al te vrijblijvend uitlegt en daaraan vergelijkbare eisen stelt als ten aanzien van het gebruik van anoniem bewijsmateriaal. Dat geldt te meer indien de kroongetuige niet ter zitting is gehoord en de zittingsrechter dus geen eigen indruk van de getuige heeft gekregen.

32 Kamerstukken II 1999-2000, 26294, nr. 6, p. 29. 


\subsubsection{Afgeschermde getuige}

De rechtsfiguur 'afgeschermde getuige' werd in de gelijknamige wet geïntroduceerd. Aanleiding voor de wet vormde een aantal rechterlijke uitspraken waarin het gebruik van informatie aangeleverd door inlichtingen- en veiligheidsdiensten voor het bewijs ter discussie stond. ${ }^{33}$ Zowel de rechtmatige herkomst als de betrouwbaarheid van die informatie kunnen in de strafzaak moeilijk getoetst worden. Zo is het vaak onmogelijk om de medewerkers van de inlichtingen- en veiligheidsdiensten als getuige ter zitting indringend te ondervragen. Zij hebben immers een plicht tot geheimhouding als het gaat om informatie die de staatsveiligheid in gevaar brengt. ${ }^{34}$ Voor zover zij al als getuige kunnen worden opgeroepen - vaak blijft ook de identiteit van de getuige verborgen om staatsveiligheidsreden - zullen zij vragen niet beantwoorden met een beroep op hun geheimhoudingsplicht. Het niet kunnen uitoefenen van het ondervragingsrecht ex artikel 6 lid 3 onder d EVRM kan vervolgens aan de bruikbaarheid van de AIVD-informatie in de weg staan. ${ }^{35}$ Teneinde deze impasse te doorbreken is het wetsvoorstel 'afgeschermde getuige' ingediend. Inmiddels is het wetsvoorstel goedgekeurd en is de wet per 1 november 2006 in werking getreden. ${ }^{36}$

In bewijsrechtelijke zin bevat de wet Afgeschermde getuige een aantal vergaande wijzigingen. Ten eerste is artikel 344 lid 1 sub $3 \mathrm{~Sv}$ aangepast. De voorwaarde dat schriftelijke bescheiden van openbare colleges en ambtenaren alleen voor het bewijs gebezigd kunnen worden indien ze bestemd zijn om tot het bewijs van enig feit of omstandigheid te dienen, is komen te vervallen. Daarmee is de weg geopend voor het gebruik van ambtsberichten van de AIVD als zelfstandig bewijsmiddel. Vroeger konden deze ambtsberichten enkel als 'overig schriftelijke bescheid' worden gekwalificeerd en gold het bijbehorende bewijsminimum, dat daaraan alleen in verband met de inhoud van andere bewijsmiddelen bewijskracht toekomt.

Een tweede wijziging is de introductie van een nieuw soort getuigenverklaring, te weten de verklaring van de afgeschermde getuige. Deze verklaring wordt afgelegd bij de rechter-commissaris teneinde deze meer informatie te geven over de herkomst en achtergronden van het aan het Openbaar Ministerie verstrekte ambtsbericht. ${ }^{37}$ Deze verklaring komt tot stand via een bijzondere procedure. Evenals bij de bedreigde getuige zijn er redenen waarom het verhoor van deze getuige

33 Rb. Rotterdam 31 december 2002, NJ 2003, 136, Hof Den Haag 21 juni 2004, NJ 2004, 432 en Rb. Rotterdam 24 januari 2005, NJ 2005, 148.

34 Art. 85 en 86 Wet op de inlichtingen- en veiligheidsdiensten 2002.

35 Zie over de toelaatbaarheid van het afschermen van relevante informatie in het licht van art. 6 EVRM: Alink 2004.

36 De wet van 28 september 2006 (afgeschermde getuigen), Stb. 2006, 460 (inwerkingtreding 1 november 2006, Stb. 2006, 461).

37 Kamerstukken I 2005-2006, 29743, nr. C, p. 5. 
niet op een gangbare manier kan plaatsvinden. De bedreigde getuige is bevreesd voor repercussies die het afleggen van zijn verklaring mogelijk tot gevolg heeft. Om die reden blijft zijn identiteit verborgen. Bij de afgeschermde getuige is een normaal verhoor door de politie of justitie niet mogelijk omdat dan mogelijk de staatsveiligheid in gevaar komt. Het bekend worden van bepaalde gegevens of de identiteit van de betrokkene wordt voorkomen door het verhoor te laten plaatsvinden bij de rechter-commissaris. De rechter-commissaris beoordeelt of de getuige als afgeschermde getuige kan worden aangemerkt. Kan de getuige als afgeschermde getuige worden gekwalificeerd, dan vindt het verhoor eveneens door de rechter-commissaris plaats. In het belang van de staatsveiligheid kan een aantal afwijkingen van een gewoon verhoor plaatsvinden. Zo kan de identiteit van de getuige verborgen blijven, ${ }^{38}$ kunnen verdachte, verdediging en officier van justitie worden uitgesloten van het bijwonen van het verhoor en kan achteraf informatie uit het proces-verbaal van het verhoor worden weggelaten of kan zelfs het gehele proces-verbaal uit het dossier verwijderd worden. Indien de getuige meent dat in het belang van de staatsveiligheid het proces-verbaal van het verhoor niet aan het dossier kan worden toegevoegd, heeft hij recht om zijn instemming op dat punt te onthouden. In dat geval dient de rechter-commissaris het procesverbaal te vernietigen.

De toetsing en beoordeling van de betrouwbaarheid van de verklaring van de afgeschermde getuige is in principe overgelaten aan de rechter-commissaris. Hij dient daarover in het proces-verbaal rekenschap af te leggen. De verdediging en de officier van justitie hebben de mogelijkheid om vragen te stellen. Zijn zij uitgesloten van het verhoor, dan kunnen vragen met behulp van telecommunicatiemiddelen of schriftelijk worden gesteld. ${ }^{39}$

In bewijsrechtelijke zin vertoont de regeling van de afgeschermde getuige veel overeenkomsten met die van de bedreigde getuige. Het uitgangspunt is hetzelfde: om andere dan strafvorderlijke belangen te beschermen, kan het verhoor van de getuige niet in de openbaarheid plaatsvinden en kunnen uit de verslaglegging van het verhoor gegevens worden geschrapt die bij bekendmaking mogelijk een inbreuk zouden maken op deze gewichtigere belangen. In geval van de bedreigde getuige is het zwaarderwegende belang gelegen in de bescherming van de getuige; in

38 Het afschermen van de identiteit van de getuige is mogelijk op grond van art. 226h lid $1 \mathrm{~Sv}$ : 'De rechter-commissaris beveelt hetzij ambtshalve, hetzij op de vordering van de officier van justitie of op het verzoek van de verdachte of van de getuige, dat ter gelegenheid van het verhoor van de afgeschermde getuige diens identiteit verborgen wordt gehouden, indien een zwaarwegend belang van de getuige of een ander dan wel het belang van de staatsveiligheid dat vereist.' Een overlap met de bedreigde getuige regeling is hier kennelijk mogelijk, aangezien niet alleen de staatsveiligheid een reden kan opleveren voor het anoniem horen, maar ook een zwaarwegend belang van de getuige of een derde.

39 Meer uitgebreid over de afgeschermde getuige: Marongiu 2005 en De Roos 2006a. 
geval van de afgeschermde getuige wordt aan de staatsveiligheid meer waarde gehecht. Dit belang rechtvaardigt vergaande beperkingen op de toetsing van de betrouwbaarheid door zowel de verdediging als de zittingsrechter. De verdediging kan onwetend blijven over de identiteit van de getuige, kan worden uitgesloten van het verhoor en kan haar ondervragingsrecht slechts op een indirecte wijze realiseren. De zittingsrechter krijgt de afgeschermde getuige in het geheel niet te zien en is voor de beoordeling van de betrouwbaarheid van diens verklaring in belangrijke mate aangewezen op hetgeen de rechter-commissaris hierover opneemt in zijn proces-verbaal. Met betrekking tot dit laatste geldt als extra beperking dat dat proces-verbaal mogelijk in zijn geheel niet aan het dossier is toegevoegd en voor zover het wel is toegevoegd, kan de zittingsrechter noch de verdediging weten of het alle relevante (belastende en ontlastende) informatie bevat die van belang is voor de beoordeling van de betrouwbaarheid van de daarin opgenomen verklaring. Evenals bij de bedreigde getuige zijn in de regeling van de afgeschermde getuige een bewijsminimum en een nadere motiveringsplicht opgenomen. Het bewijsminimum geldt alleen voor zover de afgeschermde getuige tevens anoniem blijft (art. 344a lid $2 \mathrm{~Sv}$ ). De nadere motiveringsplicht is opgenomen in artikel 360 lid 1 Sv en luidt:

1. Van het gebruik als bewijsmiddel van het proces-verbaal van een verhoor bij de rechter-commissaris of rechtbank, houdende de verklaring: (...)

- van een bedreigde of afgeschermde getuige, (...)

geeft het vonnis in het bijzonder reden.

Er is echter een belangrijk verschil in vergelijking tot de regeling van de bedreigde getuige. Weigert de getuige die als bedreigde getuige is aangemerkt een verklaring af te leggen, dan kan de rechter niet terugvallen op ander bewijsmateriaal. Wellicht ligt er nog een schriftelijke anonieme verklaring van diezelfde getuige, maar het gebruik daarvan kan de verdediging blokkeren door het verzoek om die getuige te horen. In de bedreigde getuigenregeling is op deze wijze gegarandeerd dat de verklaring van een anonymus alleen kan worden gebruikt indien het ondervragingsrecht van de verdediging is gerealiseerd.

In geval van de afgeschermde getuige is echter de verklaring van de afgeschermde getuige geen absolute voorwaarde voor het gebruik van de AIVD-informatie die in de vorm van een ambtsbericht in het dossier is opgenomen. Slechts voor zover die informatie anoniem is verstrekt, is artikel 344a lid $3 \mathrm{~Sv}$ van toepassing en kan de verdediging het gebruik daarvan blokkeren. Is echter het ambtsbericht afkomstig van een persoon wiens identiteit bekend is, dan voorziet de voorgestelde regeling niet in nadere voorwaarden voor het gebruik daarvan. Het nieuwe bewijsminimum is immers alleen van toepassing op het gebruik van de verklaring van de afgeschermde getuige afgelegd bij de rechter-commissaris en niet op het ambtsbericht zelf en geldt bovendien alleen voor zover de identiteit van de getuige verborgen blijft. 
$\mathrm{Nu}$ ligt het voor de hand om te veronderstellen dat de zittingsrechter een dergelijk ambtsbericht alleen zal gebruiken indien de verdediging de mogelijkheid heeft gehad om de getuige te ondervragen. Artikel 6 lid 3 onder d EVRM dwingt daar immers toe. De rechter zal in dat geval wel moeten verwijzen naar de bij de rechter-commissaris gevolgde procedure en het proces-verbaal dat de rechtercommissaris daarvan heeft opgemaakt. Dat laat echter onverlet dat niet dat procesverbaal, maar enkel het ambtsbericht aan de bewezenverklaring ten grondslag wordt gelegd. De verklaring van de rechter-commissaris dient in dat geval enkel ter onderbouwing van het oordeel dat de in artikel 6 EVRM opgenomen verdedigingsrechten zijn nagekomen, maar de inhoud daarvan zelf is niet redengevend voor de bewezenverklaring.

Hetzelfde geldt voor de in de wet gecreëerde nadere motiveringsplicht. Een dergelijke motiveringsplicht geldt alleen voor zover de verklaring van de afgeschermde getuige zelf voor het bewijs wordt gebruikt. Zij geldt dus niet voor het gebruik van het ambtsbericht. De rechter kan dus zijn motiveringsplicht zeer eenvoudig omzeilen, omdat het wetsvoorstel niet voorschrijft dat hij in dergelijke gevallen 'the best evidence' aan de bewezenverklaring ten grondslag moet leggen. Het is overigens de vraag of de motiveringsplicht ook geldt voor niet-anonieme verklaringen van de afgeschermde getuigen. Volgens de memorie van toelichting zal op grond van de uitbreiding van de motiveringsplicht (artikel $360 \mathrm{~Sv}$ ) de rechter in zijn uitspraak moeten doen blijken dat aan de in artikel 344a, tweede lid, Sv gestelde voorwaarden is voldaan. ${ }^{40}$ Het tweede lid van artikel 344a Sv ziet enkel op het gebruik van anoniem bewijsmateriaal. Het lijkt er dus op dat de wetgever geen algemene motiveringsplicht ten aanzien van het gebruik van de afgeschermde getuigenverklaring voor ogen had, maar slechts voor zover de afgeschermde getuige tevens een anonieme getuige is.

Mocht dat zo zijn, dan is deze motiveringsplicht een wassen neus. Enerzijds omdat zij gemakkelijk omzeild kan worden, anderzijds omdat zij niet verder reikt dan reeds thans voor het gebruik van anoniem materiaal geldt. De extra handicap met betrekking tot de beoordeling van de betrouwbaarheid van de inhoud van de verklaring, namelijk dat noch de verdediging noch de zittingsrechter zicht heeft op alle relevante - belastende en ontlastende - informatie, wordt niet gecompenseerd. Beiden moeten op het oordeel van de rechter-commissaris vertrouwen, waarbij ook geenszins gegarandeerd is dat deze beschikt over alle informatie. Het is immers de AIVD die bepaalt welke informatie aan de rechter-commissaris wordt verstrekt en welk deel daarvan ter kennis van de overige partijen mag komen. Daarmee wordt een deel van de waarheidsvinding overgelaten aan de bereidheid van inlichtingen- en veiligheidsdiensten om openheid van zaken te geven, terwijl evident is dat deze daar geen belang bij hebben. Zoals Prakken reeds lang voor de

40 Kamerstukken II 2003-2004, 29743, nr. 3, p. 23. 
inwerkingtreding van de wet opmerkte, is de enige juiste consequentie van de weigering van de AIVD om nadere en voor alle betrokkenen kenbare informatie over de inhoud van het ambtsbericht te verschaffen, uitsluiting van dat ambtsbericht van het bewijs. ${ }^{41}$ Immers, de in de wet geformuleerde nadere waarborgen, het bewijsminimum en de nadere motiveringsplicht, zullen in de praktijk geen noemenswaardige betekenis hebben.

\subsubsection{Tussenconclusie}

In artikel 360 lid 1 en $2 \mathrm{~Sv}$ is een aantal nadere motiveringsvoorschriften opgenomen ten aanzien van het gebruik van bijzondere getuigenverklaringen. Het betreft dan de verklaring van niet-beëdigde - enkel gemaande - getuigen, de mondelinge dan wel schriftelijke verklaring van een getuige wiens identiteit niet of niet volledig bekend is en de verklaring van een getuige die voor het afleggen van die verklaring een tegenprestatie heeft bedongen. Sinds 1 november 2006 is daar aan toegevoegd de verklaring van de zogeheten 'afgeschermde getuigen'. De nadere motiveringsplicht komt in al deze gevallen voort uit het feit dat de waarborgen voor de betrouwbaarheid van die verklaringen niet op gebruikelijke wijze in acht genomen kunnen worden of omdat er a priori bedenkingen kunnen bestaan met betrekking tot de betrouwbaarheid van die verklaring. Het laatste geldt bijvoorbeeld ten aanzien van de kroongetuige en in zekere zin ook ten aanzien van de verklaring van de onbeëdigde getuige. De Hoge Raad stelt echter ten aanzien van de motivering van het gebruik van de verklaring van de onbeëdigde getuige geen inhoudelijke eisen. Voldoende is dat de rechter in zijn vonnis tot uitdrukking brengt dat hij zich bewust is geweest van het feit dat de verklaring is afgelegd zonder de waarborg van de eedsaflegging. De motiveringsplicht dient hier slechts de rechter in te scherpen dat hij zeer behoedzaam met het bewijsmateriaal dient om te gaan. Niet te verwachten is dat ten aanzien van het gebruik van de verklaring van de kroongetuige de motiveringsplicht een verdergaande strekking zal hebben.

De nadere motiveringsplicht ten aanzien van het gebruik van anoniem bewijs en de verklaring van de afgeschermde getuige is een logisch gevolg van het feit dat zowel verdediging als zittingsrechter niet beschikken over alle mogelijkheden en relevante informatie om de betrouwbaarheid van die verklaring te toetsen. In dergelijke gevallen is er voor gekozen om de beoordeling van de betrouwbaarheid deels te laten geschieden door de rechter-commissaris, die naar men aanneemt wel beschikt over alle relevante informatie. Aangezien de zittingsrechter degene is die uiteindelijk verantwoordelijk is voor het feitenoordeel, dient hij expliciet in het vonnis tot uitdrukking te brengen dat hij ook zelfstandig de betrouwbaarheid van de ver-

$41 \quad$ Prakken 2004, p. 2341. 
klaringen heeft getoetst. In de jurisprudentie met betrekking tot het gebruik van anoniem bewijs komt dit ook tot uitdrukking. Ten aanzien van de motivering van de verklaring van de afgeschermde getuige valt dit nog te bezien.

Aldus kan geconcludeerd worden dat de motiveringsplichten genoemd in artikel $360 \mathrm{~Sv}$ een tweeledig karakter hebben. Enerzijds dienen zij enkel om de rechter in te scherpen dat hij behoedzaam met het bewijsmateriaal moet omgaan. Anderzijds, met name in het geval van anoniem bewijsmateriaal, dient de rechter expliciet tot uitdrukking te brengen dat hij een eigen oordeel heeft gevormd over de waarde van het bewijsmateriaal. Hij mag niet volstaan met verwijzing naar het oordeel van de rechter-commissaris daaromtrent. In geval van anoniem bewijs wordt van de feitenrechter verwacht dat hij inhoudelijke criteria gebruikt om de betrouwbaarheid te motiveren. Dit wordt grotendeels teniet gedaan doordat de Hoge Raad niet snel aanneemt dat er sprake is van bewijsmateriaal houdende verklaringen van personen wier identiteit niet blijkt.

Ten aanzien van de verklaring van de afgeschermde getuige is het al helemaal de vraag of de in de wet opgenomen motiveringsplicht enige betekenis heeft. Voor zover het gaat om een anonieme verklaring geldt het bovenstaande. In concreto zou in dat geval de motiveringsplicht reeds omzeild kunnen worden door de baas van de AIVD ter zitting te laten verklaren over hetgeen hij van een niet nader te noemen medewerker of informant heeft gehoord. In dat geval is er in de optiek van de Hoge Raad geen sprake van een anonieme verklaring. Bij het gebruik van een niet-anonieme verklaring van de afgeschermde getuige is het überhaupt de vraag of die onder artikel $360 \mathrm{~Sv}$ valt. Voor zover dat wel de bedoeling is, kan de rechter eenvoudig die nadere onderbouwing uit de weg gaan door niet het proces-verbaal van de rechter-commissaris maar het oorspronkelijke ambtsbericht onder de gebezigde bewijsmiddelen in het vonnis op te nemen. Ten aanzien daarvan geldt geen plicht tot nadere onderbouwing van de betrouwbaarheid, terwijl dat gezien de aard en herkomst van de informatie en de beperkte mogelijkheden van alle betrokken procespartijen inclusief de zittingsrechter wel degelijk gewenst is.

Het hanteren van twee verschillende criteria ten aanzien van motivering van de in artikel 360 genoemde bewijsmiddelen lijkt niet goed houdbaar. Acht men bepaalde vormen van het bewijs in abstracto dubieus, en dat is de gemeenschappelijke noemer van de in artikel 360 genoemde bewijsmiddelen, dan kan dat slechts op twee manieren worden opgelost. Ofwel men sluit deze vormen van bewijs uit, ofwel men verplicht de rechter tot het nakomen van aanvullende eisen die maken dat het met het oog op de betrouwbaarheid dubieuze karakter van deze verklaringen in het concrete geval wordt weggenomen. De enkele constatering van de rechter dat hij geen reden ziet om te twijfelen aan de juistheid van de verklaring is in dat geval onvoldoende. Hij zal in positieve zin feiten en omstandigheden moeten noemen die maken dat aan die verklaring geloof kan worden gehecht. 


\subsection{Met redenen omkleed}

In het tweede lid van artikel $359 \mathrm{~Sv}$ is een zeer algemene motiveringsplicht opgenomen:

'De beslissingen vermeld in de artikelen 349, eerste lid, en 358, tweede lid en derde lid, zijn met redenen omkleed.'

Aldus is een motiveringsplicht gecreëerd ten aanzien van een groot aantal door de rechter te nemen beslissingen. Een klein deel hiervan houdt verband met de bewijsbeslissing. De beslissingen vermeld in artikel 349 lid $1 \mathrm{~Sv}$ zien op de zogeheten voorvragen en zijn dus in bewijsrechtelijke zin niet relevant. Hetzelfde geldt in principe ook voor de beslissingen waar artikel 358 lid $3 \mathrm{~Sv}$ betrekking op heeft. Op grond van 358 lid 3 dient de rechter op verweren van de zijde van de verdediging een beslissing te geven. Er was lange tjd echter één categorie verweren die hiervan was uitgesloten en dat waren de bewijsverweren. Artikel 359 lid $2 \mathrm{~Sv}$ was alleen van belang voor de motivering van de bewijsbeslissing voor zover een verwijzing was opgenomen naar het tweede lid van artikel $358 \mathrm{~Sv}$. Met die verwijzing creëerde de wetgever in 1926 naast de specifieke motiveringsvoorschriften die op grond van artikel 359 lid 1 en 3 en 360 lid 1 Sv golden ook een algemene motiveringsplicht ten aanzien van de bewijsbeslissing.

Uit de parlementaire stukken blijkt nergens, zoals reeds eerder vermeld, waarom men ook ten aanzien van de bewijsbeslissing deze algemene motiveringsplicht naast de meer specifieke motiveringseisen noodzakelijk achtte. Sommigen meenden dat er sprake was van een vergissing. Anderen dachten dat de reden daarvoor moest worden gezocht in het feit dat de wetgever het alsnog wenselijk achtte dat de rechter zijn beslissing om de verdachte vrij te spreken zou toelichten. Ten aanzien van de vrijspraak was immers nog geen motiveringsplicht in het wetboek opgenomen. De onduidelijkheid op dit punt bracht velen er toe direct na de invoering van het Wetboek van Strafvordering te concluderen dat aan het tweede lid van artikel $359 \mathrm{~Sv}$ geen betekenis toekwam voor zover dat zag op de bewijsbeslissing. Zij hebben slechts deels gelijk gekregen, namelijk daar waar het gaat om de algemene motiveringsplicht ten aanzien van de bewijsbeslissing. Op een ander punt heeft de Hoge Raad een veel verdergaande betekenis gegeven aan het tweede lid van artikel $359 \mathrm{~Sv}$. Ondanks het feit dat het derde lid van $358 \mathrm{~Sv}$ niet zag op bewijsverweren heeft de Hoge Raad toch aangenomen dat bepaalde bewijsverweren een nadrukkelijke reactie van de rechter vereisten. Mede onder invloed van deze jurisprudentie is op 1 januari 2005 de tekst van artikel 359 lid $2 \mathrm{~Sv}$ aangevuld met de volgende zinsnede:

'Het vonnis geeft, indien de beslissing afwijkt van door de verdachte dan wel door de officier van justitie uitdrukkelijk onderbouwde standpunten, in het bijzonder de redenen op die daartoe hebben geleid.' 
Daarmee is alsnog een responsieplicht met betrekking tot bewijsverweren gecreëerd. Alvorens in te gaan op die responsieplicht zal ik stilstaan bij de vraag welke eisen op grond van het tweede lid van artikel $359 \mathrm{~Sv}$ in algemene zin aan de motivering van de bewijsbeslissing worden gesteld. Daarbij kan een onderscheid worden gemaakt tussen enerzijds de vrijspraak en anderzijds de bewezenverklaring.

\subsubsection{Motivering van de vrijspraak}

Uit artikel 359 lid 2 in samenhang met artikel 358 lid 2 Sv volgt dat een vrijspraak met redenen omkleed moet zijn. Er worden echter weinig eisen gesteld aan de motivering van een vrijspraak. Meestal volstaat de rechter met de enkele mededeling dat hij het ten laste gelegde feit niet wettig en overtuigend bewezen acht en dat hij de verdachte daarvan vrijspreekt. Het kan echter ook anders; met name in zaken die veel aandacht in de media hebben getrokken, wordt in geval van vrijspraak dat oordeel vrij uitvoerig gemotiveerd. ${ }^{42}$ De rechter is daar echter niet toe verplicht. Een summiere motivering volstaat. Sterker nog: tot 1 januari 2003 was een vrijspraak in cassatie onaantastbaar, omdat tegen een zuivere vrijspraak geen cassatie openstond. Zelfs indien de rechter een drogreden zou opvoeren om een vrijspraak te rechtvaardigen, zou daar niets tegen ondernomen kunnen worden.

\subsubsection{Toetsing van een vrijspraak in cassatie}

Het oude artikel 430 lid 1 Sv sloot cassatie tegen vrijspraken uit. Enige uitzondering was, indien in cassatie kwam vast te staan dat er sprake was van een onzuivere vrijspraak. Van een onzuivere vrijspraak is onder andere sprake indien de rechter

42 Bijvoorbeeld: de uiteindelijke vrijspraak in de Puttense moordzaak: Hof Leeuwarden 24 april 2002, LJN AE1877 en in de moord op Sedar Soares: Hof Den Haag 18 oktober 2005, LJN AU 4447. Overigens is het in dat verband opvallend dat een vrijspraak in een minder ernstige zaak, maar die toch veel commotie teweegbracht, volledig zonder motivering bleef. Het betrof een uitspraak van de Politierechter van de Rechtbank Zwolle-Lelystad d.d. 23 januari 2007 ter zake van belediging van een opsporingsambtenaar. De verdachte had de agent de woorden 'fuck you' toegevoegd, maar de politierechter zag hierin geen strafbare belediging. Teneinde te voorkomen dat deze uitspraak de indruk zou wekken dat het in algemene zin is toegestaan om zulke bewoordingen te bezigen in het bijzijn van opsporingsambtenaren, zag de persrechter zich genoodzaakt een persbericht naar buiten te brengen. De reden daarvoor was: 'Het betreffende vonnis van de politierechter kan niet op internet worden gepubliceerd. Zoals te doen gebruikelijk, heeft de politierechter namelijk mondeling vonnis gewezen, direct na het onderzoek ter terechtzitting. Vanwege de ontstane ophef en de verkeerde indruk die door de berichtgeving in de media kan zijn ontstaan, bestaat de behoefte om een nadere toelichting op het vonnis te geven'. Zie: <http://www.rechtsrpaak.nl/Gerechten/Rechtbanken/ Zwolle-Lelystad/Actualiteiten/Toelichting+op+fuck-you-vonnis.htm>. Wellicht had het meer in de rede gelegen om in een dergelijk geval de aantekening van het mondelinge vonnis te vervangen door een goed gemotiveerd schriftelijk vonnis. De rechter spreekt immers door middel van zijn vonnis en niet door middel van persberichten. 
bij zijn oordeel de grondslag van de tenlastelegging heeft verlaten. Met andere woorden: indien hij van iets vrijspreekt dat feitelijk niet is tenlastegelegd. Het gaat dan in de eerste plaats om de uitleg van de in de tenlastelegging opgenomen begrippen. Voor zover de feitenrechter tot een vrijspraak komt terwijl hij een verkeerde uitleg heeft gegeven aan de in de tenlastelegging opgenomen begrippen, kan dit oordeel in cassatie wel worden getoetst. ${ }^{43}$ Eveneens is sprake van een onzuivere vrijspraak indien de feitenrechter ten onrechte van het gehele tenlastegelegde feit vrijspreekt terwijl hij kan volstaan met een partiële vrijspraak. ${ }^{44}$ In dergelijke gevallen heeft de feitenrechter een bepaald onderdeel kennelijk als essentieel aangemerkt, terwijl dat in juridische zin geen essentieel onderdeel van de tenlastelegging is.

Per 1 januari 2003 is echter het cassatieverbod zoals opgenomen in artikel $430 \mathrm{~Sv}$ (oud) komen te vervallen. ${ }^{45}$ Reden daarvoor was dat men het vooral niet acceptabel achtte indien vrijspraken die waren gebaseerd op een onjuiste toepassing van het (jurisprudentiële) bewijsrecht niet in cassatie konden worden getoetst. ${ }^{46}$ In het bijzonder vrijspraken die steunden op een te ruime uitleg van het leerstuk van het onrechtmatig verkregen bewijs konden in cassatie niet worden getoetst. ${ }^{47}$

Met het vervallen van artikel $430 \mathrm{~Sv}$ is echter niet gezegd dat thans vrijspraken in cassatie onbeperkt kunnen worden getoetst. Ten eerste moet er in cassatie wel iets te toetsen vallen.

'Een vrijspraak behoeft alleen op grond van de algemene motiveringsplicht van het tweede lid van artikel 359 Sv te worden gemotiveerd. De motivering dat de rechter het tenlastegelegde strafbare feit niet wettig en overtuigend bewezen acht, volstaat daartoe in beginsel. En een dergelijke motivering zal in cassatie niet met succes kunnen worden bestreden. ${ }^{48}$

Voor zover de feitenrechter wel nadrukkelijk de vrijspraak motiveert, strandt toetsing in cassatie vaak op de gulden cassatieregel dat dergelijke feitelijke beslissingen zich niet lenen voor toetsing in cassatie. ${ }^{49}$ De selectie en waardering van het bewijsmateriaal is immers in principe voorbehouden aan de feitenrechter. In cassatie kan dat oordeel niet worden getoetst. Deze algemene regel geldt niet alleen voor de bewezenverklaring, maar ook voor een door de feitenrechter gegeven vrijspraak.

43 Bijvoorbeeld: HR 20 november 2001, NJ 2003, 632 m.nt. R. de Lange en PMe; HR 8 april 2003, NJ 2003, 443 en HR 28 mei 2002, NJ 2003, 142 m.nt. Sch.

44 Bijvoorbeeld: HR 19 oktober 1999, NJ 2000, 109 m.nt. JdH.

45 Wet van 31 oktober 2002 (cassatie tegen vrijspraken), Stb. 2002, 539 (inwerkingtreding 1 januari 2003, Stb. 2002, 601).

46 Kamerstukken II 2001-2002, 28204, nr. 3, p. 1. In gelijke zin: De Hullu 1989, p. 407. Zie bijvoorbeeld: HR 26 maart 2002, NJ 2002, 355 en HR 26 maart 2002, NJ 2002, 356.

47 Bleichrodt 1982 wees reeds op deze onwenselijke consequentie van art. $430 \mathrm{~Sv}$.

48 Kamerstukken II 2001-2002, 28204, nr. 3, p. 5. In gelijke zin: De Hullu 1989, p. 407 en Abels \& Nijboer 1983, p. 454-455.

49 Van Dorst 2004, p. 189. 
'Ingeval de rechter die over de feiten oordeelt, het tenlastegelegde bewezen acht, is het - volgens vaste rechtspraak van de Hoge Raad - aan die rechter voorbehouden om, binnen de door de wet getrokken grenzen, van het beschikbare materiaal datgene tot het bewijs te bezigen wat deze uit een oogpunt van betrouwbaarheid daartoe dienstig voorkomt en terzijde te stellen wat hij voor het bewijs van geen waarde acht. Deze beslissing inzake die selectie en waardering, die - behoudens bijzondere gevallen geen motivering behoeft, kan in cassatie niet met vrucht worden bestreden. Hetzelfde heeft te gelden in het tegenovergestelde geval dat de rechter op grond van de aan hem voorbehouden selectie en waardering van het bewijsmateriaal tot de slotsom komt dat vrijspraak moet volgen. ${ }^{50}$

Toetsing in cassatie van de vrijspraak betreft dus niet de feitelijke waardering van het bewijsmateriaal zelf. Die blijft voorbehouden aan de feitenrechter. Wel kan de aan de vrijspraak ten grondslag liggende motivering reden geven tot vernietiging in cassatie. Daarvan is sprake indien de vrijspraak is gebaseerd op een verkeerde uitleg van het recht. Voor zover het de uitleg van de in de tenlastelegging opgenomen begrippen betreft, was dat voor schrapping van artikel $430 \mathrm{~Sv}$ ook reeds mogelijk. Schrapping van het cassatieverbod heeft vooral consequenties voor vrijspraken die het gevolg zijn van een onjuiste toepassing van het leerstuk van onrechtmatig verkregen bewijs. ${ }^{51}$ Franken en Waling hebben echter terecht opgemerkt dat het aantal gevallen waarin dit leerstuk nog tot vrijspraken leidt zeer beperkt is en in zoverre is ook het belang van de wetswijziging zeer beperkt. ${ }^{52}$

Bovendien zal een vrijspraak in cassatie sneuvelen, indien uit de gegeven motivering blijkt dat de feitenrechter een verkeerde bewijsstandaard heeft gehanteerd. Als hij, met andere woorden, te hoge eisen stelt aan de bewezenverklaring, zoals blijkt uit het arrest van de Hoge Raad d.d. 13 juni 2006:

'Het Hof heeft in dit verband overwogen dat de mogelijkheid blijft bestaan "hoe klein en onwaarschijnlijk ook" dat C. anders dan door de messteek de bacteriële infectie heeft opgelopen en heeft op grond daarvan het causaal verband tussen die messteek en de dood van C. niet bewezen geacht. Dat oordeel kan bezwaarlijk anders worden verstaan dan dat ook een hoogst onwaarschijnlijke mogelijkheid dat een andere omstandigheid (dan de messteek en de daarop volgende noodzakelijke medische behandelingen) heeft geleid tot de dood van C., aan een bewezenverklaring van het causaal verband tussen de gedraging van de verdachte en het overlijden van C. in de weg staat. Dat oordeel geeft blijk van miskenning van de hier aan te leggen maatstaf. Immers, een hoogst onwaarschijnlijke mogelijkheid van een alternatieve gang van zaken staat niet aan bewezenverklaring van bedoeld causaal verband in de weg. ${ }^{, 53}$

50 HR 4 mei 2004, NJ 2004, 480. In gelijke zin: HR 26 oktober 2004, NJ 2004, 690.

51 Zie bijvoorbeeld: HR 5 april 2005, NJ 2005, 300.

52 Franken \& Waling 2001, p. 1369: 'De gedachte dat een vrijspraak onder invloed van het jurisprudentiële bewijsrecht veel vaker in beeld komt dan vroeger het geval was, lijkt vooral een angstbeeld te zijn dat niet door feiten is of kan worden onderbouwd'.

53 HR 13 juni 2006, NJ 2007, 48 m.nt. Y. Buruma. In gelijke zin: HR 28 november 2006, NJ 2007, 49. 
Op dit punt heeft schrapping van artikel $430 \mathrm{~Sv}$ wel degelijk een toegevoegde waarde. Voorheen was het immers niet mogelijk om in dergelijke gevallen in te grijpen. Thans kan dat wel en doet de Hoge Raad dat ook.

\subsubsection{Is het stellen van nadere motiveringseisen aan een vrijspraak gewenst?}

Een van de belangrijkste redenen waarom in cassatie de vrijspraak niet kan worden getoetst, is dat in de praktijk de feitenrechter niet gehouden is om zijn oordeel op dit punt nader te motiveren. De vraag is of het wel wenselijk is dat de rechter zijn oordeel dat hij het feit niet wettig en overtuigend bewezen acht onderbouwt. Uit de totstandkoming van het Wetboek van Strafvordering 1926 blijkt dat de wetgever een dergelijke onderbouwing niet wenselijk achtte. ${ }^{54}$ Gewezen werd onder andere op het gevaar dat aldus twee categorieën vrijgesprokenen zouden ontstaan, te weten zij die eervol en zij die oneervol worden vrijgesproken:

'Wel is waar is het ook hierbij voor den officier van justitie en den verdachte vaak van belang te weten, welk punt der aanklacht door den rechter niet bewezen wordt geacht, en zou motiveering somtijds haar nut hebben, doch in de meeste gevallen is zulks onverschillig en is het voor den verdachte ook beter, indien niet wordt onderscheiden tusschen hen, die worden vrijgesproken omdat de rechter hunne onschuld als gebleken aanneemt, en hen die niet worden veroordeeld, omdat het bewijs van het te laste gelegde niet ten volle is geleverd. ${ }^{55}$

Ook Franken en Waling baseren zich op dit argument als zij ageren tegen een uitbreiding van de motiveringsplicht. Bovendien wijzen zij erop dat de noodzaak de vrijspraak te onderbouwen er tevens toe kan leiden dat getuigen moeten horen waarom de rechter hen niet gelooft. ${ }^{56}$

Vóór een uitbreiding pleit dat in geval van een bewezenverklaring wel in het vonnis tot uitdrukking moet worden gebracht dat het oordeel op goede gronden tot stand is gekomen, terwijl daar in geval van een vrijspraak van kan worden afgezien. Dit geldt in het bijzonder indien bewijsverweren zijn gevoerd. Vooruitlopend op wat in paragraaf 6.3.1 aan de orde wordt gesteld, is in de jurisprudentie een responsieplicht ten aanzien van bepaalde door de verdediging gevoerde verweren door de Hoge Raad aangenomen. Voor zover hetgeen in die verweren te berde wordt gebracht niet door de rechter wordt gevolgd, dient hij op dat punt zijn oordeel nader te motiveren. Ingeval echter hetgeen door de verdediging wordt gesteld wordt aangenomen, is de rechter ontslagen van zijn plicht tot motivering, terwijl toch in dergelijke gevallen mag worden verwacht dat ook de andere partij, het Openbaar Ministerie, er baat bij heeft om te weten waarom de verweren worden

54 Notulen van de Staatscommissie voor de herziening van het Wetboek van Strafvordering; het verslag van $42^{\mathrm{e}}$ vergadering, p. 9-10, opgenomen in Lindenberg 2002, p. 334.

55 Kamerstukken II 1913-1914, 286, nr. 3 (MvT), p. 180.

56 Franken \& Waling 2001, p. 1371. 
gevolgd ${ }^{57}$ Daarmee wordt niet alleen de beslissing inzichtelijk voor een ieder en vatbaar voor controle in hoger beroep en cassatie, maar bovendien scherpt het de strafrechter in dat hij bij de beoordeling van verweren alle relevante aspecten in aanmerking neemt. In zoverre zou het zijn beslissing alleen maar ten goede komen. De door Franken en Waling genoemde nadelige consequentie dat daardoor wellicht expliciet in het vonnis tot uitdrukking komt dat getuigen en deskundigen niet worden geloofd, lijkt mij geen relevant argument. De beoordeling van de bewijswaarde van verklaringen van derden is een aan het rechterlijke ambt inherente taak. Teneinde die taak zo goed mogelijk te volbrengen, dient de rechter zoveel mogelijk zijn oordeel op dit punt te onderbouwen. Dat dat voor betrokkenen kan betekenen dat hun uitspraken in twijfel worden getrokken, is daarvan een directe consequentie en voor hen persoonlijk niet prettig. Echter, dergelijke belangen hebben in het strafproces, waar de materiële waarheidsvinding centraal staat, nu eenmaal een ondergeschikte betekenis.

Inmiddels heeft, zoals gezegd, de wetgever op dit punt van zich laten horen. In navolging van de voorstellen van de onderzoeksgroep Strafvordering 2001 is in artikel 359 lid $2 \mathrm{~Sv}$ de plicht opgenomen gemotiveerd te responderen op alle ter zitting ingenomen standpunten. Daarnaast heeft deze bepaling ook tot gevolg dat niet langer onderscheid wordt gemaakt tussen standpunten (verweren) van de verdediging die wel een nadere onderbouwing verlangen en standpunten van het Openbaar Ministerie die een dergelijke onderbouwing niet verlangen. Vanaf 1 januari 2005 geldt dat de rechter zowel aan de verdediging als aan het Openbaar Ministerie uitleg verschuldigd is indien hij de door hen te berde gebrachte bedenkingen niet volgt. Op de uitwerking van deze motiveringsplicht wordt in paragraaf 6.3.4 nader ingegaan.

\subsubsection{Motivering van de bewezenverklaring}

Uit de verwijzing van artikel 359 lid 2 Sv naar 358 lid 2 Sv volgt niet alleen dat de beslissing om de verdachte vrij te spreken, maar ook de beslissing om het tenlastegelegde bewezen te achten met redenen moet zijn omkleed.

Direct na inwerkingtreding van het Wetboek van Strafvordering in 1926 werd de toegevoegde waarde van deze bepaling voor het positieve bewijsoordeel ter discussie gesteld. Er bestonden immers al verschillende specifieke motiveringsvoorschriften en de vraag werd gesteld wat de algemene motiveringsplicht op basis van het tweede lid van artikel $359 \mathrm{~Sv}$ daar nog aan kon toevoegen. ${ }^{58}$ Taverne is vrij stellig in zijn opvatting. De eis van het motiveren van de bewezenverklaring

57 In gelijke zin: Simmelink 1999, p. 450: 'Als het openbaar ministerie in het requisitoir te kennen heeft gegeven dat het feit wettig en overtuigend kan worden bewezen, mag van de rechter worden verwacht dat hij uitleg geeft van het anders luidende standpunt.'

58 Zie onder andere: Taverne 1927, p. 207 en Van Veen 1977, p. 378-379. 
is zijns inziens driemaal voorgeschreven; ten eerste in lid 1 van artikel 359 (1926) op grond waarvan de inhoud van de gebezigde bewijsmiddelen moet worden opgenomen, ten tweede in lid 3 van artikel 359 (1926), dat eist dat de redengevende feiten en omstandigheden moeten worden aangewezen en tot slot in lid 2 van hetzelfde artikel dat bepaalt dat de bewijsbeslissing met redenen moet zijn omkleed. Taverne komt dan ook tot de conclusie dat overdaad schaadt en dat hetzij het derde lid dient te vervallen, hetzij de verwijzing in het tweede lid naar artikel 358 lid 2 Sv. ${ }^{59}$

\subsubsection{De uitleg van de Hoge Raad van het tweede lid}

De wetgever volgde de suggestie van Taverne niet, maar de Hoge Raad heeft wel artikel 359 lid $2 \mathrm{~Sv}$ uitgelegd conform hetgeen Taverne voorstond. In de optiek van de Hoge Raad was de bewezenverklaring voldoende met redenen omkleed indien de inhoud van de bewijsmiddelen in het vonnis was opgenomen en voldaan was aan het vereiste van artikel 359 lid $3 \mathrm{~Sv}$ (1926). ${ }^{60}$ Daarmee verwerd het tweede lid tot een samentrekking van de eisen die voortvloeiden uit het eerste en het derde lid, waarbij aan het vereiste van het derde lid was voldaan indien na het vermelden van de inhoud van de bewijsmiddelen in het vonnis werd overwogen dat deze bewijsmiddelen de redengevende feiten en omstandigheden bevatten. De conclusie van Krikke dat de wijze waarop aan het tweede en derde lid uitleg wordt gegeven een voortzetting inhield van de onder het oude wetboek gevestigde jurisprudentie is dan ook terecht. ${ }^{61}$ Het oordeel is voldoende gemotiveerd indien uit de inhoud van de bewijsmiddelen de bewezenverklaring kan volgen. Voor zover dat niet volgt, vernietigt de Hoge Raad omdat de bewezenverklaring 'niet naar de eis der wet met redenen is omkleed' of 'niet naar behoren met redenen is omkleed'. Formeel is er dus schending van het tweede lid, maar in wezen is niet voldaan aan de eis van redengevendheid. Zoals in hoofdstuk 5 al naar voren kwam, neemt de Hoge Raad niet gauw aan dat de bewezenverklaring niet kan volgen uit het door de rechter geselecteerde bewijsmateriaal.

Door het tweede lid als een samentrekking te beschouwen van het eerste en derde lid van artikel $359 \mathrm{~Sv}$ wordt tevens duidelijk dat alle andere facetten die een rol spelen bij de beoordeling van het bewijs buiten beschouwing blijven. Met name de beoordeling van de betrouwbaarheid valt daarom buiten de

59 Taverne 1927, p. 262.

60 Zie bijvoorbeeld: HR 22 oktober 1928, NJ 1929, p. 1410 m.nt. T. en HR 18 november 1935, NJ 1936, 117: 'dat het middel ten onrechte ervan uitgaat, dat bij zoogenaamd indirect bewijs de rechter in zijn vonnis moet motiveeren uit welke bewijsmiddelen in het bijzonder het door het indirect bewijs bewezen verklaarde voortvloeit'.

$61 \quad$ Krikke 1977, p. 461. 
motiveringsplicht. In constante rechtspraak beklemtoont de Hoge Raad dat de selectie en waardering van het bewijsmateriaal een taak is van de feitenrechter waarover hij geen verantwoording hoeft af te leggen. Het oordeel of het door hem geselecteerde bewijsmateriaal als betrouwbaar kan worden aangemerkt, kan derhalve in cassatie niet worden getoetst.

'In de middelen wordt miskend dat het aan de rechter die over de feiten oordeelt is voorbehouden om, binnen de door de wet getrokken grenzen, van het beschikbare materiaal datgene tot het bewijs te bezigen hetwelk hem daartoe dienstig voorkomt en datgene ter zijde te laten wat hij voor het bewijs niet bruikbaar acht en dat 's rechters oordeel te dien aanzien in cassatie niet met vrucht kan worden bestreden. ${ }^{62}$

De toevoeging 'binnen de door de wet getrokken grenzen' ziet allereerst op de eisen die voortvloeien uit het in Nederland geldende wettelijke bewijsstelsel. Het door de rechter geselecteerde bewijsmateriaal zal moeten voldoen aan de daaraan in de wet gestelde eisen en de daarin opgenomen bewijsminima. Uit hoofdstuk 2 is echter reeds gebleken dat die wettelijke beperkingen in de rechtspraak grotendeels zijn uitgehold. Ten tweede zal het bewijsmateriaal redengevend moeten zijn. Maar ook deze eis wordt in cassatie niet getoetst en vormt als zodanig geen belemmering voor de rechter om dat bewijsmateriaal te selecteren dat hem wenselijk voor komt.

Biedt aldus het Nederlandse bewijsrecht nauwelijks enige hindernis voor de rechter om in alle vrijheid te beoordelen wat hij ten grondslag legt aan een bewezenverklaring, ook het EVRM - in het bijzonder het in artikel 6 neergelegde recht op een 'fair trial' - stelt geen beperkingen aan de rechterlijke vrijheid op dit punt. Wordt in Straatsburg geklaagd over het bewijs, dan haast het Europese Hof voor de rechten van de mens zich om te overwegen dat de beoordeling van de toelaatbaarheid en de bewijswaarde van het bewijsmateriaal is overgelaten aan de rechters binnen de diverse lidstaten:

'The Court reiterates at the outset that, according to Article 19 of the Convention, its duty is to ensure the observance of the engagements undertaken by the Contracting Parties to the Convention. In particular, it is not its function to deal with errors of fact or law allegedly committed by a national court unless and in so far as they may have infringed rights and freedoms protected by the Convention. Moreover, while Article 6 of the Convention guarantees the right to a fair hearing, it does not lay down any rules on the admissibility of evidence or the way it should be assessed, which are therefore primarily matters for regulation by national law and the national courts. It is not the task of the Court to determine, as a matter of principle, whether particular types of evidence - for example unlawfully obtained evidence - may nevertheless be admitted in evidence. The question which must be answered is whether the proceedings in their entirety, including the way in which evidence was taken, were fair. ${ }^{, 63}$

62 HR 9 december 1986, NJ 1987, 561 m.nt. ThWvV. Zie ook: HR 10 december 1985, NJ 1986, 736; HR 11 maart 1986, NJ 1986, 718; HR 22 april 1986, NJ 1987, 44; HR 6 mei 1986, $N J$ 1986, 800 en HR 10 juni 1986, $N J$ 1987, 61 m.nt. C.

63 EHRM 27 januari 2004, NJ 2004, 669 m.nt. Sch. (Verhoek t. Nederland). Zie ook: 
Het ontbreken van enige uitleg over de waardering van het bewijs lijkt ook in Straatsburg geen kritiek te ontmoeten. Zo overwoog het Hof in de zaak Garcia Ruiz:

'The Court reiterates that, according to its established case-law reflecting a principle linked to the proper administration of justice, judgments of courts and tribunals should adequately state the reasons on which they are based. The extent to which this duty to give reasons applies may vary according to the nature of the decision and must be determined in the light of the circumstances of the case. Although Article $6 \S 1$ obliges courts to give reasons for their decisions, it cannot be understood as requiring a detailed answer to every argument. ${ }^{, 64}$

Met deze uitspraak in gedachten oordeelde ook de Hoge Raad dat de regel dat de selectie en waardering van het bewijsmateriaal is voorbehouden aan de rechter en dat deze daarover geen nadere verantwoording hoeft af te leggen niet in strijd is met het in artikel 6 EVRM neergelegde recht op een 'fair trial' ${ }^{65}$ Dat neemt niet weg dat ook buiten artikel 6 EVRM om de Hoge Raad het nodig heeft geacht uitzonderingen te formuleren op de hoofdregel dat de rechter geen verantwoording hoeft af te leggen over de selectie en waardering van het bewijsmateriaal. De meeste van deze uitzonderingen zijn geformuleerd naar aanleiding van zaken waarin de verdediging een uitdrukkelijk bewijsverweer had gevoerd en dit verweer was verworpen zonder dat de rechter in het vonnis expliciet aandacht had besteed aan de gronden voor verwerping van dat verweer. In een enkel uitzonderlijk geval waarin twijfel omtrent de juistheid van bepaalde feiten zich uit het dossier of uit de behandeling van de zaak aan de rechter opdringt, heeft de Hoge Raad gemeend dat de feitenrechter ook zonder een daartoe gevoerd verweer de selectie van het bewijsmateriaal moet verantwoorden. ${ }^{66}$

\subsubsection{De responsieplicht op verweren}

Ingevolge artikel 358 lid 3 in samenhang met artikel 359 lid $2 \mathrm{~Sv}$ dient de rechter in zijn vonnis uitdrukkelijk in te gaan op verweren van de zijde van de verdediging. Een dergelijke responsieplicht geldt alleen voor zover hij die verweren niet overneemt. Zoals reeds in de inleiding is aangegeven, waren de bewijsverweren volgens de wetgever in 1926 uitgesloten van deze responsieplicht. De reden daarvoor was

EHRM 21 januari 1999, 30544/96 (Garcia Ruiz t. Spanje), EHRM 12 mei 2000, NJ 2002, 180 m.nt. Sch (Khan t. Verenigd Koninkrijk); EHRM 5 november 2002, NJ 2004, 262 m.nt. Sch onder NJ 2004, 263 (Allan t. Verenigd Koninkrijk).

64 EHRM 21 januari 1999, 30544/96 (Garcia Ruiz t. Spanje).

65 HR 6 juli 1999, NJ 2000, 379 en HR 21 september 1999, NJ 2000, 380 m.nt. Kn.

66 HR 16 maart 2002, LJN AE0118. In het dossier bevonden zich twee met elkaar in tegenspraak zijnde documenten aangaande de vraag of verdachtes auto verzekerd was. Het ene document was afkomstig van de Rijksdienst voor het Wegverkeer; het andere van de verzekeraar. De Hoge Raad meende dat in een dergelijk geval de rechtbank had moeten motiveren waarom zij meer waarde hechtte aan de verklaring van de Rijksdienst voor het Wegverkeer. 
dat reeds uit de overige motiveringsplichten, in het bijzonder het vermelden van de inhoud van de gebezigde bewijsmiddelen, zou blijken dat de rechter het verweer had verworpen. Voor zover de verdediging de betrouwbaarheid of redengevendheid van het bewijsmateriaal betwistte, volgde reeds uit de opname van het bewijsmateriaal in het vonnis op grond van het eerste lid van $359 \mathrm{~Sv}$ dat de rechter dit verweer niet had overgenomen. Voor zover de verdediging meende dat bepaald bewijsmateriaal door de rechter ten onrechte buiten beschouwing was gelaten, volgde reeds uit het niet selecteren van dat bewijsmateriaal dat de rechter dat ofwel als onbetrouwbaar ofwel als niet relevant beschouwde. De verdachte kon uit het vonnis lezen dat de rechter zijn standpunt niet had gevolgd en kreeg dus 'antwoord' op zijn verweer. Tot een nadere verantwoording was de rechter niet gehouden op basis van de algemene regel dat met in achtneming van de wettelijke beperkingen selectie en waardering van het bewijsmateriaal aan de feitenrechter is voorbehouden. Desalniettemin heeft de Hoge Raad in een aantal gevallen geoordeeld dat de rechter niet kan volstaan met het enkel vermelden van de inhoud van de bewijsmiddelen ter weerlegging van een door de verdediging gevoerd verweer. De gevallen waarin de Hoge Raad een nadere motiveringsplicht aanwezig achtte kunnen worden verdeeld in drie categorieën.

De eerste categorie ziet op verweren die de redengevendheid van het bewijsmateriaal betwisten, terwijl de weerlegging van dat verweer niet zonder meer blijkt uit de inhoud van de gebezigde bewijsmiddelen. De eerder besproken dakdekkersverweren vallen onder deze categorie. In het verweer wordt de redengevendheid van het bewijsmateriaal betwist uitgaande van een bepaalde betekenis van hetgeen ten laste is gelegd en dus bewezen moet worden. Licht de rechter niet toe op welke wijze hij het tenlastegelegde heeft geïnterpreteerd, dan blijft de redengevendheid van het bewijsmateriaal onduidelijk. Het is dan ook logisch dat de Hoge Raad heeft gemeend dat bij een dergelijk - deels juridisch - verweer de rechter niet kan volstaan met enkel het weergeven van de inhoud van de door hem gebezigde bewijsmiddelen.

Ook de in paragraaf 5.2.4.4. beschreven Meer en Vaartjurisprudentie moet worden ondergebracht onder de categorie van bewijsverweren die een nadere toelichting verlangen van de rechter aangaande de redengevendheid van het geselecteerde bewijsmateriaal. In het geval van een Meer en Vaartverweer betwist de verdediging immers dat de bewijsconstructie zoals die blijkt uit de in het vonnis opgenomen bewijsmiddelen sluitend is. Zonder nadere toelichting van de rechter wordt dat gat in de bewijsconstructie niet gedicht en blijft de mogelijkheid bestaan dat de feiten die de rechter redengevend achtte voor de bewezenverklaring in zijn geheel niet redengevend hoeven te zijn. 
De tweede categorie van bewijsverweren ten aanzien waarvan de Hoge Raad een nadere motivering naast de vermelding van de inhoud van de bewijsmiddelen verlangt, zijn de zogeheten onrechtmatig verkregen bewijsverweren. Dergelijke verweren onderscheiden zich van de hiervoor besproken redengevendheidsverweren en de hierna te bespreken betrouwbaarbeidsverweren, doordat daarin niet de bewijswaarde van het bewijsmateriaal wordt betwist, maar de daaraan voorafgaande vraag over de toelaatbaarheid van het bewijs ter discussie wordt gesteld. ${ }^{67}$ Het betreft niet de uiteindelijke waardering van het bewijsmateriaal, maar de wijze waarop dat bewijsmateriaal is verkregen. Voor zover in de fase van de bewijsgaring normen niet in acht zijn genomen en de wet daaraan geen specifiek rechtsgevolg heeft verbonden, kan dat ertoe leiden dat het bewijsmateriaal dient te worden uitgesloten en dus niet aan de bewezenverklaring ten grondslag mag worden gelegd. De Hoge Raad heeft het leerstuk van onrechtmatig verkregen bewijs voor het eerst aanvaard in het arrest Bloedproef II. ${ }^{68}$ Een responsieplicht ten aanzien van verweren op dit punt werd aangenomen in het zogeheten Erwtenpistoolarrest. ${ }^{69}$

Inmiddels is het leerstuk van onrechtmatig verkregen bewijs verder uitgekristalliseerd en heeft een wettelijke grondslag gekregen in artikel 359a Sv. ${ }^{70}$ Naast bewijsuitsluiting kent artikel 359a Sv nog twee sanctiemodaliteiten indien is komen vast te staan dat het bewijs als gevolg van het niet in acht nemen van de daarvoor in het vooronderzoek geldende normen is verkregen, te weten niet-ontvankelijkheid van het Openbaar Ministerie en strafvermindering. Daarnaast is geaccepteerd dat het enkel constateren van het vormverzuim eveneens een mogelijke 'sanctie' is. De vraag welke sanctie op zijn plaats is, is aan de rechter overgelaten. De wet geeft slechts een indicatie van de factoren die daarbij een rol kunnen spelen. ${ }^{71}$ In zijn arrest d.d. 30 maart 2004 heeft de Hoge Raad een en ander toegelicht. ${ }^{72}$

Uit artikel 359a lid $3 \mathrm{~Sv}$ volgt dat de beslissing van de rechter om tot sanctionering van vormverzuimen over te gaan met redenen moet zijn omkleed. De beslissing om een verweer waarin wordt aangedrongen op toepassing van artikel 359a Sv naast

67 Het strikte onderscheid tussen rechtmatigheid en betrouwbaarheid wordt ook door de Hoge Raad gehanteerd: 'Terzijde zij opgemerkt dat art. 359a Sv niet van belang is voor vormverzuimen waardoor de betrouwbaarheid van het aldus verkregen onderzoeksmateriaal wezenlijk is beïnvloed. Dan zal het onderzoeksmateriaal immers reeds om die reden door de rechter buiten beschouwing worden gelaten.' HR 30 maart 2004, NJ 2004, 376 m.nt. YB ( r.o. 3.6.4). Anders: Dreissen 2003.

68 HR 26 juni 1962, NJ 1962, 470 m.nt. WP.

69 HR 8 april 1978, NJ 1978, 365 m.nt. ThWvV. Zie ook: HR 12 december 1978, NJ 1979, 142, m.nt. GEM.

70 Art. 359a Sv werd ingevoerd bij de Wet van 14 september 1995 (Wet vormverzuimen), Stb. 1995, 441 (inwerkingtreding 2 november 1996, Stb. 1996, 522).

71 Uitgebreid over de totstandkoming en inhoud en strekking van art. 359a Sv: Embregts 2003, p. 95 e.v. en Van Woensel 2004.

72 HR 30 maart 2004, NJ 2004, 376 m.nt. YB. Kritisch daarover Franken 2004b. 
zich neer te leggen, moet eveneens met redenen zijn omkleed. Dit aspect is vreemd genoeg niet opgenomen in artikel $359 \mathrm{a} \mathrm{Sv}$, maar volgde tot voor kort uit de jurisprudentie van de Hoge Raad. Thans vallen verweren ten aanzien van de rechtmatigheid van de bewijsgaring eveneens onder 359 lid 2, tweede volzin, Sv.

In zijn arrest d.d. 30 maart 2004 heeft de Hoge Raad uit de doeken gedaan aan welke eisen een dergelijk verweer moet voldoen wil het een expliciete reactie van de rechter daarover ontlokken. ${ }^{73}$ Deze lijn heeft de Hoge Raad doorgetrokken voor alle andere bewijsverweren die vanaf 1 januari 2005 als gevolg van het gewijzigde tweede lid gemotiveerd moeten worden weerlegd. Bij de bespreking van het nieuwe artikel 359 lid $2 \mathrm{~Sv}$ en de wijze waarop de Hoge Raad daaraan invulling heeft gegeven, zal daarop nader worden ingegaan.

De laatste categorie van verweren ten aanzien waarvan de Hoge Raad een nadere verantwoording verlangt, ziet op verweren waarin de betrouwbaarheid van het door de rechter gebezigde bewijsmateriaal ter discussie wordt gesteld. Deze wijkt in wezenlijke zin af van de voorgaande categorieën. Ten aanzien van de eerder genoemde verweren kan men blijven volhouden dat de rechter vrij is in de selectie en waardering van het bewijsmateriaal. De nadere verantwoording ten aanzien van die verweren achtte de Hoge Raad noodzakelijk omdat uit enkel het weergeven van de inhoud van bewijsmiddelen niet kan blijken dat de rechter het verweer onder ogen heeft gezien. Door het creëren van een responsieplicht op sommige betrouwbaarheidsverweren wordt het bestaande bastion van de feitenrechter, namelijk dat hij heer en meester is over de feitenvaststelling, deels doorbroken.

\subsubsection{Betrouwbaarheidsverweren}

Lange tijd heeft de Hoge Raad zich op het standpunt gesteld dat de selectie en waardering van het beschikbare bewijsmateriaal is voorbehouden aan de feitenrechter én dat hij daarover in zijn vonnis geen verantwoording hoeft af te leggen. Deels hanteert de Hoge Raad dit uitgangspunt nog steeds: de feitenrechter gaat over de feiten en de cassatierechter kan alleen binnen de grenzen van de wet daarop controle uitoefenen. Echter het uitgangspunt dat de feitenrechter daarover geen verantwoording hoeft af te leggen, is niet in alle gevallen gehandhaafd. Ook waar het de beoordeling van de betrouwbaarheid van het bewijs betreft, heeft de Hoge Raad gemeend dat in uitzonderingsgevallen van de feitenrechter mag worden verlangd dat hij nader op de bewijswaarde van het door hem geselecteerde bewijsmateriaal ingaat. Weliswaar is het aantal gevallen waarin de Hoge Raad een dergelijke uitzondering aannam uitgebreid, maar van een algemene responsieplicht

73 HR 30 maart 2004, NJ 2004, 376 m.nt. YB. 
op bewijsverweren blijkt uit die jurisprudentie niet. ${ }^{74}$ Waarom in bepaalde gevallen wel en in andere gevallen geen nadere motiveringseisen aan het bewijsoordeel worden gesteld, wordt niet geëxpliciteerd in de uitspraken van de Hoge Raad.

De Onderzoeksgroep Strafvordering 2001 zag in de jurisprudentie van de Hoge Raad aanleiding om een algemene responsieplicht op verweren en standpunten van de zijde van de verdediging respectievelijk het Openbaar Ministerie voor te stellen. Deze plicht zou dan voortkomen uit de wens om te komen tot een meer contradictoir ingericht strafproces waarbij zoveel mogelijk zou moeten worden aangesloten bij en consequenties moeten worden verbonden aan de proceshouding van betrokkenen. Een op die wijze vormgegeven strafproces brengt logischerwijze mee dat de rechter expliciet reageert op de gevoerde tegenspraak. ${ }^{75}$ Het doel van een uitgebreidere motiveringsplicht zou dan gelegen zijn in het expliciteren van de gronden waarom het standpunt van de procespartijen niet wordt gevolgd.

Mede met een beroep op de uitgangspunten van de Onderzoeksgroep Strafvordering 2001 is artikel 359 lid 2 Sv per 1 januari 2005 gewijzigd. Die wijziging houdt in dat alle uitdrukkelijk gevoerde en onderbouwde standpunten van de verdediging en het Openbaar Ministerie bij niet navolging een rechterlijke respons verdienen. Onder andere Corstens ${ }^{76}$ heeft gesuggereerd dat het gewijzigde artikel 359 lid 2 Sv met betrekking tot de weerlegging van standpunten van de verdediging een codificatie van de bestaande jurisprudentie aangaande bewijsverweren zou zijn. Het is echter de vraag of aan de gevallen waarin de Hoge Raad een nadere motivering eiste naar aanleiding van gevoerde betrouwbaarheidsverweren hetzelfde idee ten grondslag lag. Allereerst pleit daartegen dat de Hoge Raad een dergelijke plicht slechts in uitzonderlijke gevallen aanneemt. Beziet men deze gevallen nader, dan blijken deze wel degelijk een gemeenschappelijke noemer te hebben: het ter discussie gestelde bewijsmateriaal kan gezien zijn herkomst of inhoud moeilijk op zijn inhoudelijke juistheid gecontroleerd worden. Ofwel kleven er aan de bron gebreken die mogelijk de betrouwbaarheid van het bewijsmateriaal kunnen hebben beïnvloed, zoals bij de hierna te bespreken dubieuze getuigen en deskundigen, ofwel is de inhoud van het bewijsmateriaal zelf discutabel, omdat de daaraan ten grondslag liggende onderzoeksmethoden niet algemeen geaccepteerd zijn. De motiveringsplicht dient er toe de rechter het dubieuze karakter van sommige vormen van bewijs in te scherpen.

74 't Hart hield de verschillende gevallen nauwkeurig bij in zijn annotaties bij HR 14 maart 1989, NJ 1989, 747 en HR 12 maart 1996, NJ 1996, 511. Schalken zette de nummering voort in zijn annotatie bij HR 17 april 2001, NJ 2002, 107. De teller stopte bij 10. Schalken lijkt in zijn annotatie zelfs te suggereren dat de Hoge Raad uiteindelijk zal opteren voor een algemene responsieplicht: 'De uitzonderingen op de als sacraal gepresenteerde hoofdregel van de ongemotiveerde bewijskeuze worden dermate talrijk dat de vraag rijst hoe lang de Hoge Raad dat principe nog overeind kan houden.'

75 Simmelink 1999, p. 450.

76 Corstens 2005a, p. 687. 


\subsection{Dubieuze getuigen}

De eerste keer dat de Hoge Raad afweek van de gulden regel dat de selectie en waardering van het beschikbare bewijs geen nadere toelichting behoefden, betrof het gebruik van anoniem bewijs. De Hoge Raad oordeelde:

'wanneer van processen-verbaal inhoudende verklaringen van niet met name genoemde personen voor het bewijs gebruik wordt gemaakt en de betrouwbaarheid van dat materiaal door of namens de verdachte ter terechtzitting wordt betwist, dient de rechter, als hij niettemin gebruik maakt van dat materiaal voor het bewijs daaromtrent verantwoording af te leggen. ${ }^{77}$

Deze jurisprudentie kwam tot stand vóór de Wet Getuigenbescherming. ${ }^{78}$ Met de inwerkingtreding van deze wet is de motiveringsplicht van de feitenrechter met betrekking tot het anonieme bewijs neergelegd in artikel 360 lid 1 Sv. ${ }^{79}$ Het enige verschil met de oude jurisprudentie is dat de rechter thans ambtshalve tot een nadere motivering van de betrouwbaarheid van het anonieme bewijsmateriaal moet overgaan.

Een tweede categorie van getuigenverklaringen ten aanzien waarvan de Hoge Raad eiste dat de feitenrechter in zijn vonnis weergeeft waarom hij ze geloofwaardig acht, ziet op verklaringen van getuigen die in ruil voor een toezegging van het Openbaar Ministerie met betrekking tot hun eigen (mogelijke) strafzaak zijn afgelegd. ${ }^{80}$

Op gelijke wijze oordeelde de Hoge Raad ten aanzien van de kroongetuige. ${ }^{81}$ Inmiddels is ook deze motiveringsplicht opgenomen in artikel $360 \mathrm{~Sv}$.

Ten aanzien van beide soorten getuigen, de anonieme en de kroongetuigen, geldt dat de beoordeling van de juistheid van de inhoud van hun verklaringen moeilijkheden oplevert. Bij de anonieme verklaring omdat de identiteit van de bron onbekend is en aldus de verdediging en de zittingsrechter in het ongewisse blijven over de relatie tussen de getuige en de verdachte en eventuele redenen om de verdachte valselijk te beschuldigen. Bij de kroongetuige is de relatie tussen verdachte en getuige wel bekend en is dat nu juist de reden om te twijfelen aan de volledige juistheid van de door de getuige afgegeven informatie. De getuige heeft immers zelf belang bij het afleggen van een belastende verklaring.

Gezien het precaire karakter van de verklaringen ligt het in de rede dat de rechter nadrukkelijk stilstaat bij de betrouwbaarheid hiervan. Dat speelt te meer in die

77 HR 1985, 426 m.nt. ThWvV. In gelijke zin: HR 25 september 1984, NJ 1985, 427 m.nt. ThWvV; HR 11 juni 1985, NJ 1986, 59, HR 12 november 1985, NJ 1986, 409; HR 29 oktober 1985, $N J 1986,420$.

78 Wet van 11 november 1993 (getuigenbescherming) Stb. 1993, 603 (inwerkingtreding 1 februari 1994).

79 Zie paragraaf 6.2.2.

80 HR 23 mei 1995, NJ 1995, 683 m.nt. Sch.

81 HR 30 juni 1998, NJ 1998, 799 m.nt. Sch. 
gevallen waarin de rechter de getuige zelf niet heeft gehoord en dus niet zelf een indruk heeft kunnen krijgen van de getuige en deze geen (nadere) vragen heeft kunnen stellen. Bij het gebruik van anoniem bewijs is dat altijd het geval. De getuige wordt immers om zijn anonimiteit te garanderen buiten het onderzoek ter terechtzitting gehoord. De kroongetuige daarentegen zou wel ter zitting kunnen verschijnen en in zoverre bestaat de mogelijkheid de betrouwbaarheid ter zitting door middel van het stellen van vragen door en ten overstaan van de zittingsrechter te toetsen.

De achterliggende reden voor het aannemen van een nadere motiveringsplicht door de Hoge Raad moet mijns inziens worden gezocht in de bijzondere positie van de zittingsrechter in strafzaken. Hij is eindverantwoordelijke in het proces van waarheidsvinding. De officier van justitie draagt weliswaar het bewijsmateriaal aan en de verdediging moet de mogelijkheid hebben dat te betwisten of daar ander materiaal tegenover te stellen, maar de uiteindelijke waardering van het bewijs is opgedragen aan de zittingsrechter. Voor zover specifieke factoren die zelfstandige beoordeling door de zittingsrechter belemmeren of bemoeilijken, zal de rechter in zijn vonnis kenbaar moeten maken dat hij toch tot een afgewogen oordeel is gekomen. Ten anzien van het gebruik van anoniem bewijsmateriaal is deze achterliggende reden voor het eisen van een nadere motivering door de Hoge Raad ook verwoord. Hij eist immers dat de zittingsrechter een zelfstandig oordeel over de betrouwbaarheid van de anonieme verklaring formuleert. Weliswaar mag daarbij het oordeel van de rechter-commissaris worden betrokken, maar hij mag niet volstaan met de enkele verwijzing daarnaar.

Ten aanzien van de kroongetuige valt nog te bezien hoe de Hoge Raad nadere invulling geeft aan de inmiddels in artikel $360 \mathrm{~Sv}$ opgenomen motiveringsplicht. Verwacht mag echter worden dat dat in belangrijke mate afhankelijk zal zijn van de vraag in hoeverre de rechter zelf in staat is geweest de betrouwbaarheid van de verklaring te toetsen, bijvoorbeeld door de getuige zelf ter zitting te horen. Heeft de rechter de getuige niet kunnen horen of heeft de getuige bepaalde essentiële vragen daar niet beantwoord, dan zal hij voor de beoordeling van de betrouwbaarheid van de verklaring van de kroongetuige niet kunnen volstaan met een verwijzing naar het proces-verbaal van de rechter-commissaris.

\subsection{Dubieuze deskundigen}

Niet alleen ten aanzien van bepaalde getuigen is de Hoge Raad afgeweken van de regel dat de beoordeling van de betrouwbaarheid van hun verklaring impliciet kan blijven. Eenzelfde uitzondering is geformuleerd voor de deskundige, indien door de verdediging op goede gronden zijn deskundigheid in twijfel is getrokken. De eerste keer formuleerde de Hoge Raad deze uitzondering in het Schoenmakers- 
arrest. ${ }^{82}$ In deze zaak was de betrokkenheid van de verdachte bij een moord onder andere afgeleid uit een op de plaats van het delict gevonden schoenspoor. Dit schoenspoor was onderzocht door een orthopedisch schoenmaker en vergeleken met de voeten en schoeisel van de verdachte. Hij concludeerde dat hij zoveel overeenkomsten had aangetroffen dat het uitgesloten was dat iemand anders dan B. (de verdachte) die sporen heeft gezet. ${ }^{83}$ De verdediging betwistte in hoger beroep de deskundigheid van de schoenmaker daarbij onder andere wijzend op een aantal tegenstrijdigheden in zijn verklaring. Het hof legde dit verweer naast zich neer daarbij overwegende dat het de verklaring van de schoenmaker in samenhang gezien met de verklaring van een andere deskundige betrouwbaar achtte. Deze andere deskundige had overigens zelf geen onderzoek verricht.

Deze motivering achtte de Hoge Raad te mager:

'Weliswaar houdt het bestreden arrest (bewijsmiddel 15) in dat Woutersen sinds 1988 dagelijks als orthopedisch schoenmaker werkzaam is en daartoe een opleiding heeft gehad in 's-Hertogenbosch, aan welke verklaring hij ter terechtzitting in hoger beroep heeft toegevoegd dat hij per jaar ongeveer vierhonderd mensen aan orthopedisch schoeisel helpt, maar het arrest houdt niet in, noch blijkt uit het proces-verbaal van de terechtzitting in hoger beroep, dat het Hof heeft onderzocht of die deskundigheid zich mede uitstrekt tot het onderzoek aan en de analyse van schoensporen, en zo ja volgens welke methode hij het onderzoek heeft uitgevoerd en waarom hij deze methode betrouwbaar acht alsmede in hoeverre hij in staat is deze methode vakkundig toe te passen. Bij die stand van zaken kan niet worden gezegd dat de bewezenverklaring naar de eis der wet met redenen is omkleed. ${ }^{, 84}$

In geval van een serieuze betwisting van de deskundigheid zal de rechter dus in zijn vonnis moeten doen blijken dat de conclusie van de deskundige niet verder reikt dan hetgeen hij op basis van zijn kennis en ervaring zou kunnen verklaren. De conclusie van de deskundige moet voortkomen uit een door de deskundige toegepaste en betrouwbare onderzoeksmethode en tevens moet blijken dat de deskundige in staat is om deze methode vakkundig toe te passen. In geval van de schoenmaker ging het reeds mis bij de eerste voorwaarde; iemand die is opgeleid om orthopedisch schoeisel te maken en op dat gebied veel ervaring heeft, hoeft niet te beschikken over kennis en ervaring op het gebied van de analyse van schoensporen. In dat geval geldt inderdaad het gezegde: 'Schoenmaker blijf bij je leest. ${ }^{85}$

82 HR 27 januari 1998, NJ 1998, 404 m.nt. JR.

83 Het is überhaupt de vraag of een deskundige een dergelijke stellige conclusie voor zijn rekening kan nemen. Zie Broeders 2003, p. 375: 'Afgezien van categorische eliminaties, die logisch gezien doorgaans onproblematisch zijn, blijken de absolute identificaties, die bijvoorbeeld vrijwel universeel bij het dactyloscopisch bewijs worden gehanteerd, op logische gronden onaanvaardbaar.'

84 HR 27 januari 1998, NJ 1998, 404 m.nt. JR (r.o. 6.4).

85 Nijboer 2000b, p. 22. Reeds in 1928 wees Simons op het belang van dit gezegde in geval van deskundigenbewijs: "het "schoenmaker houd je bij je leest" geldt voor den deskundige voor den rechter in zeer sterke mate, opdat die deskundige het vertrouwen behoudt, waaraan hij zoozeer behoefte heeft. Het vertrouwen van het publiek in den 
De zienswijze in het schoenmakersarrest zien we ook terug in het Sinti arrest. ${ }^{86}$ Daar stond echter de deskundigheid van een tolk ter discussie. Deze had aangegeven dat hij de Sinti-taal zelf slechts voor $25 \%$ beheerste, maar dat hij voor de vertaling van de inhoud van opgenomen telefoongesprekken gebruik had gemaakt van iemand voor wie het Sinti de moedertaal was. Wie dat was, bleef onduidelijk. De Hoge Raad meende dat in een dergelijk geval het hof nader had moet verantwoorden waarom het van oordeel was dat het om een juiste vertaling ging:

'Gelet op het hiervoor weergegeven gemotiveerde verweer van de raadsman dat enerzijds betrekking heeft op de beheersing van de Sinti-taal door degene die verantwoordelijk is voor de vertaling en anderzijds op de wijze waarop de vertaling van op een geluidsband opgenomen telefoongesprekken is tot stand gekomen, had het Hof in dit geval verantwoording behoren af te leggen van zijn oordeel dat de bewijsmiddelen een betrouwbare weergave behelzen van de inhoud van die telefoongesprekken. ${ }^{87}$

De Hoge Raad refereert hier niet aan de betrouwbaarheid van de tolk als deskundige. Dat is niet vreemd, omdat het werk van de tolk niet tot uitdrukking kwam in een deskundigenrapport. Onder de bewijsmiddelen waren de schriftelijke weergaven van telefoongesprekken opgenomen en daarbij was steeds vermeld dat het gesprekken in een vreemde taal betrof en dat die gesprekken woordelijk waren vertaald. Het is echter evident dat het verweer in casu de deskundigheid van de tolk in twijfel trok. In dergelijke gevallen kan de feitenrechter niet stilzwijgend voorbij gaan aan het verweer. De betrouwbare vertaling van het bewijsmateriaal is immers een absolute voorwaarde voor de beoordeling van de betrouwbaarheid van het bewijsmateriaal zelf. Voor zover hij niet kan vertrouwen op de juistheid van die vertaling, kan hij evenmin een eigen oordeel uitspreken over de waarde van het bewijsmateriaal. ${ }^{88}$

Wat voor de tolk geldt, geldt ook voor andere deskundigen. De noodzaak tot nadere motivering komt voort uit de afhankelijke positie van de rechter in deze. Hij is bij gebrek aan eigen expertise aangewezen op externe deskundigen. Zodra er twijfels ontstaan met betrekking tot de van buiten ingebrachte deskundigheid, dient de rechter die twijfels weg te nemen door op dat punt zijn oordeel nader te onderbouwen. Uit de motivering blijkt dan dat de rechter de conclusie van de deskundige voor zijn rekening neemt en ook zonder tussenkomst van de deskundige kan verantwoorden. De motivering moet als het ware voorkomen dat de rechter de verantwoordelijkheid van het oordeel afschuift op de deskundige. Alleen hij is uiteindelijk verantwoordelijk is voor de vaststelling van de feiten.

rechter moet ongeschokt zijn, maar ook dat van den rechter in den deskundige.' Simons 1928, p. 235.

86 HR 17 april 2001, NJ 2002, 107 m.nt. Sch.

87 HR 17 april 2001, NJ 2002, 107 m.nt. Sch (r.o. 5.5).

88 In gelijke zin: Schalken in zijn annotatie bij HR 17 april 2001, NJ 2002, 107. 


\subsection{Dubieus onderzoek}

Uit het hierboven besproken schoenmakersarrest bleek dat de Hoge Raad eisen stelt niet alleen aan de deskundigheid, maar ook aan de door de deskundige gehanteerde onderzoeksmethode. Een dergelijke onderzoeksmethode dient valide te zijn. Wordt door de verdediging betwist dat de gehanteerde methode betrouwbare resultaten op kan leveren, dan dient de rechter indien hij de resultaten van het onderzoek wel voor het bewijs bezigt, expliciet op het verweer van de verdediging in te gaan. Slechts in drie uitspraken heeft de Hoge Raad een dergelijke nadere motiveringsplicht aan de feitenrechter opgelegd.

In het zogeheten poppenspelarrest stond het door het hof voor het bewijs gebezigde verslag van een orthopedagoge centraal. ${ }^{89}$ In dat verslag gaf zij de inhoud van een zogeheten spelinterview weer dat zij had afgenomen bij kinderen die vermoedelijk het slachtoffer van incest waren. Tijdens dit interview vertelden de kinderen over verschillende seksuele handelingen en met behulp van de anatomisch correcte poppen demonstreerden zij die aan de orthopedagoge. Uit het interview concludeerde de orthopedagoge dat met een aan zekerheid grenzende waarschijnlijkheid de kinderen hadden bloot gestaan aan niet leeftijdsadequate seksuele handelingen met hun vader. De validiteit van de toegepaste onderzoeksmethode werd door de verdediging betwist. ${ }^{90}$ Daarbij wees zij op literatuur en de verklaring van een sociaal pedagoog/psycho-motorisch therapeut inhoudende dat het onderzoek van de deskundige in kwestie onvolledig was geweest. De Hoge Raad oordeelde:

'Het onder 5.2 bedoelde verweer is gestaafd met een verklaring ter terechtzitting in hoger beroep van een sociaal pedagoog/psycho-motorisch therapeut. Het hof had onder deze omstandigheden het verweer niet mogen verwerpen zonder die verwerping met redenen te omkleden. In het bestreden arrest ontbreekt een zodanige verwerping. Dit heeft tot gevolg dat de bewezenverklaring niet naar de eis der wet is gemotiveerd. ${ }^{91}$

In het computergamearrest stond de vraag centraal of een bepaald spel als een kansspel dan wel een behendigheidsspel moest worden gekwalificeerd. ${ }^{92}$ Opsporingsambtenaren die het spel een aantal keren (22) hadden gadegeslagen, kwamen tot de conclusie dat de uitkomst van het spel niet te voorspellen was. Ook een croupier die gedurende drie dagen het spel had geobserveerd, kwam tot dezelfde conclusie. De verdediging daarentegen meende, zich daarbij beroepend op het verslag van een door haar aangetrokken deskundige, dat het bewuste spel een behendigheidsspel was. De conclusies van de andere deskundigen trok zij in

89 HR 28 februari 1989, NJ 1989, 748 m.nt. 'tH onder HR 14 maart 1989, NJ 1989, 747.

90 Barning \& Nijboer 1989, p. 1176 merken met betrekking tot de onderzoeksmethode op: 'Als diagnostisch instrument terzake van de vaststelling van seksueel misbruik van kinderen is de projectieve poppenmethode ten enen male ongeschikt om definitieve uitspraken omtrent 'objectief' vaststaande gegevens op te baseren.'

91 HR 28 februari 1989, NJ 1989, 748 m.nt. 'tH onder HR 14 maart 1989, NJ 1989, 747 (r.o. 5.3).

92 HR 13 mei 1997, NJ 1998, 318 m.nt. Sch. 
twijfel, omdat de vraag of iets een kans- dan wel behendigheidsspel is niet kan worden beantwoord enkel op basis van waarneming van het spel. Het spel zelf dient ook geanalyseerd te worden. De Hoge Raad was mening:

'Gelet op de aard van de onderhavige materie, had het Hof het met genoemd deskundigenrapport onderbouwde verweer, dat onmiskenbaar strekte tot betwisting van de betrouwbaarheid van de onder 4.2 weergegeven verklaringen van de verbalisanten en van Di Stasio, niet mogen verwerpen zonder ervan blijk te geven dat rapport in zijn oordeel te hebben betrokken. ${ }^{93}$

In het CBCA-arrest tenslotte werd de verklaring van een psycholoog door de verdediging in twijfel getrokken. ${ }^{94}$ Weliswaar was deze verklaring niet rechtstreeks voor het bewijs gebezigd, maar steunde het oordeel van het hof met betrekking tot de betrouwbaarheid van een minderjarige getuige wel op deze deskundigenverklaring. Door de verdediging was de betrouwbaarheid van de door psycholoog gehanteerde methode, de CBCA-methode, betwist. De CBCA-methode houdt in dat aan de hand van een 21-tal criteria de betrouwbaarheid van een getuigenverklaring kan worden getoetst. Er bestaat echter twijfel over de juistheid van die criteria, en over het aantal criteria waaraan minimaal moet zijn voldaan wil het de conclusie dat de verklaring betrouwbaar is kunnen dragen. ${ }^{95}$ Deze twijfel die ook in de literatuur aan de orde is gesteld, werd door de verdediging aan haar verweer ten grondslag gelegd. Daarnaast had zij twee schriftelijke commentaren van hoogleraren in de psychologie overgelegd, die beide de validiteit van de CBCA-methode ernstig in twijfel trokken. De Hoge Raad oordeelde in deze zaak dat het hof nader had moeten motiveren:

'In deze zaak heeft het Hof eerdergenoemd rapport van Dr. Bullens niet als bewijsmiddel gebruikt. Wel heeft het - zoals uit het hiervoor onder 4.2 overwogene volgt zijn beslissing om de verklaring van de minderjarige tot het bewijs te bezigen en dus zijn oordeel dat die verklaring geloofwaardig is mede gebaseerd op de eindconclusie van dat rapport. Gelet daarop en op de inhoud van het onder 4.3 bedoelde - met een beroep op het oordeel van andere deskundigen gestaafde - verweer had het Hof nader moeten motiveren waarom het zich bij genoemde beslissing heeft gebaseerd op de eindconclusie van het Rapport van Dr. Bullens en dat daaraan niet in de weg stond hetgeen aan het verweer ten grondslag is gelegd. In het bestreden arrest ontbreekt een zodanige motivering. Dat brengt mee dat de bewezenverklaring niet naar de eis der wet met redenen is omkleed. ${ }^{96}$

De drie zaken waarin de Hoge Raad oordeelde dat de betrouwbaarheid van de gebezigde onderzoeksmethode nader moet worden gemotiveerd, vertonen duidelijke overeenkomsten. In alle zaken werd specifiek de betrouwbaarheid van de

93 HR 13 mei 1997, $N J$ 1998, 318 m.nt. Sch (r.o. 5.2).

94 HR 30 maart 1999, NJ 1999, 451 m.nt. 'tH.

95 Zie voor een kritische beschrijving van deze methode: Rassin \& Van Koppen 2002, p. 523 e.v. en Rassin, Merckelbach \& Crombag 1997.

96 HR 30 maart 1999, $N J$ 1999, 451 m.nt. 'tH (r.o. 4.4.). 
onderzoeksmethode in twijfel getrokken. Het betrof achtereenvolgens het verhoor van kinderen met behulp van anatomisch correcte poppen, het analyseren van een spel enkel door middel van waarneming, en het beoordelen van de waarde van een getuigenverklaring door middel van de CBCA-methode. Het toepassen van deze methoden gebeurde telkens door een deskundige; in geval van de poppenmethode door een orthopedagoge, en in geval van de CBCA-methode door een psycholoog en de beoordeling van het spel door een croupier. ${ }^{97}$ Een volgende overeenkomst is dat in alle drie de zaken de bewezenverklaring in grote mate afhankelijk was van de verklaring van de deskundige. In de zaak van de Poppenmethode bleek uit de conclusie van de verklaring van de deskundige nadrukkelijk de betrokkenheid van de verdachte bij de ontucht. In de computergamezaak was de vaststelling van het karakter van het spel door de opsporingsambtenaren en croupier essentieel voor de bewezenverklaring. En in de CBCA-zaak was weliswaar de verklaring van de deskundige niet rechtstreeks voor het bewijs gebezigd, maar had het hof de betrouwbaarheid van een getuigenverklaring in kwestie volledig op de bewuste deskundigenverklaring gebaseerd. ${ }^{98}$ Behalve deze getuigenverklaring was er weinig ander bewijs waaruit de betrokkenheid van de verdachte bij het strafbare feit bleek. Een vierde overeenkomst in alle drie de gevallen is dat het verweer (of verzoek) van de verdediging telkens door de Hoge Raad wordt uitgelegd als een betwisting van de door de deskundige gehanteerde methode, onderbouwd door een beroep op een andere deskundige. Uit het mondelinge of schriftelijke verslag van de door de verdediging aangehaalde deskundige kan telkens worden opgemaakt dat het onderzoek van de 'eerste' deskundige methodologisch niet deugde en niet tot berouwbare resultaten kon leiden. In die zin wijken de bovengenoemde gevallen af van die waarin de Hoge Raad de betrouwbaarheid van een herkenning beoordeelde. ${ }^{99}$ Ten aanzien van de herkenning kwam de Hoge Raad tot het oordeel dat de betwisting van de onderzoeksmethode niet noodzakelijk met zich bracht dat de herkenning van de verdachte door de getuige ook van generlei waarde was. Simpel gezegd: ook al voldoet de onderzoeksmethode wellicht niet aan alle daaraan te stellen wetenschappelijke eisen, dit neemt niet weg dat het resultaat toch betrouwbaar kan zijn. De verdachte is hoe dan ook herkend door de getuige. ${ }^{100}$

97 In hoeverre de verklaringen van de beide opsporingsambtenaren als deskundigenverklaringen moeten worden aangemerkt blijft in deze zaak onduidelijk. De verdediging had in ieder geval hun deskundigheid in deze betwist.

98 Anders: HR 10 september 2002, NJ 2002, 474. In die zaak was de betrouwbaarheid van de getuige ook getoetst door middel van de CBCA-methode, maar het hof had de getuige ook zelf ter zitting gehoord.

99 HR 14 maart 1989, NJ 1989, 747 m.nt. 'tH; HR 8 juli 1992, NJ 1993, 407 m.nt. ThWvV; HR 17 november 1992, NJ 1993, 408 m.nt. ThWvV; HR 26 oktober 1993, NJ 1994, 100; HR 29 maart 1994, NJ 1994, 577 m.nt. Sch en HR 16 mei 2000, NJ 2000, 510.

100 Overigens heeft de Hoge Raad wel erkend dat de wijze waarop een confrontatie plaats vindt relevant kan zijn voor de vraag of wellicht de naar aanleiding daarvan verkregen verklaring inhoudende de herkenning van verdachte moet worden uitgesloten voor het 
Waar het in de eerder genoemde uitspraken op neer komt, is dat de feitenrechter wordt geconfronteerd met bepaalde voor de bewezenverklaring essentiële onderzoeksresultaten die voortvloeien uit het hanteren van een bepaalde onderzoeksmethode, terwijl de waarde van die onderzoeksmethode in de kern, en daarmee ook de waarde van de daaruit voortkomende resultaten, wordt betwist door een andere deskundige. De Hoge Raad verlangt nu van de feitenrechter dat hij - die meestal geen bijzondere expertise op dat gebied heeft - zelfstandig de betrouwbaarheid van de onderzoeksresultaten vaststelt. De feitenrechter kan bij het zelfstandig vaststellen van de bewijswaarde alleen een beroep doen op het oordeel van de eerste deskundige indien hij de kritiek van de tweede deskundige op de onderzoeksmethode pareert. Het pareren van die kritiek zal meestal niet eenvoudig zijn; de rechter beschikt immers zelf niet over de benodigde expertise. Hij zal het onderzoek op het punt van de betrouwbaarheid van de gebezigde onderzoeksmethode moeten uitbreiden, door de deskundigen ter zitting te horen en indien nodig een derde deskundige op te roepen. De daaruit verkregen inzichten moeten hem in staat stellen om tot een eigen oordeel over de betrouwbaarheid van de gebezigde methode en van de daaruit voortvloeiende onderzoeksresultaten te komen. In de motivering moet hij vervolgens tot uitdrukking brengen dat hij tot een eigen, afgewogen oordeel is gekomen en dus niet blindelings op het oordeel van een van de betrokken deskundigen heeft vertrouwd. ${ }^{101}$

Dat laat onverlet dat de feitenrechter ook op andere wijze zelfstandig de betrouwbaarheid van de onderzoeksresultaten kan toetsen. Een voorbeeld daarvan is het CBCA II-arrest. ${ }^{102}$ In die zaak was door de verdediging opgeworpen dat voor de beoordeling van de geloofwaardigheid van de getuige geen doorslaggevende betekenis moest worden toegekend aan het oordeel van de deskundige - gebaseerd op de door hem uitgevoerde analyse van de getuigenverklaring door middel van de CBCA-methode. De Hoge Raad meende allereerst dat dit verweer niet kon worden gekwalificeerd als een jurisprudentieel erkend betrouwbaarheidsverweer, ${ }^{103}$ maar daarenboven overwoog hij:

'Het Hof, dat zelf de aangevers ter terechtzitting heeft gehoord [cursivering WD], heeft het (...) rapport van dr. Soppe kennelijk redengevend geacht voor het bewijs in die zin dat het onderzoek van dr. Soppe geen aanwijzingen heeft opgeleverd dat de verklaringen

bewijs. Een verweer waarin met een beroep op concrete feiten en omstandigheden de rechtmatigheid van de bij de confrontatie gebezigde werkwijze aan de orde stelt, dient wel gemotiveerd weerlegd te worden. Zie onder andere: HR 8 juli 1992, NJ 1993, 407. Kritisch over de opstelling van de Hoge Raad aangaande de eisen te stellen aan een Oslo-confrontatie: Van Koppen \& Van der Horst 2006.

101 Schalken in zijn annotatie onder HR 13 mei 1997, NJ 1998, 318.

102 HR 10 september 2002, NJ 2002, 474.

103 Zie paragraaf 6.3.3.3. 
van de aangevers tegenover de politie niet [cursivering WD] geloofwaardig zouden zijn en dat dezen een motief hadden om de verdachte valselijk te beschuldigen., ${ }^{104}$

Het belang van deze overweging zit allereerst in de opmerking dat het hof zelf de getuigen heeft gehoord. Door het horen van de bewuste getuigen ter zitting heeft het hof zelf een oordeel kunnen vormen over de betrouwbaarheid en geloofwaardigheid van de getuigenverklaringen. De verklaring van de deskundige, die zijn oordeel baseert op een dubieuze onderzoeksmethode, is in dat geval van ondergeschikt belang, temeer daar het hof dit oordeel alleen heeft gebezigd om het tegendeel - de ongeloofwaardigheid van de getuigen - uit te sluiten. In het CBCA II-arrest kon het hof de verklaring van de deskundige wel aan zijn bewezenverklaring ten grondslag leggen, omdat het uiteindelijke oordeel over de geloofwaardigheid van de gebezigde getuigenverklaringen zelfstandig door het hof was geveld. Een nadere motivering van dat oordeel was in dat geval niet vereist.

De dubieuze onderzoeksmethodeverweren lijken qua aard veel op de eerder besproken dubieuze deskundigenverweren. Ten aanzien van beide geldt dat daarin de betrouwbaarheid van de uitkomst van het deskundigenonderzoek wordt betwist. De achterliggende reden is echter afwijkend. In het eerste geval wordt getwijfeld aan de betrouwbaarheid van de toegepaste onderzoeksmethode, in het tweede geval wordt de expertise en vakkundigheid van de deskundige zelf in twijfel getrokken. Nijboer heeft er op gewezen dat beide aspecten goed van elkaar moeten worden gescheiden bij de waardering van de deskundigenverklaringen: 'een vliegtuig is een perfect middel van vervoer, maar niet ieder kan dit middel van vervoer vlekkeloos besturen.' 105

De oorzaak van het verwarren van beide aspecten is wellicht ook gelegen in de overeenstemming van beide met betrekking tot noodzaak van motivering. Voor de vraag of de deskundige wel deskundig is, en of de door hem gehanteerde methode wel betrouwbaar is, zal de rechter in eerste instantie te rade moeten gaan bij de deskundige zelf. Hijzelf beschikt immers niet over de vereiste kennis. Wordt echter het oordeel van deze deskundige in twijfel getrokken door een andere deskundige, dan ontstaat een patstelling; de rechter kan immers niet zonder meer opteren voor de visie van één van de deskundigen. Doet hij dat wel, dan zou wellicht de indruk ontstaan dat niet de rechter de bewijswaarde van de feiten vaststelt, maar de deskundige. Teneinde dat te voorkomen dient uit zijn motivering te blijken dat hij niet enkel het oordeel van de deskundige heeft gevolgd maar tot een eigen, zelfstandig oordeel is gekomen. ${ }^{106}$ Die autonomie kan enerzijds blijken uit een nadere

104 HR 10 september 2002, NJ 2002, 474 (r.o. 3.4.3).

105 Nijboer 2000a, p. 262.

106 In dat verband is - in de woorden van Blekxtoon - de stoplap: 'De rechtbank neemt de conclusie van de deskundige over en maakt deze tot de hare' onvoldoende. Blekxtoon 2003, p. 201. 
motivering waarin de feitenrechter uit de doeken doet waarom hij ondanks de kritiek van de verdediging toch waarde hecht aan de door de deskundige verzamelde onderzoeksresultaten, ${ }^{107}$ anderzijds kan die autonomie van de strafrechter blijken uit het feit dat de rechter op andere wijze de betrouwbaarheid van het bewijsmateriaal heeft vastgesteld. Dit kan - zoals in het CBCA II-arrest - door het zelf horen van de getuige, of door ander bewijsmateriaal in het vonnis op te nemen, dat de conclusie van de gewraakte deskundigenverklaring kan ondersteunen. In zo'n geval is de feitenrechter niet verplicht op het betrouwbaarheidsverweer te reageren.

\subsubsection{Tussenconclusie}

Hoofdregel met betrekking tot de motivering van het feitenoordeel is dat de selectie en waardering van het bewijsmateriaal is voorbehouden aan de feitenrechter. De rechter hoeft in het vonnis enkel het gebezigde bewijsmateriaal op te nemen en daaruit blijkt dat hij dit bewijsmateriaal relevant en betrouwbaar acht. Een nadere verantwoording is niet nodig; bewijsverweren worden in de regel opgevangen door de bewijsmiddelen. ${ }^{108}$

De Hoge Raad heeft echter een aantal uitzondering geformuleerd op de bovenstaande regel. In sommige gevallen is die uitzondering logisch; namelijk in die gevallen waarin het verweer niet stilzwijgend wordt weerlegd door inhoud van de bewijsmiddelen. Dat geldt in geval van de zogeheten Meer en Vaartverweren en ten aanzien van de meer juridische dakdekker- en onrechtmatig verkregen bewijsverweren.

Ten aanzien van de betrouwbaarheidsverweren geldt dit echter niet; uit het feit dat de rechter het betwiste materiaal aan de bewezenverklaring ten grondslag legt, volgt reeds dat hij de verdediging niet volgt op dit punt. De beoordeling daarvan is een pure feitenkwestie, die geen nadere toelichting vereist. Dit komt tot uitdrukking in de algemene regel dat de selectie en waardering aan de feitenrechter is voorbehouden. Deze regel wordt nog steeds door de Hoge Raad gehandhaafd. De daaraan gekoppelde vrijstelling van nadere motivering wordt echter in specifieke gevallen losgelaten.

De reden daarvoor is niet gelegen in het streven naar een meer op tegenspraak gerichte procedure, zoals de Onderzoeksgroep Strafvordering 2001 voorstaat. Uit de jurisprudentie van de Hoge Raad komt de plicht tot nadere motivering voort uit de wens dat uit het vonnis kenbaar moet worden dat de rechter tot een zelfstandig oordeel over de bewijswaarde van de hem gepresenteerde onderzoeksgegevens is gekomen. In geval van dubieuze getuigen, deskundigen of onderzoeksmethoden is niet per definitie gegeven dat de rechter tot een eigen oordeel heeft kunnen komen.

107 Bijvoorbeeld: HR 6 januari 2004, NJ 2004, 200.

108 Corstens 2005a, p. 687. 
Zijn onderzoeksmogelijkheden zijn in dergelijke gevallen beperkt, ofwel omdat hij de getuige niet zelf heeft kunnen horen, ofwel omdat hij op het eerste gezicht niet beschikt over de vereiste expertise om te beoordelen of de onderzoeksresultaten voortvloeien uit deskundig onderzoek.

Door van de feitenrechter in dergelijke gevallen een nadere motivering te verlangen, wordt de rechterlijke verantwoordelijkheid voor de waarheidsvinding onderstreept. Niet partijen of andere betrokkenen, maar de rechter is uiteindelijk verantwoordelijk voor de waardering en vaststelling van de feiten. In die zin wordt de gulden hoofdregel dat het aan de rechter is voorbehouden om te oordelen over de betrouwbaarheid van het bewijsmateriaal alleen maar bevestigd. Teneinde echter die verantwoordelijkheid ook zichtbaar te maken, dient de rechter naar mate hij zich meer verlaat op externe expertise zijn oordeel over de bewijswaarde van het bewijsmateriaal meer te motiveren. ${ }^{109}$

\subsubsection{Eisen te stellen aan het verweer}

Zoals gezegd volgt uit het feit dat de Hoge Raad in een aantal gevallen een nadere motivering eist ten aanzien van de selectie en waardering van het bewijsmateriaal niet dat elk verweer van de verdediging om een rechterlijke reactie vraagt. Enerzijds is het aantal gevallen waarin de Hoge Raad een dergelijke responsieplicht aanneemt beperkt, anderzijds stelt de Hoge Raad ook eisen aan het verweer, wil het een reactie uitlokken.

Uit constante jurisprudentie van de Hoge Raad volgt dat alleen een nadere motiveringsplicht ontstaat indien de door de verdediging aangevoerde bewijsverweren tijdig zijn gedaan. Het verweer moet tijdens de feitelijke behandeling van de strafzaak zijn gevoerd. Verweren die eerst in cassatie aan de orde zijn gesteld zijn daarom niet tijdig en leiden ook niet tot een motiveringsplicht leiden. ${ }^{110}$ De tweede voorwaarde is dat verweren uitdrukkelijk ter zitting aan de orde moeten worden gesteld. Het in hoger beroep in algemene zin verwijzen naar de verweren die reeds in eerste aanleg zijn gevoerd is onvoldoende. ${ }^{111}$ Dat geldt evenzeer voor een verwijzing naar verweren die in een andere, daarmee samenhangende strafzaak zijn gevoerd. ${ }^{112}$ Wel is het toegestaan om ter zitting te volstaan met het mondeling herhalen van het verweer en vervolgens voor de onderbouwing van dat verweer te verwijzen naar de eveneens overgelegde pleitnota in eerste aanleg. ${ }^{13}$

109 In gelijke zin: Schalken in zijn annotatie onder HR 27 juni 2000, NJ 2000, 503.

110 HR 13 november 1991, NJ 1991, 278.

111 HR 15 maart 1994, NJ 1994, 511. In gelijke zin: HR 3 maart 1998, NJ 1999, 59, HR 30 juni 1998, NJ 1999, 60 m.nt. Kn en HR 16 maart 1999, NJ 1999, 369.

112 HR 18 oktober 1994, NJ 1995, 101.

113 HR 1 februari 2000, NJ 2000, 264. 
Wil er sprake zijn van een uitdrukkelijk gevoerd verweer, dan lijkt de Hoge Raad ook te eisen dat de verdediging haar verweer moet kwalificeren als een verweer dat noopt tot nadere verantwoording. Zo oordeelde de Hoge Raad dat het uitvoerige pleidooi van de raadsvrouwe met betrekking tot de betrouwbaarheid van bepaalde verklaringen en het onderzoek van de deskundige dienaangaande in de kern genomen er op neer kwam dat met de resultaten van dat onderzoek uiterst behoedzaam moest worden omgegaan. ${ }^{114}$ Uit het pleidooi volgde aldus de Hoge Raad niet dat de raadsvrouwe - gemotiveerd - had angevoerd dat de door de deskundige gehanteerde methode wetenschappelijk onverantwoord was en daarom was het hof ontslagen van zijn verplichting tot nadere verantwoording. De Hoge Raad was niet bereid om dat verweer als een jurisprudentieel erkend betrouwbaarheidsverweer te erkennen en hanteerde een zeer formalistisch standpunt. Dit in tegenstelling tot verweren die op basis van artikel 358 lid $3 \mathrm{~Sv}$ reeds tot een nadere motivering nopen. Ten aanzien van deze verweren is de Hoge Raad bereid om niet alleen naar de inhoud, maar ook naar de strekking ervan te kijken om te beoordelen of een expliciete rechterlijke respons is aangewezen. ${ }^{115}$ Indien deze wijze van interpreteren ook ten aanzien van bewijsverweren zou gelden, is niet langer de vraag of het door de verdediging aangevoerde een jurisprudentieel erkend bewijsverweer $i s$, maar of de feitenrechter het aangevoerde als zodanig had moeten verstaan. Het op een dergelijke wijze interpreteren van verweren doet meer recht aan het contradictoire karakter van de strafprocedure. De verdachte die een verweer voert, krijgt dan los van de inhoudelijke bewoordingen van zijn verweer, veel vaker antwoord op de vraag die in het verweer is vervat. Aldus ook advocaat-generaal Wortel:

'Een goede rechtsbedeling is er mee gediend dat niet wordt volstaan met hetgeen nodig is om tot een onaantastbare uitspraak te komen, maar ook boven de bestaande motiveringsplichten uitgaande inspanningen worden geleverd om uit te leggen waarom de in ernst betrokken stellingen niet worden gevolgd. ${ }^{116}$

Tot slot stelt de Hoge Raad behalve formele ook inhoudelijke eisen aan het verweer. Zo wordt van de verdediging gevergd dat zij het verweer motiveert. Waar het de feitelijke component van het verweer betreft, betekent dat dat zij concrete feiten en omstandigheden moet aandragen die haar stelling kunnen ondersteunen. ${ }^{117} \mathrm{Zo}$ dient de verdediging, indien zij de deskundigheid van de deskundige of de wetenschappelijkheid van de door hem toegepaste methode betwist, kenbaar te maken op welke gronden zij tot dat oordeel komt. Het enkel roepen dat een bepaalde onderzoeksmethode in haar algemeenheid niet betrouwbaar is, is in dat verband onvoldoende. Uit het door of namens de verdachte aangevoerde moet concreet

114 HR 10 september 2002, NJ 2002, 474.

115 Hierover uitvoerig: Knigge 1980, p. 97-111.

116 Advocaat-generaal Wortel in zijn conclusie bij HR 10 september 2002, NJ 2002, 474.

117 HR 8 juli 1992, NJ 1993, 407 m.nt. ThWvV. 
blijken dat en waarom in de gegeven strafzaak de methode tot onbetrouwbare resultaten heeft geleid. ${ }^{118}$ Het inbrengen van een andere deskundige zal dan noodzakelijk zijn. Wordt de sluitendheid van de bewijsconstructie betwist, zoals in geval van een Meer en Vaartverweer, dan dient de verdediging feiten in te brengen die het gat in de bewijsconstructie blootleggen. Het onderbouwen van het verweer met feiten moet echter niet gelijk worden gesteld met de eis dat de verdediging deze feiten moet bewijzen. Voldoende is dat de feiten aannemelijk zijn of kunnen worden. Ten aanzien van dat laatste wordt dan wel geëist dat de verdediging aangeeft op welke wijze nader onderzoek naar het bestaan van die feiten kan worden gedaan. Dat betekent dat het verweer voldoende informatie dient te bevatten voor nader onderzoek ${ }^{119}$ dan wel daarin voldoende aanleiding moet kunnen worden gevonden voor nader onderzoek. De stelling van de verdediging dat mogelijk een ander opzettelijk DNA-materiaal van verdachte op de plaats delict heeft achtergelaten, biedt te weinig aanknopingspunten voor nader onderzoek en mag als niet-aannemelijk aan de kant worden geschoven. ${ }^{120}$

Bevat het verweer tevens een juridische component, dan dient in het verweer de redenering besloten te liggen waaruit blijkt dat er sprake is van een verweer dat enkel door nadere motivering kan worden verworpen. Dat betekent dat de verdachte het verweer moet benoemen en de relevante factoren moet aanwijzen die bewijsrechtelijke consequenties kunnen hebben. Het meest uitgesproken heeft de Hoge Raad dit bepaald ten aanzien van onrechtmatig verkregen bewijsverweren. De Hoge Raad oordeelde in zijn standaardarrest over de toepassing van artikel 359a Sv dat het verweer niet enkel de feiten moet aanwijzen waaruit blijkt dat er sprake is geweest van onrechtmatig handelen, maar bovendien moet aangeven tot welke consequenties dit moet leiden met in achtneming van de daarvoor in de wet en in de jurisprudentie (nader) ontwikkelde criteria. ${ }^{121}$ Laat de verdediging dit achterwege dan is de rechter, indien hij het verweer niet accepteert, ontslagen van zijn responsieplicht:

'van de verdediging die een beroep doet op schending van een vormverzuim als bedoeld in art. 359a Sv, (mag) worden verlangd dat duidelijk en gemotiveerd aan de hand van die factoren wordt aangegeven tot welk in art. 359a Sv omschreven rechtsgevolg dit dient te leiden. Alleen op een zodanig verweer is de rechter gehouden een met redenen omklede beslissing te geven. ${ }^{122}$

De formele en materiële eisen die de Hoge Raad aan bewijsverweren stelt zijn op het eerste gezicht redelijk. Van de verdediging mag worden verwacht dat zij haar stellingen onderbouwt. Schieten met losse flodders is toegestaan, maar leidt niet

118 HR 3 juli 1995, NJ 1995, 734.

119 HR 1 juli 2003, NJ 2003, 545.

120 HR 10 december 2002, LJN AE6863.

121 HR 30 maart 2004, NJ 2004, 376 m.nt. YB.

122 HR 30 maart 2004, NJ 2004, 376 m.nt. YB (r.o. 3.7). Zie ook: HR 30 oktober 2001, NJ 2002,149 
tot resultaat. Daarbij zou echter de algemene kanttekening moeten worden gemaakt dat het nogal wat uitmaakt of de verdachte voorzien is van juridische bijstand of niet. Met name voor zover de Hoge Raad eist dat het verweer op juridisch juiste wijze wordt ingekleed en benoemd, valt te betwijfelen of men dergelijke vergaande eisen ook kan stellen aan verdachten zonder juridische bijstand. ${ }^{123}$

Los daarvan staat de vraag hoeveel men in dat verband van de verdediging mag verwachten. Zoals gezegd wordt niet geëist dat de verdediging de feiten en omstandigheden die zij aan haar verweer ten grondslag legt bewijst, maar keerzijde hiervan is wel dat de feitenrechter het verweer ongegrond mag achten met de enkele overweging dat deze feiten niet aannemelijk zijn geworden. ${ }^{124}$ Wil de verdediging voorkomen dat de rechter op een dergelijke wijze het verweer aan de kant schuift, dan zal zij meer moeten doen dan het enkele noemen van deze feiten. Dat is echter niet altijd eenvoudig. Met name in geval van onrechtmatigheidsverweren is de verdediging in belangrijke mate afhankelijk van de gegevens die haar door of vanwege het Openbaar Ministerie worden verstrekt. De mogelijkheid om haar verweer te onderbouwen, is in dat geval dus afhankelijk van de mate waarin het onderzoek voorafgaand aan de terechtzitting voldoende transparant is. Er iets voor te zeggen om in dergelijke gevallen niet te veel inhoudelijke eisen te stellen aan de feitelijke onderbouwing van het door de verdediging gevoerde verweer.

Maar ook buiten de gevallen van onrechtmatige bewijsgaring is het de vraag hoeveel men van de verdediging mag verlangen. Bij het toenemend gebruik van technisch bewijs kan men onmogelijk van de verdediging verlangen dat zij zonder vakkundige inbreng van anderen in staat is dat bewijs op zijn merites te beoordelen. Vaak blijkt ook de rechter niet in staat dit te beoordelen. Moet men nu van de verdediging verlangen dat zij op eigen gelegenheid en eigen kosten een deskundige inschakelt enkel om te bewerkstelligen dat haar verweer serieus genomen wordt? Mag in dat verband de verdediging worden tegengeworpen dat zij in een eerdere fase van het onderzoek niet om nadere onderzoekshandelingen heeft verzocht? Eenzelfde vraag kan worden opgeworpen met betrekking tot gevoerde Meer en Vaartverweren; moet de verdachte de alternatieve gang van zaken onderbouwen met (bijna) vaststaande feiten, terwijl hij nauwelijks invloed kan uitoefenen op de gang van zaken tijdens het opsporingsonderzoek?

Legt men de nadruk op het contradictoire karakter van het onderzoek ter terechtzitting en de eigen verantwoordelijkheid van de procespartijen, dan zullen deze vragen bevestigend worden beantwoord. Legt men daarentegen de nadruk op de materiële waarheidsvinding, dan zal het verweer eerder worden aangemerkt als

123 In gelijke zin: Corstens 2005a, p. 698 en Borgers \& Kristen 2005, p. 582: 'Hier dient de rechter op grond van zijn positie in het strafgeding compenserend op te treden door het feitelijke relaas van deze verdachte welwillend aan te horen, waarnodig het verhaal te preciseren door het stellen van vragen alsmede volledig uit eigen beweging en zonder richtinggeven van een raadsman de rechtsgevolgen te verbinden aan het relaas.'

124 Bijvoorbeeld: HR 31 oktober 2000, NJ 2001, 238 m.nt. Sch. 
een vingerwijzing van de verdediging dat er nader onderzoek moet plaatsvinden opdat de zittingsrechter met kracht van argumenten het verweer ofwel weerlegt ofwel volgt.

Het vreemde ten aanzien van de motiveringsplicht aangaande verweren is nu juist dat de noodzaak van die motiveringsplicht valt af te leiden uit de idee van materiële waarheidsvinding, maar de omvang van die motiveringsplicht in verregaande mate afhankelijk wordt gesteld van het optreden van de verdediging. Daarmee lijkt de rechtspraak van de Hoge Raad dubbelzinnig, de verantwoordelijkheid ligt in principe bij de zittingsrechter, maar deze kan die verantwoordelijkheid vervolgens afschuiven op de verdediging, als deze geen tijdig dan wel nadrukkelijk verweer heeft gevoerd of wel heeft nagelaten het verweer voldoende te onderbouwen.

\subsubsection{De wet van 10 november 2004: een algemene responsieplicht}

In zijn annotatie bij het arrest van de Hoge Raad d.d. 17 april 2001 vroeg Schalken zich, zoals gezegd, af hoelang de Hoge Raad de als sacraal gepresenteerde hoofdregel van de ongemotiveerde bewijskeuze nog overeind zou kunnen houden. ${ }^{125}$ Hij refereerde toen reeds aan een mogelijke wetswijziging op dit punt. Die wetswijziging is er gekomen. Bij wet van 10 november $2004^{126}$ is an artikel 359 lid 2 een nieuwe regel toegevoegd.

'Het vonnis geeft, indien de beslissing afwijkt van door de verdachte dan wel door de officier van justitie uitdrukkelijk onderbouwde standpunten, in het bijzonder de redenen op die daartoe hebben geleid.'

De totstandkoming van deze bepaling kent een bijzondere achtergrond, en mede daarom bleef in eerste instantie onduidelijk welke betekenis moest worden toegekend aan de tweede volzin. Corstens meende dat het grotendeels een codificatie van de bestaande jurisprudentie inhield. ${ }^{127}$ Anderen daarentegen meenden dat aan het gewijzigde artikel 359 lid 2 een verdergaande strekking moest worden toegekend. De onduidelijkheid is deels weggenomen door het standaardarrest van de Hoge Raad inzake de toepassing van het nieuwe artikel 359 lid 2 Sv. ${ }^{128}$ Alvorens daarop in te gaan, zal eerst aandacht worden besteed aan de bijzondere totstandkoming van de nieuwe motiveringsplicht.

125 Schalken in zijn annotatie onder HR 17 april 2001, NJ 2002, 107.

126 Wet van 10 november 2004 (aanpassing eisen motivering bewezenverklaring bekennende verdachte), Stb. 2004, 580 (inwerkingtreding 1 januari 2005, Stb. 2004, 641).

127 Corstens 2005a, p. 687

128 HR 11 april 2006, NJ 2006, 393 m.nt. Y. Buruma. 


\subsubsection{Totstandkoming}

Het gewijzigde artikel 359 lid $2 \mathrm{~Sv}$ vindt zijn oorsprong in een ingediend amendement bij het wetsvoorstel 'herijking wettelijke strafmaxima'. Het amendement had tot doel te komen tot een nadere motivering van de straf, voor zover die afweek van hetgeen de officier van justitie had geëist. Daartoe werd voorgesteld het toenmalige lid 7 als volgt te wijzigen:

'Indien een andere straf wordt opgelegd dan de officier van justitie heeft gevorderd, dan wel een straf onvoorwaardelijk wordt opgelegd die vrijheidsbeneming van langere duur medebrengt dan de officier van justitie heeft gevorderd, geeft het vonnis steeds in het bijzonder de redenen op die daartoe hebben geleid. Indien de rechtbank de officier van justitie niet volgt op dragende onderdelen in het requisitoir, motiveert zij dit [cursivering WD]. ${ }^{129}$

Achtergrond van het amendement was dat de indieners Wolfsen en Griffith - in navolging van de Minister van Justitie ${ }^{130}$ - meenden dat meer dan thans van de officier van justitie en de rechter mag worden verwacht dat zij zich rekenschap geven van de invloed van hun beslissingen op het maatschappelijk debat. Daartoe zou de officier van justitie zijn vordering moeten motiveren en de rechter op zijn beurt moeten motiveren waarom hij afwijkt van die vordering. Uit de toelichting behorende bij het amendement blijkt dat de indieners met name oog hadden voor de strafmotivering en motivering van de vrijspraak:

'Meer dan thans het geval is moet een rechterlijke uitspraak inzicht geven in de redenen die hebben geleid tot de aard en hoogte van de opgelegde straf of maatregel. Ook een vrijspraak moet (beter) worden gemotiveerd door in het vonnis op te nemen waarom de rechtbank het bewijs niet voldoende wettig en overtuigend acht. Dit kan bijvoorbeeld door in het vonnis aan te geven welk deel van de tenlastelegging niet bewezen wordt geacht. ${ }^{, 131}$

Het amendement beoogde de positie van de verdediging en die van het Openbaar Ministerie gelijk te trekken. Waar de verdediging recht heeft op een antwoord op haar verweren, zou ook de officier van justitie te horen moeten krijgen waarom zijn standpunten zoals ingenomen in zijn vordering niet worden gevolgd.

Omdat aldus het amendement niet alleen betrekking had op de strafmaat en meer in algemene zin zag op motiveringseisen, werd besloten het amendement over te hevelen naar het wetsvoorstel 'aanpassing eisen motivering bewezenverklaring bekennende verdachte'. ${ }^{132}$ Daarin zou het beter passen nu ook dat voorstel uitging van de onderliggende gedachte dat de motivering zou moeten worden toegespitst op geschilpunten. Zijn er geen geschilpunten, dan kan op de motiveringsplichten worden bezuinigd; zijn die er wel, dan dient uit het vonnis te blijken op welke

129 Kamerstukken II 2003-2004, 28484, nr. 17.

130 Kamerstukken II 2003-2004, 29271, nr. 1, p. 10.

131 Kamerstukken II 2003-2004, 28484, nr. 17, p. 2.

132 Kamerstukken II 2003-2004, 28484, nr. 34, p. 42-43. 
wijze de rechter die heeft beoordeeld. Daarbij mag geen onderscheid worden gemaakt tussen de positie van de verdediging en die van het Openbaar Ministerie. Het toespitsen van de motivering op geschilpunten was geheel in lijn met de eerder gedane voorstellen van de onderzoeksgroep Strafvordering 2001. In het eerste rapport van deze onderzoeksgroep was eveneens voorgesteld om de motiveringsplicht te laten aansluiten bij de proceshouding van de betrokkenen:

'uitwerking van dit principe brengt mee dat bij het voeren van tegenspraak 'rechterlijk gehoor' mag worden verwacht, in die zin dat van de rechter een expliciet antwoord mag worden verlangd op een aangevoerd verweer. Spiegelbeeldig geldt hetzelfde principe bij vrijspraak. Als het openbaar ministerie in het requisitoir te kennen heeft gegeven dat het feit wettig en overtuigend kan worden bewezen, mag van de rechter worden verwacht dat hij uitleg geeft van het anders luidende standpunt. ${ }^{133}$

Mede in het licht van de ideeën van de Onderzoeksgroep Strafvordering 2001 waaraan de indieners zich zoals blijkt uit hun toelichting refereerden, ${ }^{134}$ en de gewijzigde tekst kreeg het oorspronkelijke amendement een veel verdergaande strekking. Waar het eerst voornamelijk zag op de strafmotivering wordt het bereik van de bepaling uitgebreid tot alle beslissingen van de rechter. Bovendien geldt de bepaling niet alleen voor standpunten van het Openbaar Ministerie, maar ook voor die van de verdediging. De verdergaande strekking van het amendement werd ook door de minister onderkend en onderschreven:

'Op dat punt is het amendement dat ter tafel lag, te eenzijdig omdat de motivering van de afwijking van de vordering alleen de strafmaat betreft. Uit de tekst die de heer Wolfsen zojuist gebruikte, begrijp ik dat hij het eens is met de zienswijze dat (...) wij het moeten verbreden tot alle gevallen waarin in het vonnis wordt afgeweken van zaken die uitdrukkelijk zijn voorgedragen door een van de partijen. Aan de ene kant moet ik constateren dat wij dan in het kader van de vermindering van de werklast een vermeerdering introduceren. Aan de andere kant begrijp ik ook dat als het ergens over moet gaan, het moet gaan over de punten waarop wordt afgeweken. Om die reden kan ik mij vinden in het amendement., ${ }^{, 35}$

Het amendement werd aangenomen en zo ontstond de situatie dat de wet 'aanpassing eisen motivering bewezenverklaring bekennende verdachte' die oorspronkelijk was bedoeld om de werklast van rechtbanken en hoven te verminderen, uiteindelijk ook een bepaling bevatte die mogelijk tot veel meer werk zou leiden. Uit de letter-

133 Simmelink 1999, p. 450.

134 Hetgeen blijkt uit de toelichting bij het amendement; 'Strafvordering 2001 bepleit de ontwikkeling naar een contradictoire strafprocedure. Het onderhavige wetsvoorstel geeft invulling aan deze richting door bij een bekennende verdachte de procedure te vereenvoudigen. Daar tegenover staat dat de door de verdediging en/of door de officier van justitie ingenomen en onderbouwde standpunten expliciet moeten worden besproken in het vonnis als ze niet worden gevolgd. Hieronder wordt mede begrepen het geval dat de rechtbank bij vonnis afwijkt van de gemotiveerde vordering van de officier van justitie, ook indien de straf lager is.'

135 Kamerstukken II 2003-2004, 29252 enz., nr. 8, p. 21. 
lijke tekst van het gewijzigde artikel 359 lid 2 Sv volgt immers dat elk verweer van de verdediging en elk standpunt van de officier van justitie dat niet door de feitenrechter wordt overgenomen tot een nadere motivering moet leiden. Groenhuijsen verbaast zich over deze gang van zaken:

'Het is voor mij onbegrijpelijk dat de minister, die toch strak in de leer is waar het gaat om het bewaken van de werklast van de rechterlijke macht, niet groot bezwaar heeft gemaakt tegen het amendement Wolfsen/Griffiths. ${ }^{136}$

Vervolgens wordt door diverse auteurs de reikwijdte van de nieuwe bepaling bediscussieerd. Zowel Groenhuijsen ${ }^{137}$ als Fokkens ${ }^{138}$ stellen vragen bij de verhouding tussen het nieuwe artikel 359 lid $2 \mathrm{~Sv}$ en het bestaande artikel 358 lid $3 \mathrm{~Sv}$. Op grond van die laatste bepaling moeten verweren, niet zijnde bewijsverweren, gemotiveerd worden weerlegd. Thans lijkt deze verplichting twee keer te worden voorgeschreven, aangezien ook artikel 359 lid $2 \mathrm{~Sv}$ eist dat in het vonnis de beslissing om standpunten van de verdediging (verweren) niet te volgen door de rechter met redenen moeten zijn omkleed. Waar echter het nieuwe tweede lid van artikel $359 \mathrm{~Sv}$ eist dat die standpunten uitdrukkelijk en onderbouwd moeten zijn, wordt een dergelijke eis ten aanzien van verweren ex artikel 358 lid $3 \mathrm{~Sv}$ thans in de jurisprudentie niet gesteld. Dient nu de zwaardere eis ook te gelden voor verweren ex artikel 358 lid $3 \mathrm{~Sv}$ ? ${ }^{139}$ Corstens meent dat het nieuwe artikel 359 lid $2 \mathrm{~Sv}$ moet worden beschouwd als een codificatie van de bestaande jurisprudentie met betrekking tot de bewijsverweren en in zoverre geen nadere uitbreiding met betrekking tot verweren van de verdediging inhoudt. De uitbreiding zit vooral daarin dat op grond van de nieuwe bepaling ook standpunten van het Openbaar Ministerie gemotiveerd moeten worden weerlegd, bijvoorbeeld indien de rechter tot een (partiële) vrijspraak komt. ${ }^{140}$ Fokkens verwacht dat de nieuwe volzin van artikel 359 lid $2 \mathrm{~Sv}$ wel degelijk consequenties voor de motivering van bewijs-

136 Groenhuijsen 2005b, p. 358. Ook Borgers 2006, p. 748 wijst op dit problematische karakter van de wetswijziging: 'er lijkt een vrijwel ongelimiteerde motiveringsplicht te worden toegevoegd aan een - tot nu toe - overwegend gesloten stelsel van specifieke wettelijke en jurisprudentiële motiveringsplichten, zonder dat er blijk van wordt gegeven dat die verruiming ook daadwerkelijk wordt nagestreefd en zonder dat de consequenties daarvan - in het bijzonder voor wat de betreft de toename in werklast van de zittende magistratuur - expliciet worden onderkend en aanvaard'.

137 Groenhuijsen 2005 b, p. 358.

138 Fokkens 2005, p. 145-146.

139 Fokkens 2005, p. 146 beantwoordt die vraag ontkennend. In zijn optiek heeft art. 359 lid 2, tweede volzin, Sv ten opzichte van 358 lid 3 Sv een aanvullend karakter, 'welk aanvullend karakter wel de vraag oproept waarom bijvoorbeeld voor een verweer als bedoeld in art. 358 lid $3 \mathrm{~Sv}$ andere eisen gelden dan voor verweren die uitsluitend onder het bereik van 359 lid 2 Sv vallen'.

140 Corstens 2005a, p. 687. Corstens baseert zich daarbij op de uitspraak van Wolfsen, één van de indieners, inhoudende: 'Hiermee wordt aangehaakt bij de bestaande praktijk van reageren op verweren van de verdediging. Die verplichting wordt nu ook opgelegd voor betogen van de officier van justitie'. Kamerstukken II 2003-2004, 29252 enz, nr. 8 , p. 7. 
verweren én verweren met betrekking tot de op te leggen straf zal hebben. Ten aanzien van de eerste verwacht hij dat veel vaker dan nu ook betrouwbaarheidsverweren een nadrukkelijke reactie van de rechter zullen uitlokken. ${ }^{141}$ Van Oosten en Takens sluiten zich hierbij aan en geven alvast een voorzet over de wijze waarop in de toekomst betrouwbaarheidsverweren moeten worden ingekleed, willen zij de rechter dwingen tot een gemotiveerde én juiste keuze. ${ }^{142}$

\subsubsection{Uitleg van de Hoge Raad}

De onduidelijkheid over het nieuwe artikel 359 lid $2 \mathrm{~Sv}$, die mede het gevolg is van de wijze waarop het is tot stand gekomen, maakte dat een uitspraak van de Hoge Raad over betekenis en reikwijdte van de nieuwe bepaling niet lang kon uitblijven. Op 14 april 2006 was het zover. ${ }^{143}$ En in navolging van andere standaardarresten, wijst ook nu de Hoge Raad een arrest waarin stap voor stap op de juridische merites, in dit geval van artikel 359 lid $2 \mathrm{~Sv}$, wordt ingegaan. In zijn voorafgaande beschouwingen gaat de Hoge Raad in op drie aspecten van de nieuwe regeling, te weten de reikwijdte van artikel 359 lid $2 \mathrm{~Sv}$, de eisen die worden gesteld aan uitdrukkelijke onderbouwde standpunten en tot slot de omvang van de motiveringsplicht.

\subsection{De reikwijdte}

Op basis van de bewoordingen en de totstandkomingsgeschiedenis van het nieuwe artikel 359 lid 2 Sv komt de Hoge Raad tot de conclusie dat de reikwijdte van de nieuwe bepaling zeer ruim is en in principe ziet op alle betogen van zowel Openbaar Ministerie als verdediging. Voor zover de rechter de daarin verwoorde standpunten niet volgt, dient hij daarover in zijn vonnis verantwoording af te leggen. Het aannemen van een dergelijk ruim toepassingsgebied wordt beargumenteerd vanuit de belangen die gediend zijn met een uitgebreide motiveringsplicht, te weten:

'de belangen van de procesdeelnemers en de samenleving bij inzicht in de motivering van strafvonnissen alsmede (...) het belang van de zelfcontrole door de rechter en controle door de hogere rechter van de oordeelvorming van de lagere rechter.'144

Expliciet geeft de Hoge Raad aan dat artikel 359 lid 2 Sv niet slechts ziet op de codificatie van de motiveringsvoorschriften zoals die door de Hoge Raad zijn ontwikkeld. Daarmee neemt hij afstand van de door Corstens verwoorde opvatting.

141 Fokkens 2005, p. 148. In gelijke zin: advocaat-generaal Machielse in zijn conclusie bij HR 16 mei 2006, NJ 2007, 119.

142 Van Oosten en Takens 2005, p. 677

143 HR 14 april 2006, NJ 2006, 393 m.nt. Y. Buruma en $A A$ 2006, p. 745-754 m.nt. M.J. Borgers.

144 HR 14 april 2006, NJ 2006, 393 (r.o. 3.5). 
Evenmin is het toepassingsbereik beperkt tot het verlenen van aanspraak van het Openbaar Ministerie op een gemotiveerde beslissing. Thans heeft het Openbaar Ministerie een dergelijke aanspraak niet, omdat artikel 358 lid 3 juncto 359 lid 2 (oud) $\mathrm{Sv}$ en de jurisprudentie van de Hoge Raad inzake motiveringsplichten alleen zien op verweren van de zijde van de verdediging.

Ook de verhouding tot de reeds bestaande motiveringsplicht ex artikel 358 lid 3 juncto 359 lid $2 \mathrm{~Sv}$ wordt besproken. De Hoge Raad lijkt hier te opteren voor wat Fokkens het aanvullende karakter van de nieuwe bepaling heeft genoemd. Alle verweren die thans niet vallen onder artikel 358 lid $3 \mathrm{~Sv}$, dienen nu op basis van artikel 359 lid 2, tweede volzin, Sv alsnog gemotiveerd te worden. ${ }^{145}$ De reeds in artikel 358 lid $3 \mathrm{~Sv}$ genoemde responsieplicht blijft bestaan en artikel 359 lid $2 \mathrm{~Sv}$ is daarop niet van toepassing. ${ }^{146}$ De consequentie van de wetswijziging is in de eerste plaats dat thans een wettelijke responsieplicht geldt voor alle bewijsverweren en alle verweren met betrekking tot de op te leggen straf. In de tweede plaats verkrijgt het Openbaar Ministerie op basis van artikel 359 lid 2, tweede volzin, $\mathrm{Sv}$ aanspraak op een gemotiveerde weerlegging van zijn standpunten. Voor zowel Openbaar Ministerie als verdediging geldt dat zij recht hebben op een nadere motivering voor zover zij een uitdrukkelijk onderbouwd standpunt hebben ingenomen met betrekking tot de bewijsbeslissing en de beslissing over de oplegging van de straf en/of maatregel én de rechter daarvan afwijkt. ${ }^{147}$ De Hoge Raad spreekt hier nadrukkelijke over een nadere motivering omdat reeds op basis van de andere leden van artikel $359 \mathrm{~Sv}$ een motiveringsplicht bestaat. Het aanvullende karakter van 359 lid 2, tweede volzin, Sv ziet dus niet alleen op de beslissing waarvoor de bepaling geldt, maar ook op de inhoud van de motivering. ${ }^{148}$ Voor zover reeds op basis van andere wettelijke voorschriften een motiveringsplicht ten aanzien van het bewijs geldt, blijft deze bestaan en is het reageren op standpunten van de procespartijen daaraan ondergeschikt. Het belang hiervan komt aan de orde bij de bespreking van de omvang van de motiveringsplicht.

145 HR 13 juni 2006, NJ 2006, 371 (r.o. 4.2).

146 HR 20 februari 2007, $L J N$ AZ5717 (r.o. 3.4): 'In dit geval [een beroep op psychische overmacht, WD] bestond evenmin een nadere motiveringsplicht op grond van art. 359, tweede lid, Sv. De inwerkingtreding van die bepaling heeft geen verandering gebracht in de motiveringseisen die reeds op grond van art. 358, derde lid, Sv in verbinding met art. 359, tweede lid (oud), Sv bestonden ten aanzien van de in eerstgenoemd artikellid bedoelde verweren, zoals het beroep op een strafuitsluitingsgrond.'

147 Borgers 2006, p. 750 spreekt in dit verband van een 'complementaire' motiveringsplicht: 'Er is sprake van een complementaire motiveringsplicht in die gevallen waarin onder het oude recht geen motiveringsplicht bestond.'

148 Borgers 2006, p. 750: 'Het is lastiger te beoordelen of de tweede volzin van artikel 359 lid 2 Sv ook leidt tot een "verdergaande" motiveringsplicht. Het gaat dan om de vraag of dit voorschrift ertoe dwingt dat in situaties waarvoor reeds een motiveringsplicht gold, thans een meer omvattende motivering moet worden gegeven.' 


\subsection{Uitdrukkelijk onderbouwde standpunten}

Lijkt de Hoge Raad enerzijds het toepassingsgebied van artikel 359 lid 2 ruim op te vatten, anderzijds wordt dat weer voor een groot deel tenietgedaan door de zeer strenge eisen die hij stelt aan het standpunt, wil dat een reactie van de rechter kunnen uitlokken. Het standpunt dient:

'duidelijk, door argumenten geschraagd en voorzien van een ondubbelzinnige conclusie ten overstaan van de feitenrechter naar voren te zijn gebracht., ${ }^{149}$

De Hoge Raad stelt dezelfde eisen aan het standpunt als reeds ten aanzien van het onrechtmatig verkregen bewijsverweer ex artikel 359a Sv. ${ }^{150}$

De verantwoordelijkheid voor de schriftelijke vastlegging van het standpunt en de exacte bewoordingen daarvan in het proces-verbaal van de terechtzitting ligt bij de procespartijen. Zij kunnen in overeenstemming met artikel 326 lid $4 \mathrm{~Sv}$ de griffier verzoeken dat het gevoerde verweer en de gronden waarop het berust in het procesverbaal aan te tekenen. De verdediging heeft bovendien de mogelijkheid om een pleitnota over te leggen. ${ }^{151}$ Blijkt uit het proces-verbaal niet dat een verweer is gevoerd, dan wel een uitdrukkelijk standpunt is ingenomen, dan kan over het niet in acht nemen van artikel 359 lid 2 niet met succes worden geklaagd. Dat geldt ook indien in het proces-verbaal van de zitting enkel is aangetekend dat de verdachte het woord ter verdediging heeft gevoerd zonder dat de inhoud van het relaas is opgenomen in het proces-verbaal. Ook in een dergelijk geval geldt de eigen verantwoordelijkheid van procespartijen om er op toe te zien dat hun standpunt correct en volledig in het proces-verbaal wordt aangetekend. ${ }^{152}$ Alleen van de niet van rechtsbijstand voorziene verdachte wordt dat niet verwacht:

'Van de verdachte die niet door een raadsman wordt bijgestaan, kan in redelijkheid niet worden gevergd dat hij een pleitnota overlegt dan wel overeenkomstig art. 326, vierde lid, Sv aantekening verzoekt van hetgeen hij ter verdediging heeft aangevoerd. De verdachte mag erop vertrouwen dat het door de voorzitter en de griffier vastgestelde proces-verbaal de kern weergeeft van eventuele door hem naar voren gebrachte verweren en onderbouwde standpunten die tot een gemotiveerde beslissing nopen. ${ }^{153}$

149 HR 11 april 2006, NJ 2006, 393 m.nt. Y. Buruma (r.o. 3.7.1).

150 HR 30 maart 2004, NJ 2004, 376 m.nt. YB.

151 Zie voor een voorbeeld waarin het verweer niet was aangetekend in het proces-verbaal van de zitting: HR 27 juni 2006, LJN AW2473. In die zaak was namens de verdediging wel een rapport van Van Koppen overgelegd en ook aan het dossier toegevoegd. Een verweer naar aanleiding van de inhoud van dit rapport was blijkens het proces-verbaal niet gevoerd, evenmin had de raadsman een pleitnota overgelegd. De Hoge Raad hield ook hier vast aan zijn strikte uitleg: aan de inhoud van het rapport hoefde in het vonnis geen aandacht te worden besteed bij gebrek aan een terzake gevoerd verweer.

152 HR 9 januari 2007, NJ 2007, 53

153 HR 9 januari 2007, NJ 2007, 53 r.o. 3.5. 
De vraag is echter wat er dient te gebeuren als dat vertrouwen wordt geschaad; in dat geval blijkt niet dat er uitdrukkelijk onderbouwde standpunten zijn ingenomen en staat de niet van rechtsbijstand voorziene verdachte nog steeds met lege handen. Naast de eisen die worden gesteld aan de wijze waarop het standpunt moet worden gepresenteerd, gelden ook ten aanzien van de inhoud strikte voorwaarden. Het standpunt moet ten eerste goed zijn onderbouwd. Dat betekent dat verweren in de vorm van telegramstijl het niet redden. ${ }^{154}$ De enkele vordering van de officier van justitie is trouwens ook onvoldoende. ${ }^{155}$ Een tweede voorwaarde is dat het standpunt een ondubbelzinnige conclusie moet bevatten. Het noemen van bepaalde incongruenties in getuigenverklaringen zonder daaraan een consequentie te verbinden, is onvoldoende. ${ }^{156}$ Het lijkt er bovendien op dat in navolging van de rechtspraak inzake onrechtmatige bewijsgaring het standpunt moet uitmonden in een juridische consequentie ten aanzien van één van de door de rechter te beantwoorden vragen. Zo vormde bijvoorbeeld het standpunt van de verdediging dat het resultaat van een geuridentificatieproef enkel als steunbewijs mocht worden gebruikt, geen standpunt in de zin van artikel 359 lid 2 Sv. ${ }^{157}$

Het stellen van zulke hoge eisen aan het verweer veronderstelt dat aan de zijde van de procespartijen voldoende kwaliteit aanwezig is om op een dusdanig wijze hun standpunten in te kleden. Opvallend genoeg wordt met name vanuit de advocatuur erop gewezen dat niet in alle gevallen die kwaliteit gegarandeerd is. ${ }^{158}$ Men kan dit, zoals Borgers, zien als een probleem van de beroepsgroep sec, ${ }^{159}$ maar mij dunkt dat de motivering niet in de eerste plaats in het belang van de optredende raadsman is, maar bovenal dient om de verdachte inzicht te geven in de beslissing van de rechter. Het mag niet zo zijn dat hij daarvan verstoken blijft enkel en alleen omdat zijn raadsman onvoldoende precisie aan de dag legt. De feitenrechter zou zich mijns inziens niet te snel achter het niet goed functioneren van de

154 HR 28 februari 2006, LJN AU9426.

155 Het gaat dan met name om het standpunt ten aanzien van de straftoemeting. HR 3 oktober 2006, NJ 2006, 549 (r.o. 3.5.4): 'Gelet op hetgeen hiervoor is overwogen, moet worden aangenomen dat de enkele, op de voet van art. 311, eerste lid, Sv overgelegde vordering van het openbaar ministerie niet oplevert een uitdrukkelijk onderbouwd standpunt in de zin van art. 359, tweede lid, Sv. Afwijking van die enkele vordering behoeft derhalve niet op grond van laatstgemeld artikellid nader te worden gemotiveerd. Dit neemt niet weg dat zich het geval kan voordoen dat de door de rechter opgelegde straf in die mate afwijkt van de door het openbaar ministerie gevorderde straf dat de strafoplegging zonder opgave van de redenen die tot die afwijking hebben geleid, onbegrijpelijk zou zijn.'

156 HR 16 mei 2006, NJ 2007, 119.

157 HR 12 september 2006, NJ 2007, 121. In gelijke zin: HR 4 juli 2006, NJ 2006, 386.

158 Spronken 2001, p. 150: 'Al met al betekent dit dat het lot van een verdachte vaak afhangt van een kwalitatief goede verdediging'. In gelijke zin: Franken 2004a, p. 43: 'Ik zie een onrustbarende kwaliteitsvermindering - die mede het gevolg zal zijn van de werkdruk - bij alle professionele deelnemers aan het strafproces: bij rechters, bij het openbaar ministerie en bij advocaten die rechtsbijstand in strafzaken verlenen.'

159 Borgers 2006, p. 752. 
advocatuur mogen verstoppen teneinde zijn motiveringsplichten te beperken. De Hoge Raad biedt echter de feitenrechter hier alle ruimte toe en sterker nog komt hem op dit punt zelfs tegemoet:

'Het hof heeft dit onderdeel van de pleitnota kennelijk [cursivering WD] niet opgevat als een uitdrukkelijk onderbouwd standpunt in de zin van art. 359, tweede lid, Sv. Dat oordeel getuigt niet van een onjuiste rechtsopvatting en is niet onbegrijpelijk, zodat het middel tevergeefs is voorgesteld. ${ }^{, 160}$

De plicht van procespartijen om hun standpunt te onderbouwen, geldt niet alleen voor de feitelijke aanleg. Wil in cassatie een succesvol beroep op het niet naleven van de jongste motiveringsplicht gedaan worden, dan dient in het cassatiemiddel met voldoende precisie te worden aangegeven op welk met argumenten onderbouwd standpunt de klacht het oog heeft. Laat men dit achterwege, dan leidt ook dit tot een ongegrondverklaring van het middel. Een groot aantal klachten over schending van artikel 359 lid $2 \mathrm{~Sv}$ (nieuw) is reeds op dit formele punt gestrand. De Hoge Raad doet dit vrij eenvoudig af:

'Blijkens de toelichting op het middel betreft de klacht 'de verweren' die ter terechtzitting in hoger beroep zijn gevoerd. Daarbij is niet nader aangeduid op welke verweren de klacht ziet. Aldus is niet met voldoende precisie aangegeven op welke met argumenten onderbouwde standpunten het middel het oog heeft. Daarom kan het middel niet tot cassatie leiden. ${ }^{, 161}$

Het door Fokkens gesignaleerde eigenaardige verschil tussen eisen die worden gesteld aan verweren van de verdediging in de zin van artikel 358 lid $3 \mathrm{~Sv}$ en eisen die aan de onderbouwing van de standpunten ex artikel 359 lid 2, tweede volzin, $\mathrm{Sv}$ worden gesteld, is overigens door de Hoge Raad rechtgetrokken. Zoals Fokkens reeds verwachtte, worden aan verweren in de zin van artikel 358 lid $3 \mathrm{~Sv}$ even stringente eisen gesteld als thans aan standpunten in de zin van artikel 359 lid 2 Sv. De vroegere jurisprudentie waarbij een verweer in de zin van 358 lid 3 al een rechterlijke respons diende op te leveren zodra de strekking van dat verweer de rechter duidelijk had moeten zijn, ${ }^{162}$ is verlaten. De Hoge Raad overwoog:

'Het Hof heeft gelet op hetgeen door en namens de verdachte is aangevoerd de hiervoor onder 3.3.1 bedoelde verklaring van verdachte kennelijk niet opgevat als mede behelzende een beroep op noodweer. Dat is niet onbegrijpelijk in aanmerking genomen dat de verdachte ter terechtzitting in hoger beroep werd bijgestaan door een raadsman die, naar blijkt uit het proces-verbaal van de terechtzitting in hoger

160 HR 18 april 2006, NJ 2006, 394. In vergelijkbare zin: HR 18 april 2006, LJN AV2377; HR 16 mei 2006, LJN AV1581; HR 16 mei 2006, NJ 2007, 119; HR 6 juni 2006, NJ 2006, 330; HR 27 juni 2006, LJN AW2473 en HR 4 juli 2006, NJ 2006, 386.

161 HR 18 april 2006, NJ 2006, 395. Zie ook: HR 18 april 2006, LJN AU8914; HR 18 april 2006, LJN AU8913; HR 16 mei 2006, LJN AU8920 en HR 16 mei 2006, LJN AU8917.

162 Fokkens 2006, p. 26. Fokkens meent dat het niet ondenkbaar is dat de stringente eisen die worden gesteld aan verweren of standpunten in de zin van 359 lid $2 \mathrm{~Sv}$ in de toekomst ook zullen worden gesteld aan verweren in de zin van art. 358 lid $3 \mathrm{~Sv}$. 
beroep, anders dan bij de berechting in eerste aanleg, geen beroep heeft gedaan op noodweer. ${ }^{163}$

Thans geldt ook bij verweren in de zin van artikel 358 lid $3 \mathrm{~Sv}$ dat het standpunt moet worden verwoord met een duidelijke conclusie. ${ }^{164}$ Laat de raadsman dit na, dan hoeft de feitenrechter het relaas niet op te vatten als verweer en dientengevolge is de feitenrechter ook ontslagen van zijn responsieplicht.

Dat brengt ons bij de vraag in hoeverre de stringente eisen die worden gesteld aan de inkleding van het verweer ook gelden indien de verdachte niet is voorzien van juridische bijstand. Ten aanzien van de verweren in de zin van artikel 358 lid 3 Sv stelt de Hoge Raad minder strikte eisen aan de verdachte zonder raadsman dan aan de verdachte met raadsman. Dat zou ook moeten gelden voor de meer juridische verweren, zoals de dakdekkersverweren en onrechtmatig verkregen bewijsverweren. Men kan toch onmogelijk van de verdachte verlangen dat hij zijn bezwaren op de juiste wijze inkleedt. Maar ook ten aanzien van de meer feitelijke verweren is kwestieus of van de verdachte verlangd mag worden dat hij daarop het juiste juridische label plakt. Weliswaar heeft de Hoge Raad in zijn arrest d.d. 9 januari $2007^{165}$ aangegeven dat niet van een verdachte zonder rechtsbijstand kan worden verwacht dat hij een pleitnota overlegt of verzoekt om aantekening van zijn standpunt in het proces-verbaal van de zitting, maar daarmee is nog niets gezegd over de vraag welke inhoudelijke eisen aan zijn betoog moeten worden gesteld. Het is te hopen dat ook ten aanzien daarvan de Hoge Raad een zekere soepelheid van de feitenrechter zal verwachten; deze zal als vangnet moeten fungeren en welwillend de bezwaren van de verdachte moeten aanhoren en interpreteren. ${ }^{166}$

\subsection{De omvang van de motiveringsplicht}

Blijkt er sprake te zijn van een beslissing die valt onder artikel 359 lid 2, tweede volzin, Sv en is te dien aanzien door een van de procespartijen een uitdrukkelijk onderbouwd standpunt ingenomen, dan dient de rechter indien hij van dat standpunt afwijkt, deze beslissing met redenen te omkleden. Zoals reeds aangegeven wordt de motiveringsplicht met betrekking tot de bewijsverweren beschouwd als een nadere motiveringsplicht, in aanvulling op de reeds bestaande motiveringsplichten in de leden 2 en 3 van artikel 359 Sv. Het kwalificeren van de responsieplicht als een nadere motiveringsplicht heeft ook consequenties voor de omvang van die

163 HR 6 september 2005, NJ 2006, 85. In gelijke zin: HR 20 februari 2007, LJN AZ5717 (r.o. 3.4).

164 Van Dorst schreef in 2004 nog: 'Niet vereist is dat de verdachte of diens raadsman een (juist) etiket op zijn feitelijke betoog plakt'. Van Dorst 2004, p. 217. Thans lijkt mij die opvatting niet meer juist.

165 HR 9 januari 2007, NJ 2007, 53

166 In gelijke zin: Borgers 2006, p. 752 en Vegter 2005, p. 583. 
responsieplicht. De Hoge Raad heeft het echter nodig geacht om op dit punt enige relativeringen aan te brengen.

\subsection{In de uitspraak zelf ligt reeds een nadere motivering besloten}

Een nadere motivering naar aanleiding van een door partijen ingenomen standpunt is niet noodzakelijk indien de uitspraak reeds zelf voldoende gegevens bevat waarin die nadere motivering besloten ligt. Te denken valt dan aan de in het vonnis opgenomen inhoud van de bewijsmiddelen of de bewijsoverwegingen. Valt daaruit reeds de weerlegging van het bewijsverweer te destilleren, dan leidt het achterwege laten van een rechterlijke respons niet tot nietigheid.

In een aantal gevallen achtte de Hoge Raad een dergelijke relativering van de nietigheid van het vonnis op zijn plaats. Zo betwistte de verdachte in de zaak die ten grondslag lag aan de uitspraak d.d. 6 juni 2006 dat hij als medepleger van diefstal in een woning kon worden aangemerkt. Hij was noch bij de voorbereiding noch bij de daadwerkelijke uitvoering van het delict betrokken; hij was enkel op de plaats delict aanwezig geweest en zonder iets te doen naar buiten gelopen. Het verweer behoefde volgens de Hoge Raad geen expliciete respons, omdat reeds uit het opnemen van de verklaring van een van de mededaders bleek, dat verdachte wel degelijk bij de uitvoering betrokken was: ' $\mathrm{Zij}$ (waaronder verdachte) wisten dat de woning van het slachtoffer was. Het is hun eigen initiatief geweest. Zij kwamen achter mij aan lopen. ${ }^{, 167}$

In een ander geval speelde een Meer en Vaartachtige situatie. De verdachte verweerde zich tegen de tenlastegelegde bedreiging door te wijzen op de omstandigheid dat niet hij, maar zijn neef deze had gepleegd. Van zijn neef waren vingerafdrukken afgenomen en deze waren ten onrechte gekoppeld aan zijn persoonsgegevens. Ten einde dit mogelijke gat in de bewijsconstructie te dichten, had het hof de verbalisant als getuige ter zitting gehoord en deze verklaarde ( 3 jaar na dato) de verdachte te herkennen als degene die hij destijds had aangehouden. Deze verklaring was onder de bewijsmiddelen opgenomen. Op het verweer van de verdachte was niet specifiek meer ingegaan. En dat was volgens de Hoge Raad toelaatbaar:

'Gelet op de gebezigde bewijsmiddelen - in het bijzonder de verklaring van de getuige Den Brinker ter terechtzitting in hoger beroep (bewijsmiddel 4) - heeft het Hof het standpunt, dat op 16 augustus 2002 niet de verdachte, maar diens neef door de politie is aangehouden, kennelijk niet aannemelijk geacht. Aldus bevat de uitspraak voldoende gegevens waarin de nadere motivering ligt besloten aangaande het niet aanvaarden door het Hof van het onder 4.2 weergegeven standpunt. ${ }^{168}$

167 HR 6 juni 2006, LJN AW2475.

168 HR 30 mei 2006, LJN AV6203 (r.o. 4.3). 
De procureur-generaal stelt het in zijn conclusie veel duidelijker:

'Als een verdachte een verweer voert dat de strekking heeft dat het tenlastegelegde niet kan worden bewezen en de rechter komt toch tot een veroordeling op basis van de door hem geselecteerde bewijsmiddelen dan houdt de aanvulling op het verkorte vonnis in de inhoud van de bewijsmiddelen de redenen in die de rechter ertoe hebben gebracht het standpunt van de verdediging niet te volgen. ${ }^{, 169}$

Kortom: een nadere motivering is niet noodzakelijk indien de weerlegging van het verweer reeds volgt uit de inhoud van de bewijsmiddelen. En daarmee zijn we weer terug bij af. Immers, reeds vanaf de introductie van het Wetboek van Strafvordering was dit het uitgangspunt: bewijsverweren waren niet in artikel 358 lid 3 opgenomen omdat het niet aanvaarden ervan reeds kon worden afgeleid uit de inhoud van de door de rechter geselecteerde bewijsmiddelen. Daarmee lijkt artikel 359 lid $2 \mathrm{~Sv}$ weinig toegevoegde waarde te hebben voor bewijsverweren die niet reeds vielen onder de categorie jurisprudentiëel erkende bewijsverweren.

Sterker nog: ten aanzien van de wel reeds in de jurisprudentie erkende verweren lijkt het nieuwe artikel 359 lid $2 \mathrm{~Sv}$ alleen maar minder in plaats van meer motivering te vereisen. Dat geldt in ieder geval voor de zogeheten dakdekkersverweren. Op grond van de jurisprudentie van voor 1 januari 2005 diende de feitenrechter op een dergelijk verweer expliciet in te gaan. Liet hij dit achterwege, dan was er sprake van een motiveringsgebrek. Afhankelijk van de aard van het verweer hoefde dit motiveringsgebrek niet altijd tot cassatie te leiden, of leidde wel tot cassatie, maar kon de Hoge Raad zelf de zaak afdoen. In de eerste zaak waarin de Hoge Raad de reikwijdte van artikel 359 lid 2 (nieuw) aan de orde stelt, stond ook een dakdekkersverweer centraal. De verdediging betwistte dat verdachte en zijn zoon een criminele organisatie vormden, aangezien er tussen hen geen hiërarchische verhouding bestond. Het hof had geconcludeerd dat op basis van het opgenomen bewijsmateriaal een criminele organisatie kon worden aangenomen. Op het verweer zelf was het hof niet ingegaan. De Hoge Raad neemt nu echter geen motiveringsgebrek aan. Uit de bewijsconstructie van het hof volgt dat het een juiste uitleg heeft gegeven aan het begrip 'criminele organisatie'. De uitleg waarop de verdediging zich beroept is onjuist. Dat behoefde - ook in het licht van 359 lid $2 \mathrm{~Sv}$ - geen nadere toelichting. ${ }^{170}$ Daarmee gaat de Hoge Raad in ieder geval voorbij aan een aspect van de strekking van artikel 359 lid $2 \mathrm{~Sv}$, namelijk dat een nadere motivering wenselijk is met het oog op explicatie naar partijen en de samenleving. Wellicht is het voor de Hoge Raad en de feitenrechter evident dat voor het bestaan van een criminele organisatie de hiërarchische verhoudingen binnen die organisatie niet relevant zijn, maar het zou toch aardig zijn als dat ook expliciet wordt uitgelegd naar betrokkenen en het publiek. Door nu niet eens aan te nemen dat er een motiveringsgebrek is, wordt feitelijk de bestaansgrond van artikel 359 lid $2 \mathrm{~Sv}$

169 Machielse in zijn conclusie bij HR 30 mei 2006, LJN AV6203.

170 In gelijke zin: HR 13 juni 2006, NJ 2006, 345. 
ondergraven. Ook Buruma acht deze uitspraak weinig bevorderlijk voor het creëren van het besef bij feitenrechters dat zij zoveel als mogelijk hun oordeel nader moeten onderbouwen:

'Door in concreto geen schending vast te stellen lijkt het er evenwel op dat de Hoge Raad de rechters wil zeggen: trek je niets aan van de nieuwe wettelijke bepaling die tot meer motivering oproept. Het doet denken aan het de-auditu-verbod van de wet van 1926: nog datzelfde jaar werd die wet door de Hoge Raad onschadelijk gemaakt., ${ }^{171}$

Misschien wel als gevolg van Buruma's opmerking neemt de Hoge Raad in een ander geval waarbij eveneens een dakdekkersverweer onbeantwoord was gelaten, wel schending van artikel 359 lid $2 \mathrm{~Sv}$ aan. ${ }^{172}$ Het aldus terecht voorgestelde cassatiemiddel leidt echter niet tot cassatie, omdat het in de ogen van de Hoge Raad alleen verworpen had kunnen worden.

\subsection{Geen afbreuk aan begrijpelijkheid van de motivering}

Van nietigheid op grond van artikel 359 lid $8 \mathrm{~Sv}$ is ook geen sprake indien het ontbreken van een expliciete weerlegging geen afbreuk doet aan de toereikendheid en begrijpelijkheid van de motivering van de uitspraak. Dit criterium is ook voor de wijziging van artikel 359 lid $2 \mathrm{~Sv}$ een aantal malen door de Hoge Raad gehanteerd om nietigheid wegens het niet in acht nemen van bepaalde motiveringsvoorschriften af te wenden. Het betrof dan meestal gevallen waarin ten onrechte niet redengevende feiten en omstandigheden in de bewijsconstructie waren opgenomen. De Hoge Raad achtte dat dan toelaatbaar omdat het opnemen van deze feiten niet ten koste was gegaan van de begrijpelijkheid van de gegeven motivering. ${ }^{173}$

Thans wordt het criterium in een veel ruimere setting geplaatst. Het enkel niet reageren op een uitdrukkelijk onderbouwd standpunt is excuseerbaar indien desalniettemin de uitspraak van de rechter voor de betrokkenen te begrijpen moet zijn geweest. In één van de gevallen waarin de Hoge Raad zich tot op heden heeft uitgesproken over een mogelijke schending van artikel 359 lid $2 \mathrm{~Sv}$ wordt dit argument mede aangegrepen om geen motiveringsgebrek aan te nemen. In die zaak was door de verdediging bij het hof aangevoerd dat een bepaalde uitlating van de verdachte niet kon worden aangemerkt als een opzettelijke bedreiging met enig misdrijf tegen het leven gericht, nu die woorden op zich zelf beschouwd én mede gezien het feit dat verdachte stomdronken was geen redelijke vrees bij die agenten kon doen ontstaan dat zij daadwerkelijk het leven zouden laten. Het hof liet het verweer voor wat het was en veroordeelde de verdachte ter zake. Het niet responderen op het verweer vond in de ogen van de Hoge Raad genade. Uit de bewijs-

171 Buruma in zijn annotatie bij HR 11 april 2006, NJ 2006, 393.

172 HR 26 september 2006, NJ 2006, 541.

173 Paragraaf 5.2.3.5.1 en de daar vermelde jurisprudentie. 
constructie van het hof kwam naar voren dat het de juiste uitleg had gegeven aan in de tenlastelegging en bewezenverklaring opgenomen woorden 'bedreiging met enig misdrijf tegen het leven gericht'. Daarmee was dus het niet responderen op het verweer reeds toelaatbaar op basis van de in de vorige paragraaf besproken relativeringsgrond. Maar dat was niet alles. De Hoge Raad betrekt vervolgens ook het betoog van de raadsman in zijn oordeel:

'Daarbij verdient opmerking dat de aan het proces-verbaal van de terechtzitting in hoger beroep gehechte pleitnota weliswaar inhoudt - zoals in het middel wordt aangevoerd dat de raadsman aldaar heeft betoogd dat de verdachte kenbaar 'stomdronken was en niet met hem te spreken viel', maar dat diezelfde pleitnota ook inhoudt dat de raadsman heeft gesteld dat 'de aan de beide verbalisanten nageroepen woorden op zichzelf genomen voldoende zijn om bij de bedreigden de redelijke vrees te doen ontstaan dat zij het leven zouden kunnen verliezen. ${ }^{174}$

Daarmee lijkt in de ogen van de Hoge Raad de raadsman zelf in te stemmen met de door het hof gegeven interpretatie. Een nadere toelichting op dat oordeel is dan uit het oogpunt van explicatie niet meer nodig. Daarbij verdient wel opmerking dat het geven van uitleg kennelijk alleen van belang is voor degene die het verweer heeft gevoerd.

\subsection{Van ondergeschikt belang}

Een nadere relativering van het sanctioneren van het niet naleven van de motiveringsplicht is door de Hoge Raad aangenomen in geval het 'gebrek' van ondergeschikt belang is. Ook dit criterium werd al eerder door de Hoge Raad aangenomen, in die gevallen waarin de redengevendheid van het bewijsmateriaal in cassatie werd betwist. Het feit dat een bepaald onderdeel van het door de feitenrechter geselecteerde bewijsmateriaal niet redengevend was, hoefde volgens de Hoge Raad niet tot nietigheid te leiden indien dat gezien het resterende deel van de bewijsvoering van zo ondergeschikt belang was dat het een behoorlijke motivering niet in de weg stond. ${ }^{175}$

Thans krijgt dit criterium een ruimer toepassingsbereik en blijft ook het niet reageren op uitdrukkelijk onderbouwde standpunten zonder consequenties indien het in de ogen van de Hoge Raad van ondergeschikt belang is. Uit overweging 3.8.4 van het door de Hoge Raad gewezen standaardarrest blijkt dat de Hoge Raad op dit punt aansluit bij de jurisprudentie uit Straatsburg. Uit de rechtspraak van het Europese Hof voor de rechten van de mens volgt weliswaar dat de verdediging een recht heeft om te weten waarom haar standpunten niet worden gevolgd, maar dat recht gaat niet zo ver dat de nationale rechters ieder detail van de argumentatie

174 HR 18 april 2006, NJ 2006, 397 m.nt. Y. Buruma (r.o. 3.3.2.).

175 Bijvoorbeeld: HR 23 oktober 1990, NJ 1991, 171 m.nt. ThWvV. Zie nader paragraaf 5.2.3.5. 
van de verdediging hoeven te weerleggen. ${ }^{176}$ Toegepast op de bewijsbeslissing zou dit volgens de Hoge Raad betekenen dat voor zover het door partijen aangevoerde standpunt slechts in geringe mate afwijkt van de door de rechter gegeven bewijsbeslissing een noodzaak tot nadere motivering niet bestaat. Te denken valt dan aan partiële vrijspraken;

'dat de omvang van de motiveringsplicht afhankelijk is van de aard van het onderwerp en de mate waarin wordt afgeweken [cursivering WD] van het ingenomen standpunt. Zo kan bij afwijking van een 'uitdrukkelijk onderbouwd standpunt' van het openbaar ministerie of van de verdediging met betrekking tot de bewijsbeslissing met een beperktere motivering worden volstaan indien die afwijking slechts een onderdeel en niet de gehele tenlastelegging betreft. ${ }^{, 177}$

Hoe dit criterium uitwerkt bij standpunten van de verdediging valt vooralsnog niet in te zien. Betwist de verdediging bijvoorbeeld het opzet, dan lijkt mij dat gezien de aard van het onderwerp - een criterium dat de Hoge Raad hanteert geen geringe afwijking en zal wel degelijk de rechter dienen te motiveren waaruit hij het opzet afleidt. Ook het bestaan van (andere) strafverzwarende omstandigheden kan mijns inziens niet worden afgedaan als een geringe afwijking en zou dus tot een nadere motivering moeten leiden, indien op dit punt door de verdediging verweer is gevoerd.

\subsubsection{Toegevoegde waarde van de responsieplicht ex art. 359 lid $2 \mathrm{~Sv}$}

Wordt de jurisprudentie van de Hoge Raad in haar geheel beschouwd, dan ontstaat toch het beeld dat de Hoge Raad er alles aan doet om te voorkomen dat klachten over schending van artikel 359 lid $2 \mathrm{~Sv}$ hem bereiken. Het stellen van hoge motiveringseisen aan procespartijen moet een vergaande motiveringsplicht van feitenrechters beperken. Voor zover deze hindernis door partijen met succes is overwonnen, leidt vervolgens de niet inachtneming van deze motiveringsplicht niet altijd tot schending van artikel 359 lid 2 Sv. De Hoge Raad heeft criteria gegeven op grond waarvan vonnissen in cassatie kunnen worden gesauveerd. De angst dat de responsieplicht - die nogal onverwacht en zonder degelijke voorbereiding in de wet werd opgenomen - zou leiden tot een dramatische toename van de werkzaamheden van de feitenrechter en tot een stortvloed van klachten bij de Hoge Raad lijkt dan ook onterecht. De Hoge Raad heeft het bereik van artikel 359 lid 2 voor een groot deel beperkt en feitenrechters kunnen met deze beperking in het achterhoofd een redelijke inschatting maken van de noodzaak tot een nadere motivering. ${ }^{178}$

176 EHRM 9 december 1994, 18064/91 (Hiro Balani t. Spanje) (r.o. 27). In gelijke zin: EHRM 19 april 1994, 16034/90 (Van de Hurk t. Nederland).

177 HR 11 april 2006, NJ 2006, 393 m.nt. Y. Buruma (r.o. 3.8.3.).

178 In gelijke zin: Buruma 2006, p. 1085: 'Die rechtspraak [met betrekking tot art. 359 lid 2 $\mathrm{Sv}, \mathrm{WD}]$ is tot nu toe zuinig geweest.' 
Dat wil overigens niet zeggen dat - voor zover het bewijsverweren betreft - artikel 359 lid 2 Sv enkel een codificatie van de bestaande jurisprudentie is. Reeds uit de beperkte gevallen waarin de Hoge Raad een schending van artikel 359 lid $2 \mathrm{~Sv}$ heeft aangenomen, volgt dat de Hoge Raad bereid is verder te kijken dan de in de jurisprudentie aangenomen responsieplichten. Daar waar de betrouwbaarheid van het bewijsmateriaal op goede gronden wordt betwist, dient de feitenrechter ervan blijk te geven dat hij die argumenten onder ogen heeft gezien. Zo mag niet zonder nadere toelichting worden teruggegrepen op een bij de politie afgelegde belastende getuigenverklaring, indien die naderhand ten overstaan van de rechtercommissaris is teruggenomen en de verdediging een plausibele verklaring geeft voor het afleggen van de belastende verklaring. ${ }^{179}$ Voor zover het bewijs in belangrijke mate berust op de verklaring van het slachtoffer en de betrouwbaarheid van diens verklaring op specifieke punten ter discussie wordt gesteld, heeft de Hoge Raad tot twee keer toe een responsieplicht aangenomen. ${ }^{180}$ In beide zaken treft men in het arrest van de Hoge Raad het gevoerde pleidooi letterlijk aan. In beide gevallen werden daarin allerlei aspecten met betrekking tot de totstandkoming en inhoud van de belastende verklaring genoemd die mogelijk de betrouwbaarheid van die verklaring negatief hebben beïnvloed, dan wel een aanwijzing opleverden dat de verklaring niet (geheel) conform de waarheid zou zijn. Zo werd onder andere gewezen op het gebrek aan details in de verklaring, inconsistenties tussen de verschillende verklaringen en ongerijmdheden in bepaalde verklaringen. Het lijkt erop dat de Hoge Raad bereid is een responsieplicht aan te nemen indien betrouwbaarheidsverweren op een dusdanige wijze worden geconcretiseerd. Andersom heeft de Hoge Raad ook in geval van een vrijspraak, terwijl het Openbaar Ministerie nadrukkelijk de betrouwbaarheid van het bewijsmateriaal in het requisitoir aan de orde heeft gesteld, een nadere verantwoordingsplicht aangenomen. ${ }^{181}$ Buiten deze gevallen waarin de betrouwbaarheid van het bewijsmateriaal ter discussie stond, heeft de cassatierechter enkel een nadere verantwoordingsplicht aangenomen in twee zaken waarin het (voorwaardelijk) opzet werd betwist. ${ }^{182}$ Dat is echter niet verbazend; voor inwerkingtreding van het nieuwe artikel 359 lid 2 Sv bleek reeds uit bepaalde uitspraken van de Hoge Raad dat niet in alle gevallen het voorwaardelijk opzet zonder nadere toelichting kon worden aangenomen. ${ }^{183}$

179 HR 14 november 2006, NJ 2006, 632

180 HR 28 november 2006, NJ 2007, 123 m.nt. J. Reijntjes en HR 28 november 2006, NJ 2007, 122.

181 HR 9 januari 2007, NJ 2007, 124.

182 HR 16 mei 2006, NJ 2007, 120 en HR 6 februari 2007, NJ 2007, 112.

183 Anders: HR 16 januari 2007, NJ 2007, 71: 'Het Hof heeft klaarblijkelijk geoordeeld dat, in aanmerking genomen de aard van de gedragingen van de verdachte en de omstandigheden waaronder deze zijn begaan, deze gedragingen kunnen worden aangemerkt als zozeer gericht op het mogelijke gevolg - het toebrengen van letsel aan C.K. - dat het niet anders kan zijn dan dat de verdachte bewust de aanmerkelijke kans op het desbetreffende gevolg heeft aanvaard'. Advocaat-generaal Knigge meende echter dat in casu wel een nadere motivering 
Het nieuwe artikel 359 lid 2 Sv lijkt aldus wel degelijk een toegevoegde waarde te hebben. Voor zover partijen in staat zijn hun standpunten duidelijk en geschraagd met argumenten te verwoorden, mag in principe van de feitenrechter verwacht worden dat hij die argumenten in ogenschouw neemt en dat kenbaar maakt in het vonnis. Partijen hebben recht op rechterlijk gehoor. Wie echter in de veronderstelling is - zoals Fokkens ${ }^{184}$ - dat de Hoge Raad ook op inhoudelijke gronden de gegeven motivering zal toetsen, komt van een koude kermis thuis:

'Het nieuwe art. 359, tweede lid, Sv brengt geen wijziging in de vrijheid van de rechter die over de feiten oordeelt, ten aanzien van de selectie en waardering van het beschikbare bewijsmateriaal alsmede de keuze en weging van de factoren die van belang zijn voor de oplegging van de straf en/of de maatregel. Wel brengt die bepaling mee dat hij zijn beslissing dienaangaande in een aantal gevallen nader zal dienen te motiveren. ${ }^{, 185}$

De in artikel 359 lid $2 \mathrm{~Sv}$ opgenomen responsieplicht ziet enkel op de verplichting tot motivering, maar biedt zelf geen criteria voor een deugdelijke motivering. Bij gebrek aan dergelijke criteria zal in cassatie de gegeven motivering alleen op begrijpelijkheid worden gecontroleerd. Dat geldt voor een door de feitenrechter gegeven vrijspraak:

'Het Hof is met zijn oordeel dat niet wettig en overtuigend bewezen is hetgeen aan de verdachte is tenlastegelegd, afgeweken van dat standpunt [van het Openbaar Ministerie: WD], zodat het Hof ingevolgde de tweede volzin van het tweede lid van art. $359 \mathrm{~Sv}$ in zijn arrest in het bijzonder de redenen moest opgeven die daartoe hebben geleid. Opmerking verdient dat die motivering in een geval als dit in cassatie slechts op haar begrijpelijkheid kan worden getoetst. ${ }^{186}$

Maar dat geldt evenzeer de in die gevallen waarin de feitenrechter tot een bewezenverklaring is gekomen:

'Die overwegingen met betrekking tot de geloofwaardigheid en de betrouwbaarheid van de afgelegde verklaring kunnen, gelet op de aan de feitenrechter voorbehouden vrijheid in de selectie en waardering van het bewijsmateriaal, in cassatie slechts op hun begrijpelijkheid worden getoetst. ${ }^{187}$

Daarmee lijkt de effectiviteit van de in artikel 359 lid 2 opgenomen responsieplicht voor een groot deel teniet te worden gedaan. Weliswaar wordt de feitenrechter geacht afwijkingen van standpunten van partijen expliciet te verwerpen, maar toetsing

op zijn plaats was. Wellicht dat de Hoge Raad hier geen nadere motiveringsplicht aannam, omdat het in het cassatiemiddel aan de orde gestelde motiveringsgebrek niet in de sleutel van art. 359 lid $2 \mathrm{~Sv}$ was geplaatst.

184 Fokkens 2006, p. 27: 'in de eerste plaats (kan) worden vastgesteld dat de controle van de Hoge Raad op de bewijsmotivering minder formeel en meer inhoudelijk is geworden. Dat lijkt mij winst. Die meer inhoudelijke controle heeft er in het bijzonder toe geleid dat vaker op bewijsverweren moet worden gerespondeerd. De nieuwe in artikel 359 lid 2 Sv opgenomen responsieplicht kan deze ontwikkeling versterken.'

185 HR 11 april 2006, NJ 2006, 393 m.nt. Y. Buruma (r.o. 3.8.1).

186 HR 13 juni 2006, LJN AV8527 (r.o. 3.6).

187 HR 21 november 2006, LJN AZ 0216 (r.o. 3.5). 
van de gronden waarop die verwerping steunt, gebeurt slechts marginaal. Dat maakt de weg voor de feitenrechter vrij om standpunten van partijen met behulp van standaardoverwegingen te weerleggen. In zijn conclusie bij het standaardarrest van de Hoge Raad inzake toepassing van artikel 359 lid 2 Sv werd dit dilemma al door Knigge geschetst:

'Een weinig indringende toetsing kan leiden tot met behulp van kant en klare bouwstenen in elkaar geknutselde standaardmotiveringen, waardoor art. 359 lid 2 Sv goeddeels zou worden uitgehold. Serieuze handhandhaving van het nieuwe motiveringsvoorschrift daarentegen brengt vergaande bemoeienis met de feiten mee, en daarmee tevens een enorme taakverzwaring van de toch al zwaar belaste cassatierechter. ${ }^{188}$

In hoeverre de overbelasting van de Hoge Raad in deze een reeel argument is weet ik niet, maar de taakverdeling tussen feitenrechter en cassatierechter is dat van oudsher wel. Kennelijk wenst de Hoge Raad daarin geen verandering te brengen. In dat geval is echter de meerwaarde van artikel 359 lid 2 Sv sterk afhankelijk van de eigen takkopvatting van de feitenrechters. Zijn zij bereid ook zonder controle van bovenaf hun motiveringsverplichtingen een meer inhoudelijke invulling te geven? Eerdere ervaringen met de plicht tot het aanwijzen van de redengevende feiten en omstandigheden biedt geen best vooruitzicht. Dat geldt eens temeer indien men de bestaande werklast van de lagere rechters in aanmerking neemt.

\subsubsection{Promis}

Ondanks de in de vorige paragraaf geuite scepsis loopt er op dit moment een project waarvan de inzet is te komen tot een betere motivering van strafvonnissen. Het project is geëntameerd door de Raad voor de Rechtspraak en heeft tot doel om met gelijke inzet van mensen en middelen tot een betere motivering van vonnissen te komen. ${ }^{189}$ Los van de eisen van de Hoge Raad heeft de Raad voor de Rechtspraak het wenselijk gevonden om te bezien of het niet mogelijk is om te komen tot meer begrijpelijke vonnissen. Het doel van Promis is:

'te komen tot een betere communicatie tussen strafrechter, betrokkenen en de samenleving als geheel'. ${ }^{190}$

Een bijzonderheid van het promis-project is dat gedurende de eerste pilot het gewijzigde artikel $359 \mathrm{~Sv}$ in werking trad. Hoewel het project en het gewijzigde artikel $359 \mathrm{~Sv}$ een gemeenschappelijke achtergrond hebben, is de uitwerking daarvan verschillend. De gemeenschappelijk achtergrond is de reeds door de Onderzoeksgroep Strafvordering 2001 geformuleerde wens om te komen tot een meer

188 Knigge in zijn conclusie bij HR 11 april 2006, NJ 2006, 393 m.nt. Y. Buruma (overweging 54).

189 Een aspect van het project, te weten dat in de zogeheten Promis-vonnissen de inhoud van de bewijsmiddelen niet hoeft te worden vermeld, kwam reeds aan de orde in paragraaf 4.4.5.

190 Promis Evaluatierapport 2005, p. 48. 
op tegenspraak gericht eindonderzoek in strafzaken. Consequentie van dit uitgangspunt is dat de omvang van zowel het onderzoek ter zitting als de onderbouwing van het eindoordeel afhankelijk is van de opstelling van procespartijen. Waar zij niet tijdig of voldoende beargumenteerd verzoeken om nader onderzoek of om nadere uitleg, kan het onderzoek en de motivering beperkt blijven tot het hoogst noodzakelijke. Dit principe is het verst doorgevoerd bij de bekennende verdachte; een verdachte die bekent heeft kennelijk geen behoefte aan nadere uitleg. In zijn zaak kan de bewijsmotivering beperkt blijven tot het verwijzen naar de relevante passages in het procesdossier. Dat geldt zowel voor de reguliere vonnissen op grond van artikel 359 lid $3 \mathrm{~Sv}$, als voor de promis-vonnissen.

Op een ander punt - de motivering naar aanleiding van door partijen ingenomen standpunten - wijkt het promis-project af van hetgeen thans op grond van artikel 359 lid 2, tweede volzin gangbaar is. Waar, zoals uit paragraaf 6.3.4.2.2 bleek, de Hoge Raad hoge eisen stelt aan het standpunt, wil dit als een standpunt in de zin van artikel 359 lid 2 worden aangemerkt en dus een responsieplicht met zich brengen, geldt een dergelijke strenge eis niet in Promis. Bovendien is ten aanzien van bepaalde bewijskwesties de promis-rechter uit zichzelf genoodzaakt tot het geven van een nadere motivering. Indicaties ${ }^{191}$ voor een nadere bewijsmotivering ook buiten hetgeen ter zitting is aangevoerd zijn:

1. het (deels) ontkennen (van het opzet) door verdachte;

2. het gebruik van voorwaardelijk opzet;

3. tegenstrijdigheid tussen verschillende (getuigen)verklaringen of interne tegenstrijdigheid van een verklaring;

4. de aanwezigheid van ontlastende verklaringen of ander ontlastend materiaal;

5. het gebruik van ingetrokken (getuigen)verklaringen;

6. bestrijding van de betrouwbaarheid van de getuigenverklaring;

7. het gebruik maken van schakelbewijs; en

8. het verbazingscriterium. ${ }^{192}$

Binnen het project verbetering van de motivering van strafvonnissen is de begrijpelijkheid van vonnissen dus niet enkel aan het optreden van procespartijen overgelaten. Het geven van uitleg is niet alleen van belang voor betrokken partijen, maar ook het publiek dient overtuigd te raken van de juistheid van het vonnis, hetgeen gezien het doel van het project, te weten het verbeteren van de communicatie tussen strafrechter en de samenleving niet verbazend is. Daarbij is het echter in grote mate aan de rechter zelf overgelaten wanneer hij een nadere uitleg geeft, hetgeen blijkt uit het laatste criterium, het zogeheten verbazingscriterium. In hoeverre het bewijs in strafzaken tot discussie heeft geleid in raadkamer is immers

191 Promis II Projectplan 2006, bijlage I.

192 In Promis I wordt dit opschreven als: 'een uitgebreide discussie in raadkamer'. Zie Promis II Projectplan 2006, bijlage V. 
voor het publiek niet zichtbaar. Bovendien valt op dat ten aanzien van twee van de genoemde criteria ook nu reeds een nadere motiveringsplicht geldt. Het betreft dan het gebruik van voorwaardelijk opzet en schakelbewijs. In beide gevallen kan immers veelal de redengevendheid van bewijsmateriaal niet direct uit het opnemen van het bewijsmateriaal in het vonnis volgen en is een nadere toelichting noodzakelijk.

\subsection{Conclusie}

De selectie en waardering van het bewijsmateriaal is voorbehouden aan de feitenrechter die daarover geen verantwoording hoeft af te leggen. Slechts in uitzonderingsgevallen wordt van de rechter verwacht dat hij zijn oordeel op dit punt nader motiveert. Zo is in artikel $360 \mathrm{~Sv}$ een nadere motiveringsplicht opgenomen terzake van het gebruik van bewijsmateriaal dat bij voorbaat twijfels oproept over de betrouwbaarheid of ten aanzien waarvan de toetsing van die betrouwbaarheid problematisch is. Het betreft dan verklaringen van onbeëdigde getuigen en kroongetuigen respectievelijk anonieme en afgeschermde getuigen. De plicht tot een aanvullende motivering dient dan de rechter bewust te maken van het dubieuze karakter van het bewijsmateriaal respectievelijk ter bevestiging van de eigen verantwoordelijkheid van de rechter inzake de waarheidsvinding.

Een meer wezenlijke aantasting van het uitgangspunt dat de rechter de betrouwbaarheid van het bewijsmateriaal niet hoeft te onderbouwen, volgde uit de jurisprudentie van de Hoge Raad. In een aantal gevallen eiste de Hoge Raad dat de feitenrechter in zijn vonnis de door of namens de verdachte gevoerde verweren, indien hij ze niet aannam, gemotiveerd diende te verwerpen. Een dergelijke responsieplicht werd aangenomen terzake van Meer en Vaartverweren, dakdekkersverweren, onrechtmatig verkregen bewijsverweren en specifieke betrouwbaarheidsverweren. Ten aanzien van de eerste drie genoemde categorieën was een nadere motivering wenselijk omdat uit de selectie van de bewijsmiddelen niet kon volgen dat de rechter het bewijsverweer onder ogen had gezien. De reden voor een nadere onderbouwing van de verwerping van betrouwbaarheidsverweren vloeide voort uit het streven zichtbaar te maken dat de rechter tot een eigen beslissing was gekomen en zich niet te zeer had laten leiden door bijvoorbeeld het oordeel van de in de zaak betrokken deskundige.

In de op 1 januari 2005 in werking getreden wijziging van artikel 359 lid $2 \mathrm{~Sv}$ is de rechtspraak van de Hoge Raad met betrekking tot de responsieplicht op verweren doorgetrokken. Zij is echter in twee opzichten ruimer. Enerzijds moet in het vonnis niet alleen op de standpunten van de verdediging worden ingegaan, maar ook op die van het Openbaar Ministerie, anderzijds moet gezien de bewoordingen van artikel 359 lid $2 \mathrm{~Sv}$ de rechter op elk goed gevoerd verweer responderen. De verruimingen komen voort uit een ander idee dat ten grondslag ligt aan de motiveringsplicht. Niet de eigen verantwoordelijkheid van de zittingsrechter aangaande het proces van 
waarheidsvinding moet uit de motivering naar voren komen, maar veeleer het contradictoire karakter van de strafprocedure wordt met de nadere motiveringsplicht bevestigd. Hierin ligt besloten dat het geding in strafzaken zich moet concentreren op punten die partijen verdeeld houden.

In zijn standaardarrest met betrekking tot de inhoud en reikwijdte van deze nieuwe motiveringsplicht heeft de Hoge Raad de omvang van deze nadere motiveringsplicht drastisch beperkt. Enerzijds worden hoge eisen gesteld aan de inkleding van het standpunt, wil het in aanmerking komen voor een gemotiveerde weerlegging, anderzijds leidt het niet responderen niet in alle gevallen tot nietigheid op grond van artikel 359 lid $8 \mathrm{~Sv}$.

De vaststelling dat artikel 360 lid 1 en 2 Sv en artikel 359 lid 2 nadere motiveringseisen stellen aan het feitenoordeel van de rechter betekent echter nog niet dat daarmee ook het uitgangspunt van vrije selectie en waardering van het bewijsmateriaal is verlaten. De Hoge Raad houdt daaraan vast en consequentie daarvan is dat de Hoge Raad niet bereid is om op dit punt het oordeel van de feitenrechter verdergaand te toetsen dan alleen op zijn begrijpelijkheid. Bij gebrek aan inhoudelijke toetsing is echter de concrete invulling van de nadere motiveringsverplichting voor een groot deel overgelaten aan de feitenrechter. Indien gewenst, kan hij zijn toevlucht nemen tot standaardoverwegingen, die de toets in cassatie kunnen doorstaan. In dat geval is met het nieuwe artikel 359 lid $2 \mathrm{~Sv}$ en de uitbreiding van artikel $360 \mathrm{~Sv}$ weinig gewonnen. Sterker nog: artikel 359 lid 2, tweede volzin, Sv legt de verantwoordelijkheid voor de nadere motivering volledig bij de procespartijen. Voor zover zij geen standpunten naar voren brengen of deze standpunten niet op een juiste wijze inkleden, kan de rechter geheel afzien van een nadere motivering. Daarmee lijkt de verantwoordelijkheid voor de waarheidsvinding in strafzaken in Nederland, althans de verantwoordelijkheid voor onderbouwing van het oordeel op dit punt, te worden afgeschoven op procespartijen. In dat verband is het zinvol om een kijkje over de grens bij onze Oosterburen te nemen. In Duitsland dient de feitenrechter ambtshalve het feitenoordeel te motiveren en wordt de gegeven motivering in cassatie op inhoudelijke gronden getoetst. 



\section{Bewijs en bewijsmotivering in Duitsland}

\subsection{Inleiding}

Evenals in het Nederlandse bewijsrecht worden in het Duitse bewijsrecht verschillende eisen gesteld aan het oordeel dat de verdachte de hem verweten gedraging heeft gepleegd. Deze eisen hebben onder andere tot doel te garanderen dat het uiteindelijke oordeel zoveel mogelijk overeenstemt met de werkelijkheid. ${ }^{1}$ Het in acht nemen van deze eisen biedt geen garantie dat het uiteindelijke oordeel van de rechter in strafzaken een waarheidsgetrouwe reconstructie is van de feiten die zijn voorgevallen. Echter, met het stellen van regels ten aanzien van het bewijsoordeel wordt een poging gedaan om zoveel mogelijk te streven naar materiële waarheidsvinding, voor zover die binnen de strafrechtelijke context relevant is.

Het Duitse bewijsrecht wordt gekenmerkt door een strikte scheiding tussen enerzijds de regels die de bewijsvoering ter zitting normeren en anderzijds de regels die gelden ten aanzien van de bewijswaardering. ${ }^{2}$ Daarbij geldt als uitgangspunt:

'daß die Präsentation der Beweismittel umso gebundener sein müsse, je freier die Beweiswürdigung ist."

De bewijsvoering ter zitting is in Duitsland wettelijk genormeerd. De bewijswaardering daarentegen is in principe vrij, zij het dat de rechter alleen dat in de bewijswaardering mag betrekken wat conform de regels met betrekking tot de bewijsvoering ter zitting is gepresenteerd.

De gebondenheid van de feitenrechter met betrekking tot de bewijsvoering komt allereerst tot uitdrukking in het beginsel der formele onmiddellijkheid, zoals dat in $\S 261 \mathrm{StPO}$ is verwoord:

'Über das Ergebnis der Beweisaufnahme entscheidet das Gericht nach seiner freien, aus dem Inbegriff der Verhandlung geschöpften [cursivering WD] Überzeugung.'

De rechter mag alleen dat bewijsmateriaal in de bewijswaardering betrekken, dat tijdens het onderzoek ter terechtzitting aan de orde is gekomen. Bovendien dient

1 Buiten beschouwing blijven in dit hoofdstuk die beperkingen die voortvloeien uit de idee dat de strafrechtspleging op een behoorlijke wijze dient te geschieden. Met andere woorden: op de rechtmatigheid van de bewijsgaring zal niet nader worden ingegaan.

2 Strate 2002, p. 615: 'die strikte Trennung freier Beweiswürdigung und einer ihr vorausgegangenen, an die wohldurchdachten Förmlichkeiten des Gesetzes gebundenen Beweiserhebung prägt den Rechtsgang des strafprozessualen Hauptverfahrens.'

3 Kunert 1979, p. 413. Aldus ook Meurer 1986, p. 960: 'Die strikte Trennung von gebundener Beweiserhebung und freier Beweiswürdigung in Anerkennung vielfältiger Wechselwirkung ist eine unverzichtbare Errungenschaft des modernen Strafprozesses.' 
het ter zitting gepresenteerde bewijs aan bepaalde eisen met betrekking tot de vorm (en inhoud) te voldoen, wil de feitenrechter dit voor het bewijs kunnen gebruiken. ${ }^{4}$ Zo worden nadere eisen gesteld aan sommige bewijsmiddelen en dienen in principe de beginselen der materiële onmiddellijkheid, mondelinge procesvoering en openbaarheid in acht genomen te worden. Deze voorwaarden vloeien voort uit het feit dat op de bewijsbeslissing in strafzaken het zogeheten Strengbeweisverfahren van toepassing is.

Worden enerzijds de rechter beperkingen opgelegd met betrekking tot datgene wat hij uiteindelijk aan zijn bewijsbeslissing ten grondslag mag leggen, anderzijds geldt er ook een plicht voor de rechter om alles dat mogelijk relevant is voor die beslissing ter zitting te onderzoeken. Dit laatste vloeit voort uit het beginsel der materiële waarheidsvinding, zoals dat tot uitdrukking komt in $\S 244$ Abs. 2 StPO. Tegenover de gebondenheid in de fase van de bewijsvoering staat de relatieve vrijheid ten aanzien van bewijswaardering. In $\S 261$ StPO ligt naast het beginsel van formele onmiddellijkheid dit uitgangspunt van de vrije bewijswaardering besloten. De rechterlijke vrijheid ten aanzien van de waardering van het bewijs blijkt ook uit de afwezigheid van wettelijke bewijsminima. Wettelijke bepalingen waarin is opgenomen dat een bewezenverklaring niet mag berusten op één enkel bewijsmiddel ontbreken in het Duitse strafprocesrecht. Dat betekent echter niet dat de rechter volledig vrij is in de waardering van het conform de bewijsvoeringsregels verkregen bewijsmateriaal. In de jurisprudentie is sinds de jaren ' 50 van de vorige eeuw een duidelijke tendens te bespeuren waarin de vrijheid van de rechter met betrekking tot de bewijswaardering steeds meer aan banden werd gelegd. Deze beperking vloeit voort uit het feit dat het begrip 'overtuiging' zoals dat in $\S 261$ StPO wordt gehanteerd in de loop der jaren een andere betekenis heeft gekregen. Thans geldt dat de feitenrechter weliswaar vrij is in de waardering van het op juiste wijze ter zitting gepresenteerde bewijs, maar dat hij in zijn vonnis tot uitdrukking moet brengen dat hij ten aanzien van de bewijsbeslissing alle feiten en omstandigheden heeft betrokken die relevant zijn voor zijn beslissing. Bovendien dient hij bij de waardering van het bewijs de regels van de logica en algemene ervaringsregels in acht te nemen, en mag het vonnis op dit punt geen tegenstrijdigheden en leemtes bevatten.

In dit hoofdstuk zal worden ingegaan op de verschillende eisen die in het Duitse strafprocesrecht worden gesteld aan de bewijsvoering. Achtereenvolgens komen het formele onmiddellijkheidsbeginsel, de wettigheid van de bewijsmiddelen, het beginsel van mondelinge procesvoering, het materiële onmiddellijkheidsbeginsel en de rechterlijke onderzoeksplicht aan bod. Ten aanzien van elk van deze uitgangspunten wordt bezien in hoeverre zij de bewijsvoering in strafzaken normeren.

$4 \quad$ Eisenberg 2002, p. 76. 
Het beginsel van openbaarheid wordt niet apart beschreven. Voor zover het invloed heeft op de bewijsvoering ter zitting, die in principe in het openbaar dient plaats te vinden, wordt het besproken in de context van de overige beginselen.

In het tweede deel van dit hoofdstuk staat de bewijswaardering centraal. Daarbij zal eerst de ontwikkeling van het begrip 'overtuiging' in de Duitse jurisprudentie worden besproken, ${ }^{5}$ om vervolgens de eisen in kaart te brengen die daaruit voortvloeien ten aanzien van de motivering van de bewijsbeslissing.

\subsection{Het formele onmiddellijkheidsbeginsel}

Een van de meest wezenlijke uitgangspunten van het Duitse bewijsrecht is het onmiddellijkheidsbeginsel. Daarbij wordt een onderscheid gemaakt tussen de formele en materiële kant van dit beginsel. De formele kant ziet op de vraag waar en ten overstaan van wie het bewijsmateriaal gepresenteerd moet worden. Het materiële onmiddellijkheidsbeginsel heeft daarentegen betrekking op de inhoud van het bewijsmateriaal en kan het best worden omschreven als het best-evidence beginsel. Op het materiële onmiddellijkheidsbeginsel wordt in paragraaf 7.3.3 ingegaan.

Het formele onmiddellijkheidsbeginsel eist dat de bewijsvoering plaatsvindt tijdens het onderzoek ter terechtzitting ten overstaan van de rechter; alles wat relevant is voor de bewijsbeslissing moet tijdens de behandeling van de strafzaak ter zitting aan de orde worden gesteld. In dit beginsel komt tot uitdrukking dat uitsluitend het onderzoek ter terechtzitting het moment én de plaats is waar het bewijsmateriaal dat betrekking heeft op de strafzaak moet worden geïntroduceerd.

'So betrachtet besagt der Grundsatz formeller Unmittelbarkeit grundsätzlich nichts mehr, als daß die Beweisaufnahme gerade durch das erkennende Gericht und nur in der Hauptverhandlung (die freilich auch außerhalb des Gerichtssaals stattfinden kann) zu erfolgen hat und da $\beta$ das Beweisgebäude hier vollständig aufgebaut werden muß., ${ }^{, 6}$

Dit komt ook tot uitdrukking in $\S 261$ StPO, dat eist dat de overtuiging van de rechter moet volgen uit 'dem Inbegriff der Verhandlung'. Door de bewijsvoering te binden aan het onderzoek ter terechtzitting wordt gegarandeerd dat de rechter zich een eigen en onafhankelijk oordeel kan vormen over het bewijs. Hij kan slechts aan zijn oordeel ten grondslag leggen hetgeen hij zelf - zonder tussenkomst van een ander - heeft waargenomen.

5 Waar in dit hoofdstuk wordt verwezen naar rechtspraak van het Bundesgerichtshof is deze - voor zover het uitspraken betreft gegeven na 1 januari 2000 - via de website van het Bundesgerichtshof beschikbaar: <http://www.bundesgerichtshof.de/>.

6 Geppert 1979, p. 136.

7 Geppert 1979, p. 124 onderscheidt twee aspecten van de formele onmiddellijkheid: onmiddellijkheid ten aanzien van de plaats van de waarneming, te weten het onderzoek ter 
Uit $§ 261$ StPO volgt enerzijds een verbod om feiten en omstandigheden aan zijn bewijsbeslissing ten grondslag te leggen die de rechter anders dan tijdens de terechtzitting ter kennis zijn gekomen. Anderzijds bevat het een gebod om alles dat onderdeel uitmaakt van de behandeling ter zitting in de bewijswaardering te betrekken. Dat laatste betekent niet alleen dat de rechter de aldaar gebleken feiten en omstandigheden, maar ook de indruk die hij heeft gekregen van de verdachte, getuigen en andere personen in zijn oordeel moet betrekken. Logischerwijze volgt dan ook uit het formele onmiddellijkheidsbeginsel dat de rechter die niet in staat is het bewijsmateriaal ter zitting waar te nemen (tijdelijk, als gevolg van slaap of in zijn algemeenheid, als gevolg van een handicap), zijn overtuiging niet vormt naar aanleiding van het onderzoek ter terechtzitting. Deelname van een blinde rechter, in ieder geval als voorzitter, aan de behandeling van strafzaken is dan ook op grond van het formele onmiddellijkheidsbeginsel uitgesloten.

'Die Mitwirkung eines blinden Richters in einer tatrichterlichen Hauptverhandlung berührt hingegen den Grundsatz der Unmittelbarkeit. § 261 StPO verlangt nämlich, $\mathrm{da} ß$ das Gericht seine Überzeugung aus dem Inbegriff der Verhandlung schöpft. Hierzu gehören nicht nur die zwischen den Verfahrensbeteiligten gesprochenen Worte; vielmehr sind auch visuelle Eindrücke von maßgebender Bedeutung. Der Richter muß auch von der Haltung und den Reaktionsweisen der Prozeßbeteiligten, vor allem des Angeklagten, durch aufmerksame Beobachtung Eindrücke gewinnen können, die möglicherweise für seine Beweiswürdigung bedeutsam werden können. ${ }^{8}$

Opgevat als een verbod om bewijsmateriaal dat buiten de zitting om ter kennis van de rechter is gekomen aan zijn bewijsbeslissing ten grondslag te leggen, is het formele onmiddellijkheidsbeginsel het centrale beginsel met betrekking tot de bewijsvoering. Het waarborgt dat alleen die feiten en omstandigheden die op de zitting zijn gepresenteerd in de oordeelsvorming van de rechter worden betrokken. Zo moet hij bijvoorbeeld feiten die hem bekend zijn uit een andere strafzaak buiten beschouwing laten. ${ }^{9}$ Dit geldt evenzeer voor feiten die hem bekend zijn uit persoonlijke wetenschap. ${ }^{10}$

Daarmee is niet gezegd dat alles wat op de zitting naar voren is gebracht onderdeel mag uitmaken van de rechterlijke oordeelsvorming. Zoals reeds in de inleiding aangegeven, wordt de bewijsvoering in strafzaken niet alleen genormeerd door het formele onmiddellijkheidsbeginsel. Daarnaast worden eisen gesteld aan de vorm waarin het bewijsmateriaal ter zitting moet worden gepresenteerd en

terechtzitting, en onmiddellijkheid ten aanzien van de persoon die moet waarnemen, te weten de oordelende rechter.

$8 \quad$ BGH 17 december 1987, BGHSt 35, 164.

9 Eisenberg 2002, p. 91. Er is in dat geval sprake van zogeheten 'dienstliches Wissen'.

10 Wel is het mogelijk dat de rechter bijvoorbeeld een getuige zijn persoonlijke kennis voorhoudt. Bevestigt de getuige hetgeen hem is voorgehouden, dan kan zo via deze getuigenverklaring alsnog de persoonlijke wetenschap van de rechter tot onderdeel van de behandeling ter terechtzitting worden gemaakt. 
moeten het materiële onmiddellijkheidsbeginsel en het beginsel van mondelinge procesvoering in acht worden genomen. Deze eisen vloeien voort uit het feit dat op de bewijsbeslissing in strafzaken het zogeheten Strengbeweisverfahren van toepassing is.

\subsection{Het 'Strengbeweisverfahren'}

In het Duitse strafprocesrecht wordt een onderscheid gemaakt tussen het Strengbeweisverfahren en het Freibeweisverfahren. Het Strengbeweisverfahren is van toepassing op het vaststellen van feiten ter beantwoording van de vragen of de verdachte het feit heeft begaan en of hij terzake schuldig is en zo ja, welke straf moet worden opgelegd. ${ }^{11}$ Enigszins gechargeerd zou men kunnen zeggen dat het Strengbeweis van toepassing is op de hoofdvragen zoals die in Nederland in artikel $350 \mathrm{~Sv}$ zijn geformuleerd. Het oordeel over de vraag of de verdachte het hem verweten feit heeft begaan valt in het Duitse procesrecht dus ook onder het Strengbeweisverfahren.

Het Strengbeweisverfahren stelt beperkingen aan de rechterlijke vrijheid om elke vorm van bewijs in de bewijswaardering te betrekken. Deze beperkingen zijn tweeërlei. Enerzijds is de rechter ten aanzien van de wettelijke bewijsmiddelen gebonden aan bepaalde (vorm)voorschriften. Anderzijds mag hij slechts dat bewijsmateriaal in de bewijswaardering betrekken ten aanzien waarvan een aantal bewijsrechtelijke beginselen in acht zijn genomen. Het niet in acht nemen van deze beginselen leidt - in principe - tot uitsluiting van het bewijs dat in strijd met deze beginselen is verkregen. De beginselen die op het Strengbeweisverfahren van toepassing zijn, zijn, zoals gezegd, het onmiddellijkheidsbeginsel, het beginsel van mondelinge procesvoering, en het beginsel der openbaarheid der zitting. Bovengenoemde beginselen komen ook (deels) tot uitdrukking in de wettelijke bepalingen met betrekking tot de bewijsopname ter zitting ( $\S 244$ tot en met 257 StPO).

Het Freibeweisverfahren is van toepassing op beslissingen buiten het onderzoek ter terechtzitting en op alle overige ter zitting te nemen beslissingen. ${ }^{12}$ Het betreft dan beslissingen met betrekking tot vragen zoals 'zijn de wettelijke termijnen in acht genomen', 'is de verdachte verhandlungsfähig, 'is een getuige beschikbaar', 'is de deskundige wel deskundig', enz. ${ }^{13}$ Voor de beantwoording van dergelijke

11 Eisenberg 2002, p. 76.

12 G. Herdegen, aant. 10-12 bij § 244 StPO, in: Pfeiffer 2003.

13 Ook de vraag of een verdachte onder druk een verklaring heeft afgelegd ( $§ 136 \mathrm{a}$ StPO), en derhalve het bewijs onrechtmatig is verkregen, wordt als processueel beschouwd, waarop het Freibeweisverfahren van toepassing is. BGH 28 juni 1961, BGHSt 16, 166. Eisenberg 2002, p. 78 stelt dit uitgangspunt van het Bundesgerichtshof ter discussie: 'Angesichts der verfahrensrechtlichen Bedeutung dieser Vorschrift und des materiellen Beweiswertes, der der Aussage im Falle ihrer Verwertung beigemessen wird, ist eine Aufklärung im Strengbeweisverfahren (...) zu verlangen.' 
vragen mag de rechter uit elke beschikbare bron informatie putten en is hij niet gebonden aan bovengenoemde beginselen. Hij mag dus ter beantwoording van deze meer processuele vragen gebruik maken van informatie die hem heeft bereikt buiten de zitting om, of waarvan hij op de hoogte is gekomen door middel van een op schrift gestelde verklaring van een getuige. Wel dient de rechter in het kader van het Freibeweisverfahren het bewijsmateriaal waarop hij zijn beslissingen doet steunen, kenbaar te maken ter zitting, zodat partijen in de gelegenheid zijn om daarop te reageren. Bovendien is hij in het Freibeweisverfahren ook gebonden aan het beginsel der materiële waarheidsvinding. Hij dient dus alle relevante feiten en omstandigheden ambtshalve te onderzoeken. ${ }^{14}$

Voor zover het vaststellen van bepaalde feiten of omstandigheden relevant is voor de beantwoording van zowel processuele vragen als de bewijsvraag geldt het regime van het Strengbeweis. In dat geval wordt gesproken van doppelrelevante Tatsachen. ${ }^{15}$

\subsubsection{De wettigheid van het bewijs}

In het Strengbeweisverfahren is de rechter dus gebonden aan wettige bewijsmiddelen. Deze wettige bewijsmiddelen zijn de verklaring van de getuige en de deskundige, de eigen waarneming van de rechter en schriftelijke bescheiden. Ten aanzien van de vraag of de verdachte het hem verweten feit heeft begaan, dient de feitenrechter regels die zijn gesteld met betrekking tot deze bewijsmiddelen in acht te nemen. Bezien vanuit het Nederlandse recht lijkt dit te betekenen dat de rechter slechts de overtuiging mag bekomen op grond van de inhoud van deze wettige bewijsmiddelen. Deze veronderstelling is echter onjuist. Het begrip 'bewijsmiddel' in de Duitse strafvordering heeft een andere betekenis dan in Nederland gebruikelijk is.

Ten aanzien van de vraag of bepaald bewijsmateriaal voor het bewijs kan worden gebruikt, is in het Nederlandse bewijsrecht bepalend of de vorm en de inhoud van dat bewijsmateriaal voldoet aan een in de wet genoemd bewijsmiddel. Zo dient de verklaring van de getuige ter zitting te zijn afgelegd, en mag hij alleen feiten en omstandigheden bevatten die hijzelf heeft waargenomen of ondervonden. In artikel 342 lid $1 \mathrm{~Sv}$ wordt dus zowel de wijze waarop de verklaring tot stand is gekomen alsmede de inhoud van die verklaring gereguleerd. Voldoet een verklaring daaraan niet, dan mag in principe de inhoud van de verklaring niet aan de bewezenverklaring ten grondslag worden gelegd.

In het Duitse recht wordt echter daar waar een wettig bewijsmiddel is vereist, slechts de vorm waarin het bewijsmateriaal ter zitting moet worden gepresenteerd genormeerd. Zo geldt bijvoorbeeld ten aanzien van de getuigenverklaring dat de

14 Eisenberg 2002, p. 77.

15 Eisenberg 2002, p. 78-79. 
getuige voorafgaand aan zijn verklaring moet worden gemaand de waarheid te zeggen ( $\$ 57 \mathrm{StPO}) .{ }^{16}$ Ten aanzien van de schriftelijke bescheiden geldt dat deze ter zitting moeten worden voorgelezen ( $\$ 249$ StPO), willen die in de bewijswaardering kunnen worden betrokken. Beziet men de wettelijke bepalingen die betrekking hebben op de wettige bewijsmiddelen, dan valt op dat daarin geen inhoudelijke eisen aan het bewijsmateriaal worden gesteld. Dat betekent niet dat - bijvoorbeeld in het Duitse bewijsrecht niet geldt dat een getuige alleen kan verklaren over feiten en omstandigheden die hij zelf heeft waargenomen of ondervonden; maar dit aspect komt enkel aan de orde in de fase van de bewijswaardering:

'Die Verknüpfung des Beweismittelbegriffs mit den Formen ihrer Einführung bedeutet keine inhaltliche Präzisierung der Beweistätigkeit, denn sie normieren hauptsächlich Zulässigkeitsfragen und spielen eine mindere Rolle während der Beweiswürdigung und der Überzeugungsbildung. ${ }^{17}$

Dit verklaart ook waarom in het Duitse recht in tegenstelling tot het Nederlandse onder de wettige bewijsmiddelen niet de verklaring van de (mede)verdachte voorkomt. Ten aanzien van de verklaring van de verdachte zijn in het Duitse Wetboek van Strafvordering geen bepalingen opgenomen die de vorm van deze verklaring op enigerlei wijze reguleren. ${ }^{18} \S 244$ Abs. 1 StPO bepaalt slechts:

'Nach der Vernehmung des Angeklagten folgt die Beweisaufnahme.'

Het staat de verdachte vrij om al dan niet te verklaren en voor zover hij verklaart is hij niet verplicht de waarheid te spreken. Bij gebrek aan beperkingen op dit punt is het dus slechts een academische vraag of de verklaring van de verdachte wel of niet in het kader van het Strengbeweisverfahren thuis hoort. ${ }^{19}$

Hieruit mag echter niet de conclusie worden getrokken dat hetgeen de verdachte ter zitting verklaart niet voor het bewijs mag worden gebezigd. Het feit dat in het Duitse bewijsrecht een aantal wettige bewijsmiddelen wordt genoemd, leidt er dus niet toe dat andere vormen van bewijs zijn uitgesloten, zoals dat bijvoorbeeld in Nederland het geval is. Van een uitputtende opsomming van bewijsmiddelen is dus geen sprake. De verklaring van de verdachte ter zitting is dus wel degelijk een

16 Met ingang van 1 september 2004 kent het Duitse recht ingevolge het 'Erste Justizmodernisierungsgesetz vom 24.8.2004'( $B G B l$. I 2004, $2198 \mathrm{ff}$ ) geen algemene plicht om getuigen en deskundigen ter zitting te beëdigen. $§ 59$ Abs. 1 StPO luidt sindsdien: 'Zeugen werden nur vereidigt, wenn es das Gericht wegen der ausschlaggebenden Bedeutung der Aussage oder zur Herbeiführung einer wahren Aussage nach seinem Ermessen für notwendig hält. Der Grund dafür, dass der Zeuge vereidigt wird, braucht im Protokoll nicht angegeben zu werden, es sei denn, der Zeuge wird außerhalb der Hauptverhandlung vernommen.'

17 Dedes 1992, p. 70.

18 Hooguit komt hier $\S 136$ a StPO in aanmerking. In deze bepaling is vastgelegd dat op de verdachte geen druk mag worden uitgeoefend om een verklaring van een bepaalde strekking af te leggen. Het niet in acht nemen van deze bepaling leidt in principe tot bewijsuitsluiting.

19 G. Herdegen, aant. 1 bij $\S 244$ StPO, in: Pfeiffer 2003. 
'middel' waarop de rechter zijn overtuiging mag baseren. ${ }^{20}$ Sterker nog, in de fase van de bewijswaardering zal de rechter nadrukkelijk op hetgeen door de verdachte is gesteld moeten ingaan, wil er sprake zijn van een volledige bewijswaardering. ${ }^{21}$ Het Duitse bewijsrecht kent derhalve wel het begrip 'wettig bewijsmiddel', maar daaraan moet slechts een beperkte betekenis worden toegekend. De eis van wettigheid van bewijs houdt slechts in dat bewijsmateriaal - voor zover het als wettig bewijsmiddel kan worden gekwalificeerd - aan de in de wet gestelde vormvoorschriften moet voldoen wil het onderdeel kunnen uitmaken van de Beweisaufnahme.

\subsubsection{Het beginsel van mondelinge procesvoering}

Een van de consequenties van het uitgangspunt dat op de bewijsvraag het Strengbeweisverfahren van toepassing is, is dat het beginsel van mondelinge procesvoering in acht moet worden genomen. De mondelinge procesvoering wordt als een algemeen strafvorderlijk uitgangspunt erkend, hoewel het nergens uitdrukkelijk in het Duitse strafprocesrecht is opgenomen. ${ }^{22}$ In strafprocessuele zin heeft het in eerste instantie tot doel de interne en externe openbaarheid van de behandeling van strafzaken te garanderen. Alle voor de beoordeling van strafzaken relevante feiten en omstandigheden moeten door middel van het gesproken woord tijdens de behandeling van de strafzaak worden ingevoerd, opdat procesdeelnemer en het publiek de inhoud van de processtof kunnen kennen.

Als strafprocessueel beginsel heeft het echter ook belangrijke consequenties voor de bewijsvoering. Deze dient immers ook mondeling te geschieden. De mondelinge introductie van het bewijs ter zitting wordt als een garantie voor de waarheidsvinding beschouwd.

'Die Anschaulichkeit des gesprochenen Wortes, der persönliche Eindruck, der Tonfall der Rede, die Möglichkeit schneller Berichtigung oder sofortiger Ergänzungsfragen und die Aussprache gewissermaßen "Auge in Auge" dienen der Wahrheitsfindung und führen zum Vorzug der mündlichen Rede gegenüber dem toten Buchstaben. ${ }^{23}$

Het beginsel van mondelinge procesvoering ligt in het verlengde van het formele onmiddellijkheidsbeginsel. Beide beogen te garanderen dat het onderzoek ter terechtzitting geldt als de centrale fase van het geding waar het gaat om de presentatie van de feiten en omstandigheden die relevant zijn voor de uiteindelijke beoordeling van de strafzaak. Het onderscheid tussen beide beginselen is daarin gelegen dat

20 In de Duitse literatuur wordt in dit verband een onderscheid gemaakt tussen bewijsmiddelen in engere zin en bewijsmiddelen in ruimere zin. Bijvoorbeeld: G. Herdegen, aant. 13 bij $\S 244$ StPO, in: Pfeiffer 2003.

21 Daarover nader $§ 7.5 .3 .4 .1$

22 Meestal wordt het indirect uit artikel 261 StPO afgeleid. Daar wordt het begrip Verhandlung uitgelegd als zijnde de mondelinge behandeling van de strafzaak.

23 Geppert 1979, p. 141. 
het formele onmiddellijkheidsbeginsel meer is gericht op de rechter, en geldt als een voorwaarde voor diens onafhankelijke en zelfstandige oordeelsvorming. Het beginsel van mondelinge procesvoering daarentegen kan veeleer als een garantie voor de overige procesdeelnemers worden beschouwd, in die zin dat een mondelinge procesvoering hen de gelegenheid biedt het beschikbare bewijsmateriaal aan te horen en indien gewenst daarop te reageren. In die zin kan het beginsel van een mondelinge procesvoering worden beschouwd als een absolute voorwaarde voor een contradictoire procesvoering, het aanschouwelijke dialectische discours dat in het kader van de waarheidsvinding zo belangrijk is. ${ }^{24}$ Als bewijsbeginsel wordt het beginsel van de mondelinge procesvoering in het Duitse recht ook wel in verband gebracht met het recht van de verdediging op rechterlijk gehoor, zoals dat in $\S 103$ lid 1 Grundgesetz ${ }^{25}$ is vastgelegd. ${ }^{26}$ Zoals onder andere Pfeiffer doet:

'Es dürfen also einer gerichtlichen Entscheidung regelmäßig nur solche Tatsachen und Beweisergebnisse zugrunde gelegt werden, zu denen die Beteiligten Stellung nehmen können. Art. 103 abs. 1 GG will also auch verhindern, dass das Gericht ihm bekannte, dem Beschuldigten aber verschlossene Sachverhalte zu dessen Nachteil verwertet. ${ }^{27}$

Het belang van de mondelinge procesvoering wordt het duidelijkst met betrekking tot schriftelijke processtukken. Voor zover dergelijke stukken al als bewijs toelaatbaar zijn, kan niet worden volstaan met een verwijzing naar deze stukken, maar moet de inhoud ervan in principe letterlijk worden voorgelezen. ${ }^{28}$ Dit dient niet alleen de interne en externe openbaarheid van de terechtzitting, maar ook wordt daarmee het contradictoire element van het strafproces onderstreept.

Ook volgt uit het beginsel van mondelinge procesvoering dat feiten van algemene bekendheid uitdrukkelijk ter zitting besproken moeten worden. Evenals in Nederland behoeven feiten van algemene bekendheid - in Duitsland offenkundige Tatsachen geheten - geen bewijs. Er wordt ten aanzien daarvan een onderscheid gemaakt tussen Algemeinkundigkeit en Gerichtskundigkeit. Feiten die voor ieder verstandig mens bekend zijn of waarvoor geldt dat deze kennis eenvoudig te achterhalen is, worden als algemeinkundig gekwalificeerd. ${ }^{29}$ Deze feiten hoeven geen bewijs, maar moeten wel ter zitting genoemd worden, zodat daar niet alleen de bekendheid (de Algemeinkundigkeit), maar ook de geldigheid (de Algemeingültigkeit) van deze feiten ter discussie kan worden gesteld.

Onder gerichtskundige feiten worden die feiten verstaan die de rechter beroepshalve bekend zijn. Niet gerichtskundig zijn feiten die de rechter uit persoonlijke bron bekend zijn. Evenmin feiten die een andere rechter in een andere strafzaak

24 Garé 1994, p. 59

$25 \S 103$ Abs. 1 luidt: 'Vor Gericht hat jedermann Anspruch auf rechtliches Gehör'.

26 Zie onder andere: Eisenberg 2002, p. 87.

27 Pfeiffer 2003, p. 23.

28 § 249 Abs. 1 StPO.

29 Eisenberg 2002, p. 70. 
heeft vastgesteld. Omdat het gebruik van feiten die de rechter beroepshalve kent mogelijkerwijze de indruk wekt dat de feitenvaststelling geheim zou zijn of het gevaar bestaat dat die feiten ondeugdelijk zijn vastgesteld of niet in het juiste verband worden gebezigd, wordt in de rechtspraak geëist dat dergelijke feiten tijdens het onderzoek ter terechtzitting worden genoemd.

'Schon durch die Übernahme frühere, eigener Feststellung werden die Regeln des förmlichen Beweisrechts, insbesondere die Gründsätze der Unmittelbarkeit und des Rechtlichen Gehörs (Art. 103 Abs 1 GG) durchbrochen und der Entscheidung uU [unter Umständen, WD] Tatsachen zugrunde gelegt, die der Nachprüfung durch die Prozeßbeteiligten entzogen sind. Daher müssen als gerichtskundig zu erörternde Tatsachen zum Gegenstand der Behandlung gemacht worden sein, etwa dergestalt, dass das Gericht darauf hinweist, es werde diese möglicherweise in einschlägiger Weise seiner Entscheidung zugrunde legen., ${ }^{30}$

Uit het beginsel van mondelinge procesvoering wordt geen algemene responsieplicht van de rechter op verweren afgeleid. Ook uit het in $\S 103$ lid 1 GG neergelegde recht op rechterlijk gehoor volgt een dergelijke plicht niet:

'Die Gerichte haben zwar die Pflicht, die Ausführungen der Verfahrensbeteiligten zur Kenntnis zu nehmen und in Erwägung zu ziehen; sie sind jedoch nicht verpflichtet, sich mit jedem Vorbringen in den Entscheidungsgründen ausdrücklich zu befassen. ${ }^{31}$

\subsubsection{Het materiële onmiddellijkheidsbeginsel}

In het Strengbeweisverfahren is de rechter eveneens gebonden aan het materiële onmiddellijkheidsbeginsel. In paragraaf 2.1 is reeds het onmiddellijkheidsbeginsel in formele zin aan de orde gekomen. In formele zin ziet het onmiddellijkheidsbeginsel op de plaats waar en ten overstaan van wie het bewijs ter zitting gepresenteerd moet worden. In materiële zin opgevat heeft het betrekking op de vraag welk bewijsmateriaal gepresenteerd mag worden.

'Die materielle Komponente der Unmittelbarkeit verlangt, dass das Gericht die Tatsachen aus der Quelle selbst schöpft und sich grundsätzlich nicht mit Beweissurrogate begnügt., ${ }^{32}$

Het belang van het materiële onmiddellijkheidsbeginsel ligt daarin dat de rechter niet alleen in staat wordt gesteld alle relevante feiten en omstandigheden ter terechtzitting te verzamelen, maar ook dat hij een volledig beeld krijgt van de context waarin die feiten en omstandigheden zijn waargenomen of ondervonden, opdat hij zich een oordeel kan vormen over de juistheid of betrouwbaarheid van die waarneming. Logischerwijze krijgt hij die context beter in beeld als hij de meest 'originele' bron ter zitting kan aanschouwen en waar mogelijk hoort en ondervraagt.

30 Eisenberg 2002, p. 73.

31 Pfeiffer 2003, p. 23.

32 Eisenberg 2002, p. 87. 
'Denn verständlicherweise bringt jede Beweisreproduktion in aller Regel eine Abschwächung und Trübung des Beweismaterials mit sich, und zwar vor allem im Bereich des Personalbeweises: Wird beispielsweise eine persönliche Aussage durch ein Vernehmungsprotokoll ersetzt, so hängt die Qualität des reproduzierenden Beweises (der Vernehmungsniederschrift) verständlicherweise von der exakten und erschöpfenden Fragestellung der Verhörsperson und von der Genauigkeit der jeweiligen Niederschrift ab. ${ }^{33}$

Het materiële onmiddellijkheidsbeginsel beoogt dus de kwaliteit van de waarheidsvinding te garanderen. ${ }^{34}$ Het richt zich weliswaar in eerste instantie tot de rechter, die geen genoegen moet nemen met bewijssurrogaten, maar ook de overige procespartijen hebben daar belang bij. Ook zij moeten in de gelegenheid worden gesteld de (meest) oorspronkelijke bron waaruit het bewijs voorvloeit te aanschouwen, te horen, aan vragen te onderwerpen en indien gewenst ter discussie te stellen. In die zin is het materiële onmiddellijkheidsbeginsel nauw verbonden met het hierboven genoemde beginsel van de mondelinge procesvoering en het recht op rechterlijk gehoor, die beide een contradictoire procesvoering garanderen. ${ }^{35}$ Immers, slechts indien het bewijs mondeling in zijn meest directe (onmiddellijke) vorm wordt gepresenteerd, is het voor procespartijen mogelijk de inhoud op betrouwbaarheid te controleren, en indien nodig die betrouwbaarheid ter discussie te stellen.

In het Duitse procesrecht is het materiële onmiddellijkheidsbeginsel wat betreft de eisen die te stellen zijn aan de bewijsvoering niet volledig doorgevoerd. Deels komt het beginsel tot uitdrukking in de hieronder nog uiteen te zetten onderzoeksplicht van de rechter. Deze plicht brengt onder andere met zich dat de rechter waar mogelijk ambtshalve het 'beste' bewijs ter zitting introduceert. Voor het overige komt het - waar het de bewijsvoering betreft - tot uitdrukking in $\S 250$ StPO waarin is bepaald dat in principe aan schriftelijke verklaringen van getuigen, deskundigen en verdachten, zoals die zijn vastgelegd tijdens het vooronderzoek, geen waarde toekomt:

'Beruht der Beweis einer Tatsache auf der Wahrnehmung einer Person, so ist diese in der Hauptverhandlung zu vernehmen. Die Vernehmung darf nicht durch Verlesung des über eine frühere Vernehmung aufgenommenen Protokolls oder einer schriftlichen Erklärung ersetzt werden.'

In $\S 250$ StPO komt de algemene gedachte tot uitdrukking dat op schrift gereproduceerd bewijsmateriaal van minder waarde is dan bewijsmateriaal dat mondeling ten overstaan van procespartijen ter zitting wordt gepresenteerd. Derhalve wordt de

33 Geppert 1979, p. 128

34 Geppert 1979, p. 214

35 In gelijke zin: Garé 1994, p. 77-78. Zij ziet het onmiddellijkheidsbeginsel niet alleen als bewijsbeginsel, maar tevens als structuurbeginsel. In die laatste zin garandeert het onder andere de openbaarheid van de strafprocedure, almede het contradictoire karakter van het onderzoek ter terechtzitting. 
zittingsrechter opgedragen in dergelijke gevallen niet te volstaan met het schriftelijke verslag van de waarnemingen van personen, maar dient hij zelf deze personen ter zitting te horen. De schriftelijke weergave moet immers als een ondeugdelijke vervanging van de persoonlijke verklaring van de getuige, deskundige of verdachte ter zitting worden beschouwd.

De reikwijdte van $\S 250 \mathrm{StPO}$ is aldus beperkt tot het zogeheten 'persoonlijke bewijs'. Schriftelijke stukken waarin geen verklaringen van personen zijn opgenomen, vallen derhalve buiten het bereik. Evenmin is op grond van $\S 250 \mathrm{StPO}$ een mondelinge de-auditu-verklaring van de bewijsvoering uitgesloten. Verklaart een getuige ter zitting wat hij een ander heeft horen zeggen, dan staat $§ 250$ StPO niet aan het gebruik van deze verklaring in de weg. ${ }^{36}$ Wel kunnen beperkingen aan het gebruik van deze verklaring volgen in het kader van de bewijswaardering.

Bovendien worden op het uitgangspunt van uitsluiting van schriftelijke verklaringen van personen in § $251 \mathrm{StPO}$ uitzonderingen geformuleerd. Zo mag met toestemming van procespartijen een schriftelijke de-auditu-verklaring voor het bewijs gebezigd worden. Stemt de verdediging echter niet in, dan gelden strikte voorwaarden voor het gebruik van de schriftelijke de-auditu-verklaring waarbij onderscheid wordt gemaakt tussen een de-auditu-verklaring afkomstig van een (onderzoeks)rechter (het eerste lid van $\S 251$ StPO) of van een andere persoon, meestal een opsporingsambtenaar (het tweede lid van $\S 251 \mathrm{StPO}$ ).

Ten anzien van het gebruik van een rechterlijke de-auditu-verklaring geldt de eis dat het verhoor door de rechter had plaatsgevonden conform de daaraan in de wet gestelde eisen. Zo dient de verdediging te worden uitgenodigd om bij dit verhoor aanwezig te zijn, dient zij in de gelegenheid te worden gesteld om vragen te stellen, en moet - indien gewenst - een tolk aanwezig zijn. Bovendien dient de aldus gehoorde getuige gewezen te worden op eventuele verschoningsrechten. Het niet in acht nemen van deze voorschriften betekende tot voor kort dat de verklaring van de getuige zoals die door de onderzoeksrechter was opgetekend van het bewijs was uitgesloten. Evenmin was het mogelijk om de onderzoeksrechter ter zitting te horen om op die wijze alsnog de verklaring van de getuige bij monde van de onderzoeksrechter in het onderzoek ter terechtzitting te importeren.

36 BGH 22 September 1987, BGHR StPO § 250 Satz 1 Unmittelbarkeit 1: 'Der Bundesgerichtshof hat wiederholt ausgesprochen, daß die Vernehmung eines sachferneren anstelle des sachnäheren Zeugen nicht dem Grundsatz der Unmittelbarkeit, der in $\S 250$ StPO seinen Niederschlag gefunden hat, widerspreche, es vielmehr eine Frage der dem Gericht obliegenden Aufklärungspflicht und der Beweiswürdigung sei, ob es sich mit dem sachferneren Zeugen begnügen dürfe (BGHSt 1, 373, 376; 6, 209; 17, 382, 384; 32, $115,123)$. Es war daher nicht von vornherein unzulässig, den ermittelnden Kriminalbeamten darüber zu vernehmen, was er im Zuge seiner Ermittlungen festgestellt hat. Eine solche Verfahrensweise kann allenfalls mit der Aufklärungsrüge angegriffen werden.' 
In mei 2000 heeft het Bundesgerichtshof bepaald dat het niet in acht nemen van de voorschriften met betrekking tot het verhoor van de onderzoeksrechter niet langer tot bewijsuitsluiting hoeft te leiden. In het betreffende geval was de verdediging niet uitgenodigd voor het verhoor bij de onderzoeksrechter, en had derhalve ook niet de mogelijkheid gehad om de getuige aldaar te ondervragen. Ter zitting beriep de getuige zich op het verschoningsrecht, waardoor ook daar het ondervragingsrecht niet gerealiseerd kon worden. Dit gebrek hoefde naar het oordeel van het Bundesgerichtshof niet te leiden tot de tot dan toe gangbare conclusie dat zowel de door de onderzoeksrechter op schrift gestelde verklaring als de mondelinge verklaring van de onderzoeksrechter ter zitting met betrekking tot het verhoor van de getuige uit de bewijsvoering moesten worden geschrapt:

'Der Senat hält eine Beweiswürdigungs-Lösung für sachgerechter als ein Verwertungsverbot für den Rückgriff auf den Vernehmungsrichter. Bei der BeweiswürdigungsLösung darf zwar auf den Vernehmungsrichter zurückgegriffen werden, allerdings sind dann - ähnlich wie beim anonymen Zeugen - besonders strenge Beweis- und Begründungsanforderungen aufzustellen. ${ }^{37}$

De keuze van het Bundesgerichtshof om bij schending van het ondervragingsrecht van de verdediging niet langer voor een bewijsuitsluitingsgrond te kiezen, maar strengere eisen te stellen aan de motivering van de bewezenverklaring komt voort uit zijn analyse van de rechtspraak van het Europese Hof voor de rechten van de mens met betrekking tot artikel 6 lid 3 EVRM. Op grond daarvan komt het tot de conclusie:

'Für die konventionskonforme Auslegung des deutschen Strafprozeßrechts ist eine Gesamtbetrachtung des Verfahrens vorzunehmen. Dazu gehört, daß das gesamte Beweisverfahren im Lichte des Fragerechts gesehen werden muß (vgl. Fall Barber à Nr. 76). Nach der Rechtsprechung des EGMR kommt es dabei zudem auch auf die Art und Weise der Beweiserhebung an. Unter diesem Gesichtspunkt stellt der EGMR zwar in erster Linie auf das Beweisverfahren und weniger auf die Beweiswürdigung selbst ab. Jedoch findet im Rahmen der Gesamtbetrachtung auch die Beweiswürdigung Berücksichtigung, wie gerade die Differenzierung des EGMR in den Fällen Unterpertinger und Asch zeigt. ${ }^{, 38}$

Onder andere Gleß heeft zich kritisch uitgelaten over deze uitspraak van het Bundesgerichtshof. ${ }^{39}$ Het oordeel slaat immers een bres tussen het tot dan toe geldende strikte onderscheid tussen bewijsgaring en presentatie ter zitting enerzijds en bewijswaardering anderzijds. Uitgangspunt van het Duitse strafproces is immers dat alleen wat conform de in de wet opgenomen regels is vergaard en ter zitting is gepresenteerd in de bewijswaardering kan worden betrokken. De aldus in de wet opgenomen regels hebben tot doel een minimum aan deugdelijkheid van

37 BGH 25 juli 2000, 1 StR 169/00.

38 BGH 25 juli 2000, 1 StR 169/00.

39 Gleß 2001, p. 3607. In gelijke zin: Fezer in zijn Anmerkungen bij BGH 25 juli 2000, 1 StR 169/00, Juristenzeitung 2001, p. 359. 
het bewijsmateriaal te garanderen. Zij zijn het gevolg van het inzicht dat bepaalde feiten, naar hun aard of door de wijze waarop zij bekend zijn geworden of de vorm waarin zij aan de rechter gepresenteerd worden op voorhand moeten worden uitgesloten opdat zij niet in de oordeelsvorming van de rechter worden betrokken. Door de rechter in de fase van de bewijsgaring en presentatie nadrukkelijk te binden, kan hem in de fase van de bewijswaardering een zekere beoordelingsvrijheid worden gegeven. Dit strikte onderscheid wordt echter op de helling gezet als de rechter de vrijheid krijgt om 'fouten' in de fase van de bewijsgaring en presentatie ter zitting te corrigeren in de fase van de bewijswaardering. Daarmee wordt hem een discretionaire bevoegdheid gegeven, waar die voorheen ontbrak of slechts bestond binnen de door de wet aangegeven grenzen.

Concluderend kan worden gesteld dat de bewijsvoering ter zitting ten dele door het materiële onmiddellijkheidsbeginsel zoals neergelegd in $\S 250$ StPO wordt genormeerd. In principe dient immers de rechter geen genoegen te nemen met bewijssurrogaten. Waar bewijs in de vorm van verklaringen van personen beschikbaar is, mag de rechter niet volstaan met een schriftelijk bescheid. Voor zover de wetgever uitzonderingen op dit principe toelaat, dient de wijze waarop die verklaring is verkregen overeen te komen met de wijze waarop een dergelijke verklaring ter zitting tot stand komt. Dit betekent in ieder geval dat het ondervragingsrecht van de verdediging - hét kenmerk van een contradictoire procesvoering - moet zijn gegarandeerd.

De laatste jaren is echter een tendens te bespeuren waarin het Bundesgerichtshof afstand neemt van deze strikte regels met betrekking tot de bewijsvoering. Werden eerst slechts in specifieke gevallen inbreuken op het ondervragingsrecht getolereerd (verklaringen van buitenlandse getuigen in het kader van de kleine rechtshulp ${ }^{40}$ en anonieme verklaringen van zogeheten $V$-Leute ${ }^{41}$ ), thans leidt de niet inachtneming van het ondervragingsrecht van de verdediging in zijn algemeenheid niet meer tot uitsluiting van dergelijke schriftelijke verklaringen. Wel zal de rechter uitdrukkelijk op de tekortkomingen met betrekking tot de totstandkoming van deze verklaring bij de bewijswaardering moeten ingaan. Hij zal moeten motiveren waarom hij ondanks het ontbreken van een directe confrontatie van rechter en procespartijen met de originele bron, de inhoud van die verklaring betrouwbaar acht. Daarmee is echter een voorschrift met betrekking tot bewijsvoering dat bij niet in achtneming leidt tot bewijsuitsluiting, verworden tot een voorschrift dat enkel de vrijheid van de bewijswaardering enigszins aan banden legt.

40 BGH 22 april 1952, BGHSt 2, 300.

41 BGH 5 december 1984, BGHSt 33, 83. 


\subsubsection{Het beginsel van materiële waarheidsvinding}

In het Strengbeweisverfahren is de rechter gebonden aan bepaalde bewijsmiddelen, aan het onmiddellijkheidsbeginsel in formele en materiële zin én aan het beginsel van mondelinge procesvoering. Daarmee wordt de wijze van bewijsvoering ter zitting genormeerd, in die zin dat het niet in acht nemen van de voorgeschreven vormen ertoe leidt dat het bewijsmateriaal niet in de bewijswaardering mag worden betrokken. Maar de bewijsvoering wordt niet alleen in negatieve, maar ook in positieve zin genormeerd. Dit laatste volgt uit het beginsel van materiële waarheidsvinding, ${ }^{42}$ zoals dat in $\S 244$ Abs. 2 StPO is vastgelegd:

'Das Gericht hat zur Erforschung der Wahrheit die Beweisaufnahme von Amts wegen auf alle Tatsachen und Beweismittel zu erstrecken, die für die Entscheidung von Bedeutung sind.'

Uit $\S 244$ Abs. 2 StPO volgt derhalve een gebod voor de feitenrechter om zijn onderzoek uit te breiden tot alle voor de beoordeling van de strafzaak relevante feiten en omstandigheden. Alvorens op de omvang van deze onderzoeksplicht nader in te gaan, is het zinvol de herkomst van deze bepaling kort te belichten.

\subsubsection{De historie van $\$ 244$ Abs. 2 StPO}

De ambtshalve onderzoeksplicht van de Duitse strafrechter is in 1935 in het toen geldende Duitse wetboek van strafvordering opgenomen. $\S 244$ Abs. 2 RStPO luidde:

'Das Gericht hat von Amts wegen alles zu tun was zur Erforschung der Wahrheit notwendig ist.'

Tot die tijd was de onderzoeksplicht van de rechter nadrukkelijk gekoppeld aan verzoeken van procespartijen om bepaalde feiten ter zitting te onderzoeken of bepaalde bewijsmiddelen te vergaren. Dergelijke verzoeken (Beweisanträge) konden echter in het merendeel van de gevallen worden afgewezen, namelijk indien naar het oordeel van de feitenrechter verder onderzoek niet noodzakelijk was voor het verkrijgen van zijn overtuiging in de strafzaak. Voor zover er al voor 1935 een ambtshalve onderzoeksplicht gold, was die in cassatie niet toetsbaar. In cassatie werd er vanuit gegaan dat:

‘der Tatrichter sei sich seiner Aufklärungspflicht hinreichend bewußt gewesen’. 43

42 Het beginsel van materiële waarheidsvinding wordt in de literatuur ook wel aangeduid met: Amtsermittlungsgrundsatz, Untersuchungsprinzip, Instruktionsprinzip, gerichtliche Amtsaufklärungspflicht of Inquisitionsgrundsatz. Ten aanzien van die laatste merkt Geppert op dat deze terminologie niet juist is, omdat het ten onrechte een verband legt met het vroegere inquisitoire proces. Geppert 2003, p. 256.

43 Fezer 2000, p. 848. 
Vanaf 1932 werd echter de mogelijkheid van de verdediging om Beweisanträge in te dienen vergaand teruggebracht door verschillende wetswijzigingen. Deze wijzigingen zijn niet los te zien van nationaal-socialistische ontwikkelingen in Duitsland en hadden tot doel:

'den Einfluß der Verfahrensbeteiligten zurückzudrängen und das autoritäre Element des Strafverfahren zu stärken. ${ }^{, 44}$

Zo wordt in 1932 de mogelijkheid om Beweisanträge in te dienen in hoger beroep volledig afgeschaft. In 1935 volgt dan een codificering van de reeds in de rechtspraak ontwikkelde afwijzingsgronden voor Beweisanträge. Een verzoek tot het horen van een deskundige of om bewijs via de eigen waarneming van de rechter te verkrijgen, kon worden afgewezen als dit naar het oordeel van de rechter niet noodzakelijk was. Ten aanzien van verzoeken om schriftelijke bescheiden ter zitting in te voeren en getuigen ter zitting te horen golden meer objectieve eisen. Echter ook deze meer objectieve afwijzingsgronden werden in 1939 afgeschaft. Vanaf 1 september 1939 gold voor alle verzoeken:

'Das Gericht kann eine Beweiserhebung ablehnen, wenn es nach freiem Ermessen die Erhebung zur Erforschung der Wahrheit nicht für erforderlich hält.'

In de aldus ontstane wettelijke situatie zag het Reichsgericht (de Duitse cassatierechter tot 1950) zich genoodzaakt om aan de inmiddels in 1935 gecodificeerde onderzoeksplicht verdergaande eisen te stellen teneinde de omvang van het onderzoek ter terechtzitting naar alle relevante feiten en omstandigheden te garanderen. Dit betekende dat de cassatierechter vonnissen vernietigde waaruit bleek dat de rechter bepaalde onderzoekshandelingen achterwege had gelaten, met de overweging dat deze niet noodzakelijk waren aangezien de rechter reeds op het beschikbare bewijsmateriaal zijn overtuiging kon baseren. Het Reichsgericht verbood in deze jurisprudentie de feitenrechter bij de beantwoording van de vraag of hij nadere onderzoekshandelingen ter zitting moest ondernemen, vooruit te lopen op zijn uiteindelijke oordeel. Dit verbod wordt in de Duitse literatuur het Beweisantizipationsverbot genoemd. ${ }^{45}$

Opvallend is dat de ontwikkeling van de onderzoeksplicht van de strafrechter ook nadat in 1950 het Beweisantragsrecht voor de procesdeelnemers in volle glorie werd hersteld ${ }^{46}$ niet tot stilstand kwam. Het feit dat in 1950 in de wet meer objectieve criteria voor het afwijzen van Beweisanträge werden opgenomen en de rechter dergelijke verzoeken dus niet langer kon afwijzen op grond van zijn subjectieve oordeel over de noodzaak van de verzochte handelingen, leidde niet tot een minder vergaande onderzoeksplicht van de feitenrechter. In tegendeel: na

44 Fezer 2000, p. 851.

45 Uitgebreid over het Beweisantizipationsverbot: Schulenburg 2002.

46 Gesetz zur Wiederherstellung der Rechtseinheit v. 20.9.1950 (BGBl. s. 455). 
1950 stelde het Bundesgerichtshof steeds hogere eisen aan de feitenrechter waar het de omvang van het onderzoek ter terechtzitting betrof:

'Das Gericht muß von Amts wegen Beweise erheben, wenn ihm aus den Akten oder aus dem Stoff der Verhandlung noch Umstände oder Möglichkeiten bekannt oder erkennbar sind, die bei verständiger Würdigung der Sachlage begründete Zweifel an der Richtigkeit der (auf Grund der bisherigen Beweisaufnahme erlangten) Überzeugung wecken müssen. $\mathrm{Ob}$ das der Fall ist und der Tatrichter zum Gebrauch eines weiteren Beweismittels gedrängt war, entscheidet das Revisionsgericht.(...) Bei einer solchen allein auf Rückschlüssen basierenden Überzeugung von der (Mit-) Täterschaft des Angeklagten drängten die Umstände zur Beweiserhebung über ein sich aus den Akten ergebendes mögliches Alibi des Angeklagten, der sich - abgesehen von einer allgemeinen Unschuldsbeteuerung - zur Sache nicht eingelassen hat. Denn je weniger gesichert ein Beweisergebnis erscheint und je gewichtiger die Unsicherheitsfaktoren sind, desto größer ist der Anlaß für das Gericht, trotz der erlangten Überzeugung weitere erkennbare Beweismöglichkeiten zu benutzen. ${ }^{47}$

Of de feitenrechter tot nadere onderzoekshandelingen had moeten komen, wordt door de cassatierechter zelf beoordeeld. Niet langer is sprake van een marginale toetsing van het oordeel van de feitenrechter, maar veeleer beoordeelt de cassatierechter of hij in het gegeven geval zelf de onderzoekshandeling zou hebben verricht of achterwege zou hebben gelaten. Bij de beoordeling van de noodzaak van de uitbreiding van het onderzoek ter terechtzitting spelen dan vervolgens wel verschillende aspecten een rol, zoals het onderwerp van de bewijsbeslissing, de bewijswaarde van eventueel nader te onderzoeken feiten of bewijsmiddelen, datgene wat al aan bewijsmateriaal beschikbaar is, de waarde van het reeds beschikbare bewijsmateriaal en de mogelijke conclusies die de feitenrechter daaruit denkt te kunnen trekken.

Uit de hierboven geschetste ontwikkeling van de ambtshalve onderzoeksplicht van de Duitse strafrechter blijkt dat deze in eerste instantie sterke samenhang vertoonde met de mogelijkheid voor procespartijen om ter zitting nadere onderzoeksvoorstellen te doen en de criteria op grond waarvan dergelijke voorstellen konden worden afgewezen. Echter na 1950 blijkt een tweede factor bepalend te zijn voor het versterken van het zogeheten Instruktionsprinzip, namelijk het besef dat de ambtshalve onderzoeksplicht noodzakelijk is indien de waardering van het bewijs aan diezelfde feitenrechter wordt overgelaten. Slechts indien de rechter zicht heeft op alle relevante feiten en omstandigheden, kan hij tot een afgewogen en verantwoorde beslissing komen met betrekking tot het bewijs in strafzaken. Waar dus de rechter vrijheid wordt gelaten met betrekking tot de waardering van het bewijs, mag een controle op de omvang van zijn onderzoekshandelingen niet ontbreken. In die zin vullen het beginsel van de vrije bewijswaardering en het beginsel van materiële waarheidsvinding elkaar aan. Het een kan niet zonder het ander:

47 BGH 9 mei 1996, BGHR StPO § 244 Abs. 2 Aufdrängen 6. 
'Die freie Beweiswürdigung darf nicht der Aufklärungspflicht entgegengehalten werden, denn die erstere darf erst dann einsetzen, wenn die letztere erfüllt ist: ohne vollständige Aufklärung bzw. deren Versuch kann die Beweiswürdigung immer nur eine vorläufige sein und daher ungeeignet, eine weitere Aufklärung als unnötig abzublocken. Der Vorrang gebührt zeitlich und logisch der Aufklärungspflicht; sie ist Voraussetzung einer danach einsetzenden Beweiswürdigung. ${ }^{48}$

\subsubsection{Volledige feitenvaststelling}

Uit de kort geschetste historie van de onderzoeksplicht van de Duitse strafrechter blijkt dat deze is ontstaan als reactie op het ontbreken van mogelijkheden van procespartijen, voornamelijk de verdediging, om verzoeken tot nader onderzoek in te dienen. Thans staat de onderzoeksplicht van de strafrechter hier los van:

'Das Gericht wird dann von seiner Pflicht zur Aufklärung nicht dadurch befreit, daß ihm das Verfahrensrecht die Möglichkeit gibt, den Antrag unter bestimmten Gesichtspunkten abzulehnen (BGHSt 10,119). ${ }^{49}$

De rechter dient ambtshalve het onderzoek uit te breiden tot alle voor de bewijsbeslissing relevante feiten en omstandigheden. Deze plicht geldt als een noodzakelijke voorwaarde voor de vrije bewijswaardering. De reikwijdte van de rechterlijke onderzoeksplicht volgt logischerwijze uit het beginsel van de vrije bewijswaardering; de rechter dient het onderzoek ter terechtzitting uit te breiden tot die feiten en omstandigheden die voor een rationele waardering van alle tot dan toe beschikbare feiten nodig is. ${ }^{50}$ In de rechtspraak komt dit tot uitdrukking in het criterium dat de rechter beschikbaar bewijsmateriaal ter zitting moet onderzoeken indien ook maar een kleine kans bestaat dat het gebruik van dat materiaal een ander licht op de strafzaak kan werpen. Het Bundesgerichtshof overwoog:

'Das Gebot der Wahrheitsforschung, das zu den grundlegenden, das gesamte Strafverfahren beherrschenden Prinzipien gehört, verpflichtet den Richter, jedes taugliche und erlaubte Mittel im Ringen um die Wahrheit einzusetzen. Der Richter muß die Beweismittel erschöpfen, wenn auch nur die entfernte Möglichkeit einer Änderung der durch die vollzogene Beweisaufnahme begründeten Vorstellung von dem zu

48 Walter 1979, p. 295.

49 BGH 23 november 1969, BGHSt 23,187 en 188.

50 In gelijke zin: het Bundesverfassungsgericht: 'Beweisaufnahme und Beweiswürdigung stehen in vielfacher Verschränkung. So wie § 244 Abs. 2 StPO das Gericht verpflichtet, alle bekannten Beweismittel vollständig zu erheben, verpflichtet $§ 261$ StPO, über alle auf der Grundlage des materiellen Rechts entscheidungserheblichen Beweisfragen eine vollständige Beweiswürdigung vorzunehmen und diese dem Urteil zu Grunde zu legen (vgl. Fezer, Stv 1995, p. 95). Dabei müssen nicht nur die unmittelbaren Beweise erhoben, sondern auch die zu ihrer Würdigung erforderlichen Umstände (u.a. zur Glaubwürdigkeit der Zeugen und Glaubhaftigkeit ihrer Angaben) ihrerseits im Rahmen der Beweisaufnahme aufgeklärt und zum Gegenstand der nachfolgenden Würdigung gemacht werden.' BVerfGE 30 april 2003, 2 BvR 2045/02 (r.o. 35) <http://www. Bundesverfassungsgericht.de/>. 
beurteilenden Sachverhalt in Betracht kommt. Die Erfahrung lehrt, daß gerade die Beurteilung geistig-seelischer Vorgänge, die auch bei sorgfältiger Prüfung den Anschein voller Zuverlässigkeit bietet, durch die Erhebung eines weiteren Beweises doch wider Erwarten sich wesentlich ändern kann. In Grenzfällen wird der Richter daher eher ein Zuviel als ein Zuwenig tun müssen. ${ }^{51}$

$\S 244$ Abs. 2 StPO stelt niet alleen in kwantitatieve zin eisen aan de onderzoeksactiviteiten van de rechter, maar ook in kwalitatieve zin. Ten behoeve van zijn ambtshalve onderzoek dient de rechter het materiële onmiddellijkheidsbeginsel in acht te nemen. Zo dient hij ter opheldering van de feiten:

'sich des sachnächsten Beweismittels zu bedienen und dieses Beweismittel in der nach den Gegebenheiten bestmöglichen Form zu verwenden ${ }^{, 52}$

Het Bundesverfassungsgericht spreekt in dit verband van het Gebot bestmöglicher Sachaufklärung. ${ }^{53}$ Desalniettemin zijn beperkingen op de plicht tot ambtshalve onderzoek mogelijk. In geval getuigen niet beschikbaar zijn is het Bundesgerichtshof bereid om uitzondering op de Aufklärungsplicht aan te nemen. Daar staat dan wel een nadere motiveringsplicht tegenover. Zoals tot uitdrukking kwam in de uitspraak van het Bundesgerichtshof d.d. 4 maart 2004 waarin de betrokkenheid van een verdachte bij de aanslagen in New York van 11 september aan de orde was. In die zaak kon een uit de Verenigde Staten afkomstige ontlastende getuige niet gehoord worden, omdat de Amerikaanse en Duitse autoriteiten daar niet aan meewerkten. Het Bundesgerichtshof meende dat de beperkte onderzoeksmogelijkheden in de bewijswaardering moesten worden betrokken:

'Kann ein zentrales Beweismittel wegen einer Sperrerklärung oder einer verweigerten Aussagegenehmigung nicht in die Hauptverhandlung eingeführt werden, obwohl ohne die Sperrerklärung oder verweigerte Aussagegenehmigung die Erhebung des Beweises ein Gebot der Aufklärungspflicht gewesen wäre (§ 244 Abs. 2 StPO) bzw. ein Beweisantrag des Angeklagten auf Erhebung des Beweises aus keinem der in $\S 244$ Abs. 3-5 StPO genannten Ablehnungsgründe hätte zurückgewiesen werden können, muß der Tatrichter die hierdurch bedingte Einschränkung seiner Erkenntnismöglichkeiten sowie die Beschneidung der Verteidigungsrechte des Angeklagten bei seiner Überzeugungsbildung berücksichtigen und in den Urteilsgründen im Rahmen der Beweiswürdigung erörtern. Andernfalls ist seine Beweiswürdigung lückenhaft und der Anspruch des Angeklagten auf ein faires, rechtsstaatliches Verfahren (Art. 20 Abs. 3 i. V. m. Art. 2 Abs. 1 GG; Art. 6 Abs. 1 MRK) verletzt. ${ }^{54}$

In de praktijk komt het zelden voor dat een strafrechtelijk vonnis in cassatie wordt vernietigd op grond van het feit dat de strafrechter zijn onderzoeksplicht onvoldoende is nagekomen. Fezer schrijft dit onder andere toe aan het feit dat

51 BGH 23 november 1969, BGHSt 23,187 en 188 .

52 BGH 18 mei 2000, 4 StR 647/99.

53 BVerfGE 30 april 2003, 2 BvR 2045/02 (r.o. 34).

54 BGH 4 maart 2004, 3 StR 218/03. 
feitenrechters anticiperen op de rechtspraak van het Bundesgerichtshof. ${ }^{55}$ In geval van twijfel zullen zij eerder besluiten alsnog het onderzoek ter terechtzitting uit te breiden, of uitdrukkelijk te overwegen waarom nader onderzoek in het gegeven geval niet nodig of mogelijk was.

Een andere reden voor het gebrek aan uitspraken op dit punt in cassatie is gelegen in de wijze waarop de cassatierechtspraak in Duitsland vorm is gegeven. Zo is een cassatieschriftuur alleen ontvankelijk indien uitdrukkelijk de redenen voor cassatie in de schriftuur worden genoemd. De algemene reden voor cassatie is evenals in Nederland, schending van het recht. ${ }^{56}$ Vervolgens wordt een onderscheid gemaakt tussen verkeerde toepassing van het materiële recht (een zogeheten Sachrüge) of verkeerde toepassing van het formele recht (een Verfahrensrüge). Indien degene die cassatie heeft ingesteld van mening is dat het materiële recht verkeerd is toegepast, dan kan hij volstaan met 'er rüge die Verletzung materiellen Rechts'. Wordt echter verkeerde toepassing van het formele recht als grond voor de cassatie aangevoerd, dan dient in de cassatieschriftuur uitdrukkelijk gesteld te worden op welk punt het formele recht is geschonden, waaruit dat blijkt, en waarom schending van het formele recht van invloed is geweest op de uitkomst van het geding. Deze eisen worden gesteld om te voorkomen dat de cassatierechter ambtshalve het hele dossier moet doornemen op zoek naar mogelijke strafprocessuele vormfouten.

Het niet nakomen van de onderzoeksplicht is in de Duitse optiek een zogeheten verfahrensrechtliche Rüge - meer specifiek: een zogeheten Aufklärungsrüge. Voor degene die op grond daarvan het strafrechtelijke oordeel in cassatie aanvecht, geldt een vergaande motiveringsplicht. ${ }^{57}$ In veel gevallen is daaraan niet voldaan, en om die reden is het beroep in cassatie dan ook niet ontvankelijk:

'Eine zulässige Aufklärungsrüge erfordert gemäß $§ 344$ Abs. 2 Satz 2 StPO die Darlegung aller Umstände und Vorgänge, die für die Beurteilung der Frage, ob sich dem Gericht die vermißte Beweiserhebung aufdrängen mußte, bedeutsam sein konnten. Wird gerügt, daß das Gericht bestimmte Zeugen nicht vernommen hat, ist insbesondere der Inhalt etwaiger früherer Aussagen mitzuteilen (BGH NJW 2000, 370, 371 m.w.N.). ${ }^{, 58}$

55 Fezer 2000, p. 860.

56 §37 StPO luidt: '(1) Die Revision kann nur darauf gestützt werden, dass das Urteil auf einer Verletzung des Gesetzes beruhe. (2) Das Gesetz ist verletzt, wenn eine Rechtsnorm nicht oder nicht richtig angewendet worden ist.'

57 De feiten moeten zodanig in de schriftuur worden weergegeven dat de cassatierechter zonder een blik in het dossier alle relevante gegevens voor handen heeft. Fezer 1999, p. 342.

58 BGH 21 september 2000, 1 StR 634/99. 
Fezer acht dit een minder goede ontwikkeling. ${ }^{59}$ Waar in materiële zin steeds minder beperkingen worden gesteld aan de Aufklärungsrüge, wordt nu in toenemende mate een procedurele barrière opgeworpen. Het gevolg van het stellen van zulke strenge motiveringseisen aan de Aufklärungsrüge is dat tegenwoordig in gevallen waarin naar het oordeel van een van de procespartijen de strafrechter zijn onderzoeksplicht heeft verzaakt, niet de onvolledige feitenvaststelling, maar de onvolledige waardering van het bewijs als cassatiegrond wordt aangevoerd. Deze laatste cassatiegrond wordt beschouwd als een Sachrüge waaraan geen nadere motiveringseisen worden gesteld. In wezen gaat het echter om dezelfde klacht, namelijk dat de rechter niet alle relevante feiten en omstandigheden in zijn oordeel heeft betrokken. Daarbij kan in het midden blijven of de rechter deze feiten en omstandigheden niet in zijn oordeel heeft betrokken omdat hij er geen onderzoek naar heeft gedaan, of dat hij dit wel heeft gedaan, maar vergeten is daarop in de motivering van zijn bewijsbeslissing nadrukkelijk in te gaan. In het laatste geval wordt wel gesproken van een Darstellungsrüge. Deze is echter in de praktijk nauwelijks te onderscheiden van de Aufklärungsrüge. ${ }^{60}$

\subsection{Tussenconclusie}

Uitgangspunt van het Duitse bewijsrecht is dat de rechter vrij is in de bewijswaardering, maar dat de wijze waarop het bewijsmateriaal ter zitting moet worden gepresenteerd, aan regels is gebonden. Belangrijkste eis ten aanzien van de bewijsvoering is dat deze ter zitting geschiedt. Dit volgt uit het formele onmiddellijkheidsbeginsel dat ook in $\S 261 \mathrm{StPO}$ is neergelegd. Bovendien geldt ten aanzien van de bewijsbeslissing het zogeheten 'Strengbeweisverfahren'. Dit betekent dat de rechter bewijsmateriaal slechts in de vorm van een wettig bewijsmiddel mag presenteren met alle daaraan gekoppelde wettelijke vereisten. Voor zover dat niet reeds uit de geëiste wettigheid van de bewijsmiddelen volgt, moet de rechter bij de bewijsvoering het beginsel van mondelinge procesvoering en het materiële onmiddellijkheidsbeginsel in acht te nemen. Deze beide beginselen beogen ieder op hun manier ook een contradictoire procesvoering te garanderen.

Is het bewijsmateriaal niet of niet op de juiste-justizformige - wijze tijdens het onderzoek ter terechtzitting gepresenteerd, dan mag de feitenrechter het niet in de bewijswaardering betrekken. Daarenboven wordt van hem verwacht dat hij het onderzoek ter terechtzitting uitbreidt tot alle voor het bewijsoordeel mogelijk

59 Fezer 1999, p. 342-343: 'Die Strenge der Revisionsgerichte in diesem Bereich zeigt durchaus Wirkung: Viele Verfahrensrügen scheitern an diesen formalen Hürden, entweder, weil sich der Revisionsführer in den Kommentaren nicht sorgfältig informiert hat oder weil ihm trotz allen Bemühens ein "Lapsus" unterlaufen ist.'

60 Fezer 1999, p. 351. 
relevante feiten en omstandigheden. Dit laatste vloeit voort uit de ambtshalve rechterlijke onderzoeksplicht, zoals die in $\S 244$ Abs. 2 StPO is neergelegd.

Door de rechter in de fase van de bewijsvoering - het onderzoek ter terechtzitting te binden aan wettelijke regels, worden de feiten en omstandigheden geselecteerd die hij in de daarop volgende fase - de waardering van die feiten en omstandigheden - mag én moet betrekken. Deze selectie heeft tot doel de rechter een deugdelijk fundament te verschaffen voor zijn uiteindelijke oordeel. Dit fundament bestaat uit al het voor het oordeel relevante ${ }^{61}$ bewijsmateriaal ten aanzien waarvan een minimum aan betrouwbaarheid kan worden gegarandeerd. Dat minimum wordt gevormd door het in acht nemen van bovengenoemde beginselen. Deze beginselen garanderen dat de rechter, het Openbaar Ministerie én de verdediging de gelegenheid hebben gehad het bewijsmateriaal waar te nemen, te onderzoeken én voor zover gewenst ter discussie te stellen. Voor zover een van deze partijen het aan een dergelijke gelegenheid heeft ontbroken, mag het bewijsmateriaal niet in de bewijswaardering betrokken worden. Bezien vanuit dit perspectief is ook begrijpelijk waarom de uitspraak van het Bundesgerichtshof waarin het niet in acht nemen van het ondervragingsrecht van de verdediging niet leidde tot uitsluiting van de bewuste verklaring, als een aantasting van het Duitse bewijsrecht in zijn kern wordt beschouwd. Gleß merkt hierover op:

'Die Unterscheidung zwischen Beweiserhebung und Beweisverwertung einerseits und Beweiswürdigung andererseits ist eine Grundfeste, auf der die deutsche Dogmatik zum Beweisrecht ruht. Gegenstand der Beweiswürdigung kann ein Beweismittel nur und erst dann sein, wenn zuvor die Frage der Verwertbarkeit positiv beantwortet ist. ${ }^{62}$

\subsection{De bewijswaardering}

In het Duitse strafproces is gekozen voor het uitgangspunt van vrije bewijswaardering. Dit uitgangspunt komt tot uitdrukking in $\S 261$ StPO:

'Über das Ergebnis der Beweisaufnahme entscheidet das Gericht nach seiner freien, aus dem Inbegriff der Verhandlung geschöpften Überzeugung.'

Op het eerste gezicht lijkt daarmee het beginsel van de vrije bewijswaardering goed verankerd in het Duitse strafprocesrecht. Deze indruk wordt versterkt door de afwezigheid van bewijsminima. ${ }^{63}$ Echter, in de praktijk is de strafrechter slechts in

61 In gelijke zin: het Bundesverfassungsgericht in zijn uitspraak d.d. 30 april 2003, NJW 2003 , p. 2445: 'Beweisaufnahme und Beweiswürdigung stehen in vielfacher Verschränkung. So wie § 244 II StPO das Gericht verpflichtet, alle bekannten Beweismittel vollständig zu erheben, verpflichtet $\S 261$ StPO, über alle auf der Grundlage des materiellen Rechts entscheidungserheblichen Beweisfragen eine vollständige Beweiswürdigung vorzunehmen und diese dem Urteil zu Grunde zu legen.'

62 Gleß 2001, p. 3606.

63 Alleen in $\S 190$ StGB en in $\S 274$ StPO treft men wettelijke bewijswaarderingsregels 
beperkte mate vrij in de waardering van het bewijsmateriaal. Ondanks het bepaalde in $\S 261$ StPO heeft het Bundesgerichtshof vergaande eisen gesteld aan de wijze waarop feitenrechters hun oordeel aangaande de bewijsbeslissing dienen vorm te geven. Deze eisen leidt het Bundesgerichtshof af uit het begrip 'overtuiging' zoals dat in $\S 261 \mathrm{StPO}$ is opgenomen. De overtuiging van de feitenrechter kan, aldus het Bundesgerichtshof, niet enkel gezien worden als zijn puur subjectieve mening over de vraag of de verdachte het feit al dan niet begaan heeft, maar veronderstelt dat de feitenrechter zijn overtuiging baseert op feiten en omstandigheden die in objectieve zin zijn oordeel kunnen dragen. Een dergelijke uitleg van het begrip 'overtuiging' stelt het Bundesgerichtshof in staat te controleren of de feiten en omstandigheden die de feitenrechter aan zijn oordeel ten grondslag legt, geschikt zijn om als basis van zijn subjectieve overtuiging te dienen. De reden waarom het Bundesgerichtshof tot een dergelijke vergaande interpretatie van $\S 261$ StPO is gekomen, houdt nauw verband met de ontstaansgeschiedenis van $\S 261$ StPO.

\subsubsection{De ontstaansgeschiedenis van $§ 261$ StPO}

De ontstaansgeschiedenis van $\S 261$ StPO gaat terug tot de $19^{\mathrm{e}}$ eeuw. In het begin van de $19^{\mathrm{e}}$ eeuw was Duitsland verdeeld in verschillende zelfstandige staten, die ieder een eigen strafproces en eigen strafprocesrecht kenden. De Franse revolutie en de consequenties die deze daar had voor de strafrechtspleging lieten ook het toenmalige 'Duitsland' niet onberoerd. Echter niet in alle zelfstandige staten werd het gedachtegoed van de Franse revolutie op gelijke wijze uitgewerkt. Enerzijds waren er Duitse staten waar de Franse Code d'Instruction Criminelle gold, en waar dus juryrechtspraak was ingevoerd. Anderzijds waren er staten waar nog steeds het oude Duitse inquisitoire strafproces gold. Met betrekking tot de waardering van het bewijs ontstond er ten gevolge hiervan een tweespalt. In die staten waarin de juryrechtspraak was ingevoerd, werden de daarvoor geldende strenge bewijswaarderingsregels afgeschaft. Van juryleden kon immers niet verlangd worden dat zij op rationele wijze bewijsregels konden toepassen. In die staten waarin ook na de Franse revolutie werd vastgehouden an het oude 'Duitse' procesrecht werden de in de wet neergelegde positieve bewijsregels

aan. § 190 StGB luidt: 'Ist die behauptete oder verbreitete Tatsache eine Straftat, so ist der Beweis der Wahrheit als erbracht anzusehen, wenn der Beleidigte wegen dieser Tat rechtskräftig verurteilt worden ist. Der Beweis der Wahrheit ist dagegen ausgeschlossen, wenn der Beleidigte von der Behauptung oder Verbreitung rechtskräftig freigesprochen worden ist.' Daarmee wordt ingeval van belediging de rechter voorgeschreven dat volledige bewijskracht toekomt aan een strafrechtelijke veroordeling. § 274 StPO ziet op de bewijswaarde van het proces-verbaal ter zitting: 'Die Beobachtung der für die Hauptverhandlung vorgeschriebenen Förmlichkeiten kann nur durch das Protokoll bewiesen werden. Gegen den diese Förmlichkeiten betreffenden Inhalt des Protokolls ist nur der Nachweis der Fälschung zulässig.' 
gehandhaafd. Werd dus in de eerst genoemde staten het bewijsoordeel volledig overgelaten aan het intuitieve waarheidsgevoel van de juryleden, in de laatstgenoemde werd het oordeel van de rechter strikt gebonden aan wettelijke bewijsregels die geen ruimte lieten voor zijn eigen overtuiging.

Opmerkelijk genoeg werd de invoering respectievelijk het voortbestaan van beide systemen gegrond op de aan de Franse revolutie ten grondslag liggende ideeën. Invoering van juryrechtspraak werd gemotiveerd door te verwijzen naar de noodzaak van een onafhankelijke en onpartijdige oordeelsvorming in strafzaken. Bovendien werd door invoering van de jury ook tegemoet gekomen aan de idee van de volkssoevereiniteit. Aan de andere kant werd de noodzaak van wettelijke bewijsregels voor beroepsrechters eveneens gebaseerd op de idee van het voorkomen van willekeurige rechterlijke beslissingen. Immers, alleen door de rechter te binden aan de wet kon voorkomen worden dat hij misbruik maakte van zijn positie. $^{64}$

In de aanloop naar een codificatie van het strafprocesrecht voor alle Duitse staten (in 1877) ontstond noodzakelijkerwijze een discussie over de vraag welk van beide stelsels in het nationale wetboek moest worden opgenomen. In die discussie werd onder andere door Von Feuerbach de juryrechtspraak fel bekritiseerd. Hij schrijft:

'Die Geschworenen mit ihrem Instinkt erscheinen hier nicht anders, denn ein Methodisten- oder Quäkerverein, der in dumpfer Gedankenlosigkeit auf den Lichtstrahl der natürlichen Offenbarung harrt, so wie die letzten auf eine Erleuchterung von oben., ${ }^{, 65}$

Ook volgens Jarcke kon de juistheid van het waarheidsoordeel niet alleen op de overtuiging van juryleden gebaseerd worden:

'weil sonst die Wahrheit immer dort zu finden sein müsse, wo eine Überzeugung vorhanden sei. ${ }^{66}$

Kortom: het aan de juryrechtspraak ten grondslag liggende idee van de conviction intime wordt langzaam verlaten en vervangen door de gedachte dat het waarheidsoordeel in strafzaken op rationele gronden moet berusten. Aan de andere kant werd ook het positieve bewijsstelsel zoals dat in andere Duitse staten nog gold onder vuur genomen. In 1846 schreef de Pruisische Minister van Justitie Von Savigny dat:

'das, was wir Gewißheit einer Thatsache nennen, auf so vielen einzelnen, in ihrer Zusammenwirkung nur dem einzelnen Fall angehörenden Elementen beruht, daß sich dafür gar keine wissenschaftlichen allgemeinen Gesetze geben lasse',

64 Schmitt 1992, p. 156 spreekt in dit verband spreekt van de 'Beweistheorie gegen richterliche Willekür'.

65 Von Feuerbach 1813, p. 119

66 Jarcke 1825, p. 99. 
Maar daaruit volgde zijns inziens niet

'daß die Richter überhaupt von der Verpflichtung entbunden werden nach Gründen und Regeln zu urteilen und hiervon Rechenschaft zu geben'. ${ }^{67}$

Opvallend is dan ook dat al in de loop van de $19^{\mathrm{e}}$ eeuw in diverse staten het positief wettelijke bewijsstelsel werd vervangen door een negatieve variant. ${ }^{68}$ In deze negatief-wettelijke bewijsstelsels bleven weliswaar bewijsregels bestaan, maar deze leidden er niet toe dat de rechter tegen zijn overtuiging in moest veroordelen. De bewijsregels eisten een minimum aan (betrouwbaar) bewijs alvorens tot een bewezenverklaring kon worden overgegaan, zij dwongen de rechter echter niet een bewezenverklaring uit te spreken indien dat tegen zijn innerlijke overtuiging inging.

Maar ook het negatief-wettelijk bewijsstelsel was niet vrij van kritiek. Zo werd onder andere beweerd dat het stelsel innerlijk tegenstrijdig zou zijn. Enerzijds wordt het mogelijk en noodzakelijk geacht om algemene bewijswaarderingsregels in de wet op te nemen waaraan de rechter bij zijn oordeelsvorming is gebonden. Anderzijds wordt de overtuiging als uiteindelijk doorslaggevende argument voor de bewijsbeslissing gezien. Met dit laatste wordt feitelijk de algemene geldigheid van de wettelijke bewijswaarderingsregels geweld aangedaan. Bovendien bleek in de praktijk dat het negatief-wettelijk bewijsstelsel er toe leidde dat verdachten soms moesten worden vrijgesproken, terwijl de rechter wel overtuigd was van hun schuld. Teneinde te voorkomen dat in dergelijke gevallen de verdachte volledig vrij uit ging, werd met behulp van een truc alsnog een straf uitgedeeld (Institut der Instanzentbindung) ${ }^{69}$ Hiermee werd echter de idee dat ten grondslag lag aan het negatief-wettelijk bewijsstelsel - binding van de rechter aan minimumregels ondergraven.

Het is niet verwonderlijk dat gezien het bovenstaande bij de invoering van de Reichsstrafprozessordnung (RStPO) op 1 februari 1877 voor een volledige afschaffing van de wettelijke bewijswaarderingsregels en invoering van het beginsel van vrije bewijswaardering werd gekozen. ${ }^{70} \S 260 \mathrm{RStPO}$ luidde:

67 Von Savigny 1858, p. 484 en 486

68 Zo werd het negatief-wettelijk bewijsstelsel opgenomen in het strafprocesrecht van Würtemberg (1843) en Baden (1845). In de overige staten werd weliswaar op dit punt de wet niet aangepast, maar werd de bestaande wetgeving in het licht van de negatiefwettelijke bewijstheorie geïnterpreteerd. Schmitt 1992, p. 163.

69 Schmitt 1992, p. 154

70 Het uitgangspunt van vrije bewijswaardering voor de beroepsrechter werd voor het eerst geformuleerd in het 'Preußische Gesetz vom 17. Juli 1846 betr. das Verfahren in den bei dem Kammergericht und bei dem Kriminalgericht in Berlin zu führenden Untersuchungen'. Art. 19 bepaalde: 'Der erkennende Richter hat fortan unter genauer Prüfung aller Beweise für die Anklage und Verteidigung nach seiner freien, aus dem Inbegriffe der vor ihm erfolgten Verhandlung geschöpften Überzeugung zu entscheiden, ob der 
'Über das Ergebnis der Beweisaufnahme entscheidet das Gericht nach seiner freien, aus dem Inbegriff der Verhandlung geschöpften Überzeugung.'

Daarbij moet echter voor ogen worden gehouden dat het beginsel van de vrije bewijswaardering voortkwam uit het besef dat het onmogelijk was een volledig stelsel aan bewijswaarderingsregels in de wet op te nemen dat in iedere individuele strafzaak tot het vinden van de waarheid zou kunnen leiden. ${ }^{71}$ Bovendien verzette het toen nog bestaande instituut van juryrechtspraak zich tegen het bestaan van wettelijke bewijswaarderingsregels. Van juryleden kon men onmogelijk verwachten dat zij hun oordeel rationeel zouden onderbouwen. Fezer vat de aldus bij invoering van de Reichsstrafprozessordnung ontstane situatie als volgt bondig samen:

'Und schließlich ging der Gesetzgeber der RStPO davon aus, dass die Beweiswürdigung als eine rein tatrichterliche Angelegenheit der revisiongerichtlichen Überprüfung von vornherein völlig entzogen sei. Ich vermute, daß hinter all dem die einseitige Orientierung am ,Wahrspruch der Geschworenen' stand und eine etwas blauäugige Überschätzung der damals neuen Grundsätze der Mündlichkeit und Unmittelbarkeit. ${ }^{, 72}$

\subsubsection{Het begrip 'overtuiging'}

Met de afschaffing van de juryrechtspraak in $1924^{73}$ wordt de vraag of het oordeel van de strafrechter op zijn puur subjectieve overtuiging kan worden gebaseerd niet alleen in de literatuur, maar ook in de rechtspraak weer actueel.

In de rechtspraak van het Reichsgericht wordt met betrekking tot de bewijswaardering gesteld dat niet te hoge eisen aan de overtuiging van de - professionele - rechter moeten worden gesteld. Absolute zekerheid is immers niet mogelijk. De strafrechter zal genoegen moeten nemen met een aan zekerheid grenzende waarschijnlijkheid. Voldoende is dat de rechter zelf van mening is dat zijn oordeel aan dit criterium voldoet.

'Weil absolute Erkenntnis im Sinne letzter Sicherheit menschenunmöglich sei, müsse auch der Richter sich mit einem so hohen Grad von Wahrscheinlichkeit begnügen, wie er bei möglichst erschöpfender und gewissenhafter Anwendung der vorhandenen Mittel der Erkenntnis entsteht. Ein solcher Grad von Wahrscheinlichkeit gilt als Wahrheit und das Bewußtsein des Erkennenden von dem Vorliegen einer so ermittelten hohen Wahrscheinlichkeit als Überzeugung von der Wahrheit. ${ }^{74}$

Angeklagte schuldig oder nichtschuldig oder ob der Angeklagte von der Anklage zu entbinden sei.'

71 In gelijke zin: Alwart 1992, p. 552: 'Der Grundsatz der freien Beweiswürdigung bedeutet bekanntlich eine Abkehr vom System der Beweisregeln.'

72 Fezer 1995, p. 96.

73 De juryrechtspraak werd afgeschaft bij de wet van 4 januari 1924 (RG Verordnung über Gerichtsverfassung und Strafprozeß. I, S.15); beter bekend als de Eminger Reform genoemd naar de toenmalige Minister van Justitie Erich Eminger.

74 RGSt 61, 202 (206), zoals weergegeven door Geppert 2004, p. 107. 
In deze uitspraak wordt door het Reichsgericht allereerst de waarheid in strafzaken teruggebracht tot een aan zekerheid grenzende waarschijnlijkheid, waarbij vervolgens de subjectieve overtuiging van de rechter alleen dient te gelden ten aanzien van deze afgezwakte vorm van waarheid of zekerheid. ${ }^{75}$ Van de feitenrechter wordt niet verlangd dat hij zijn persoonlijke overtuiging in het vonnis beredeneert. In de daarop volgende jurisprudentie van het Bundesgerichtshof wordt na enige aarzeling afstand genomen van deze opvatting van het Reichsgericht. In zijn uitspraak d.d. 9 februari 1957 overweegt het Bundesgerichtshof:

'Freie Beweiswürdigung bedeutet, daß es für die Beantwortung der Schuldfrage allein darauf ankommt, ob der Tatrichter die Überzeugung von einem bestimmten Sachverhalt erlangt hat oder nicht; diese persönliche Gewißheit ist für die Verurteilung notwendig, aber auch genügend. Der Begriff der Überzeugung schließt die Möglichkeit eines anderen, auch gegenteiligen Sachverhaltes nicht aus; vielmehr gehört es gerade zu ihrem Wesen, daß sie sehr häufig dem objektiv möglichen Zweifel ausgesetzt bleibt. Denn im Bereich der vom Tatrichter zu würdigenden Tatsachen ist der menschlichen Erkenntnis bei ihrer Unvollkommenheit ein absolut sicheres Wissen über den Tathergang, demgegenüber andere Möglichkeiten seines Ablaufs unter allen Umständen ausscheiden müßten, verschlossen. Es ist also die für die Schuldfrage entscheidende, ihm allein übertragene Aufgabe des Tatrichters, ohne Bindung an gesetzliche Beweisregeln und nur seinem Gewissen verantwortlich zu prüfen, ob er die an sich möglichen Zweifel überwinden und sich von einem bestimmten Sachverhalt überzeugen kann oder nicht. ${ }^{76}$

Het begrip 'overtuiging' wordt door het Bundesgerichtshof evenals het Reichsgericht subjectief ingevuld. Het verschil met de jurisprudentie van het Reichsgericht is daarin gelegen, dat de rechter volledig overtuigd moet zijn. In tegenstelling tot de opvatting van het Reichsgericht kan de feitenrechter niet volstaan met een Fürwahrscheinlichhalten, maar moet hij de door hem vastgestelde feiten persoonlijk Fürwahrhalten. ${ }^{77}$ Uit de zinsnede 'diese persönliche Gewißheit ist für die Verurteilung notwendig, aber auch genügend', blijkt echter dat het Bundesgerichtshof nog niet wil weten van een vergaande toetsing van de bewijswaardering; de subjectieve overtuiging van de rechter is doorslaggevend voor de waardering van het bewijs. Dat betekent echter niet dat in cassatie de overtuiging van de feitenrechter onaantastbaar is. Zo is de rechter gebonden aan de regels van de logica en algemeen erkende ervaringsregels:

'(E)s gebe wissenschaftliche Erkenntnisse, denen eine unbedingte, jeden Gegenbeweis mit anderen Mitteln ausschließende Beweiskraft zukomme, und der Tatrichter müsse solche allgemein als gesichert geltende Erkenntnisse als richtig hinnehmen, selbst wenn er ihre Grundlagen im Einzelnen nicht selbst erschöpfend nachprüfen könne (vgl BGHSt 5,34; 6,70). Denn der Tatrichter ist den Gesetzen des Denkens und der

75 Herdegen 1999, p. 312: 'Der Begriff der Wahrheit werd mit dem Prädikat "subjektive oder relative" versehen und die so relativierte Wahrheit wird mit dem Repräsentationsgehalt der richterlichen Überzeugung gleichgesetzt'.

76 BGH 9 februari 1957, BGHSt 10, 208.

77 Albrecht 1983, p. 488. 
Erfahrung unterstellt; wo eine Tatsache auf Grund wissenschaftlicher Erkenntnis feststeht, ist für eine richterliche Feststellung und Überzeugungsbildung naturgemäß kein Raum mehr. ${ }^{, 78}$

Bovendien mag de feitenrechter niet te hoge eisen stellen aan een vrijspraak. Het bestaan van de theoretische mogelijkheid dat de feiten zich anders hebben voorgedaan dan tenlastegelegd, staat niet aan een bewezenverklaring in de weg:

'Ein Rechtsfehler läge nur vor, wenn das Schwurgericht zwar von der Täterschaft des Angeklagten im Sinne des Eröffnungsbeschlusses überzeugt gewesen wäre, aber gleichwohl irrtümlicherweise angenommen hätte, deshalb nicht verurteilen zu dürfen, weil nach Abwägung aller Umstände immerhin noch die theoretische Möglichkeit eines von der gewonnenen richterlichen Überzeugung abweichenden Geschehensverlaufs bestehe, ein anderer Beurteiler also noch Zweifel an der Täterschaft des Angeklagten haben könne. ${ }^{79}$

In latere uitspraken van het Bundesgerichtshof komt het laatstgenoemde aspect terug, in die zin dat de rechter geen absolute zekerheid hoeft te hebben over de juistheid van zijn oordeel, maar dat hij genoegen kan nemen met een aan zekerheid grenzende waarschijnlijkheid. Of er sprake is van een slechts theoretische abstracte mogelijkheid dat de verdachte het hem tenlastegelegde feit niet heeft gepleegd, dient hij te beoordelen aan de hand van hetgeen de algemene levenservaring hem leert.

'Die Feststellung von Tatsachen verlangt keine absolute, von niemandem anzweifelbare Gewissheit. Es genügt vielmehr, daß ein nach der Lebenserfahrung ausreichendes Maß an Sicherheit besteht, demgegenüber vernünftige Zweifel nicht laut werden können. Außer Betracht zu bleiben haben solche Zweifel, die eines realen Anknüpfungspunktes entbehren und sich lediglich auf die Annahme einer bloß gedanklichen, abstrakttheoretischen Möglichkeit gründen. ${ }^{, 80}$

De uitspraak van het Bundesgerichtshof uit 1957 kan worden beschouwd als de eerste aanzet tot een nadere definiëring van het begrip 'overtuiging'. Onduidelijk is echter of - mede gezien het feit dat de feitenrechter wel is gebonden aan de regels van logica en algemene ervaringsregels - het Bundesgerichtshof nu daadwerkelijk koos voor een (pure) subjectieve overtuigingsleer. ${ }^{81}$ Voor zover dat het

78 BGH 9 februari 1957, BGHSt 10, 208.

79 BGH 9 februari 1957, BGHSt 10, 208. Opvallend is dat de Hoge Raad in Nederland bijna 50 jaar later een vergelijkbare uitspraak doet, t.w.: HR 13 juni 2006, NJ 2007, 48 m.nt. Y.Buruma.

80 BGH 23 juni 1999, NStZ-RR 99, 332. In gelijke zin: BGH 12 september 1996, BGHR BMG § 29 Beweiswurdigung 15; BGH 6 december 2000, 2 StR 372/00 en BGH 14 november 2001, 3 StR 276/01.

81 Enige jaren daarvoor had het Bundesgerichtshof namelijk een uitspraak gewezen die mogelijk tegen een subjectieve overtuigingsleer sprak. In BGH NJW 1951, 122 werd overwogen: 'Für sie [de overtuiging, WD] ist erforderlich, aber auch genügend, daß ein nach der Lebenserfahrung ausreichendes $\mathrm{Ma} ß$ an Sicherheit besteht, dem gegenüber vernünftige Zweifel nicht mehr laut werden können.' Hieruit zou kunnen worden afgeleid dat het Bundesgerichtshof kennelijk niet alleen de subjectieve overtuiging als voldoende voor een veroordeling cq. vrijspraak voor ogen had. In gelijke zin: Herdegen 2000, p. 37. 
geval is, stapt het Bundesgerichtshof in zijn latere jurisprudentie van deze leer af door in toenemende mate eisen te stellen aan de waardering van het bewijs door de feitenrechters.

Deels kwamen deze eisen reeds voort uit de uitspraak van 1957 waarin werd gesteld dat de feitenrechter is gebonden aan de regels van de logica en algemene ervaringsregels. In de recente rechtspraak is deze eis, inhoudelijk erop neerkomend dat de bewijswaardering foutloos moet zijn, door het Bundesgerichtshof nader uitgewerkt. Het vonnis mag met betrekking tot de waardering van de daarin opgenomen feiten evenmin onduidelijkheden, leemtes en contradicties bevatten. Deze eisen worden in de jurisprudentie standaard als volgt weergegeven:

'Die Beweiswürdigung ist Sache des Tatrichters; die revisionsgerichtliche Prüfung beschränkt sich darauf, ob diesem Rechtsfehler unterlaufen sind. Das ist in sachlichrechtlicher Hinsicht der Fall, wenn die Beweiswürdigung widersprüchlich, unklar oder lückenhaft ist oder gegen Denkgesetze oder gesicherte Erfahrungssätze verstößt. ${ }^{82}$

Wezenlijker ten aanzien van de invulling van het begrip 'overtuiging' is echter dat vanaf 1957 steeds vaker vonnissen in cassatie worden vernietigd omdat de feitenrechter niet alle relevante feiten en omstandigheden in de bewijswaardering heeft betrokken. In de visie van het Bundesgerichtshof is in dergelijke gevallen de feitenrechter op onvolledige gronden tot zijn overtuiging gekomen. In de cassatierechtspraak werden aanvankelijk bewezenverklaringen van de feitenrechters vernietigd omdat zij slechts gebaseerd waren op een zogeheten 'bloot vermoeden' ${ }^{83}$ Naderhand - in de jaren negentig van de vorige eeuw - specificeert het Bundesgerichtshof deze eis, door van feitenrechters te eisen dat zij hun oordeel baseren op een tragfähige Tatsachengrundlage.$^{84}$ De persoonlijke overtuiging van de rechter wordt door dit criterium niet vervangen, maar wordt aangevuld met de eis voor de feitenrechter dat hij inzichtelijk maakt op welke feiten en omstandigheden hij die overtuiging baseert. Uit deze rechtspraak volgt dat het begrip 'overtuiging' twee componenten kent. Enerzijds de subjectieve component, bestaande uit de persoonlijke overtuiging van de rechter dat door hem vastgestelde feiten juist zijn ('das Fürwahrhalten'). Anderzijds een meer objectieve component, bestaande uit feiten en omstandigheden die dit oordeel kunnen dragen.

'Die ständige Beachtung und Prüfung der objektiven Komponente der Überzeugungsbildung - also die Wahrscheinlichkeitsebene - hat damit eine begrenzende und kontrollierende Funktion gegenüber zu frühzeitiger subjektiver Überzeugung. ${ }^{85}$

82 BGH 8 februari 2000, 5 StR 310/99.

83 BGH 7 juni 1979, BGHSt 29, 18; BGH 11 maart 1987, BGHR StPO § 261 Vermutung 1; BGH 23 juni 1988, BGHR StPO § 261 Vermutung 4 en BGH 4 november 1988, BGHSt 36, 1.

84 Nack 2002, p. 512 en BGH 13 augustus 1991, 5 StR 231/91; BGH 6 april 1990, BGHR StPO § 261 Identifizierung 6; BHG 24 november 1992, BGHR StPO § 261 Vermutung 11 en BGH 8 november 1996, BGHR StPO § 261 Überzeugungsbildung 26.

85 Albrecht 1983, p. 490. 
In de jurisprudentie vanaf 1957 is aldus een tendens zichtbaar waarin het Bundesgerichtshof afstapt van de 'pure' subjectieve overtuigingstheorie. Daarbij zijn steeds wisselende criteria zichtbaar. Soms worden vonnissen (meestal vrijspraken) vernietigd omdat zij niet in overeenstemming zijn met de 'algemene levenservaring', andere (meestal bewezenverklaringen) houden in cassatie geen stand omdat zij slechts gebaseerd zijn op een vermoeden. Vanaf de jaren tachtig komt steeds vaker het criterium van een tragfähige Tatbestand in beeld. In de literatuur wordt deze rechtspraak van het Bundesgerichtshof door het merendeel van de schrijvers verwelkomd ${ }^{86}$ Ook Herdegen, een van de rechters in het Bundesgerichtshof, is fervent voorstander van een verdergaande toetsing van het bewijsoordeel in cassatie, maar bekritiseert het ontbreken van een duidelijk toetsingscriterium. ${ }^{87}$ Met andere woorden: wanneer is het bewijsoordeel in strijd met hetgeen de algemene levenservaring ons leert, ${ }^{88}$ wanneer is er slechts sprake van een bloot vermoeden, of wanneer kunnen feiten en omstandigheden in objectieve zin het oordeel van de rechter dragen? Wat is kortom de standaard voor het bewijs in strafzaken, als kennelijk de subjectieve overtuiging van de rechter dat niet of niet alleen is?

Deze vraag wordt in de jaren negentig van de vorige eeuw door het Bundesgerichtshof beantwoord. In zijn uitspraak d.d. 29 juli 1991 kiest het Bundesgerichtshof voor het criterium van de 'hoge waarschijnlijkheid':

'Die richterliche Überzeugung setzt neben [cursivering WD] der persönlichen Gewißheit des Richters objektive Grundlagen voraus. Die müssen aus rationalen Gründen den Schluß erlauben, daß das festgestellte Geschehen mit hoher Wahrscheinlichkeit mit der Wirklichkeit übereinstimmt. Das ist der Nachprüfung durch das Revisionsgericht zugänglich. Deshalb müssen die Urteilsgründe erkennen lassen, daß die Beweiswürdigung auf einer tragfähigen, verstandesmäßig einsichtigen Tatsachengrundlage beruht und daß die vom Gericht erzogene Schlußfolgerung nicht etwa nur eine Annahme ist oder sich als bloße Vermutung erweist, die letztlich nicht mehr als einem Verdacht zu begründen vermag. ${ }^{89}$

86 Onder andere: Fezer 1995, p. 99 en Herdegen 1999, p. 318.

87 Herdegen 1999, p. 323: 'Noch ist die Frage offen, wie der normative Maßstab zu bestimmen ist, der das Kriterium dafür sein solle, ob die tatrichterlichen BeweiswertEinschätzungen und Sachverhaltsannahmen dem Geltungsanspruch genügen'.

88 Herdegen 1999, 321 heeft nadrukkelijk stelling genomen tegen het criterium van de algemene levenservaring voor het waarderen van bewijs in strafzaken: 'Diese Beweiswürdigungstheorie unterscheidet mithin der Vernunft gemäße, zu respektierende und nicht der Vernunft gemäße und deshalb nicht zu respektierende Zweifel der Tatgerichte. Auf die Frage, was unvernünftige Zweifel sind, antwortet sie, es handele sich um Zweifel, die durch das nach der Lebenserfahrung ausreichende Maß an Sicherheit nicht zum Schweigen gebracht werden. Und auf die Frage, wie das ausreichende $\mathrm{Ma} ß$ an Sicherheit zu verstehen sei, gibt sie zur Antwort, es handele sich um das Beweismaß, das nur dem vernünftigen Zweifel Einflußnahme auf die tatrichterliche Entscheidung gestattet.' Het is met andere woorden volgens Herdegen een inhoudsloos criterium.

89 BGH 29 juli 1991, 5 StR 278/91. Zie ook: BGH 13 augustus 1991, 5 StR 231/91; BGH 6 april 1990, BGHR StPO § 261 Identifizierung 6; BHG 24 november 1992, BGHR StPO § 261 Vermutung 11 en BGH 8 november 1996, BGHR StPO $§ 261$ Überzeugungsbildung 26. 
In deze uitspraak wordt nadrukkelijk afstand genomen van de uitspraak van het Bundesgerichtshof in 1957. Niet langer is alleen de persoonlijke overtuiging van de rechter doorslaggevend. Van de feitenrechter wordt verwacht dat hij zijn overtuiging baseert op feiten en omstandigheden die zijn oordeel kunnen dragen. Er moet in de woorden van het Bundesgerichtshof sprake zijn van een tragfähige Tatsachengrundlage. Of dat zo is, kan alleen maar blijken uit de motivering van het bewijsoordeel. Er worden dus - naast de rechterlijke subjectieve overtuiging - eisen gesteld aan de kwaliteit van de aan de bewezenverklaring ten grondslag liggende argumentatie. Uit die argumentatie moet blijken dat de door de rechter vastgestelde feitenconstellatie met een hoge mate van waarschijnlijkheid overeenkomt met de werkelijkheid. ${ }^{90}$

'Das Beweismaß der hohen Wahrscheinlichkeit soll sicherstellen, daß die Annahmen des Tatgerichts über das, was der Fall war (Rekonstruktion' des Tatgeschehens) (...) und der darauf gestützte Urteilsspruch intersubjektiv akzeptabel sind, rationaler, sachkundiger Kritik standzuhalten vermögen. ${ }^{91}$

Daarmee wordt de overtuiging gekoppeld aan een motiveringsverplichting voor de strafrechter. Waar het Duitse Wetboek van Strafvordering een dergelijke motiveringsplicht ten aanzien van de bewijsbeslissing niet kent, wordt zij alsnog via een ruime interpretatie van het begrip 'overtuiging' in $\S 261$ StPO aan de feitenrechter opgelegd. ${ }^{92}$ De reikwijdte van deze motiveringsplicht en hoe de motivering in concrete strafzaken gestalte krijgt, wordt in de volgende paragrafen aan de orde gesteld.

\subsubsection{De motivering van het bewijsoordeel}

Uit de wijze waarop het Bundesgerichtshof thans invulling geeft aan het begrip 'overtuiging' volgt dat eisen worden gesteld aan de wijze waarop de feitenrechter

90 Het criterium van de 'hoge waarschijnlijkheid' is ook door het Bundesverfassungsgericht in zijn uitspraak d.d. 30 april 2003, NJW 2003, 2444 overgenomen: 'Während die frühere Rechtsprechung Schlußfolgerungen des Tatgerichts, die nach der Lebenserfahrung möglich sind, genügen ließ, wird nunmehr vorausgesetzt, dass der Schuldspruch auf einer tragfähigen Beweisgrundlage aufbaut, die die objektiv hohe Wahrscheinlichkeit der Richtigkeit der Beweisergebnisse ergibt. Wenngleich die Beweiswürdigung von Gesetzes wegen "frei", das heißt keinen Beweisregeln unterworfen ist, hat die obergerichtliche Rechtsprechung aus den wissenschaftlichen, insbesondere den kriminalistischen, forensischen und aussagepsychologischen Untersuchungen gewonnene Erfahrungsregeln, Grundsätze für die Beweiswürdigung und ihre Darlegung in den Urteilsgründen entwickelt, die bei Nichteinhaltung die Aufhebung in der Revision zur Konsequenz haben.'

91 Herdegen 1999, p. 326.

$92 \S 267$ StPO vereist wel dat in het vonnis de bewezenverklaring moet worden opgenomen. En voor zover daarbij feiten en/of omstandigheden zijn afgeleid uit andere feiten en/of omstandigheden zouden deze ook in het vonnis genoemd moeten worden. Niet inachtneming van de laatstgenoemde voorwaarde leidt echter niet tot vernietiging van het vonnis. Er is sprake van een zogeheten 'soll-bepaling'. 
zijn oordeel inkleedt. Concreet betekent dit dat in strafrechtelijke vonnissen na de vaststelling van de feiten een apart deel in het vonnis wordt opgenomen onder de noemer Beweiswürdigung. ${ }^{93}$ Slechts indien tegen het vonnis geen tijdig rechtsmiddel wordt ingesteld kan de bewijswaardering achterwege blijven. ${ }^{94}$

De inhoudelijke toetsing van de bewijswaardering komt in de jurisprudentie van het Bundesgerichtshof tot uitdrukking in de volgende bewoordingen:

'Die Beweiswürdigung ist hier jedoch nicht fehlerhaft, sie ist insbesondere nicht widersprüchlich, unklar oder nicht erschöpfend und verstößt auch nicht gegen Denkgesetze oder Erfahrungssätze. Die Überzeugungsbildung der Strafkammer beruht auf einer tragfähigen Tatsachengrundlage. Alle von ihr gezogenen Schlußfolgerungen sind plausibel, zwingend brauchen sie nicht sein. ${ }^{, 95}$

Enerzijds moet de waardering van het bewijs foutloos zijn, anderzijds volgt uit het criterium van een tragfähige Tatsachengrundlage dat de feitenrechter alle voor het bewijsoordeel relevante feiten en omstandigheden in de motivering van het bewijsoordeel moet betrekken. Deze laatste voorwaarde stelt de cassatierechter in gelegenheid de volledigheid van de bewijswaardering in cassatie te toetsen.

De onvolledigheid van de bewijswaardering kan op twee manieren blijken. ${ }^{96}$ Ten eerste kan de rechter een conclusie hebben getrokken waarbij hij feiten die hij wel vermeldt in het vonnis, maar die mogelijk tegen die conclusie spreken onvoldoende heeft afgewogen. In dat geval is er sprake van een leemte of onduidelijkheid in de bewijswaardering. Doordat de rechter in zijn vonnis onvoldoende duidelijkheid verschaft over de waardering van de daarin genoemde feiten, is het voor de cassatierechter niet mogelijk de bewijswaardering van de feitenrechter te doorgronden. In cassatie kan dus de juistheid van de bewijswaardering niet worden getoetst en in dergelijke gevallen wordt vermoed dat deze onjuist is.

Ten tweede kan de feitenrechter een bepaalde conclusie hebben getrokken zonder in te gaan op mogelijke alternatieve verklaringsmogelijkheden. Deze alternatieven kunnen betrekking hebben op de gehele feitenvaststelling of op onderdelen daarvan, bijvoorbeeld de betrouwbaarheid van een getuigenverklaring. In dat geval heeft hij niet alle relevante feiten en omstandigheden in het vonnis opgenomen. Er is sprake van een onvolledige weergave van de relevante feiten en omstandigheden in het vonnis, die noodzakelijkerwijze leidt tot een onvolledige bewijswaardering. De cassatierechter kan immers door een gebrekkig inzicht in alle aan het oordeel ten grondslag liggende feiten de wijze waarop de feitenrechter de wel in het vonnis vermelde feiten en omstandigheden heeft gewaardeerd niet controleren.

93 Nader over de vormgeving van Duitse strafvonnissen: Dreissen 2006b.

94 Ook in Duitsland kent men evenals in Nederland de mogelijkheid van het wijzen van een verkort vonnis ( $\$ 267$ Abs. 4 StPO). In een dergelijk verkort vonnis mag echter niet de feitenvaststelling zelf ontbreken.

95 BGH 17 mei 2001, 4 StR 412/00.

96 Fezer 1995, p. 99. 
Het ontbreekt in dergelijke gevallen aan een erschöpfende Beweiswürdigung of een Gesamtwürdigung aller Umstände.

Kort samengevat dient de feitenrechter zijn vonnis zodanig in te kleden dat alle voor het bewijsoordeel relevante feiten en omstandigheden daarin worden genoemd én op juiste wijze in de waardering van het bewijs worden betrokken. Meer specifiek betekent dit dat de bewijswaardering geen fouten, leemtes of onduidelijkheden mag bevatten in die zin dat feiten die in het vonnis worden genoemd ook in de waardering van het bewijs moeten worden betrokken, en dat de bewijswaardering volledig moet zijn. Dat laatste houdt in dat de rechter in zijn vonnis geen feiten achterwege mag laten die voor de uiteindelijke waardering relevant zijn. In de volgende paragrafen zullen de bovengenoemde drie eisen afzonderlijk worden besproken. Tot slot van dit hoofdstuk zal op enkele bijzondere bewijsconstructies worden ingegaan ten aanzien waarvan het Bundesgerichtshof specifieke motiveringseisen heeft gesteld.

\subsubsection{Bewijswaarderingsfouten}

Van een daadwerkelijke fout in de bewijswaardering is sprake indien de conclusie die de feitenrechter heeft getrokken niet logisch of dwingend volgt uit het in zijn vonnis weergegeven bewijsmateriaal. Wagner spreekt in dit verband van een $a b s o-$ luter Beweiswürdigungsmangel. ${ }^{97}$ Heel evident is hiervan sprake indien uit het oordeel van de feitenrechter blijkt dat deze zich heeft schuldig gemaakt aan een cirkelredenering ${ }^{98}$ of bepaalde rekenfouten heeft gemaakt, zoals bij de berekening van de kans dat een bepaald DNA-profiel bij een willekeurige derde voorkomt. ${ }^{99}$ Ook tegenstrijdigheden kunnen als fouten ten aanzien van de bewijswaardering worden gekwalificeerd. Dat is bijvoorbeeld het geval als de feitenrechter aanneemt dat er geen aanwijzingen zijn voor een valse beschuldiging door een getuige, terwijl in het vonnis tevens vermeld is dat de bewuste getuige en de verdachte met ruzie uit elkaar zijn gegaan. ${ }^{100}$

97 Wagner 1994, p. 292

98 Zo kan men de ongeloofwaardigheid van getuige $\mathrm{X}$ niet afleiden uit de geloofwaardigheid van getuige $\mathrm{Y}$, die verklaart dat getuige $\mathrm{X}$ niet geloofwaardig is. BGH 29 juli 1998, NStZ 99,421: 'Der BGH sieht hierin einen Zirkelschluß. Die Unglaubwürdigkeit der Zeuginnen, die ihren Sohn bzw. Bruder als unglaubwürdig und notorischen Lügner bezeichneten, wird damit nämlich letztlich mit Hinweis auf die Glaubwürdigkeit des Zeugen belegt, was indes zu beweisen war.' Zie ook: BGH 3 september 1992, 1 StR 559/92.

99 BGH 20 juni 1996, StV 1996, 883: 'Auf einem beim Angekl. nach der Tat gefundenen 1.000 DM-Schein war Blut, mit Merkmalen, die auch das Blut des Opfers besitzt. Die identische Merkmalskombination soll in der mitteleuropäischen Bevölkerung mit einer Häufigkeit von 3\% auftreten. Die Häufigkeit der Merkmalskombination betrage 1:30.000. Der BGH rügt diese Ausführungen des Landgerichts als widersprüchlich, denn bei $3 \%$ betrage die Häufigkeit der Merkmalskombination 1:33 (nicht 1:30.000).'

100 BGH 17 oktober 1979, 3 StR 361/79. Vergelijkbaar: BGH 16 mei 1995, BGHR StPO 
Fouten met betrekking tot de bewijswaardering kunnen ook verband houden met het gebruik van algemene ervaringsregels. In de Duitse rechtspraak worden diverse ervaringsregels onderscheiden. Het eerste onderscheidend criterium is dat met betrekking tot de kenbaarheid van deze ervaringsregels. Dit criterium is met name van belang voor de vraag of dergelijke regels nader bewijs behoeven en hoe zij ter zitting moeten worden gepresenteerd. Voor zover ervaringsregels kennis bevatten die voor iedere verstandige en ervaren persoon bekend of op eenvoudige manier te achterhalen is, kan die kennis als algemeinkundig gekwalificeerd worden. Dit betekent dat dergelijke ervaringsregels geen bewijs behoeven (het betreft zogeheten offenkundige Tatsachen), maar wel moeten dergelijke ervaringsregels ter zitting aan de orde worden gesteld. Over het algemeen worden regels die voortvloeien uit de algemene levenservaring en wetenschappelijke inzichten als algemeinkundig aangemerkt.

Het tweede criterium waarop ervaringsregels worden ingedeeld betreft de mate waarin zij als algemeen geldend (allgemeingültig) kunnen worden aangemerkt. In dat opzicht wordt onderscheiden tussen die ervaringsregels die bestaan uit zogeheten waarschijnlijkheidsuitspraken en dwingende ervaringsregels. De vraag of een ervaringsregel dwingend is of dat daaruit alleen maar een waarschijnlijkheidsoordeel volgt, is van belang voor de bewijswaardering. Dwingende ervaringsregels moet de rechter in principe in acht nemen bij de bewijswaardering. Ten aanzien van algemeen erkende wetenschappelijke inzichten geldt dat deze als dwingend worden beschouwd. De feitenrechter mag in zijn bewijswaardering hieraan niet voorbij gaan.

'Dem vom Landgericht angenommenen Tathergang steht der wissenschaftlich gesicherte Erfahrungssatz entgegen, daß die Entzündung von Heizöl mit einem Flammpunkt von $55^{\circ}$ Celsius - nicht ohne weiteres bei Raumtemperaturen mittels einer Flamme möglich ist. ${ }^{101}$

Neemt de feitenrechter ten onrechte de algemene geldigheid van een ervaringsregel aan, dat leidt dit eveneens tot vernietiging in cassatie.

'Ein Erfahrungssatz, daß mit $1 \mathrm{~kg}$ Heroï in einschlägigen Kreisen nicht unbewaffnet Handel getrieben wird, besteht nicht. Erfahrungssätze sind die aufgrund allgemeiner Lebenserfahrung oder wissenschaftlicher Erkenntnisse gewonnenen Regeln, die keine Ausnahme zulassen und eine an Sicherheit grenzende Wahrscheinlichkeit zum Inhalt haben. Eine derartige Regel bezüglich einer Bewaffnung beim Handeltreiben mit Betäubungsmitteln gibt es nicht. Es ist rechtsfehlerhaft, wenn der Tatrichter von einem nicht bestehenden Erfahrungssatz ausgeht. ${ }^{102}$

$\S 261$ Beweiswürdigung, widerspruchliche 4: 'Indem das Landgericht einerseits hervorhebt, daß die Zeugin im Kernbereich glaubhafte und zutreffende Angaben gemacht hat, es andererseits aber an der Richtigkeit besonders gewichtiger Vorwürfe durchgreifende Zweifel hat, erweist sich seine Beweiswürdigung als widersprüchlich.'

101 BGH 24 november 1988, BGHR StPO § 261 Erfahrungssatz 4.

102 BGH 8 september 1999, BGHR StPO $§ 261$ Erfahrungssatz 6. 
Voor zover de feitenrechter een niet dwingende ervaringsregel aan de bewijswaardering ten grondslag legt, moet hij zich er terdege van bewust zijn dat toepassing van deze regels slechts tot een waarschijnlijkheidsoordeel leidt. Hij zal daarom moeten nagaan in hoeverre aan deze regel ook in het specifieke geval gelding toekomt. Mogelijke alternatieve verklaringen moet de rechter onder ogen zien en in zijn bewijswaardering betrekken. Doet hij dat niet, dan is er geen sprake van een erschöpfende Beweiswürdigung:

'Wahrscheinlichkeitsaussagen die ein bestimmtes Ergebnis als naheliegend erscheinen lassen, muß es insoweit Rechnung tragen, daß es sich mit ihnen auseinandersetzt und an Hand weiterer Beweisanzeichnen prüft, ob diese ausreichen, um die Wahrscheinlichkeit zur Gewißheit zu machen. Setzt sich das Gericht über eine solche Wahrscheinlichkeitsaussage hinweg, muß es im Urteil die Gründe dafür aufzeigen, wenn es seiner Verpflichtung zur erschöpfenden Beweiswürdigung genügen will., ${ }^{103}$

In dit laatste geval is geen sprake van een bewijswaarderingsfout, maar bevat de bewijswaardering op dat punt een leemte. Er is sprake van een relativer Beweiswürdigungsmangel. ${ }^{104}$

\subsubsection{Bewijswaardering bevat onduidelijkheden of leemtes}

Mag enerzijds de bewijswaardering geen fouten bevatten, anderzijds wordt van de rechter geëist dat de bewijswaardering volledig is. Dit laatste betekent niet dat de rechter alles wat tijdens de behandeling ter terechtzitting aan de orde is geweest in de bewijswaardering moet betrekken. Een verklaring van een getuige die niet relevant is voor de uiteindelijke beoordeling mag bij de waardering buiten beschouwing worden gelaten.

'Ein sachlich-rechtlicher Fehler liege nur dann vor, wenn sich aus den Urteilsgründen selbst zur Vermeidung von Unklarheiten und Mißverständnissen die Notwendigkeit ergebe, sich mit der Aussage eines Zeugen im Detail auseinanderzusetzen, so etwa bei einer Verurteilung allein auf die Aussage des Tatopfers hin. ${ }^{105}$

De leemte of onduidelijkheid moet dus uit het vonnis zelf blijken. Daarvan kan sprake zijn indien de betrouwbaarheid van een getuigenverklaring onderbouwd wordt door te wijzen op een eerdere verklaring van deze getuige, zonder de inhoud van die verklaringen in het vonnis op te nemen. Als de verklaring van een getuige in tegenspraak is met de positie die de verdachte heeft ingenomen, ${ }^{106}$ kan niet worden volstaan met het enkel in het vonnis vermelden van de verklaring van de getuige. In dat geval wordt van de feitenrechter verlangd dat hij de punten waarop de verdachte

103 Gollwitzer 2001, aant. 47 bij § 261 .

104 Wagner 1994, p. 293

105 Wagner 1994, p. 293.

106 In Duitse vonnissen wordt de bewijswaardering in een apart deel opgenomen. Dit deel begint met de weergave van het standpunt van de verdachte: erkent hij de feiten of niet. 
deze verklaring betwist in het vonnis weergeeft en op discrepanties tussen die verklaring van de verdachte en getuige uitdrukkelijk ingaat. Hiervan is bijvoorbeeld sprake indien ondanks het feit dat door beide verdachten de dwang wordt betwist, toch zonder verdere toelichting op basis van de verklaring van het slachtoffer wordt geconcludeerd dat er sprake is van niet vrijwillige seksuele contacten.

'Die Beweiswürdigung des Landgerichts, die wesentlich aus dieser isoliert wiedergegebenen Äußerung auf einen von der Zeugin [het slachtoffer, WD] geleisteten und von den Angeklagten nicht erkannten Widerstand schließt, ist damit in einem entscheidenden Punkt lückenhaft., ${ }^{107}$

In een dergelijk geval moet naar het oordeel van het Bundesgerichtshof ook de verklaring van de beide verdachten in de bewijswaardering worden opgenomen, evenals de context waarin het slachtoffer haar belastende verklaring heeft afgelegd. Het ontbreken daarvan maakt dat de bewijswaardering onvoldoende inzichtelijk is, zodat ook controle van de cassatierechter op de bewijswaardering onmogelijk wordt. Leemtes in de bewijswaardering kunnen zich ook voordoen, indien de feitenrechter te snel een bepaalde conclusie trekt. Zo kan uit het feit dat het (vermeende) slachtoffer van een zedendelict kort daarna wordt gezien door een vriendin die verklaart dat het slachtoffer een bedrukte indruk maakte, niet direct de conclusie worden getroffen dat het seksuele contact tussen het slachtoffer en de verdachte onvrijwillig was. Zoals blijkt uit de volgende overweging van Bundesgerichtshof:

'Da aus dem Urteil ersichtlich ist, daß der Zeuge Bu. mit der Zeugin [het slachtoffer, WD] seit 1983 befreundet ist, hätte die Kammer als naheliegenden Umstand für die Bedrücktheit der Zeugin gegenüber dem Zeugen Bu. auch würdigen müssen, daß sie aus Scham gegenüber diesem bedrückt war. Der Tatrichter muß sich mit seinen Feststellungen unter allen für das Urteil wesentlichen Gesichtspunkten auseinandersetzen, wenn sie geeignet sind, das Beweisergebnis zu beeinflussen (BGH VRS 53, 110). ${ }^{108}$

Van een te snelle, voortijdige conclusie was ook in het onderstaande geval sprake:

'Diese für die Überführung des Angeklagten wesentliche Bekundung hält das Landgericht für glaubhaft, weil sie durch die Art der Verletzungen und die Blutspuren am Tatort bestätigt werde. Das Landgericht führt aus: 'Was I. [de getuige, WD] berichtet hat, könnte er nur wissen, wenn er es gesehen hatte'. I. könne von diesen Umständen nicht aus anderen, im Urteil näher bezeichnete Quellen erfahren haben. Diese Überlegung trägt nicht. Aus den Spuren kann nur geschlossen werden, daß I. das Tatgeschehen selbst zutreffend beschrieben hat. Über die Person des Täters sagen diese

107 BGH 26 november 1999, 2 StR 461/99.

108 BGH 10 december 1986, BGHR StPO $§ 261$ Beweiswürdigung, unzureichende 5. In gelijke zin: BGH 3 februari 1993, 5 StR 715/92. Daar luidde de overweging: 'Im Ergebnis bleibt als äußerer, dem Senat vermittelter Anhaltspunkt für die Richtigkeit der Angaben der Nebenklägerin lediglich der Umstand, daß sie bei Verlassen der Wohnung ihre Bluse, ihren Schmuck und Tabak zurückgelassen hat. Aber auch ein solches Verhalten steht der Einlassung des Angeklagten nicht von vornherein entgegen. Es wäre auch mit der Einlassung des Angeklagten vereinbar, etwa dann, wenn die Nebenklägerin ein Einverständnis zu sexuellen Handlungen bereute.' 
Spuren indes nichts. Aus die Richtigkeit der Aussage zum Tatgeschehen ohne weiteres auf die Richtigkeit der Aussage über den Täter zu schließen, verbot sich hier angesichts des Umstands, daß weitere Personen als Täter oder sonst als Beteiligte in Betracht kamen und daß nach den Urteilsfeststellungen I. über die unmittelbar Beteiligten bei den ersten polizeilichen Vernehmungen falsche Angaben gemacht hat. ${ }^{109}$

Dergelijke leemtes in de bewijswaardering houden verband met de algemene ervaringsregels die de feitenrechter expliciet of impliciet aan de waardering van het bewijs ten grondslag legt. Voor zover dergelijke ervaringsregels slechts een waarschijnlijkheidsoordeel inhouden, moet de rechter op aspecten ingaan die mogelijk voor of tegen de geldigheid van deze ervaringsregel spreken. Doet hij dat niet, dan zal het vonnis in cassatie vernietigd worden.

\subsubsection{Onvolledige bewijswaardering in geval van een bewezenverklaring}

Zoals uit de vorige paragraaf is gebleken, eist het Bundesgerichtshof dat de bewijswaardering geen leemtes en onduidelijkheden bevat. Maatgevend daarvoor is hetgeen de feitenrechter zelf in zijn vonnis vermeldt. Verwijst hij in zijn vonnis naar ander bewijsmateriaal, dan kan hij niet volstaan met een verwijzing, maar moet hij de inhoud daarvan in het vonnis noemen en in de waardering daarvan inzichtelijk maken.

In dergelijke gevallen wordt dus in het vonnis zelf al gewezen op het bestaan van feiten en omstandigheden die mogelijk tegen de conclusie van de feitenrechter spreken. De leemte bestaat dan daarin dat de feitenrechter deze feiten en omstandigheden niet of onvoldoende heeft gewaardeerd.

De bewijswaardering kan echter ook onvolledig zijn omdat de feitenrechter in zijn vonnis voorbijgaat aan feiten en omstandigheden die mogelijk zijn oordeel hadden kunnen beïnvloeden. Door deze feiten en omstandigheden in het vonnis niet te noemen, ontbreekt een 'tragfähige verstandesmäßig einsichtige Tatsachengrundlage', die noodzakelijk is om te toetsen of de door rechter vastgestelde feitenconstellatie met hoge waarschijnlijkheid overeenstemt met de werkelijkheid. De overtuiging moet haar grondslag vinden in rationele gronden. Weliswaar is geen absolute zekerheid vereist, maar wel moet uit het vonnis blijken dat de rechter op die punten waarop redelijkerwijze twijfel mogelijk is geweest, die twijfel heeft weggenomen. Er moet met andere woorden sprake zijn van een 'erschöpfende Beweiswürdigung'.

'Nur wenn sich der Tatrichter mit allen wesentlichen für und gegen den Angeklagten sprechende Umstände auseinandergesetzt hat, kann seine subjektive Überzeugung eine rechtsfehlerfreie Entscheidungsgrundlage bilden. ${ }^{, 10}$

109 BGH 19 november 1996, StV 1998, 117.

110 BGH 14 april 1993, 3 StR 604/92. 
Dit betekent dat de rechter in zijn oordeel moet ingaan op voor de hand liggende alternatieve scenario's. Ten aanzien van deze scenario's geldt dat zij niet alleen mogelijk moeten zijn, maar vooral ook voor de hand moeten liggen. Voor de hand liggend is een alternatieve hypothese als zij met de in het vonnis genoemde feiten niet minder goed in overeenstemming te brengen is dan de hypothese die de feitenrechter heeft gevolgd. Het Bundesgerichtshof verwoordt het als volgt:

'Bestehen bei der Bewertung einer durch die Beweisaufnahme gewonnenen Erkenntnis mehrere tatsächlichen Möglichkeiten, muß er sich, wenn auch nicht mit allen theoretisch denkbare, so doch mit alle nahe liegenden Möglichkeiten auseinandersetzen [cursivering, WD]. Naheliegend ist eine Möglichkeit jedenfalls dann, wenn sie nach Sachlage mit den Beweistatsachen nicht weniger gut zu vereinbaren ist als die von ihm angenommene Möglichkeit., 111

Deze alternatieven kunnen niet alleen betrekking hebben op de gehele feitenconstellatie, bijvoorbeeld de verdachte is in zijn geheel niet betrokken geweest bij het tenlastegelegde feit, maar ook op delen van de bewijsconstructie, zoals de beoordeling van de betrouwbaarheid van een getuigenverklaring. Laat de feitenrechter een belangrijke aanwijzing die mogelijk tegen de betrokkenheid van de verdachte of de betrouwbaarheid van de getuigenverklaring pleit buiten beschouwing, dan kan dit tot vernietiging van de uitspraak in cassatie leiden.

Problematisch ten aanzien van dergelijke zogeheten Darstellungsrügen is de vraag hoe de cassatierechter op de hoogte raakt van het bestaan van feiten en omstandigheden die mogelijk tegen de bewezenverklaring pleiten. De cassatierechter kan immers in cassatie op grond van een zogeheten Sachrüge alleen dat beoordelen wat in het vonnis is opgenomen. De feitenrechter daarentegen is niet verplicht om alle uit het onderzoek ter terechtzitting naar voren gekomen informatie in het vonnis op te nemen. Feiten die hij niet relevant acht, kan hij in het vonnis buiten beschouwing laten. Bovendien kan het zijn dat deze feiten in het geheel niet aan de orde zijn gekomen tijdens het onderzoek ter zitting, omdat de feitenrechter het onderzoek ter terechtzitting op dit punt niet heeft uitgebreid.

Hier nu ligt de wezenlijke uitbreiding van de controle op de bewijswaardering door het Bundesgerichtshof. Het Bundesgerichtshof verlangt dat de feitenrechter al die feiten en omstandigheden weergeeft die voor de begrijpelijkheid van het vonnis en de controleerbaarheid daarvan in cassatie noodzakelijk zijn. ${ }^{112}$

111 BGH 14 september 1993, 1 StR 450/93.

112 Wagner heeft zich hiertegen sterk afgezet. Zijns inziens mag de bewijsmotivering niet afhankelijk worden gemaakt van de mate waarin dit in cassatie kan worden getoetst. Ook indien volgens Wagner de bewijsmotivering mogelijke fouten bevat, wil dit nog niet zeggen dat de feitenrechter op onterechte gronden tot zijn overtuiging is gekomen. Wagner betwist dus het oorzakelijk verband tussen overtuiging en de motivering van het bewijsoordeel. De motiveringsplicht volgt ziens inziens uit de grondwet en dient losgekoppeld te worden van de inhoud van het bewijsoordeel. Zie Wagner 1994, p. 299: 'Verfassungsrecht ist nicht schon deshalb verletzt, weil Tatsachenfeststellungen fehlerhaft 
'Maßgebend sind stets die Umstände des Einzelfalles. Nach diesen beurteilt sich, was das Gericht ausführen muß um aufzuzeigen, daß es seiner Pflicht zu einer rational nachvollziehbaren und umfassenden Beweiswürdigung genügt hat., ${ }^{113}$

Het niet noemen van deze feiten en omstandigheden in het vonnis, leidt tot het vermoeden dat van een volledige bewijswaardering in de zin van $\S 261$ StPO geen sprake is geweest. Daarbij is niet van belang of het ontbreken van deze feiten in het vonnis het gevolg is van een slechte redactie van het vonnis dan wel het gevolg is van een gebrekkig onderzoek ter terechtzitting.

In het laatste geval zou dit in cassatie in de vorm van een Aufklärungsrüge aan de orde moeten worden gesteld. Zoals reeds in paragraaf 7.3.4.2 is uiteengezet worden echter aan deze cassatiegrond hoge motiveringseisen gesteld, zodat in de praktijk het vonnis in cassatie meestal wordt aangevochten op grond van een Darstellungsrüge waaraan deze eisen niet worden gesteld. In wezen stellen de Aufklärungsrüge en de Darstellungsrüge hetzelfde probleem aan de orde: de feitenrechter heeft niet alle voor de bewijswaardering relevante feiten in de motivering van zijn vonnis opgenomen. Daarbij maakt het geen verschil of die feiten wel of niet ter terechtzitting zijn gebleken. Doorslaggevend is dat zij kennelijk niet bij de waardering van het bewijs zijn betrokken, terwijl dit voor een rationele onderbouwing van het bewijsoordeel wel noodzakelijk was. ${ }^{114}$

De rechtspraak waarin het Bundesgerichtshof eist dat de feitenrechter ingaat op voor de hand liggende alternatieve feitenconstellaties heeft enige verwantschap met de rechtspraak van de Hoge Raad ten aanzien van feitelijke Meer en Vaartverweren. Belangrijk onderscheid is echter dat de Hoge Raad slechts van de Nederlandse feitenrechter eist dat deze op mogelijke alternatieven ingaat als daartoe door de verdachte of zijn raadsman tijdig een goed onderbouwd verweer is gevoerd. De verantwoordelijkheid voor het aandragen van feiten en omstandigheden die de alternatieve hypothese ondersteunen, ligt dus bij de verdediging. In de Duitse rechtspraak daarentegen wordt van de feitenrechter geëist dat hij zelf mogelijke alternatieven onder ogen ziet, en deze - indien aannemelijk - in zijn bewijsconstructie op eigen initiatief weerlegt, op straffe van vernietiging van het vonnis in cassatie.

Bovendien reikt de jurisprudentie van het Bundesgerichtshof veel verder dan de Meer en Vaartrechtspraak van de Hoge Raad. De Duitse rechtspraak ziet namelijk ook op de onderbouwing van het oordeel dat bepaald bewijsmateriaal als betrouwbaar moet worden aangemerkt. Waar dit oordeel in de Nederlandse rechtspraak in

sind. Verfassungsrechtlich ist deshalb auch nicht geboten, daß der Revisionsrichter unter Ausschöpfung seiner Möglichkeiten unrichtige Urteile zu verhindern hat.'

113 Gollwitzer 2001, aant. 59 op § 267.

114 Hanack wijst er mijns inziens terecht op dat door de rechtspraak van het Bundesgerichtshof met betrekking tot de eisen te stellen aan de bewijswaardering het traditionele onderscheid tussen de Verfahrensrüge en de Sachrüge dreigt te verwateren. Hanack 2003, aant. 127128 op $\S 337$ StPO. 
principe aan de feitenrechter is overgelaten, wordt van de Duitse feitenrechter verwacht dat hij ook op dit punt alle relevante feiten en omstandigheden in zijn oordeel betrekt. Zo niet, dan ontbeert zijn oordeel een tragfähige Grundlage.

\subsubsection{Bijzondere bewijsconstructies}

Dat in tegenstelling tot de Nederlandse strafrechter zijn Duitse collega wel degelijk zijn oordeel over de betrouwbaarheid en relevantie van het aan zijn bewijsbeslissing ten grondslag liggende bewijsmateriaal in zijn vonnis moet expliciteren, volgt nog veel nadrukkelijker uit rechtspraak van het Bundesgerichtshof waarin deze met betrekking tot bepaalde bewijsconstructies specifieke eisen stelt aan de bewijswaardering. In deze paragraaf komt een aantal van deze bewijsconstructies aan de orde. Het feit dat ze hier als specifieke bewijswaarderingseisen worden neergezet, wil niet zeggen dat ze niet ook onder de algemene eisen met betrekking tot bewijswaardering kunnen vallen. Het door het BGH gehanteerde criterium van een tragfähige Tatsachengrundlage is in die zin zo ruim dat het merendeel van de in deze paragraaf te noemen gevallen daar gemakkelijk onder te rubriceren is. Het overzicht in deze paragraaf is niet volledig, maar geeft slechts een indicatie van de eisen die in de Duitse rechtspraak worden gesteld aan de bewijswaardering door de strafrechter.

\subsection{De enkele verklaring van de verdachte}

Zoals reeds in paragraaf 7.3.1 uiteengezet worden aan de verklaring van de verdachte als bewijsmiddel geen specifieke voorschriften verbonden. Uit $\S 244$ Abs. 1 StPO blijkt dat de verdachte de mogelijkheid wordt gegeven zich ter zake van het tenlastegelegde feit uit te laten. Hij is daartoe niet verplicht. In het vonnis moet echter wel telkens vermeld worden op welke wijze de verdachte zich ter zitting heeft geuit. ${ }^{115}$ Daarbij kan de verdachte hebben afgezien van enige verklaring, ${ }^{116}$ kan hij het feit hebben ontkend ${ }^{117}$ of bekend. ${ }^{118}$

De verklaring van de verdachte vormt het uitgangspunt voor de bewijswaardering. Bij gebrek aan wettelijke bewijsminima kan in principe een bewezenverklaring

115 In gelijke zin: Niemöller 1984, p. 436: 'Wie sich der Angeklagte zum Anklagevorwurf gestellt hat, ist für die Beweiswürdigung naturgemäß von wesentlicher Bedeutung. Seine Einlassung muß daher, soweit sie für Schuld- und Rechtsfolgenfragen erheblich sein kann, grundsätzlich mitgeteilt und gewürdigt werden.'

116 In dat geval begint de bewijswaardering met een zinsnede in de trant van: 'Der Beschuldigte hat sich in der Hauptverhandlung zu dem Vorwurf aus der Antragschrift nicht geäußert.'

117 Bijvoorbeeld: 'Zur Tat erklärte die Angeklagte, dass ... [volgt ontkenning van de betrokkenheid, WD]. Diese Einlassung der Angeklagten ist widerlegt.'

118 Bijvoorbeeld verwoord als: 'Der unter B. festgestellte Sachverhalt beruht auf der Einlassung des Angeklagten, der im wesentlichen geständig war, sowie auf den nachfolgend aufgeführten Beweismitteln.' 
gebaseerd worden op een enkele bekentenis van de verdachte. ${ }^{119}$ In dat geval dient de rechter van de juistheid van de inhoud van die verklaring overtuigd te zijn. Dit veronderstelt allereerst dat de inhoud van die verklaring meer dient te omvatten dan een globale erkenning van het tenlastegelegde feit. Indien een bekentenis beperkt is tot een processuele formaliteit waarin onvoldoende feiten met betrekking tot het tenlastegelegde feit aan de orde komen, is de bekentenis als grondslag voor de bewezenverklaring onvoldoende. ${ }^{120}$ Bovendien kunnen uit de inhoud van de verklaring zelf reeds twijfels naar voren komen met betrekking tot de betrouwbaarheid daarvan. Bijvoorbeeld indien de verdachte verklaart over feiten die reeds geruime tijd geleden hebben plaatsgevonden:

'Wenn das Tatgericht einen Angeklagten aufgrund dessen eigener Einlassung verurteilt, so setzt dies voraus, daß es sich von der Richtigkeit dieser Einlassung überzeugt hat. Bei einfach gelagerten Sachverhalten mögen nähere Darlegungen hierzu unter Mitteilung des Inhalts des Geständnisses entbehrlich sein. Das gilt aber nicht wenn - wie hier angesichts des länger zurückliegenden, sich über vier Jahre erstreckenden Tatzeitraums und der Vielzahl der einzelnen, nach Lieferanten, Betäubungsmitteln und Mengen unterschiedlichsten Rauschgiftsgeschäfte - Zweifel bestehen können, daß der Angeklagte an das Tatgeschehen eine auch in den Einzelheiten genügende Erinnerung hat. ${ }^{121}$

\subsection{Het zwijgen van de verdachte}

Uitgangspunt van het Duitse recht is dat alleen de verklaring van de verdachte voor het bewijs gebezigd mag worden. Aan het zwijgen van de verdachte mag geen bewijswaarde worden toegekend. ${ }^{122}$ Dat geldt ook indien de verdachte in eerste instantie van zijn zwijgrecht gebruik heeft gemaakt en pas in een latere fase van de strafzaak een (ontlastende) verklaring heeft afgelegd.

'Auffällig ist auch das Verhalten des Angeklagten W. nach seiner Festnahme. Wäre er tatsächlich unschuldig gewesen, wäre zu erwarten gewesen, daß er sich sofort in entsprechende Weise erklärt und nicht erst nach zwei Monaten Untersuchungshaft eine dahingehende Einlassung vorbringt, zumal er bereits 4.8.1995 einen Verteidiger hatte. Diese Ausführungen lassen besorgen, daß das Landgericht aus dem anfänglichen

119 BGH 26 augustus 1993, BGHSt 39, 310.

120 BGH 10 juni 1998, BGHR StPO § 261 Überzeugungsbildung 31 'Daß der Angeklagte das Geständnis erst abgelegt hat, nachdem ihm für diesen Fall ein bestimmtes Strafmaß in Aussicht gestellt worden war, brauchte das Landgericht nicht daran zu hindern, es für glaubhaft zu halten. Wie der Bundesgerichtshof bereits betont hat, darf eine Absprache über das Strafmaß allerdings nicht dazu führen, daß ein so zustande gekommenes Geständnis dem Schuldspruch zugrunde gelegt wird, ohne daß sich das Gericht von dessen Richtigkeit überzeugt. Das Gericht bleibt dem Gebot der Wahrheitsfindung verpflichtet. Das Geständnis muß daher auf seine Glaubhaftigkeit überprüft werden; sich hierzu aufdrängende Beweiserhebungen dürfen nicht unterbleiben (BGHSt 43,195-StV 1997, 583).'

121 BGH 5 december 1995, StV 1996, 214.

122 BGH 26 oktober 1983, BGHSt 32, 140. 
Schweigen des Angeklagten einen Schluß zu dessen Nachteil gezogen hat. Solches wäre unzulässig. ${ }^{123}$

Uitzonderingen op het algemene uitgangspunt dat het zwijgen niet tegen de verdachte gebruikt mag worden, laat het Bundesgerichtshof overigens wel toe in die gevallen waarin de verdachte slechts deels zwijgt:

'Schweigt ein Angeklagter nicht umfassend, sondern macht er zu einen bestimmten Sachverhalt eines einheitlichen Geschehens Angaben zur Sache und unterläßt insoweit lediglich die Beantwortung bestimmter Fragen, so kann dieses Schweigen nach der Rechtsprechung des BGH von indizieller Bedeutung sein. ${ }^{124}$

\title{
7.5.3.4.3 Het liegen van de verdachte
}

Bevat een verklaring van de verdachte een vastgestelde leugen, dan kan dit gegeven voor de bewijsconstructie gebezigd worden. Daarbij wordt echter door de cassatierechter telkens aangegeven dat niet te snel uit het liegen van de verdachte zijn betrokkenheid bij het hem verweten feit moet worden geconcludeerd. Ook een onschuldige verdachte kan immers redenen hebben om niet conform de waarheid te verklaren. Uit de motivering van de uitspraak moet derhalve blijken dat er geen andere reden voor het liegen aan te wijzen is:

\begin{abstract}
'Insbesondere muß sich das Tatgericht bei der Beweiswürdigung bewußt sein, daß eine wissentlich falsche Einlassung des Angeklagten ihren Grund nicht nur darin haben kann, daß er die ihm zur Last gelegte Tat begangen hat und verbergen will, vielmehr auch eine andere Erklärung finden kann. Soll die nachgewiesene Lüge als Belastungsindiz dienen, setzt dies voraus, daß mit rechtsfehlerfreier Begründung dargetan wird, warum eine andere Erklärung nicht in Betracht kommt oder den Umständen nach so fern liegt, daß sie ausscheidet. ${ }^{125}$
\end{abstract}

In het geval dat de verdachte heeft gelogen over zijn alibi, komt onder omstandigheden wel bewijswaarde toe aan de leugen van de verdachte, namelijk als de verdachte het valse alibi heeft verzonnen, omdat hij over daderwetenschap beschikte. In dergelijke gevallen kan de feitenrechter de leugen voor het bewijs gebruiken, maar dient hij in zijn vonnis wel het nodige te verantwoorden:

'Eine nachweisbar erlogene Alibibehauptung kann vor allem dann ein belastendes Indiz sein, wenn sie im Wege der Vorwegverteidigung darauf gerichtet ist, einen den Ermittlungsbehörden noch nicht bekannten Tatumstand zu entkräften, den nur der Täter wissen kann. Solches Täterwissen könnte den Schluß auf die Täterschaft begründen. In Fällen dieser Art ist der Tatrichter gehalten, die Umstände des Vor-

123 BGH 26 juni 1997, 1 StR 212/97. In gelijke zin: BGH 24 maart 1999, 1 StR 78/99, NStZ-RR 2000, 37: 'Daß der Angeklagte nicht schon bei seiner polizeilichen Vernehmung, sondern erst in der Hauptverhandlung zur Sache ausgesagt hat, darf bei der Beweiswürdigung nicht berücksichtigt werden (BGHSt 20, 281; BGH MDR 1971, 18).'

124 BGH 19 januari 2000, BGHR StPO § 261 Aussageverhalten 20

125 BGH 17 mei 2000, 3 StR 161/00. 
bringens der falschen Alibibehauptung zu erörtern. Wenn der Angeklagte ein solches falsches Alibi bei seiner Vernehmung im Ermittlungsverfahren behauptet, sind in der Regel - und auch so hier - besondere Begründungsanforderungen an das Urteil zu stellen. Der Tatrichter ist dann gehalten, sich einerseits mit der Aussageentstehung, der Vernehmungstechnik und der Protokollierung und andererseits mit dem damaligen - etwa durch Vorhalte zustande gekommenen - Informationsstand des Angeklagten und dessen Verteidigungsstrategie auseinanderzusetzen. ${ }^{126}$

Onder zeer specifieke voorwaarden kan dus een leugenachtige alibibewering van de verdachte voor het bewijs gebruikt worden. Dat is echter uitgesloten indien het alibi van de verdachte niet is komen vast te staan of de verdachte slechts beweert dat hij ten tijde van het delict niet op de plaats van het delict aanwezig is geweest. Uit het uitblijven van bewijs ten aanzien van een ontlastende bewering, volgt geen aanwijzing van het tegendeel:

'Der Angeklagte ist nicht gehalten, sein Alibi zu beweisen; er hat aber das Recht, einen Alibibeweis anzutreten. Mißlingt dieser Beweis, so fällt damit eine ihm zustehende Verteidigungsmöglichkeit weg. Dies bedeutet, daß gegebenenfalls eine schon anderweit gewonnene Überzeugung des Tatrichters nicht erschüttert wird. Der Fehlschlag kann jedoch für sich allein, das heißt ohne Rücksicht auf seine Gründe und Begleitumstände, noch kein Beweisanzeichen dafür sein, daß der Angeklagte der Täter ist. Dabei handelt es sich um die Anwendung eines allgemeinen, über die Fälle des Alibivorbringens hinausreichenden Grundsatzes, der besagt, daß eine für widerlegt erachtete Behauptung des Angeklagten nicht ohne weiteres ein Täterschaftsindiz abgibt. Dieser Grundsatz beruht letztlich darauf, daß eine Strafrechtsordnung, die für jede Verurteilung den vollen Beweis der Tat fordert und Zweifel daran stets zugunsten des Angeklagten ausschlagen läßt, es nicht hinnehmen kann, wenn schon das bloße Fehlen entlastender Umstände als Belastungsindiz gewertet wird., ${ }^{127}$

\subsection{Aussage gegen Aussage}

In strafzaken waarin de ontkennende verklaring van de verdachte op wezenlijke punten alleen door de verklaring van een getuige wordt tegengesproken, en de feitenrechter desalniettemin besluit tot veroordeling van de verdachte, dient de motivering van dat oordeel aan hoge eisen te voldoen. Het gaat dan om gevallen die in de jurisprudentie van het Bundesgerichtshof worden gekwalificeerd als Aussage gegen Aussage. Een dergelijke bewijsconstructie komt veelvuldig voor in zedenzaken waarin de (gedeeltelijke) ontkenning van de verdachte alleen wordt weersproken door de verklaring van het slachtoffer. Van belang is dat de feitenrechter in zijn vonnis nadrukkelijk in gaat op de verklaring van deze 'kroongetuige' en in het vonnis motiveert waarom hij deze verklaring betrouwbaar acht. Zo moet uit de bewijsoverwegingen in het vonnis blijken dat alle omstandigheden die de betrouwbaarheid van de verklaring in twijfel zouden kunnen trekken of juist zouden kunnen

126 BGH 31 maart 1999, BGHR StPO § 261 Überzeugungsbildung 33.

127 BHG 5 juli 1995, BGHSt 41,153. 
bevestigen bij de beoordeling van de betrouwbaarheid zijn betrokken. Ook al gaat het om omstandigheden die zien op bijzaken in de verklaring van de getuige. ${ }^{128}$ Het belang van een dergelijke bijzondere betrouwbaarheidsbeoordeling is onder andere gelegen in het feit dat de verdachte zelf weinig verdedigingsmogelijkheden heeft in dergelijke gevallen. ${ }^{129}$

'Beruht - wie hier - die Überzeugung des Gerichts von der Täterschaft des Angeklagten allein auf der Aussage der einzigen Belastungszeugin, ohne daß weitere belastende Indizien vorliegen, so sind an die Überzeugungsbildung des Tatrichters strenge Anforderungen zu stellen. Der Tatrichter muß sich bewußt sein, daß die Aussage dieser Zeugin einer besonders gründlichen Glaubhaftigkeitsprüfung zu unterziehen ist, zumal der Angeklagte in solchen Fällen wenig Verteidigungsmöglichkeiten durch eigene Äußerungen zur Sachlage besitzt. Eine lückenlose Gesamtwürdigung ist dann von besonderer Bedeutung. Nach der Rechtsprechung des Bundesgerichtshofs müssen die Urteilsgründe erkennen lassen, daß der Tatrichter alle Umstände, die die Entscheidung beeinflussen können, erkannt und in seine Überlegungen einbezogen hat. ${ }^{130}$

Bij de waardering van de betrouwbaarheid van de belastende verklaring dient de feitenrechter niet alleen alle aanwijzingen die voor of tegen de betrouwbaarheid van de verklaring spreken afzonderlijk in de bewijswaardering te betrekken. Hij moet bovendien oog hebben voor het geheel der feiten en omstandigheden dat de betrouwbaarheid in twijfel zou kunnen trekken. Er moet sprake zijn van een zogeheten 'Gesamtwürdigung'.

'Bei der Beurteilung der Glaubwürdigkeit der Angaben des Tatopfers darf sich der Tatrichter nicht darauf beschränken, Umstände, die gegen die Zuverlässigkeit der Aussage sprechen können, gesondert und einzeln zu erörtern sowie getrennt voneinander $\mathrm{zu}$ prüfen, und festzustellen, daß sie jeweils nicht geeignet seien, die Glaubwürdigkeit in Zweifel zu ziehen. Selbst wenn nämlich jedes einzelne die Glaubwürdigkeit der Angaben möglicherweise in Frage stellende Indiz noch keine Bedenken gegen die den Angeklagten belastende Aussage aufkommen ließe, so kann doch eine Häufung von - jeweils für sich erklärbaren - Fragwürdigkeiten bei einer Gesamtschau zu durchgreifenden Zweifeln an der Richtigkeit eines Tatvorwurfs führen. ${ }^{131}$

Het Bundesgerichtshof verlangt van feitenrechters dat zij in geval van Aussage gegen Aussage op specifieke punten - voor zover daartoe aanleiding bestaat - de betrouwbaarheid van de belastende verklaring toetsen. ${ }^{132}$ Deze toetsing moet tot uitdrukking komen in het vonnis, opdat de cassatierechter in staat is de juistheid c.q. volledigheid van de bewijswaardering te toetsen.

Zo dient de rechter in bepaalde gevallen nadrukkelijk in te gaan op de wijze waarop de verklaring van de getuige tot stand is gekomen. Dit speelt onder andere bij kinderen die als getuigen optreden. Daar waar kinderen beweren slachtoffer te zijn

128 BGH 9 november 1999, StV 2000, 243.

129 BGH 29 juli 1998, BGHR StPO § 261 Beweiswürdigung 15.

130 BGH 27 maart 2003, 3 StR 446/02. In gelijke zin: BGH 19 oktober 2000, 1 StR 439/00.

131 BGH 18 juni 1997, BGHR StPO § 261 Beweiswürdigung 14.

132 Zie voor een voorbeeld van een vonnis in geval van 'Aussage gegen Aussage' bijlage I. 
geworden van een delict, wordt deze verdenking meestal in eerste instantie in familieverband geuit. In het vonnis zal de feitenrechter op dit aspect dat mogelijk de betrouwbaarheid negatief beïnvloedt moeten ingaan.

'Wenn zudem - was hier ersichtlich der Fall ist - vor Beginn der strafrechtlichen Ermittlungen 'private Befragungen' zu den Tatvorwürfen erfolgt sind, so ist der Beweiswert belastender Angaben - insbesondere vor dem Hintergrund familiärer Auseinandersetzungen und bei dem Kind möglicherweise geweckter Erwartungen zum Inhalt seiner Aussage - besonders kritisch zu prüfen. ${ }^{, 133}$

In geval de getuige verschillende verklaringen heeft afgelegd én deze onderling op wezenlijke punten van elkaar afwijken, moet de strafrechter de inhoud van deze verklaringen in het vonnis opnemen en bovendien in het vonnis nadrukkelijk motiveren waarom hij toch de getuigenverklaring voor het overige geloofwaardig acht.

'Allein auf Angaben des einzigen Belastungszeugen, dessen Aussage in einem wesentlichen Detail als bewußt falsch anzusehen ist, kann eine Verurteilung nicht gestützt werden (Senatsurteil BGHSt 44,153, 158 ff.). Will der Richter der Aussage im übrigen folgen, müssen Indizien für deren Richtigkeit vorliegen, die außerhalb der Aussage selbst liegen. Daher muß der Richter dann, wenn die Aussage dieses Zeugen in einem wesentlichen Punkt von seinen früheren Angaben abweicht, im Urteil darlegen, daß keine bewußt falschen Angaben vorgelegen haben. Andernfalls kann das Revisionsgericht nicht prüfen, ob der Tatrichter den Grundsätzen des genannten Senatsurteils gefolgt ist., ${ }^{, 134}$

Een ander belangrijk punt bij de beoordeling van de betrouwbaarheid is dat de feitenrechter, indien de veroordeling in belangrijke mate afhankelijk is van één getuige, onderzoekt in hoeverre deze getuige reden heeft om de verdachte te belasten. In dergelijke gevallen kan niet worden volstaan met de opmerking dat redenen voor een valse beschuldiging niet zijn gebleken.

'Für den Tatrichter war ein weiterer "entscheidender Gesichtspunkt" für seine Überzeugungsbildung zur Glaubhaftigkeit der Zeugenaussage der Nebenklägerin der Umstand, daß "kein plausibles Motiv für die Offenbarung der Geschehnisse erkennbar" sei, "wenn nicht die sexuellen Verfehlungen des Angeklagten an der Geschädigten tatsächlich stattgefunden hätten" (UA S. 10). Diese Erwägung bleibt ohne tatsächlichen Beleg, da es im Urteil an jeglichen näheren Feststellungen zu Anlaß und Umständen der Tatoffenbarung fehlt. ${ }^{, 135}$

Redenen om de verdachte valselijk te beschuldigen moeten onder meer worden onderzocht in die gevallen waarin kinderen één van hun ouders belasten, terwijl gelijktijdig een echtscheidingsprocedure en/of mogelijke voogdijkwesties aanhangig zijn. ${ }^{136}$ Buiten het geval van zedendelicten speelt deze problematiek bij strafbare feiten waarin de enige belastende verklaring afkomstig is van een mede-

133 BGH 23 mei 2000, 1 StR 156/00.

134 BGH 17 november 1998, BGHR StPO $§ 261$ Beweiswürdigung 17. In gelijke zin: BGH 29 juli 1998, BGHSt 44, 153; BGH 19 oktober 2000, BGHR StPO § 261 Beweiswürdigung 23.

135 BGH 13 december 2000, 5 StR 540/00.

136 BGH 5 november 1997, BGHR StGB § 176 Abs. 1 Beweiswürdigung 3. 
verdachte. De niet uit te sluiten mogelijkheid dat de verdachte de schuld op een ander probeert af te schuiven, zichzelf een geringer aandeel in het delict toedicht of mogelijk andere betrokkenen een hand boven het hoofd wenst te houden, maakt een nadrukkelijke toetsing van de betrouwbaarheid op dit punt noodzakelijk. ${ }^{137}$ Verwant aan het bovenstaande zijn die gevallen waarin de belastende getuige in een latere fase van het strafgeding alsnog een beroep doet op het verschoningsrecht. De feitenrechter zal in het vonnis moeten uiteenzetten dat het beroep op het verschoningsrecht niet tot doel had de beoordeling van de betrouwbaarheid van de verklaring onmogelijk te maken:

'Die Urteilsgründe verhalten sich insbesondere nicht dazu, in welchem Stadium ihrer Vernehmung und in welchem Zusammenhang die Zeugin den zunächst erklärten Verzicht auf ihr Zeugnisverweigerungsrecht widerrufen hat. Dessen hätte es aber bedurft. Denn dieses Aussageverhalten konnte möglicherweise zu Zweifeln an der Glaubwürdigkeit der Geschädigten Anlaß geben, so etwa, wenn sie lediglich eine vorbereitete Erklärung wiedergegeben und deren Überprüfung durch Nachfragen verhindert hätte, oder wenn sie nach Vorhalten von Widersprüchen in ihrer Aussage oder zu den Bekundungen anderer Beweispersonen in die Zeugnisverweigerung »geflüchtet« wäre. ${ }^{138}$

Tot slot dient de feitenrechter de inhoud van de belastende getuigenverklaring aan de hand van zogeheten kwaliteitskenmerken te toetsen.

'Zur Durchführung der Analyse der Aussagequalität sind auf der Basis der dargestellten Annahmen Merkmale zusammengestellt worden, denen indizielle Bedeutung für die Entscheidung zukommen kann, ob die Angaben der untersuchten Person auf tatsächlichem Erleben beruhen. Es handelt sich um aussageimmanente Qualitätsmerkmale (z.B. logische Konsistenz, quantitativer Detailreichtum, raumzeitliche Verknüpfungen, Schilderung ausgefallener Einzelheiten und psychischer Vorgänge, Entlastung des Beschuldigten, deliktsspezifische Aussageelemente), deren Auftreten in einer Aussage als Hinweis auf die Glaubhaftigkeit der Angaben gilt. ${ }^{, 139}$

Een dergelijke toetsing van de inhoud van de getuigenverklaring is in geval van Aussage gegen Aussage noodzakelijk. ${ }^{140}$ In beginsel dient de rechter deze toetsing zelf te verrichten. ${ }^{141}$ Hij kan daarbij de hulp van een deskundige inroepen. Noodzakelijk is dat echter niet. ${ }^{142}$ Slechts indien de rechter meent dat de beoordeling van de betrouwbaarheid van de getuigenverklaring zijn eigen kennis en kunde

137 BGH 3 mei 1991, BGHR StPO $§ 261$ Mitangeklagte 2.

138 BGH 22 januari 1992, BGHR StPO § 261 Aussageverhalten 12.

139 BGH 30 juli 1999, BGHSt 45,164.

140 Nack 2002, p. 559 en Jansen 2004, p. 35. Beide auteurs geven een uitgebreid overzicht van de rechtspraak van het Bundesgerichtshof met betrekking tot de inhoudelijke toetsing van de belastende getuigenverklaring en de daarbij te hanteren betrouwbaarheidcriteria, zoals de mate waarin de getuige zichzelf belast, gedetailleerdheid van de verklaring, 'Erinnerungslücken', 'Aussageerweiterung im Randgeschehen, Verflechtung, Schilderung von Gefühlen, gefühlsmäßiger Nachklang'.

141 Bijvoorbeeld: BGH 15 september 1998, StV 1998, 635.

142 BGH 30 juli 1999, BGHSt 45, 164. 
te boven gaat (bijvoorbeeld in het geval de getuige geestelijk zwakbegaafd is), moet hij een deskundige inschakelen. ${ }^{143}$

Voor zover de analyse van een getuigenverklaring aan een deskundige wordt opgedragen, kan de rechter niet volstaan met een verwijzing naar de deskundigenverklaring. Hij dient de wezenlijke delen van deze verklaring in het vonnis op te nemen en de bevindingen van de deskundige tot de zijne te maken. Wijkt hij echter van het oordeel van de deskundige af, dan dient hij eveneens de inhoud van het verslag in het vonnis op te nemen en te motiveren waarom hij de deskundige in zijn conclusie(s) niet volgt. ${ }^{144}$

De inhoudelijke toetsing van de getuigenverklaring - de zogeheten Aussageanalyse - heeft veel overeenkomsten met de ook in Nederland gebruikte CBCA-methode. ${ }^{145}$ Van belang is echter dat de Duitse rechtspraak eist dat niet alleen de inhoud van de verklaring, maar ook de totstandkoming van de verklaring, de context waarin die is afgelegd, de afwijkingen ten opzichte van eerder afgelegde verklaringen en de reden voor het afleggen van een verklaring bij de beoordeling van de betrouwbaarheid moeten worden betrokken. ${ }^{146}$ Bovendien worden door het Bundesgerichtshof de beperkingen van de betrouwbaarheidsanalyse onderkend:

'Ein zwingender Schluß von einem festgestellten Merkmal auf die Glaubhaftigkeit von Angaben der untersuchten Person ist keinesfalls möglich. Methodisch unzulässig ist es auch, aus dem Vorliegen einer bestimmten Anzahl von Merkmalen im Sinne eines Schwellenwertes auf die Qualität einer Aussage zu schließen. Nur im Einzelfall können auch einzelne Realkennzeichen ausreichen, um den Erlebnisbezug einer Aussage anzunehmen. Fehlen derartige Merkmale, kann umgekehrt nicht unbedingt eine bewußt unwahre Aussage angenommen werden, da dies durch verschiedene Faktoren (z.B. Angst, Erinnerungslücken) verursacht worden sein kann. Darüber hinaus ist stets zu beachten, daß die Realkennzeichen ungeeignet sind, zur Unterscheidung zwischen einer wahren und einer suggerierten Aussage beizutragen. ${ }^{147}$

Ten aanzien van de hierboven genoemde aspecten die een indicatie vormen voor de al dan niet betrouwbaarheid van de getuigenverklaring dient het vonnis alle

143 BGH 21 mei 1969, BGHSt 23, 8. Het inschakelen van deskundigen bij de beoordeling van de betrouwbaarheid van de verklaring dient te gebeuren zodra zich bijzondere omstandigheden voordoen. Meestal liggen die bijzondere omstandigheden in de persoon van de getuige. Thans wordt echter door feitenrechters vrij snel de hulp van een deskundige ingeschakeld. Fischer 1994, p. 2: 'Nach dem skurilen Motto 'Lieber zuviel als zu wenig' werden beim geringsten Anzeichen von 'Besonderheiten' Glaubwürdigkeitsgutachten beantragt und eingeholt'. Uitgebreid over de beoordeling van de betrouwbaarheid van getuigenverklaringen: Jansen 2004.

144 BGH 27 maart 2003, BGHR StPO § 261 Sachverständiger 9.

145 Voluit: Criteria Based Contents Analyses. Zie over de inhoud van deze methode: Rassin \& Van Koppen 2002, p. 523 e.v.

146 Rassin \& Van Koppen 2002, p. 527: 'CBCA beperkt zich tot de analyse van de uiteindelijke verklaring en negeert cruciale informatie over al hetgeen heeft plaatsgevonden in de aanloop naar het officiële verhoor.'

147 BGH 30 juli 1999, BGHSt 45, 164. 
relevante feiten en omstandigheden te vermelden die het mogelijk maken om de uiteindelijke waardering van de rechter in cassatie te toetsen. Laat hij dit na, dan is er sprake van een Darstellungsrüge en kan op grond daarvan het vonnis in cassatie vernietigd worden.

Is bijvoorbeeld voor de feitenrechter de gedetailleerdheid van de verklaring reden om aan te nemen dat de verklaring betrouwbaar is, dan dient hij de inhoud van die verklaring en de daarin opgenomen details in het vonnis op te nemen. ${ }^{148}$ Hetzelfde geldt indien het niet afwijken van eerdere verklaringen een indicatie vormt voor de betrouwbaarheid van die verklaring.

'Bei der Beweiswürdigung beschränkt sich die Urteilsbegründung darauf, daß der leugnende Angeklagte durch die Aussage der Zeugin überführt werde, die vor Gericht einen glaubwürdigen Eindruck gemacht habe und die ihre ins Detail gehenden Bekundungen in lückenloser Konstanz durchgängig vom Ermittlungsverfahren bis zur Hauptverhandlung gemacht habe. Was die Zeugin jeweils ausgesagt hatte und welche Details sie insbesondere mitgeteilt hat, wird nicht wiedergegeben. ${ }^{149}$

Gaat de feitenrechter in het vonnis wel op alle voor de betrouwbaarheidsvraag relevante feiten en omstandigheden in, dan kan in cassatie de bewijswaardering inhoudelijk worden getoetst. Voor zover daarin fouten, leemtes of onduidelijkheden voorkomen, kan alsnog het oordeel worden vernietigd. Meestal zal in dat geval het niet in acht nemen van wetenschappelijke (psychologische) inzichten reden zijn om de bewijswaardering inhoudelijk af te keuren. Bevat de motivering geen fouten, leemtes of onduidelijkheden, dan is het oordeel in cassatie onaantastbaar. Het is de cassatierechter immers niet toegestaan zijn eigen overtuiging in plaats van die van de feitenrechter te stellen.

\subsection{Verklaring van horen zeggen}

In het Duitse strafproces wordt een onderscheid gemaakt tussen mondelinge en schriftelijke de-auditu-verklaringen. Mondelinge verklaringen van horen zeggen zijn in beginsel toelaatbaar. De verklaring van een getuige ter zitting, inhoudende wat hij een ander heeft horen zeggen, mag de rechter ten grondslag leggen aan zijn bewijsbeslissing. Dit betekent ook dat verklaringen van getuigen bij monde van een opsporingsambtenaar of onderzoeksrechter tijdens het onderzoek ter terechtzitting kunnen worden gepresenteerd. De wettelijke regeling verzet zich daar niet tegen. Immers, op grond van $\S 250 \mathrm{StPO}$ is het de rechter (buiten de gevallen genoemd in $\S 251 \mathrm{StPO}$ ) slechts ontzegd verklaringen van personen te vervangen door op schrift gestelde verklaringen.

148 BGH 13 december 2000, 5 StR 540/00.

149 BGH 16 oktober 1992, StV 1993, 235. Zie ook: BGH 3 maart 1995, BGHR StPO § 267 Abs. 1 Satz 1 Beweisergebnis 8; BGH 29 juli 2003, 4 StR 253/03 en BGH 29 juli 2003, 4 StR 253/03. 
'Der Bundesgerichtshof hat wiederholt ausgesprochen, daß die Vernehmung eines sachferneren anstelle des sachnäheren Zeugen nicht dem Grundsatz der Unmittelbarkeit, der in $\S 250$ StPO seinen Niederschlag gefunden hat, widerspreche, es vielmehr eine Frage der dem Gericht obliegenden Aufklärungspflicht und der Beweiswürdigung sei, ob es sich mit dem sachferneren Zeugen begnügen dürfe (BGHSt 1, 373, 376; 6, 209; 17, 382, 384; $32,115,123)$. Es war daher nicht von vornherein unzulässig, den ermittelnden Kriminalbeamten darüber zu vernehmen, was er im Zuge seiner Ermittlungen festgestellt hat., ${ }^{150}$

Deze vaststelling heeft echter niet tot gevolg dat de rechter volledig vrij is om een dergelijke de-auditu-verklaring aan zijn bewijsbeslissing ten grondslag te leggen. Enerzijds kan het beginsel der materiële waarheidsvinding ( $\$ 244$ Abs. 2 StPO) meebrengen dat de rechter voor zover dat mogelijk is toch de originele bron ter zitting hoort. ${ }^{151}$ Anderzijds moet de rechter zich bij de vraag welke waarde hij aan een dergelijke verklaring hecht bewust zijn van het feit dat het om een gereproduceerde verklaring gaat. Aan een gereproduceerde verklaring is het risico verbonden dat bij de reproductie bepaalde relevante feiten en omstandigheden uit het oog worden verloren. ${ }^{152}$ Deze zouden van invloed kunnen zijn op de betekenis en betrouwbaarheid van de wel in die verklaring genoemde feiten en omstandigheden. ${ }^{153}$ Dat de feitenrechter zich bewust is geweest van dit gevaar moet blijken uit de motivering van de bewijsbeslissing in die zin dat daarin zichtbaar wordt dat de feitenrechter bij de toetsing en waardering van de inhoud van de verklaring behoedzaam te werk is gegaan.

'In solchen Fällen ist der Tatrichter allerdings gehalten, den Beweiswert dieses weniger sachnahen Beweismittels bei seiner Überzeugungsbildung besonders vorsichtig zu prüfen und zu würdigen.' 154

Zo dient hij feiten en omstandigheden die door middel van de de-auditu-verklaring ter kennis zijn gekomen in het vonnis weer te geven. ${ }^{155}$ En dient hij - indien deze op bepaalde punten afwijken van andere verklaringen - ook deze discrepanties in het vonnis weer te geven. ${ }^{156}$ Bovendien dient hij nadrukkelijk onderzoek te doen

150 BGH 22 september 1989, BGHR StPO $§ 250$ Satz 1 Unmittelbarkeit 1.

151 Zie paragraaf 7.3.4 waarin reeds uiteen werd gezet dat uit het beginsel der materiële waarheidsvinding ook kwalitatieve eisen volgen met betrekking tot de bewijsvoering. In dat verband wordt ook wel gesproken van het Gebot bestmöglicher Sachaufklärung.

152 Zie onder andere: BGH 1 augustus 1962, BGHSt 17, 382: 'Bei einem Zeugen vom Hörensagen besteht zunächst ganz allgemein eine erhöhte Gefahr der Entstellung oder Unvollständigkeit in der Wiedergabe von Tatsachen, die ihm von demjenigen vermittelt worden sind, auf den sein Wissen zurückgeht. Je größer die Zahl der Zwischenglieder, desto geringer ist der Beweiswert der Aussage. Schon dieser Gesichtspunkt mahnt zur Vorsicht.'

153 Zie ook: Eisenberg 2002, p. 388: 'Indes ist es nach allgemeinem empirischen Erkenntnisstand erwartungsgemäß, dass mittelbare Zeugen je nach Vorverständnis und Erwartungshaltung nicht ungeleitet wahrnehmen oder gar in ihrem Zustandekommen beeinflußt haben.'

154 BGH 16 april 1986, BGHSt 33,178.

155 BGH 31 maart 1989, BGHSt 36, 159: 'Die Aussagen der Verhörspersonen über die Angaben des Informanten sind im Urteil möglichst eingehend und genau darzustellen.'

156 Eisenberg 2002, p. 388-389. 
naar de omstandigheden waaronder zowel de originele getuige de waarnemingen heeft gedaan, als de getuige van horen zeggen diens verklaring heeft verkregen. Met betrekking tot de betrouwbaarheid van de originele bron en diens waarnemingen mag hij zich niet volledig laten leiden door hetgeen de getuige van horen zeggen hem daarover vertelt. In dat geval zou immers de waardering niet langer in handen van de rechter zijn. ${ }^{157}$

Ten aanzien van bepaalde de-auditu-verklaringen stelt het Bundesgerichtshof aanvullende eisen met betrekking tot de bewijswaardering en de weergave daarvan in het vonnis. Het gaat dan met name om anonieme getuigen en getuigen ten aanzien waarvan de verdediging niet in de gelegenheid is geweest hen te ondervragen. In beide gevallen heeft het Bundesgerichtshof feitelijk een bewijsminimum gecreëerd, inhoudende dat zowel de verklaring van de anonieme getuige als de verklaring van de getuige ten aanzien waarvan het ondervragingsrecht in de zin van artikel 6 lid 3 onder d EVRM niet is gerealiseerd moeten worden bevestigd door ander bewijsmateriaal. ${ }^{158}$

'Die von dem Vernehmungsbeamten wiedergegebenen [anonieme, WD] Aussagen sind deshalb besonders kritisch zu würdigen. Auf sie kann eine Feststellung regelmäßig nur dann gestützt werden, wenn diese Bekundungen durch andere nach der Überzeugung des Tatrichters wichtige Beweisanzeichen bestätigt werden. Das Gericht muß sich den Grenzen seiner Überzeugungsbildung stets bewußt sein, sie wahren und dies in den Urteilsgründen zum Ausdruck bringen (BGHSt 17,382,385f.; BVerfGE 57, 250, $292 \mathrm{f}$. m. w. Nachw.; Paulus in KMR 7. Aufl. § 250 Rdn. 22 ff.). ${ }^{, 159}$

\subsection{Conclusie}

Hoewel de letterlijke tekst van $\S 261$ StPO en de afwezigheid van wettelijke bewijswaarderingsregels de indruk wekken dat de Duitse rechter evenals zijn Nederlandse collega vrij is in de vaststelling en waardering van de feiten, is daar in de praktijk geen sprake van. Dit is toe te schrijven aan de rechtspraak van het

157 BGH 5 februari 1986, BGHSt 34, 15: 'Bei seiner neuen Entscheidung wird das Oberlandesgericht näher darzulegen haben, auf welche Weise die »Quelle« in den Besitz ihrer Erkenntnisse gekommen ist, um insoweit eine Nachprüfung zu ermöglichen und Fehler bei der Einschätzung des Beweiswerts der Mitteilungen dieses Gewährsmannes ausschließen zu können.'

158 Gössel 2002, p. 392 heeft kritiek op deze rechtspraak van het Bundesgerichtshof: 'Das Revisionsgericht greift massiv in die freie Beweiswürdigung des Tatrichters ein, wenn es diesem vorschreibt, diese Regel beachten zu sollen - auch wenn dies nur "regelmäßig" so sein solle, so liegt darin eine Regel für die Beweiswürdigung und also eine nach $§ 261$ StPO unzulässige Beweisregel.'

159 BGH 16 april 1985, BGHSt 33,178. Zie voor het bewijsminimum inzake verklaringen van horen zeggen onder andere: BGH 25 juli 2000, BGHSt 46, 93: 'Deshalb gilt auch hier wie beim gesperrten Zeugen (BGHSt 17,382, 386): Auf die Angaben des Vernehmungsrichters kann eine Feststellung regelmäßig nur dann gestützt werden, wenn diese Bekundungen durch andere wichtige Gesichtspunkte außerhalb der Aussage bestätigt werden.' 
Bundesgerichtshof vanaf 1957 met betrekking tot $\S 261$ StPO. Daarin werd de subjectieve overtuiging van de rechter niet langer als voldoende grondslag voor het bewijsoordeel geaccepteerd. Deze rechtspraak heeft tot gevolg gehad dat aan het bewijsoordeel in strafzaken strenge motiveringseisen werden gesteld, die tot doel hadden de cassatierechter in staat te stellen de bewijswaardering inhoudelijk te toetsen. Daartoe moet de feitenrechter in het vonnis alle feiten en omstandigheden noemen die zowel voor als tegen zijn uiteindelijke conclusie spreken. Bovendien moet hij in zijn vonnis inzichtelijk maken dat hij al deze feiten en omstandigheden heeft afgewogen. Deze waardering kan in cassatie worden getoetst op consistentie en volledigheid. De jurisprudentie inzake Aussage gegen Aussage biedt een prachtige illustratie van hetgeen het Bundesgerichtshof bij de bewijsmotivering voor ogen heeft.

De eisen die het Bundesgerichtshof stelt aan de bewijsmotivering en de controle daarop worden in de literatuur over het algemeen positief beoordeeld:

'Eine Beschneidung dieser Prüfung mittels einer Beseitigung der Pflicht zur Darlegung der Beweiswürdigung will niemand. Der Grund dafür liegt im heutigen Verständnis von der Aufgabe der Urteilsgründen. Sie sind nicht in erster Linie rechtsmittelbezogen, sondern haben - nicht ausschließlich, aber vor allem - eine selbständige, auf die Rechtsordnung insgesamt bezogene Funktion. Neben der Unterrichtung des Angeklagten und den darin liegenden Zwecken, insbesondere der Anerkennung seiner Würde als einer Person, der offen zu begegnen ist, sollen Urteilsgründe die Bewährung der Rechtsordnung dokumentieren und Rechtsfrieden stiften., ${ }^{, 160}$

Dat neemt niet weg dat er ook kritiek is op de vergaande toetsing in cassatie van de feitenvaststelling en de bewijswaardering. ${ }^{161}$ Het Bundesgerichtshof zou allereerst de taakverdeling tussen de feitenrechter en cassatierechter onvoldoende in het oog houden. Door een vergaande toetsing van de feitenvaststelling en de waardering van die feiten zou de cassatierechter immers op de stoel van de feitenrechter gaan zitten. Bij gebrek aan kennis van alle feiten uit de strafzaak en de onmogelijkheid om zelf onderzoek te doen, zou hij zich terughoudender moeten opstellen. ${ }^{162}$ Deze kritiek wordt door de voorstanders weerlegd door erop te wijzen dat de waardering van het bewijs in strafzaken een rechtsvraag is. De bewijswaardering moet immers voldoen aan het criterium van hoge waarschijnlijkheid. ${ }^{163}$ Het stellen van een dergelijk criterium is zinloos indien dat in cassatie niet getoetst zou kunnen worden. ${ }^{164}$ Bovendien is het de cassatierechter niet toegestaan de overtuiging

160 Jähnke 1999, p. 364.

161 Maul 1988, p. 418-419.

162 Detter 2000, p. 705: 'Andererseits wäre bei einer erweiterten Entscheidungsbefugnis [van de cassatierechter, WD] auch zu bedenken, daß damit eine Verantwortung für die Entscheidung des Falles auf das Revisionsgericht abgewälzt wird, die dieses angesichts seiner Stellung im Instanzenzug und seiner - tatsächlichen - Erkenntnisse vom Verfahren nicht übernehmen könnte und sollte.'

163 Herdegen 1992, p. 534

164 Meyer-Goßner 1997, p. 473. 
van de feitenrechter te vervangen door zijn eigen overtuiging, en is dus van een daadwerkelijke rollenverwisseling geen sprake. ${ }^{165}$

Een tweede punt van kritiek op de rechtspraak van het Bundesgerichtshof is er in gelegen dat hiermee de grenzen van de cassatierechtspraak te ver worden opgerekt. De cassatieprocedure heeft vooral tot doel rechtszekerheid en rechtseenheid te garanderen. Deze kritiek vindt zijn grondslag in het feit dat de extensieve interpretatie van $\S 261$ StPO meestal wordt verklaard door het ontbreken van een tweede feitelijke instantie in zogeheten schwere Kriminalität. ${ }^{166}$ Teneinde gerechtelijke dwalingen in zware strafzaken te voorkomen, was aldus Fezer de cassatierechter wel gedwongen enige controle op de bewijsconstructies van de feitenrechter in dergelijke zaken uit te oefenen:

'Sie haben eine eigene Verantwortung für die Richtigkeit und Vollständigkeit der tatsächlichen Urteilsgrundlage verspürt und diese übernommen, soweit ihnen auch ohne Hauptverhandlung eine Beurteilungsmöglichkeit zu Verfügung steht., ${ }^{167}$

Degenen die het belang van de cassatieprocedure vooral zien in het bewaken van de rechtszekerheid en rechtseenheid hebben grote moeite met de uitbreiding van de controle in cassatie op de feitenvaststelling en waardering. Zij menen dan ook dat het voorkomen van gerechtelijke dwalingen niet een taak is van de cassatierechter, en dat de oplossing van dit probleem moet worden gezocht in een uitbreiding van het rechtsmiddelenstelsel. Daarbij wordt echter uit het oog verloren dat de eisen met betrekking tot de bewijswaardering ook gelden in strafzaken waarin wel is voorzien in een tweede feiteninstantie.

Tot slot wordt de rechtspraak van het Bundesgerichtshof wel bekritiseerd omdat deze ten koste zou gaan van een efficiënte strafrechtspleging. Om te voldoen aan de eisen die het Bundesgerichtshof stelt, worden feitenrechters gedwongen uitvoerige vonnissen te schrijven. In vergelijking tot de Nederlandse vonnissen zijn de Duitse uitspraken inderdaad behoorlijk langer. In het bijzonder Foth ${ }^{168}$ en Hanack ${ }^{169}$

165 Fezer 1999, p. 336 heeft onder andere dit aspect bekritiseerd. Naar zijn mening kan de cassatierechter altijd wel iets in het vonnis vinden dat niet voldoet aan de motiveringseisen zoals die door het Bundesgerichtshof worden gesteld. Voor zover hijzelf dus niet overtuigd van de schuld of onschuld van de verdachte kan hij altijd een reden vinden om het vonnis in cassatie te vernietigen. 'Ob Darstellungslücken und -mängel zur Aufhebung führen, hängt vielfach von dem eigenen Überzeugungsbildungsprozeß des Revisionsrichters in der Sache ab und weniger davon, ob der Tatrichter bestimmten formalen Begründungsanforderungen gerecht geworden ist.'

$166 \S 120$ Gerichtsverfassungsgesetz en Geppert 2004, p. 113.

167 Fezer 1999, p. 334.

168 Foth 1997, p. 206: 'So wird der Anteil an richterliche Arbeitszeit, den die Abfassung des schriftlichen Urteils beansprucht immer länger. Fast kann man manchmal den Eindruck gewinnen, nicht die Findung des Urteilsspruch, sondern seine schriftliche Begründung sei die wesentliche Arbeit des Tatrichters.'

169 Hanack 2003, aant. 129 op $\S 337$ StPO. Hanack meent dat de rechtspraak van het Bundesgerichtshof te ver is doorgeschoten. Dat moet volgens hem 'angesichts der oft kaum berechenbaren Anforderungen, die das Revisionsgericht im Einzelfall stellt (...) 
hebben op grond daarvan bezwaren tegen de extensieve interpretatie van het Bundesgerichtshof. Het zou leiden tot een enorme verzwaring van de werklast van de feitenrechter. Daartegen wordt door het Bundesgerichtshof zelf ingebracht dat vonnissen vaak te lang zijn, omdat daarin complete verhandelingen worden opgenomen die voor de beoordeling van de bewijswaardering niet noodzakelijk zijn:

'Der Senat sieht sich erneut veranlaßt, darauf hinzuweisen, daß die schriftliche Urteilsgründe nicht dazu dienen, den Inhalt der in der Hauptverhandlung erhobenen Beweise zu dokumentieren. Sie sollen das Ergebnis der Hauptverhandlung wiedergeben und die Nachprüfung der getroffenen Entscheidung ermöglichen. (...) Mit der Beweiswürdigung soll der Tatrichter lediglich belegen, warum er bestimmte, bedeutsame tatsächliche Umstände so festgestellt hat. ${ }^{170}$

den Tatrichter verunsichern und zu immer größerer Schreibarbeit drängen'.

170 BGH 3 juni 1997, 4 StR 213/97 en BGH 14 mei 1997, 3 StR 193/97 (rechtspraak genoemd door Meyer-Goßner 1997, p. 473). 



\section{Waarheidsvinding: Duitsland en Nederland vergeleken}

\subsection{Inleiding}

Het onderzoek in strafzaken heeft tot doel om te komen tot een uitspraak over de vraag of de verdachte het hem verweten feit heeft begaan. Wordt deze vraag positief beantwoord, dan moet vervolgens worden bezien of dit tot oplegging van een sanctie moet leiden en zo ja, welke. Het bewijzen van het tenlastegelegde feit is zo bezien de cruciale fase in een strafzaak. Kan dit bewijs niet worden geleverd, dan dient de verdachte te worden vrijgesproken. Wordt het bewijs wel geleverd, dan komt men toe aan de fase waarin het materiële strafrecht kan worden toegepast op de bewezen feiten.

Deze voorstelling van zaken is enigszins gesimplificeerd, omdat het veronderstelt dat het bewijzen van het tenlastegelegde feit niets van doen heeft met het materiële strafrecht. Dit is ten onrechte, omdat in de bewoordingen van het tenlastegelegde feit al elementen van het materiële strafrecht zijn opgenomen. Termen als 'opzettelijke', 'in vereniging', 'eerbaarheid', etc. hebben ieder hun eigen strafrechtelijke betekenis. De inhoud van deze begrippen hoeft niet overeen te komen met de betekenis die daaraan toekomt in het gewone menselijke verkeer. Bij het bewijs van deze onderdelen van de tenlastelegging is echter de strafrechtelijke betekenis maatgevend. Overigens is hier een duidelijke wisselwerking merkbaar tussen bewijskwesties en de uitleg van strafrechtelijke begrippen. Kwalificatieve termen waarvan het bewijs moeilijk is te leveren, willen nog wel eens op een zodanige manier worden uitgelegd dat het bewijs daarvan eenvoudiger wordt. ${ }^{1}$ Een mooi voorbeeld daarvan is de wijze waarop het begrip 'opzet' wordt uitgelegd. $^{2}$ Ook ten aanzien van het begrip 'medeplegen' is een dergelijke wisselwerking merkbaar. Het oordeel over de feiten, de bewijsvraag, is dus niet geheel los te beschouwen van het materiële strafrecht.

Los van deze kwestie is het bewijs in strafzaken in principe vergelijkbaar met het bewijs zoals dat bij empirische wetenschappen wordt geleverd. ${ }^{3}$ De wijze waarop bijvoorbeeld een patholoog aantoont dat een persoon op een bepaald moment aan

1 In gelijke zin: Nijboer 1999c, p. 49: 'En zo worden gevallen waarin de feiten mogelijk nog wel een probleem zouden kunnen zijn tot gevallen waarin dat minder het geval is.' Reijntjes 2004.

3 In gelijke zin: Van Dijck 1922, p. 9: 'Het verklarend onderzoek in de concrete wetenschappen breng ik hier, in de lijn der denkbeelden van Heymans, enkel naar voren als dat type onderzoekingen, waarbij het feitelijk onderzoek in strafzaken zich aansluit.' 
een bepaalde ziekte is overleden, zou in principe niet moeten verschillen van de wijze waarop de strafrechter vast stelt dat de verdachte op een bepaald moment op een bepaalde plaats aanwezig was. Beiden bepalen hun conclusies aan de hand van waarnemingen waarop algemene ervaringsregels worden toegepast. Dat de patholoog bij zijn waarneming gebruik maakt van bepaalde apparatuur en dat de door hem gehanteerde ervaringsregels wetenschappelijk erkend zijn, lijkt op het eerste gezicht zijn conclusie een hogere status te geven. Maar in wezen is ook zijn gevolgtrekking niet absoluut zeker. ${ }^{4}$ Evenals de vaststelling van de feiten door de rechter is ook de conclusie van de wetenschapper ervaringsafhankelijk. ${ }^{5}$ Dit betekent dat zowel de wijze van waarneming als ook de geldigheid van de ervaringsregels ter discussie kunnen worden gesteld op het moment dat nieuwe inzichten daartoe aanleiding geven. Dit laat onverlet dat de strafrechter in zijn onderzoek aan meer beperkingen is onderworpen dan de wetenschapper; het betreft dan met name normatieve grenzen die in acht moeten worden genomen. Op dat punt wordt in paragraaf 8.3.1 nader ingegaan.

De overeenkomst tussen de bewijzende activiteiten van de rechter en die van een andere ervaringsafhankelijke onderzoeker ligt dus daarin dat de getrokken conclusies geen absolute zekerheid opleveren. ${ }^{6}$ Er kan slechts een waarschijnlijkheidsoordeel worden uitgesproken waarbij de mate van waarschijnlijkheid afhankelijk is van de betrouwbaarheid van de waarneming en de geldigheid van de toepasselijke ervaringsregel. Binnen het strafrechtelijke discours wordt dit gebrek aan absolute zekerheid ook onderkend. Van de rechter wordt niet verlangd dat hij onomstotelijk vaststelt dat de verdachte het hem tenlastegelegde feit heeft begaan. Wel dient hij te streven naar 'materiële waarheidsvinding'.

In dit hoofdstuk zal worden ingegaan op het proces van waarheidsvinding in strafzaken; welke bewijsmaat dient te worden gehanteerd en welke beperkingen aan het proces van waarheidsvinding inherent zijn. Vervolgens zal worden bezien in hoeverre, ondanks de bestaande 'handicaps', kan worden gegarandeerd dat de rechter in strafzaken tot een beslissing komt waarbij de uitkomst - de juridische waarheid ${ }^{7}$ - en de 'werkelijke' waarheid elkaar niet te veel ontlopen. Dit kan

4 Sommigen wetenschappers zijn daar niet van doordrongen. Binnen de forensische wetenschappen geldt dat onder andere voor de dactyloscopisten. Zij formuleren hun conclusies als absolute waarheden. Zie daarover: Broeders 2005a en in reactie daarop Zeelenberg 2005.

$5 \quad$ Nijboer 2000a, p. 23.

6 In gelijke zin: Nijboer 1978 en Crijns \& Van de Meij 2005, p. 47: 'Vanuit epistemologisch perspectief kan zelfs worden beweerd dat 'de waarheid' als zodanig niet bestaat of in ieder geval niet gekend kan worden. Vanuit dat perspectief zal men dus te allen tijde genoegen moeten nemen met een bepaalde afbeelding, voorstelling of perceptie van de waarheid. Deze afbeelding kan de 'werkelijke waarheid 'slechts in meer of mindere mate benaderen, zij kan er evenwel nooit mee gelijk gesteld worden.'

7 Ook Cleiren 2001, p. 11 spreekt over juridische waarheidsvinding: 'Juridische waarheidsvinding is dus meer dan het vinden van feiten: het is het vormgeven van een feitencomplex vanuit een juridisch perspectief, dus binnen processuele kaders. Formeelrechtelijke regels 
geschieden door het stellen van regels aangaande de presentatie van het bewijs, de bewijswaardering en motiveringseisen. Opvallend is dat de normering van het bewijsoordeel in Nederland in belangrijke mate afwijkt van de wijze waarop die in Duitsland vorm heeft gekregen.

\subsection{Materiële waarheidsvinding}

De rechter in strafzaken moet zoveel als mogelijk de 'materiële waarheid' in de concrete strafzaak proberen te benaderen. Het begrip 'materiële waarheid' heeft een tweeledige betekenis. Enerzijds ziet het op de mate van zekerheid die voor het oordeel in strafzaken vereist is. Anderzijds ziet het op de verantwoordelijkheid van de rechter voor het achterhalen van de 'waarheid'.

\subsubsection{De bewijsstandaard in strafzaken}

De mate van zekerheid die voor het bewijsoordeel in strafzaken vereist is, is moeilijk te bepalen. Over het algemeen wordt aangenomen dat in strafzaken een hoge mate van waarschijnlijkheid vereist is. Daartoe wordt gewezen op de verstrekkende gevolgen die een veroordeling in strafzaken voor de verdachte heeft. Het feit dat hij mogelijk van zijn vrijheid wordt beroofd of anderszins ingrijpende consequenties in zijn persoonlijke leven ondervindt, kan enkel worden gerechtvaardigd indien met de grootst mogelijke zekerheid komt vast te staan dat de verdachte zich daadwerkelijk schuldig heeft gemaakt aan een strafbaar feit. Binnen de strafrechtspleging wordt het bestaan van een 'gerechtelijke dwaling' als een nachtmerrie ervaren. ${ }^{8}$ Niet alleen voor de betrokkene die ten onrechte is veroordeeld, maar ook voor de strafrechtspleging zelf. Het vertrouwen in de strafrechtelijke keten wordt immers direct ondermijnd op het moment dat dergelijke 'bedrijfsongevallen' bekend worden. ${ }^{9}$

In het Amerikaanse recht hanteert men in strafzaken het begrip beyond reasonable doubt. Daarmee wordt aangegeven dat bij redelijke twijfel de verdachte moet worden vrijgesproken. Niet iedere twijfel leidt tot vrijspraak. De twijfel mag niet slechts denkbeeldig zijn en moet bovendien zodanig zijn dat ieder redelijk denkend mens daarin een aanleiding ziet om af te zien van het verbinden van consequenties aan het belastende bewijsmateriaal. Het begrip 'reasonable doubt' wordt in het Amerikaanse recht meestal afgezet tegen het begrip preponderance of the evidence. Dit laatste is de bewijsstandaard in civiele zaken. Preponderance

over feitenonderzoek en over de daaraan te verbinden waardering door de rechter maken dus deel uit van juridische waarheidvinding.'

$8 \quad$ Verburg 2005, p. 296.

9 Daarmee wil ik overigens niet zeggen dat mogelijke gerechtelijke dwalingen zo veel mogelijk verborgen moeten worden gehouden. 
of the evidence wil eigenlijk zeggen dat het bewijs dat pleit voor de in het geding zijnde hypothese zwaarder telt dan het bewijs dat daar tegen spreekt. In vergelijking daarmee is de bewijsstandaard in strafzaken - tot uitdrukking komend in het begrip beyond reasonable doubt - veel hoger. Het bewijs dat voor de hypothese spreekt moet zodanig zijn dat het geen ruimte meer laat voor gerede twijfel.

De Duitse rechtspraak sluit in principe bij dit criterium aan. Maar in tegenstelling tot het Amerikaanse recht wordt de mate van zekerheid niet negatief, maar positief geformuleerd. Vereist wordt dat het oordeel in strafzaken met een hoge mate van waarschijnlijkheid overeenstemt met de werkelijkheid:

'Die richterliche Überzeugung setzt neben der persönlichen Gewißheit des Richters objektive Grundlagen voraus. Die müssen aus rationalen Gründen den Schluß erlauben, daß das festgestellte Geschehen mit hoher Wahrscheinlichkeit mit der Wirklichkeit übereinstimmt. ${ }^{10}$

In Nederland is in tegenstelling tot Duitsland en de Verenigde Staten nooit expliciet aandacht besteed aan de mate van waarschijnlijkheid waarmee het oordeel in strafzaken moet komen vast te staan. Artikel $338 \mathrm{~Sv}$ eist dat de rechter overtuigd is. Algemeen wordt verondersteld dat aan de bewezenverklaring hoge eisen worden gesteld: er moet meer dan waarschijnlijkheid zijn. ${ }^{11}$ Nijboer spreekt in dit verband van een zeer klemmende graad van waarschijnlijkheid dat de verdachte het feit heeft begaan. ${ }^{12}$

\subsubsection{De onderzoeksplicht van de rechter}

Naast de mate van zekerheid waarmee in strafzaken de feiten worden vastgesteld, ziet het begrip materiële waarheidsvinding in Nederland ook op de vraag wie verantwoordelijk is voor de waarheidsvinding. In strafzaken komt die verantwoordelijkheid toe aan de rechter. De rechterlijke eindverantwoordelijkheid vloeit voort uit de idee dat hij onafhankelijk, onpartijdig en onbevooroordeeld is en in die zin in staat is om tot een objectieve oordeelvorming te komen. ${ }^{13}$ Nijboer spreekt in dit verband van een procesmaxime. ${ }^{14}$ De rechter dient op basis van het ter zitting gepresenteerde bewijsmateriaal tot een conclusie te komen over de betrokkenheid

10 BGH 29 juli 1991, 5 StR 278/91. Zie ook: BGH 13 augustus 1991, 5 StR 231/91; BGH 6 april 1990, BGHR StPO § 261 Identifizierung 6; BGH 24 november 1992, BGHR StPO § 261 Vermutung 11 en BGH 8 november 1996, BGHR StPO § 261 Überzeugungsbildung 26.

11 Corstens 2005 a, p. 633

12 Nijboer 2000a, p. 86.

13 In gelijke zin: Melai 1975 en A.M. van Woensel, aant. 2 op art. 338-344 (suppl. 91 oktober 1994), in Melai/Groenhuijsen e.a.: 'Met het oog op de belangen die in het strafgeding op het spel staan, is aan de rechter ter terechtzitting een actieve rol toegekend: hij onderzoekt zelfstandig wat naar voren wordt gebracht teneinde zich een beeld te vormen van wat zich heeft afgespeeld ter zake van het tenlastelegde feit.'

14 Nijboer 1999b, p. 28. 
van de verdachte bij het hem tenlastegelegde feit. De rechter is tevens verantwoordelijk voor de volledigheid van dit onderzoek. Meent hij dat dit onderzoek moet worden uitgebreid, bijvoorbeeld door het (nader) horen van getuigen en deskundigen, dan kan hij daartoe ambtshalve beslissen. ${ }^{15}$ De ambtshalve onderzoeksbevoegdheid staat in principe los van de mogelijkheid van partijen om de rechter om nadere onderzoekshandelingen te verzoeken.

Het begrip materiële waarheid opgevat in deze zin staat tegenover het in het civiele recht gebruikte begrip 'relatieve waarheid'. In het civiele recht staat niet zo zeer de werkelijke toedracht van het geval centraal (de materiële waarheid), als wel de toedracht zoals die blijkt uit de door of namens partijen verstrekte gegevens. ${ }^{16}$ De verantwoordelijkheid voor de feitenvaststelling in civiele zaken ligt daarmee in belangrijke mate bij partijen. Voor zover partijen de in het geding gestelde feiten niet betwisten, worden deze als vaststaand aangenomen. Zij behoeven geen nader onderzoek. Voor het overige wordt het bewijsoordeel in civiele zaken genormeerd door middel van bewijslastregels. Aan de hand daarvan draagt de rechter het bewijs van bepaalde feiten op aan één van de partijen. Het uiteindelijke bewijsoordeel in civiele zaken is in principe de constatering van de rechter dat partijen in voldoende mate en overtuigend aan de bewijsopdracht hebben voldaan. Het civiele recht kent dus in tegenstelling tot het strafrecht aan de rechter geen verantwoordelijkheid toe met betrekking de omvang van het onderzoek. De civiele rechter is in die zin lijdelijk; hij laat zich leiden door hetgeen partijen al dan niet naar aanleiding van een daartoe gegeven bewijsopdracht aandragen. ${ }^{17}$ Dat geldt in gelijke zin voor het Amerikaanse strafproces. Ook daar ligt de verantwoordelijkheid voor de omvang van het onderzoek bij partijen. Aan de hand van de door partijen ter zitting aan de orde gestelde feiten dient een onafhankelijke instantie - de jury dan wel de rechter - tot een oordeel te komen over de feiten. De genoemde onafhankelijkheid ziet dan vooral daarop dat degene die uiteindelijk de beslissing neemt op geen enkele wijze eerder betrokken is geweest bij het onderzoek naar de

15 Aldus ook: Mevis, Reijntjes en Wöretshofer 2001, p. 48: 'Hier hebben we te doen met een inquisitoir, en toch heilzaam, trekje van ons strafproces.'

16 In gelijke zin: Melai 1961, p. 88 en A.M. van Woensel, aant. 8 op art. 338-344 (suppl. 91 oktober 1994), in Melai/Groenhuijsen e.a: 'bij de relatieve waarheid valt de nadruk op de soevereiniteit van de civiele partijen met betrekking tot de onderzoeksmogelijkheden van de rechter'. Knigge 2006, p. 34 spreekt in dit verband van formele waarheid of partijwaarheid.

17 Dat uitgangspunt lijkt overigens steeds minder strikt. Borgers \& Kristen 1999, p. 871: 'Er is een tendens waarneembaar dat de civiele rechter actief gebruik maakt van die mogelijkheden [om onderzoek te verrichten naar de materiële waarheid, WD]. Deze tendens wordt gestuurd door velerlei factoren, waaronder de wens de rechter zo min mogelijk te belemmeren bij het vinden van de materiële waarheid en het streven naar een informele en efficiënte procesvoering.' In gelijke zin: Reijntjes 1980, p. 79. 
feiten. Daarmee wordt de kans op vooringenomenheid bij de beoordelaar zoveel mogelijk beperkt. ${ }^{18}$

\subsection{Begrenzing van de materiële waarheidsvinding}

Uit de vorige paragrafen bleek dat het bewijsoordeel in strafzaken niet met absolute zekerheid kan worden gegeven. Dat neemt niet weg dat de strafrechter desalniettemin een oordeel moet ${ }^{19}$ geven dat met grote mate van waarschijnlijkheid overeenstemt met de werkelijkheid. Daarbij geldt in strafzaken dat de verantwoordelijkheid voor het onderzoek naar die feiten en het uiteindelijke oordeel daarover volledig bij de rechter ligt. Hij kan zich niet zoals in civiele zaken lijdelijk opstellen, maar hij moet zelf 'de waarheid' proberen te achterhalen.

Onderzoek naar de feitelijke toedracht van het tenlastegelegde feit is echter niet onbegrensd. Allereerst geldt er een beperking in tijd. Het onderzoek in strafzaken kan niet eeuwig duren. Dat geldt zowel voor het vooronderzoek als het onderzoek ter terechtzitting. Vanaf het moment dat de verdachte mag verwachten dat er tegen hem een strafvervolging wordt ingesteld, geldt dat de uiteindelijke berechting binnen een redelijke termijn moet geschieden. Dit heeft tot gevolg dat de rechter niet eindeloos kan talmen en allerlei tijdrovende onderzoeken kan (laten) verrichten. ${ }^{20}$ Een tweede beperking ziet op de juridische context waarin het onderzoek plaatsvindt. Zowel het Nederlandse Wetboek van Strafvordering als de Duitse Strafprozessordnung kennen talloze bepalingen die direct dan wel indirect de waarheidsvinding van de rechter beïnvloeden. Voor een deel komen deze bepalingen voort uit het streven de oordeelsvorming van de rechter te kanaliseren en te objectiveren. Deze bepalingen zien op het garanderen van een bepaald minimum van betrouwbaarheid van de onderzoeksresultaten. Andere bepalingen zien echter niet zo zeer op het garanderen van goede waarheidsvinding, maar moeten er voor waken dat het onderzoek in strafzaken op behoorlijke manier plaatsvindt. ${ }^{21}$ Daarbij staat de

18 Burnham 2006, p. 81: 'We all have a natural urge to impose order on chaos by evaluating and categorizing information as we hear it. But decision-makers are under a special pressure to do so, since they must decide the case. The result is a strong inclination in the decisionmaker early on - while the information is still being gathered - to start theorizing about what the evidence means. Even passive decisionmakers may engage in preliminary theorizing. But decisionmakers who actively investigate cannot avoid doing so. An investigator cannot possibly determine what questions to ask or what direction to take the investigation next without first assessing the meaning of the information that is already known.'

19 Drion 1966, p. 414: 'Het bijzondere van de rechterlijke beslissing (...) schuilt in de noodzaak, dat een beslissing genomen wordt, in de definitiviteit van die beslissing, en in de objectiviteit die er van wordt geëist.'

20 Corstens 2005a, p. 633. In gelijke zin: Fokkens 1984, p. 3.

21 In gelijke zin: Cleiren 2001, p. 16: 'De normering van de procedures van waarheidsvinding in ons strafrecht vloeit voort uit het publiek karakter daarvan en is dientengevolge 'strenger' dan bijvoorbeeld het civiele recht. Zij biedt waarborgen voor zowel de betrouw- 
bescherming van grond- en mensenrechten centraal. Met name deze laatste categorie kan het waarheidsvindingsproces van de strafrechter beperken. Het in acht nemen van deze regels brengt met zich dat niet al het gewenste bewijsmateriaal kan worden vergaard. Is het bewijs verkregen in strijd met deze regels, dan kan dit tot gevolg hebben dat de rechter dit bij zijn uiteindelijke bewijsoordeel niet mag betrekken.

Een laatste beperking van het onderzoek in strafzaken ziet op de taak van de rechter daarin. De strafrechter moet - zoals hiervoor reeds werd aangegeven - op basis van eigen onderzoek komen tot een bewijsoordeel. De verantwoordelijkheid voor de waarheidsvinding in de concrete strafzaak ligt bij hem. In werkelijkheid is echter de strafrechter in grote mate afhankelijk van het onderzoek van anderen. Daarbij kan niet alleen gedacht worden aan het voorbereidend onderzoek dat verricht is door opsporingsambtenaren, maar ook aan onderzoek dat verricht wordt door deskundigen.

\subsubsection{Beperkingen met het oog op een behoorlijke waarheidsvinding}

Wie het Nederlandse Wetboek van Strafvordering en zijn Duitse equivalent in zijn geheel doorneemt, kan niet anders dan tot de conclusie komen dat vele daarin opgenomen regels het feitenonderzoek betreffen. Zo bestaat bijvoorbeeld de regulering van het opsporingsonderzoek voornamelijk uit het uitdelen van bevoegdheden aan opsporingsambtenaren om met behulp van die bevoegdheden een gerezen verdenking tot klaarheid te brengen. Daarnaast kennen het Wetboek en de daaraan verwante wetten en regelingen diverse regels waarin de wijze waarop bewijs moet worden verzameld nader wordt gereguleerd, zoals ten aanzien van het DNA-onderzoek en de ademanalyse. Ook het Duitse procesrecht kent een groot aantal regels met betrekking tot het feitenonderzoek in strafzaken.

Het merendeel van deze regels ziet echter niet - althans niet direct - op het verzekeren van de inhoudelijke juistheid van de verkregen onderzoeksresultaten. Zij hebben veel meer tot doel te garanderen het gebruik van die bevoegdheden niet willekeurig geschiedt. $\mathrm{Zij}$ komen voort uit de gedachte dat het handelen van de overheid is gebonden aan regels. En dat navolging van die regels moet voorkomen dat ten onrechte, dan wel zonder redelijke grond onschuldigen in een strafrechtelijk onderzoek worden betrokken, en dus ten onrechte inbreuk zou worden gemaakt op hun rechten en vrijheiden. Deze regels worden ethische of behoorlijkheidsregels genoemd. ${ }^{22}$ In navolging van het bestuursrecht zou men ook kunnen spreken van regels die voortvloeien uit de beginselen van behoorlijke strafrechtspleging.

baarheid van de te construeren waarheid als voor de behoorlijkheid van de procedure waarlangs die constructie tot stand komt.'

22 Nijboer 2000a, 30 en 56. 
De meest wezenlijke van deze behoorlijkheidsregels is die, welke de aanvang van het onderzoek bepaalt. Slechts indien er een redelijk vermoeden bestaat dat een strafbaar feit is gepleegd, mag het strafrechtelijke onderzoeksinstrumentarium van stal worden gehaald. Het gebruik maken van strafrechtelijke onderzoeksbevoegdheden heeft immers in de meeste gevallen tot gevolg dat inbreuken worden gemaakt op rechten van burgers. Zo kan het vermoeden dat een strafbaar feit is gepleegd voor politie en justitie aanleiding zijn om huizen te doorzoeken, personen te ondervragen, verdachten aan te houden en voor nader onderzoek ter beschikking van justitie te houden, personen aan een onderzoek aan lichaam en kleding te onderwerpen etc. Het spreekt voor zich dat politie en justitie niet zonder enige aanleiding inbreuk mogen maken op vrijheids- en persoonlijkheidsrechten van burgers. Die aanleiding wordt gevonden in het redelijke vermoeden dat een strafbaar feit is gepleegd en de verwachting dat dit vermoeden in nader onderzoek kan worden bevestigd, dan wel zo snel mogelijk kan worden weerlegd. Voor zover het onderzoek is gericht op betrokkenheid van een specifieke persoon bij het strafbare feit, dient ten aanzien van hem een redelijk vermoeden van schuld te bestaan. Naarmate de onderzoeksbevoegdheden een grotere inbreuk maken op rechten, dient ook het vermoeden sterker te zijn. Zo mag bijvoorbeeld een verdachte slechts preventief van zijn vrijheid worden beroofd, indien tegen hem ernstige bezwaren bestaan. Deze ernstige bezwaren zien niet op de persoon van de verdachte, maar op de mate van verdenking die jegens hem is gerezen.

De relatie tussen de verdenking en de inzet van onderzoeksbevoegdheden kan worden beschouwd als het normatieve kader waarbinnen men in het kader van het strafrechtelijke onderzoek moet opereren. De bevoegdheden mogen slechts met het oog op strafrechtelijke handhaving en slechts voor zover zij redelijkerwijze kunnen bijdragen aan dat doel worden ingezet. Ontbreekt die link, omdat bijvoorbeeld op basis van de dan beschikbare informatie niet valt in te zien hoe de inzet van bevoegdheden kan bijdragen aan de opheldering van het strafbare feit, dan dient de bewuste richting in het onderzoek niet te worden ingeslagen. Daarmee wordt voorkomen dat onnodig rechten van de burgers waaronder de (potentiële) verdachte worden geschaad. ${ }^{23}$

Met de Wet bijzondere opsporingsbevoegdheden is in Nederland het redelijke vermoeden dat een strafbaar feit is gepleegd als startpunt van het opsporings-

23 De vereiste verdenking en de eis dat de inzet van onderzoeksbevoegdheden moet bijdragen aan die verdenking voorkomt niet alleen willekeurige inbreuken op grond- en mensenrechten, maar heeft ook een positief effect op de waarheidsvinding. De vereiste graad van verdenking maakt immers dat de reeds beschikbare informatie kritisch wordt getoetst. Die toetsing vindt meestal plaats door een derde en wellicht hogere autoriteit, die tevens moet beoordelen in hoeverre uitbreiding van het onderzoek kan leiden tot bevestiging van het bestaande vermoeden, dan wel een andere richting in het onderzoek moet worden ingeslagen. Het vermoeden van schuld biedt aldus een criterium voor kritische zelfreflectie, en maakt interne controle op het opsporingsonderzoek mogelijk. Zie daarover meer uitgebreid: Garé 1997. 
onderzoek verlaten. Het opsporingsonderzoek kan reeds aanvangen indien het vermoeden bestaat dat een strafbaar feit wordt beraamd. Het betreft dan strafbare feiten die in georganiseerd verband plaatsvinden en een ernstige inbreuk op de rechtsorde opleveren (art. 132a Sv). Het uitbreiden van het opsporingsonderzoek naar een eerdere fase is met name bedenkelijk omdat daarmee het verband tussen verdenking en inzet van opsporingsmiddelen wordt verbroken. In plaats daarvan wordt de inzet van opsporingsmiddelen gekoppeld aan de mate waarin bepaalde misdrijven de samenleving schokken. Het gevaar daarvan is dat ook de kans dat onschuldigen in het strafrechtelijk onderzoek worden betrokken steeds groter wordt.

Een tweede ethische beperking van het onderzoek in strafzaken ziet op de positie van de verdachte. Zodra het strafrechtelijk onderzoek gericht is op de opheldering van de vraag of hij enige betrokkenheid heeft bij het geconstateerde feit, geldt als uitgangspunt dat hij niet actief hoeft mee te werken aan dat onderzoek. Hij hoeft niet uit eigen beweging aan politie en justitie bewijsmateriaal over te leggen waarvan het bestaan nog onbekend is. Dit komt het meest prominent tot uiting in het recht van de verdachte om te zwijgen (art. $29 \mathrm{~Sv}$ en $\S 136 \mathrm{StPO}$ ). Hoewel het voor de voortgang van het onderzoek in bepaalde gevallen zeker wenselijk zou zijn dat de verdachte zou verklaren over hetgeen hij ten tijde van het delict deed, kan hij daartoe niet verplicht worden. Van de verdachte kan niet worden verlangd dat hij meewerkt aan zijn eigen veroordeling. Uit respect voor zijn persoon mag men dit niet van hem verlangen ${ }^{24}$ Het is primair aan het Openbaar Ministerie om de zaak tegen de verdachte rond te maken. Vervolgens is het aan de rechter om onder andere op basis van de in het vooronderzoek verzamelde gegevens te bezien in hoeverre het Openbaar Ministerie daarin is geslaagd.

Buiten het verdenkingscriterium en het beginsel dat de verdachte niet aan zijn eigen veroordeling hoeft mee te werken, bevatten het Nederlandse Wetboek van Strafvordering en de Duitse Strafprozessordnung tal van bepalingen die de bevoegdheden van overheidsfunctionarissen binnen het onderzoek nader normeren. Schending van regels kan de kwalificatie 'onrechtmatig overheidsoptreden' opleveren en als zodanig gevolgen hebben voor het bewijsoordeel. Zowel in Duitsland als in Nederland kan dit er toe leiden dat - ook op het eerste gezicht

24 Corstens 2005a, p. 273. Het zwijgrecht en de daarmee verwante bepaling dat de verdachte tijdens het onderzoek niet onder druk mag worden gezet kan ook worden gezien als een waarborg voor de deugdelijke waarheidsvinding. Het niet in acht nemen van deze bepalingen kan er immers toe leiden dat de verdachte onder de druk bezwijkt en vervolgens elke gewenste verklaring aflegt. Daarmee is echter geenszins gegarandeerd dat de inhoud van die verklaring overeenstemt met hetgeen werkelijk gebeurd is. De bekentenis van Cees B. in de Schiedammer parkmoord heeft dit (helaas) geïllustreerd. In gelijke zin: Eisenberg 2002, p. 243: 'Gleichwohl schützt die Vorschrift [§ 136a StPO; WD] faktisch auch die Wahrheitsfindung vor Gefährdungen, da zB eine erpresste oder erschlichene Aussage oft mehr von Resignation oder Angst des Beschuldigten in der Vernehmungssituation als durch die Wahrheit bestimmt sein wird.' 
betrouwbaar - bewijsmateriaal moet worden uitgesloten. In die zin kan de strafrechter in zijn opdracht om de waarheid in de concrete zaak te achterhalen worden beperkt. In Duitsland wordt dit probleem onderkend en geaccepteerd, hetgeen tot uitdrukking komt in de stelling 'Wahrheit nicht um jeden Preis'. In Nederland daarentegen heeft men de voor het onderzoek naar de waarheid nadelige consequenties van het leerstuk van onrechtmatig verkregen bewijs proberen te ondervangen door introductie van artikel 359a Sv. Deze bepaling biedt de strafrechter de mogelijkheid om onrechtmatigheden in het vooronderzoek ook op andere wijzen te sanctioneren, bijvoorbeeld door strafvermindering dan wel de enkele vaststelling dat onrechtmatig is gehandeld.

Voor zover echter onrechtmatig overheidshandelen leidt tot bewijsrechtelijke consequenties, moet voor ogen worden gehouden dat dit geen verband houdt met de intrinsieke waarde van het bewijs. Het leerstuk van onrechtmatig verkregen bewijs staat zowel in Duitsland als in Nederland in het teken van de bescherming van de grond- en mensenrechten. ${ }^{25}$ Als sanctionerend wordt opgetreden tegen het niet in acht nemen van regels bij de bewijsgaring, dan gebeurt dit slechts om te expliciteren dat politie en justitie zich aan de grondwettelijke en verdragsrechtelijke grenzen hebben te houden. Bescherming van de integriteit van de strafrechtspleging - een van de pijlers van het leerstuk van onrechtmatig verkregen bewijs ziet dus niet op elk onrechtmatig handelen van opsporingsambtenaren. Het niet in acht nemen van vormvoorschriften die toezien op het garanderen van de kwaliteit van het bewijs, hoe onbehoorlijk men dit ook mag vinden, heeft geen consequenties in het kader van de beoordeling van de rechtmatigheid. ${ }^{26}$ Dit laat onverlet dat bij de uiteindelijke waardering van het bewijs daaraan door de rechter wel consequenties kunnen worden verbonden. In die zin ook de Hoge Raad:

'Terzijde zij opgemerkt dat art. 359a Sv niet van belang is voor vormverzuimen waardoor de betrouwbaarheid van het aldus verkregen onderzoeksmateriaal wezenlijk is beïnvloed. Dan zal het onderzoeksmateriaal immers reeds om die reden door de rechter buiten beschouwing worden gelaten. ${ }^{27}$

Het feit dat artikel 359a Sv niet ziet op schending van regels die beogen de betrouwbaarheid van het onderzoeksresultaat te garanderen, leidt er bijvoorbeeld toe dat het niet in acht nemen van regels opgenomen in het Besluit maatregelen in het belang van het onderzoek ten aanzien van de Oslo-confrontatie nooit zal leiden tot bewijsuitsluiting op grond van artikel 359a Sv. ${ }^{28}$ Dit tot groot ongenoegen

25 Zie voor een uitgebreide beschrijving van de Duitse invulling van het leerstuk van onrechtmatig verkregen bewijs: Embregts 2003.

26 Bijvoorbeeld: Hof Den Bosch 9 februari 2004, $L J N$ AO322 (r.o. 2.2-2.2.16) en HR 22 februari 2005, $L J N$ AR5714 (conclusie advocaat-generaal 102-106).

27 HR 30 maart 2004, NJ 2004, 376 m.nt. YB (r.o. 3.6.4).

28 Op grond van oudere jurisprudentie gold dat overigens ook al. Het niet op juiste wijze uitvoeren van een Oslo-confrontatie wordt door de Hoge Raad alleen als onrechtmatige bewijsverkrijging beschouwd als het in strijd is met een eerlijke procesvoering. Hoge 
van Van Koppen en Van der Horst, die zich dan ook terecht afvragen wat dan de toegevoegde waarde is van dat Besluit. Het is kennelijk toch aan de rechter overgelaten hoe hij de bewijswaarde van een herkenning beoordeelt ook al zijn daarbij de minimumgaranties niet in acht genomen. ${ }^{29}$ Wagenaar heeft gelijke vragen met betrekking tot de status van de 'Aanwijzing opsporing seksueel misbruik in afhankelijkheidsrelaties'. De aanwijzing heeft tot doel de kwaliteit van de aangifte met het oog op waarheidsvinding te vergroten, maar niet-naleving van de in de aanwijzing opgenomen regels hoeft geen consequenties te hebben. ${ }^{30}$

\subsubsection{Rechterlijke afhankelijkheid bij de waarheidsvinding}

Een tweede beperking van het onderzoek in strafzaken ziet zoals gezegd op de positie van de rechter. Hij dient een zelfstandig oordeel te vormen over de vraag of de verdachte het hem tenlastegelegde feit heeft gepleegd. Echter, met betrekking tot die zelfstandigheid kunnen wel enige kanttekeningen worden gemaakt. Ten eerste is de rechter niet in staat het volledige onderzoek in strafzaken zelf te verrichten en is hij dus voor een deel van het onderzoek afhankelijk van anderen. Maar ook de aard van het onderzoek kan meebrengen dat de rechter is aangewezen op ter zake meer deskundige personen.

\subsubsection{Afhankelijkheid in verband met de omvang van het onderzoek}

Waarheidsvinding in strafzaken vangt echter niet aan bij het onderzoek ter terechtzitting. Voorafgaand aan de zitting hebben politie en Openbaar Ministerie al het nodige werk gedaan. De aangifte is opgenomen, de plaats van het delict is bezocht en onderzocht op sporen, getuigen en deskundigen zijn gehoord, de verdachte is aangehouden en gehoord, voorwerpen zijn in beslag genomen en nader onderzocht,

Raad 8 juli 1992, NJ 1993, 407 m.nt. ThWvV. Voor zover de herkenning niet in strijd met een eerlijke procesvoering is, maar desalniettemin niet correct is verlopen is de rechter vrij om te bepalen of hij de herkenning voor het bewijs bezigt of niet. Nader hierover: Borgers 1995.

29 Van Koppen \& Van der Horst 2006, p. 792-793. Schrijvers merken vervolgens op dat rechters bij de beoordeling van de bewijswaarde van de herkenning de simpele logica van een confrontatie miskennen: 'De getuige moet bij een herkenning uitsluitend afgaan op het eigen herinneringsbeeld van de dader en dus moeten alle andere mogelijkheden op grond waarvan de getuige te weten kan komen wie de verdachte is, worden uitgesloten.'

30 Wagenaar 2006, p. 72: 'De enige manier om officieren van justitie te dwingen zich aan normen te conformeren is door bij wet alle bewijs dat niet volgends de regels is verkregen onrechtmatig te verklaren.' In de door Wagenaar besproken zaak oordeelde het Hof overigens dat de slordige manier waarop de aangifte was opgenomen de zaak in zijn geheel oncontroleerbaar makt en sprak de verdachte vrij. 
enz. De omvang van het opsporingsonderzoek verschilt nogal per zaak en is onder andere afhankelijk van de wijze waarop het delict bij de politie bekend wordt. ${ }^{31}$ Kan het opsporingsonderzoek worden afgerond en leidt dit tot een vervolging, dan wordt het procesdossier overgedragen aan de rechter ter zitting. Het procesdossier bevat de schriftelijke verslaglegging van het onderzoek tot dan toe. Stukken die niet relevant zijn voor de zaak zijn daaruit weggelaten. Te denken valt dan aan delen van het onderzoek die geen resultaat hebben opgeleverd. De behandelend officier van justitie is verantwoordelijk voor de samenstelling van het dossier. Op verzoek van de verdediging kan de rechter nog stukken aan het dossier toevoegen. Het procesdossier vormt het uitgangspunt voor het onderzoek ter terechtzitting. Dit heeft onder andere tot consequentie dat de uitkomst van het opsporingsonderzoek in grote mate het onderzoek ter terechtzitting zal bepalen. De door de politie vastgestelde feiten en omstandigheden zullen altijd in de richting van de verdachte wijzen als de persoon die het feit heeft gepleegd. Voor de verdachte ontlastende feiten komt men zelden tegen in het procesdossier, omdat die ofwel niet zijn opgespoord of als niet relevant ter zijde zijn geschoven. ${ }^{32}$ In zijn algemeenheid kan men zeggen dat politie en justitie - gedreven door hun taak om misdrijven op te lossen - alleen bewijs zullen zoeken dat hen daarbij helpt en voor zover een verdachte bekend is alleen bewijs zullen zoeken dat de vervolging en veroordeling van deze persoon zal vergemakkelijken. ${ }^{33}$ Het onderzoek is dan meestal gericht op verificatie van het bij politie en justitie levende scenario en niet op falsificatie daarvan. ${ }^{34}$ Naar anleiding van de Schiedammer parkmoord is dit verschijnsel wel als 'tunnelvisie' betiteld. ${ }^{35}$

De rechter, die voorafgaand aan de terechtzitting het dossier bestudeert, moet zich bewust zijn van het feit dat het dossier eenzijdig is opgebouwd. Bovendien dient hij te beseffen dat ook hij zich door het dossier laat beïnvloeden. Het dossier bevat in principe alle informatie die het verhaal van de officier van justitie, dat de verdachte schuldig is, ondersteunt. Het is dus niet zo dat de rechter volledig blanco aan de behandeling van de zaak begint. ${ }^{36}$ Op basis van het dossier is bij hem al een vermoeden van schuld van de verdachte aanwezig. Dat is niet - zoals

31 De Poot, Bokhorst, Van Koppen en Muller 2004.

32 Crombag, Van Koppen en Wagenaar 1992, p. 51.

33 Anderson 1999, p. 62.

34 Het enkel gericht zijn op verificatie van het in de hoofden van opsporingsambtenaren bestaande scenario kan leiden tot het zogeheten sturend verhoren van verdachten en getuigen. Zie daarover en de wijze waarop men dat sturende verhoren kan detecteren: Israëls \& Van Koppen 2006.

35 Zie onder andere over het verschijnsel tunnelvisie: Boorsma 2005 en uitgebreid over de psychologische achtergronden en mogelijke tegenmaatregelen: Crombag 2006.

36 In gelijke zin: Wagenaar \& Crombag 2002, p. 839: 'Het vermoeden rijst daarom dat de voorlopige oordeelsvorming die een gevolg is van dossierstudie, van invloed is op de wijze waarop de rechter ter zitting gegevens verzamelt en waardeert.' 
Crombag c.s terecht beweren - een verwijt aan de rechter, maar eerder een feitelijke vaststelling. ${ }^{37}$

\subsubsection{Afhankelijkheid in verband met de aard van het onderzoek.}

Niet alleen de omvang van het onderzoek in strafzaken heeft tot gevolg dat de rechter afhankelijk is van het onderzoek dat anderen reeds hebben verricht. Ook de aard van het onderzoek leidt tot die conclusie. In toenemende mate is het onderzoek in strafzaken van technische aard. ${ }^{38}$ Zeker in zaken waarin het strafbare feit heeft plaatsgevonden zonder dat derden daarvan getuige waren, is de vaststelling van dat feit en de betrokkenheid van de verdachte daarbij afhankelijk van wat men wel noemt 'stille getuigen'. Sporenonderzoek moet dan aanknopingspunten bieden voor het verder onderzoek in de strafzaak. Daarbij kan gedacht worden aan vingerafdrukken, afdrukken van schoensporen en bandensporen, het vinden van dna-materiaal op de plaats delict, het achterhalen van telefoonverkeer, stemherkenning, geuridentificatie, ballistisch onderzoek, medisch onderzoek etc. ${ }^{39}$ Van de rechter kan onmogelijk verlangd worden dat hij zelf voldoende kennis heeft om de deugdelijkheid, volledigheid en de accuratesse waarmee het forensisch onderzoek is uitgevoerd te beoordelen. Bovendien kan hij de conclusies van dit onderzoek bij gebrek aan eigen wetenschap op het betreffende gebied moeilijk op waarde schatten. Hij is dan afhankelijk van het oordeel van de deskundige op dit gebied. Het is niet vreemd om te veronderstellen dat de strafrechter bij gebrek aan eigen solide kennis op dit gebied, geneigd zal zijn het oordeel van de deskundige te volgen. Daarbij moet hij zich echter wel bewust zijn van het feit dat ook de kennis binnen de forensische wetenschappen geen absolute geldigheid heeft. ${ }^{40}$

37 Dubieuze zaken 1992, p. 52: 'Het is een algemene eigenaardigheid in het denken van mensen dat zij confirmerende informatie zwaarder laten wegen dan disconfirmerende informatie.'

38 Uit onderzoek van het WODC blijkt dat in 2003 in 85000 zaken onderzoek is gedaan door de technische recherche. 22368 zaken werden voor nader onderzoek doorgestuurd naar het NFI. $40 \%$ hiervan heeft betrekking op DNA-onderzoek; $23 \%$ op onderzoek van verdovende middelen en $13 \%$ op toxicologisch onderzoek. Zie M.J.G. Jacobs, M.Y. Bruinsma, J.W.M.J. van Poppel en J.A. Moors, Inzet, organisatie en kwaliteit van de forensisch-technische opsporing bij de politie in Nederland, Den Haag: WODC Ministerie van Justitie 2005. Het rapport is opgenomen als bijlage bij Kamerstukken II 2005-2006, 30300 VI, nr. 108.

39 Zie voor een overzicht van de verschillende vormen van forensisch onderzoek Broeders 2004.

40 Zo wijzen Schoon \& Van Koppen 2002 en Boksem \& Frijters 2005 op de beperkte bewijswaarde van een positieve geurherkenning, Broeders \& Rietveld 1995 en Broeders $2002 \mathrm{~b}$ op de beperkingen van de auditieve confrontatie en Van Koppen \& Wagenaar 2002 op de mogelijke problemen bij het herkennen van personen door ooggetuigen. In meer algemene zin wijzen Merckelbach, Crombag \& Van Koppen 2003, p. 710 op de funeste invloed van verwachtingseffecten op forensische expertise: 'Dat self-fulfilling 
Overigens geldt dit niet alleen ten aanzien van technische vormen van onderzoek. In toenemende mate dringt binnen de strafrechtspleging de gedachte door dat getuigen een bijzonder feilbare bron van bewijs vormen. Getuigen kunnen liegen, slecht waarnemen, beïnvloed worden of niet in staat zijn om op accurate wijze hun herinnering van de waarneming in een verklaring over te brengen. Bij de beoordeling van de betrouwbaarheid van getuigenverklaring doet de strafrechter steeds vaker een beroep op psychologische deskundigheid. Ten aanzien daarvan merkte Rassin op:

'Het (is) van belang dat juristen hun verwachtingen over de psychologische wetenschap naar beneden bij stellen. Op veel vragen die de rechter zelf niet kan beantwoorden, weet ook de psycholoog het antwoord niet. Wetenschappelijke kennis is gewoonweg beperkt. ${ }^{41}$

De opmerking van Rassin is zeker niet alleen van toepassing op de rechtspsychologie, maar ziet op elke wetenschap. Hoewel zeker de natuurwetenschappen en de daaraan gelieerde forensische wetenschappen het imago hebben dat zij volledig waardevrij zijn en in objectieve zin de werkelijkheid blootleggen, kan dit echter niet verhullen dat ook in deze wetenschappen conclusies zijn gebouwd op bepaalde aannames. ${ }^{42}$ Binnen de forensische wetenschappen wordt van oudsher uitgegaan van het principe van uniciteit en individualisatie. Dit veronderstelt dat de bronnen waarvan sporen afkomstig zijn uniek en onveranderlijk zijn. In zijn proefschrift heeft Broeders uitvoerig beschreven dat deze aannames onjuist zijn. ${ }^{43}$ In de forensische wetenschap kan enkel een oordeel over de mate van waarschijnlijkheid dat een bepaald spoor van een bepaalde bron afkomstig is worden uitgesproken. ${ }^{44}$ Een deterministisch oordeel, inhoudende dat het spoor wel of niet van de bron afkomstig is - zoals dat in de dactyloscopie gebruikelijk is - is onmogelijk. $^{45}$

prophecies bestaan is evident, maar dat zij ook het quasi-objectieve oordeel van specialisten kunnen vertroebelen is tegen-intuïtief.'

41 Rassin 2002, p. 354.

42 Nijboer 2002, p. 8-9 spreekt in dit verband van institutionalisering van een vakterrein tot discipline en noemt als voorbeeld de dactyloscopie: 'De genoemde axiomatische aanname van de uniciteit van de vingersporen van ieder mens is niet wetenschappelijk onderbouwd en het vergelijken blijft een element van subjectiviteit behouden. Wat wij aan dit voorbeeld zien, is dat het desbetreffende gebied (...) een ontwikkeling heeft doorgemaakt, waarbij de erkenning langzamerhand nauwelijks nog ter discussie staat.'

43 Broeders 2003, p. 150-152.

44 Zie over hoe dat waarschijnlijkheidsoordeel onder woorden moet worden gebracht en welke schalen daarbij gebruikt moeten worden: Broeders 1999.

45 Broeders 2002a, p. 1791; 'Maar er is eigenlijk nog een groter probleem met de dactyloscopie. Door de wijze waarop dit type bewijs door de beoefenaren ervan is gepresenteerd, is vanaf het begin de illusie gewekt dat wetenschappelijke, althans forensische onderzoek tot absolute identificaties of beter gezegd individualisaties kan leiden. Dat is echter een misvatting.' In gelijke zin: Broeders 2005a en een reactie van Zeelenberg 2005. 
De rechter dient zich bewust te zijn van de beperkte mogelijkheden van de forensische wetenschappen en mag zich dus niet ter legitimatie van zijn beslissing achter het oordeel van de deskundige verschuilen. Daarmee schuift hij een deel van zijn verantwoordelijkheid af. ${ }^{46}$ In plaats daarvan dient hij - bewust van de feilbaarheid van de wetenschap - het oordeel van de deskundige kritisch te benaderen en daar waar mogelijk ter discussie te stellen. Hij zal zelfstandig moeten bezien in hoeverre het oordeel van de deskundige wordt bevestigd door andere informatie, dan wel of er gegevens beschikbaar zijn die niet in overeenstemming zijn met het oordeel van de deskundige. Dat vereist dat de rechter op zijn minst op de hoogte is van de uitgangspunten van het forensisch onderzoek en waar nodig de deskundige vraagt om zijn oordeel nader ter zitting te expliciteren. ${ }^{47}$

\subsection{Waarborgen voor een deugdelijke waarheidsvinding}

De vaststelling dat de rechter zelfstandig tot een oordeel moet komen waaruit met hoge mate van waarschijnlijkheid blijkt dat de verdachte het feit heeft begaan, en tegelijkertijd in zijn onderzoek in verregaande mate afhankelijk is van anderen, roept de vraag op in hoeverre dat oordeel nader moet worden genormeerd. Die nadere normering zou dan een minimum aan methodologische juistheid moeten garanderen.

Zowel in Duitsland als in Nederland treft men in de wetgeving bepalingen aan die met het oog op een deugdelijke oordeelsvorming van de rechter zijn geschreven. Daarbij kan een onderscheid worden gemaakt tussen regels die de kwaliteit van het onderzoek ter terechtzitting beogen te garanderen en regels die specifiek betrekking hebben de wijze waarop de resultaten van dat onderzoek door de rechter gewaardeerd dienen te worden. Tot slot wordt aandacht besteed aan de mogelijkheid om het feitenoordeel voor te leggen aan een andere feitenrechter.

\subsubsection{De beslissing tot vervolging}

Tijdens het vooronderzoek vindt de normering van de bewijsgaring vooral plaats met het oog op de bescherming van een behoorlijke strafrechtspleging. De deugdelijkheid van het onderzoek en de aldus verkregen resultaten is voor het merendeel overgelaten aan de beoordeling van autoriteiten die in het vooronderzoek actief zijn. De enige waarborg voor een deugdelijk onderzoek is gelegen in de hiërarchische controle op het onderzoek. Zowel in Nederland als in Duitsland

46 Gutwirth 1993, p. 456.

47 In gelijke zin: Crombag 2000, p. 1663: 'De wetenschap en haar resultaten zijn zo alom aanwezig in onze samenleving, dat voor goed begrip over wat er gaande is, kennis en inzicht in de methoden van proefondervindelijk onderzoek onontbeerlijk zijn voor ieder die beslissende verantwoordelijkheid draagt.' 
is het Openbaar Ministerie verantwoordelijk voor het onderzoek in strafzaken, zoals dat plaatsvindt voorafgaand aan de zitting.

Op basis van de onderzoeksresultaten beoordeelt het Openbaar Ministerie of een vervolging opportuun en haalbaar is. In Duitsland heeft het Openbaar Ministerie iets minder ruimte, in die zin dat daar in principe vervolging moet plaatsvinden. ${ }^{48}$ Alleen indien er sprake is van een onvoldoende verdenking moet de Staatsanwaltschaft afzien van vervolging. Een besluit tot vervolging moet echter nog door een rechter worden geaccordeerd in het zogeheten Zwischenverfahren. Wil de Staatsanwaltschaft daadwerkelijk tot vervolging overgaan, dan dient het een Anklage te formuleren en deze voor te leggen aan een rechter. Op basis van die Anklage, waarin ook het beschikbare bewijsmateriaal dat tegen de verdachte spreekt moet worden opgenomen, beslist de rechter of er voldoende verdenking is om de zaak voor de bevoegde rechtbank te brengen. Doel van het Zwischenverfahren is om de verdachte een openbare behandeling te besparen indien er op voorhand rekening mee moet worden gehouden dat hij wordt vrijgesproken. Het beschermt de verdachte dus tegen lichtvaardige vervolgingen van de kant van de Staatsanwaltschaft.

In Nederland kennen wij een dergelijke rechtsingangprocedure niet meer. Wel kan de verdachte indien hij van mening is dat vervolging op voorhand niet tot enig resultaat kan leiden, een bezwaarschrift tegen de dagvaarding indienen. ${ }^{49}$ Zelden zal echter het gebrek aan bewijs een buitenvervolgingstelling tot gevolg hebben. Slechts indien het hoogst onwaarschijnlijk is dat een strafrechter, later oordelend, door de voor hem geleverde bewijsvoering het tenlastegelegde feit geheel of gedeeltelijk bewezen zal achten, zal een bezwaarschrift op feitelijke gronden resultaat hebben.$^{50}$ In de bezwaarschriftprocedure wordt dus de feitelijke grondslag voor de vervolging zeer marginaal getoetst. De rechter die oordeelt over het bezwaarschrift mag niet op de stoel van de zittingsrechter gaan zitten. Het is hem niet toegestaan, zoals in Duitsland wel het geval is, ${ }^{51}$ om - indien nodig - tijdens de bezwaarschriftprocedure reeds bewijsmateriaal aan te horen of te laten overleggen. Evenmin kan in de bezwaarschriftprocedure het tenlastegelegde feit op aandrang van de

48 Uitzonderingen op dit principe zijn geformuleerd in de $\S \S 153$ tot en met $154^{\mathrm{e}} \mathrm{StPO}$.

49 In de door Wagenaar 2006, p. 125 e.v. beschreven zaak Timo Janssen/OM was dat overigens te laat. De verdachte pleegde zelfmoord nog voordat de zaak op de zitting kwam. In de ogen van Wagenaar bevatte het dossier echter onvoldoende bewijs om de vervolgingsbeslissing te kunnen dragen. In zijn naschrift merkt Wagenaar op: 'In ons rechtsbestel is de officier van justitie een magistraat die de waarheidsvinding dient, en niet een Amerikaans soort aanklager die probeert zo veel mogelijk zaken te winnen. Dat is van belang, omdat de controle op het doen en laten van de officier van justitie minimaal is, en de klachtenprocedure eigenlijk niet-bestaand. Wanneer het openbaar ministerie zijn taak gaat verschuiven in de richting van een Amerikaanse aanklager, maar zonder de bijbehorende checks and balances, gaat er iets grondig mis in ons rechtsbestel.'

50 Corstens 2005a, p. 516

51 Zie $§ 202$ StPO. 
rechter wordt gewijzigd. Dit laatste kan in Duitsland wel; de rechter kan besluiten dat de aanklacht wordt aangepast, in die zin dat bepaalde strafverzwarende omstandigheden uit de aanklacht moeten worden verwijderd.

\subsubsection{De behandeling ter terechtzitting}

Slechts in geval het onderzoek in de voorfase bij voorbaat geen voldoende feitelijke grondslag biedt voor een vervolging, zal - in Duitsland eerder dan in Nederland - dit tot een buitenvervolgingstelling leiden. Dat betekent dat de controle op de deugdelijkheid van de bewijsgaring en de uiteindelijke onderzoeksresultaten voornamelijk plaats vindt tijdens het onderzoek ter terechtzitting. Daartoe kent zowel de Nederlandse als de Duitse strafvordering verschillende bepalingen.

Allereerst kan dan gewezen worden op een aantal vormvoorschriften ten aanzien van het ter zitting te presenteren bewijsmateriaal. De meest in het oog springende zijn in dit verband de eisen met betrekking tot de beëdiging van getuigen en deskundigen. Voor zover getuigen en deskundigen ter zitting worden gehoord, moeten zij de eed dan wel de belofte afleggen. De eed en de belofte zijn ervoor bedoeld dat de getuige dan wel de deskundige zich bewust is van het belang van zijn verklaring en dat hem wordt ingeprent dat hij conform de waarheid dient te verklaren respectievelijk dat hij zijn taak als deskundige naar zijn geweten zal vervullen. De getuige en deskundige die in weerwil van de eed of de belofte de verdenking op zich laden niet conform de waarheid te verklaren, lopen het risico dat zij worden aangehouden en vervolgd voor meineed. Het belang van de eedsaflegging voor de waarheidsvinding is echter door menigeen betwist. In Duitsland heeft dit er ook toe geleid de eis van beëdiging in het merendeel van de gevallen te laten varen. ${ }^{52}$

Wezenlijker voor het onderzoek naar de feitelijke toedracht ter terechtzitting zijn de bepalingen waarin het onmiddellijkheidsbeginsel is opgenomen en waarin mogelijkheden zijn gecreëerd ter uitbreiding van het feitenonderzoek. Al deze bepalingen zien erop toe de rechter en met hem de procespartijen een zo volledig en waarheidsgetrouw mogelijk beeld van de relevante feiten in de strafzaak te bieden.

$52 \S 59$ StPO luidt na inwerkingtreding van het Justizmodernisierungsgesetz op 1 september 2004: '(1) Zeugen werden nur vereidigt, wenn es das Gericht wegen der ausschlaggebenden Bedeutung der Aussage oder zu Herbeiführung einer wahren Aussage nach seinem Ermessen für notwenig hält. Der Grund dafür, dass ein Zeuge vereidigt wird, braucht im Protokoll nicht angegeben zu werden, es sei denn, der Zeuge wird außerhalb der Hauptverhandlung vernommen. (2) Die Vereidigung der Zeugen erfolgt einzeln und nach ihrer Vernehmung. Soweit nichts anderes bestimmt ist, findet sie in der Hauptverhandlung statt.' 


\subsubsection{Het onmiddellijkheidsbeginsel}

Het onmiddellijkheidsbeginsel is met betrekking tot de waarheidsvinding in strafzaken wel omschreven als een wezenlijk uitgangspunt van het strafproces. ${ }^{53}$ Het onmiddellijkheidsbeginsel veronderstelt dat het voor de uiteindelijke beoordelaar van belang is de meeste directe vorm van het bewijs ter zitting gepresenteerd te krijgen. Dat betekent dat indirecte vormen van bewijsvoering minder geschikt zijn. Het belang van een directe bewijsvoering komt het best tot uitdrukking ten aanzien van het getuigenbewijs. Het is in dit verband beter om de getuige zelf ter zitting te horen dan genoegen te nemen met de schriftelijke verslaglegging van het verhoor door een ander, of de verklaring van een getuige ter zitting wat hij een ander heeft horen zeggen. Het voordeel van een directe bewijsvoering boven een indirecte is dat de aanwezigen ter zitting een indruk kunnen krijgen van de persoon van de getuige, het non-verbale gedrag kunnen zien, in de gelegenheid zijn om de persoon nadere vragen te stellen en indien nodig de getuige kunnen confronteren met andere - wellicht tegengestelde - informatie. Daarmee is ook meteen het nadeel van een indirecte bewijsvoering geschetst. Daar waar informatie wordt verkregen door tussenkomst van andere personen, is de kans groot dat bij de overdracht van die informatie delen daarvan verloren gaan of anders worden weergegeven dan oorspronkelijk bedoeld was. Zeker als getuigenverklaringen niet letterlijk worden geverbaliseerd. Het onmiddellijkheidsbeginsel opgevat als bewijsbeginsel biedt een tegenwicht tegen de in paragraaf 8.3.2.1 weergegeven afhankelijkheid van de rechter met betrekking tot de onderzoeksresultaten uit het vooronderzoek. Door de rechter de gelegenheid te geven om zichzelf een indruk te vormen van het in het vooronderzoek vergaarde bewijsmateriaal is hij ook beter in staat dat bewijsmateriaal op zijn waarde te schatten. Hij en met hem de verdediging en het Openbaar Ministerie kunnen de getuige onderwerpen aan een nader verhoor om daarmee de context waarin de door de getuige gedane waarneming is gedaan beter in beeld te krijgen. Bovendien kunnen tijdens het verhoor ter zitting eventuele onduidelijkheden of omissies in de verklaring worden verhelderd dan wel worden aangevuld.

Een onmiddellijke bewijsvoering hoeft geen consequenties te hebben voor de bewijswaardering. Het ziet er slechts op dat de rechter the best evidence in de zin van de meest directe bron onder ogen krijgt. Daarmee is niet gezegd dat dit ook the best evidence is, als het gaat om de waardering van dat bewijsmateriaal. De verklaring van een getuige opgenomen in een proces-verbaal van een opsporingsambtenaar direct nadat het strafbare feit is gepleegd, kan om verschillende redenen

53 Garé 1994, p. 184: 'Een strafproces dat onvoldoende tegemoet komt aan het onmiddellijkheidsbeginsel doet daarmee in dezelfde mate afbreuk aan de openbaarheid, de autonoom rechterlijke functie (scheiding der machten) en het contradictoire karakter van het strafproces.' 
betrouwbaarder worden geacht dan de verklaring die diezelfde getuige later aflegt ter terechtzitting. Het ligt voor de hand dat door het verloop van tijd details in de verklaring verloren gaan, of juist - doordat de getuige meer te weten is gekomen over het strafbare feit - nader worden ingekleurd. Andersom kan de verklaring ter zitting ook een toegevoegde waarde hebben, omdat de getuige in een bredere context wordt gevraagd naar hetgeen hij heeft waargenomen. Zo kunnen bijvoorbeeld in het opsporingsonderzoek feiten over het hoofd gezien zijn die voor het beoordelen van de juistheid van de waarneming van belang zijn. Te denken valt aan de plaats waar vandaan de getuige de waarneming heeft gedaan, het beschikbare licht, de beïnvloeding van de getuige door anderen etc. De waarde van het onmiddellijkheidsbeginsel als bewijsbeginsel ${ }^{54}$ ligt er nu juist in dat de rechter in staat wordt gesteld mogelijke discrepanties tussen de oorspronkelijke verklaring en de verklaring ter zitting te toetsen en deze waar mogelijk te verklaren. De rechter wordt daarin gesteund door de verdediging en het Openbaar Ministerie, die ieder vanuit hun eigen optiek hun voorkeur voor een van beide verklaringen zullen toelichten.

De wijze waarop in Nederland en Duitsland het onmiddellijkheidsbeginsel in juridische zin wordt ingevuld verschilt aanzienlijk. Direct na de invoering van het Nederlandse Wetboek van Strafvordering in 1926 oordeelde de Hoge Raad dat het gebruik van verklaringen van getuigen waarvan de inhoud niet door de getuige zelf kenbaar is gemaakt aan de rechter, niet in strijd is met artikel 342 of $344 \mathrm{~Sv}^{55}$ Het is dus toegelaten dat de rechter de bewijsbeslissing baseert op de mondelinge verklaring van een getuige of de schriftelijke verklaring van een opsporingsambtenaar, inhoudende dat zij een ander iets hebben horen zeggen over het tenlastegelegde feit. In beide gevallen is dus het ontbreken van de mogelijkheid voor de rechter en de verdediging om de oorspronkelijke bron te raadplegen en te ondervragen geen beletsel om de inhoud van diens verklaring toch voor het bewijs te bezigen. Deze jurisprudentie van de Hoge Raad heeft volgens Pompe het nieuwe Wetboek van Strafvordering een groot deel van zijn waarde ontnomen. ${ }^{56}$ $\mathrm{Zij}$ heeft er toe geleid dat in Nederland strafzaken voor een groot deel op basis van de stukken uit het vooronderzoek kunnen worden behandeld en beoordeeld. Het oproepen van getuigen ter zitting is niet meer nodig. ${ }^{57}$

In zijn arrest van 1994 heeft de Hoge Raad echter onder invloed van artikel 6 EVRM iets van deze jurisprudentie teruggenomen. Voor zover de betrokkenheid van de verdachte in belangrijke mate alleen blijkt uit een getuigenverklaring afgelegd tegenover een opsporingsambtenaar en deze getuige niet ter zitting is

54 Garé 1994, p. 74-75.

55 HR 20 december 1926, NJ 1927, 85.

56 Pompe 1959, p. 46-47.

57 Nijboer merkt hierover op Nederland wel degelijk het onmiddellijkheidsbeginsel kent, maar dat de uitwerking daarvan in vergelijking tot andere landen 'extreem minimalistisch' was. Zie Nijboer 1999d, p. 108. 
gehoord, mag deze verklaring niet voor het bewijs gebezigd worden. Het ontbreken van de mogelijkheid voor de verdediging om de getuige te ondervragen, leidt in dergelijke gevallen tot vrijspraak. Slechts indien de verdediging niet verzoekt om het horen van de getuige of de verklaring van de getuige wordt bevestigd door ander bewijsmateriaal is dit anders.

Opvallend in deze jurisprudentie is dat niet zo zeer de waarheidsvinding door de onafhankelijke rechter centraal staat, maar veel meer het recht van de verdediging om belastend bewijsmateriaal te toetsen. Binnen het Nederlandse strafprocesrecht ligt dus - onder invloed van het EVRM - steeds meer de nadruk op een accusatoir proces waarbinnen het beginsel van equality of arms een belangrijke rol is toebedeeld. De verdediging moet de mogelijkheid hebben om het belastende bewijsmateriaal te toetsen en ter discussie te stellen. Voor zover de verdediging die gelegenheid heeft gehad - ter zitting of elders - is het vervolgens aan de rechter om te beoordelen welke waarde hij aan het bewijsmateriaal toekent.

Waarheidsvinding door de rechter is wel van belang indien er twee verklaringen liggen van dezelfde getuige, die beide in het vooronderzoek zijn afgelegd. Voor zover deze verklaringen elkaar tegenspreken en de 'ontlastende' verklaring is afgelegd ten overstaan van een rechter (bijvoorbeeld de rechter-commissaris), dient de zittingsrechter de getuige op te roepen ter zitting. Het oproepen ter zitting heeft dan tot doel de rechter zelf in staat te stellen beide verklaringen op hun merites te beoordelen. Dit laat onverlet dat in die gevallen waarin de oproeping van de getuige geen effect sorteert, de zittingsrechter vervolgens vrij is om de belastende verklaring aan de bewezenverklaring ten grondslag te leggen. Een nadere verantwoording is niet vereist.

Tegen deze minimale doorvoering van het beginsel van onmiddellijkheid in Nederland steekt de Duitse wijze van procesvoering schril af. In Duitsland geldt het uitgangspunt dat al het bewijs op de meest directe wijze op de zitting wordt gepresenteerd. Dat betekent dat alle getuigen en deskundigen op de zitting moeten verschijnen, en slechts hun verklaringen daar afgelegd voor het bewijs kunnen worden gebezigd. Voor zover hun verklaringen met betrekking tot de door hen gedane waarneming reeds in het vooronderzoek in een proces-verbaal van een opsporingsambtenaar zijn neergelegd, mag deze verklaring niet ter zitting worden voorgelezen. Zij kan dus niet meewerken aan de oordeelsvorming, omdat de rechter slechts mag oordelen op basis van het bewijsmateriaal dat ter zitting is voorgehouden. De getuige zelf of de opsporingsambtenaar die de verklaring heeft opgenomen, dient ter zitting te worden gehoord.

Het verbod om door middel van schriftelijke bescheiden waarnemingen van getuigen in het strafproces te introduceren, is neergelegd in $\S 250 \mathrm{StPO}$. Dat neemt niet weg dat deze schriftelijke verklaringen wel degelijk voor het bewijs kunnen worden gebruikt. Allereerst bepaalt $\S 250$ Abs. 1 StPO dat het verboden is om getuigenverklaringen te vervangen door schriftelijke bescheiden. Het aanvullen van 
een getuigenverklaring ter zitting door hetgeen in het proces-verbaal is neergelegd is echter niet verboden. Dit gebeurt meestal door de getuige eerdere verklaringen voor te houden om zo zijn geheugen op te frissen. Bevestigt hij vervolgens de inhoud van deze eerdere verklaringen, dan kan alsnog de inhoud van de eerdere verklaring via een omweg voor het bewijs gebezigd worden. Bovendien kent het uitgangspunt van $\S 250$ een aantal wettelijke uitzonderingen. Zo mag het procesverbaal van verhoor van de getuige door een rechter wel ter zitting gepresenteerd worden indien de getuige niet beschikbaar is voor het verhoor ter zitting. ${ }^{58}$ Het proces-verbaal van een niet-rechterlijke autoriteit mag tijdens het onderzoek ter terechtzitting worden geïntroduceerd, indien partijen hiermee akkoord gaan. ${ }^{59}$ De wijze waarop in Duitsland het onmiddellijkheidsbeginsel vorm heeft gekregen, maakt duidelijk dat men in Duitsland meer belang hecht aan de mondelinge overdracht van informatie. Simpel gezegd: het papier praat niet terug en de daarin opgenomen informatie kan onmogelijk door de rechter worden geverifieerd:

'Indem das Gesetz dem Beweis durch Zeugen und Sachverständige, soweit dieser möglich ist, den Vorrang vor dem Urkundenbeweis einräumt, ermöglicht es dem Gericht, von den Wahrnehmungspersonen einen persönlichen Eindruck zu gewinnen; zugleich sichert es die Ausübung des Fragerechts (...) und die Anspruch des Angeklagten auf richterliches Gehör., ${ }^{60}$

De voorkeur voor mondelinge presentatie van het bewijs, maakt dat men in het Duitse strafproces in principe niet afwijzend staat tegenover het gebruik van mondelinge de-auditu-verklaringen. Deze mogen in tegenstelling tot schriftelijke verklaringen zonder beperkingen in het proces worden ingevoerd. Wel kan deze vorm van indirecte bewijsvoering een invloed hebben op de uiteindelijke waardering van het bewijs door de rechter.

\subsubsection{De rechterlijke onderzoeksplicht}

Zowel in Nederland als in Duitsland is de waarheidsvinding in strafzaken in principe opgedragen aan de rechter. Hij is weliswaar deels afhankelijk van hetgeen in een eerdere fase in het onderzoek door andere autoriteiten is verricht, maar dit ontslaat hem niet van zijn plicht om naar eer en geweten het onderzoek in de strafzaak te verrichten. In de woorden van Melai:

'de rechter is de in het wetboek aangewezen hoeder van de deugdelijkheid en de volledigheid van het onderzoek, hetgeen ook hieruit blijkt dat hij de zorg heeft voor het kenbaar maken van de stukken en dat hij los van partijen alsnog een gerechtelijk vooronderzoek kan doen instellen. ${ }^{, 61}$

$58 \S 250$ Abs. 1 StPO.

$59 \S 250$ Abs. 2 StPO.

60 H. Diemer, aant. 1 bij $\S 250$ StPO, in: Pfeiffer 2003.

61 Melai 1981, p. 65. 
Hij kan in zijn onderzoek gesteund worden door de overige procespartijen. In eerste instantie kan dan gedacht worden aan het Openbaar Ministerie, dat primair verantwoordelijk is voor het aandragen van feitenmateriaal dat de vervolging rechtvaardigt. Maar ook de verdediging kan daarbij behulpzaam zijn door ter zitting een ander licht op de zaak te werpen. Daartoe kan zij verzoeken doen tot het horen van relevante getuigen en deskundigen of bepaalde verweren voeren, die de relevantie en betrouwbaarheid van het bewijsmateriaal ter discussie stellen of waarin de door het Openbaar Ministerie naar voren gebrachte bewijsconstructie wordt betwist.

De toegevoegde waarde van de verdediging voor de waarheidsvinding kan niet worden onderschat. $\mathrm{Zij}$ heeft er belang bij te voorkomen dat de rechter al te gauw het door het Openbaar Ministerie geschetste scenario zal volgen. Dat neemt echter niet weg dat zowel in het Duitse als het Nederlandse bewijsrecht de uiteindelijke verantwoordelijkheid voor de waarheidsvinding bij de rechter ligt.

In het Duitse procesrecht is dit uitgangspunt ook nadrukkelijk verwoord in $\S 244$ Abs. 2 StPO:

'Das Gericht hat zur Erforschung der Wahrheit die Beweisaufnahme von Amts wegen auf alle Tatsachen und Beweismittel zu erstrecken, die für die Entscheidung von Bedeutung sind.'

De Aufklärungspflicht van de Duitse rechter moet worden bezien in het licht van de vrije bewijswaardering. Daar waar de rechter in wettelijke zin niet wordt beperkt in de waardering van het bewijs, moet hij in ieder geval - alvorens hij een oordeel velt - beschikken over alle voor dat oordeel relevante feiten en omstandigheden. Alleen in dat geval kan worden gezegd dat de rechter tot een afgewogen rationeel oordeel is gekomen. In deze context is het niet verwonderlijk dat het niet in acht nemen van de rechterlijke onderzoeksplicht in cassatie kan worden getoetst. Hoewel hoge eisen worden gesteld aan de cassatieschriftuur op dit punt, heeft het Bundesgerichtshof in verschillende uitspraken te kennen gegeven dat het niet uitputten van de onderzoeksplicht van de feitenrechter tot cassatie leidt.

In het Nederlandse bewijsrecht is de rechterlijke onderzoeksplicht niet zo nadrukkelijk opgenomen. Wel wordt de feitenrechter de gelegenheid geboden het onderzoek ter terechtzitting uit te breiden indien hem dat noodzakelijk lijkt. Artikel $315 \mathrm{~Sv}$ geeft hem de bevoegdheid getuigen en deskundigen ter zitting op te roepen en niet ter zitting beschikbare geschriften en stukken van overtuiging te laten produceren. In tegenstelling tot het Duitse recht is dit echter geen verplichting; hij is daartoe bevoegd. Het niet uitoefenen van deze bevoegdheid heeft echter geen consequenties. De rechter is volledig vrij om te bepalen of hij voldoende gegevens heeft om een oordeel te geven. Wel kan de verdediging de rechter verzoeken om van zijn bevoegdheid gebruik te maken. In dergelijke gevallen dient zij echter nadrukkelijk te motiveren waarom nader onderzoek noodzakelijk 
is. ${ }^{62}$ Daarmee lijkt in Nederland de ambtshalve onderzoeksplicht van de rechter te worden afgeschoven op de verdediging. Slechts in die gevallen waarin zij nadrukkelijk en goed onderbouwd de rechter verzoekt het onderzoek ter terechtzitting uit te breiden, kan dit mogelijk tot uitbreiding van het onderzoek leiden. Wijst echter de rechter het verzoek af, dan kan hij meestal volstaan met de opmerking dat de noodzaak van nader onderzoek niet is gebleken. Een dergelijke motivering is in cassatie zelden aanvechtbaar. Slechts voor zover de afwijzing in strijd is met de eis van een eerlijke procesvoering kan dit in cassatie aan de orde worden gesteld. Of zich zo een geval voordoet, is afhankelijk van de omstandigheden van de desbetreffende zaak. Daarbij kan worden gedacht aan onder meer a) de gronden waarop het verzoek steunt; b) het belang van het gevraagde (tegen) onderzoek in het licht van - bijvoorbeeld - de aanwezigheid van ander bewijsmateriaal dan wel de overtuigende kracht die pleegt te worden toegekend aan het bestreden onderzoeksresultaat; c) de omstandigheid dat het verzoek is gedaan op een zodanig tijdstip dat een dergelijk onderzoek nog mogelijk is, en d) de omstandigheid dat het verzoek redelijkerwijs eerder had kunnen worden gedaan. ${ }^{63}$ Beziet men deze criteria, dan is duidelijk dat het initiatief tot nader onderzoek bij de verdediging ligt. Dat blijkt met name uit het laatste criterium. De rechter mag afzien van nader onderzoek, indien de verdediging reeds eerder een verzoek had kunnen doen. Heeft bijvoorbeeld de verdediging niet eerder op reguliere wijze het verzoek tot oproepen van een getuige ex artikel 263 jo. $287 \mathrm{~Sv}$ gedaan, dan kan zij bij een later verzoek om de getuige op te roepen het deksel op haar neus krijgen. De rechter mag dus bij afwijzing van verzoeken om toepassing van artikel $315 \mathrm{~Sv}$ argumenten betrekken die in principe los staan van de waarheidsvinding. Voor zover de - overigens niet limitatief opgesomde - criteria wel verband houden met de waarheidsvinding zijn zij negatief gesteld. Vooral het criterium 'de overtuigende kracht van het bestreden onderzoeksresultaat' is dubieus. Het lijkt er immers van uit te gaan dat de rechter al zijn oordeel heeft gevormd en niet meer open staat voor andere denkrichtingen. Met Mevis kan men zich afvragen of in Nederland niet veel meer de zittingsrechter zelf verantwoordelijk moet worden geacht voor het realiseren van een eerlijk proces, en als wezenlijk onderdeel daarvan een deugdelijke waarheidsvinding. ${ }^{64}$ In dat geval zou de rechter ook ambtshalve tot nader onderzoek moeten besluiten, indien nader onderzoek mogelijk de eerdere onderzoeksresultaten in positieve dan wel negatieve zin zou beïnvloeden.

62 HR 10 februari 2004, NJ 2004, 452 m.nt. Kn.

63 HR 8 februari 2005, NJ 2005, 514 m.nt. PMe.

64 Mevis in zijn annotatie bij HR 8 februari 2005, NJ 2005, 514 m.nt. PMe. In gelijke zin: Franken 2006a, p. 35: 'Evenmin is mij duidelijk hoe de geoorloofde passiviteit van de strafrechter zich verhoudt tot het uitgangspunt dat deze een zelfstandige verantwoordelijkheid heeft voor de kwaliteit en de uitkomst van het strafgeding.' 
Pas dan kan de rechter tot een afgewogen oordeel komen met betrekking tot de waarde die hij onderzoeksresultaten toekent. ${ }^{65}$

\subsubsection{De waardering van het bewijsmateriaal}

De normering van het bewijsoordeel kan tot slot vorm krijgen in het formuleren van specifieke wettelijke voorschriften met betrekking tot de bewijswaardering. Op dit punt is eveneens een duidelijk onderscheid te zien tussen de Duitse en de Nederlandse strafvordering.

In Nederland is gekozen voor een zogeheten negatief-wettelijk bewijsstelsel. Dit betekent dat de rechter gebonden is aan wettelijke bewijsmiddelen en bewijsminimumvoorschriften. Zoals uit hoofdstuk 2 is gebleken hebben echter deze regels veel van hun waarde verloren. Dat geldt zowel voor de limitatieve opsomming van de bewijsmiddelen, de inhoudelijke normering van elk van die bewijsmiddelen als de bewijsminima. Op alle punten heeft de Hoge Raad de feitenrechter meer ruimte gegeven. Men kan concluderen dat het negatief-wettelijk bewijsstelsel zoals dat in Nederland bij de inwerkingtreding van het Wetboek van Strafvordering in 1926 is opgenomen, is verworden tot een vrij bewijsstelsel. De enkele beperkingen die nog aan het bewijsmateriaal worden gesteld zijn van zodanig algemene aard, dat ook indien die regels niet in het wetboek zouden zijn opgenomen rechters deze ook uit zichzelf zouden toepassen. Te denken valt dan bijvoorbeeld aan voorschrift dat getuigen enkel mogen verklaren over hetgeen zij zelf hebben waargenomen of ondervonden.

In Duitsland daarentegen is, zoals uit hoofdstuk 7 voren kwam, van meet af aan gekozen voor een vrij bewijsstelsel. Dat betekent dat het Duitse strafprocesrecht in principe geen bepalingen kent die de rechter binden bij de beoordeling van de bewijswaarde van het hem gepresenteerde bewijs. De Duitse feitenrechter is niet gebonden aan een limitatieve opsomming van bewijsmiddelen en evenmin kent het Duitse strafprocesrecht bepalingen die van de rechter verlangen dat hij - wil hij tot een bewezenverklaring kunnen komen - een bepaald minimum aan bewijs moet hebben. Wel is de rechter in het zogeheten Strengbeweisverfahren gebonden aan wettige bewijsmiddelen. Maar de eisen die aan deze bewijsmiddelen worden gesteld, zijn niet inhoudelijk van aard en zien vooral op de wijze waarop die bewijsmiddelen ter zitting moeten worden gepresenteerd.

65 In gelijke zin: Nijboer 1994, p. 18: 'Wat betreft het onderzoek in de zaak is het [het proces ter zitting, WD] een beslissende fase: in een contradictoire behandelng van de zaak onder leiding van een actieve rechter kunnen alle aspecten en alle betrokken belangen onder ogen worden gezien.' 


\subsection{Tussenconclusie}

In het voorgaande is nadrukkelijk ingegaan op de wijze waarop de waarheidsvinding in strafzaken in Duitsland en Nederland is genormeerd.

In Nederland wordt de kwaliteit van de waarheidsvinding vooral gegarandeerd door de rechter in de fase van de bewijswaardering te binden aan wettelijke regels die voortvloeien uit het negatief-wettelijk bewijsstelsel. Daarmee wordt beoogd dat het uiteindelijke oordeel een minimum aan betrouwbaarheid bevat. Het meest duidelijk komt dit tot uitdrukking in de bewijsminima. De rechter mag niet oordelen op basis van de verklaring van één getuige of enkel op basis van de verklaring van de verdachte. De omschrijving van de wettelijke bewijsmiddelen bevat bovendien ook een zekere garantie. De informatie die de rechter in de vorm van een bewijsmiddel ontvangt, moet immers zijn te herleiden tot een zintuiglijke waarneming. Op conclusies en gissingen van andere personen mag de rechter zijn oordeel niet baseren. Bovendien lag in de limitatieve opsomming van de bewijsmiddelen van oudsher de waarborg besloten dat andere informatiebronnen - die mogelijk minder betrouwbaar zijn - zijn uitgesloten.

Het negatief-wettelijk bewijsstelsel heeft echter veel van zijn waarde verloren. Weliswaar is de opsomming van de bewijsmiddelen in de wet nog steeds limitatief, maar in de praktijk is het mogelijk om elke vorm van informatie op een of andere manier onder een van de genoemde bronnen te brengen. De inhoudelijke eisen die aan elk van de bewijsmiddelen worden gesteld, worden in cassatie niet al te streng getoetst. En tot slot leveren de bewijsminima zelden een belemmering op. Dit laatste omdat zij niet gelden ten aanzien van het bewijs van elk onderdeel van de tenlastelegging, maar slechts zien op het bewijs van de gehele tenlastelegging.

In Duitsland daarentegen is gekozen voor een stelsel van vrije bewijswaardering. Het Duitse bewijsrecht kent derhalve geen bepalingen die op een of andere wijze de rechter bij de uiteindelijke waardering van het ter zitting gepresenteerde bewijsmateriaal binden. Het uitgangspunt van de vrije bewijswaardering heeft echter een keerzijde. De rechter is wel gebonden aan strikte regels met betrekking tot de bewijsvoering. Ter zitting mag in het Strengbeweisverfahren alleen informatie worden gepresenteerd in de vorm van een wettig bewijsmiddel en bovendien geldt het onmiddellijkheidsbeginsel. Dat betekent dat informatie - in principe enkel in een mondelinge vorm ter zitting gepresenteerd mag worden. De normering van het bewijsoordeel in Duitsland is dus voornamelijk gericht op de presentatie van het bewijsmateriaal ter zitting. Van oudsher heeft dit tot doel de rechter in staat te stellen zich een goed en zo volledig mogelijk beeld te vormen van het beschikbare bewijsmateriaal. Dat daarenboven ook de partijen de gelegenheid krijgen het bewijsmateriaal te toetsen, wordt niet gezien als een zelfstandige eis van deugdelijke waarheidsvinding. Bijdragen van partijen worden beschouwd als welkome aanvulling op de rechterlijke plicht tot waarheidsvinding. In dat opzicht 
wijkt het Duitse recht ook wezenlijk af van het Nederlandse. Waar in Nederland de rechter wel bevoegd is het onderzoek ambtshalve uit te breiden, kan hij daartoe echter niet worden verplicht.

Het wezenlijke verschil in normering van het bewijsoordeel in Duitsland en Nederland is dus gelegen in de fase waarop die normering betrekking heeft. In Nederland is dat op de fase van de bewijswaardering. In Duitsland ziet dit vooral op de fase waarin het bewijs ter zitting wordt gepresenteerd, de fase van de bewijsvoering. Dit onderscheid kan ook verklaren waarom in Duitsland en Nederland de eisen die worden gesteld aan de bewijsmotivering uiteenlopen.

\subsection{Motivering als sluitstuk van de waarheidsvinding in strafzaken}

Zowel in Nederland als in Duitsland wordt gestreefd naar materiële waarheidsvinding. De wijze waarop dit doel wordt benaderd, is echter verschillend. In Duitsland ligt de nadruk op de normering van het onderzoek ter zitting, waarbij aan de rechter een belangrijke rol is toebedeeld waar het de omvang en kwaliteit van het onderzoek ter zitting betreft. Het Duitse strafprocesrecht kent echter geen bepalingen met betrekking tot de bewijswaardering. In Nederland daarentegen ligt de nadruk op de normering van de uiteindelijke bewijswaardering, hetgeen tot uiting komt in wettelijke bewijswaarderingsregels. Waar het de omvang en kwaliteit van het onderzoek betreft, valt op dat de Nederlandse strafrechter daar in formele zin voor verantwoordelijk is, maar dat feitelijk die verantwoordelijkheid in toenemende mate bij de procespartijen wordt gelegd. In ieder geval kan de rechter niet verplicht worden het onderzoek ambtshalve uit te breiden.

Het verschil in benadering met betrekking tot de wijze waarop de waarheid moet worden achterhaald, komt ook tot uitdrukking in de functie die in beide landen aan de motivering wordt toegekend. Daarbij kan een onderscheid worden gemaakt tussen het opnemen van de plicht tot motivering als zijnde een noodzakelijk gevolg van de wettelijke bewijsvoerings- en bewijswaarderingsregels en een motiveringsplicht die zelfstandige eisen aan het bewijsoordeel in strafzaken stelt. In het eerste geval zou ik willen spreken van een formele motiveringsplicht. De tweede door mij genoemde plicht houdt een materiële motiveringsplicht in.

\subsubsection{De formele motiveringsplicht in Nederland}

De wijze waarop het bewijsoordeel in strafzaken is genormeerd, heeft in alle gevallen gevolgen voor de motivering van de bewezenverklaring. Uit het vonnis zal immers moeten blijken of de met betrekking tot het bewijsoordeel gestelde eisen zijn nageleefd. Zou een dergelijke motiveringseis niet worden gesteld, dan komt daarmee tevens het nut van de bewijsregels te vervallen. 
In Nederland heeft de motivering van oudsher in het teken gestaan van de naleving van de wettelijke bewijsvoorschriften. Dit kwam al tot uitdrukking in de discussies die in de $19^{\mathrm{e}}$ en begin van de $20^{\mathrm{e}}$ eeuw zijn gevoerd over het in Nederland in te voeren bewijsstelsel. Voorstanders van een vrij bewijsstelsel waarin de waardering van het bewijs wordt overgelaten aan het oordeel van de rechter, kenden aan de motivering een meer inhoudelijk karakter toe. Zij meenden dat het onmogelijk was om algemene regels te formuleren die voor elke afzonderlijke strafzaak algemeen toepasbaar waren. Bij gebrek aan dergelijke regels meenden zij dat de rechter in zijn vonnis tot uitdrukking moest brengen op basis waarvan en met in achtneming van welke wetenschappelijke en algemene ervaringsregels hij tot zijn oordeel was gekomen.

Tegenstanders van een vrij bewijsstelsel meenden echter dat de motivering een onvoldoende waarborg voor een deugdelijke waarheidsvinding kon zijn. Immers, de motivering kon alleen worden afgedwongen als de wet die eis stelde. Voor zover de wet die eis al zou stellen, zou bij gebrek aan duidelijke criteria onmogelijk de inhoud van die motivering op zijn juistheid kunnen worden gecontroleerd. Een vrij bewijsstelsel zou in de ogen van de tegenstanders leiden tot een vrijbrief voor de rechter om het bewijsmateriaal te waarderen op de wijze die hem goed dunkt. Bovendien werden bezwaren geuit die verband hielden met de rechtsgelijkheid en rechtzekerheid. Teneinde willekeur te voorkomen kozen zij voor een bewijsstelsel waarin de rechter werd gebonden aan wettelijke bewijsregels. Weliswaar konden deze bewijsregels niet in alle gevallen garanderen dat het oordeel van de rechter met de 'werkelijkheid' overeen kwam, maar zij sloten in ieder geval uit dat de rechter enkel en alleen op gevoelsindrukken zou oordelen en bovendien werd een minimum aan betrouwbaarheid gegarandeerd. Aan de hand van de bewijsregels kon in cassatie gecontroleerd worden of de feitenrechter dit minimum in acht had genomen. Daarmee werd in ieder geval voor een deel rechtsgelijkheid en rechtszekerheid ten aanzien van het bewijsoordeel gegarandeerd.

Zoals in hoofdstuk 2 uiteengezet, hebben uiteindelijk de tegenstanders van het vrije bewijsstelsel het pleit gewonnen. In het Wetboek van 1926 werd een negatief-wettelijk bewijsstelsel ingevoerd. Vanaf 1926 zijn ook de in dat Wetboek opgenomen motiveringsverplichtingen ten aanzien van de bewezenverklaring altijd in het licht van dat bewijsstelsel gezien. Dit betekende dat van de rechter slechts werd verlangd dat hij in het vonnis tot uitdrukking bracht dat hij de wettelijke bewijsregels in acht had genomen.

Aan de eis wordt voldaan indien de rechter in zijn vonnis de inhoud van de bewijsmiddelen opneemt. Aan de hand van die inhoud kan worden gecontroleerd of de rechter zijn oordeel baseert op informatie die uit een wettig bewijsmiddel afkomstig is. Als belangrijkste inhoudelijke eis ten anzien van het bewijs geldt dan dat de informatie op zintuiglijke waarneming moet kunnen worden teruggevoerd. Daarmee wordt voorkomen dat conclusies en gissingen van de informant 
in de oordeelsvorming van de rechter doordringen. Bovendien kan aan de hand van de inhoud van de bewijsmiddelen worden beoordeeld of de wettelijke bewijsminima in acht zijn genomen.

Het belang van de formele motiveringsplicht voor de materiële waarheidsvinding is afhankelijk van de inhoud van de wettelijke bewijsregels die zij beoogt te handhaven. In Nederland is de waarde om tweeërlei redenen zeer beperkt. De eerste reden is gelegen in het feit dat het Nederlandse bewijsrecht slechts regels geeft die een minimum aan betrouwbaarheid garanderen. De tweede reden is dat de Hoge Raad deze minimumregels bovendien met een zekere soepelheid interpreteert. Ten aanzien van de eis dat verklaringen alleen betrekking mogen hebben op waarneming en ondervindingen door de verklarende persoon zelf gedaan of ondervonden, is de Hoge Raad weinig kritisch. Voor zover de verklarende persoon ook zaken aanhaalt die als een conclusie of gissing kunnen worden aangemerkt, worden deze als waarneming van een indruk of gevoelen van deze persoon geïnterpreteerd. Ook de in de wet geformuleerde bewijsminima hebben een zeer betrekkelijke waarde. Zij zien immers op de gehele tenlastelegging en niet op elk of bepaalde onderdelen daarvan. De meest vergaande beperking op het wettelijke bewijsrecht komt voort uit het de-auditu-arrest. Waar in artikel $342 \mathrm{~Sv}$ wordt geëist dat de getuige alleen ter zitting mag verklaren, heeft de Hoge Raad reeds in 1926 bepaald dat dit niet betekent dat een getuige niet mag verklaren wat hij van een ander heeft gehoord. Dit laatste geldt ook ten aanzien van de schriftelijke verklaring van de opsporingsambtenaar. Ook hij mag in zijn procesverbaal weergeven wat hij van andere getuigen heeft vernomen. Deze rechtspraak heeft vervolgens de weg geopend voor het gebruik van verklaringen van anonieme personen, ten aanzien waarvan de betrouwbaarheid door de zittingsrechter in zijn geheel niet zelfstandig gecontroleerd kan worden.

De lijst met voorbeelden waarin het bewijsrecht aan waarde heeft ingeboet, kan nog worden uitgebreid, maar vooralsnog volstaat de conclusie dat motivering van de bewezenverklaring op dit punt nauwelijks nog enige waarde heeft voor de materiële waarheidsvinding. Deze conclusie wordt nog versterkt door het feit dat in tal van gevallen de wet niet langer eist dat de rechter de inhoud van de bewijsmiddelen in het vonnis opneemt. In dergelijke gevallen blijft dus überhaupt onduidelijk of aan het wettelijke minimum is voldaan.

\subsubsection{De formele motiveringsplicht in Duitsland}

In tegenstelling tot het Nederlandse bewijsrecht kent het Duitse bewijsrecht geen voorschriften met betrekking tot de bewijswaardering, die de rechter binden. In zijn vonnis hoeft hij dus ook niet te verantwoorden of hij dergelijke voorschriften heeft nageleefd. 
Zoals echter in hoofdstuk 7 naar voren is gekomen, is de Duitse strafrechter wel gebonden aan wettelijke bepalingen ten aanzien van de presentatie van het bewijs. Hij mag evenals de Nederlandse strafrechter alleen bewijs bezigen dat ter zitting is gepresenteerd. Echter bepaald bewijsmateriaal mag überhaupt niet ter zitting worden geïntroduceerd. In het Strengbeweisverfahren geldt de eis dat het bewijsmateriaal slechts in de vorm van een bewijsmiddel mag worden gepresenteerd. Bewijsmateriaal bestaande uit verklaringen van personen die aan het papier zijn toevertrouwd, mag slechts in uitzonderlijke gevallen worden gebruikt.

Wordt in weerwil van deze bepalingen toch bewijsmateriaal ten grondslag gelegd aan het bewijsoordeel, dan leidt dit tot vernietiging van het vonnis. Er is dus in Duitsland een dogmatische scheiding tussen hetgeen ter zitting mag worden gepresenteerd en hetgeen in de bewijswaardering mag worden betrokken. Wat niet mag worden gepresenteerd, mag niet in de bewijswaardering worden betrokken. Daarentegen moet alles wat wel ter zitting is gepresenteerd en dat relevant is voor het bewijsoordeel door de rechter in zijn uiteindelijke afweging van het bewijsmateriaal worden betrokken.

Het aan deze scheiding ten grondslag liggende principe is dat van een contradictoire behandeling ter zitting. Daar moet het bewijsmateriaal op een zodanige wijze worden gepresenteerd dat het zo goed als mogelijk op zijn waarde kan worden getoetst. Dat betekent dat niet alleen de rechter zoveel mogelijk de originele bron moet kunnen aanschouwen en ondervragen, maar dat geldt ook voor de verdediging. Het Bundesgerichtshof is echter voor een deel teruggekomen op deze dogmatische scheiding. Steeds vaker neemt het aan dat het niet in acht nemen van regels met betrekking tot de bewijsvoering niet hoeft te leiden tot bewijsuitsluiting. Het gebruik van een verklaring van de getuige afgelegd in het vooronderzoek zonder dat de raadsman van verdachte daarbij aanwezig was, leidt bijvoorbeeld niet automatisch tot uitsluiting van die verklaring. Compensatie voor het gebrek aan tegenspraak ter zitting moet dan volgens het Bundesgerichtshof worden gevonden in een uitgebreidere motivering van de rechter aangaande de waarde van het aldus 'gebrekkige' bewijsmateriaal. ${ }^{66}$ Ook bij verklaringen van anonieme personen ${ }^{67}$

66 BGH 25 juli 2000, 1 StR 169/00: 'Der Senat hält eine Beweiswürdigungs-Lösung für sachgerechter als ein Verwertungsverbot für den Rückgriff auf den Vernehmungsrichter. Bei der Beweiswürdigungs-Lösung darf zwar auf den Vernehmungsrichter zurückgegriffen werden, allerdings sind dann - ähnlich wie beim anonymen Zeuge - besonders strenge Beweis- und Begründungsanforderungen aufzustellen'.

67 BGH 20 juni 1994, BGHR StPO § 261 Zeuge 17: 'Nach ständiger Rechtsprechung des Bundesgerichtshofs ist bei der Beurteilung der Aussage eines »Zeugen vom Hörensagen « besondere Vorsicht geboten. Handelt es sich bei den von ihm bezeugten Angaben um diejenigen eines anonymen Gewährsmannes, so darf darauf eine Feststellung regelmäßig nur dann gestützt werden, wenn diese Angaben durch andere wichtige Beweisanzeichen bestätigt worden sind.' In gelijke zin: BGH 1 augustus 1962 BGHSt 17, 382; BGH 5 december 1984, BGHSt 33, 83; BGH 31 maart 1989, BGHSt 36, 159 en BGH 14 februari 1997, BGHR StPO § 261 Überzeugungsbildung 27. 
en verklaringen van getuigen uit het buitenland ${ }^{68}$ kiest het Bundesgerichtshof niet voor bewijsuitsluiting, maar geldt een uitgebreide motiveringsplicht.

\subsubsection{Materiële motiveringsplicht in Nederland}

Waar de formele motiveringsplicht in Nederland dus kennelijk geen of weinig toegevoegde waarde heeft voor de waarheidsvinding is dit wellicht anders ten aanzien van die gevallen waarin van de rechter ook buiten de bewijsregels om wordt geëist dat hij zijn oordeel motiveert. Het Nederlandse strafprocesrecht kent een drietal vormen van een dergelijke motiveringsplicht. Twee daarvan creëren een ambtshalve plicht tot motivering.

De eerste betreft de redengevendheid van het bewijs. Zoals in hoofdstuk 5 is gebleken, valt deze eis in principe samen met de hierboven genoemde formele motiveringseis. De in het vonnis opgenomen bewijsmiddelen mogen slechts redengevende feiten en omstandigheden bevatten. De rechter hoeft echter in het vonnis niet uit te wijden over de vraag waarom hij de feiten redengevend acht. Slechts in het geval dat uit de gebezigde bewijsmiddelen feiten en omstandigheden blijken die van wezenlijke betekenis zijn en pertinent niet redengevend kunnen zijn, leidt dit in cassatie tot vernietiging van het vonnis.

Een tweede materiële motiveringsplicht volgt uit artikel 360 lid $1 \mathrm{~Sv}$. Ten aanzien van de daar genoemde bewijsmiddelen dient de rechter nadrukkelijk te motiveren waarom hij ze betrouwbaar acht. Het gaat dan om verklaringen van personen, waarvan om uiteenlopende redenen de betrouwbaarheid op het eerste gezicht kan worden betwijfeld. Artikel $360 \mathrm{~Sv}$ eist van de rechter dat hij zelfstandig de betrouwbaarheid van die verklaringen onderzoekt en in het vonnis tot uitdrukking brengt op welke gronden hij tot een positief oordeel dienaangaande is gekomen. Ten aanzien van kinderen en kroongetuigen is de achtergrond van deze nadere motiveringsplicht dat zij mogelijk zelf als bron van waarneming niet geloofwaardig zijn. Kinderen omdat zij mogelijk niet in staat zijn om op goede wijze waar te nemen, moeite hebben met het overbrengen van hun waarneming of in belangrijke mate beïnvloedbaar zijn door anderen. De geloofwaardigheid van kroongetuigen is op het eerste gezicht dubieus omdat zij belang hebben bij het afleggen van een voor een ander belastende verklaring. Ten aanzien van (deels) anonieme, en afgeschermde getuigen speelt het probleem dat de betrouwbaarheid van de inhoud van hun verklaring niet (volledig) kan worden getoetst.

De Hoge Raad stelt echter niet al te hoge eisen aan de motivering van de rechter op dit punt. Wel wordt ten aanzien van de anonieme verklaring gesteld dat de rechter de betrouwbaarheid niet alleen op het oordeel van de rechter-commissaris dienaangaande mag baseren. Hij moet dus tot een zelfstandig oordeel komen. De

68 BGH 22 april 1952, BGHSt 2, 300. 
Hoge Raad stelt echter geen materiële eisen aan de toetsing van die betrouwbaarheid. Onduidelijk blijft hoe de rechter de betrouwbaarheid moet toetsen en welke graad van waarschijnlijkheid als uitgangspunt geldt. Deze nadere motiveringsplicht heeft dus wel degelijk tot doel de materiële waarheidsvinding te optimaliseren, maar ziet daarbij vooral op één aspect daarvan, te weten de rechterlijke verantwoordelijkheid voor die waarheidsvinding.

Tot slot wordt een nadere verantwoording van de rechter verwacht indien door de verdediging een bewijsverweer is gevoerd. Deze motiveringsplicht geldt dus niet ambtshalve, en zij vindt haar oorsprong in de jurisprudentie. Sinds 1 januari 2005 is zij ook in het tweede lid van artikel $359 \mathrm{~Sv}$ vastgelegd. De responsieplicht ten aanzien van bewijsverweren zoals die door de Hoge Raad was gecreëerd en de responsieplicht zoals die in artikel 359 lid 2 is neergelegd zijn echter niet gelijk aan elkaar. De jurisprudentiële responsieplicht was in omvang beperkt en bovendien beoogde zij andere doelen. Enerzijds voorzag zij in een leemte in de wet. Op grond van het wettelijke systeem verdiende een bewijsverweer geen bijzondere reactie omdat de weerlegging van het verweer bleek uit de door de rechter in het vonnis opgenomen bewijsmiddelen. Ten aanzien van dakdekkersverweren, Meer en Vaartverweren en onrechtmatig verkregen bewijsverweren gaat die redenering echter niet op. Vandaar dat de Hoge Raad in die gevallen van feitenrechters eiste dat zij uitdrukkelijk op de verweren moesten antwoorden. De noodzaak tot nadere motivering in geval van bepaalde betrouwbaarheidsverweren vloeit voort uit een meer met de waarheidsvinding verbonden doel: de rechter moet laten zien dat hij het door hem gebruikte bewijsmateriaal zelfstandig heeft beoordeeld. Daar waar de indruk zou kunnen ontstaan dat hij voor de bewijswaardering te zeer afhankelijk is van het oordeel van een ander - bijvoorbeeld de rechter-commissaris, de deskundige of een tolk - dient hij die indruk weg te nemen door een nadere motivering van zijn oordeel op dat punt.

De thans in artikel 359 lid $2 \mathrm{~Sv}$ neergelegde responsieplicht wijkt qua strekking af; de plicht tot nadere motivering komt voort uit het streven het onderzoek in strafzaken te beperken tot datgene wat door procespartijen wordt betwist. Zoals ook blijkt uit de woorden van de Minister van Justitie:

'Wat verandert, is dat de rechter zijn beslissing meer motiveert in het licht van wat procespartijen naar voren hebben gebracht en verdeeld houdt. ${ }^{, 69}$

Dat betekent dat in geval niets betwist wordt geen nadere motivering vereist is. En andersom geldt evenzeer: als er wel iets wordt betwist, dan vraagt dit in principe om een reactie als dat standpunt niet wordt gevolgd. Daarmee is de motivering niet meer direct gekoppeld aan de waarheidsvinding, maar komt daarin veeleer het recht op 'rechterlijk gehoor' tot uiting. Procespartijen hebben recht op antwoord op bezwaren die door hen zijn ingebracht. Voor zover die bezwaren betrekking hebben

69 Kamerstukken II 2003-2004, 29255, nr. 5, p. 2. 
op het bewijs kan dat natuurlijk een positief effect hebben op de bewijsbeslissing. Immers, teneinde die bezwaren te kunnen weerleggen zal de rechter argumenten moeten vinden in het onderzoek ter terechtzitting en het daar gepresenteerde bewijsmateriaal. Opvallend is echter dat de Hoge Raad in zijn jurisprudentie met betrekking tot het nieuwe artikel 359 lid 2 Sv reeds heeft aangegeven dat hij de door de rechter gegeven motivering niet inhoudelijk zal toetsen. De toetsing in cassatie is en blijft marginaal; enkel in geval de gegeven motivering nietbegrijpelijk is, volgt cassatie.

Door de motiveringsplicht te koppelen aan het optreden van procespartijen wordt de omvang en kwaliteit van de waarheidsvinding gekoppeld aan de inbreng van procespartijen. De rechterlijke verantwoordelijkheid voor de waarheidsvinding bestaat weliswaar nog wel, maar de rechter hoeft die verantwoordelijkheid pas te laten blijken op het moment dat één van de partijen daarom vraagt.

\subsubsection{Materiële motiveringsplicht in Duitsland}

De Duitse strafvordering kent eigenlijk nauwelijks een formele motiveringsplicht. Het gebrek aan wettelijke bewijswaarderingsregels is daaraan debet. Slechts de regels met betrekking tot de bewijsvoering leiden tot een zekere formele verantwoording, in die zin dat bewijsmateriaal dat niet ter zitting aan de orde is of mocht worden gesteld door de rechter niet in de bewijswaardering mag worden betrokken. Bij de normering van het bewijsoordeel ligt van oudsher de nadruk op het onderzoek ter terechtzitting. Daar wordt het geschikte van het minder geschikte bewijsmateriaal gescheiden. Voor het overige is de rechter vrij in de waardering van het ter zitting gepresenteerde bewijsmateriaal. Dit is als zodanig ook in het Duitse strafprocesrecht verwoord in $\S 261$ StPO. Dat neemt niet weg dat vanaf 1957 in de Duitse jurisprudentie een ontwikkeling is ingezet die in toenemende mate van de strafrechter eist dat hij in zijn vonnis alle relevante feiten en omstandigheden afweegt. Voor zover de rechter feiten in het vonnis noemt, moet uit de motivering blijken op welke wijze hij die in zijn oordeelsvorming heeft betrokken. Daarenboven eist het Bundesgerichtshof ten aanzien van specifieke bewijsconstructies dat de rechter nadrukkelijk op bepaalde omstandigheden ingaat. Laat hij dit achterwege, dan is de bewijswaardering onvolledig en wordt deze in cassatie vernietigd. Daarbij maakt het geen verschil of de rechter die omstandigheden vergeten is te noemen in zijn vonnis of dat hij daar in het geheel geen onderzoek naar heeft gedaan. Een volledige bewijswaardering vereist dat de Duitse strafrechter bepaalde aspecten onder ogen moet hebben gezien en dat uit de motivering moet blijken welke deze zijn en hoe hij die heeft gewaardeerd.

Typerend aan de rechtspraak van het Bundesgerichtshof is de betekenis die aan de waarheidsvinding in strafzaken wordt toegekend. Onderkend wordt dat het niet mogelijk is om in absolute zin zekerheid te verkrijgen, maar dat desalniettemin 
het bewijsoordeel met een hoge mate van waarschijnlijkheid met de werkelijkheid overeen moet stemmen. Dit inhoudelijke criterium bepaalt de eisen die aan de motivering worden gesteld. De rechter moet in zijn vonnis kenbaar maken dat hij alle mogelijke relevante feiten en omstandigheden die zowel voor als tegen zijn subjectieve overtuiging spreken heeft onderzocht en in zijn uiteindelijke oordeelsvorming heeft betrokken. Door de motiveringsplicht op deze wijze in te vullen, wordt aan de subjectieve overtuiging een meer objectieve component toegevoegd. Het bewijsoordeel wordt daarmee voorzien van een feitelijke onderbouwing die maakt dat de persoonlijke overtuiging van de rechter niet als enige grondslag voor het oordeel dient. De rechter zal teneinde die feitelijke onderbouwing te kunnen geven, het onderzoek ter zitting zodanig moeten uitbreiden dat hij beschikt over alle voor het oordeel relevante feiten en omstandigheden. Daarmee wordt enerzijds duidelijk dat de rechter zelf verantwoordelijk is voor de waarheidsvinding in de concrete strafzaak. Anderzijds wordt via de motiveringseisen wederom het belang van het onderzoek ter terechtzitting centraal gesteld. Daar zal ten overstaan van de partijen alle informatie moeten worden vergaard en gepresenteerd. De rechter dient er voor te waken dat hij reeds in die fase beschikt over al het materiaal waarmee hij uiteindelijk zijn oordeel kan onderbouwen. Laat hij dit na, dan kan dit er toe leiden dat de bewijswaardering in hoger beroep of cassatie als onvolledig wordt gekwalificeerd.

Binnen het Duitse strafprocesrecht is dus het onderzoek ter terechtzitting de centrale plaats voor de bewijsnormering. Enerzijds wordt bewijsmateriaal uitgesloten dat niet voldoet aan de eisen die daaraan in de wet worden gesteld. Anderzijds dient daar al het bewijsmateriaal gepresenteerd te worden dat het subjectieve oordeel van de rechter van een meer objectief fundament kan voorzien. Daarbij geldt als criterium 'hoge waarschijnlijkheid'. Dit criterium geldt ten aanzien van zowel de vrijspraak als de bewezenverklaring.

De in de Duitse jurisprudentie gecreëerde motiveringsplicht leidt in de praktijk tot specifieke bewijswaarderingsregels. Waar bijvoorbeeld de verklaring van de getuige tegenover die van de verdachte staat, zal de rechter in zijn vonnis nadrukkelijk op de ontstaansgeschiedenis van beide verklaringen moeten ingaan, mogelijke discrepanties tussen verschillende verklaringen van dezelfde persoon moeten verklaren en in bepaalde gevallen zal hij voor de beoordeling van de betrouwbaarheid van verklaringen de hulp van een deskundige moeten inschakelen. De aan de beoordeling van de betrouwbaarheid ten grondslag liggende wetenschappelijke inzichten moet hij in zijn vonnis verantwoorden.

\subsection{Het hoger beroep}

In de vorige paragrafen is de wijze waarop de waarheidsvinding is genormeerd besproken. Daarbij is de taak van de cassatierechter waar het de handhaving van 
wettelijke bewijs- en motiveringsregels betreft nadrukkelijk aan de orde gekomen. Het belang van hoger beroep, als tweede feitelijke instantie is echter nog buiten beschouwing gebleven. Op dit punt bestaat een duidelijk verschil tussen het Duitse en het Nederlandse recht.

Een van de meest wezenlijke waarborgen in Nederland voor een juist oordeel in strafzaken is de mogelijkheid om tegen het vonnis in eerste aanleg hoger beroep in te stellen. Het belang van het hoger beroep wordt meestal onderstreept door te wijzen op twee mogelijke functies; enerzijds de mogelijkheid van herstel van rechterlijke fouten, anderzijds de mogelijkheid om leemtes in de behandeling in eerste aanleg op te vullen. ${ }^{70}$ In appel wordt de strafzaak opnieuw behandeld. Dat betekent dat in principe het feitenonderzoek opnieuw aanvangt. De verdachte wordt gehoord en getuigen en deskundigen kunnen in hoger beroep andermaal worden gehoord. Bovendien kan het onderzoek in hoger beroep worden uitgebreid met nieuw onderzoek. Niet eerder gepresenteerd schriftelijk bewijs kan worden geïntroduceerd en ook kunnen getuigen en deskundigen worden gehoord die in eerste aanleg nog niet waren gehoord. Niet is vereist dat het onderzoek in eerste aanleg volledig wordt herhaald. De appelrechter mag in zijn oordeelsvorming ook het onderzoek in eerste aanleg en het daar gepresenteerde bewijsmateriaal betrekken, ${ }^{71}$ maar is niet gebonden aan het oordeel van zijn collega in eerste aanleg. De waarde van het hoger beroep is dus dat een tweede rechterlijke instantie op basis van een (deels) eigen onderzoek tot een geheel eigen onafhankelijk oordeel komt. Het moge duidelijk zijn dat de waarheidsvinding in strafzaken is gediend met een dergelijke tweede beoordeling van de feiten. Al was het maar omdat uit een tweede screening van het bewijsmateriaal toch punten naar voren kunnen komen, die in eerste aanleg over het hoofd zijn gezien. Dat geldt overigens niet alleen voor de rechter, maar ook voor het Openbaar Ministerie en de verdediging. Ook zij kunnen bij de nadere bestudering van het dossier en het vonnis in eerste aanleg tot andere inzichten zijn gekomen. Voor de verdediging kan dit overigens ook het gevolg zijn van een wisseling in de persoon (of personen) die de rechtsbijstand verleent. Een onwelgevallige beslissing in eerste aanleg kan voor de verdachte aanleiding zijn om zijn heil te zoeken bij een andere, misschien meer gespecialiseerde, advocaat. Het hoger beroep in Nederland, zoals hierboven beschreven, wordt getypeerd als een middenstelsel; het houdt het midden tussen een geheel nieuwe behandeling en een behandeling waarbij alleen mogelijke fouten in eerste aanleg worden gecorrigeerd. Per 1 maart 2007 is echter het karakter van het hoger beroep in Nederland gewijzigd. ${ }^{72}$ Het middenstelsel is vervangen door een meer 'voortbouwend' hoger beroep. Daarbij wordt het geding in hoger beroep geconcentreerd rond die

70 De Hullu 1989, p. 108.

71 Art. 422 Sv.

72 Wet van 5 oktober 2006 (stroomlijnen hoger beroep), Stb. 2006, 470 (inwerkingtreding 1 maart/1 juli 2007, Stb. 2007, 70). 
kwesties waar expliciet tegen wordt geopponeerd. Waar geen verschil van mening over bestaat, kan buiten beschouwing blijven. ${ }^{73}$ Van partijen wordt verwacht dat zij hun grieven tegen het vonnis in eerste aanleg uiterlijk bij aanvang van het onderzoek ter zitting kenbaar maken. ${ }^{74}$ Laten zij dat achterwege, dan zal de behandeling in hoger beroep beperkt blijven tot hetgeen de rechter ambtshalve noodzakelijk acht. Artikel 416 lid 2 Sv luidt thans:

'Het gerechtshof richt het onderzoek ter terechtzitting op de bezwaren die door de verdachte en het openbaar ministerie worden ingebracht tegen het vonnis, in eerste aanleg gewezen, en op hetgeen overigens nodig is.'

Het toespitsen van het hoger beroep op punten die partijen verdeeld houden, leidt er toe dat het onderzoek in hoger beroep wordt beperkt. Weliswaar kan de rechter ambtshalve het onderzoek uitbreiden, maar evenals in eerste aanleg is hij daartoe niet verplicht. Het feit dat de verdediging reeds in een vroeg stadium moet aangeven welke punten zij onderwerp van debat wil laten zijn bij de behandeling in hoger beroep, kan ertoe leiden dat de rechter onwillig wordt om in een latere fase het onderzoek nog uit te breiden. In ieder geval zal dit ertoe leiden dat de rechter zwaardere eisen zal stellen aan dergelijke verzoeken. Thans geldt dit al voor het oproepen van getuigen. Worden deze niet ruim voor de behandeling in hoger beroep opgegeven, dan zal een verzoek nadien alleen moeten worden toegewezen indien de rechter dit noodzakelijk acht. ${ }^{75}$ Evenals ten aanzien van de motiveringsplicht ligt ook aan de wijziging van het stelsel van rechtsmiddelen de gedachte ten grondslag dat in toenemende mate de omvang en kwaliteit van het onderzoek ter terechtzitting afhankelijk wordt gemaakt van de inbreng van procespartijen. 'Piepen' zij niet, dan kan de rechter zonder nadere verantwoording het onderzoek in strafzaken beperken tot datgene wat hij noodzakelijk acht.

Weliswaar is met de per 1 maart 2007 ingegane wijziging van het hoger beroep een behoorlijke beperking doorgevoerd met betrekking tot de omvang van het onderzoek in hoger beroep, dat neemt niet weg dat voor het merendeel van de strafzaken nog wel een tweede feitelijke behandeling openstaat. Alleen voor de lichtste feiten geldt dat geen beroep openstaat of dat er ingevolgde het nieuwe artikel 410a Sv eerst verlof moet worden gevraagd.

In Duitsland is dat echter niet het geval. Daar kent men - vreemd genoeg ${ }^{76}-$ alleen in de minder zware zaken de mogelijkheid van appel en staat nu juist in de zwaarste zaken geen hoger beroep open. Uitsluiting van het recht op hoger beroep in deze zaken is terug te leiden tot de gedachte dat deze zaken één keer zeer uitgebreid - met in achtneming van de beginselen van onmiddellijkheid en oraliteit - worden

73 Kamerstukken II 2005-2006, 30320, nr. 3. p. 8

74 Art. 410 lid 1 en $416 \mathrm{~Sv}$.

75 Art. 418 lid 3 Sv.

76 In gelijke zin: Kühne 2003, p. 532. 
behandeld. ${ }^{77}$ Herhaling van dit onderzoek in hoger beroep zou tot een onacceptabele vertraging van de berechting leiden en de bestrijding van de criminaliteit, zeker in grote zaken, zou dan in gevaar komen. Ook het nut van het hoger beroep wordt in twijfel getrokken. Door het tijdsverloop wordt het ophelderen van de strafzaak steeds moeilijker. Bovendien bestaat het gevaar dat de rechter in eerste aanleg, wetende dat zijn oordeel in hoger beroep kan worden gecorrigeerd, zijn verantwoordelijkheid minder serieus zal nemen en het onderzoek in eerste aanleg oppervlakkig zal verrichten. ${ }^{78}$

Het onevenwichtige systeem van rechtsmiddelen ondervindt in Duitsland veel kritiek. Voorstellen om tot een meer gewogen systeem te komen, zijn echter gestrand. Onenigheid bestond over de vraag of het rechtsmiddel van hoger beroep moest worden uitgebreid tot de zware zaken, of dat het rechtsmiddel in zijn geheel, dus ook in de minder zware zaken, moest worden afgeschaft. In deze discussie speelt het belang van het onderzoek ter terechtzitting een wezenlijke rol. Handhaven van de volledigheid van dit onderzoek in hoger beroep, dus met behoud van het onmiddellijkheidsbeginsel en het beginsel van mondelinge procesvoering, staat op gespannen voet met het belang van een tijdige en efficiënte berechting. Voorstanders van het uitbreiden van het hoger beroep in zware zaken menen dat concessies moeten worden gedaan op dit punt. Tegenstanders houden vast aan een volledig onderzoek. Inmiddels is echter de noodzaak van aanpassing van het wettelijke systeem deels weggenomen door de uitgebreide feitelijke toetsing door het Bundesgerichtshof in cassatie. Zonder wettelijke grondslag heeft het Bundesgerichtshof het noodzakelijk geacht meer grip te krijgen op het feitenoordeel in strafzaken teneinde gerechtelijke dwalingen te voorkomen. ${ }^{79}$ Deze zogeheten erweiterte Revision leidt ertoe dat ook in cassatie het feitenoordeel van de lagere rechter vergaand kan worden getoetst. Komt men in cassatie tot de conclusie dat het feitenoordeel onvoldoende of met niet steekhoudende feiten en argumenten is gemotiveerd, dan vindt terugverwijzing plaats en heeft alsnog een tweede feitelijke behandeling van de strafzaak plaats. Daarmee kan ook in individuele gevallen de 'juistheid' van het oordeel worden gegarandeerd.

\subsection{Conclusie}

Waarheidsvinding in strafzaken is een precaire aangelegenheid. Er wordt gestreefd naar een oordeel dat zo veel als mogelijk overeenstemt met de werkelijkheid. Echter zekerheid daarover zal nooit bestaan. In principe is de rechter verantwoordelijk voor de waarheidsvinding, maar deels is hij afhankelijk van anderen. Zo vindt

Fezer 1975, p. 292-293.

Kühne 2003, p. 533.

Fezer 1999, p. 333-334. 
het merendeel van het onderzoek in strafzaken plaats voorafgaand aan de zitting. Bovendien wordt het onderzoek steeds vaker verricht door deskundigen.

Het gebrek aan absolute zekerheid gecombineerd met de afhankelijke positie van de rechter maakt het noodzakelijk de vaststelling van de feiten in strafzaken op zodanige wijze te normeren dat de kans op fouten zo gering mogelijk is. De meest voor de hand liggende wijze van normering is door middel van het bewijsrecht. In het bewijsrecht worden regels gesteld ten aanzien van de bewijsvoering ter zitting en de bewijswaardering. Hoewel zowel in Duitsland als in Nederland wordt gestreefd naar materiële waarheidsvinding onder verantwoordelijkheid van de strafrechter, is uit het bovenstaande gebleken dat het bewijsrecht in beide landen op essentiële punten verschilt.

In het Duitse recht ligt de nadruk op de normering van het onderzoek ter terechtzitting. Door eisen te stellen aan de kwaliteit van het bewijs dat daar gepresenteerd mag worden, voorkomt men dat de rechter inferieure vormen van bewijs bezigt. Het meest nadrukkelijk komt dit tot uiting in de wijze waarop het onmiddellijkheidsbeginsel in Duitsland wordt gehanteerd. Teneinde de rechter en met hem de procespartijen, in staat te stellen het bewijsmateriaal te toetsen, worden in principe schriftelijke verklaringen uitgesloten van het bewijs. Bovendien worden in Duitsland hoge eisen gesteld aan de onderzoekstaak van de zittingsrechter. Hij dient alles wat mogelijk de uitkomst van de strafzaak zou kunnen beïnvloeden te onderzoeken. Dat betekent ook dat hij waar mogelijk de meest directe bron waaruit het bewijsmateriaal voortvloeit moet raadplegen. Het niet naleven van deze onderzoeksplicht kan in cassatie worden getoetst. Het Duitse strafprocesrecht kent geen regels die de rechter voorschrijven op welke wijze hij het bewijsmateriaal moet waarderen.

Het Nederlandse bewijsrecht daarentegen normeert niet zozeer het onderzoek ter terechtzitting, maar de uiteindelijke beslissing van de rechter. Door een stelsel van bewijsregels wordt het de rechter ontzegd bepaalde vormen van bewijs te gebruiken. Voor zover uit die regels ook volgt dat de presentatie van het bewijs ter zitting dient te geschieden, zijn die in de jurisprudentie grotendeels uitgehold. Voldoende is dat het bewijsmateriaal de verdachte wordt voorgehouden. Niet noodzakelijk is dat de meest directe bron ter zitting wordt gepresenteerd. De Nederlandse bewijsregels schrijven de rechter voor dat hij slechts bepaalde bronnen mag hanteren en bovendien wordt de waarde van bepaalde bewijsmiddelen beperkt. Dit laatste komt vooral tot uitdrukking in de bewijsminima. De waarde van deze bewijsregels in de Nederlandse strafpraktijk is echter zeer gering. Enerzijds omdat zij gezien hun algemene geldigheid slechts minimumeisen stellen aan het bewijsmateriaal. Anderzijds omdat de Hoge Raad deze minimumeisen ook nog zeer beperkt heeft uitgelegd. Hoewel in Nederland de rechter in formele zin verantwoordelijk is voor de waarheidsvinding in strafzaken, bestaat er geen ambtshalve plicht van de rechter om het onderzoek ter terechtzitting uit te breiden. 
Hij is daartoe bevoegd en in bepaalde gevallen kan hij verzoeken van de verdediging daartoe niet afwijzen, maar het oordeel over de genoegzaamheid van het onderzoek is aan hemzelf voorbehouden.

Het verschil in accent van het bewijsrecht werkt ook door in de motiveringsplicht van de strafrechter. In Duitsland is het gebrek aan wettelijke bewijswaarderingsregels en hoger beroep in de zware zaken gecompenseerd door in de jurisprudentie vergaande inhoudelijke eisen te stellen aan de motivering van het bewijsoordeel. In het vonnis moet de rechter kenbaar maken dat hij alle voor het bewijsoordeel relevante feiten en omstandigheden heeft afgewogen. Voor zover hij bepaalde feiten en omstandigheden niet heeft onderzocht en dus ook niet kan hebben afgewogen, kan deze leemte in het vonnis in cassatie aan de orde worden gesteld. De hoge eisen die het Bundesgerichtshof stelt aan de bewijsmotivering hebben tot gevolg dat de feitenrechter wordt gedwongen zijn onderzoek ter terechtzitting uit te breiden tot alle mogelijk voor en tegen de verdachte sprekende feiten en omstandigheden. Slechts dat stelt hem in staat een vonnis te wijzen dat voldoet aan de eisen die het Bundesgerichtshof stelt bij bepaalde bewijsconstructies, zoals die van Aussage gegen Aussage.

In Nederland daarentegen staat de bewijsmotivering in het teken van het wettelijke bewijsrecht. In het vonnis hoeft de rechter slechts kenbaar te maken dat hij de wettelijke bewijsregels in acht heeft genomen. Het opnemen van de inhoud van de bewijsmiddelen is in dat geval voldoende. Tot een nadere verantwoording van zijn oordeel is de rechter niet gehouden. Daar waar het materiële bewijsrecht aan waarde heeft ingeboet en bovendien de eis dat het vonnis de inhoud van de bewijsmiddelen moet bevatten in veel gevallen niet meer wordt gesteld, heeft deze formele motiveringsverplichting eigenlijk geen betekenis meer.

Ook de overige meer materiële motiveringseisen dragen nauwelijks bij aan de normering van het bewijsoordeel. Dat geldt zeker ten aanzien van de eis dat de rechter de redengevende feiten en omstandigheden in de bewijsmiddelen moet aanwijzen. Deze eis viel in de praktijk samen met de eis dat de inhoud van de bewijsmiddelen in het vonnis moest worden weergegeven. Per 1 januari 2005 is deze situatie ook zo in de wet vastgelegd. De nadere motiveringsplicht zoals opgenomen in artikel 360 lid $1 \mathrm{~Sv}$ is ook beperkt. Bij gebrek aan een inhoudelijk toetsingscriterium is volstrekt onduidelijk welke eisen worden gesteld aan de motivering van de betrouwbaarheid van de in dat artikel genoemde verklaringen. De Hoge Raad weigert ook op dat punt een inhoudelijke controle uit te voeren. Alleen ten aanzien van de verklaringen van bedreigde getuigen heeft de Hoge Raad één randvoorwaarde gesteld, inhoudende dat de toetsing van de betrouwbaarheid niet enkel gebaseerd mag zijn op het oordeel van de rechter-commissaris dienaangaande. Daarmee wordt wel de eigen verantwoordelijkheid van de straf- 
rechter voor de waarheidsvinding benadrukt, maar blijft onduidelijk welke criteria gehanteerd moeten worden om tot een meer rationele waardering te komen.

De in de jurisprudentie ontwikkelde en thans in artikel 359 lid $2 \mathrm{~Sv}$ vastgelegde responsieplicht daarentegen biedt mogelijkheden om ook in Nederland tot een meer inhoudelijke motivering van het bewijsoordeel te geraken. Een motivering naar aanleiding van verweren heeft echter voor de materiële waarheidsvinding een aantal nadelen. Allereerst ligt het initiatief daartoe bij de verdediging. De kwaliteit van het verweer is afhankelijk van het niveau en mogelijkheden - zowel qua tijd en financiën als qua onderzoeksbevoegdheden - van deze procespartij. Ten tweede zou bij afwezigheid van een verweer bij de rechter de indruk kunnen ontstaan dat er geen noodzaak is om het bewijs nadrukkelijk ter zitting te onderzoeken en nog minder om ambtshalve zijn beslissing nader te motiveren dan ingevolge de wet en jurisprudentie strikt noodzakelijk is. Indien deze ontwikkeling in de jurisprudentie verder wordt gevolgd, komt daarmee een einde aan het aan ons strafprocesrecht ten grondslag liggende principe dat de rechter verantwoordelijk is voor de materiële waarheidsvinding. Gelijk als in civiele zaken wordt de verantwoordelijkheid voor de omvang en kwaliteit van het onderzoek en de noodzaak tot motivering van het bewijsoordeel in toenemende mate bepaald door partijen. ${ }^{80}$ De rechter behoudt weliswaar de mogelijkheid om zelfstandig dat onderzoek uit te breiden en om ambtshalve zijn oordeel te motiveren, maar wordt daartoe niet verplicht. Deze ontwikkeling is ook bij de behandeling in hoger beroep zichtbaar. Het onderzoek in hoger beroep is in principe beperkt tot hetgeen partijen tijdig als discussiepunten hebben aangedragen.

Het meest problematische bezwaar tegen de in artikel 359 lid 3 en artikel 360 lid 1 en $2 \mathrm{~Sv}$ opgenomen motiveringsvoorschriften is dat de toetsing ervan op een zeer marginale manier geschiedt. In tegenstelling tot het Bundesgerichtshof toetst de Hoge Raad de door rechters gegeven motiveringen niet op hun volledigheid. De Hoge Raad eist niet van feitenrechters, zoals het Bundesgerichtshof dat wel doet, dat zij de algemene ervaringsregels en wetenschappelijke uitgangspunten expliciteren die aan hun bewijsoverwegingen ten grondslag liggen. Bij gebrek aan dergelijke uitwijdingen kan in cassatie het oordeel slechts beperkt worden getoetst.

80 In gelijke zin: Nijboer 2000c, p. 101. Nijboer merkt ten aanzien hiervan op dat deze verschuiving niet bezwaarlijk is als de rechter zich maar bewust blijft van het feit dat hij zelf verantwoordelijk is voor de compleetheid en deugdelijkheid van het onderzoek. In gelijke zin: Prakken 2003, p. 835; 'In een systeem als het onze, waarin de rechter verantwoordelijkheid draagt voor het eindresultaat past een ambtshalve controle op het proces en niet een geïnstitutionaliseerd vertrouwen van de rechter in de juistheid van een bekentenis van de verdachte, of de weloverwogenheid van diens afstand, en ook niet in de zorgvuldigheid van de doorzoekende politie.' 



\section{$9 \quad$ Het belang van de motivering}

\section{$9.1 \quad$ Inleiding}

Het belang van de motivering van het rechterlijk oordeel wordt veelal in verband gebracht met de noodzakelijke legitimering van dat oordeel. Slechts door van de rechter te verlangen de gronden waarop zijn oordeel rust te expliciteren, komt aan dat oordeel gezag toe. Motivering is echter niet de enige factor die bijdraagt aan de legitimering van het rechterlijk oordeel. Daarnaast kan gewezen worden op de institutionele eisen die worden gesteld aan de rechterlijke macht, de wijze waarop de procedure in strafzaken is vormgegeven en de binding van de rechter aan het recht. Al deze factoren bieden ieder voor zich waarborgen voor een optimale waarheidsvinding en een eerlijk proces. De motivering is echter, zoals in dit hoofdstuk zal worden betoogd, de meest bepalende, aangezien bij gebrek aan motivering ook de overige factoren verworden tot holle frasen, die als zodanig onvoldoende gezag aan rechterlijke uitspraken kunnen verlenen. Juist uit de motivering moet blijken dat de overige legitimerende factoren tot hun recht zijn gekomen. De inhoudelijk aan de motivering te stellen eisen worden dus mede bepaald door de eisen die worden gesteld aan de legitimiteit van dat oordeel. Alvorens op die eisen in te gaan, zal allereerst op de noodzaak tot legitimering van het rechterlijk oordeel worden ingegaan en de wijze waarop daaraan tegemoet kan worden gekomen.

\subsection{De legitimering van het rechterlijk oordeel}

Het oordeel van de rechter mag niet slechts een machtswoord zijn, maar moet zodanig zijn ingebed dat dat oordeel voor de betrokkenen en voor het publiek aanvaardbaar is. Aanvaarding van het rechterlijk oordeel is noodzakelijk voor het vertrouwen in de rechtspraak. Het vertrouwen in de rechtspraak is op zijn beurt een voorwaarde voor het vertrouwen in de strafrechtspleging als geheel. De uitspraak van de rechter is immers het sluitstuk van de strafrechtelijke procedure die tot doel heeft een einde te maken aan het bestaande conflict. Een conflict waarbij de inzet van het strafrecht ten nadele van een burger aan de orde is. Het is aan de rechter om te beoordelen of het materiële strafrecht moet worden toegepast, of met andere woorden sanctionerend door de overheid moet worden opgetreden. Bij die beoordeling staat niet alleen de gedraging van de verdachte ter discussie, maar ook het optreden van de overheid. De overheid heeft immers als enige de mogelijkheid om een strafrechtelijke vervolging te starten naar 
aanleiding van een door haar geëntameerd strafrechtelijk onderzoek. Daarbij is zij niet geheel vrij; de strafrechtelijke autoriteiten zijn in hun onderzoeks- en vervolgingsmogelijkheden beperkt door de wet, verdragen en de beginselen van een behoorlijke strafrechtspleging, teneinde te verzekeren dat het gebruik van het aan de overheid toekomende geweldsmonopolie de grenzen van het toelaatbare niet overschrijdt. Het strafprocesrecht kan, aldus Corstens, worden beschouwd als het geheel van regels dat bij de verwezenlijking van het materiële strafrecht in acht moet worden genomen opdat het overheidsoptreden als redelijk, fatsoenlijk en beschaafd kan worden aangemerkt. ${ }^{1}$ Het is vervolgens aan de rechter om in een aan hem voorgelegde strafzaak niet alleen te beoordelen of het door de overheid aan de verdachte gemaakte verwijt terecht is, maar ook of de overheid in haar streven naar handhaving van het strafrecht niet te ver is doorgeschoten. In het oordeel van de rechter komt aldus de aan de strafrechtspleging inherente spanning tussen enerzijds het algemene belang van handhaving van de rechtsorde en anderzijds rechtsbescherming van het individu tot uitdrukking. Spreekt de rechter vrij of komt hij op andere gronden niet toe aan het opleggen van een sanctie, dan kan dat - zeker in de ogen van het slachtoffer - een teken zijn dat de overheid niet slaagt in zijn taak om het strafrecht te handhaven. ${ }^{2}$ Wordt echter een verdachte veroordeeld waarvan achteraf komt vast te staan dat die veroordeling ten onrechte is geweest, dan roept dit vragen op met betrekking tot de rechtsbeschermende kant. Is het strafprocesrecht voldoende uitgerust om dergelijke rechterlijke dwalingen te voorkomen?

Het is dan ook niet verwonderlijk dat aan het oordeel van de rechter hoge eisen worden gesteld. De persoon van de rechter en de wijze waarop zijn oordeel totstandkomt moeten ons verzekeren van een juiste toepassing van het materiële strafrecht. Die juiste toepassing houdt enerzijds in dat de waarheidsvinding in strafzaken op een eerlijke en deugdelijke manier plaatsvindt. Anderzijds moet daaruit ook blijken dat het de overheid menens is met de handhaving van de normen die zo belangrijk worden gevonden dat ze hun weg naar het strafrecht hebben gevonden. ${ }^{3}$

Het gezag van een rechterlijke uitspraak bestaat niet alleen bij gratie van het feit dat die is gegeven door een daartoe aangewezen autoriteit. ${ }^{4}$ Er moet meer zijn dan enkel vertrouwen in die autoriteit, dat maakt dat die uitspraak door direct betrokkenen, maar ook door het publiek wordt aanvaard. Het vertrouwen moet met andere woorden een deugdelijke grondslag hebben. Slechts in dat geval kan worden gezegd dat het oordeel van de rechter is gelegitimeerd in die zin dat het

Corstens 2005a, p. 9.

Zie hierover uitgebreid De Roos 2000.

Beijer, Brants, Van Lent \& Pelser 2002, p. 3.

Knigge in zijn conclusie onder HR 11 april 2006, NJ 2007, 393 m.nt. Y. Buruma. 
zowel recht doet aan de rechtsbeschermende kant als aan de instrumentele kant van het strafrecht. ${ }^{5}$

\subsubsection{Legitimering van het bewijsoordeel}

De noodzaak om het vertrouwen in de rechtspraak ook in formele zin kracht bij te zetten, geldt in versterkte mate voor het feitenoordeel in strafzaken. Geen enkele uitspraak, maar zeker niet die waarin de inzet van het geweldsmonopolie van de staat aan de orde is, kan immers op begrip rekenen indien niet met een grote mate van zekerheid kan worden gegarandeerd dat de daaraan ten grondslag liggende feiten 'waar' zijn. Waarheidsvinding is in die zin een conditio sine qua non voor een legitieme bestraffing. ${ }^{6}$ Maar ook vrijspraken moeten gelegitimeerd worden. Het niet sanctionerend optreden van de overheid als gevolg van een ondeugdelijke feitelijke grondslag moet evenzeer geaccepteerd kunnen worden. In dat geval staat niet zozeer acceptatie door de verdachte burger centraal, maar dient het vertrouwen van het publiek in een deugdelijke rechtshandhaving gewaarborgd te worden. Blijkt dat de vrijspraak het gevolg is van onvolledig, ondeugdelijk of onbehoorlijk onderzoek van de zijde van justitie, dan zal dit een reactie van het publiek oproepen. Dat mag immers verwachten dat de overheid de taak van waarheidsvinding, die exclusief aan haar is opgedragen, naar behoren uitoefent. Anderzijds moet diezelfde overheid ook kunnen garanderen dat onschuldige burgers worden gevrijwaard van strafvervolging en straf. Deze hybride positie van de overheid heeft tot gevolg dat hoge eisen moeten worden gesteld aan het proces van waarheidsvinding in strafzaken. Complicerende factor daarbij is dat nooit met absolute zekerheid de juistheid van het feitenoordeel kan worden vastgesteld. Er is immers geen algemeen geldend criterium waaraan de juistheid van het feitenoordeel kan worden getoetst. Dat geldt zowel voor een bevrijdend als een belastend feitenoordeel. Het probleem dat aldus ontstaat, is welke eisen aan dat oordeel moeten worden gesteld opdat zowel de rechtshandhavende functie als de rechtsbeschermende functie tot hun recht komen. Stelt men te hoge eisen aan het bewijs in strafzaken, dan bestaat de kans dat schuldigen hun straf ontlopen. Stelt men minder hoge eisen, dan loopt men het risico dat onschuldigen niet alleen onterecht onderwerp van strafrechtelijk onderzoek worden, maar bovendien na het doorlopen van het volledige onderzoek veroordeeld worden. Het is dit dilemma dat aan het eind van de $19^{\mathrm{e}}$ eeuw en het begin van de $20^{\mathrm{e}}$ eeuw onderwerp van debat was, toen de vraag werd gesteld welk bewijsstelsel ten grondslag moest worden

Foqué \& 't Hart 1990.

Brants, Mevis en Prakken 2001, p. 4. In gelijke zin: Nijboer \& Jarigsma 2006, p. 24: 'er kan slechts op een juiste manier recht worden gesproken wanneer de onderliggende vaststellingen (zo) juist (mogelijk) zijn.' 
gelegd aan het Wetboek van Strafvordering, en dat treffend is verwoord door Pols:

'Maar men kan toegeven dat, naarmate men een hoogeren graad van zekerheid vordert voor veroordeeling, het aantal schuldigen dat daaraan ontsnapt grooter zal zijn. Dat is zeker een nadeel, maar dat verre wordt overwogen door de meerdere zekerheid, dat geen onschuldigen zullen worden veroordeeld. (...) Op dat punt ben ik van de oude leer dat het beter is dat tien schuldigen worden vrijgesproken, dan één onschuldige wordt veroordeeld. ${ }^{7}$

De keuze van de wetgever voor de handhaving van het negatief-wettelijk bewijsstelsel in het Wetboek van Strafvordering van 1926 kan ook op deze door Pols als 'oude leer' aangeduide gedachte worden teruggevoerd. Het dilemma tussen rechtsbescherming en rechtshandhaving werd dus in het voordeel van het eerste beslist, en dat komt onder andere tot uitdrukking in het beginsel 'in dubio pro reo'. De vraag is echter of het stellen van wettelijke beperkingen aan het bewijsoordeel dat oordeel in voldoende mate legitimeert. Temeer daar de in het Wetboek van Strafvordering opgenomen bewijsregels veel van hun waarde hebben verloren en in veel gevallen het bewijsoordeel in materiële zin slechts valt terug te voeren op de rechterlijke overtuiging. Dat dit een onvoldoende grondslag is voor legitimering van het feitenoordeel is evident. Het komt er immers op neer dat wij vertrouwen in het bewijsoordeel van de rechter moeten hebben omdat hij - de rechter overtuigd is van de juistheid ervan. Het accepteren van de rechterlijke overtuiging als enige maatstaf voor de juistheid van het feitenoordeel in strafzaken staat gelijk aan het geven van een vrijbrief aan de rechter om te oordelen zoals hem goeddunkt. Dat kan nimmer een voldoende grond voor vertrouwen opleveren. Dit laat onverlet dat de overtuiging als maatstaf voor het feitenoordeel niet kan worden gemist. Bij gebrek aan eenduidig criterium dat absolute zekerheid verschaft over de juistheid van de vastgestelde feiten en de noodzaak om tot een (tijdige) beslissing te komen, zal uiteindelijk het subjectieve oordeel van de rechter - zijn overtuiging - de doorslag moeten geven. De rechterlijke overtuiging is in die zin een noodzakelijke, maar niet voldoende voorwaarde voor de juistheid van het feitenoordeel. ${ }^{8} \mathrm{Er}$ is meer vereist wil dat oordeel als legitiem kunnen worden aangemerkt.

7 Pols, p. 361-362.

8 In gelijke zin: A.M. van Woensel, aant. 7 op art. 338-344 (suppl. 91 oktober 1994), in Melai/Groenhuijsen e.a.: 'uiteindelijk (vormt) de overtuiging van de rechter de normatieve brug (...) tussen datgene wat met - grote - waarschijnlijkheid is vast te stellen en datgene wat als 'waarheid' wordt aangenomen.' 


\subsection{Vormen van legitimering}

Aan de noodzaak van legitimering van het rechterlijk (feiten)oordeel kan op verschillende wijzen worden tegemoet gekomen. ${ }^{9}$ Ten eerste kunnen eisen worden gesteld aan de persoon of instantie die het oordeel uitspreekt, opdat het vertrouwen in die persoon en instantie ook in meer objectieve zin gestalte krijgt. Ten tweede is de binding aan het op democratische wijze tot stand gekomen recht een factor die het oordeel van de rechter meer gezag geeft. De marges waarbinnen hij oordeelt, worden daardoor immers verkleind. Een derde belangrijke voorwaarde voor het kunnen accepteren van de uitspraak van de rechter als 'de juiste' is gelegen in de wijze waarop dat oordeel tot stand komt. Deze procedurele component kent twee verschillende aspecten. Enerzijds de openbaarheid van de zitting en het in het openbaar uitspreken van het vonnis, waarmee ook voor niet procesdeelnemers de wijze waarop het oordeel tot stand komt inzichtelijk kan worden. Anderzijds de openheid van de procedure voor procesdeelnemers. In dat verband wordt wel gesproken van procedurele rechtvaardigheid. De mogelijkheid tot tegenspraak is daarin een wezenlijke factor. Tot slot, maar niet in de laatste plaats, is de mate van acceptatie van rechterlijke uitspraken afhankelijk van de inhoud van het vonnis zelf.

\subsubsection{De rechter}

De bevoegdheid om straffend op te treden is in Nederland, zoals in alle westerse landen, toegekend aan de overheid. De monopolisering van de strafrechtelijke handhaving komt voort uit de wens om eigenrichting te voorkomen. Reacties op aangedaan 'onrecht' kunnen, indien zij worden overgelaten aan de gedupeerde, onterecht of buitenproportioneel zijn. Door de verantwoordelijkheid voor de strafrechtelijke handhaving bij de overheid te leggen, wordt beoogd het sanctionerend optreden los te koppelen van de emoties die vaak normovertredingen vergezellen en die op hun beurt een objectieve en juiste oordeelsvorming belemmeren. De toedeling van de strafrechtshandhaving aan de overheid brengt echter ook een bepaalde spanning met zich. Enerzijds mogen burgers verwachten dat de overheid tegen normovertredingen optreedt teneinde de maatschappelijke vrede te bewaren, anderzijds moet voorkomen worden dat burgers ten onrechte door diezelfde overheid als normovertreders worden aangemerkt. Deze spanning kan worden opgeheven door het optreden van de overheid aan strikte regels te binden en de uiteindelijke beoordeling van de vraag of er sanctionerend moet worden opgetreden

9 Prakken spreekt in de verband van het bewijs als toetssteen van het strafrecht: "van het bewijs hangt af wat er in het proces terechtkomt van de ideologische beginselen legaliteit en schuld.' De relevante beginselen zijn volgens haar: 1) gebondenheid aan regels, 2) onafhankelijke verantwoordelijkheid en 3) openbaarheid en controleerbaarheid. Jessurun d'Oliviera-Prakken 1976, p. 14 e.v. 
op te dragen aan personen die op gepaste afstand staan van die overheid, en tegelijkertijd in emotionele zin niet worden bevangen door vooringenomenheid. ${ }^{10}$ In veel landen is om die reden de rechtspraak opgedragen aan onafhankelijke, onpartijdige en professionele rechters. ${ }^{11}$

De onafhankelijkheid van de rechter geldt in de eerste plaats ten aanzien van de uitvoerende macht. Die onafhankelijkheid is volgens Corstens bij uitstek het middel om het gezag van de strafrechtspraak te vestigen. ${ }^{12}$ Door belangrijke beslissingen in handen van een onafhankelijke rechter te leggen, wordt een gunstige voorwaarde geschapen voor beslissingen die recht doen aan zowel de belangen van de samenleving als de belangen van het individu. De onafhankelijkheid wordt gegarandeerd doordat rechters voor het leven worden benoemd en buiten de zitting en hun vonnis om geen verantwoording hoeven af te leggen aan andere instanties. Een ander aspect van de rechterlijke onafhankelijkheid ziet op het feit dat rechters niet gebonden kunnen worden aan uitspraken van collega's. Per concrete strafzaak moet een eigen afweging worden gemaakt. De uitkomst daarvan kan niet worden gedicteerd door hetgeen collega-rechters in andere zaken hebben beslist. Door in staatsrechtelijke en rechtspositionele zin rechters een onafhankelijke status te geven, wordt voorkomen dat zij zich door andere belangen laten leiden die mogelijk een juiste en rechtvaardige oordeelsvorming vertroebelen.

De onpartijdigheid van de rechter is een tweede wezenlijke voorwaarde voor de legitimering van de rechtspraak. Stamhuis schrijft hierover:

'De maatschappelijk acceptatie van de rechtspraak staat of valt bij een gedegen regeling van de onpartijdigheid van de rechter. Wat hier op het spel staat is het vertrouwen, dat rechterlijke instanties hebben bij de justitiabelen. ${ }^{13}$

De eis van onpartijdigheid is niet uitdrukkelijk in het Wetboek van Strafvordering opgenomen. Eén aspect ervan treffen we aan in artikel 271 lid $2 \mathrm{~Sv}$ waarin is bepaald dat de zittingsrechter geen blijk mag geven van overtuiging omtrent schuld of onschuld van de verdachte. Deze bepaling ziet alleen op de uiting van

10 In gelijke zin: Cleiren \& De Roos 2002, p. 177: 'de rechter (is) de taak toebedeeld om als 'derde beslissende instantie' de knoop door te hakken. De vervulling van die rol vereist afstand: het geschil wordt op een juridisch niveau opgelost.' Behalve voordelen zijn er volgens de schrijvers ook nadelen verbonden aan die afstandelijkheid: 'Anderzijds heeft die afstand in hoge mate een vervreemdend effect. Dat geldt allereerst voor het slachtoffer en de nabestaanden. Hun verdriet, boosheid en wraakgevoelens hebben geen plaats op het juridische niveau van het strafproces.'

11 In gelijke zin: Brants \& Van Lent 2001, p. 169: 'Garanties voor zowel waarheidsvinding als eerlijk proces stoelen in hoge mate op het vertrouwen in de professionaliteit van het gehele strafrechtelijke apparaat en in het bijzonder in die van de onpartijdige en onafhankelijke rechter' en De Roos 2003, p. 68: 'Het gaat niet in de eerste plaats om de kennis van het recht, hoewel dat aspect zeker in een moderne complexe maatschappij van groot belang is, maar vooral om de attitude van de beslisser: onafhankelijk, onpartijdig en wars van willekeur.'

12 Corstens 2005a, p. 123

13 Stamhuis 1999, p. 145. 
vooringenomenheid. Uit artikel 6 EVRM en de daarop geënte rechtspraak volgt meer specifiek dat de rechter noch in persoonlijke noch in professionele zin eerder bij de strafzaak betrokken mag zijn geweest of enige binding mag hebben met de daarbij betrokken personen. ${ }^{14}$ Een dergelijke betrokkenheid of binding zou niet alleen zijn besluitvorming kunnen vertroebelen, maar ook - indien hij zich al aan een eventuele beïnvloeding zou kunnen onttrekken - de schijn van vooringenomenheid met zich brengen en daarmee wantrouwen bij de verdachte of derden kunnen opwekken. Met betrekking tot de eerdere professionele betrokkenheid kan artikel $268 \mathrm{~Sv}$ worden genoemd. In dat artikel wordt de rechter-commissaris die enig onderzoek in de zaak heeft gedaan, uitgesloten van deelname aan het onderzoek ter terechtzitting.

Voor het overige kent de Nederlandse strafvordering geen algemene regels met betrekking tot de samenstelling van gerechtelijke colleges. Wel kan de rechter op het moment dat duidelijk is dat hij zich reeds in een eerder stadium met de zaak zelf of met de daarin optredende partijen heeft bemoeid, uit eigen beweging (art. 517-518 Sv) of na een daartoe gedaan verzoek van de procespartijen zich terugtrekken uit de zaak (art. 521-525 Sv). De Nederlandse rechtspraak sluit overigens niet uit dat rechters die in een eerdere fase reeds op enige manier zijn betrokken bij de strafzaak, zich later als zittingsrechter wederom over die zaak moeten buigen. Dit doet zich vooral voor in die gevallen waarin de rechter in het vooronderzoek heeft geoordeeld over de (voortduring van de) voorlopige hechtenis. Hij heeft zich dan ook een oordeel gevormd over de vraag of er tegen de verdachte ernstige bezwaren bestaan. Daarmee is toch in zekere zin door de rechter reeds vooruitgelopen op het uiteindelijke feitenoordeel. Dit is echter volgens de Hoge Raad niet problematisch; de professionaliteit van de rechters moet in dergelijke gevallen voldoende waarborg bieden voor een onpartijdige beoordeling. ${ }^{15}$

Daarmee ben ik uitgekomen bij het laatste punt dat de legitimiteit van het rechterlijke oordeel mogelijk ondersteunt, te weten het feit dat in Nederland de rechtspraak enkel is opgedragen aan beroepsrechters. In 1813 is nadrukkelijk gekozen voor het afschaffen van de juryrechtspraak. Deze was kort daarvoor - in 1811 - door de Fransen ingevoerd. De jury werd beschouwd als een vanuit het buitenland opgedrongen instituut, dat onvoldoende waarborgen bevatte voor een

14 EHRM 24 mei 1989, NJ 1990, 627 m.nt. PvD (Hauschildt t. Denemarken).

15 HR 26 mei 1992, NJ 1992, 676 m.nt. 'tH (r.o 6.4): 'Bij de beoordeling van een beroep op het ontbreken van onpartijdigheid van de rechter in de zin van art. 6 eerste lid EVRM dient voorop te staan dat een rechter uit hoofde van zijn aanstelling moet worden vermoed onpartijdig te zijn, tenzij zich uitzonderlijke omstandigheden voordoen die zwaarwegende aanwijzingen opleveren voor het oordeel dat een rechter jegens de verdachte een vooringenomenheid koestert, althans dat de bij de verdachte dienaangaande bestaande vrees objectief gerechtvaardigd is'. In gelijke zin: HR 30 juni 1992, NJ 1993, 194 m.nt. Sch; HR 29 september 1992, NJ 1993, 58 m.nt. Kn; HR 9 januari 2001, NJ 2001, 141 en HR 20 april 2004, NJ 2005, 241 m.nt. Kn. 
juiste en rechtvaardige oordeelsvorming. Het veronderstelde gebrek aan kennis bij lekenrechters was één van de belangrijkste overwegingen om te kiezen voor een professionele rechtspraak. Aan dit argument kwam bovendien meer waarde toe, omdat men in Nederland het bewijsoordeel in strafzaken aan wettelijke regels wilde binden en niet zoals in Frankrijk de conviction intime doorslaggevend achtte voor een bewezenverklaring. Het gebrek aan kennis bij lekenrechters over de wijze waarop deze bewijsregels zouden moeten worden toegepast, vormde een argument om de lekenrechtspraak buiten de deur te houden. Het voordeel van juryrechtspraak, namelijk dat het oordeel wordt uitgesproken door gelijken en dat daarmee ook een democratische vorm van legitimiteit aan het oordeel wordt gegeven, achtte men weinig overtuigend. In tegenstelling tot in Frankrijk stond het functioneren van de beroepsrechter niet ter discussie en was er dus ook in dat opzicht geen noodzaak voor juryrechtspraak. Het algemeen gevoelen was toen - en is deels nu nog - dat het vertrouwen in de rechtspraak beter kan worden gewaarborgd door het exclusief opdragen van die rechtspraak aan professionele, daartoe opgeleide ambtenaren, dan door het betrekken van burgers in de strafrechtspleging. Aan de andere kant heeft het opdragen van het oordeel aan burgers als bijkomende voordeel dat daarmee de openbaarheid en de begrijpelijkheid van de bewijsvoering toenemen. ${ }^{16}$ Het bewijs moet immers ten overstaan van de juryleden worden gepresenteerd op een zodanige wijze dat zij dat zonder voorkennis kunnen volgen. Naar aanleiding van de Schiedammer parkmoord waarin Cees B., naar achteraf is komen vast te staan, zowel in eerste aanleg als in hoger beroep ten onrechte was veroordeeld, is het betrekken van burgers bij de strafrechtspleging genoemd als één van de mogelijkheden om het vertrouwen in de strafrechtspraak te herstellen. ${ }^{17}$ Met name het gevaar van tunnelvisie bij politie en Openbaar Ministerie en de doorwerking daarvan op het onderzoek ter terechtzitting zou door de inzet van burgers bij de berechting kunnen worden tegengegaan. Zij worden immers - doordat zij geen voorkennis hebben van het dossier - niet bevangen door een zekere vooringenomenheid ten aanzien van de schuld van de verdachte. Bovendien werken zij niet dagelijks samen met het Openbaar Ministerie, zodat een portie gezond wantrouwen ten opzichte van de vervolgingsautoriteit in stand blijft. In Nederland lijkt overigens ook nu geen voedingsbodem te bestaan voor invoering van de juryrechtspraak. ${ }^{18}$ Men hecht sterk aan de professionaliteit van de rechter. Daarbij speelt met name een rol dat de rechter in tegenstelling tot leken een specifieke opleiding heeft gevolgd en veel ervaring heeft. Dat die ervaring

16 Corstens 2005a, p. 134.

17 B.J. Eerdmans en E.P.M. Schreijen, Betrek burger actief bij behandelen strafzaken, NRC-Handelsblad 7 november 2005, p. 7.

18 Ondanks het feit dat de juryrechtspraak of deelname van leken aan de rechtspraak getuige het aantal publicaties op dat punt weer op belangstelling kan rekenen. Zie onder andere: Brants 2004, Buruma 2006, De Hert 2006, De Roos 2006b en 2007 en Groenhuijsen 2005a. 
ook een averechts effect kan hebben, is reeds opgemerkt. Met betrekking tot de opleiding: die is veelal beperkt tot de juridische aspecten van de rechtshandhaving. Het vaststellen van de feiten, een noodzakelijk aan de toepassing van het materiële strafrecht voorafgaande kwestie, blijft binnen de juridische opleidingen onderbelicht. Het is ook niet zonder reden als Wagenaar en Crombag opmerken dat het vertrouwen in de rechterlijke wijsheid bij de waardering van het bewijs naïef en niet gerechtvaardigd is. ${ }^{19}$

\subsubsection{Binding aan het recht}

Behalve de waarborgen waarmee het rechterlijk ambt is omkleed, is ook de binding aan het recht een wezenlijke bijdrage aan de legitimatie van het rechterlijk oordeel. ${ }^{20}$ De rechter is bij het vellen van zijn oordeel allereerst gebonden aan het op democratische wijze tot stand gekomen materiële en formele recht. Hij mag slechts een veroordeling uitspreken, indien de aan de verdachte verweten gedraging als zodanig in het materiële strafrecht als strafwaardig is gekwalificeerd. Ontbreekt een delictsomschrijving of is deze niet volledig van toepassing op het aan de rechter voorgelegde geval, dan zal dit leiden tot vrijspraak dan wel ontslag van rechtsvervolging. Ook de door de rechter op te leggen sancties zijn van te voren beperkt. Het Wetboek van Strafrecht kent slecht bepaalde sanctiemodaliteiten en per delict is aangegeven binnen welke marges de rechter van die modaliteiten gebruik mag maken.

De binding aan het recht geldt ook specifiek ten aanzien van het bewijsoordeel in strafzaken. De wetgever in 1926 was zich bewust van het belang en de precaire aard van het feitenoordeel in strafzaken. Slechts indien zekerheid bestaat over de feiten kan met recht sanctionerend worden opgetreden. Zekerheid over de feiten is echter geen vaststaand gegeven. Bij gebrek aan een eenduidig criterium waaraan de waarheid of juistheid van bepaalde feiten kan worden getoetst, kan onmogelijk een absolute garantie worden gegeven voor de juistheid van het feitenoordeel in strafzaken. Het is met name deze onzekerheid die de Nederlandse wetgever ertoe heeft gebracht het feitenoordeel te binden aan bepaalde minimumeisen. Deze eisen komen tot uitdrukking in het wettelijke bewijsstelsel zoals dat heeft vorm gekregen in de afdeling 'Bewijs' van het Wetboek van Strafvordering. Naast de vereiste rechterlijke overtuiging dient de rechter de in deze afdeling opgenomen beperkingen in acht te nemen. Dat betekent dat hij enerzijds slechts een bepaald aantal, nader in de wet omschreven, bewijsmiddelen mag hanteren en anderzijds bepaalde bewijsminima in acht moet nemen. Het stellen van deze beperkingen aan het bewijsoordeel had tot doel om een minimum aan betrouwbaarheid te garanderen

19 Wagenaar \& Crombag 2002, p. 852.

20 In gelijke zin: Malsch \& Nijboer 2005, p. 22: 'De legitimatie van de rechterlijke macht vloeit voor een belangrijk deel voort uit de zogenoemde rule of law'. 
en te voorkomen dat onschuldigen ten onrechte zouden worden veroordeeld. De keerzijde, namelijk dat schuldigen wellicht de dans zouden ontspringen bij gebrek aan wettelijk bewijs, heeft de wetgever op de koop toe genomen.

Uit hoofdstuk 2 blijkt evenwel dat veel van de in de wet gestelde beperkingen aan het bewijsoordeel nauwelijks nog enige betekenis hebben. Reeds vanaf het moment van inwerkingtreding van het Wetboek van Strafvordering heeft de Hoge Raad tal van bewijsrechtelijke voorschriften gerelativeerd of zeer beperkt uitgelegd. De meest wezenlijke aantasting van het wettelijke bewijsstelsel betrof de aanvaarding van het testimonium de auditu. Daarmee werd feitelijk het limitatieve stelsel van bewijsmiddelen doorbroken. Ook de beperkte uitleg van de bewijsminima, namelijk dat zij zien op de hele tenlastelegging en dus geenszins vereisen dat de betrokkenheid van de verdachte uit twee verschillende bronnen moet blijken, heeft de toegevoegde waarde van het wettelijke bewijsstelsel als waarborg voor juiste feitenoordelen ernstig aangetast. Thans hebben de in artikel 338 en verder Sv genoemde regels voor de waarheidsvinding nauwelijks nog enige betekenis; zij kunnen - op de wijze waarop zij nu worden uitgelegd - nauwelijks de deugdelijkheid van het feitenoordeel garanderen. De wettelijke bewijsregels vormen slechts nog een formele horde voor de rechter bij de inrichting van het vonnis. In materiële zin is de overtuiging van de rechter doorslaggevend. De onderzoeksgroep Strafvordering 2001 onderkent dit deels en meent dan ook dat, indien een nieuwe bewijsregeling wordt overwogen, moet worden afgezien van een inhoudelijke definiëring en begrenzing van de toegelaten bewijsmiddelen. ${ }^{21}$ De bewijsminima ten aanzien van de verklaring van de verdachte en de getuige wenst zij te handhaven, echter zonder daaraan meer eisen te stellen dan thans op basis van de jurisprudentie gebeurt.

\subsubsection{Procedurele eisen}

Naast het stellen van eisen aan de beoordelende instantie en de binding van die instantie aan het recht is veel van de legitimiteit van het oordeel in strafzaken afhankelijk van de context waarin dat oordeel tot stand komt. De wijze waarop het oordeel in procedurele zin tot stand komt, bepaalt in hoge mate of de uitkomst van die procedure kan worden geaccepteerd. ${ }^{22}$ De procedure moet enerzijds zodanig worden vormgegeven dat de direct betrokkenen daarin een stem hebben. Met andere woorden: de mogelijkheid van tegenspraak moet daarin zijn gegarandeerd.

21 Simmelink 1999, p. 438.

22 In gelijke zin: Crombag \& Van Koppen 2002, p. 784, die onder andere verwijzen naar het onderzoek van Thibaut \& Walker (1975) waarin de vraag aan de orde werd gesteld in hoeverre het oordeel van mensen over de rechtvaardigheid van een rechterlijke beslissing afhankelijk is van de procedure die bij het nemen van die beslissing is gevolgd. Met name de mogelijkheid om invloed te kunnen uitoefenen op de informatie die de beslisser bereikt alvorens die zijn beslissing neemt, blijkt een relevante factor te zijn als het gaat om de vraag of mensen de uitkomst van een procedure rechtvaardig achten. 
Anderzijds moet de procedure in algemene zin zo zijn vormgegeven dat buitenstaanders het rechterlijk vonnis als uitvloeisel van die procedure kunnen accepteren en de rechter als autoriteit in deze accepteren. Dit laatste wordt voornamelijk gewaarborgd door de openbaarheid van de zitting en het in het openbaar uitspreken van het vonnis.

\subsubsection{Tegenspraak}

Door Habermas is gewezen op de legitimerende werking van de procedure; niet zo zeer concrete morele waarden en normen legitimeren het recht, maar de juridische procedures (voor zowel de totstandkoming als de toepassing van het recht) waarin ruimte is voor morele argumentatie, en waarin de idee van onpartijdigheid is geïnstitutionaliseerd. ${ }^{23}$ Bij de vraag, aan welke voorwaarden deze juridische procedures moeten voldoen, baseert Habermas zich op de structuur van het debat. Alleen een debat kan een door een ieder geaccepteerde uitkomst genereren, indien er tijdens dat debat sprake is van wat hij noemt een 'ideale gesprekssituatie'. ${ }^{24}$ Deze ideale gesprekssituatie kent een aantal voorwaarden. Zo dienen de deelnemers zich waarachtig te uiten, opdat uitgesloten is dat zij met verborgen bedoelingen aan het discours deelnemen of anderen manipuleren. Daarnaast dienen de deelnemers een gelijke kans te hebben om aan het discours deel te nemen en om hun meningen te uiten. Tot slot mogen er geen machtsverschillen tussen de participanten aan het debat bestaan, wil dat debat tot een voor ieder acceptabele uitkomst leiden. Met de ideale gesprekssituatie geeft Habermas de context weer waarin wij ons laten overtuigen door argumenten. De ideale gesprekssituatie moet niet alleen zoveel mogelijk worden benaderd bij de totstandkoming van het recht, maar ook bij de toepassing van het recht in concrete zaken. Het recht is immers nooit af en in die zin moet de mogelijkheid bestaan om ook in de rechtszaal de geldigheid van het recht ter discussie te stellen. Binnen het toepassingsdiscours, de aanduiding

23 Habermas 1986, p. 563: 'Legitimierende Kraft haben vielmehr Verfahren, die Begründungsforderungen und den Weg zu ihrer argumentativen Einlösung institutionalisieren. Die Legitimationsquelle darf zudem nicht einseitig, nicht nur am Ort sei es der politischen Gesetzgebung oder der Rechtsprechung gesucht werden. (...) Ein im moralisch-praktischen Sinne rationaler Kern rechtlichter Verfahren schält sich erst heraus, wenn man analysiert, wie sich über die Idee der Unparteilichkeit sowohl der Normenbegründung als auch der Anwendung von verbindlichen Regelungen ein konstruktiver Zusammenhang zwischen geltendem Recht, Gesetzgebungsverfahren und Verfahren der Rechtsanwendung herstellt.'

24 Habermas 1997, p. 279: 'Wenn wir einander von etwas überzeugen wollen, verlassen wir uns intuitiv immer schon auf eine Praxis, worin wir eine hinreichende Annäherung an die idealen Bedingungen einer gegen Repression und Ungleichheit in besonderer Weise immunisierten Sprechsituation unterstellen - eine Sprechsituation, in der Proponenten und Opponenten einen problematisch gewordenen Geltungsanspruch thematisieren und, von Handlungs- und Erfahrungsdruck entlastet, in hypothetischer Einstellung mit Gründen und nur mit Gründen prüfen, ob der vom Propenenten verteidigte Anspruch zurecht besteht.' 
van Habermas voor het debat in de rechtszaal, dienen procedurele regels een institutioneel kader te scheppen, ter verzekering van een zo open mogelijke communicatie onder tijdelijke, sociale en pragmatische condities zonder afbreuk te doen aan de logica van argumentatie. ${ }^{25}$ De tijdelijke voorwaarden zien er op dat de beslissing tot stand komt binnen een redelijke termijn; sociale voorwaarden zien op de symmetrische relatie tussen de procespartijen, en de pragmatische voorwaarden zien op het feit dat het rechtsconflict van tevoren voldoende is afgebakend. Deze procedurele regels dienen ter compensatie voor het feit dat de voorwaarden voor een ideale gesprekssituatie nooit volledig kunnen worden gerealiseerd, en derhalve niet het nemen van de enige juiste beslissing kunnen garanderen.

In Nederland is voor wat betreft het strafrecht de theorie van Habermas geconcretiseerd door Peters. Peters vat evenals Habermas het recht op als een kritische discussie. ${ }^{26}$ Naar de mening van Peters is de geldigheid van strafrechtelijke normen gebaseerd op de veronderstelling dat zij moeten kunnen worden gerechtvaardigd en tegen kritiek moeten kunnen worden verdedigd indien de geldigheid ervan in twijfel wordt getrokken.

'De burger moet zich niet verplicht voelen om dingen op bevel aan te nemen en regels te gehoorzamen alleen omdat zij overeenkomen met bestaande praktijken en afkomstig zijn van een bevoegd gezag, maar de burger moet zich te allen tijde vrij voelen de juistheid van regels, bevelen en beleid te betwisten, en de burger moet menen dat hij dan recht heeft op redelijk en overtuigende antwoorden, welke hij bereid is als normatieve premissen voor zijn eigen handelen te aanvaarden. ${ }^{27}$

Hierin ligt ook volgens Peters de uiteindelijke legitimatie van het recht; namelijk dat het in een contradictoire procedure ter discussie kan worden gesteld. De belangrijkste functies van deze contradictoire procedure zijn volgens Peters het garanderen van een adequate constatering en kritische evaluatie van feiten, de bescherming van het individu tegen de staat, en het mogelijk maken van participatie in de rechtsvorming door de burger. ${ }^{28}$

Uit het eerste punt blijkt dat Peters het belang van een contradictoire procedure niet alleen ziet voor de totstandkoming en handhaving van rechtsnormen, maar ook nadrukkelijk betrekt op het feitenoordeel in strafzaken. Een procedure op

25 Habermas 1997, p. 288.

26 In gelijke zin: Nijboer 2003, p. 60: "Als "de" waarheid niet zomaar voor handen is, ook niet voor een 'behoedzame'rechter is er alle reden - gelet op het enorme belang van vrijheid dat onder andere en met name voor de verdachte op het spel staat - te streven naar een stijl van procederen die opener is voor andere visies op - en interpretaties van - gedrag dan de manier waarop thans de meeste strafzaken verlopen.'

27 Peters 1986, p. 235-236. In gelijke zin: Selznick \& Nonet 1978, p. 56, die spreken over legitimaty in depth, inhoudende dat het recht als criterium van legitimiteit aan kracht toeneemt naar mate het niet enkel verwijst naar een autoriteit die met gezag bekleed is (bijvoorbeeld de formele wetgever), maar in concreto daden van gezag, zoals wetstoepassing, afzonderlijk worden getoetst.

28 Peters 1972a, p. 31. 
tegenspraak draagt zijns inziens bij aan een volledige en deugdelijke vaststelling van de feiten. Het gebrek aan tegenspraak in het vooronderzoek in strafzaken kan slechts ten dele worden gecompenseerd door tegenspraak tijdens het onderzoek ter zitting. In de optiek van Peters vereist een volledige en deugdelijke vaststelling van de feiten dat in elke fase van de procedure tegenspraak mogelijk moet worden gemaakt. ${ }^{29}$

In Nederland is de mogelijkheid tot tegenspraak ter zitting in formele zin in belangrijke mate gerealiseerd. Partijen kunnen indien gewenst het ingebrachte bewijsmateriaal ter discussie stellen en ook zelf binnen bepaalde marges nieuw bewijsmateriaal andragen. In het vooronderzoek is echter de mogelijkheid tot tegenspraak zeer beperkt. Met een beroep op het onderzoeksbelang wordt de verdediging vaak geweerd bij de ondervraging van de verdachte en getuigen. ${ }^{30}$ De verslaglegging van bepaalde onderzoekshandelingen geschiedt soms niet, omdat dit in de ogen van de vervolgende instantie niet relevant zou zijn, of wordt pas in een laat stadium aan de verdediging ter beschikking gesteld. De achtergestelde positie van de verdediging in het vooronderzoek, met name in het opsporingsonderzoek, kan weliswaar gerechtvaardigd worden met een beroep op het onderzoeksbelang van het Openbaar Ministerie, maar heeft ontegenzeggelijk gevolgen voor de behandeling in het eindonderzoek. De door Habermas en Peters vereiste symmetrie van procespartijen teneinde tegenspraak te kunnen genereren, is immers niet gegarandeerd. De verdediging is voor de mogelijkheid van tegenspraak in sterke mate afhankelijk van het optreden van het Openbaar Ministerie en de rechtercommissaris in het vooronderzoek; in hoeverre zijn zij bereid het onderzoek voorafgaand aan de zitting uit te breiden tot zaken die voor de verdediging relevant zijn om effectief gebruik te kunnen maken van haar recht op tegenspraak. Die afhankelijkheid wordt nog versterkt doordat in Nederland de bewijsgaring hoofdzakelijk plaatsvindt in het vooronderzoek en het onderzoek ter zitting in de praktijk veelal beperkt is tot verificatie van de (belastende) onderzoeksresultaten uit het vooronderzoek, een ontwikkeling die het gevolg is van de de-auditurechtspraak.

Het is dan ook niet voor niets dat in het Nederlandse systeem van strafvordering een compensatie moet worden gevonden voor het gebrek aan tegenspraak tijdens het vooronderzoek. Die compensatie is ten eerste gevonden in het creëren van

29 Specifiek toegepast op tegenspraak door de verdediging spreekt Boksem 2007, p. 7 in dit verband van een effectief recht op verdediging, inhoudende dat 'de verdediging in staat wordt gesteld de resultaten van het strafproces te beïnvloeden. Dat kan bijvoorbeeld door het (doen) oproepen en horen van getuigen, en het inschakelen van deskundigen. Daarnaast is het van belang dat de processuele condities zodanig zijn dat de verdediging ook daadwerkelijk invloed kan hebben op de uitkomst van het strafproces.'

30 In gelijke zin: Spronken 2003, p. 21: 'In de inquisitoire systemen is het recht op bijstand in de voorfase van het strafproces dan ook geen algemeen recht, maar een recht dat ondergeschikt is aan het onderzoeksbelang.' 
mogelijkheden tot uitbreiding van het onderzoek of controle op de uit het vooronderzoek verkregen onderzoeksresultaten op verzoek van de verdediging, bijvoorbeeld door het oproepen van getuigen en deskundigen ter zitting. Een tweede compensatie dient zich an in de vorm van een actieve, niet lijdelijke rechter. De zittingsrechter moet ook los van hetgeen door het Openbaar Ministerie in het procesdossier is aangedragen zelf onderzoek doen naar de toedracht van het feit. Hij kan daarbij door de verdediging worden aangespoord, maar zal ook uit eigen beweging indien de zaak daartoe aanleiding geeft onderzoek moeten doen. Het Wetboek van Strafvordering geeft de zittingsrechter daartoe ook de mogelijkheid. In de bepalingen 315 en $316 \mathrm{~Sv}$ wordt de zittingsrechter de mogelijkheid geboden om nader onderzoek te verrichten of te doen verrichten en om zelf getuigen en deskundigen op te laten roepen. Voor zover de medewerking van het Openbaar Ministerie daarvoor vereist is, leidt weigering daarvan tot nietontvankelijkheid van het Openbaar Ministerie.

De vraag is echter of de eigen verantwoordelijkheid van de zittingsrechter voor de materiële waarheidsvinding voldoende compensatie biedt voor de ongelijkheid tussen partijen als het gaat om de mogelijkheid tot tegenspraak, zeker in die gevallen waarin de verdediging onder de maat blijft. Allereerst kan het al dan niet gebruik maken van de onderzoeksbevoegdheden door de zittingsrechter niet worden afgedwongen. Een verzoek van de verdediging om daarvan gebruik te maken, kan op zeer algemene gronden worden geweigerd (de rechter is de noodzaak van nader onderzoek niet gebleken). Controle op de juistheid van dit oordeel in cassatie is bijna niet mogelijk. Ten tweede wreekt zich hier de professionaliteit van de rechter. In het merendeel van de zaken levert immers het onderzoek voorafgaand aan de terechtzitting geen enkele reden op om te twijfelen aan de juistheid en volledigheid van de vergaarde gegevens. Het vertrouwen in de justitiële autoriteiten belast met de opsporing en vervolging is dientengevolge groot. De rechter zal dan ook niet snel op eigen initiatief aannemen dat het onderzoek moet worden uitgebreid. Op de verdediging rust een zware stelplicht wil zij de rechter overtuigen dat nader onderzoek vereist is. Die plicht brengt met zich dat feiten en omstandigheden aannemelijk moeten worden gemaakt die tot uitbreiding van het onderzoek dwingen. Echter, als gevolg van de achtergestelde positie van de verdediging in het vooronderzoek zal het niet altijd makkelijk zijn om bepaalde feiten en omstandigheden aannemelijk te maken. Dat speelt zeker in die zaken waarin een deel van het onderzoek is afgeschermd, bijvoorbeeld indien tijdens het onderzoek gebruik wordt gemaakt van anonieme bronnen. Maar ook in zaken waarin geen redenen zijn om de herkomst van onderzoeksresultaten af te schermen, zal het de verdediging niet makkelijk vallen om de rechter tot nader onderzoek te laten overgaan. Veelal kan dat onderzoek niet meer plaatsvinden door tijdsverloop of gebrek aan onderzoeksmateriaal. Getuigen zijn niet meer te traceren of sporen 
zijn niet veiliggesteld of - erger nog - niet bewaard. ${ }^{31}$ Maar ook zal vaak het doen van nader onderzoek geen andere resultaten opleveren. Te denken valt dan aan een hernieuwde confrontatie van een getuige met de verdachte.

\subsubsection{Externe openbaarheid}

Het feit dat procedures zodanig moeten zijn ingericht dat zij de mogelijkheid tot tegenspraak bieden, garandeert dat alle door partijen ingebrachte bezwaren onder ogen komen van de rechter, die daar op zijn beurt bij het uitspreken van zijn oordeel rekening mee moet houden. De contradictoire procedure is aldus voor de betrokken procespartijen één van de aspecten die het oordeel van de rechter legitimeren. Echter het oordeel in strafzaken dient niet alleen partijen te overtuigen. De strafrechtspleging is een publiek belang en daarmee dient ook het publiek inzicht te krijgen in de wijze waarop de strafrechtspleging functioneert. Dit laatste wordt gerealiseerd door het strafproces toegankelijk te maken voor het publiek. In Nederland zijn zittingen openbaar en wordt ook het vonnis in het openbaar uitgesproken.

De externe openbaarheid van de rechtspraak wordt gezien als een wezenlijke waarborg voor een goede en rechtvaardige rechtspleging. Het draagt bij aan de hoofddoelen van de strafvordering, namelijk: optimale waarheidsvinding en waarborging van het recht op een eerlijk proces waarmee zowel de belangen van de verdachte als die van de samenleving worden behartigd. Door strafzaken in principe niet achter gesloten deuren te behandelen, wordt publieke controle op het functioneren van de rechter mogelijk. De mogelijkheid van publieke controle op haar beurt, legitimeert het optreden van alle betrokken overheidsinstanties waarmee het in een rechtsstaat essentiële vertrouwen in de rechtspleging wordt gehandhaafd. De openbaarheid van het strafproces kan als zodanig een kwaliteitsbevorderend effect hebben. De rechter die weet dat zijn optreden door buitenstaanders wordt gadegeslagen, zal naar men aanneemt zijn taak beter uitoefenen. Daarnaast moet het belang van de openbaarheid met name worden gezien in het licht van de publieke functie van de strafrechtspleging, hetgeen tot uitdrukking komt in adagium justice done and seen to be done. ${ }^{32}$ Dat betekent enerzijds dat de zichtbaarheid van de rechtspleging ook mogelijk maakt dat van buitenaf invloed kan worden uitgeoefend op de rechtspleging. Anderzijds heeft het tot consequentie dat ook van het strafproces een preventieve functie uitgaat. Voor buitenstaanders wordt immers duidelijk dat het strafrecht wordt gehandhaafd. ${ }^{33}$

De publieke controle op de strafrechtspleging is in Nederland zeer beperkt. Weliswaar zijn strafzittingen in principe voor iedereen toegankelijk, maar dit garandeert

31 Dat leidt overigens niet tot enige sanctie: HR 14 januari 2003, NJ 2003, 288 m.nt. YB.

32 Brants \& Van Lent 2001, p. 145.

33 Brants \& Van Lent 2001, p. 152-156. 
niet dat burgers die zittingen bijwonen daadwerkelijk hetgeen zich daar afspeelt kunnen volgen. Het feit dat het merendeel van het onderzoek reeds voorafgaand aan de zitting heeft plaatsgevonden en dat ter zitting veelal wordt volstaan met het - meestal in verkorte vorm - reproduceren van de resultaten van dat onderzoek, maakt dat zeker het onderzoek naar de feiten weinig inzichtelijk is voor buitenstaanders. ${ }^{34}$ Het horen van getuigen en deskundigen ter zitting is eerder uitzondering dan regel.

Bovendien heeft de uitbreiding van het strafrecht met talloze strafbepalingen ertoe geleid dat afhandeling van alle strafzaken via de rechter niet langer mogelijk was. Een groot deel van de strafzaken vindt nooit zijn weg naar de rechter. Deels omdat deze zaken reeds door middel van een transactie zijn afgehandeld, deels omdat in toenemende mate gebruik wordt gemaakt van meer op het bestuursrecht georiënteerde afdoeningsmodaliteiten, waarbij in eerste instantie de beoordeling niet plaatsvindt door de rechter, maar door de officier van justitie als bestuursorgaan. Typerend voor al deze vormen van niet-rechterlijke afdoening is dat zij ook niet zichtbaar zijn voor het publiek. ${ }^{35}$

\subsubsection{Motivering}

De vraag of wij een oordeel, ongeacht welk oordeel dan ook, accepteren als juist wordt voornamelijk bepaald door de argumenten die daarvoor worden aangedragen. Daarbij spelen de bovengenoemde aspecten van legitimiteit wel degelijk een rol. Bepaalde personen geloven wij eerder op hun woord dan anderen, zeker als blijkt dat zij zelf geen belang hebben bij een beslissing in deze of gene richting. Ook het feit dat deze personen gebonden zijn aan algemeen geldende volgens democratisch principe tot stand gekomen regels draagt bij aan de waarde van hun beslissing. En dat laatste geldt ook indien gedurende de procedure waaruit deze beslissing volgt de mogelijkheid heeft bestaan om alle mogelijke argumenten te berde te brengen en de beslissing tot stand is gekomen onder het wakend oog van het publiek. Echter, de juistheid van de beslissing wordt daarmee niet gegarandeerd.

Onafhankelijkheid, legaliteit en openbaarheid (intern en extern) vormen slechts het kader waarin de beslissing tot stand komt en dragen op hun manier bij aan de acceptatie van de beslissing. Zij zijn voor de legitimiteit van de beslissing onontbeerlijk, omdat voor zover deze uitgangspunten niet zijn gerealiseerd, de indruk kan ontstaan dat de beslissing mogelijk op andere dan de gegeven 'goede gronden' tot stand is gekomen. Zij creëren aldus een basis voor een juiste oordeelsvorming. Daarmee is echter niet gezegd dat het oordeel in alle gevallen juist is. Ook onaf-

34 De Roos 2003, p. 65

35 Daarover meer uitgebreid: Nijboer 2005. 
hankelijke, onpartijdige en professionele rechters maken fouten, de wetgever kan onmogelijk alle gevallen van te voren overzien en daarvoor een uitputtende regeling geven en tot slot, een volgens de regels verlopen openbare procedure is geen garantie voor een juiste uitkomst.

Dat maakt dat behalve de institutionele eisen die aan de rechterlijke macht worden gesteld, de beperkingen die in de wet worden gesteld en waarborgen waarmee de procedure is omgeven, aan het rechterlijk oordeel alleen gezag toekomt indien daaruit blijkt dat alle voor de beslissing relevante aspecten op juiste wijze zijn afgewogen. Dat een dergelijke afweging heeft plaatsgevonden, kan alleen blijken indien de rechter wordt verplicht om de gronden die aan zijn oordeel ten grondslag liggen te expliciteren. Uit de motivering kan vervolgens ook blijken of de overige factoren die de legitimiteit van de beslissing moeten waarborgen in acht zijn genomen. Zo kan uit de motivering volgen dat de rechter de wettelijke eisen die aan het bewijsoordeel worden gesteld in acht heeft genomen. Ook de waarborg van tegenspraak kan tot uiting komen in de motivering door van de rechter te verlangen dat hij verweren nadrukkelijk in het vonnis opneemt en aangeeft op welke gronden hij deze al of niet volgt. Dat is voldaan aan de eisen van onafhankelijkheid, onpartijdigheid, professionaliteit zal niet direct uit de motivering van het vonnis volgen, maar deze waarborgen krijgen wel meer cachet indien de rechter ook inhoudelijk zijn oordeel motiveert. Uit de motivering zal dan blijken dat de rechter zich niet heeft laten leiden door andere belangen, en dat hij beschikt over voldoende kennis en capaciteiten. Ook de openbaarheid van de strafrechtspleging wint door het stellen van motiveringseisen aan waarde. Het biedt immers het publiek een handvat voor zijn democratische controlefunctie.

Het belang van de motivering is dus inderdaad gelegen in het feit dat het bijdraagt aan de legitimering van het rechterlijk oordeel. Maar in vergelijking tot de overige factoren die maken dat wij het oordeel van de rechter niet enkel aannemen omdat het is uitgesproken door een daartoe bevoegde autoriteit, kan de motivering worden beschouwd als het noodzakelijke sluitstuk voor legitimering. Zonder motivering bestaat de kans dat onafhankelijkheid, onpartijdigheid en professionaliteit van de rechter enkel worden verondersteld zonder dat in concreto zichtbaar hoeft te worden gemaakt dat de rechter zich alleen door relevante informatie en belangen heeft laten leiden. Zonder motivering blijft onduidelijk hoe de rechter de inbreng van partijen heeft gewaardeerd. Zonder motivering verwordt de openbare zitting en in het openbaar uitgesproken vonnis tot een formele aangelegenheid die geen aanknopingspunt biedt voor effectieve democratische controle. Zonder motivering hebben ten slotte ook wettelijke beperkingen die worden gesteld aan het oordeel geen betekenis, omdat niet blijkt of de rechter ze in acht heeft genomen. Kortom: niet de procedure zelf en de daarbij in acht genomen wettelijke bepaling legitimeren 
de uitkomst van de procedure zoals wel door Luhmann ${ }^{36}$ is verkondigd, maar de aan de beslissing ten grondslag liggende argumenten, zoals Habermas meent, legitimeren de beslissing. De procedure en de wettelijke normeringen dienen enkel om de rechtstrijd af te bakenen en om voorwaarden te creëren waardoor het beste argument wint. In de woorden van Habermas:

'Die Gerichtsverfahrungsordnungen institutionalisieren die richterlichen Entscheidungspraxis in der Weise, dass sich Urteil und Urteilsbegründung als Ergebnis eines Argumentationsspiels verstehen lassen, welches in besonderer Weise programmiert ist. (...), wobei die prozessrechtliche Einrichtung juristische Diskurse nicht in das Innere ihrer Argumentationslogik eingreifen darf.,

De aan de beslissing ten grondslag liggende motivering moet dan wel kenbaar worden en vervolgens weer vatbaar zijn voor discussie. Daarmee is ook het belang van rechtsmiddelen gegeven. Zonder de mogelijkheid om de beslissing en de daaraan ten grondslag liggende argumentatie aan te vechten, zou ook de gegeven argumentatie slechts een pro forma betekenis hebben. Zij krijgt pas inhoudelijke betekenis op het moment dat zij vatbaar wordt voor kritiek. ${ }^{38}$

\subsection{Functies van de motivering van de bewijsbeslissing}

Het in de vorige paragraaf geschetste belang van de motivering komt ook tot uitdrukking in de in de literatuur genoemde functies van de motivering. In dat verband wordt gewezen op het feit 1) dat motivering controle op de inhoudelijke juistheid van die uitspraak mogelijk maakt (de controlefunctie), 2) dat door de verplichting tot motivering de rechter wordt gedwongen zich nauwkeurig rekenschap te geven van zijn beslissing (de inscherpingsfunctie) en 3) dat de motivering de uitspraak inzichtelijk maakt (de explicatiefunctie). In volgende paragrafen wordt op elk van deze functies ingegaan en bezien in welk motiveringsvoorschrift zij tot uiting komen en in hoeverre die bepalingen in het licht van de functie effectief zijn.

\subsubsection{De controlefunctie}

De motivering van de uitspraak dient er mede toe deze uitspraak vatbaar te maken voor controle in hoger beroep en cassatie. De mogelijkheid om het vonnis voor te leggen aan een hogere rechterlijke instantie is een belangrijke voorwaarde

36 Luhmann 1969

37 Habermas, 1997, p. 288.

38 Habermas 1997, p. 290: 'Der Zweck der Rechtsmittel besteht zunächst darin, im Interesse der Parteien durch die Überprüfung der erlassenen Entscheidungen richtige deshalb gerechte Entscheidungen zu bekommen. Die bloße Möglichkeit der Überprüfung zwingt außerdem die Gerichte zu einer sorgfältigen Begründung.' 
voor het accepteren van de juistheid van die beslissing. Het feit dat procespartijen de mogelijkheid hebben om een second opinion te vragen, draagt bij aan de acceptatie van die beslissing. Wordt immers van die mogelijkheid door belanghebbenden geen gebruik gemaakt, dan pleit dit voor de juistheid van de beslissing. Wordt evenwel van die mogelijkheid wel gebruik gemaakt, dan zal het enkele gegeven dat niet één maar twee instanties zich over de zaak hebben gebogen bijdragen aan aanvaarding van de uiteindelijke beslissing.

De oorspronkelijke bewijsmotiveringsvoorschriften hadden alle tot doel controle op de bewijsbeslissing in hoger beroep en cassatie mogelijk te maken. Zij zagen alle op de handhaving van de in het wetboek direct of indirect opgenomen bewijsvoorschriften. Zo dient het vermelden van de inhoud van de bewijsmiddelen ter controle op de wettigheid van de bewijsmiddelen en het in acht nemen van de bewijsminima. De eis van redengevendheid werd opgenomen ter vervanging van het bewijsmiddel der aanwijzingen. Ook de eis van nadere motivering in geval de verklaring van een onbeëdigde getuige voor het bewijs werd gebruikt, was in het wetboek van 1926 terechtgekomen als gevolg van het schrappen van oude bewijsregels dienaangaande.

In feite hebben deze bepalingen nog steeds deze functie, maar is de betekenis daarvan beperkt. De mate waarin het bewijsoordeel vatbaar is voor controle in hoger beroep en cassatie is immers afhankelijk van de omvang van de motiveringsplicht zelf en de omvang van de toetsing door de hogere rechter. Worden aan het oordeel van de feitenrechter geen motiveringseisen gesteld, dan valt in hoger beroep en cassatie op dit punt niets te toetsen. Andersom geldt dat het stellen van motiveringseisen vanuit het controleperspectief weinig zinvol is indien de hogere rechter de gegeven motivering niet toetst. Het uitblijven van controle biedt feitenrechters de mogelijkheid om niet meer in het vonnis op te nemen dan strikt gezien noodzakelijk is om het vonnis in hoger beroep dan wel cassatie overeind te houden. Binnen de Nederlandse strafvordering hebben beide factoren een rol gespeeld bij de uiteindelijke ontwikkeling van de motiveringsvoorschriften. Zoals in hoofdstuk 3 is gebleken is controle op het vermelden van de inhoud van de bewijsmiddelen altijd vrij strikt geweest. Echter op dat punt heeft met name de wetgever veel uitzonderingen gecreëerd. Deze hebben er toe geleid dat men in nog maar een fractie van het totale aantal berechte strafzaken de inhoud van de bewijsmiddelen aantreft. Bovendien is het achterliggende belang van het vermelden van de inhoud van de bewijsmiddelen voor een groot deel achterhaald. Controle op de wettigheid van de bewijsmiddelen heeft - zoals bleek in hoofdstuk 2 - nog maar een beperkte toegevoegde waarde omdat de eisen die aan de inhoud van bewijsmiddelen werden gesteld door de Hoge Raad sterk zijn gerelativeerd. Ook de uitleg van de bewijsminima is zodanig geweest dat slechts in uitzonderingsgevallen daaraan niet wordt voldaan. De overige motiveringsvoorschriften zijn nooit uit de verf gekomen omdat in hoger beroep en cassatie de wijze waarop 
aan deze voorschriften door de lagere rechter gevolg was gegeven niet erg indringend wordt getoetst.

\subsubsection{Controle in hoger beroep}

Het ontbreken van die controle in hoger beroep vloeit voort uit de aard van het hoger beroep zoals dat gedurende lange tijd in Nederland vorm heeft gehad. Het gehanteerde middenstelsel hield in dat de zaak in hoger beroep opnieuw werd behandeld. De appelrechter was in principe niet gebonden aan de door de rechter in eerste aanleg gegeven beslissing en de daaraan gekoppelde argumentatie. Hij kon immers tot een geheel eigen oordeel komen en dat in plaats stellen van het oordeel van de rechter in eerste aanleg. In appel stond derhalve de motivering van de in eerste aanleg gegeven beslissing zelf niet ter discussie en hoefde ook de tweede feitenrechter niet expliciet aan te geven op welke punten hij de redenering in het eerder gegeven vonnis volgde dan wel daar van afweek. De in eerste aanleg gegeven gronden voor het bewijsoordeel werden dus slechts impliciet gecontroleerd. Met ingang van 1 maart 2007 is het middenstelsel verlaten en daarvoor in de plaats is het voortbouwend hoger beroep getreden. Het vonnis in eerste aanleg en de daartegen geuite grieven vormt nu wel het vertrekpunt voor de behandeling in appel. Onduidelijk is of dit nu ook betekent dat de rechter in appel indien hij afwijkt van het oordeel gegeven in eerste aanleg dat expliciet moet motiveren. Het gewijzigde karakter van het appel brengt dit logischerwijze met zich, maar een specifieke bepaling op dit punt ontbreekt. Te vrezen valt dat ook het gewijzigde hoger beroep niet tot gevolg heeft dat in appel expliciet op de inhoud van het vonnis in eerste aanleg zal worden ingegaan en dat het hof zal volstaan met vernietiging van het vonnis zonder opgave van redenen.

\subsubsection{Controle in cassatie}

Is de controle op motivering van het vonnis in eerste aanleg een impliciete, dat ligt anders voor de motivering van het oordeel in hoger beroep. In cassatie wordt dat oordeel en de daaraan ten grondslag liggende motivering direct getoetst. Echter, de omvang van die toetsing is beperkt. En ook dat heeft te maken met de aard van de procedure. In cassatie vindt geen nieuwe beoordeling van de feiten plaats, maar beperkt de beoordeling zich tot de vraag of de rechter tot het door hem gegeven feitenoordeel is gekomen met inachtneming van de regels die daarvoor gelden. Slechts in geval van schending van het recht of verzuim van vormen zal in cassatie het oordeel worden vernietigd. De enige wijze waarop de Hoge Raad binnen deze cassatiegronden het feitenoordeel kan toetsen, is aan de hand van de gegeven motivering. Het niet in acht nemen van de in de wet opgenomen 
motiveringsvoorschriften leidt immers tot nietigheid ${ }^{39}$ en vormt een vormverzuim. Mede gezien het feit dat de Hoge Raad zelf geen feitenonderzoek doet, en dus de door de feitenrechter vastgestelde feiten als vaststaand aanneemt, is de controle op de inhoudelijke juistheid van die motivering zeer beperkt.

Dat geldt in de eerste plaats voor de in de wet opgenomen eis van redengevendheid van het bewijsmateriaal. Zoals in hoofdstuk 4 beschreven, weigerde de Hoge Raad reeds in 1926 bij gebrek aan in de wet genoemde criteria op dit punt het gebezigde bewijsmateriaal te toetsen. Het in het derde lid van artikel $359 \mathrm{~Sv}$ opgenomen motiveringsvoorschrift verwerd ondanks de grootse bedoelingen van de wetgever tot een dode letter. Enkel in geval van aperte en niet excuseerbare niet-redengevendheid van het bewijsmateriaal grijpt de Hoge Raad in.

Ook ten aanzien van de betrouwbaarheid van het gebezigde bewijsmateriaal is toetsing in cassatie marginaal. Volgens vaste rechtspraak is de feitenrechter hierin vrij en kan in cassatie op dit punt het oordeel van de feitenrechter niet worden aangevochten. De Hoge Raad heeft weliswaar ten aanzien van specifieke bewijsverweren geëist dat de feitenrechter een nadere toelichting geeft op het gebruik van het bewijsmateriaal, maar zoals in hoofdstuk 6 is geconcludeerd, diende die motivering er met name toe zichtbaar te maken dat de rechter tot een eigen beslissing was gekomen. Controle in cassatie bleef dan ook tot dat punt beperkt. Voor de in artikel 360 opgenomen nadere motiveringsplichten geldt in wezen hetzelfde. Ook de daar genoemde motiveringsplichten hebben een beperkte strekking. De feitenrechter moet uit zijn motivering laten blijken dat hij ofwel zich bewust is geweest van het dubieuze karakter van het bewijsmateriaal, ofwel zelfstandig de bewijswaarde daarvan heeft beoordeeld. Inhoudelijke overwegingen die ingaan op de kwaliteit van het bewijsmateriaal zijn niet vereist, hetgeen er in de praktijk toe leidt dat vaak algemene, weinig zeggende standaardoverwegingen in vonnissen van feitenrechters verschijnen.

\subsubsection{De inscherpingsfunctie}

Eén van de meest wezenlijke functies die aan de motivering wordt toegekend, is dat de motivering er toe bijdraagt dat de rechter zich terdege bewust wordt van de beslissing die hij moet nemen en de factoren die daarbij een rol spelen. Wordt immers van hem enkel verwacht dat hij de knoop doorhakt, dan kan hij volstaan met in het vonnis opnemen van de conclusie van zijn beraadslagingen. Welke argumenten tijdens zijn beraad een rol hebben gespeeld, hoeft hij niet te vermelden. Onduidelijk blijft dan ook of de rechter alle relevante argumenten onder ogen heeft gezien. Wordt daarentegen van de rechter verlangd dat hij zijn beslissing onderbouwt, dan betekent dit dat de rechter niet alleen moet instaan voor de

39 Art. 359 lid 8 en 360 lid 4 Sv. 
juistheid van zijn conclusie, maar ook de redenering die hem daartoe heeft gebracht voor zijn rekening neemt. ${ }^{40}$ De plicht tot rationele onderbouwing heeft tot gevolg dat de rechter eventuele subjectieve elementen in zijn gedachtegang onderkent en uitsluit. ${ }^{41}$

De verplichting tot motivering maakt de rechter bovendien bewust van het feit dat hij als enige verantwoordelijk is voor het uiteindelijke oordeel. Uit de motivering moet dan ook blijken dat hij tot een eigen, rationeel te verantwoorden conclusie is gekomen. De juistheid van eerder door andere in het strafproces betrokken personen getrokken conclusies mag hij niet enkel aannemen omdat zij instaan voor de juistheid. Van de rechter wordt verlangd dat hij dergelijke conclusies alleen overneemt als hij ze tot de zijne heeft gemaakt. Daartoe zal hij wel argumenten moeten aandragen.

De plicht tot motivering draagt zo bezien bij aan het concretiseren van de institutionele eisen die aan het rechtersambt worden gesteld, te weten de onafhankelijkheid, onpartijdigheid en professionaliteit. Door van de rechter te eisen dat hij zijn oordeel onderbouwt, wordt hij gedwongen inzichtelijk te maken dat het onderzoek ter terechtzitting hem voldoende informatie heeft verschaft op basis waarvan hij zelfstandig tot een conclusie is gekomen zonder terug te vallen op het oordeel van anderen. Ten aanzien van het feitenoordeel in strafzaken betekent dit dat de rechter de onderzoeksresultaten van politie en justitie niet enkel mag aannemen omdat zij instaan voor de juistheid. Hetzelfde geldt voor het oordeel van de deskundige. Uit de motivering moet blijken dat de rechter de waarde van het ter zitting gepresenteerde bewijsmateriaal zelfstandig heeft beoordeeld en dat hij de beschikking had over voldoende gegevens om tot een dergelijk zelfstandig oordeel te komen. De motiveringsplicht bezien vanuit de inscherpingsfunctie vloeit als het ware voort uit de eis van de materiële waarheidsvinding die aan ons strafproces ten grondslag ligt. Niet partijen, maar de rechter is verantwoordelijk voor de waarheidsvinding. Bovendien veronderstelt materiële waarheidsvinding dat het feitenoordeel met een hoge mate van waarschijnlijkheid overeenkomt met hetgeen zich in werkelijkheid heeft afgespeeld. Of dat het geval is, kan niet enkel worden aangenomen op basis van het gegeven dat de rechter overtuigd is. Aan die overtuiging komt pas waarde toe indien zij steunt op argumenten, die

40 In gelijke zin: Corstens 2005b, 1733: 'door te motiveren wordt de rechter scherper met de te beantwoorden vragen geconfronteerd, dan wanneer hij mag volstaan met het weergeven van conclusie. Dat kan er vervolgens toe leiden dat rechters zich actiever opstellen ten aanzien van de opsporingsresultaten' en Israëls 2006, p. 195: 'Een uitgebreide motivering dwingt de rechter om na te denken over de vraag hoe het bewijs nu precies in elkaar zit.'

41 Ook Buruma heeft kennelijk het oog op de inscherpingsfunctie als hij schrijft: 'Uiteindelijk is motivering het formuleren van argumenten bij een genomen beslissing, al kan het besef van het bestaan van de eis tot motivering het proces van besluitvorming verdiepen.' Buruma 1996, p. 13. 
kenbaar moeten worden gemaakt en kunnen worden getoetst op hun geldigheid. $^{42}$

De inscherpingsfunctie is een noodzakelijke aanvulling op de controlefunctie. Wettelijke bewijsregels bieden slechts minimumgaranties waaraan bewijsoordelen in abstracto moeten voldoen. Het abstracte en basale karakter van die bewijsregels leidt er toe dat in de concrete strafzaak de strafrechter een grote discretionaire bevoegdheid toekomt met betrekking tot de beoordeling van de bewijswaarde van het hem gepresenteerde bewijsmateriaal. ${ }^{43}$ De rechter mag deze bevoegdheid niet naar eigen inzicht toepassen, maar zal uit de motivering van zijn oordeel moeten laten blijken dat zijn oordeel steunt op argumenten die zijn beslissing kunnen dragen. Dat die argumentatie niet volledig sluitend kan zijn, vloeit voort uit het gegeven dat de waarheidsvinding in strafzaken ook geen gesloten systeem is. Een zekere mate van onzekerheid blijft bestaan en ten aanzien daarvan is de subjectieve overtuiging van de rechter doorslaggevend.

De inscherpingsfunctie van de motivering is als zodanig niet letterlijk terug te vinden in de motiveringsbepalingen, maar kan worden afgeleid uit het zeer algemeen gestelde motiveringsvoorschrift van artikel 359 lid 2 eerste volzin Sv: de beslissingen (...) zijn met redenen omkleed. Het tweede lid van artikel $359 \mathrm{~Sv}$ heeft lange tijd geen voor het bewijsoordeel relevante betekenis gehad. Vanaf de jaren tachtig heeft het voorschrift in de jurisprudentie van de Hoge Raad meer inhoud gekregen. In bepaalde gevallen oordeelde de Hoge Raad dat de vrijheid van de feitenrechter met betrekking tot de selectie en waardering van het bewijsmateriaal wel degelijk nader moest worden verantwoord, namelijk in die gevallen waarin de verdediging op goede gronden het gebruik van bepaald bewijsmateriaal ter discussie had gesteld. In dergelijke gevallen, zoals naar voren kwam in paragraaf 6.3.3, moest de rechter laten blijken dat hij het verweer van de verdediging onder ogen had gezien en, voor zover hij het niet overnam, aangaf om welke redenen het niet slaagde. De gevallen waarin de Hoge Raad een dergelijke responsieplicht aannam, hadden één gemeenschappelijk kenmerk. Het betrof meestal kwesties waarin twijfels konden rijzen over de vraag of de feitenrechter zelfstandig de waarde van het hem gepresenteerde bewijsmateriaal kon beoordelen. Teneinde die twijfels weg te nemen, diende de rechter in de motivering tot uitdrukking te

42 In gelijke zin: Buruma 2005, p. 76: 'Motivering kan ten derde als vorm van zelfcontrole voordelen ter ontdekking van de materiële waarheid opleveren. De motivering heeft dan tot doel eraan bij te dragen dat het proces leidt tot een feitelijk en juridisch juiste uitspraak en tot de door de rechter gewenste straf: het doel is juistheid (of effectiviteit).'

43 In gelijke zin: Abels \& Nijboer 1981, p. 269: 'De uitspraken van de Hoge Raad strekken er niet in de eerste plaats toe (bindende) voorschriften te geven aan de lagere rechter. Het is weliswaar van belang voor de rechter te weten wat de Hoge Raad ontoelaatbaar acht, maar dit levert alleen een buitengrens op. Hierbinnen bestaat dan nog een aanzienlijke ruimte voor de rechter, waarin hij zelfstandig kan opereren.' 
brengen dat hij tot een onafhankelijk en onpartijdig oordeel was gekomen op basis van zijn eigen kennis. Zeer duidelijk wordt dat in gevallen waarin de expertise van een ingeschakelde deskundige of tolk wordt betwist. Was die betwisting voldoende onderbouwd, dan kon de rechter niet volstaan met het enkel opnemen van de verklaring bij de bewijsmiddelen, maar diende hij uitdrukkelijk in het vonnis te overwegen waarom hij de deskundige of tolk capabel achtte en diens mening tot de zijne maakte. Hij moest met andere woorden duidelijk maken dat hij zijn waarheidsvindende taak niet afschoof op een ander.

Hetzelfde idee ligt ten grondslag aan de nadere motiveringsplichten ten aanzien van het anonieme bewijs en de verklaring van de afgeschermde getuige, beide opgenomen in artikel $360 \mathrm{~Sv}$. Ten aanzien van deze bewijsmiddelen geldt dat de ambtshalve rechterlijke onderzoeksplicht naar de betrouwbaarheid van de inhoud van die bewijsmiddelen op een of andere wijze wordt beperkt. De rechter zal dan in zijn vonnis kenbaar moeten maken dat hij ondanks die handicap zelfstandig die betrouwbaarheid heeft onderzocht. Hij mag zich dus niet verschuilen achter het oordeel van de rechter-commissaris.

Uit de totstandkoming van en jurisprudentie met betrekking tot de in artikel 359 lid $2 \mathrm{~Sv}$ opgenomen responsieplicht op standpunten van procespartijen blijkt dat die bepaling geen direct aan de materiële waarheidsvinding gerelateerde functie heeft. Artikel 359 lid $2 \mathrm{~Sv}$ is dan ook reeds om die reden geen codificatie van de jurisprudentie van de Hoge Raad aangaande bewijsverweren. Deze bepaling moet veeleer in verband worden gebracht met de hierna te bespreken explicatiefunctie.

Kan aldus de oude jurisprudentie met betrekking tot de motiveringsplicht naar aanleiding van bewijsverweren en artikel $360 \mathrm{~Sv}$ in verband worden gebracht met de inscherpingsfunctie van de motivering, dat wil niet zeggen dat die functie ook volledig tot zijn recht komt. Belangrijkste oorzaak is dat de Hoge Raad weigert de nadere motiveringsplichten ook inhoudelijk te toetsen. Voldoende is dat uit de motivering blijkt dat de rechter zich bewust is geweest van zijn - ondanks zijn formeel onafhankelijke status - afhankelijke positie. Evenmin verplicht de cassatierechter de feitenrechter - buiten verzoeken van de verdediging om - tot het doen van nader onderzoek waaruit wellicht aanwijzingen naar voren zouden kunnen komen die behulpzaam zouden kunnen zijn bij de waardering van het bewijsmateriaal. De strafrechter heeft wel een ambtshalve onderzoeksbevoegdheid, maar geen ambtshalve onderzoeksplicht.

\subsubsection{De explicatiefunctie}

De explicatiefunctie van de motivering wijkt af van de controle- en inscherpingsfunctie van de motivering in die zin dat zij niet specifiek gekoppeld is aan de normering van het oordeel dat gemotiveerd dient te worden. Het ziet op de plicht 
van de rechter om betrokkenen en het publiek in te lichten en uitleg te geven over zijn oordeel. Die plicht vloeit voort uit het feit dat de rechter oordeelt in een democratisch vacuüm. Het vonnis met de daarin opgenomen motivering is de enige vorm van verantwoording die de rechter aflegt. Buiten het vonnis om kan en mag de rechter niet spreken. Het geheim van de raadkamer verzet zich daartegen. Dat maakt dat wil aan het oordeel van de rechter enig inhoudelijk gezag toekomen, de rechter in het vonnis de vereiste inlichtingen en uitleg moet geven. Dit uitgangspunt ligt ook ten grondslag aan het project verbetering motivering strafvonnissen en is zeer duidelijk verwoord door de toetsingscommissie van het project:

'Het doel van PROMIS is te komen tot een betere communicatie tussen de strafrechter, betrokkenen en de samenleving als geheel. Met die communicatie staat voor de rechterlijke macht een groot belang op het spel. Duidelijk gemaakt zal moeten worden dat we in een rechtsstaat leven, die wordt gekenmerkt door het bestrijden van willekeur. Dat is niet alleen in het belang van de rechterlijke macht zelf, die mede daaraan haar gezag ontleent. Het is ook van belang voor de betrokkenen en de samenleving als geheel. Uit onderzoek blijkt telkens weer dat de rechter in onze samenleving nog steeds een groot gezag geniet. Maar het is een broos bezit. De laatste jaren is ook de rechter steeds vaker onder vuur komen te liggen niet alleen in de media, maar ook - en de laatste jaren steeds vaker - in de politiek. (...) De belangrijkste bijdrage die de rechter aan de communicatie kan leveren ligt daarom besloten in zijn vonnis. Daarmee beschikt hij over een machtig instrument om te laten zien dat we in een rechtsstaat leven waarin willekeur naar vermogen wordt bestreden. ${ }^{, 4}$

Zoals ook uit dit citaat volgt is uitleg van de rechter niet alleen bedoeld voor de betrokkenen in het strafproces en niet in de laatste plaats de verdachte, maar ook voor het publiek. Zij hebben er recht op om te weten op welke gronden de rechter tot zijn oordeel is gekomen. Meer specifiek hebben zij er recht op om te weten op welke wijze de rechter de inbreng van betrokkenen in het strafproces heeft gewaardeerd.

Dat geldt in de eerste plaats voor de verdachte die zijn betrokkenheid bij het hem tenlastegelegde feit ontkent. Hij mag verwachten dat de rechter indien hij het feit bewezen acht hem uitlegt waarom hij aan die ontkenning geen waarde heeft gehecht en waarom door hem ingebrachte verweren terzijde zijn geschoven. Bovendien dient hij uit het vonnis te kunnen lezen of er redenen zijn om het oordeel aan een hogere instantie voor te leggen. Hetzelfde geldt voor de officier van justitie; ook hij mag verwachten dat de rechter in geval van een vrijspraak expliciet in het vonnis uiteenzet waarom het door de officier van justitie aangedragen bewijsmateriaal kennelijk niet voldoende was om tot een bewezenverklaring te komen. Het geven van uitleg aan de procespartijen heeft zo bezien niet alleen een democratische, maar ook een waarheidsvindende functie. Het stelt immers procespartijen in staat om te beoordelen op welke gronden hun inbreng in het proces is beoordeeld. Met die kennis kunnen zij vervolgens de juistheid

44 Promis Evaluatieverslag 2005, p. 50. 
van het rechterlijk bewijsoordeel zelf beoordelen en indien gewenst voorleggen aan een hogere instantie. Het is, in de woorden van Habermas, een noodzakelijke voorwaarde voor de voortzetting van het debat in hoger beroep.

Maar ook andere betrokkenen in het strafproces, zoals getuigen en deskundigen, zouden uit het vonnis moeten kunnen lezen hoe en op welke gronden de rechter hun inbreng heeft gewaardeerd. ${ }^{45}$ Deskundigen klagen vaak over het feit dat zij zelden te horen krijgen of hun rapportage gevolgd is en zo nee, waarom niet. ${ }^{46}$ Ook lagere rechters zouden als betrokkenen in het strafproces moeten worden beschouwd zodra hun oordeel is voorgelegd aan een hogere instantie. Het feit dat hun aanvankelijke beslissing ter discussie wordt gesteld, vraagt om een gedegen uitleg van de hogere instantie, waarom deze het oordeel in stand houdt dan wel vernietigt. Daar kan overigens ook een kwaliteitsverbeterend effect van uitgaan. De rechter die weet waarom zijn oordeel geen stand houdt in appel, zal daaruit lering trekken voor toekomstige gevallen.

Behalve betrokkenen in het strafproces die ieder voor zich belang kunnen hebben bij het feit dat de rechter uitlegt hoe hij tot zijn beslissing is gekomen, heeft het 'publiek in het algemeen' belang bij rechterlijke uitleg. Willen rechters in concrete strafzaken en de rechterlijke macht als geheel aanspraak maken op vertrouwen, dan dienen hun uitspraken de gronden te bevatten waarop zij rusten.

'Het expliciet maken van alle stappen in een rechterlijke redenering is de enige wijze waarop de rechter zijn uiteindelijke beslissing kan legitimeren, zowel ten opzichte van de betrokken verdachte burger als ten opzichte van de gemeenschap in het algemeen. ${ }^{47}$

De motivering van de rechterlijke oordelen ten behoeve van het publiek moet worden beschouwd als het sluitstuk van de eis van externe openbaarheid. ${ }^{48}$ Openbaarheid van de zitting heeft immers slechts zin indien het publiek ook inzicht krijgt in de daarop gebaseerde beslissing. Voor zover uit die beslissing niet blijkt welke waarde de rechter aan het ter zitting gepresenteerde bewijsmateriaal toekent en hoe hij de bijdragen van de officier van justitie en de verdediging heeft gewaardeerd, zou wellicht de indruk kunnen ontstaan dat de behandeling ter zitting slechts een pro forma aangelegenheid is. Het feit dat het vonnis ook bestemd is

45 Nijboer 1987, p. 126.

46 Broeders 2002a, p. 1797: 'In een rechtssysteem waarin de motiveringsplicht wel bestaat maar om een aantal redenen verre van optimaal functioneert is het voor deskundigen moeilijk een idee te krijgen van het effect van hun inspanningen.' In gelijke zin: Crombag 2000, p. 1663-1664: 'In de meestal summiere motivering van het vonnis komt zo'n deskundigen-bericht zelden voor, hetgeen overigens niet zonder meer hoeft te betekenen dat de rechter er ook niets aan gehad heeft. En als hij er niets aan gehad en daarom er niets mee gedaan heeft, dan moet je er in de meeste gevallen naar raden wat de reden daarvan was. Dat frustreert niet alleen de nieuwsgierigheid van de deskundige, het berooft hem ook van het leereffect dat heldere terugkoppeling teweeg zou kunnen brengen.'

47 Mevis 1998, p. 20.

48 Brants \&Van Lent 2001, p. 169. 
voor het grote publiek veronderstelt dat niet alleen het vonnis beschikbaar is, maar bovendien de inhoud ervan te begrijpen is voor het grote publiek. Het is dan ook vaak met een beroep op de explicatiefunctie van de motivering dat gevraagd wordt om meer begrijpelijke vonnissen.

De explicatiefunctie van de motivering wordt geacht te zijn geïncorporeerd in artikel 121 van de Grondwet, waarin is bepaald dat terechtzittingen in het openbaar plaatsvinden en vonnissen de gronden inhouden waarop zij rusten. De koppeling aan de openbaarheid van de terechtzitting maakt duidelijk dat niet alleen de betrokken procespartijen, maar ook burgers in het algemeen recht hebben op uitleg, wil aan het vonnis in dit opzicht een legitimerende werking toekomen. Terecht heeft Mevis erop gewezen dat bij de uitwerking van deze bepaling in het Wetboek van Strafvordering dit algemeen rechtstatelijke principe is ondergesneeuwd. ${ }^{49}$ Geen van de specifieke motiveringsbepalingen ziet expliciet op dit aspect van de explicatiefunctie. ${ }^{50}$ Veeleer is de gedachte dat waar uitleg wordt gegeven aan de verdachte dit ook kan gelden als uitleg voor het grote publiek. Dat uitgangspunt is ook terecht; er zou geen onderscheid moeten bestaan tussen hetgeen de verdachte enerzijds en hetgeen het publiek anderzijds te horen krijgt. Dat veronderstelt echter dat de uitleg die de verdachte krijgt ook geschikt is voor ieder ander. Dat is vaak niet het geval; simpelweg omdat bijvoorbeeld het publiek niet beschikt over het procesdossier en dus bijvoorbeeld verwijzingen daarnaar niet kan nalezen.

Wordt de uitwerking van de grondwettelijke explicatieplicht in het Wetboek van Strafvordering nader beschouwd, dan blijkt nog een tweede beperking. Uitleg wordt alleen gegeven wanneer daarom gevraagd wordt en ook dat geldt pas sinds relatief korte tijd. Geen van de oorspronkelijk in 1926 in het Wetboek van Strafvordering opgenomen motiveringsplichten heeft daadwerkelijk tot doel het geven van uitleg aan de betrokkenen. Het vermelden van de inhoud van de bewijsmiddelen ziet op controle op de wettigheid, toereikendheid en naderhand ook op de redengevendheid van het door de rechter gebezigde bewijsmateriaal. De in artikel 360 $\mathrm{Sv}$ opgenomen nadere motiveringsplicht diende ter vervanging van de eerdere bewijsregels en heeft dus een hoofdzakelijk controlerende functie. En tot slot: het oorspronkelijke tweede lid van artikel $359 \mathrm{~Sv}$ zag niet op bewijsverweren en had voor het overige lange tijd geen betekenis voor de bewijsbeslissing. Voor zover het dat wel kreeg toen de Hoge Raad daaruit een responsieplicht op specifieke

49 Mevis 1998, p. 22-23.

50 Buruma 2005, p. 74 is overigens niet zo overtuigd van het belang van uitleg naar het publiek: 'Voor de samenleving als geheel ligt de noodzaak om bewijsbeslissingen en strafmaatbeslissingen nader te motiveren ook niet voor de hand - die samenleving krijgt zelden rechterlijke uitspraken onder ogen. Misschien is verder motiveren voor de legitimiteit jegens de samenleving alleen nodig in geval van een opmerkelijke vrijspraak of een onverwacht lage straf.' 
verweren afleidde, had dat niet primair tot doel de betrokkenen uitleg te geven, maar was dat vooral om te benadrukken dat de feitenrechter zelfstandig tot een eigen beslissing was gekomen. Alleen de vanaf 1 januari 2005 geldende responsieplicht naar aanleiding van door partijen ingenomen standpunten komt enigszins tegemoet aan de explicatiefunctie. Deze is echter beperkt tot het geven van uitleg aan partijen en bovendien geldt zij alleen indien daarom expliciet gevraagd wordt. Wordt de motivering in het licht van de explicatiefunctie beperkt tot bijdragen van het Openbaar Ministerie en de verdediging, daarmee is echter niet gezegd dat in alle gevallen deze partijen een expliciet antwoord krijgen op door hen ingenomen stellingen. In het arrest van de Hoge Raad d.d. 11 april 2006 is de responsieplicht van de rechter sterk gerelativeerd; de Hoge Raad neemt niet snel een motiveringsplicht aan, en voor zover hij dat wel doet, leidt niet-leving ervan lang niet in alle gevallen tot nietigheid. ${ }^{51}$ Bovendien speelt de explicatiefunctie in de ogen van de Hoge Raad kennelijk geen rol in die gevallen waarin geen rechtsmiddel wordt ingesteld, want dan wordt de feitenrechter niet verplicht tot gemotiveerd weerleggen van door partijen ingenomen standpunten. Zoals in hoofdstuk 3 is gebleken is daarmee in meer dan $95 \%$ van de zaken een nadere explicatie niet noodzakelijk. Slechts de zogeheten promis-vonnissen komen meer tegemoet aan de explicatiefunctie in die zin dat motivering niet in alle gevallen afhankelijk wordt gesteld van het handelen van procespartijen. Dat geldt zowel voor de in te nemen standpunten als voor het instellen van het rechtsmiddel.

Tot slot geldt ook hier - evenals ten aanzien van de controle en inscherpingsfunctie - dat de Hoge Raad de door de feitenrechters gegeven motiveringen niet inhoudelijk zal toetsen. De controle is beperkt tot de vraag of de feitenrechter aan zijn responsieplicht heeft voldaan. Voor zover de explicatiefunctie dus al ten grondslag ligt aan de nieuwe in artikel 359 lid $2 \mathrm{~Sv}$ opgenomen responsieplicht eist zij slechts dat de rechter uitlegt; de inhoud van die uitleg is minder van belang.

\subsection{De verhouding tussen de verschillende motiveringsfuncties}

In de voorgaande paragraaf is gebleken dat de motivering verschillende functies heeft en dat deze elkaar deels aanvullen. Dat is evident met betrekking tot de controlefunctie en de inscherpingsfunctie. Beide functies zien op de normering van het rechterlijke bewijsoordeel; uit de motivering moet blijken dat de abstracte minimumnormen in acht zijn genomen (de controlefunctie) en de rechter in het concrete geval een juiste afweging van de relevante feiten en omstandigheden heeft gemaakt. Beide functies dragen direct bij aan het verzekeren van een juiste, althans zo goed mogelijke uitkomst van het strafproces.

51 HR 11 april 2006, NJ 2006, 393 m.nt. Y. Buruma. 
De explicatiefunctie is in principe niet gericht op de inhoudelijke normering van het bewijsoordeel. Zij ziet in de eerste plaats op de manier van motiveren. In de explicatiefunctie ligt de opdracht aan de rechter de motivering zodanig vorm te geven dat die niet alleen voor betrokkenen, maar ook voor het publiek begrijpelijk is. De verhouding van de explicatiefunctie tot de controle- en inscherpingsfunctie is afhankelijk van de invulling die daaraan wordt gegeven. Zij kan aanvullend dan wel beperkend zijn. Van aanvulling is sprake indien de rechter buiten de bestaande ambtshalve motiveringsplichten om besluit tot nadere uitleg naar aanleiding van bijvoorbeeld een opgeworpen verweer. In deze zin is zij dienend aan de materiële waarheidsvinding. Het biedt immers partijen de mogelijkheden om bewijskwesties op te werpen die de rechter mogelijk over het hoofd ziet én die hij alleen onder aanvoering van relevante feiten en argumenten kan verwerpen of aannemen. Beperkend is zij indien de omvang van de motivering afhankelijk wordt van hetgeen door partijen ter discussie is gesteld. In dat geval wordt de verantwoordelijkheid voor de omvang en kwaliteit van de waarheidsvinding verschoven van de rechter naar partijen. ${ }^{52}$

Zoals in de vorige paragraaf eveneens bleek, komen geen van de bovengenoemde functies volledig tot hun recht in de bestaande motiveringsplichten met betrekking tot de bewezenverklaring. De reden daarvoor is tweeledig. Ten eerste zijn de plichten ofwel in de loop der tijd door de wetgever zodanig beperkt of worden deze door de Hoge Raad zodanig beperkt uitgelegd, dat daaraan nauwelijks enige toegevoegde waarde voor de normering van de waarheidsvinding toekomt. Dat geldt voor de plicht tot het opnemen van de inhoud van de bewijsmiddelen in het vonnis ex artikel 359 lid 1 en de nadere motiveringsplichten opgenomen in artikel $360 \mathrm{~Sv}$. Ten tweede - en dat geldt voor alle motiveringsplichten - toetst de Hoge Raad de door de door feitenrechters gegeven motivering enkel op begrijpelijkheid; slechts indien deze onbegrijpelijk of ontoereikend is, grijpt de Hoge Raad in. Deze terughoudendheid geeft feitenrechters de mogelijkheid om te volstaan met zeer summiere en weinig concrete motiveringen. ${ }^{53}$ Dat geldt eens te meer nu ook

52 Naar aanleiding van de rechterlijke dwaling in de Schiedammer parkmoord merkt Van den Emster 2005, p. 295 op dat er twee lessen zijn te leren. De eerste ziet op het gebruik van bekentenissen voor het bewijs. 'De tweede les is, dat de rechter steeds zelf verantwoordelijk is voor de waarheidsvinding, zowel ten opzichte van het openbaar ministerie, als ten opzichte van de verdachte en de verdediging, ongeacht of die procespartijen het over de noodzaak van een onderzoekshandeling eens zijn. De strafrechter zal ook deze les als vanzelfsprekend ervaren.'

53 In gelijke zin: Broeders 2000, p. 70 (met verwijzing naar Anderson 1999): 'Een belangrijk punt van kritiek op het functioneren van het Nederlandse strafrechtssysteem wordt gevormd door het ontbreken van een controle die verder gaat dan een formele toets, waardoor dit door Anderson in Complex Cases (p. 48) als auditmodel omschreven systeem niet goed functioneert.' 
de Hoge Raad niet bereid is het bewijsoordeel op andere dan de minimale wettelijke gronden te toetsen.

Ook de onlangs in de wet neergelegde responsieplicht naar aanleiding van door procespartijen ingenomen standpunten heeft geen toegevoegde waarde. Hoewel formeel de feitenrechter verantwoordelijk blijft voor de deugdelijkheid van het bewijsoordeel, kan - zeker gezien het feit dat die rechterlijke verantwoordelijkheid slechts in beperkte mate kan worden getoetst - de koppeling van de motivering aan de inbreng van procespartijen makkelijk leiden tot het afschuiven van verantwoordelijkheden op procespartijen. Voor zover partijen niet ageren tegen het ingebrachte bewijsmateriaal mag de rechter aannemen dat dit deugdelijk is. De noodzaak tot nader onderzoek en tot beredenering waarom die resultaten wettig, rechtmatig verkregen, relevant en betrouwbaar zijn, is niet aanwezig. ${ }^{54}$ Gekoppeld aan de eerder vastgestelde onwilligheid van de Hoge Raad om het bewijsoordeel meer inhoudelijk te toetsen, heeft de in artikel 359 lid 2 Sv opgenomen explicatieplicht eerder een negatief dan een positief effect op de waarheidsvinding. Het kan er toe leiden dat - afhankelijk van de kwaliteit en mogelijkheden van de verdediging - de waarheidsvinding beperkt blijft tot hetgeen de rechter van het Openbaar Ministerie krijgt voorgeschoteld.

\subsection{Lessen uit Duitsland}

Zoals in hoofdstuk 7 is gebleken kent Duitsland geen wettelijke motiveringsplicht ten aanzien van het bewijsoordeel. Dat heeft het Bundesgerichtshof er echter niet van weerhouden van de feitenrechters te verlangen hun overtuiging in strafzaken te objectiveren. In tegenstelling tot de Nederlandse cassatierechter toetst het Bundesgerichtshof de gegeven motiveringen wel inhoudelijk. Niet zoals in Nederland aan wettelijke bewijsregels - die kent het Duitse recht niet - maar wel aan algemene ervaringsregels en wetenschappelijke inzichten. Daarbij geldt als maatstaf dat het oordeel met hoge waarschijnlijkheid moet overeenkomen met de werkelijkheid. Dat geldt zowel voor een vrijspraak als voor een bewezenverklaring. De Duitse cassatierechter geeft geen eigen oordeel over de feiten in strafzaken, maar beziet slechts of de feitenrechter alle relevante factoren zichtbaar en met in achtneming van de juiste criteria heeft afgewogen.

Deze toetsing gaat beduidend verder dan de toetsing van het feitenoordeel zoals die door de Hoge Raad wordt uitgevoerd. De toetsing van de Hoge Raad is beperkt tot de inachtneming van de wettelijke bewijs- en motiveringsregels. De bewijsregels zijn grotendeel uitgehold en de motiveringsregels stellen geen eisen

54 In gelijke zin: Pelser 2002, p. 57: 'Doordat er zonder tegenspraak weinig of geen aandacht aan de bewijsmotivering hoeft te worden besteed, gaat zelfs een mogelijkheid tot inscherping van de rechter op termijn - niet meer relevant voor de concrete zaak, maar wel een leermoment - verloren.' 
aan de inhoud van de motivering. Het is slechts een formele motiveringseis die in cassatie inhoudelijk slechts marginaal - op begrijpelijkheid - getoetst wordt.

In Duitsland daarentegen dwingt het Bundesgerichtshof de feitenrechters tot het weergeven van de redenering op een zodanige manier dat in cassatie de volledigheid, de consistentie en de geldigheid getoetst kunnen worden zonder dat de cassatierechter op de stoel van de feitenrechter gaat zitten. Van de feitenrechter wordt verlangd dat hij alle voor de bewijsbeslissing relevante - belastende en ontlastende - feiten en omstandigheden afweegt en dat zichtbaar maakt in het vonnis. Een op deze wijze vormgegeven motiveringsplicht dwingt de rechter zijn onderzoek uit te breiden tot alle in aanmerking komende scenario's. Voor zover dat al niet volgt uit de specifieke eisen die de cassatierechter stelt aan de motivering volgt dat uit de Aufklärungspflicht van de rechter.

Daarmee wordt tegemoet gekomen aan het meest wezenlijke belang van de motivering van de bewijsbeslissing, te weten het bijdragen aan een juiste ${ }^{55}$ beslissing. ${ }^{56}$ Motivering veronderstelt dat de rechter beschikt over feiten en argumenten waarop hij zijn beslissing baseert. ${ }^{57}$ Tot die feiten en argumenten dient hij het onderzoek ter zitting uit te breiden. Hij dient niet alleen het belastende verhaal van het Openbaar Ministerie op zijn juistheid te onderzoeken, maar ook het mogelijke tegenverhaal in zijn onderzoek te betrekken. ${ }^{58}$ Alleen dan is hij in staat zijn uiteindelijke beslissing inhoudelijk te motiveren. ${ }^{59}$ De motiveringsplicht is in die

55 Juist in de betekenis zoals door Habermas 1997, p. 277 gedefinieerd: 'Richtigkeit bedeutet rationale, durch gute Gründe gestützte Akzeptabilität.'

56 Anders: Buruma 2006, p. 1088. Buruma beziet de motivering in het licht van het betrekken van burgers bij de rechtspraak. In de rechtspraak moet zijns inziens tot uitdrukking komen dat de inhoud van de wet een gedeelde waarde is. Buruma gaat daarbij volledig voorbij aan het feit dat motivering van de bewijsbeslissing weinig van doen heeft met gedeelde waardes die in de wet besloten liggen, maar veel meer met de kwaliteit van de waarheidsvinding. Hetgeen tot uitdrukking komt in zijn woorden: 'Om het onbehagen en de onvrede van de burgers te lenigen moeten rechters een minder bloedeloze - ja meer naar moralisme neigende benadering kiezen dan ze nu doen en meer aandacht besteden aan het spreken dan aan het schrijven. Het beoogde doel van zo'n benadering is niet zozeer dat de kwaliteit van de afdoening van de individuele zaak verbetert, als wel dat rechters aldus bijdragen aan een voorstelling van de samenleving als een samenleving waarin gedeelde menselijke waarden niet zijn teloorgegaan.'

57 In gelijke zin: Barning \& Nijboer 1989, p. 1176-1177: 'Het aanscherpen van de controle op de bewijsconstructie door de cassatierechter is een belangrijk middel om de rechtspraktijk te sturen. De motiveringseisen met betrekking tot de bewezenverklaring werpen hun schaduw vooruit naar de normering van de bewijsbeslissing. Die beslissing wordt immers mede beïnvloed door de af te leggen verantwoording. De bewijsbeslissing zelf behelst een sluitstuk van het onderzoek. Zowel in het vooronderzoek als ter terechtzitting beïnvloeden de eisen die bij de bewijsbeslissing worden gesteld op hun beurt de gang van zaken bij het onderzoek.'

58 In gelijke zin: met betrekking tot het gebruik de CBCA-methode: Crombag \& Wagenaar 2000, p. 95: 'Zowel het verhaal als het tegenverhaal behoeven zorgvuldige analyse. Dat geldt zowel voor de rechter als voor de deskundige die hem op onderdelen bijstaat.'

59 In gelijke zin: A.M. van Woensel, aant. 6 op art. 338-344 (suppl. 91 oktober 1994), in 
zin niet beperkt tot het enkel aansporen van de rechter dat hij zich bewust moet zijn van zijn eigen verantwoordelijkheid voor het feitenoordeel in strafzaken of tot de inachtneming van de wettelijke bewijsregels, maar bewerkstelligt dat de rechter die verantwoordelijkheid ook daadwerkelijk waarmaakt. Daarbij kan hij zich niet verschuilen achter algemene nietszeggende motiveringen ${ }^{60}$ of achter het optreden van de procespartijen.

Voor zover in Nederland de materiële waarheidsvinding met de daaraan gekoppelde eigen verantwoordelijkheid van de rechter voor die waarheidsvinding nog steeds centraal staat, mag de motivering niet worden overgelaten aan de bereidheid van feitenrechters om meer dan de minimale onderbouwing in vonnissen op te nemen. Waar het onderzoek ter terechtzitting en de beslissing naar aanleiding van dat onderzoek in één hand liggen, is het gevaar aanwezig dat het onderzoek niet verder zal reiken dan voor de beslissing noodzakelijk is. Zeker als daarbij wordt bedacht dat de rechter in Nederland voor de feitenverzameling in grote mate afhankelijk is van hetgeen politie en justitie hem aandragen en hij zonder serieuze bewijsrechtelijke belemmering die feiten ten grondslag kan leggen aan zijn beslissing. Het is om die reden dat ook het project verbetering motivering strafvonnissen (Promis) - hoe lovenswaardig ook - niet primair zal bijdragen aan betere, dat wil zeggen inhoudelijk juistere bewijsoordelen. Binnen Promis is het immers de rechter zelf die de omvang van het onderzoek en de omvang en inhoud van de motivering bepaalt. Die combinatie van factoren maakt dat de rechter kan volstaan met een beperkte of nietszeggende motivering.

Willen we zo goed als mogelijk garanderen dat het bewijsoordeel in strafzaken overeenstemt met de werkelijkheid, dan moeten we meer verlangen van de rechter. De wetenschap dat nooit met zekerheid de ware toedracht van de feiten kan worden vastgesteld, zou er niet toe moeten leiden dat we dus maar genoegen nemen met de subjectieve overtuiging van de rechter, maar dat we het bereik van die subjectieve overtuiging zoveel mogelijk indammen. ${ }^{61}$ Dat kan door van

Melai/Groenhuijsen e.a.: 'De enkele omstandigheid dat de beslisser weet dat hij met inachtneming van bepaalde regels zijn beslissing zal moeten motiveren, zal ongetwijfeld reeds op die oordeelsvorming invloed hebben.'

60 Den Hartog 2005, p. 222-223 merkt hierover op: 'Met name in het geval waarin de motiveringen worden overgelaten aan de secretaris, bestaat het gevaar dat wordt teruggevallen op nietszeggende standaardoverwegingen. Dit is geen verwijt naar de secretaris toe. De secretaris kan vaak niet anders. Hij moet beslissingen uitleggen die hij niet heeft genomen en als de rechter er geen uitleg bij geeft, rest hem niet zo veel meer dan terug te vallen op standaardoverwegingen.' Deze praktijk roept de vraag op waarom motiveringen aan gerechtssecretarissen worden overgelaten.

61 In gelijke zin: Peters 1972b, p. 53: 'de bewezenverklaring is geen machtspreuk van een autoriteit noch ook is de innerlijke overtuiging van die autoriteit laatste maatstaf, maar de redelijkheid van de bewijsconstructie. Niet het overtuigd-zijn van de rechter, maar het overtuigend-zijn van zijn oordeel is het belangrijkst.' Zo ook met betrekking tot het expliciteren van algemene ervaringsregels die ten grondslag liggen aan de bewijsredenering van de strafrechter. Reijntjes 2006b, p. 58: 'Bij het gebruik van geëxpliciteerde 
de rechter te eisen dat hij zijn beslissing zodanig inkleedt dat die beslissing ter discussie kan worden gesteld en voor zover dat gebeurt ook op inhoudelijke gronden kan worden getoetst. ${ }^{62}$ Alleen op die manier kan worden gegarandeerd dat de rechter alle relevante feiten en omstandigheden - belastend en ontlastend - onder ogen heeft gezien.

\subsection{Conclusie}

De motiveringsvoorschriften ten aanzien van de bewijsbeslissing zoals opgenomen in de artikelen 359 en $360 \mathrm{~Sv}$ en de wijze waarop die door de Hoge Raad worden uitgelegd en getoetst, hebben nauwelijks enige betekenis voor de normering van het bewijsoordeel. De mate waarin tegemoet wordt gekomen aan de controle-, inscherpings- en explicatiefunctie van de motivering is afhankelijk van de bereidheid van de feitenrechter om meer uitleg te geven dan strikt genomen noodzakelijk is. Die bereidheid is afhankelijk van het belang dat de rechter zelf toekent aan de motivering, de mate waarin partijen hem daartoe uitdagen en de financiële ruimte die hij krijgt om meer tijd aan strafzaken te besteden. Het project 'Promis' draagt bij aan het besef van de rechter dat hij meer uitleg moet geven; het kan als het ware een cultuurverandering binnen de rechterlijke macht teweegbrengen. Ook het optreden van procespartijen en dan met name de verdediging kan de rechter ertoe bewegen meer uitleg te geven. Naarmate de verdediging meer en beter verweer voert - en dat is in toenemende mate het geval - zal dat de rechter dwingen om ook buiten de juridische grenzen om de argumenten voor en tegen een bewezenverklaring voor een ieder kenbaar af te wegen. Daar staat helaas tegenover dat het meer inhoudelijk motiveren ook meer tijd, en dus meer geld kost. In een tijd waarin de managers van rechtbanken een steeds grotere greep krijgen op de rechtspraak lijkt motivering van vonnissen te worden beschouwd als een luxe artikel, waarvoor alleen ruimte wordt gecreëerd als het niks kost of leidt tot bezuiniging elders. Indien echter de motivering van de bewijsbeslissing wordt beschouwd als een noodzakelijk onderdeel van de normering van de bewijsbeslissing om te garanderen dat de rechter tot een goed of zo goed mogelijk feitenoordeel komt, zouden financiële afwegingen geen rol van betekenis mogen

ervaringsregels bevindt de rechter zich nog aan de rationele zijde van de bewijsvoering maar wanneer hij ander eigen wetenschap bezigt, wordt snel de grenslijn overschreden naar de irrationele zijde, die van de rechterlijke overtuiging.'

62 Groenhuijsen 2004, p. 153 meent eveneens dat de rechter in staat is zijn overtuiging nader te onderbouwen. Hij kiest echter niet voor toetsing van het bewijsoordeel als middel om de rechter zover te krijgen dat hij zijn oordeel nader verklaart, maar meent dat een mentaliteitsverbetering bij de rechter voldoende is: 'De rechter die bereid is op dit terrein het achterste van zijn tong te laten zien, is daartoe doorgaans ook zeer wel in staat. Wat nodig is, is een verandering van mentaliteit, een zekere openheid om verantwoording af te leggen over de redenen van de genomen beslissing.' 
spelen. De enige manier om dat te bewerkstelligen is door de rechters te verplichten hun oordeel te onderbouwen. De Hoge Raad zou in navolging van het Bundesgerichtshof feitenrechters moeten dwingen hun bewijsoordelen te voorzien van een motivering die het oordeel kan dragen. Dat vereist echter dat de Hoge Raad ook inhoudelijke controle uitoefent op die motivering door de inhoud ervan niet alleen te toetsen op begrijpelijkheid, maar ook in navolging van zijn Duitse collega te bezien of die in overeenstemming is met algemene ervaringsregels en wetenschappelijke inzichten. Daarmee wordt de Hoge Raad niet een derde feitenrechter, maar wel een cassatierechter die erkent dat ook het bewijsoordeel in strafzaken een juridisch oordeel is en dus meer is dan enkel de overtuiging van de feitenrechter. 


\section{Bijlage: voorbeeld Duits strafvonnis}

Aktenzeichen: 2 KLs 122 Js 5713/2003

IM NAMEN DES VOLKES!

U R T E I L

Die 2. Strafkammer bei dem Landgericht Regensburg erkennt in der Strafsache gegen

H. Ernest, geb. 25.2.1957 R., Kreis Michigan, Vereinigte Staaten, amerikanischer Staatsangehöriger, verheiratet, Altenpfleger, wh. Fuhrn 22, 92431 Neunburg V. Wald, dzt. Justizvollzugsanstalt Regensburg. Eltern: H. Mike u. Dana.

wegen sex. Nötigung

in der öffentlichen Sitzung vom 28.5.2004

aufgrund der Hauptverhandlung vom 17.05.2004 und 28.05.2004,

an der teilgenommen haben:

Vorsitzender Richter am Landgericht Dr. Lang

als Vorsitzender

Richter am Landgericht Rösl

als beisitzender Richter

Josef Hofmeister, Bad Abbach-Peising

Georg Hausner, Regensburg

als Schöffen

Staatsanwältin als Grlin Eisvogel

als Beamtin der Staatsanwaltschaft

Rechtsanwalt Kaiser, Regensburg

als Verteidiger

Rechtsanwalt Schindler, Neutraubling

als Vertreter der Nebenklage

Lehner, Justizangestellter

als Urkundsb. der Geschäftsstelle

\section{zu Recht:}

1. Der Angeklagte ist schuldig der sexuellen Nötigung und wird deswegen zu einer Freiheitsstrafe von

verurteilt.

4 Jahren

2. Der Angeklagte hat die Kosten des Verfahrens einschließlich der notwendigen Auslagen des Nebenklägers zu tragen.

Angewendete Vorschriften:

$\S \S 178$ Abs. 1 a.F., 21 StGB. 


\section{Gründe:}

I.

\section{(Persönliche Verhältnisse des Angeklagten)}

Der nicht vorbestrafte Angeklagte Ernest $\mathrm{H}$. ist am 25.2.1957 in Rogercity, Kreis Michigan in den Vereinigten Staaten von Amerika als Sohn der Eheleute Mike und Dana H. geboren. Er ist zusammen mit zwei Geschwistern bei der Grosmutter mütterlicherseits aufgewachsen, weil die Mutter unter häufigen Erkrankungen litt und der Vater sich nicht um die Kinder kümmerte. Der Angeklagte hat in den USA die Mittlere Reife absolviert und sich anschließend von 1976 bis 1986 als Berufssoldat verpflichtet. Er war dabei seit etwa Mitte 1983 in der Bundesrepublik Deutschland stationiert. Nach seiner Entlassung aus der Armee übte der Angeklagte verschiedene Tätigkeiten, u.a. bei einer Speditionsfirma aus. Er unterzog sich im Jahr 2000 einer 3 Jahre dauernden Umschulung zum Altenpfleger. Vor seiner Inhaftierung am 6.5.2004 war der Angeklagte arbeitslos.

Der Angeklagte heiratete erstmals 1979; die Ehe wurde 1989 geschieden. Aus der Ehe sind die beiden Söhne Steven (geboren 27.12.1980) sowie James (geboren 30.5.1983) hervorgegangen. 1990 heiratete der Angeklagte seine derzeitige Ehefrau Monika, geb. K. Aus der Ehe hervorgegangen sind die Kinder Sonja (geboren 25.10.1985), Tobias (geboren 14.10.1990), Corinna (geboren 2.4.1996), Lukas (geboren 3.11.1999), Anna-Lena geboren 17.2.2001), Lisa (geboren 24.3.2002) sowie Angelina (geboren 20.1.2004). Die Familie H. wohnte bis zum September 1993 in Schwarzenbach, Landkreis Weiden, bis zum 29.6.1996 in Thonlohe, Gemeinde Hemau und anschließend in Albertshofen, ebenfalls Gemeinde Hemau im Landkreis Regensburg. Aus Anlag der gegenständlichen Tatvorwürfe zog der Angeklagte in Absprache mit dem Kreisjugendamt Regensburg Ende 2003 aus der gemeinsamen Wohnung in Albertshofen aus, um hierdurch die Herausnahme der übrigen Kinder aus dem Familienverband abzuwenden. Er lebte bis zu seiner Verhaftung in Neunburg v. Wald.

Von schweren Erkrankungen und Unfällen ist der Angeklagte bislang verschont geblieben.

II

\section{(Zur Person des Tatopfers)}

Der am 30.5.1983 geborene James H. ist zusammen mit seinem älteren Bruder Steven im Alter von ca. 6 Monaten mit seinem Vater nach Deutschland gekommen, wo der Angeklagte in Hohenfels bei Weiden stationiert war. Nachdem er zunächst von seiner späteren Stiefmutter, die beim Angeklagten als Kindermädchen beschäftigt war, betreut wurde, lebte er bis zu seinem 7. Lebensjahr in einem Kinderheim in Windischeschenbach und nach der Heirat des Angeklagten seit April 1991 zusammen mit seinem Bruder in der gemeinsamen Wohnung der Eheleute in Schwarzenbach. Die Kinder waren dabei oft sich selbst überlassen, da der Vater sich wenig um die Erziehung kümmerte und dessen Ehefrau weitgehend mit der Haushaltsführung für die mehrköpfige Familie in Anspruch genommen war.

James H. wurde im September 1990 in die Volksschule in Windischeschenbach eingeschult. Wegen seiner schlechten Leistungen wurde er mit Wirkung ab 10.9.1991 in eine Schule für Lernbehinderte in Eschenbach überwiesen. Ab dem Schuljahr 1993/94 besuchte er die Schule zur individuellen Lernförderung in Deuerling, welche er im Schuljahr 1998/99 mit guten bis sehr guten Noten abschloss. Nach Angaben seines inn in der 8. und 9. Klasse der Förderschule begleitenden Lehrers, des Zeugen Hiebinger, war James $\mathrm{H}$. dabei ein fleißiger, gewissenhafter und stets ehrlicher Schüler. Anschließend trat James H. In die Hauptschule in Deuerling über und machte dort den qualifizierenden Abschluss, wobei er gute Leistungen (Notendurchschnitt 2,27) erzielte und sich den fehlenden Lernstoff der Hauptschule im Selbststudium in den Sommerferien 1999 aneignete.

Nach der unter III beschriebenen Tat verschlechterte sich das Verhältnis zwischen James $\mathrm{H}$. und seinem Vater, es kam zu heftigen verbalen und auch handgreiflichen Auseinandersetzungen. Der Angeklagte und Seine Ehefrau wandten sich daraufhin gegen Ende des Jahres 
1999 um Unterstützung an das Kreisjugendamt Regensburg. James H. wurde sodann am 22.1.2000 in die Jugendwohngruppe des Kinderheims in Hemau im Rahmen einer Maßnahme der Hilfe zur Erziehung nach dem KJHG aufgenommen. Dort zeigte er zunächst autoaggressives Verhalten und hatte Essstörungen; beides besserte sich nach ca. 1 Jahr Heimaufenthalt. Seit Mitte Juli 2002 verfügt James H. im Rahmen einer Maßnahme des betreuten Wohnens über eine eigene Wohnung. Er hat zwischenzeitlich eine Lehre als Industriemechaniker/Systemtechniker absolviert und arbeitet derzeit bei $1 \mathrm{i}$ einer Zeitarbeitsfirma in Bogen.

III

(Die Tat)

Zu einem nicht mehr näher feststellbaren Zeitpunkt nach dem Umzug der Familie $\mathrm{H}$. nach Albertshofen (29.6.1996) und vor dem Wechsel von James H. von der Förderschule in die Hauptschule (September 1999) unternahm an einem sonnigen Tag der Angeklagte zusammen mit seinem Sohn James, der zu diesem Zeitpunkt noch über keine sexuellen Erfahrungen verfügte, im Waldgebiet zwischen Albertshofen und Otterzhofen im Gemeindegebiet Hemau einen Spaziergang. Dabei gelangte man zu einem Jägerhochstand, der sich an einem Feldweg am Beginn einer Fichtenschonung $\mathrm{Ca} .100 \mathrm{~m}$ links neben der Ortsverbindungsstrasse zwischen Albertshofen und Otterzhofen befindet. Der Hochstand verfügt in einer Höhe von $3 \mathrm{~m}$ über eine ca. 1,40 m lange und ebenso breite überdachte Kanzel, welche an den vier Seitenwänden jeweils eine kleinere längliche Glasscheibe aufweist; bezüglich der Einzelheiten wird auf Bild 1 der in Augenschein genommenen Lichtbildtafel (BI. 255 d.A.) Bezug genommen, § 267 Abs. 1 Satz 3 StPO. James H., der mit einem T-Shirt und einer langen Hose bekleidet war, bestieg den Hochstand, um von dort einen Rundblick zu nehmen. Ihm folgte der Angeklagte. Unter dem Vorwand, er habe sich bei dem Waldspaziergang möglicherweise Zecken geholt, forderte der Angeklagte seinen Sohn auf, dieser solle sein T-Shirt ausziehen, seine Hose herunterziehen und sich hinlegen. James $\mathrm{H}$. kam dem Verlangen, sich zu entkleiden nach, und legte sich bäuchlings auf den Boden der Kanzel des Hochstands. Der Angeklagte zog dem Jungen dann die Unterhose nach unten. Er drückte James $\mathrm{H}$. die Beine auseinander und hielt dessen Handgelenke mit seinen Händen fest, um eine Gegenwehr zu verhindern, legte sich auf seinen Sohn und drang dann mit seinem erigierten Penis in den After des Jungen ein. Obwohl James H. seinen Vater während der Durchführung des für inn schmerzhaften Analverkehrs aufforderte, aufzuhören, kam der Angeklagte dem nicht nach, sondern hielt James weiter an den Handgelenken fest und vollzog den Analverkehr bis zum Samenerguss.

Sodann verließ der Angeklagte mit seinem Sohn den Hochstand und forderte an dessen Fuß James $H$. auf, nunmehr bei inm den Analverkehr durchzuführen. Unter dem Eindruck des soeben Erlebten und aus Angst vor Konsequenzen kam James $\mathrm{H}$. diesem Verlangen nach. Da er dabei Schwierigkeiten hatte, eine Erektion zu bekommen, manipulierte der Angeklagte selbst am Geschlechtsteil seines Sohns.

James $\mathrm{H}$. drang dann in den After seines Vaters ein und vollzog den Analverkehr ebenfalls bis zum Samenerguss. Er rannte nach diesem Vorfall nach Hause und sperrte sich in sein Zimmer ein. James H. erlitt durch den Vollzug des Analverkehrs durch den Angeklagten eine blutende Verletzung im Afterbereich, die inn noch ca. 14 Tage lang schmerzte. Es kann nicht ausgeschlossen werden, dass die Steuerungsfähigkeit des Angeklagten im Tatzeitpunkt wegen einer Störung der Sexualpräferenz erheblich vermindert i.S.d. § 21 StGB war.

\section{IV}

\section{(Beweiswürdigung)}

1. Die Feststellungen zu den persönlichen und wirtschaftlichen Verhältnissen des Angeklagten beruhen auf dessen eigenen Angaben; der Werdegang von James $\mathrm{H}$. wurde von diesem in der beschriebenen Weise geschildert. Dass der Zeuge James $\mathrm{H}$. bei seiner Aufnahme in die Jugendwohngruppe des Kinderheims in Hemau autoaggressives Verhalten zeigte und Eßstörungen hatte, ergibt sich aus der Bekundung der Zeugin Kurz, die als beim Kreisjugendamt Regensburg angestellte Sozialpädagogin den Zeugen dort betreute. Die Zeugin hat berichtet, 
dass sich James $\mathrm{H}$. während der ersten Zeit seines Heimaufenthalts mehrmals kleinere Verletzungen in der Hand (Einritzungen) zugefügt habe; einmal habe er sich an der linken Hand verbrannt und zunächst angegeben, dass inm versehentlich der Wasserkocher ausgekommen wäre, wobei er ihr in der Folgezeit eingestanden habe, dass er sich absichtlich verbrüht habe. James $\mathrm{H}$. habe auch häufig das Essen verweigert und zunächst deutlich abgenommen. Dies habe sich jedoch nach ca. 1 Jahr Heimaufenthalt normalisiert.

2a) Der Angeklagte bestreitet die inm angelastete Tat. Er hat sich dahingehend eingelassen, dass die Anschuldigung falsch sei. Er habe zu keinem Zeitpunkt sexuelle Handlungen an seinem Sohn James vorgenommen noch solche von ihm bei sich vornehmen lassen. Er habe sich mit seinem Sohn stets schlecht vertragen, mit diesem oft gestritten. Sein Sohn lebe in einer Phantasiewelt. Er sei mit diesem nie auf einem Jägerstand gewesen. Er habe seit dem Jahr 2000 praktisch keinen Kontakt mehr mit seinem Sohn. Als Grund für die Falschbezichtigung vermute er, dass sein Sohn inm übel nehme, dass er inn falsch behandelt habe, ihn z.B. in eine falsche Schule geschickt habe. Womöglich gebe James inm auch die Schuld, dass er von seiner leiblichen Mutter weg sei und diese nicht kenne.

b) Der Angeklagte wird überführt durch die Angaben des Zeugen James H., der den Sachverhalt so, wie unter III dargestellt, geschildert hat. Das Gericht hat keinen Zweifel an der Glaubhaftigkeit der Angaben des Zeugen James H. Die Kammer ist sich bewußt, dass in einem Fall wie dem vorliegenden, in dem Aussage gegen Aussage steht und die Entscheidung allein davon abhängt, welchen Angaben das Gericht folgt, alle Umstände, die die Entscheidung beeinflussen können, in die Überlegungen einzubeziehen sind und dass in einem solchen Fall eine Gesamtwürdigung aller Indizien - sowohl der belastenden wie der entlastenden - geboten ist (vgl. BGH NStZ-RR 1998, 16 ff). Die von der Kammer in diesem Sinne vorgenommene Gesamtwürdigung führt zu dem Ergebnis, dass der Angeklagte der unter III dargestellten Tat überführt ist.

aa) Der Zeuge James H. macht auf das Gericht einen glaubwürdigen Eindruck. Es fiel dem Zeugen sichtlich schwer, über den Vorfall zu berichten; er machte seine Angaben, insbesondere im Hinblick auf die Geschehnisse im und um den Jägerstand, nur stockend und zögernd. Der Zeuge wirkte emotional berührt, bei der Schilderung des eigentlichen Tathergangs brach er zunächst in Tränen aus, so dass die Verhandlung unterbrochen werden musste.

Der Zeuge war sichtlich um wahrheitsgemäße Angaben bemüht. Dies zeigt sich etwa dadurch, dass der Zeuge trotz intensiver Befragung hierzu nicht ein in der Lage war, den Vorfall zeitlich näher - als erfolgt - einzugrenzen. Auf Nachfrage, ob der Angeklagte beim Vollzug des Analverkehrs besonders brutal vorgegangen sei, hat dies der Zeuge verneint; er habe diesen zwar als sehr schmerzhaft empfunden, er erkläre sich dies aber damit, dass dies für ihn der erste Sexualkontakt in dieser Form gewesen sei und er über keinerlei Erfahrung verfügt habe, die vom Angeklagten angewendete Gewalt habe "lediglich" darin bestanden, dass dieser während des Vollzugs des Analverkehrs auf inm gelegen und seine Hände an den Gelenken festgehalten habe.

bb) Die Angaben des Zeugen James H. zum Tathergang waren detailliert und lassen auf eigenes Erleben schließen.

Der Zeuge hat geschildert, dass er an dem besagten Tag auf Aufforderung des Angeklagten mit diesem in den Wald gegangen sei, um Pilze zu suchen. Man sei im Laufe des Vormittags - es sei sonnig und heiß gewesen - losgegangen. Er habe damals ein graues/gelbes T-Shirt und lange Hosen getragen. Er habe damals knabenhaft, nämlich zierlich und kleiner als heute, gewirkt und sei wohl schon in der Pubertät gewesen, was er daraus schließe, dass er zum damaligen Zeitpunkt bereits Schambehaarung aufgewiesen habe. Sie seien kreuz und quer gegangen, zuerst auf Schotterwegen, dann quer durch den Wald, durch Gestrüpp und Unterholz und schließlich seien sie zu dem Jägersitz gegangen. Es habe sich dabei um einen komfortablen Jägersitz, einer Art Häuschen mit verglasten Fenstern und Eingangstüre gehandelt, 
das "komplett zu" gewesen sei und in dessen Inneren sich Sitzgelegenheiten sowie ein Teppich am Boden befunden habe. Der Zeuge sei dann den Jägerstand hochgegangen, weil er die Aussicht liebe, der Angeklagte sei mitgegangen. Der Angeklagte hätte schließlich dann geäußert, dass sie sich eventuell Zecken geholt hätten und sich der Zeuge deshalb entkleiden und auf den Bauch legen solle. Daraufhin habe er sich zum Teil ausgezogen, nämlich das Hemd abgelegt und die Hose halb heruntergezogen. Der Angeklagte habe sich dann auf inn gelegt und inn 'gefickt', was sehr wehgetan habe. Dabei habe der Angeklagte inn an den Handgelenken mit den Händen festgehalten und sich darauf gestützt, weswegen er sich nicht bewegen konnte und sich auch nicht wehren konnte. Obwohl der Zeuge dem Angeklagten gesagt habe, dieser solle aufhören, sei der Angeklagte dem nicht nachgekommen. Der Angeklagte hätte beim Vollzug des Analverkehrs einen Samenerguss gehabt. Dies schließe er daraus, dass der Zeuge es damals so empfunden hätte, als hätte er eine "Art Durchfall gehabt", es sei eine wässrig-klebrige Masse zum Vorschein gekommen. Der Zeuge habe dabei auch festgestellt, dass er geblutet habe, er habe 14 Tage lang Blutungen gehabt, so lange habe inm auch die Verletzung am After geschmerzt. Es sei dann irgendwie unbequem gewesen, so dass der Angeklagte und der Zeuge den Jägersitz verlassen hätten, dabei hätte der Angeklagte Kauderwelsch, unverständliches Zeug, gemurmelt. Am Fuß des Jägersitzes habe der Angeklagte dann den Zeugen aufgefordert, dass er das gleiche mit inm tun solle, der Angeklagte habe dabei mit zittriger nervöser Stimme gesprochen. Der Zeuge sei von dem vorangegangenen Erlebnis noch ganz fertig gewesen und habe auch Angst vor Konsequenzen gehabt, so dass er es nicht gewagt habe, sich zu widersetzen. Dabei habe er Erektionsprobleme gehabt; um diese zu beheben, habe er an seine damalige Freundin, mit der er aber noch keinen geschlechtlichen Kontakt gehabt habe, gedacht, auch habe der Angeklagte so lange an dem Glied des Zeugen manipuliert, bis es steif gewesen sei. Er sei dann in den After des Angeklagten eingedrungen, wobei er damit größte Schwierigkeiten gehabt habe, weil er darin keine Erfahrung gehabt hatte. Es sei schließlich dann zu einem Samenerguss - wie genau wisse er nicht mehr - gekommen, wobei dies sein erster bewusster Samenerguss gewesen sel. Er denke schon, dass es beim Vollzug des Analverkehrs durch inn Probleme gab, könne er sich aber hieran nicht mehr genau erinnern, das Ganze sei wie ein Alptraum gewesen. Anschließend sei er aus dem Wald nach Hause gerannt und habe sich in seinem Zimmer eingesperrt. Der Zeuge hat weiter geschildert, dass er wegen des Vorfalls nicht bei einem Arzt gewesen sei, sich aber wegen der Blutung am After selbst gebastelte Einlagen aus Klopapier In die Unterhose geschoben habe, was ca. 14 Tage gedauert habe. Er sei nach diesem Ereignis aggressiv, zynisch und rebellisch geworden und habe die "Brechsucht" gehabt. Auch heute falle es inm äußerst schwer, über dieses Ereignis, das er noch nicht verarbeitet habe, zu sprechen. Der Zeuge KHK Porsche hat in diesem Zusammenhang bekundet, dass er aufgrund der Angaben des Zeugen nach dem Hochstand die Kanzel in dem von diesem beschriebenen Waldstück zwischen Albertshofen und Otterzhofen gesucht habe. Er habe dabei festgestellt, dass ca. $100 \mathrm{~m}$ links neben der Ortsverbindungssstraße zwischen Albertshofen und Otterzhofen auf halber Strecke ein Feldweg direkt zu dem Hochstand mit Kanzel führe, der sich am Beginn eines Waldgebietes in einer Fichtenschonung befinde. Diesen Hochstand habe er zusammen mit dem Zeugen am 10.4.2003 gegen 14.00 Uhr aufgesucht, der Zeuge $\mathrm{H}$. sei sich zunächst nicht sicher gewesen, ob es sich um den betreffenden Hochstand von damals gehandelt habe. Der Hochstand sei sowohl links als auch rechts mit einer Art Sitzbank mit Stoffbezug versehen gewesen und am Boden mit einem Teppichbodenrest ausgelegt gewesen. Nachdem der Zeuge diesen Teppichboden nach oben gezogen habe, sei ein kleines rotes "Steckerl" eines ehemaligen Eislöffels zum Vorschein gekommen, den der Zeuge schon damals, als sich der Vorfall ereignete, bemerkt hatte. Dadurch sei er sich sicher gewesen, dass es sich hierbei um den Hochstand gehandelt habe, auf welchem der Angeklagte den Analverkehr mit inm durchgeführt habe. Der Hochstand sei dann vom Zeugen gemessen worden, er sei von quadratischer Form mit einer Seitenlänge von ca. 1,40 m gewesen und habe sich in ca. $3 \mathrm{~m}$ Höhe befunden. Die Kuppe bzw. Kanzel des Hochstandes weise an allen 4 Seiten jeweils eine kleinere längliche Glasscheibe auf. Der Hochstand wurde von dem Zeugen fotografiert, die entsprechende Lichtbildtafel (BI. $255 \mathrm{ff}$ d.A.) in Augenschein genommen. Auch dieses vom Zeugen Porsche geschilderte Wieder erkennen 
des Hochstands durch den Zeugen spricht nach Auffassung der Kammer für die Glaubhaftigkeit von dessen Angaben.

cc) Ein weiteres Indiz für die Glaubhaftigkeit der Aussage des Zeugen James $\mathrm{H}$. ist die Aussagekonstanz im Kerngeschehen. Denn der Zeuge hat den in Frage stehenden Vorgang im Wesentlichen in gleicher Weise im Rahmen der polizeilichen sowie der ermittlungsrichterlichen Vernehmung und der Befragung durch die Sachverständige Dr. Loohs geschildert.

Der Zeuge KHK Porsche, der James H. am 20.3.2003 einvernommen hat, hat bekundet, dass inm der Zeuge berichtet habe, dass der - erste - massive Übergriff seitens seines Vaters im Zusammenhang mit einem Waldspaziergang erfolgt ist. Dabei habe James $\mathrm{H}$. erhebliche Schwierigkeiten mit der zeitlichen Einordnung des Geschehens gehabt, er sei schließlich der Meinung gewesen, es müsse sich Ca. im Herbst 1995 oder 1996 ereignet haben, wobei er sich nicht endgültig festlegen wollte. Sein Vater habe inn damals aufgefordert, mit inm in den Wald zu gehen, um Pilze zu sammeln. Man sei dann zu Fuß auf dem Fuß- und Radweg gegangen, der von Albertshofen nach Otterzhofen führe. Man sei dann zu einem Waldstück gelangt, bei dem sich ein so genannter Jägerhochsitz befunden habe, von dem aus man die Ortsverbindungsstraße zwischen Albertshofen und Otterzhofen schwach habe erkennen können. Es habe sich um einen Hochsitz gehandelt, der oben geschlossen gewesen sei und über eine Tür und mehrere Fenster verfügt habe. Der Zeuge James $H$. sei dann auf den Hochsitz gestiegen, um sich die Gegend zu betrachten. Der Angeklagte sei nachgekommen und habe inn aufgefordert, sich auszuziehen, well er ihn nach Zecken absuchen wollte. Daraufhin habe der Zeuge sein TShirt ausgezogen und seine Hose bis zu den Knien hinuntergezogen. Der Angeklagte habe den Zeugen dann aufgefordert, sich auf den Boden auf den Bauch zu legen. Der Zeuge habe dann bemerkt, wie inm die Unterhose heruntergezogen würde und unmittelbar darauf gespürt, dass sich der Angeklagte auf ihn legte. Dieser habe seine Beine auseinandergedrückt und mit seinen Händen die Handgelenke des Zeugen festgehalten. Der Zeuge habe dann gespürt, dass etwas Hartes und Glitschiges in seinen After eingedrungen sei, dass sein Vater Auf- und Abbewegungen gemacht und dabei auch gestöhnt habe. Er habe dann gemerkt, wie der Angeklagte anscheinend einen Samenerguss hatte, jedenfalls habe er etwas Feuchtes gespürt. Dadurch, dass sein Vater in inn eingedrungen sei, habe er Schmerzen gespürt. Der Angeklagte habe inn dann aufgefordert, bei ihm dasselbe zu machen. Der Zeuge sei deswegen wütend gewesen, weil er Schmerzen gehabt und am After geblutet habe. Da er zunächst nicht erregt gewesen sei, habe er versucht, durch Vorstellungen eine Erektion zu bekommen; gleichzeitig habe der Angeklagte, auf dem Bauch liegend, mit seiner rechten Hand nach hinten gegriffen und damit am Glied des Zeugen manipuliert. Nachdem dieser eine Erektion hatte, sei er In den After seines Vaters eingedrungen und habe sich darin so lange hin und herbewegt, bis er einen Samenerguss gehabt habe. Der Zeuge sei anschließend von dem Ganzen so geschockt gewesen, dass er auf direktem Weg nach Hause gelaufen und sich dort in sein Zimmer eingesperrt habe.

Der Zeuge Dr. Liegl hat in diesem Zusammenhang bekundet, dass er in seiner Eigenschaft als Ermittlungsrichter beim Amtsgericht Regensburg James H. am 1.4.2003 als Zeugen vernommen habe. Auch nach seiner Erinnerung hatte der einvernommene Zeuge erhebliche Schwierigkeiten mit der zeitlichen Eingrenzung des Geschehens. Er sei sich dann aber relativ sicher gewesen, dass sich der erste Vorfall im Wald auf einem Hochsitz ereignet habe zu einem Zeitpunkt, als er zwischen 14 und 16 Jahre alt gewesen sei. Er sei damals mit seinem Vater in den Wald gegangen, um glaublich nach Beeren zu suchen. Es sei im Dreieck Albertshofen, Thonlohe und Waltenhofen gewesen. Der Zeuge habe die Gegend von einem Hochstand aus anschauen wollen. Es sei ein breit gebauter, komfortabler Hochstand mit drei Fenstern gewesen. Es sei dann zur Sache gegangen d.h., er habe sich ausziehen müssen, weil sein Vater ihn angeblich nach Zecken absuchen wollte. Auf Aufforderung seines Vaters habe er sich auf den Boden des Jägerstands gelegt, sein Vater habe sich auf inn draufgelegt. Er könne nur noch sagen, dass inn dieser eindeutig "gefickt" habe und dass es weh getan habe. Dabei habe der Angeklagte die Handgelenke des Zeugen festgehalten. Der Analverkehr sei dabei bis zum Samenerguss durchgeführt worden. Es habe dem zeugen verdammt weh getan, als der Angeklagte bei ihm eingedrungen sei; er habe diesen auch aufgefordert, dass dieser aufhören solle, er habe aber 
nicht von inm abgelassen. Es sei dann aber auch noch weiter gegangen, denn der Angeklagte habe den Zeugen aufgefordert, das gleiche mit ihm zu machen. Der Zeuge habe sich dann - so gut es ginge, es sei ja seine erste sexuelle Erfahrung gewesen - auf den Angeklagten gelegt und es könne auch sein, dass er bei inm eingedrungen sei. Auf Nachfrage habe der Zeuge angegeben, dass er dabei Schwierigkeiten gehabt habe, einen "Ständer" zu haben. Er habe deshalb an alles mögliche gedacht und den Angeklagten aus Angst zufrieden stellen wollen. Er sei dann nach dem Vorfall nach Hause gerannt und habe seine Zimmertür von innen verklemmt.

Die Sachverständige Dr. Loohs hat berichtet, dass sie mit dem Zeugen H. am 20. und 21.8. sowie am 8.12. Explorationsgespräche durchgeführt habe. Dabei habe ihr der Zeuge erzählt, dass der erste sexuelle "Kontakt" mit seinem Vater auf einem Jägerhochstand im Bereich bei Albertshofen gewesen sei. Der Angeklagte habe inm dabei erklärt, dass er inn nach Zecken absuchen wolle und sich der Zeuge deshalb ausziehen solle. Der Angeklagte habe sich dann auf den Zeugen gelegt und sei mit seinem Glied in dessen After eingedrungen und habe den Analverkehr bis zum Samenerguss durchgeführt. Dann habe der Angeklagte den Zeugen aufgefordert, dasselbe auch bei inm zu machen. Er habe zunächst Erektionsschwierigkeiten gehabt, es sei ihm dann jedoch gelungen, den Analverkehr bis zum Samenerguss durchzuführen. Den Angaben der Sachverständigen zufolge hat der Zeuge die Tat in den Details im Wesentlichen so wie in der Hauptverhandlung geschildert.

Der Zeuge James $\mathrm{H}$. hat somit auch in vorangegangenen Vernehmungen und Befragungen im Kernbereich konstante Aussagen hinsichtlich des Tatvorwurfs gemacht. Ungenauigkeiten, etwa die Schwierigkeiten, das Geschehen zeitlich näher einzuordnen, oder der Zweck des Waldspaziergangs sowie der Umstand, wo der Zeuge den Analverkehr mit dem Angeklagten durchführen sollte, nämlich auf dem Hochstand oder im Bereich des Hochstands, betreffen nur Randbereiche und sind kein Argument gegen die Glaubhaftigkeit der Angaben des Zeugen.

Die Kammer hat in diesem Zusammenhang berücksichtigt, dass der Zeuge im Rahmen seiner ermittlungsrichterlichen Vernehmung abweichend von den übrigen Vernehmungen sich nicht sicher war, ob er den Analverkehr mit seinem Vater durchgeführt hat oder nicht. Der Zeuge hat hierzu in der Hauptverhandlung erklärt, dass er sich damals in einer besonders schwierigen Situation befunden habe, er sei entnervt gewesen, weil inm wiederholt kurz nach den polizeilichen Vernehmungen dieselben Fragen gestellt worden seien, weshalb er dann öfters gesagt habe, er wisse etwas nicht mehr genau. Dies deckt sich mit den Angaben des zeugen Dr. Liegl, der hierzu bekundet hat, dass er noch nie einen Zeugen erlebt habe, der während einer Vernehmung so angespannt und von einer Vernehmung körperlich so mitgenommen gewesen sei wie der Zeuge James $\mathrm{H}$.; sein Eindruck sei gewesen, dass dem Zeugen eine Aussage äußerst schwer gefallen sei. Dass der Zeuge $\mathrm{H}$. sich auf dieses durchaus zum Kernbereich des Geschehens gehörende Detail in der ermittlungsrichterlichen Vernehmung nicht festlegen wollte, läßt sich daher mit der vom Zeugen geschilderten damaligen besonderen Befindlichkeit erklären, berührt aber die Glaubhaftigkeit der Angaben, welche der Zeuge in der Hauptverhandlung machte, nicht.

dd) Da ein Zusammenhang mit familiären Auseinandersetzungen nicht von vornherein auszuschließen war, hat die Kammer die Entstehung und Entwicklung der Aussage des Zeugen James H. aufgeklärt. Dabei wurde festgestellt dass der Zeuge erstmals Ende November 2002 konkrete Angaben darüber gemacht hat, dass er von seinem Vater sexuell missbraucht worden ist.

Die als Sozialpädagogin heim Kreisjugendamt tätige Zeugin Kurz hat berichtet dass sie James H. seit Januar 2000, als dieser ins Kinderheim in Hemau gekommen sei, bis zum heutigen Tag betreue. James habe dabei im Heim immer schon Andeutungen gemacht, dass es ganz schlimm zu Hause sei, was sein Vater gemacht habe. Sie habe das dahingehend interpretiert, dass körperliche Übergriffe von Seiten des Vaters gegenüber seinem Sohn stattgefunden hätten. Sie habe den Eindruck gehabt, dass James im Laufe des Heimaufenthalts zunehmend Vertrauen zu ihr gefaßt habe. Es habe sich dann Ende November 2002 in der Wohnung des Zeugen ein Gespräch ergeben, in dessen Verlauf inr James gesagt habe, dass er von seinem Vater sexuell 
missbraucht worden sei. Dabei habe er keine Details genannt und zum Ausdruck gebracht, dass er nicht wisse, ob er Anzeige deswegen erstatten solle. Er habe sie auch gebeten, niemandem etwas davon zu erzählen.

Der Zeuge Schauer, Erziehungsleiter des Kinderheims in Hemau, hat bekundet, dass er von dem Missbrauchsvorwurf erstmals im Rahmen eines Teamgesprächs mit der Zeugin Kurz am 27.11.2002 erfahren habe. Er habe daraufhin am 18.12.2002 ein persönliches Gespräch mit James H. geführt. Dabei sei im einzelnen nicht darüber gesprochen worden, was mit James passiert sei. Nachfolgend habe am 22.1.2002 ein Gespräch mit dem anwaltschaftlichen Vertreter der Einrichtung, Rechtsanwalt Schindler stattgefunden. Dort habe James dargestellt, dass er um der Gerechtigkeit Willen und auch aus Sorge um die Geschwister seinen Vater bei der Polizei anzeigen wolle. Auch In diesem Zusammenhang sei nicht konkret von den einzelnen Taten gesprochen worden. Da James geäußert habe, das Erlebte nur schwer schildern zu können, sei ein externer Psychologe, der Zeuge Christian König eingeschaltet worden.

Der Zeuge König hat berichtet, dass er am 13.3.2003 im Kinderheim Hemau ein 2-stündiges Gespräch mit dem Zeugen James H. geführt habe. Ziel sei es gewesen, die Aussage von James zu Protokoll zu nehmen, da James sich schwer tun würde, diese zu formulieren. Er habe ein Gesprächsprotokoll gefertigt, bei dem er darauf geachtet habe, nur das aufzuschreiben, was inm der Zeuge H. gesagt habe. Er habe den Zeugen erzählen lassen, ihn nach jeweils 5 bis 10 Minuten unterbrochen, um das Gesagte niederzuschreiben. Er habe dabei den Eindruck gehabt, dass James versucht habe, seinen Vater zu entschuldigen, dass dieser eine schwere Kindheit gehabt habe und deshalb nichts dafür könne. Zwischendurch sei auch Wut auf den Vater herausgekommen, die aber zu keinen Tiraden gegen diesen geführt habe. Nach seinem Eindruck habe er den Vorfall eher heruntergespielt, er habe sich geschämt über das was passiert ist zu erzählen. Er habe auch geäußert, dass er nicht wisse, ob er die Sache durchstehe. Dabei habe James einen Vorfall im Wald geschildert, bei dem der Angeklagte mit inm auf einem Jägerstand den Analverkehr durchgeführt habe und anschließend der Zeuge den Analverkehr mit dem Angeklagten habe durchführen müssen. In beiden Fällen sei dabei der Verkehr bis zum Samenerguss erfolgt.

Die Kammer hält aufgrund der glaubhaften Angaben des Zeugen König eine Beeinflussung des Zeugen aufgrund dieser vom Zeugen durchgeführten Befragung des Geschädigten im Hinblick auf die zu erstattende Anzeige für ausgeschlossen. Sie wird in ihrer Auffassung auch bestätigt durch die Angaben der Sachverständigen Dr. Loohs, welche die vom Zeugen König anlässlich der Befragung am 13.3.2003 angefertigte Videoaufnahme im Rahmen ihrer Exploration sich angesehen hat und dabei bestätigt hat, dass der Zeuge König die Befragung des Zeugen $\mathrm{H}$. so wie geschildert durchgeführt habe, eine Suggestivbefragung habe ausweislich des Videos nicht stattgefunden.

Aufgrund der dargestellten Entstehungsgeschichte zur Entwicklung der Aussage hält die Kammer es für ausgeschlossen, dass - wie vom Angeklagten vermutet - der Zeuge James H. unwahre Angaben gemacht hat, um sich an seinem Vater etwa für etwaige Defizite im Rahmen der Erziehung zu rächen. Denn die ersten Angaben des Zeugen gegenüber Dritten darüber, dass inm von Seiten seines Vaters sexuelle Gewalt widerfahren sei, erfolgten zu einem Zeitpunkt, als der Zeuge James $\mathrm{H}$. schon lange aus dem Familienverband ausgeschieden war. Der Zeuge befand sich seit Anfang Januar 2000 im Kinderheim Hemau und hatte seit diesem Zeitpunkt, wie auch der Angeklagte eingeräumt hat, keinen Kontakt mehr zur Familie. Zum Zeitpunkt der Strafanzeige am 18.3.2003 hatten sich die Lebensverhältnisse des Zeugen stabilisiert; es ging inm gesundheitlich besser, er hatte seine berufliche Ausbildung absolviert. Dies spricht dafür, dass der Zeuge, wie er selbst formuliert hat, erst ab diesem Zeitpunkt die nötige Kraft gefunden hat, sich mit diesem Abschnitt seines Lebens auseinanderzusetzen. Den Angaben der Zeugen Kurz, Schauer und König lässt sich auch entnehmen, dass dem Zeugen H. die Entscheidung, Strafanzeige gegen seinen Vater zu erstatten, erkennbar schwer gefallen ist. Er hat auch zunächst, wie die Zeugen Kurz und Schauer bekundet haben, keine Details bezüglich der Tat angegeben. Zum Zeitpunkt der Anzeigeerstattung bestanden auch, wie der Angeklagte selbst eingeräumt hat, keine aktuellen Familienkonflikte. 
In diesem Zusammenhang hält die Kammer es auch für ausgeschlossen, dass James $\mathrm{H}$. unrichtige Angaben gemacht hat, um seine Schwester Sonja H. zu rehabilitieren, die zeitlich zuvor den Angeklagten ebenfalls wegen sexueller Übergriffe zur Anzeige gebracht hat, wobei dieses Ermittlungsverfahren aber eingestellt wurde.

Aufgrund von Angaben der Zeugin Sonja H. wurde im August 1999 gegen den Angeklagten ein Strafverfahren eingeleitet. Dabei lag ihm zur Last, im Zeitraum von ca. September 1995 bis 1998 seine Tochter Sonja in 10 bis 15 Fällen dadurch sexuell missbraucht zu haben, dass er ihr an die nackte Brust und an die Scheide gefasst und sie gestreichelt habe und In 1 Fall seinen Penis an den Oberschenkeln der Tochter bis zum Samenerguss gerieben habe. Dieses unter dem Aktenzeichen 140 Js 15605/99 bei der Staatsanwaltschaft Regensburg geführte Ermittlungsverfahren wurde mit Verfügung vom 17.2.2000 nach $\S 170$ Abs. 2 StPO mangels hinreichenden Tatverdachts eingestellt. Dabei ist in der Einstellungsbegründung u.a. ausgeführt, dass die Zeugin Sonja H. im Ermittlungsverfahren sehr widersprüchliche Angaben gemacht habe und diese einer Glaubwürdigkeitsuntersuchung unterzogen worden sei. Nach dem Ergebnis des erholten Gutachtens der Sachverständigen Dr. Loohs bestünden Zweifel an den Angaben der Geschädigten. Da ein zeitlicher Zusammenhang zwischen der Einstellung des Verfahrens und der vom Zeugen James $\mathrm{H}$. erstatteten Strafanzeige gegen seinen Vater nicht besteht und im Übrigen aus den bereits angeführten Gründen, insbesondere aus einer Analyse der Entstehung der Aussage, sich Motive für eine Falschaussage nicht herleiten lassen, hält die Kammer es auch für ausgeschlossen, dass der Angeklagte mit seiner eigenen Anzeige versucht hat, die damaligen Angaben seiner Schwester Sonja auf der Basis einer konstruierten Falschbelastung des Angeklagten zu unterstützen.

ee) Die Kammer hat bei ihrer Prüfung der Glaubhaftigkeit der Aussage des Zeugen James $\mathrm{H}$. auch berücksichtigt, dass zwei weitere vom Zeugen geschilderte sexuelle Übergriffe seitens des Angeklagten inm gegenüber von der Staatsanwaltschaft mit Verfügung vom 29.12.2003 gemäß $\S 170$ II StPO eingestellt worden sind. Zur Begründung ist dabei ausgeführt, dass die Erinnerung des Geschädigten James $\mathrm{H}$. an diese Vorfälle, die dieser im Rahmen seiner polizeilichen und ermittlungsrichterlichen Vernehmungen sowie im Rahmen der Explorationstermine bei der Sachverständigen geschildert habe, weit weniger präsent und detailliert gewesen sei. Die aussagepsychologische Begutachtung habe insoweit ergeben, dass hinsichtlich dieser weiteren geschilderten Vorfälle der Detaillierungsgrad der Angaben für ein hinreichend sicheres diagnostisches Urteil aus aussagepsychologischer Sicht nicht ausreiche. Zweifel an der Glaubwürdigkeit des Zeugen haben sich hierdurch nicht ergeben.

Der Zeuge James $\mathrm{H}$. hat auch Im Rahmen seiner Einvernahme vor der Kammer angegeben, dass es noch zu zwei weiteren Vorfällen seitens seines Vaters ihm gegenüber gekommen sei, einmal zu Hause und einmal im Wald, er könne diese aber nicht näher schildern, das stehe er nicht durch. Diese Begründung hält die Kammer für nachvollziehbar. Die Schilderung des unter III dargestellten Vorfalls Im Einzelnen hat den Zeugen erkennbar erheblich emotional belastet und er hat sich glaubhaft außer Stande gesehen, die nach seinen Angaben weiter erfolgten sexuellen Übergriffe seines Vaters näher zu schildern.

ff) Auch die Angaben der Zeugin Monika H., der Ehefrau des Angeklagten, waren nicht geeignet, die Glaubwürdigkeit des Zeugen James H. zu erschüttern.

Die Zeugin hat bekundet, dass sie sich den Anklagevorwurf nicht erklären könne; der Angeklagte habe auf ihr Befragen hin diesen ständig abgestritten. Sie habe mit dem Angeklagten ein normales Sexualleben geführt und keine homosexuellen Neigungen bei diesem festgestellt. Ihre im Rahmen der polizeilichen Vernehmung gemachten Angaben, wonach der Angeklagte mit seinem Sohn James zu keinem Zeitpunkt allein im Wald gewesen war, hat die Zeugin so nicht aufrechterhalten. Sie hat auf entsprechenden Vorhalt einräumen müssen, dass es durchaus Gelegenheiten gegeben hat, bei denen sie nicht zu Hause gewesen sei und bei denen der Angeklagte mit seinem Sohn einen Waldspaziergang habe machen können. 
gg) Auch aus der Aussage des Zeugen Hibinger, des Klassenlehrers des Zeugen James $\mathrm{H}$. im 8. und 9. Schuljahr, ergeben sich keine Anhaltspunkte, an der Glaubwürdigkeit des Zeugen H. zu zweifeln.

Der Zeuge Hibinger wurde von der Verteidigung als Zeuge dafür benannt, dass James $\mathrm{H}$. in der Lage gewesen sei, diesem gegenüber glaubhaft einen Sachverhalt vorzutäuschen; denn der Zeuge habe sich während eines Skilageraufenthalts im Jahr 1998 krank gemeldet, obwohl keine Erkrankung habe festgestellt werden können. Der Zeuge Hiebinger hat in der Hauptverhandlung bekundet, dass James am Abend des ersten Tags im Skilager über Magenbeschwerden geklagt habe, weshalb er den Schüler auf Empfehlung eines Kollegen in eine nahe gelegenes Krankenhaus gefahren habe. Die dortige Diagnose habe zwar keinen Befund ergeben, der Zeuge habe aber nicht den Eindruck gehabt, dass James simuliert habe, sondern dass dieser die geltend gemachten Beschwerden tatsächlich empfunden habe. Dies decke sich auch mit dem von ihm während der Schulzeit gewonnenen Eindruck, wonach James stets ehrlich gewesen sel.

hh) Schließlich haben sich auch keine Anhaltspunkte für eine fehlende Aussagetüchtigkeit des Zeugen James H. ergeben.

Die Sachverständige Dr. Loohs hat berichtet, dass sie bei der Exploration des Zeugen eine Überprüfung von dessen Aussagetüchtigkeit durchgeführt habe. Sie habe dabei das Intelligenztestverfahren CFT 20 angewendet, der Zeuge habe dabei einen Überdurchschnittlichen Gesamt-IQ von 122 IQ-Punkten erzielt. Im Rahmen der Gedächtnisprüfung habe sich gezeigt, dass James $\mathrm{H}$. über ein detailliertes autobiografisches Erinnerungsvermögen verfüge. Nach ihrer Einschätzung sei der Zeuge sichtlich in der Lage, Ereignisse verzerrungsfrei wahrzunehmen, im Gedächtnis abzuspeichern und diese bei Erfragungen zu schildern. Dieser Befund deckt sich im Übrigen mit dem Eindruck der Kammer vom Aussageverhalten des Zeugen in der Hauptverhandlung.

Die Sachverständige hat sich auch mit der Frage befaßt, inwieweit James $\mathrm{H}$. unter einem mangelnden Realitätsbezug leide und - wie vom Angeklagten behauptet - in einer Phantasiewelt leben könnte und ob es deshalb zu den Anschuldigungen dem Angeklagten gegenüber gekommen sei. Dabei habe sie festgestellt, dass der Zeuge sich offensichtlich gerne mit Science-Fiction und Fantasy beschäftige und diesbezüglich Literatur und Filme konsumiere sowie Gesellschafts- und Computerspiele aus diesem Genre besitze. Daraus könnten jedoch keine Hinweise für einen etwaigen Mangel an Realitätsbezug des Zeugen abgeleitet werden. Die Sachverständige habe zudem das klinische Persönlichkeitsverfahren MMPI-2 durchgeführt, um über die reine Verhaltensbeobachtung hinaus abklären zu können, ob eventuell eine zusätzliche psychiatrische Begutachtung des Zeugen indiziert sein könnte. Das Testprofil des Zeugen sei allerdings bis auf die Werte zur familiären Disharmonie und -Entfremdung unauffällig ausgefallen, so dass aus ihrer Sicht eine diesbezügliche weitere Abklärung nicht erforderlich erscheine. Auch insoweit hat die Kammer aufgrund des von ihr vom Zeugen gewonnenen Eindrucks in Übereinstimmung mit dem Befund der Sachverständigen keinen Anlass gesehen, die Aussagetüchtigkeit des Zeugen einer weiteren Überprüfung durch Erholung eines psychiatrischen Gutachtens zu unterziehen.

ii) Ein weiteres Indiz für die Glaubhaftigkeit der Aussage des Zeugen James H. ist der Befund des von der Sachverständigen Dr. Loohs erstatteten Glaubwürdigkeitsgutachtens, welches nach Überzeugung der Kammer wissenschaftlichen und von der höchstrichterlichen Rechtssprechung aufgestellten Anforderungen an Glaubwürdigkeitsgutachten genügt.

Die Sachverständige hat berichtet, dass sie bei James H. Explorationen zur Familienanamnese, zur Biographie, zur Sexualanamnese, zur Erhebung von Kompetenzmerkmalen sowie zur Sache durchgeführt habe. Dabei seien folgende diagnostische Verfahren zur Anwendung gekommen:

- Aussagepsychologische Exploration zum inkriminierten Geschehen

- Exploration zur Anzeigensituation und Aussagengenese

- Exploration zur Biographie und den persönlichen Lebensumständen des Zeugen

- Erhebung individueller Vergleichsstandards anhand von: 
Gedächtnisprüfung mit Schilderung von erlebten Episoden im themenneutralen Bereich, speziell von besonderen Lebensereignissen

- Intelligenzverfahren CFT 20

- Klinisches Verfahren MMPI-2

- Sexualanamnese

- Diskussion zum Verständnis der Zeugenpflichten

Weiter hat die Sachverständige berichtet, dass sie bei der Begutachtung davon ausgegangen sei, dass der zu prüfende Sachverhalt nicht gegeben sei, dass etwa eine absichtliche Falschaussage, Fremdbeeinflussung oder Autosuggestion vorliege. Dabei habe sie die Ausgangshypotese, dass für die Angaben von James $\mathrm{H}$. keine Erlebnisbasis für die fraglichen Übergriffe von dessen Vater angenommen werden könne, wie folgt ausdifferenziert:

Hypothese 1:

James $\mathrm{H}$. habe die gegen den Vater erhobenen Vorwürfe frei erfunden; innerhalb der Familie bestehe ein erhebliches Konfliktpotential zwischen den Eltern Kindern und den Eltern, wobei bereits im Jahr 1999 Sonja $\mathrm{H}$. ihren Vater wegen eines angeblichen sexuellen Missbrauchs angezeigt habe, dieses Verfahren jedoch eingestellt worden sei. Auf diesem Hintergrund könnte James $\mathrm{H}$. auf der Basis verschiedener denkbarer Motive seinen Vater beschuldigen: Er könnte davon überzeugt sein, dass die damaligen Angaben seiner Schwester korrekt waren und versuchen, sie mit einer eigenen Anzeige auf der Basis einer konstruierten Aussage zu unterstützen; er habe zum damaligen Zeitpunkt mitbekommen, dass die Anzeige von Sonja die Familie in erhebliche Bedrängnis gebracht habe. Er könnte die Aussage frei erfunden haben, um die Familie in Schwierigkeiten zu bringen und sich so für vermeintlich erlittenes Unrecht zu rächen; James $\mathrm{H}$. könnte aufgrund eigener negativer Erfahrung mit den Eltern im Sinne von Misshandlungen seine jüngeren Geschwister schützen wollen und habe deswegen sexuelle Übergriffe erfunden; möglicherweise habe er das inkriminierte Geschehen erfunden, um sich so eine Rechtfertigung für eigenes Fehlverhalten (Aggression) zurecht zu legen.

Hypothese 2:

Die Angaben von James H. könnten auf Fremdquellen zurückgehen, etwa dass der Zeuge diese aus Medienberichten, denkbaren Schilderungen anderer Jungen aus dem Heim etc. konstruiert habe.

Hypothese 3:

Generell müsse geprüft werden, inwieweit bei James H. ein Defizit in der Realitätsüberwachung vorliegen könne, da er nach Aktenlage in einer "Fantasiewelt" lebe und möglicherweise aufgrund einer psychiatrisch relevanten Störung unter Wahrnehmungs- oder Gedächtnisstörungen leide. Dies wäre eine Frage der Aussagetüchtigkeit.

Die Sachverständige ist unter Zugrundelegung der genannten Untersuchungshypothesen zu dem Ergebnis gelangt, dass die Aussage des Zeugen James H. in Bezug auf den geschilderten Vorfall im Jägerstand eine ausgesprochen hohe aussagepsychologische Qualität aufweise, die aussageimmanenten und auch die aussageübergreifenden Realkennzeichen seien in hoher bis sehr hoher Qualifizierung in der Aussage vertreten, sodass sich ein Erlebnisbezug dieser Angaben mit hinreichender Sicherheit annehmen lasse. Die aufgestellten Hypothesen 1 bis 3 ließen sich eindeutig verwerfen. Gegen eine erfundene Falschaussage spreche, dass der Zeuge die Anzeige erst drei Jahre, nachdem er aus dem Elternhaus ausgezogen sei, erstattet habe und dass sich im zeitlichen Kontext der Anzeigenerstattung keinerlei aktuellen Konflikte mit den Eltern abgezeichnet hätten. Hätte der Zeuge die Absicht gehabt, durch die Anzeige seine Geschwister zu schützen, so hätte es nahe gelegen, dass die Anzeige gleich im Anschluss, etwa noch im Jahr 2000 erstattet worden wäre, etwa um seine Schwester Sonja zu unterstützen. Auch das Falschaussagemotiv, sich für eigenes Fehlverhalten rechtfertigen zu müssen, scheide aus, da die Beweisaufnahme ergeben habe, dass der Zeuge sich derzeit unauffällig 
verhalte und sich beruflich und gesundheitlich stabilisiert habe. Die Hypothese 2 könne verworfen werden und zwar zunächst auf der Basis des Ergebnisses der Aussagenanalyse, speziell der vorhandenen ungewöhnlichen Details, die in der vorgefundenen Form schwerlich aus Fremdquellen übernommen worden sein könnten. Schließlich sei der Zeuge, wie bereits ausgeführt, aussagetüchtig gewesen.

Eine Gesamtwürdigung aller dargestellten Indizien führt daher zu dem Ergebnis, dass die Angaben, die der Zeuge James $\mathrm{H}$. gemacht hat und die unter III dargestellt sind, der Wahrheit entsprechen und der Angeklagte mithin des inm gemachten Tatvorwurfs überführt ist.

3) Zur Frage der Schuldfähigkeit des Angeklagten hat der Sachverständige Dr. Ottermann, Ärztlicher Direktor des Bezirkskrankenhauses Straubing, einer forensisch-psychiatrischen Klinik, ein Gutachten erstattet.

Der Sachverständige hat dabei ausgeführt, dass er am 29.03.2004 eine körperlich-neurologische Untersuchung des Angeklagten vorgenommen habe, wobei sowohl der internistische Befund wie auch der neurologische Befund unauffällig gewesen seien. Eine psychiatrische Exploration habe er nicht durchführen können, da diese der Angeklagte verweigert habe. Vorausgesetzt, der Tatvorwurf treffe zu, kommt der Sachverständige zu dem Ergebnis, dass sich beim Angeklagten deutliche Hinweise auf eine Störung der Sexualpräferenz im Sinne einer schweren anderen seelischen Abartigkeit gemäß §§ 20, 21 StGB ergeben habe. Diese liege im Bereich des homosowie heterosexuellen Spektrums mit inzestuöser Neigung, wobei zu einer etwaigen Latenz ebenso wenig wie zu einer etwaigen Progression dieser Störung Angaben gemacht werden könnten. Die vom Zeugen James $\mathrm{H}$. geschilderte anale Penetration sei nur durch einen groben Eingriff durchzuführen, was auf sadistische Neigungen des Angeklagten schließen lasse. Um diese dargelegten Störungen der Sexualpräferenz näher abklären zu können, müsste eine komplette psychiatrische und testpsychologische Untersuchung des Angeklagten durchgeführt werden, welche sich über einen Zeitraum von 15 bis 20 Stunden erstrecken würde. Da diese Untersuchung der Angeklagte verweigere, könne er die Voraussetzungen einer erheblich verminderten Steuerungsfähigkeit im Sinne des § 21 StGB anhand der dargelegten Anknüpfungstatsachen nicht sicher ausschließen. Demgegenüber bestünden keinerlei Anhaltspunkte für das Vorliegen der Voraussetzungen des $§ 20$ StGB.

Die Kammer schließt sich dem Gutachten des forensisch erfahrenen Sachverständigen nach Überprüfung an. Sie geht zu Gunsten des Angeklagten von einer nicht ausschließbaren erheblichen Verminderung der Steuerungsfähigkeit gemäß $§ 21$ StGB aus. Eine Unterbringung des Angeklagten gemäß $\S 81$ StPO zur weiteren Abklärung des beim Angeklagten im Raum stehenden Krankheitsbildes kam nicht in Betracht. Der Angeklagte hat kategorisch eine Mitwirkung bei der Untersuchung auch im Rahmen einer etwaigen Unterbringung im Bezirkskrankenhaus Straubing verweigert. Der Sachverständige Dr. Ottermann hat hierzu ausgeführt, dass dann eine Unterbringung zur Beobachtung nichts bringe, da die anzustellenden Untersuchungen eine Mitarbeit des Probanden erfordern würden.

\section{V \\ (rechtliche Würdigung)}

Der Angeklagte war der sexuellen Nötigung gemäß § 178 I StGB In der Bekanntmachung der Neufassung des Strafgesetzbuches vom 10.03.87 (a. F.) schuldig zu sprechen.

Er hat dadurch, dass er James $\mathrm{H}$. vor und während der Durchführung des Analverkehrs an den Handgelenken festgehalten hat, durch Einsatz von körperlicher Gewalt diesen zur Duldung der sexuellen Handlung gezwungen.

Für eine tatbestandliche Gewaltanwendung im Sinne des $\S 178$ StGB ist nicht unbedingt ein größerer Kraftaufwand erforderlich. Es reicht aus, dass es sich um eine nicht ganz unerhebliche, gegen den Körper gerichtete Einwirkung handelt, die vom Opfer als körperlicher Zwang 
empfunden wird; hierfür genügt das Festhalten der Hände des Tatopfers an den Handgelenken (vgl. Tröndle/Fischer, § 177 Nr. 6).

Die Kammer hat auch keinen Zweifel daran, dass das Festhalten der Hände nach dem Willen des Angeklagten der Vornahme der sexuellen Handlung tatsächlich gedient hat; denn der Angeklagte musste bei Vornahme der erstrebten sexuellen Handlung mit Widerstand des Opfers rechnen, als er für dieses überraschend den Analverkehr durchgeführt hat. Der Angeklagte hat auch nachdem er von seinem Sohn aufgefordert worden war, aufzuhören, den Geschädigten weiter festgehalten und den Analverkehr weiter vollzogen, was ebenfalls für die finale Verknüpfung von Nötigungsmittel mir der Herbeiführung der sexuellen Handlung spricht.

VI

\title{
(Strafzumessung)
}

1. Die gegen den Angeklagten zu verhängende Freiheitsstrafe war dem Strafrahmen des $\S 178$ I StGB a. F. zu entnehmen, da sich bei der nach $\S 2$ III StGB gebotenen konkreten Betrachtungsweise diese Strafvorschrift als das mildere Gesetz darstellt, well sie einen Strafrahmen umfasst, der im Regelfall Freiheitsstrafe von 1 Jahr bis zu 10 Jahren und im minder schweren Fall Freiheitsstrafe von 3 Monaten bis zu 5 Jahren umfasst. Denn nach der derzeit aufgrund des 6. Strafrechtreformgesetzes geltenden Rechtslage sieht der Tatbestand der sexuellen Nötigung gemäß § 177 I StGB einen Regelstrafrahmen vor, der von Freiheitsstrafe von 1 Jahr bis zu 15 Jahren und im minder schweren Fall von 6 Monaten bis zu 5 Jahren reicht, unabhängig davon dass das Verhalten des Angeklagten das Regelbeispiel des $\S 177$ II Nr. 1 StGB mit einem Regelstrafrahmen von 2 Jahren bis 15 Jahren erfüllen würde.

\author{
2. Den Regelstrafrahmen des $\S 178$ । StGB a. F. hat die Kammer gemä $\S \S 21,49$ । StGB \\ gemildert.
}

Die Voraussetzungen für die Annahme eines minder schweren Falls im Sinn des § 178 II StGB a. F. lagen beim Angeklagten nicht vor. Ein minder schwerer Fall ist dann anzunehmen, wenn bei der Gesamtwürdigung von Tat und Täterpersönlichkeit die für den Täter sprechenden Umstände derart überwiegen und von den erfahrungsgemäß gewöhnlich vorkommenden Fällen in einem solchen Maße abweichen, dass die Anwendung des Ausnahmestrafrahmen geboten erscheint. Dabei hat die Kammer bedacht, dass schon das Vorliegen eines vertypten Milderungsgrundes, vorliegend die Vorschrift des $\S 21 \mathrm{StGB}$, für sich allein zur Annahme eines minder schweren Falles führen kann.

Bei der somit zu treffenden Abwägung aller wesentlichen belastenden und entlastenden Umstände hat die Kammer zu Gunsten des Angeklagten berücksichtigt, dass er nicht vorbestraft ist und einen Strafeindruck dadurch erhalten hat, dass er sich seit 06.05.2004 in Untersuchungshaft befindet. Zu Gunsten des Angeklagten war auch zu werten, dass die Tat nicht ausschließbar bereits knapp 8 Jahre zurückliegt und die vom Angeklagten zur Durchführung des Analverkehrs angewendete Gewalt nicht sehr erheblich war. Strafmildernd wirkten sich auch die in der Persönlichkeit des Angeklagten liegenden Umstände aus, die vom Sachverständigen Dr. Ottermann zur Anwendung des $\S 21$ StGB herangezogen wurden.

Strafschärfend war zu werten, dass der Angeklagte bei seinem Sohn die Durchführung des Analverkehrs, also einer besonders erniedrigenden sexuellen Handlung, erzwungen hat, wobei er den Analverkehr trotz der Aufforderung seines Sohnes, aufzuhören, bis zum Samenerguss durchgeführt hat. Er hat beim Vollzug des Analverkehrs dem Opfer Schmerzen und eine blutende Wunde im Afterbereich zugefügt, dessen Folgen der Zeuge James H. noch über einen Zeitraum von ca. 14 Tagen verspürte. Der Angeklagte hat zudem gravierende sexuelle Handlungen an seinem leiblichen, damals noch minderjährigen Sohn vorgenommen; Zwar konnte hier eine tateinheitliche Verurteilung wegen sexuellen Missbrauchs eines Schutzbefohlenen gemäß § 174 । Nr. 3 StGB nicht erfolgen, weil insoweit Strafverfolgungsverjährung eingetreten ist; doch durfte die in diesem - über $\S 177$ StGB hinaus - die ungestörte sexuelle Entwicklung des Kindes bei den Eltern besonders schützenden - Tatbestand zum Ausdruck kommende straferschwerende 
Tatbegehungsmodalität der sexuellen Nötigung zum Nachteil des Angeklagten berücksichtigt werden (vgl. BGH NStZ - RR 98, S. 175). Strafschärfend war auch zu werten, dass der Angeklagte sein Opfer noch dadurch weiter gedemütigt hat, dass er es veranlasste, auch bei inm den Analverkehr durchzuführen.

Ein minder schwerer Fall liegt daher unter Abwägung der vorgenannten Umstände nicht vor. Angesichts der gravierenden straferschwerenden Umstände beim Angeklagten kommt vielmehr den zu Gunsten des Angeklagten sprechenden Aspekten kein derart wesentliches Gewicht zu, so dass die Anwendung des Ausnahmestrafrahmens nach Auffassung der Kammer verfehlt wäre. Es begründen weder die allgemeinen (nicht vertypten) Milderungsgründe einen minder schweren Fall noch kann ein solcher unter Heranziehung eines vertypten Milderungsgrunds des $521 \mathrm{StGB}$ angenommen werden.

Die Kammer hat bei der Strafzumessung im Einzelnen die vorgenannten strafschärfenden und strafmildernden Umstände berücksichtigt. Unter deren Abwägung erschien eine Freiheitsstrafe von 4 Jahren tat- und schuldangemessen.

\section{VII}

Die Kostenentscheidung ergibt sich aus $\S \S 464,465,472$ I StPO.

Dr. Lang

Vorsitzender Richter

am Landgericht
Rösl

Richter

am Landgericht 


\section{Samenvatting}

In dit boek staat de vraag centraal of de motiveringsvoorschriften aangaande de bewijsbeslissing in strafzaken bijdragen aan de functies die de motivering dient te vervullen. De functies van motivering zijn: controle, inscherping en explicatie. De controlefunctie houdt in dat uit de motivering moet blijken dat de regels voor de te nemen beslissing in acht zijn genomen en biedt de direct betrokkenen de mogelijkheid de gegeven beslissing in hoger beroep dan wel cassatie ter discussie te stellen. De inscherpingsfunctie haakt aan bij het gegeven dat de rechter doordat hij de beslissing schriftelijk moet motiveren, scherper met de te beantwoorden vragen wordt geconfronteerd. De explicatiefunctie, tenslotte, ziet er op toe dat de rechter door middel van de gegeven motivering aan betrokkenen en het publiek uitlegt op welke gronden hij tot zijn beslissing is gekomen. De controlefunctie en de inscherpingsfunctie garanderen de deugdelijkheid van de beslissing. De motivering, bezien vanuit het perspectief van deze functies, dient ter handhaving van, respectievelijk aanvulling op de bestaande bewijsregels. Of de motivering voldoet aan deze functies is mede afhankelijk van de omvang van het bewijsrecht. De explicatiefunctie heeft in veel mindere mate een bewijsrechtelijke betekenis en moet vooral gezien worden in het licht van het garanderen van een onafhankelijke, onpartijdige en openbare rechtspraak.

De studie begint met een historische verkenning van de bewijs- en motiveringsregels. Daaruit blijkt dat er vanaf de inwerkingtreding van het eerste Wetboek van Strafvordering in 1838 een aanwijsbaar verband bestaat tussen de bewijs- en motiveringsregels. Dit komt duidelijk naar voren in de discussies die in de $19^{\mathrm{e}}$ eeuw over de handhaving van het negatief-wettelijk bewijsstelsel zijn gevoerd. In een dergelijk stelsel is de rechter niet volledig vrij in de selectie en waardering van bewijs maar is hij gebonden an specifiek in de wet omschreven bewijsmiddelen en bijbehorende bewijsregels. Tegenstanders van dit stelsel wijzen erop dat de toepassing van algemene bewijsregels noodgedwongen leidt tot onjuiste resultaten in individuele strafzaken. Zij achten de deugdelijkheid van het bewijsoordeel beter gediend indien de rechter verplicht wordt dit oordeel te onderbouwen. Bij de invoering van het Wetboek van Strafvordering in 1926 werd maar deels aan die kritiek tegemoet gekomen. Zo werden de bewijsregels met betrekking tot het gebruik van het bewijsmiddel der aanwijzingen en de verklaring van niet-beëdigde getuigen geschrapt en deels vervangen door nadere motiveringsplichten. Daarvoor in de plaats kwamen de plicht tot het aanwijzen van de redengevende feiten (deels nog terug te vinden in het huidige art. 359 lid $3 \mathrm{~Sv}$ ) en de 
nadere motiveringsplicht in geval van het gebruik van verklaringen van onbeëdigde getuigen (thans nog opgenomen in art. $360 \mathrm{~Sv}$ ). In het ontwerp van de Staatscommissie-Ort werden eveneens de bewijsminima afgeschaft en vervangen door een nadere motiveringsplicht indien de rechter het bewijs zou willen baseren op de enkele verklaring van de verdachte of één getuige. Bij de uiteindelijke behandeling werd dit voorstel echter geschrapt met als consequentie dat het negatief-wettelijk bewijsstelsel - inclusief de minimumbewijsregels - in essentie gehandhaafd bleef. Wel werden naast de twee al eerder genoemde motiveringsvoorschriften nog twee andere motiveringsvoorschriften in het wetboek opgenomen, te weten: het vonnis bevat de inhoud van de gebezigde bewijsmiddelen en de bewijsbeslissing is met redenen omkleed.

De wijze waarop aan de bewijsregels vanaf 1926 uitleg is gegeven, komt aan bod in hoofdstuk 3 en kan met één woord worden omschreven: ruim. Op alle punten die kenmerkend zijn voor het negatief-wettelijk bewijsstelsel, heeft de Hoge Raad water bij de wijn gedaan. Zo is van een limitatieve opsomming van de bewijsmiddelen allang geen sprake meer, omdat door middel van de door de Hoge Raad goedgekeurde de-auditu-constructie feitelijk alle vormen van bewijs door middel van een andere persoon mondeling dan wel schriftelijk kunnen worden overgebracht. Ook de extensieve uitleg van het bewijsmiddel 'eigen waarneming' heeft bijgedragen aan de afbraak van het limitatieve stelsel. Bovendien hebben de wettelijke bewijsminima nauwelijks enige betekenis omdat zij betrekking hebben op de gehele bewezenverklaring en dus niet eisen dat de betrokkenheid van de verdachte uit meer dan één bron moet blijken. Tot slot heeft de Hoge Raad ook specifieke eisen aan de bewijsmiddelen weinig strikt uitgelegd, zoals bijvoorbeeld de eis dat getuigen alleen mogen verklaren over zaken die zijzelf hebben waargenomen of ondervonden. Slechts van Straatsburgse zijde zijn nadere normerende eisen aan het bewijsoordeel gesteld. Deze vloeien voort uit het recht van de verdediging op het horen van getuigen. Een recht dat een uitwerking is van het in artikel 6 EVRM neergelegde recht op een 'fair trial'. De Hoge Raad is vervolgens wel zeer terughoudend in de toepassing van de Straatsburgse normen.

In de hoofdstukken 4 tot en met 6 wordt ingegaan op de specifieke motiveringsplichten zoals die in 1926 zijn opgenomen in het Wetboek van Strafvordering. In het verlengde van de totstandkomingsgeschiedenis van het wetboek zou men verwachten dat naarmate de wettelijke bewijsregels minder strikt zijn, het ontstane vacuüm in de normering van het bewijsoordeel wordt opgevuld door nadere motiveringseisen. Die verwachting is echter onjuist.

In hoofdstuk 4 staat de plicht tot het vermelden van de inhoud van de bewijsmiddelen in het vonnis centraal. Hoewel deze eis in de opvatting van de wetgever niet tot de motiveringsregels werd gerekend, is zij sinds lange tijd de meest 
wezenlijke vorm van verantwoording van het bewijsoordeel. Door het opnemen van de inhoud van de door de rechter gebezigde bewijsmiddelen kan worden gecontroleerd of het bewijsmateriaal voldoet aan de wettelijke eisen, redengevend is voor het bewezenverklaarde en of het voldoende is met het oog op de in de wet neergelegde bewijsminima. Bovendien heeft de Hoge Raad lange tijd het belang van de bepaling benadrukt omdat door het opnemen van de inhoud van de bewijsmiddelen de verdachte op eenvoudige wijze kennis kan nemen van het ten laste van hem gebezigde bewijsmateriaal.

Op de eis van het opnemen van de inhoud van de bewijsmiddelen in het veroordelende vonnis zijn echter vele uitzonderingen. De meest wezenlijke is wel, dat alleen wanneer een rechtsmiddel wordt ingesteld het vonnis moet worden aangevuld met alle voor de bewijsbeslissing relevante gegevens. Anders kan worden volstaan met een verkort vonnis waarin met betrekking tot de bewijsbeslissing uitsluitend de conclusie is terug te vinden. Bij uitspraken van alleensprekende rechters en bij bekennende verdachten hoeft zelfs nadat hoger beroep of cassatie is ingesteld niet de volledige inhoud van het ten laste van de verdachte gebezigde bewijsmateriaal in het vonnis te worden opgenomen. De rechter kan dan volstaan met een verwijzing naar de vindplaats van het bewijsmateriaal in het dossier. Ook in het in 2004 gestarte project Promis - dat tot doel heeft de motivering van strafvonnissen te verbeteren - is de vermelding van de inhoud van de bewijsmiddelen als motiveringseis grotendeels komen te vervallen. Bovendien blijken sommige rechtbanken nadat hoger beroep is ingesteld het vonnis in het geheel niet aan te vullen met de inhoud van de gebezigde bewijsmiddelen of een verwijzing naar de vindplaats van die bewijsmiddelen. Een praktijk die wordt gerechtvaardigd door te wijzen op de inhoud van de behandeling in hoger beroep. Daar wordt de zaak volledig opnieuw behandeld en kunnen eventuele fouten in het vonnis in eerste aanleg - ook het volledig ontbreken van het belastende bewijsmateriaal - zonder verdere consequenties - worden gecorrigeerd.

In hoofdstuk 5 staat de relevantie van het bewijs centraal. De eis dat enkel relevant bewijsmateriaal ten grondslag mag worden gelegd aan de bewezenverklaring kwam in het Wetboek van Strafvordering van 1926 tot uiting in de plicht tot het aanwijzen van de redengevende feiten en omstandigheden. In 2005 is de plicht tot het aanwijzen komen te vervallen en thans is het voldoende als de inhoud van de bewijsmiddelen zoals die in het vonnis is opgenomen redengevend is. De wijziging is een codificatie van de reeds sinds de invoering van het wetboek bestaande praktijk. De aanwijzing hield immers niet meer in dan dat de rechter in zijn vonnis een standaardzinsnede opnam in de trant van: 'dat de in het vonnis opgenomen bewijsmiddelen de redengevende feiten en omstandigheden bevatten waarop de rechter zijn overtuiging steunt'. Door hiermee genoegen te nemen, heeft de in artikel 359, derde lid, Sv opgenomen motiveringsregel nooit 
dat kunnen waarmaken wat de wetgever ermee beoogde, namelijk: dat de rechter in het vonnis zijn logische gedachtegang kenbaar maakt. Vooral bij het gebruik van indirecte bewijsconstructies is dat te betreuren. In dergelijke gevallen hoeft de strafrechter namelijk niet in het vonnis tot uitdrukking te brengen wat hij waaruit heeft afgeleid. De vermelding van het bewijsmateriaal zonder nadere toelichting is voldoende. De Hoge Raad grijpt slechts in indien de bewezenverklaring (of delen daarvan) niet uit het bewijsmateriaal kan volgen.

In geval van bijzondere bewijsconstructies, zoals het gebruik van het zwijgen en het liegen van de verdachte voor het bewijs en het schakelbewijs, zal de rechter de redengevendheid van 'het bewijsmateriaal' nader moeten toelichten, omdat uit het enkel opnemen van de inhoud van het bewijsmateriaal de betekenis daarvan voor de bewezenverklaring niet blijkt. Dat geldt ook voor het weerleggen van de zogeheten Meer- en Vaartverweren. In die gevallen waarin de redengevendheid van het bewijs niet zonder meer blijkt of wordt betwist, zal de feitenrechter een nadere motivering in het vonnis moeten opnemen. Die kan in veel gevallen bestaan uit de vermelding van een standaardoverweging, zoals 'kennelijk bedoeld om de waarheid te bemantelen', 'de verdachte geen de redengevendheid van het bewijsmateriaal ontzenuwende verklaring heeft gegeven' of dat 'hetgeen door de verdediging is gesteld niet aannemelijk is geworden'.

De betrouwbaarheid van het bewijs komt aan de orde in hoofdstuk 6. In de beoordeling van de betrouwbaarheid van het bewijsmateriaal is de rechter in principe vrij. Die vrijheid komt tot uitdrukking in de standaardoverweging van de Hoge Raad: 'de selectie en waardering van het bewijsmateriaal is voorbehouden aan de feitenrechter'. De rechter hoeft over die selectie en waardering geen verantwoording af te leggen. Op die regel wordt een uitzondering gemaakt in artikel $360 \mathrm{~Sv}$. Voor zover de rechter gebruik maakt van onbeëdigde verklaringen, verklaringen van (deels) anonieme personen, kroongetuigen en afgeschermde getuigen dient hij het gebruik daarvan ambtshalve te motiveren. De ratio van deze motiveringsplicht is gelegen in het gegeven dat de genoemde vormen van bewijs naar hun aard onbetrouwbaar kunnen zijn, of de zelfstandige controle van die betrouwbaarheid door de zittingsrechter wordt bemoeilijkt. Door een extra motivering van de rechter te eisen, wordt hij zich bewust van het precaire karakter van deze vormen van bewijs, of wordt uit het vonnis duidelijk dat hij zelfstandig de betrouwbaarheid van het bewijsmateriaal heeft onderzocht. De aan artikel $360 \mathrm{~Sv}$ ten grondslag liggende gedachte wordt echter tekortgedaan doordat de Hoge Raad de reikwijdte van die bepaling heeft beperkt. Zo hoeft de feitenrechter niet snel aan te nemen dat er sprake is van een onbeëdigde verklaring of anonieme verklaring en is dientengevolge een nadere motivering niet vereist.

Een tweede uitzondering op het uitgangspunt van de vrije selectie en waardering vindt zijn grondslag in de jurisprudentie van de Hoge Raad. Hoewel lange tijd 
aan het tweede lid van artikel $359 \mathrm{~Sv}$ (beslissingen zijn met redenen omkleed) voor de bewijsbeslissing geen betekenis toekwam, heeft de Hoge Raad daarin vanaf de jaren tachtig verandering gebracht. In een aantal specifieke gevallen eist hij dat de strafrechter de selectie en waardering wel nader toelicht in het vonnis. Voorwaarde is dat de verdediging op dat punt een duidelijk en goed onderbouwd verweer heeft gevoerd. Waar het de betrouwbaarheid van het bewijsmateriaal betreft, heeft de Hoge Raad een dergelijke responsieplicht aangenomen ten aanzien van het gebruik van de verklaring van de anonieme getuige, de kroongetuige en de deskundige wiens deskundigheid of de betrouwbaarheid van de door hem gehanteerde methode wordt betwist. De eerste twee gevallen zijn inmiddels in artikel $360 \mathrm{~Sv}$ opgenomen en ten aanzien daarvan geldt thans een ambtshalve motiveringsplicht. Ten aanzien van de overige gevallen is ook een wettelijke regeling gecreëerd. Vanaf januari 2005 geldt dat elk uitdrukkelijk en onderbouwd standpunt enkel onder aanvoering van gronden door de rechter naast zich neergelegd kan worden (art. 359 lid 2, tweede volzin, Sv). Deze motiveringsplicht geldt ook voor standpunten van het Openbaar Ministerie. De wettelijke regeling wijkt niet alleen af van de vroegere jurisprudentie waar het de omvang van de motiveringsplicht betreft, maar ook de ratio van de motiveringsplicht is afwijkend. In die gevallen waarin de Hoge Raad een nadere motiveringsplicht aannam, had dat onder andere tot doel in het vonnis tot uitdrukking te brengen dat de uiteindelijke verantwoordelijkheid voor de waarheidsvinding bij de strafrechter ligt en dus niet bij de rechter-commissaris of de deskundige. De responsieplicht zoals thans neergelegd in de tweede volzin van artikel 359 lid 2 Sv heeft veeleer tot doel de waarheidsvinding te structureren, waarbij in toenemende mate de nadruk komt te liggen op de bijdragen van partijen. In het strafproces en ook het resultaat daarvan - het vonnis - moet men zich concentreren op zaken die partijen verdeeld houden. Een toenemende nadruk op inbreng van partijen zal de rechterlijke verantwoordelijkheid voor de vaststelling van de relevante feiten en omstandigheden naar de achtergrond doen verschuiven.

Uit de hoofdstukken 3 tot en met 6 kan de conclusie worden getrokken dat het bewijsrecht in Nederland veel minder strikt wordt uitgelegd, dan men op grond van de inhoud en achtergrond van de wettelijke regels zou mogen verwachten. Bovendien is de rechterlijke vrijheid met betrekking tot de vaststelling en waardering van de feiten niet gecompenseerd door een meer strikte uitleg van de motiveringsvoorschriften. Alleen de per 1 januari 2005 ingevoerde algemene responsieplicht en zijn voorlopers in de jurisprudentie zouden kunnen duiden op een hernieuwde belangstelling voor een nadere normering van het bewijsoordeel door het stellen van nadere motiveringseisen. Echter, de eisen die worden gesteld aan het standpunt wil het een respons van de rechter kunnen ontlokken, de relativeringen van de nietigheidsanctie die de Hoge Raad reeds heeft geformuleerd 
en het ontbreken van een inhoudelijke toetsing van de gegeven respons in cassatie wijzen erop dat een nadere normering van het bewijsoordeel kennelijk niet wordt beoogd. Doel is motivering op maat te bieden, in die zin dat de rechter enkel uitleg hoeft te geven over zijn oordeel indien hem dat expliciet en onder aanvoering van alle relevante argumenten wordt gevraagd.

Hoe anders is de situatie in Duitsland, die in hoofdstuk 7 aan de orde komt. Duitsland kent in tegenstelling tot Nederland geen negatief-wettelijk bewijsstelsel. In principe zijn alle vormen van bewijs toegestaan, mits die met inachtneming van de daarvoor geldende eisen ter zitting worden geïntroduceerd. Dat betekent dat aan de eisen van mondelinge procesvoering en formele en materiële onmiddellijkheid moet zijn voldaan. Is daaraan voldaan, dan is de rechter vrij in de waardering van het bewijs, hetgeen ook nadrukkelijk in $\S 261$ StPO is opgenomen. In Duitsland ligt dus de nadruk op de normering van de bewijsvoering en veel minder op de bewijswaardering. Toch heeft het Bundesgerichtshof geoordeeld dat voor het bewijsoordeel de subjectieve overtuiging van de rechter onvoldoende is. Die overtuiging moet zijn grondslag vinden in objectief vastgestelde feiten en moet in overeenstemming zijn met algemene ervaringsregels en wetenschappelijke inzichten. Op dat punt wordt in cassatie controle uitgeoefend en teneinde die controle mogelijk te maken, dient de Duitse strafrechter alle voor de bewijsbeslissing relevante feiten en omstandigheden in zijn vonnis te vermelden en daadwerkelijk af te wegen. Laat hij dat achterwege, dan kan dat betekenen dat hij zijn ambtshalve onderzoeksplicht niet is nagekomen, dan wel dat de bewijswaardering onvolledig is. In specifieke gevallen - zoals bij Aussage gegen Aussage of het zwijgen van de verdachte - heeft het Bundesgerichtshof feitelijk gedicteerd welke aspecten de rechter bij de bewijswaardering moet betrekken en in het vonnis moet opnemen.

Het verschil tussen Nederland en Duitsland op het punt van motivering is opmerkelijk. Immers, waar in Nederland specifieke in de wet opgenomen motiveringsplichten van begin af aan van hun betekenis zijn beroofd, is in Duitsland de rechterlijke vrijheid met betrekking tot bewijswaardering in weerwil van een uitdrukkelijke bepaling ( $\$ 261 \mathrm{StPO}$ ) aan banden gelegd. Een tweede opmerkelijk verschil is dat het initiatief tot motivering in Duitsland volledig bij de strafrechter ligt en daar geldt dus niet - zoals in Nederland - dat motivering slechts geïndiceerd is indien partijen aangeven de bewijsbeslissing ter discussie te willen stellen door het voeren van verweer. Een derde verschil is gelegen in de omvang van de toetsing van het feitenoordeel in cassatie. Die toetsing is in Nederland in vergelijking tot Duitsland zeer beperkt.

De verschillen vinden hun oorsprong in een afwijkend bewijs- en strafprocesrecht. In beide landen is getracht in de wet een systeem op te nemen dat de deugdelijkheid van het bewijsoordeel in hoge mate kan garanderen. In Duitsland is gekozen 
voor een stelsel waarbij de nadruk ligt op de bewijspresentatie ter zitting opdat de rechter in staat is het beschikbare bewijsmateriaal zelfstandig te toetsen. In Nederland is de nadruk gelegd op het normeren van de fase van bewijswaardering door middel van wettelijke bewijsregels. Binnen het negatief-wettelijk bewijsstelsel krijgt de motivering een hoog formeel karakter; de nadruk komt te liggen op controle op de wettelijke eisen en minder op de inhoud van het bewijsmateriaal. De oorspronkelijke nadruk op de bewijsvoering en dus in mindere mate op de bewijswaardering heeft in Duitsland ook geleid tot een vergaande ambtshalve onderzoeksplicht van de strafrechter, die ook in cassatie kan worden getoetst. De ratio achter die onderzoeksplicht is dat daar waar de rechter niet wordt gebonden aan bewijs(waarderings)regels, in ieder geval moet worden gegarandeerd dat hij over alle voor de te nemen beslissing relevante feiten en omstandigheden beschikt. Dat het Bundesgerichtshof het noodzakelijk achtte, de rechterlijke vrijheid met betrekking tot de bewijswaardering aan banden te leggen, heeft aan het belang van de onderzoeksplicht van de strafrechter geen afbreuk gedaan. Sterker nog: het is evident dat een dergelijke onderzoeksplicht aan betekenis wint, indien de rechter tevens verplicht wordt de uit zijn onderzoek naar voren komende feiten en omstandigheden in zijn beslissing te betrekken en af te wegen.

Een laatste verschil tussen beide landen betreft de toetsing van het bewijsoordeel in cassatie. Waar in Nederland de cassatierechter de bewijsbeslissing zeer terughoudend toetst, voert zijn Duitse collega een veel verdergaande controle uit. Uit het vonnis van de Duitse rechter moet blijken dat hij alle relevante factoren onder ogen heeft gezien en in zijn oordeel heeft betrokken met inachtneming van algemene ervaringsregels en wetenschappelijke inzichten. Deze verdergaande toetsing kan mede worden verklaard door het ontbreken van de mogelijkheid van hoger beroep in zware strafzaken. De toetsing van de bewijswaardering stelt het Bundesgerichtshof in staat om de deugdelijkheid en volledigheid van het feitenonderzoek te controleren. Voor zover daarin gebreken worden geconstateerd, zal het vonnis in cassatie worden vernietigd en volgt verwijzing. Op die manier kan alsnog - weliswaar via een omweg - de waarborg van twee feitelijke instanties worden geboden.

Het laatste hoofdstuk staat in het teken van het belang van de motivering en de daaraan gekoppelde functies. Het belang van de motivering is gelegen in de legitimatie van de uiteindelijk door de rechter te nemen beslissing. Uit de motivering moet blijken dat de rechter tot een juiste beslissing is gekomen. De waarborgen voor een juiste beslissing zijn gelegen in de gebondenheid aan de wet, de kwaliteit van de beslisser (onafhankelijk, onpartijdig en deskundig) en de mogelijkheid tot tegenspraak. In hoeverre in het concrete geval die waarborgen in acht zijn genomen, kan uitsluitend blijken uit het vonnis en de daarin opgenomen motivering. In zoverre is de motivering een wezenlijke voorwaarde voor het garanderen van goede waar- 
heidsvinding. Uit de motivering moet blijken dat de wettelijke grenzen die gelden ten aanzien van het bewijsoordeel in acht zijn genomen, moet tot uitdrukking komen dat de rechter tot een eigen (onafhankelijk en onpartijdig) en deskundig oordeel is gekomen en moet de rechter ervan blijk geven de bijdragen van partijen te hebben gezien en te hebben gewogen. Daarmee wordt de controle-, respectievelijk de inscherpingsfunctie van de motivering aangesproken. De explicatiefunctie ziet in mindere mate op het waarborgen van een goede waarheidsvinding en heeft met name tot doel de communicatie tussen rechter en betrokkenen - procespartijen en het publiek - te optimaliseren. Door het geven van uitleg komt aan de uitspraak van de rechter en aan de rechtspraak in algemene zin meer gezag toe.

De bewijsmotivering in Nederland staat van oudsher in het teken van de controlefunctie en inscherpingsfunctie. Zij heeft echter veel van haar waarde verloren doordat de Hoge Raad de bewijsregels ruim en de motiveringsplichten beperkt heeft uitgelegd. Het resultaat daarvan is dat er op bewijsrechtelijk gebied weinig te controleren valt en de juridische noodzaak om in het vonnis te laten zien dat de rechter alle relevante feiten en omstandigheden onder ogen heeft gezien niet altijd aanwezig is. De enige uitzondering daarop is de per 1 januari 2005 opgenomen responsieplicht op standpunten van partijen. Hoewel de Hoge Raad ook daar een restrictieve uitleg aan heeft gegeven, zou daar desalniettemin een het bewijsoordeel normerende functie vanuit kunnen gaan. Maar daarvoor is vereist dat in cassatie het bewijsoordeel meer stringent wordt getoetst. Vooralsnog lijkt de Hoge Raad echter niet het voorbeeld van zijn Duitse collega op dat punt te willen volgen. Daarmee lijkt de responsieplicht vooral gericht te zijn op het geven van uitleg aan betrokkenen en het publiek zonder dat die uitleg zelf inhoudelijk kan worden getoetst. Bovendien is de uitleg alleen vereist als partijen daar expliciet om vragen. Laten zij dat achterwege, of voldoen ze niet aan de daarvoor geldende vormvereisten, dan zou dit voor de rechter een teken kunnen zijn dat er geen noodzaak tot nadere motivering bestaat. 


\section{Summary}

The core topic of this study is the extent to which in criminal cases the existing requirements set for reasoned decisions as to the facts sufficiently meet the functions which such reasoned decisions must perform. These functions are: control, raising the court's awareness and explication. The function of control implies that it must become clear from the statement of reasons given by the court that the rules governing the decision to be taken have been observed and that the parties directly involved are given the opportunity on appeal to raise questions about the decision before a Court of Appeal or the Netherlands Supreme Court. The function of raising the court's awareness is linked to the idea that if a court knows in advance that it must provide the reasons for its decision in writing and so does, it will be faced with specific questions that need to be answered. The function of explication, finally, refers to the court explaining to the parties involved and the public, by way of the included reasons, on what grounds it has arrived at its decision. The functions of control and awarenessraising both relate to guaranteeing the correctness of the decision and, seen from the perspective of these functions, the statement of reasons serves to enforce or supplement the existing rules of evidence. The degree to which the statement of reasons meets these functions is therefore in part dependent on the extent and scope of the law of evidence. The function of explication has a far lesser direct impact in an evidentiary sense and must rather be viewed in the light of guaranteeing an independent, impartial and public administration of justice.

The study commences with an historical exploration of the rules of evidence and the rules governing the express statement of reasons. The exploration shows that, since the coming into effect of the first Code of Criminal Procedure in 1838, there has been a clear link between the rules of evidence and those governing the express statement of reasons. This connection is found most clearly in the debate that raged during the 19th century on maintaining the limited statutory evidentiary system introduced in 1838, in which the Dutch Code of Criminal Procedure contains an exhaustive list of the means of evidence and minimum standards of proof. Opponents to this system pointed out that the application of general rules of evidence must necessarily lead to incorrect results in individual criminal cases. They deem that the correctness of the decision as to the facts is better served if the court is obliged to give the reasons for its decision. When the Code of Criminal Procedure of 1926 was introduced, this criticism was only partly met. A number of unsuitable rules of evidence were abolished and partly replaced by 
additional duties imposed on the court to state its reasons. This applies to the abolishment of inference as a means of evidence (het bewijsmiddel der aanwijzingen) and the use of non-sworn witness statements. In their place came the duty to expressly underpin the relevance of facts - still found in part in Article 359, par. 3, Dutch Code of Criminal Procedure (DCCP) - and the duty to state additional reasons where use is made of non-sworn witness statements - still found in Article 360 DCCP. In the draft of the Ort Commission (Staatscommissie Ort) the minimum standards for establishing proof were abolished and replaced by a duty to provide additional reasons where the court wishes to base the proof on the sole statement of the defendant or a sole witness statement. In the final stage, this proposal was dropped and as a result the statutory (DCCP) evidentiary system - with its exhaustive list of the means of evidence and minimum standards for establishing proof - has been maintained in essence. However, apart from the two requirements as to reasoned decisions referred to above, two additional requirements were laid down in the Code, namely: the requirement that the judgment must contain the content of the means of evidence employed and that the decision as to the facts must be reasoned.

Chapter 3 discusses the way in which subsequently, after 1926, the rules of evidence have been interpreted. Such interpretation can be summed up by a single word: broadly. To all aspects that are characteristic of the rules of evidence laid down in the DCCP, the Netherlands Supreme Court has made exceptions through its case law. For example, for a long time now, the list of the means of evidence has been non-exhaustive, because all forms of evidence may, in effect, be conveyed indirectly, orally or in writing, as a result of the testimomium-deauditu (hearsay testimony) construction approved by the Netherlands Supreme Court. A broad interpretation of the means of evidence of the court's 'own observation' has also contributed to the erosion of the limited statutory evidentiary system. The statutory minimum standards for establishing proof are hardly relevant, because they relate to the alleged facts as a whole and therefore do not require that the involvement of the defendant must be evident from more than a single source. And finally, the Netherlands Supreme Court has construed rather broadly the specific requirements set for the means of evidence, for instance the provision that witnesses may only testify about what was observed or experienced personally. Only the Strasbourg Court has imposed further normative requirements in relation to the decision as to the facts. These ensue from the right of the defence to hear witnesses, which is an elaboration of the right to a fair trial laid down in Article 6 ECHR. The Netherlands Supreme Court has subsequently exercised considerable restraint in applying the Strasbourg norms. 
Chapters 4 through 6 deal with the specific duties to expressly state the reasons for the court's decision, as incorporated into the DCCP in 1926. In view of the framing history of the Code, the expectation could be that the less strict the statutory rules of evidence are, the more the resulting vacuum in regulating the decision as to the facts would be filled by further reasoning requirements. This expectation is false, however.

The main topic of Chapter 4 is the court's duty to disclose the content of the means of evidence in the judgment. Although originally, according to the legislator, this requirement was not intended as a rule governing reasoned decisions, for a long time it proved to be the main source of accountability for the decision as to the facts. The inclusion in the judgment of the content of the means of evidence employed by the court allows determination of whether or not the evidence satisfies the statutory requirements; of whether it is relevant for what has been established as proven; and of whether it is sufficient, in view of the minimum standards of proof prescribed by the DCCP. In addition, for a long time the Netherlands Supreme Court stressed the importance of the provision, because it is easy for the defendant to find out about the evidence against him if the content of the means of evidence is included in the judgment.

There are, however, many exceptions to the requirement that the content of the means of evidence must be included in the convicting judgment. The most essential is that, only where an appeal is lodged against the judgment, must all data relevant to the decision as to the facts be added to the judgment. Until such moment or where no appeal is lodged, it is sufficient to write an abridged judgment in which only the conclusion relating to the decision as to the facts is found. Where decisions by single judges (unus rule) are concerned, and in the case of a confessing defendant, the full content of the evidence against the defendant need not be included, even after an appeal has been lodged with a Court of Appeal or the Netherlands Supreme Court. A reference by the court as to the provenance of the evidence - the case file - suffices. The requirement of stating the reasons for judicial decisions by including the content of the means of evidence employed neither applies, to a large degree, in the Promis project, a project aimed at improving express reasoning in criminal judgments, which was started in 2004. In addition, it has emerged that some district courts, after an appeal has been lodged, fail to add the data pertaining to the means of evidence employed or a reference to the source of these means of evidence. The courts defend such practice by pointing at the content of the appellate proceedings. In such proceedings, the case is re-tried in full and possible errors in the judgment, such as the failure to include, in the judgment, evidence against the accused, may be corrected without further consequences. 
Chapter 5 deals with the requirement that the evidence must be relevant. This requirement was expressed in the Code of Criminal Procedure by the court's duty to indicate which facts and circumstances are relevant. In 2005, this duty was repealed and at present it is sufficient if the content of the means of evidence, as included in the judgment, is relevant. The change is, in effect, a codification of existing practice going back to the introduction, in 1926, of the Code. All the duty entailed, after all, was that the court, in its judgment, included a standard phrase to the effect that: 'the means of evidence listed in the judgment contain the relevant facts and circumstances on which the court has founded its conviction'. Since this practice was accepted by the Netherlands Supreme Court, the reasonedjudgment rules included in Article 359, par. 3 DCCP, have never accomplished what was intended by the legislator, namely that the court, in its judgment, discloses its logical thought process. This is regrettable, especially if a construction is used whereby proof is inferred from circumstantial evidence. In such cases, the criminal court does not have to express in the judgment what it has inferred from which facts and circumstances. Listing the evidence without further explanation suffices. The Netherlands Supreme Court will only intervene if the court's decision as to the facts cannot be inferred from the evidence.

In the case of special evidentiary constructions, such as using the fact that the defendant remains silent or lies, or the use of similar past occurrences as evidence (schakelbewijs), the court must provide an explanation of the relevance of the evidence, because a mere listing of the content of the evidence does not show its relevance for the court's decision to convict. This also holds true for the refutation of evidence by what is referred to as Meer en Vaart defences. At issue here is whether there may be an alternative explanation for the evidence. In those cases, in which the relevance of the evidence is not automatically evident or is disputed, the trier of fact must state additional reasons in its judgment. In many instances, such a statement could consist in the inclusion of a standard phrase, such as 'clearly intended to cover up the truth', 'not supplied a statement which invalidates the relevance of the evidence', or 'what has been adduced by the defence is not persuasive'.

The reliability of evidence is discussed in Chapter 6 . Assessment of the reliability of evidence is premised on the court's discretion. This discretion is expressed in the following standard consideration of the Netherlands Supreme Court: 'selection and evaluation of the evidence is reserved for the trier of fact'. The court is not obliged to give account of its selection and evaluation. An exception to this rule is laid down in Article 360 DCCP. Where the court uses non-sworn statements, statements by (partly) anonymous persons, accused turned state witness and shielded witnesses, it must state the reason for such use ex officio. The reason for this duty to state reasons lies in the fact that these forms of evidence, by their 
nature, may be unreliable or that independent review of their reliability by the adjudging court is made more difficult. The duty to state the reasons for its decision purports either to make the court aware of the precarious character of these forms of evidence, or to express, in the judgment, that it has independently examined the reliability of the evidence. This noble purpose is partly undone by the case law of the Netherlands Supreme Court in which the scope of Article 360 DCCP has been limited; the trier of fact, for example, does not have to readily assume that the statement is a non-sworn statement or an anonymous statement within the meaning of Article 360 DCCP.

A second exception to the premise of discretionary selection and evaluation is founded in the case law of the Netherlands Supreme Court. Although for a long time the second requirement, laid down in paragraph 2 of Article 359 DCCP, that the decision as to the facts must be reasoned, lacked significance, from the eighties onwards, the Netherlands Supreme Court began to alter this. In a number of specific cases, it demanded that the criminal court, in its judgment, give its reasons for its selection and evaluation of the evidence, provided that the defence has conducted an unambiguous and well-founded defence in relation to this issue. Regarding the reliability of evidence, the Netherlands Supreme Court has assumed such a duty of reply in relation to statements by anonymous witnesses, accused turned state witness, and expert witnesses whose expertise is disputed, or where the reliability of the method employed by them is contested. The first two instances are now listed in Article 360 DCCP and with regard to these there is a duty to state reasons ex officio. Statutory rules have also been created where the other instances are concerned. From January 2005 onwards, the rule is that each express and reasoned assertion put forward by the defence or the Public Prosecutor's Office may only be rejected by the court by stating the grounds for such rejection (Article 359, par. 2, second full sentence DCCP). The statutory rules do not only depart from previous case law as to the extent of the court's duty to state reasons for its decision, but the underlying reason for the duty to state reasons differs as well. In those cases, in which the Netherlands Supreme Court accepted a duty to state additional reasons, this was intended, among other things, to have expressed, in the judgment, that the criminal court, rather than the examining magistrate or the expert witness, bears the ultimate responsibility for uncovering the truth. The duty to reply as laid down in the second full sentence of Article 359, par. 2 DCCP is much more intended to give structure to the uncovering of the truth, in which increasingly the emphasis is placed on the parties' position in the matter. In criminal proceedings and the outcome of these - the judgment -, the focus must be on matters that divide the parties. Increasing emphasis on what the parties submit will push the court's responsibility for establishing the relevant facts and circumstances to the background. 
From Chapters 3 through 6 it may be concluded therefore that in the Netherlands the rules of evidence are interpreted far less narrowly than is to be expected on the grounds of the content and background of the statutory rules. Moreover, judicial discretion in establishing and evaluating the facts is not compensated by a more narrow interpretation of the rules on stating reasons. Only the general duty to reply, effective from 1 January 2005, and its predecessors in case law could be evidence of a renewed interest in further regulation of the decision as to the facts, because additional requirements relating to the stating of reasons are set. However, the requirements set for obtaining a reply from the court to the assertions submitted by the defence or the prosecution, the playing down of the sanction of nullity formulated by the Netherlands Supreme Court and the absence of a substantive evaluation of the reply given are an indication that further regulation of the decision as to the facts is clearly not envisaged. The aim is to have a tailored statement of reasons, in the sense that the court must only explain its judgment if this is expressly requested by a party to the proceedings and where such a request is accompanied by all relevant arguments.

How different the situation in Germany, as discussed in Chapter 7. In contradistinction to the Netherlands, Germany does not have a limited statutory evidentiary system. All forms of evidence are allowed, in principle, providing they are presented to the court according to the relevant requirements. This means that the rules regarding the presentation of evidence in court, both as to form and content, must have been met. If these have been complied with, it is at the court's discretion to evaluate the evidence. This has been expressly laid down in $\S 261$ Strafprozessordnung (StPO). In Germany, the emphasis is therefore on regulation of the presentation of the evidence in court and far less on the court's evaluation of the evidence. Nevertheless, the Bundesgerichtshof has held that it does not suffice for the decision as to the facts that the court is persuaded by the evidence. Such persuasion must have its foundation in the objective establishment of facts and must be in accordance with rules of general experience and scientific insights. In this respect, control is exercised in last instance and, to enable such control, the German criminal court must include in its judgment all facts and circumstances relevant to the decision as to the facts and must effectively weigh these. If it fails to do so, this may mean that it has not complied with its duty to investigate ex officio, or that it has not been thorough in evaluating the evidence. In specific cases - as in the case of conflicting statements (Aussage gegen Aussage) or the accused's silence - the Bundesgerichtshof has in effect dictated which aspects the court must involve in evaluating the evidence and include in the judgment.

There is a remarkable difference between the Netherlands and Germany regarding the inclusion of the reasons for the court's decision, since in Germany, in spite 
of an express provision ( $\$ 261$ StPO), the court's discretion in respect of the evaluation of the evidence has been curtailed by the imposition of rules on stating reasons, whereas in the Netherlands there are specific statutory provisions governing the duty to state reasons, which from the very beginning have been robbed of their significance. A second remarkable difference is that in Germany the initiative to state the reasons for the decision lies exclusively with the criminal court, and therefore the rule followed in the Netherlands that stating reasons is only prescribed if the parties, by conducting a defence, indicate that they wish to discuss the decision as to the facts does not apply. A third difference is the extent of lastinstance review of the decision as to the facts. Compared to Germany, in the Netherlands such review is very limited.

The above differences are caused by a deviating law of evidence and criminal procedure. In both countries, an attempt was made to incorporate into the law a system which could guarantee the correctness of the decision as to the facts. In Germany, a choice was made for a system in which the emphasis lies on presentation of the evidence before the court, so that the court is able independently to evaluate the available evidence. In the Netherlands, on the other hand, the emphasis has been placed on regulating, by means of statutory rules of evidence, the phase in which the evidence is evaluated. Within the limited statutory evidentiary system, the stating of reasons is of a predominantly procedural character, the emphasis shifting to control of statutory requirements with much less emphasis placed on the content of the evidence.

The original emphasis on presentation of the evidence in court and therefore less on evidence evaluation has resulted in Germany as well in a far-reaching duty for the criminal court to investigate ex officio, which duty may be reviewed in lastinstance proceedings. The reason behind such a duty is that, where the court is not bound by rules governing evidence evaluation, there must be a guarantee, in any case, that it has at its disposal all relevant facts and circumstances in order to take the decision. The fact that the Bundesgerichtshof deemed it necessary to curtail the court's discretion in relation to evaluation of the evidence, has not negatively affected the importance of the court's duty to investigate. On the contrary, it is evident that such a duty to investigate gains in significance, if a court is also obliged to involve and weigh the facts and circumstances that have emerged as a result of its investigation.

The final difference between Germany and the Netherlands relates to review of the decision as to the facts by the last-instance court. Whereas in the Netherlands the Netherlands Supreme Court will exercise much more restraint in reviewing the decision as to the facts and conducts a marginal test as to the reasonableness of the decision, its German counterpart conducts a much more intensive review. Judgments by German courts must show that the court has examined all relevant 
facts and has involved these in its decision, while observing rules of general experience and scientific insights. This evaluation goes much further and may be explained in part by the absence of a means of appeal in serious criminal cases. Review of the evaluation of the evidence enables the Bundesgerichtshof to check the correctness and completeness of the investigation into the facts. Where defects are discovered, the judgment will be quashed in last-instance proceedings before the Netherlands Supreme Court and the case will be referred back. Thus, the guarantee that the facts will be evaluated by two courts is preserved, be it by detour.

The final chapter is dedicated to the importance of the inclusion of the reasons for the court's decision and the concomitant functions. Stating reasons is important, because it legitimises the decision ultimately taken by the court. The statement of reasons must show that the court has arrived at the correct decision. Arriving at a correct decision is safeguarded by the fact that the court is subject to the law; by the quality of the decision maker (independent, impartial and knowledgeable); and by the possibility to dispute the evidence. The question as to whether in a specific case these safeguards have been observed only becomes evident from the judgment and the statement of reasons included in it. In that respect, the statement of reasons is therefore an essential condition for guaranteeing a proper search for the truth. The statement must show that the statutory limits applying to the decision as to the facts have been observed; it must demonstrate that the court has arrived at its decision in an independent, impartial and knowledgeable way and show that the court has examined and assessed the weight of the parties' assertions. Here, the functions of control and awareness raising are invoked. The function of explication contributes to a lesser extent to guaranteeing a proper search for the truth. Its main goal is to maximise communication between the court and those involved - the parties to the proceedings and the public. By providing an explanation, the court's judgment and the administration of justice in general gain in authority.

In the Netherlands, the reasoned statement as to proof has traditionally been dominated by the functions of control and awareness raising. However, it has lost much of its value, because the Netherlands Supreme Court has narrowly construed the rules governing evidence and the duty to state the reasons for the decision. As a result, there is little control to be exercised in the area of the law of evidence and there is not always a legal necessity to show, in the judgment, that the court has examined all relevant facts and circumstances. The only exception to this is the duty to reply to the assertions of the parties as included in the DCCP per 1 January 2005. Although the Netherlands Supreme Court has also construed this duty narrowly, it could nevertheless serve to regulate the decision as to the facts. This, however, would require that the decision as to the facts be more intensively reviewed in last-instance appellate proceedings. Thus far, the Netherlands Supreme 
Court does not seem to wish to follow the example set by its German counterpart in this respect. And so the duty to reply seems to be aimed predominantly at providing an explanation to the parties involved and to the public, without there being a possibility of subjecting the explanation itself to judicial review. Moreover, such an explanation is only required where the parties expressly so request. If they fail to do so, or if they fail to meet the applicable procedural requirements, this could be an indication for the court that there is no need for an additional statement of reasons.

Translation by:

Louise Rayar, B. tr 



\title{
Literatuur
}

\author{
Abels \& Nijboer 1981 \\ I.M. Abels en J.F. Nijboer, De feiten spreken voor zich en de rechter kent het recht, Delikt en \\ Delinkwent 1981, p. 265-275.
}

\section{Abels \& Nijboer 1983}

I.M. Abels en J.F. Nijboer, Vrijspraak en ontslag van alle rechtsvervolging in verband met de bescherming van de vrijspraak in cassatie, Rechtsgeleerd Magazijn Themis 1983, p. 445-455.

Abels 2005

I.M. Abels, Toezeggingen aan getuigen in strafzaken of toch deals met criminelen, Ars Aequi 2005, p. 861-864.

Adviescommissie Strafrecht NOvA 2005

Adviescommissie Strafrecht van de Nederlandse Orde van Advocaten, Stroomlijnen hoger beroep, $<$ http://www.advocatenorde.nl/wetenregelgeving/adviezen.asp $>$ preadvies nr. 419 aangeboden aan de Minister van Justitie d.d. 10 januari 2005.

Albrecht 1983

P-A, Albrecht, Überzeugüngsbildung und Sachverständigenbeweis in der neueren strafrechtlichen Judikatur zur freien Beweiswürdigung, Neue Zeitschrift für Strafrecht 1983, p. 486-493.

Alink \& Van Zeben 2006

M.J. Alink en P.D.J. van Zeben, Getuigen in het Nederlandse strafproces, Nijmegen: Wolf Legal Publishers 2006.

\section{Alink 2004}

M.J. Alink, AIVD-informatie als bewijs in het strafproces, in: P.D. Duyx, P.D.J. van Zeben (red.), Via Straatsburg: opstellen ter gelegenheid van de benoeming van prof. mr. B.E.P. Myjer tot rechter in het Europese Hof voor de Rechten van de Mens aangeboden door het Ressortsparket te Amsterdam op 11 oktober 2004, Nijmegen: Wolf Legal Publishers 2004, p. 155-179.

Alwart 1992

H. Alwart, Darf ein Angeklagter aus Mangel an Beweisen verurteilt werden? - Eine Studie zur Überzeugungsbildung des Strafrichters (\$ 261 StPO), Goltdammer's Archiv für Strafrecht 1992, p. $545-568$.

\section{Anderson 1999}

T.J. Anderson, The Netherlands criminal justice system: an audit model of decision-making, in: M. Malsch \& J.F. Nijboer (red.), Complex Cases; perspectives on the Netherlands criminal justice system, Amsterdam: Thela Thesis 1999.

Asser 1827

C. Asser, Vlugtige beschouwingen van eenige voorname beginselen des strafregts in verband met het ontwerp des lijfstraffelijks wetboeks, Amsterdam: Gebroeders Van Cleef 1827.

\section{Barning \& Nijboer 1989}

L.Barning en J.F. Nijboer, Het anatomisch correcte poppenarrest, Nederlands Juristenblad 1989 , p. 173-1177.

\section{Bender \& Nack 1995}

R. Bender en A. Nack, Tatsachenfeststellung vor Gericht; Glaubwürdigkeits- und Beweislehre (Band I) -Vernehmungslehre (Band II), München: C.H. Beck 1995.

Beijer 1994

A. Beijer, 'Plea bargaining' in de Verenigde Staten, in: M. Hildebrandt (red.), Plea bargaining in Holland?, Arnhem 1994, p. 63-69.

Beijer, Brants, Van Lent \& Pelser 2002

A. Beijer, C.H. Brants, L. van Lent en C.M. Pelser, Openbare strafrechtspleging - Nederlandse strafrechtsdagen 2002, Deventer: Kluwer 2002, p. 1-8. 
Blaauw 2002

J.A. Blaauw, De Puttense moordzaak; reconstructie van een dubieus moordonderzoek, Baarn: De Fontein 2002.

\section{Bleichrodt 1982}

C. J. G. Bleichrodt, Art. $430 \mathrm{~Sv}$ en het onrechtmatig verkregen bewijs, Delikt en Delinkwent 1982, p. 476-486.

Blekxtoon 2003

R. Blekxtoon, Technisch bewijs, Proces 2003, p. 199-201.

Blok \& Besier 1925

A.J. Blok en L. Ch. Besier, Nederlandse strafproces, deel II, Haarlem: H.D. Tjeenk Willink \& Zoon 1925.

Bockwinckel \& De Vries 1999

J. Bockwinkel en P. de Vries, 'Een vlo krijgen is niet vies, een vlo houden wel', interview met prof. dr. W.A. Wagenaar, Ars Aequi 1999, p. 26-33.

Bok 1893

W. Bok, De aanwijzing der toegepaste wetsartikelen in het strafvonnis, Haarlem: J.H. Warnier 1893.

\section{Boksem 1996}

J. Boksem, Op den grondslag der telastlegging; beschouwingen naar aanleiding van het Nederlandse grondslagstelsel, Nijmegen: Ars Aequi Libri 1996.

Boksem \& Frijters 2004

J. Boksem en J.E.R. Frijters, Een positieve geuridentificatie proef dient vrijwel altijd in een tegenonderzoek te worden herhaald!, Nederlands Juristenblad 2004, p. 729-734.

Boksem \& Frijters 2005

J. Boksem, en J.E.R. Frijters, De geuridentificatieproef als bewijsmiddel in strafzaken, Strafblad 2005, p. 63-83.

Boksem 2007

J. Boksem, Met raad en daad; gedachten over de positie van de verdediger in strafzaken, Deventer: Kluwer 2007.

\section{Boorsma 2005}

J. Boorsma, Doofblind strafrecht; tunnelvisie in grote strafzaken, Proces 2005, p. 58-65.

Borgers 1995

M.J. Borgers, Rechtmatigheid en betrouwbaarheid van daderidentificaties door ooggetuigen, Ars Aequi 1995, p. 177-183.

Borgers 2006

M.J. Borgers, De tweede volzin van artikel 359 lid 2 Sv, Ars Aequi 2006, p. 745-754.

Borgers \& Kristen 1999

M.J. Borgers en F.G.H. Kristen, Bewijsrisico, bewijslast en bewijslast in het strafproces, Ars Aequi 1999, p. 866-877.

Borgers \& Kristen 2005

M.J. Borgers en F.G.H. Kristen, Verweren en responderen, Delikt en Delinkwent 2005, p. 568-588.

Borst 1985

W.L. Borst, De bewijsmiddelen in strafzaken, Arnhem: Gouda Quint 1985.

Bosch 2000

A.G. Bosch, De ontwikkeling van het strafrecht in Nederland van 1795 tot 2000, Nijmegen: Ars Aequi Libri 2000.

\section{Bossers 1987}

G. Bossers, 'Welk eene natie die de jurij gehad heeft, en ze weder afschaft' De jury in de Nederlandsche rechtspraktijk, Delft: Eburon 1987.

Brants 2004

C.H. Brants, Mag het volk ook meedoen? De leek en het Nederlandse strafproces, in: A.H. Klip, A.L. Smeulers en M.W. Wolleswinkel, KriTies - Liber amicorum et amicarum voor prof. mr. E. Prakken, Deventer: Kluwer 2004, p. 129-146. 


\section{Brants, Mevis \& Prakken 2001}

C.H. Brants, P.A.M. Mevis en E. Prakken, Legitieme strafvordering - Rechten van de mens als inspiratie in de 21ste eeuw, in: C.H. Brants, P.A.M. Mevis en E. Prakken (red.), Legitieme strafvordering. Rechten van de mens als inpiratie in de 21ste eeuw, Antwerpen/Groningen: Intersentia Rechtswetenschappen 2001, p. 1-21.

\section{Brants \& Van Lent 2001}

C.H. Brants en L. van Lent, Het beginsel van externe openbaarheid - algemene beschouwingen bij het onderzoek ter terechtzitting (suppl. 126 december 2001), in: Melai/Groenhuijsen e.a.

Broeders 1999

A.P.A. Broeders, Enige overwegingen bij het gebruik van waarschijnlijkheidsconclusies in het forensisch onderzoek, Delikt en Delinkwent 1999, p. 389-407.

Broeders 2000

A.P.A. Broeders, De forensisch deskundige in Nederland, Trema 2000, p. 366-372.

Broeders 2002a

A.P.A. Broeders, Daubert en Saks: het einde van de klassieke identificatiecrimininalistiek?, Nederlands Juristenblad 2002, p. 1786-1798.

Broeders 2002b

A.P.A. Broeders, Het herkennen van stemmen, in: P.J. van Koppen, D.J. Hessing, H.L.G.J. Merckelbach en H.F.M. Crombag (red.), Het recht van binnen; psychologie van het recht, Deventer: Kluwer 2002, p. 573-596.

\section{Broeders 2003}

A.P.A. Broeders, Op zoek naar de bron; over de grondslagen van de criminalistiek en de waardering van het forensisch bewijs, Deventer: Kluwer 2003.

Broeders 2004

A.P.A. Broeders, Forensisch onderzoek van A tot Z, Justitiële Verkenningen 2004, nr. 1, p. 20-38.

Broeders 2005a

A.P.A. Broeders, De advocaat en de schoenmaker - over de rol van de advocaat als poortwachter voor het deskundigenbewijs. Strafblad 2005, p. 11-26.

Broeders 2005b

A.P.A. Broeders, Vingers, kogels, haren, oren en andere sporen - over de waarde van klassieke forensische identificatiemethoden. Strafblad 2005, p. 121-126.

\section{Broeders 2005c}

A.P.A. Broeders, Ontwikkelingen in de criminalistiek; van vingerspoor tot DNA-profiel - van zekerheid en waarschijnlijkheid, Den Haag: Boom Juridische uitgevers 2005.

Brouns 1987

P.J.H.M. Brouns, Eisen te stellen aan een bewijsredenering, Delikt en Delinkwent 1987, p. 487-501.

Brouns 2001

P.J.H.M. Brouns, De bewijsmotivering in strafzaken, in: G. Knigge (red.), Leerstukken van strafprocesrecht, Deventer: Gouda Quint 2001, p. 179-207.

Brouwer 2005

D. Brouwer, Nieuwe regeling getuigenverhoor dwingt tot actiever procederen, Advocatenblad 2005, p. 288-292.

Bruijn 1885

J. Bruijn, De rol der aanwijzingen in het bewijsrecht, Utrecht: J. de Kruyff 1885.

Burnham 2006

W. Burnham, Introduction to the law and legal system of the United States, Thomson/West 2006.

Buruma 1996

Y. Buruma, De aandacht van de strafrechter, Deventer: Gouda Quint 1996.

Buruma 2003

Y. Buruma, Het object van appèl in strafzaken, in: R.H. Happé (red.), Hoger beroep in de steigers, Den Haag: Boom Juridische uitgevers 2003, p. 109-118. 


\section{Buruma 2005}

Y. Buruma, Motiveren waarom???, in: A. Harteveld, D.H. de Jong, E. Stamhuis (red.), Systeem in ontwikkeling. Liber amicorum G. Knigge, Nijmegen: Wolf Legal Publishers 2005, p. 71-88.

\section{Buruma 2006}

Y. Buruma, Recht spreken in de dramademocratie, Delikt en Delinkwent 2006, p. 1077-1088.

Claery 1984

E.W. Cleary, McCormick on evidence, St. Paul: West Publishing 1984.

Cleiren 2001

C.P.M. Cleiren, Waarheid in het strafrecht: niet tot elke prijs, in: C.P.M. Cleiren, R.H. de Bock en C.J.M. Klaassen (red.), Het procesrecht en de waarheidsvinding, Preadvies vereniging voor Procesrecht, Den Haag: Boom Juridische uitgevers 2001, p. 9-31.

Cleiren \& De Roos 2002

C.P.M. Cleiren en Th. de Roos, Democratisering van de strafrechtspleging, in: K. Boonen, C.P.M. Cleiren, R. Foqué en Th.A. de Roos (red.), De weging van 't Hart; idealen, waarden en taken van het strafrecht. Liber Amicorum voor prof. mr. A.C. 't Hart, Deventer: Kluwer 2002, p. 171-188.

Corstens 1993

G.J.M. Corstens (red.), Rapporten herijking strafvordering 1993, Arnhem: Gouda Quint 1993.

Corstens 2003

G.J.M. Corstens, De bekennende verdachte, Nederlands Juristenblad 2003, p. 2237.

Corstens 2005a

G.J.M. Corstens, Het Nederlands strafprocesrecht, Deventer: Kluwer 2005.

\section{Corstens 2005b}

G.J.M. Corstens, Rechterlijke dwalingen, Nederlands Juristenblad 2005, p. 1733.

\section{Crijns \& Van de Meij 2005}

J. Crijns en P. van der Meij, Over de grenzen van de materiële waarheidsvinding, in: R.H. Haveman \& H.C Wiersinga (red.), Langs de randen van het strafrecht, Nijmegen: Wolf Legal Publishers 2005.

\section{Crombag 2000}

H.F.M. Crombag, Rechters \& Deskundigen, Nederlands Juristenblad 2000, p. 1659-1665.

Crombag 2006

H.F.M. Crombag, Over tunnelvisie, Trema 2006, p. 273-279.

Crombag \& Cohen 1991

H.F.M. Crombag en M.J. Cohen, Ook rechters maken menselijke fouten, in: P.J. van Koppen en H.F.M. Crombag (red.), De menselijke factor; psychologie voor juristen, Arnhem: Gouda Quint 1991, p. 227-243.

Crombag, Merckelbach \& Van Koppen 2003

H.F.M. Crombag, H.L.G.J. Merckelbach en P.J. van Koppen, Hoge verwachtingen. Over het corrumperend effect van verwachtingen op forensische expertise, Nederlands Juristenblad 2003, p. 710-716.

Crombag \& Van Koppen 2002

H.F.M. van Koppen en P.J. van Koppen, Rechtvaardigheid, in: P.J. van Koppen, D.J. Hessing, H.L.G.J. Merckelbach en H.F.M. Crombag (red.), Het recht van binnen; psychologie van het recht, Deventer: Kluwer 2002, p. 775-783.

Crombag, Van Koppen \& Wagenaar 1992

H.F.M. Crombag, P.J. van Koppen, P.J. en W.A.Wagenaar, Dubieuze zaken; de psychologie van strafrechtelijk bewijs, Amsterdam/Antwerpen: Contact 1992.

Crombag, Van Koppen \& Wagenaar 1997

H.F.M. Crombag, P.J. van Koppen, P.J. en W.A. Wagenaar, De waarde van bewijs in strafzaken, in: P.J. van Koppen, D.J. Hessing \& H.F.M. Crombag (red.), Het hart van de zaak; psychologie van het recht, Deventer: Gouda Quint 1997, p. 245-259.

Crombag \& Wagenaar 2000

H.F.M. Crombag en W.A. Wagenaar, Audite et alteram partem, Trema 2000, p. 93-96.

Cuypens 1975

M. Cuypens, Die Revisibilität der strafrichterlichen Beweiswürdigung, Bochum: Univ. 1975. 


\section{Damaska 1997}

M.R. Damaska, Evidence Law Adrift, New Haven/London: Yale University Press 1997.

De Bosch Kemper 1838-1840

J. de Bosch Kemper, Wetboek van Strafvordering, naar deszelfs beginselen ontwikkeld, en in verband gebragt met de algemeene regtsgeleerdheid met een bijvoegsel bevattende formulieren en voorbeelden der ambtsverrigtingen van regters-commissarissen, officieren van justitie, griffiers, hulpofficieren, enz., Eerste Deel, Tweede Deel en Derde Deel, Amsterdam: Johannes Müller 1838.

De Bosch Kemper 1865

B. de Bosch Kemper, De strafivordering in hare hoofdtrekken beschouwd, Amsterdam: Johannes Müller 1865, p. 1-262.

Dedes 1992

C. Dedes, Beweisverfahren und Beweisrecht, Berlin: Duncker \& Humblot 1992.

De Hert 2006

P. de Hert, Jury en leken in Nederland: een identiteitsonderzoek, Nederlands Juristenblad 2006, p. 2226-2231.

\section{De Hullu 1989}

J. de Hullu, Over rechtsmiddelen in strafzaken, Arnhem: Gouda Quint 1989.

De Jong 2003

D.H. de Jong, De aanmerkelijke kans, in: M.S. Groenhuijsen en J.B.H.M. Simmelink (red.), Glijdende schalen. Liber amicorum J. de Hullu, Nijmegen: Wolf Legal Publishers 2003, p. 217-224.

De Jong \& Kessler 2002

D.H. de Jong en M. Kessler, De HIV-test voor het voorwaardelijke opzet en andere leerstukken, Nederlands Juristenblad 2002, p. 2230-2237.

De Jong van Beek en Donk 1866

J. de Jong van Beek en Donk, Eenige historische beschouwingen over de leer van het bewijs in strafzaken, Nieuwe bijdragen voor regtsgeleerdheid en wetgeving 1866, p. 339-356.

Den Hartog 1994

J.D. den Hartog, Enkele opmerkingen over 'plea bargaining' in het Duitse strafproces, in: $M$. Hildebrandt P.T.C. van Kampen en J.F. Nijboer (red.), Plea Bargaining in Holland?, Arnhem 1994, p. 57-62.

\section{Den Hartog 2005}

J.D. den Hartog, De selectie en waardering van bewijsmateriaal, in: A. Harteveld, D.H. de Jong en

E. Stamhuis (red.), Systeem in ontwikkeling. Liber amicorum G. Knigge, Nijmegen: Wolf Legal

Publishers 2005, p. 217-230.

De Pinto 1843

A. de Pinto, Iets over het bewijs door aanwijzingen in strafzaken, Themis regtskundig tijdschrift 1843, p. 171-189.

\section{De Pinto 1845}

A. de Pinto, Iets over het motiveren van vonnissen, Themis regtskundig tijdschrift 1845, p. 396-409 en 174-186.

\section{De Pinto 1886}

A.A. de Pinto, Het herziene Wetboek van Strafvordering (met eene inleiding en aanteekeningen ontleend aan en n.a.v. de herzieningsontwerpen, de daartoe betrekkelijke stukken en de daarover gevoerde beraadslagingen), Tweede Deel, Zwolle 1886.

De Poot, Bokhorst, Van Koppen en Muller 2004

C.J. de Poot, R.J. Bokhorst, P.J. van Koppen \& E.R. Muller, Rechercheportret; over dilemma's in de opsporing, Alphen aan den Rijn: Kluwer 2004.

De Ridder 1900

N. de Ridder, Opmerkingen over bewijs en bewijsleer in strafzaken, Tijdschrift voor Strafrecht 1900, p. 279-297.

Derksen 2006

T. Derksen, Lucia de B.: reconstructie van een gerechtelijke dwaling, Diemen: Veen Magazines 2006. 


\section{De Roos 2000}

Th. A. de Roos, Het grote onbehagen; emotie en onbegrip over de rol van het strafrecht, Amsterdam: Balans 2000.

\section{De Roos 2003}

Th. A. de Roos, Burger en strafrechtspleging. Is het strafrechtelijk discours passé, Justitiële Verkenningen 2003, nr. 1, p. 62-73.

\section{De Roos 2005}

Th. A. de Roos, De Schiedamse parkmoordzaak. Vrouwe Justitia zegt sorry en likt haar wonden maar heeft zij iets geleerd?, Nederlands Juristenblad 2005, p. 1782-1785.

De Roos 2006 a

Th. A. de Roos, Bewijs met bijzondere getuigen, Strafblad 2006, p. 5-12.

\section{De Roos $2006 b$}

Th. A. de Roos, Is de invoering van lekenrechtspraak in de Nederlandse strafrechtspleging gewenst?, Tilburg 2006, <http://www.justitie.nl/images/20061120_5453193b\%20 lekenrechtspraak. doc_tcm34-27040.pdf $>$.

\section{De Roos 2007}

Th.A. de Roos, De meerwaarde van leken in de strafrechtspraak, Strafblad 2007, p. 115-123.

\section{Detter 2000}

K. Detter, Ausbau der Rechtskontrolle tatrichterlicher Beweiswürdigung und Strafzumessung, in: Karlmann Geiss e.a. (red.), Festschrift aus Anlaß des fünfzigjährigen Bestehens von Bundesgerichtshof, Bundesanwaltschaft und Rechtsanwaltschaft beim Bundesgerichtshof, Köln: Carl Heymann Verlag 2000, p. 679-706.

Detter 2001

K. Detter, Revision in Strafsachen, Baden-Baden: Nomos 2001.

De Vos 2004

A.F. de Vos, Door statistici veroordeeld?, Nederlands Juristenblad 2004, p. 686-688.

De Vos 2006

A.F. de Vos, Onschuldig rekenwerk. Een Bayesiaanse analyse van de parkmoord, Nederlands Juristenblad 2006, p. 572-576.

\section{De Winter 2007}

R.E. de Winter, Stroomlijning van het hoger beroep in economische strafzaken, in: P.G. Wiewel en R.E. de Winter (red.), Stroomlijning van het hoger beroep in strafzaken, Nijmegen: Ars Aequi Libri 2007, p. 127-135.

\section{Domela Nieuwenhuis 1911}

J. Domela Nieuwenhuis, Het bewijs in strafzaken in de Nederlandse Juristenvergadering, Tijdschrift voor het Strafrecht 1911, p. 35-48.

\section{Döhring 1964}

E. Döhring, Die Erforschung des Sachverhalts im Prozess: Beweiserhebung und Beweiswürdigung: ein Lehrbuch, Berlin: Duncker \& Humblot, 1964.

\section{Dreissen 2003}

W.H.B. Dreissen, Naar een behoorlijke en betrouwbare strafrechtspleging; meer redenen voor bewijsuitsluiting, in: P.L. Bal, E. Prakken en G.E. Smaers (red.), Veiligheid en vergelding? Een bezinning over de aard en functie van het strafrecht in de postmoderne risicomaatschappij, Deventer: Kluwer 2003, p. 115-124.

\section{Dreissen 2004a}

W. Dreissen, Het wetsvoorstel 'Motivering van de bewezenverklaring bij een bekennende verdachte', Delikt en Delinkwent 2004, p. 789-808.

Dreissen 2004b

W.H.B. Dreissen, Redengevende feiten en omstandigheden, in: A.H. Klip, A.L. Smeulers en M.W. Wolleswinkel (red.), KriTies Liber amicorum et amicarum voor prof. mr. E. Prakken, Deventer: Kluwer 2004, p. 171-186.

\section{Dreissen 2006a}

W. Dreissen, Vonnissen zonder bewijsmiddelen, Nederlands Juristenblad 2006, p. 85-86. 


\section{Dreissen 2006b}

W. Dreissen, Het feitenoordeel in Nederland en Duitsland: vorm en inhoud vergelijken, Trema 2006, p. 242-246.

\section{Drion 1966}

H. Drion, Bewijzen in het recht, Rechtsgeleerd Magazijn Themis 1966, p. 406-431.

Dubelaar 2006

M.J. Dubelaar, Hoe verder met de deskundige?, in: C.P.M. Cleiren e.a. (red.), Op zoek naar samenhang, Deventer: Kluwer 2006, p. 91-109.

Eisenberg 2002

U. Eisenberg, Beweisrecht der StPO - Spezialkommentar, München: C.H. Beck 2002.

Elffers 2003

H. Elffers, Bij toeval veroordeeld? Statistische analyse van dienstroosterdata in het strafproces, Nederlands Juristenblad 2003, p. 1812-1814.

Elffers 2005

H. Elffers, Dienstroosterdata in het strafproces, in: M.J. Sjerps en J.A. Coster van Voorhout (red.), Het onzekere bewijs - gebruik van statistiek en kansberekening in het strafrecht, Deventer: Kluwer 2005, p. 133-152.

Embregts 2003

M.C.D. Embregts, Uitsluitsel over bewijsuitsluiting, Deventer: Kluwer 2003.

Enschede 1959

C.J. Enschede, Motivering en motief, Zwolle: W.E.J. Tjeenk Willink 1959.

Enschede 1966

C.J. Enschedé, Bewijzen in het strafrecht, Rechtsgeleerd Magazijn Themis 1966, p. 488-518.

Feith 1910

R. Feith, Het bewijs in strafzaken, Handelingen der Nederlandsche Juristen-Vereeniging, 1910, p. 1-95.

\section{Fezer 1975}

G. Fezer, Möglichkeiten einer Reform der Revision in Strafsachen: eine Untersuchung unter besonderer Berücksichtigung der gegenwärtigen Vorschläge zur Rechtsmittelreform, Tübingen: Mohr 1975.

Fezer 1995

G. Fezer, Tatrichterlicher Erkenntnisprozeß - Freiheit der Beweiswürdigung, Strafverteidiger 1995, p. 95-101.

\section{Fezer 1999}

G. Fezer, Pragmatismus und Formalismus in der Revisionsgerichtlichen Rechtsprechung, in: U. Ebert e.a. (red.), Festschrift für Ernst-Walter Hanack zum 70. Geburtstag am 30 August 1999, Berlin: De Gruyter 1999, p. 331-353.

Fezer 2000

G. Fezer, Amtsaufklärungsgrundsatz und Beweisantragsrecht, in: C-W. Canaris e.a. (red.), 50 Jahre Bundesgerichtshof-Festgabe aus der Wissenschaft-Bd. IV, 2000, p. 847-881.

\section{Fezer 2001}

G. Fezer, Die 'Herabstufung'eines Beweisantrags in der Revisionsinstanz - Zugleich eine Kritik am sog. Konnexitätsprinzip, in: A. Eser e.a. (red.), Strafverfahrensrecht in Theorie und Praxis Festschrift für Lutz Meyer-Gossner zum 65. Geburtstag, München: C.H. Beck 2001, p. 629-643.

Fincke 1973

M. Fincke, Die Gewißheit als hochgradige Wahrscheinlichkeit, Goltdammer's Archiv für Strafrecht 1973, p. 266-272.

\section{Fischer 1994}

T. Fischer, Glaubwürdigkeitsbeurteilung und Beweiswürdigung - von der Last der 'ureignen Aufgabe', Neue Zeitschrift für Strafrecht 1994, p. 1-5.

Fokkens 1984

J.W. Fokkens, Bewijzen in het strafprocesrecht, Zwolle: Tjeenk Willink 1984. 


\section{Fokkens 2004}

J.W. Fokkens, Getuigen tussen Straatsburg en Den Haag, in: P.D. Duyx, P.D.J. van Zeben (red.), Via Straatsburg: opstellen ter gelegenheid van de benoeming van prof. mr. B.E.P. Myjer tot rechter in het Europese Hof voor de rechten van de mens aangeboden door het Ressortsparket te Amsterdam op 11 oktober 2004, Nijmegen: Wolf Legal Publishers 2004, p. 143-154.

\section{Fokkens 2005}

J.W. Fokkens, De wijziging van artikel 359 lid 2 Sv: een stap op weg naar een contradictoir strafproces, in: A. Harteveld, D.H. de Jong en E. Stamhuis (red.), Systeem in ontwikkeling. Liber amicorum G. Knigge, Nijmegen: Wolf Legal Publishers 2005, p. 139-149.

\section{Fokkens 2006}

J.W. Fokkens, Veranderingen in het bewijsrecht, Strafblad 2006, p. 19-27.

Foqué \& 't Hart 1990

R. Foqué en A.C. 't Hart, Instrumentaliteit en rechtbescherming, Arnhem: Gouda Quint 1990.

Foth 1997

E. Foth, Tatgericht, Revisiongericht - wer würdigt die Beweise? Deutsche Richter Zeitung 1997, p. 201-208

\section{Franken \& Prakken 2003}

A.A. Franken en E. Prakken, Evenwicht in appel, in: C.H. Brants, P.A.M. Mevis, E. Prakken en J.M. Reijntjes (red.), Op zoek naar grondslagen Strafvordering 2001 ter discussie, Den Haag: Boom Juridische uitgevers 2003, p. 97-114.

Franken \& Waling 2001

A.A. Franken en C. Waling, De actuele betekenis van artikel 430 Sv, Nederlands Juristenblad 2001, p. 1366-1371.

\section{Franken 2004a}

A.A. Franken, Voor de vorm, Den Haag: Boom Juridische uitgevers, 2004.

\section{Franken 2004b}

A.A. Franken, Een effectief middel tegen vormverzuimen?, in: P.D. Duyx en P.D.J. van Zeben (red.), Via Straatsburg. Via Straatsburg: opstellen ter gelegenheid van de benoeming van prof. mr. B.E.P. Myjer tot rechter in het Europese Hof voor de rechten van de mens aangeboden door het Ressortsparket te Amsterdam op 11 oktober 2004, Nijmegen: Wolf Legal Publishers 2004, p. 207-220.

Franken 2006a

A.A. Franken, Strafrechtelijk bewijs: enkele hoofdlijnen in de recente jurisprudentie, Strafblad 2006, p. 28-35.

\section{Franken 2006b}

A.A. Franken, De rol van de rechter-commissaris: tussen ideaal en praktijk, Delikt en Delinkwent 2006, p. 266-276.

\section{Freund 2001}

G. Freund, Die Tatfrage als Rechtsfrage - 'Persönliche Gewissheit', 'objektive Schuldwahrscheinlichkeit' und rechtsgenügender Beweis, in: A. Eser e.a. (red.), Strafverfahrensrecht in Theorie und Praxis - Festschrift für Lutz Meyer-Gossner zum 65. Geburtstag, München: C.H. Beck 2001, p. 409-429.

\section{Frijda 1988}

L. Frijda, Verantwoord beslissen; enkele opmerkingen over de explicatiefunctie van het strafvonnis, Delikt en Delinkwent 1988, p. 407-421.

Garé 1993

D.M.H.R. Garé, Bekennende verdachten; de plannen rond de vereenvoudigde procedure in strafzaken, Nederlands Juristenblad 1993, p. 409-414.

\section{Garé 1993}

D.M.H.R. Garé. De overtuiging van de rechter op basis van de stukken uit het vooronderzoek; waarom moeilijk doen als ook de verdachte vindt dat het makkelijk kan?, in: M. Hildebrandt e.a. (red.), Een afzonderlijke procedure voor de bekennende verdachte?, Arnhem: Gouda Quint 1993 p. 65-70. 
Garé 1994

D.M.H.R. Garé, Het onmiddellijkheidsbeginsel in het Nederlandse strafproces, Arnhem: Gouda Quint 1994.

Garé 1997

D.M.H.R. Garé, Rechtsbescherming en waarheidsvinding; vorm en inhoud hangen samen, Delikt en Delinkwent 1997, p. 335-343.

Garé \& Mevis 2000

D.M.H.R. Garé en P.A.M. Mevis, Over het oproepen van getuigen ter terechtzitting en getuigenbewijs in strafzaken, Nijmegen: Ars Aequi Libri 2000.

Garé \& Spronken 1997

D. Garé en T. Spronken, Wet bedreigde getuigen niet 'Straatsburg-proof': De zaak-Van Mechelen e.a. tegen Nederland, Advocatenblad 1997, p. 545-550.

Gebhardt 1939

H. Gebhardt, Die Freiheit des Strafrichters bei der Beweiswürdigung, Würzburg: Mayr 1939.

Geppert 1979

K. Geppert, Der Grundsatz der Unmittelbarkeit im deutschen Strafverfahren, Berlin: Walter de Gruyter 1979.

\section{Geppert 2003}

K. Geppert, Amtsaufklärungspflicht ( $§ 244$ Abs. 2 StPO) und Aufklärungsrüge im Strafprozess, Juristische Ausbildung 2003, p. 255-262.

Geppert 2004

K. Geppert, Der Grundsatz der freien Beweiswürdigung (§ 261 StPO), Juristische Ausbildung 2004, p. 105-113.

Gleß 2001

S. Gleß, Zur 'Beweiswürdigungs-Lösung' des BGH, Neue Juristische Wochenschrift 2001, p. 3606-3607.

\section{Gollwitzer 2001}

W. Gollwitzer, Die Strafprozessordnung und das Gerichtsverfassungsgesetz: Grosskommentar/ Löwe-Rosenberg, Band 4 § 213-295, Berlin: de Gruyter Recht 2001.

\section{Gollwitzer 2002}

W. Gollwitzer, Überlegungen zur Dokumentation von Hauptverhandlung und Urteil im Strafverfahren, in: D. Dölling en V. Erb (red.), Festschrift für Karl Heinz Gössel zum 70. Geburtstag am 16. Oktober 2002, Heidelberg: C.F. Müller Verlag 2002, p. 543-564.

\section{Gompertz 1885}

E.M. Gompertz, De motivering van strafvonnissen, Hilversum: Joh's Geradts \& Comp. 1885.

\section{Gössel 2002}

K.H. Gössel, Über Beweisverwertung, Beweiswürdigung und Beweisregeln. in: E. Graul.en G. Wolf (red.), Gedächtnisschrift für Dieter Meurer, Berlin: de Gruyter Recht 2002, p. 381-393.

Grapperhaus \& De Rooij 1989

M. J. Grapperhaus en H. J. I. M. de Rooij, Bewijsverweren; een overzicht, in: G.A.M. Strijards e.a. (red.), De derde rechtsingang nader bekeken - opstellen aangeboden aan C. Bronkhorst, Arnhem: Gouda Quint 1989, p. 115-135.

\section{Grasnick 1993}

W. Grasnick, Wahres über die Wahrheit - auch im Strafprozess, in: J. Wolter (red.), 140 Jahre Goltdammer's Archiv für Strafrecht - eine Würdigung zum 70. Geburtstag von Paul-Günter Pötz, Heidelberg: v. Decker 1993, p. 55-75.

\section{Gratama 1854}

M.S. Gratama, Eenige bedenkingen omtrent de voorschriften van ons Wetboek van Strafvordering aangaande het bewijs der misdrijven, Opmerkingen en mededeelingen betreffende het Nederlandsche regt 1854 , p. 213-241.

\section{Groenhuijsen 2004}

M.S. Groenhuijsen, Bewijsrecht als toetssteen voor de systematiek van een Wetboek van Strafvordering. Pleidooi voor een vrij bewijsstelsel, in: A.H. Klip, A.L. Smeulers en M.W. Wolleswinkel 
(red.), KriTies. Liber amicorum et amicarum voor prof. mr. E. Prakken, Deventer: Kluwer 2004, p. 147-158.

\section{Groenhuijsen 2005a}

M.S. Groenhuijsen, Jury en andere vormen van lekenrechtspraak. Over onbehagen, legitimiteit, onderbuik en cultuur, Delikt en Delinkwent 2005, p. 831-841.

\section{Groenhuijsen 2005b}

M.S. Groenhuijsen, Over toeval in het wetgevingsdebat over strafprocesrecht: de uitbouw van een contradictoir gedingstructuur in strafzaken, Delikt en Delinkwent 2005, p. 351-359.

\section{Groenhuijsen \& De Hullu 2002}

M.S. Groenhuijsen en J. de Hullu, Het hoger beroep, in: M.S. Groenhuijsen en G. Knigge (red.), Dwangmiddelen en rechtsmiddelen, Deventer: Kluwer 2002, p. 329-434.

\section{Gutwirth 1993}

S. Gutwirth, Waarheidsaanspraken in recht en wetenschap: een onderzoek naar de verhouding tussen recht en wetenschap met bijzondere illustraties uit het informaticarecht, Brussel: VUB Press 1993.

\section{Habermas 1997}

J. Habermas, Faktizität und Geltung. Beiträge zur Diskurstheorie des Rechts und des demokratischen Rechtsstaats, Frankfurt am Main: Suhrkamp 1997.

\section{Hamer \& Van Poelgeest 2006}

G.P. Hamer en J.M. van Poelgeest, Recht op het horen van minderjarige getuigen in zedenzaken?, Strafblad 2006, p. 90-101.

Haentjes 2007

R.C.P. Haentjens, Het verlofstelsel als middel de toegang tot de appèlrechter in strafzaken te stroomlijnen, in: P.G. Wiewel en R.E. de Winter (red.), Stroomlijning van het hoger beroep in strafzaken, Nijmegen: Ars Aequi Libri 2007, p. 31-59.

Hamm 1998

R, Hamm, Die Revision in Strafsachen, Berlin: Walter de Gruyter 1998.

Hamm 2000

R. Hamm, Zur Revisibilität der Beweiswürdigung in Fällen von 'Aussage gegen Aussage', Strafverteidiger-Forum 2000, p. 253-257.

\section{Hanack 1977}

E-W. Hanack, Maßstäbe und Grenzen richterlicher Überzeugungsbildung im Strafprozeß, Juristische Schulung 1977, p. 727-732.

Hanack 2003

E-W. Hanack (red.), Die Strafprozessordnung und das Gerichtsverfassungsgesetz: Grosskommentar/ Löwe-Rosenberg, Band $5 \S \S 296-373 a$, Berlin: de Gruyter Recht 2003.

't Hart 2001

A.C. 't Hart, De autonomie van het strafrecht, Delikt en Delinkwent 2001, p. 237-250.

Herdegen 1984

G. Herdegen, Bemerkungen zum Beweisantragsrecht, Neue Zeitschrift für Strafrecht 1984, p. 97-103.

Herdegen 1985

G. Herdegen, Tatgericht und Revisionsgericht, in: G. Herdegen, Beweisantragsrecht, Beweiswürdigung, strafprozessuale Revision: Abhandlungen und Vorträge, Baden-Baden: Nomos 1995, p. 60-77.

\section{Herdegen 1987}

G. Herdegen, Bemerkungen zur Beweiswürdigung, Neue Zeitschrift für Strafrecht 1987, p. 193-199.

Herdegen 1992

G. Herdegen, Die Überprüfung der tatsächlichen Feststellungen durch das Revisionsgericht auf Grund der Sachrüge, Strafverteidiger 1992, p. 527-534 en p. 590-597.

\section{Herdegen 1998}

G. Herdegen, Anmerkung zu BGH 3.9.1997, 5 StR 237/97, Juristische Zeitung 1998, p. 53-56. 


\section{Herdegen 1999}

G. Herdegen, Die strafprozessualen Beweiswürdigungstheorien des Bundesgerichtshofs, in: U. Ebert e.a. (red.), Festschrift fur Ernst-Walter Hanack zum 70. Geburtstag am 30 August 1999, Berlin: de Gruyter, 1999, p. 311-329.

Herdegen 2000

G. Herdegen, Die Eingriffe des Revisionsgerichts in die tatrichterliche Beweiswürdigung, in: $\mathrm{O}$.

Lagodny (red.), Der Strafprozess vor neuen Herausforderungen? - Über den Sinn oder Unsinn von Unmittelbarkeit und Mündlichkeit im Strafverfahren, Baden-Baden: Nomos 2000, p. 27-46.

\section{Herdegen 2003}

G. Herdegen, Strafrichtliche Aufklärungspflicht und Beweiswürdigung, Neue Juristische Wochenschrift 2003, p. 3515-3516.

\section{Hielkema 1991}

J. Hielkema, Hoe betrouwbaar is de opsporingsambtenaar als ooggetuige?, Tijdschrift voor de Politie 1991, p. 351-356.

\section{Hielkema 1996}

J. Hielkema, Deskundigen in Nederlandse strafzaken, Den Haag: Sdu 1996.

Hildebrandt 1993

M. Hildebrandt (red.), Een afzonderlijke procedure voor de bekennende verdachte?, Arnhem: Gouda Quint 1993.

\section{Hildebrandt 2004}

M. Hildebrandt, Wetenschap in rechte, Trema Special 2004, p. 187-195.

\section{Horselenberg, Merckelbach, Crombag \& Van Koppen 2002}

R. Horselenberg, H.L.G.J. Merckelbach, H.F.M. Crombag en P.J. van Koppen, Getuigen helpen herinneren, in: P.J. van Koppen, D.J. Hessing, H.L.G.J. Merckelbach en H.F.M. Crombag (red.), Het recht van binnen; psychologie van het recht, Deventer: Kluwer 2002, p. 445-464.

Horstink-von Meyenfeldt \& Bos 2005

S.J.E. Horstink-van Meyenfeldt en W. Bos, De communicerende strafrechtspleging, in: J.H. Crijns, P.P.J. van der Meij \& G.K. Schoep (red.), De taak van de strafrechtswetenschap, Den Haag: Boom Juridische uitgevers 2005, p. 95-108.

\section{Huber 2004}

M. Huber, Das Strafurteil - Grundfragen zu Aufbau und Abfassung von Verurteilung, Freispruch und Einstellung, München: C.H. Beck 2004.

\section{Huls, Mevis \& Visscher 2003}

N.J.H. Huls, P.A.M. Mevis en N. Visscher, De kloof tussen rechtspraak en samenleving - Hoe klantvriendelijk is de rechter?, Justitiële Verkenningen 2003, afl. 1, p. 11-31.

Israëls 2006

H. Israëls, Moord in Wamel - bewijs met liegende getuigen, Den Haag: Boom Juridische uitgevers 2006.

\section{Jacobs 2004}

M. Jacobs, Bekennen en ontkennen van verdachten; een onderzoek naar de proceshouding van verdachten naar aanleiding van het wetsvoorstel strekkende tot een vereenvoudigde bewijsmotivering bij bekennende verdachten, Den Haag: WODC 2004, <http://www.wodc.nl/ >.

Jacobs, Bruinsma, Van Poppel \& Moors 2005

M.J.G. Jacobs, M.Y. Bruinsma, J.W.M.J. van Poppel en J.A. Moors, Inzet, organisatie en kwaliteit van de forensisch-technische opsporing bij de politie in Nederland, Den Haag: WODC Ministerie van Justitie 2005.

\section{Jahn 2000}

M. Jahn, Der praktische Fall - Strafrechtsklausur: Eine revisionsbedürftige Revision, Juristische Schulung 2000, p. 383-387.

Jahn 2001

M. Jahn, Grundlagen der Beweiswürdigung und Glaubhaftigkeitsbeurteilung im Strafverfahren, Juristische Ausbildung 2001, p. 450-456. 


\section{Jähnke 1999}

B. Jähnke, Über die Befungnis des Revisionsgerichts zur Nachprüfung der tatrichterlichen Beweiswürdigung, in: U. Ebert e.a. (red.), Festschrift für Ernst-Walter Hanack zum 70. Geburtstag am 30 August 1999, Berlin: De Gruyter 1999, p. 355-367.

Jähnke 2001

B. Jähnke, Zur Abgrenzung von Verfahrens- und Sachrüge, 2001, in: A. Eser e.a. (red.), Strafverfahrensrecht in Theorie und Praxis - Festschrift für Lutz Meyer-Gossner zum 65. Geburtstag, München: C.H. Beck 2001, p. 559-569.

Jansen 2004

G. Jansen, Zeuge und Aussagepsychologie, Heidelberg: C.F. Müller 2004.

\section{Jarcke 1825}

C.E. Jarcke, Bemerkungen über die Lehre vom unvöllständigen Beweise, vornehmlich in Bezug auf die außerordentlichten Strafen, Neues Archiv des Criminalrechts, Band 8, 1825, p. 97.

Jerouschek 1992

G. Jerouschek, Wie frei ist die freie Beweiswürdigung? - Überlegungen zur Genese, Funktion and zu Perspektiven eines strafprozessualen Rechtsinstituts, Goltsdammer Archiv für Strafrecht 1992, p. 493-515.

\section{Jessurun d'Oliveira-Prakken 1976}

E. Jessurun d'Oliviera-Prakken, Bewijs als toetssteen van strafrecht, in: C. Kelk e.a. (red.), Recht, macht en manipulatie, Utrecht/Antwerpen: Het Spectrum 1976, p. 13-46.

\section{Jolles 1874}

J.A. Jolles, Art. 211 Wetboek van Strafvordering; het arrest moet met redenen omkleed zijn, Themis: regtskundig tijdschrift 1874, p. 460-476.

Jolles 1927

J.M. Jolles, De nieuwe strafvordering in de praktijk, Weekblad van het Regt 11636, p.7.

Jongstra 1863

A.F. Jongstra, Over de wettelijke bewijsregelen, Nieuwe bijdragen voor de regtsgeleerdheid en wetgeving 1863, p. 577-614.

Jongstra 1868a

A.F. Jongstra, Over wettelijke bewijsregelen, Heereveen: F. Hessel 1868.

\section{Jongstra $1868 b$}

A.F. Jongstra, Over wettelijke bewijsregelen; repliek aan $\mathrm{mr}$ W. Modderman. Nieuwe Bijdragen voor de regtsgeleerdheid en wetgeving, 1868, p. 5-26.

Jörg 1993

N. Jörg, Waarom bekennen?, in: M. Hildebrandt e.a. (red.), Een afzonderlijke procedure voor de bekennende verdachte?, Arnhem: Gouda Quint 1993, p. 87-92.

\section{Karsten 1910}

E.H. Karsten, Over de bewijsleer in het strafproces, Tijdschrift voor Strafrecht 1910, p. 357-377.

Keller 1999

R. Keller, Verwissenschaftlichung versus Rationalität der strafprozessualen Beweiswürdigung, Goltdammer's Archiv für Strafrecht 1999, p. 255-271.

\section{Kirberger 1914}

G. Kirberger, Het bewijs in het ontwerp wetboek van strafvordering en de motiveering van strafvonnissen, Tijdschrift voor Strafrecht 1914, p. 441-452.

\section{Kluth 1999}

W. Kluth, Beweiserhebung und Beweiswürdigung durch das Bundesverfassungsgericht, Neue Juristische Wochenschrift 1999, p. 3513-3519.

\section{Knigge 1980}

G. Knigge, Beslissen en motiveren (de artt. 348,350, 358 en 359 Sv), Alphen aan den Rijn: H.D. Tjeenk Willink 1980. 


\section{Knigge 2006}

G. Knigge, De schijn van waarheid, in: N.J.M. Kwakman (red.), Partijautonomie of materiële waarheid? - bijdragen afscheidssymposium G. Knigge d.d. 15 september 2005, Den Haag: Boom Juridische uitgevers 2006, p. 33-43.

Kortenhorst 1990

B.M. Kortenhorst, De motiveringsverplichting in strafzaken; een analyse van de artikelen 358 en 359 van het Wetboek van Strafvordering, Arnhem: Gouda Quint 1990.

\section{Krauß 1975}

D. Krauß, Das Prinzip der materiellen Wahrheit im Strafprozeß, in: G. Grünwald e.a. (red.), Festschrift für Friedrich Schaffstein zum 79. Geburtstag am 28 Juli 1975, Göttingen: Otto Schwartz \& Co 1975, p. 411-431.

Krikke 1977

A. Krikke, Bewijsmotivering en overweging onder de streep in strafvonnissen, Rechtsgeleerd Magazijn Themis, p. 446-478.

\section{Kühne 2003}

H-H. Kühne, Strafprozessrecht: eine systematische Darstellung des deutschen und europäischen Strafverfahrensrechts, Heidelberg: C.F. Müller 2003.

Kunert 1979

K.H. Kunert, Strafprozessuale Beweisprinzipien im Wechselspiel, Goltdammer's Archiv für Strafrecht 1979, p. 401-413.

\section{Küper 1984}

W. Küper, Historischer Bemerkungen zur freien Beweiswürdigung im Strafprozeß, in: K. Wasserburg en W. Haddenhorst (red.), Wahrheit und Gerechtigkeit im Strafverfahren, Festgabe für Karl Peters, Heidelberg 1984, p. 23-46.

\section{Lampe 1988}

E-J. Lampe, Richterliche Überzeugung, in: O. von Gamm e.a. (red.), Strafrecht, Unternehmensrecht, Anwaltsrecht - Festschrift für Gerd Pfeiffer, Köln: Carl Heymanns Verlag 1988, p. 353-377.

Lemke 1999

M. Lemke e.a. (red.), Heidelberger Kommentar zur Strafprozeßordnung, Heidelberg: C.F. Müller 1999.

Lindenberg 2002

K. Lindenberg, Van Ort tot Oro - een verzameling van de werken die hebben geleid tot het Oorspronkelijk Regeringsontwerp van een nieuw Wetboek van Strafvordering (1914), Groningen: Rijksuniversiteit Groningen 2002.

\section{Loddenkemper 2003}

F. Loddenkemper, Revisibilität tatrichterlicher Zeugenbeurteilung: eine Auseinandersetzung mit der neueren Rechtsprechung der Strafsenate des BGH, Baden-Baden: Nomos, 2003.

Luhmann 1969

N. Luhmann, Legitimation durch Verfahren, Neuwied am Rhein: Luchterhand 1969.

Luther 1994

H. Luther, Freie Beweiswürdigung und ihre revisionsgerichtliche Überprüfung im Strafverfahren, Neue Justiz 1994, p. 294-299 en p. 346-350.

Machielse 2005

A.J.M. Machielse, Alweer getuigen, in: A.H.E.C. Jordaans, P.A.M. Mevis en J. Wöretshofer (red.), Praktisch Strafrecht; liber amicorum Jan Reijntjes, Nijmegen: Wolf Legal Publishers 2005, p. 437452.

Malsch 2003

M. Malsch, De leek als rechter en de rechter als leek, Justitiële Verkenningen 2003, afl. 1, p. 47-61.

Malsch 2005

M. Malsch, Geregisseerde openbaarheid: Het O.M. en de zichtbaarheid van transacties, Justitiële Verkenningen 2005, nr. 6, p. 113-127. 


\section{Malsch \& Nijboer 1999}

M. Malsch en J.F. Nijboer (red.), Complex cases - perspectives on the Netherlands criminal justice system, Amsterdam: Thela Thesis 1999.

\section{Malsch \& Nijboer 2005}

M. Malsch en J.F. Nijboer, De zichtbaarheid van het recht-openbaarheid van de strafrechtspleging, Deventer: Kluwer 2005.

\section{Marongiu 2005}

D. Marongui, Afgeschermde getuigen; niet aan beginnen!, Ars Aequi 2005, p. 793-801.

\section{Maul 1984}

H. Maul, Die gerichtliche Aufklärungspflicht in der Sicht der Rechtsprechung des Bundesgerichtshofs, in: K. Wasserburg e.a. (red.), Wahrheit und Gerechtigkeit im Strafverfahren. Festgabe für Karl Peters aus Anlass seines 80. Geburtstag, Heidelberg: Muller 1984, p. 47-60.

\section{Maul 1988}

H. Maul, Die Überprufung der tatsächlichen Feststellungen durch das Revisionsgericht in der neueren Rechtsprechung des Bundesgerichtshofes, in: O. von Gamm e.a. (red.), Strafrecht, Unternehmensrecht, Anwaltsrecht - Festschrift für Gerd Pfeiffer, Köln: Carl Heymanns Verlag 1988, p. $409-424$

\section{Maul 2000}

H. Maul, Aussage gegen Aussage, Strafverteidiger-Forum 2000, p. 257-260.

\section{Melai 1961}

A.L. Melai, Het waarheidsprobleem in het strafproces (1961), in: A.L. Melai, Polariteit en Tegenspraak; een selectie uit het werk van A.L. Melai, Arnhem: Gouda Quint 1992, p. 85-104.

Melai 1968

A.L. Melai, Het gezag van norm en feit in strafzaken, Arnhem: Gouda Quint-Brouwer 1968.

Melai 1975

A.L. Melai, De onbevangen strafrechter, Delikt en Delinkwent 1975, p. 124-127.

\section{Melai 1981}

A.L. Melai, Het strafgeding: polariteit en tegenspraak, in: A.L. Melai, Polariteit en Tegenspraak; een selectie uit het werk van A.L. Melai, Arnhem: Gouda Quint 1992, p. 1-83.

Melai/Groenhuijsen e.a.

A.L. Melai \& M.S. Groenhuijsen e.a., Het wetboek van strafvordering, Deventer: Kluwer (losbladig). Merckelbach \& Boelhouwer 2002

H.L.G.J. Merckelbach en A.J.W. Boelhouwer, Leugendetectie, in: P.J. van Koppen, D.J. Hessing, H.L.G.J. Merckelbach en H.F.M. Crombag (red.), Het recht van binnen; psychologie van het recht, Deventer: Kluwer 2002, p. 649-666.

\section{Merckelbach, Crombag \& Van Koppen 2003}

H.L.G.J. Merckelbach, H.F.M. Crombag, en P.J. van Koppen, Hoge verwachtingen. Over het corrumperend effect van verwachtingen op forensische expertise, Nederlands Juristenblad 2003, p. 710-716.

\section{Meurer 1985}

D. Meurer, Beweis und Beweisregel im deutschen Strafprozess, in: R.D. Herzberg (red.), Festschrift fur Dietrich Oehler zum 70. Geburtstag, Köln: Carl Heymans Verlag KG 1985, p. 357-377.

\section{Meurer 1986}

D. Meurer, Beweiserhebung und Beweiswürdigung, in: H.J. Hirsch e.a. (red.), Gedächtnisschrift für Hilde Kaufmann, Berlin: Walter de Gruyter 1986, 947-960.

\section{Meurer 1989}

D. Meurer, Beweiswürdigung, Überzeugung und Wahrscheinlichkeit, in: H. Jeschek und T. Vogler (red.), Festschrift für Tröndle zum 70. Geburtstag am 24. August 1989, Berlin: Walter de Gruyter 1989, p. 533-549.

Mevis 1992

P.A.M. Mevis, Ingekort en weggelaten; de praktijk van kop-staartvonnissen in de strafrechtspleging, Arnhem: Gouda Quint 1992. 


\section{Mevis 1998}

P.A.M. Mevis, Constitutioneel strafrecht, Deventer: Gouda Quint 1998.

Mevis 2000

P.A.M. Mevis, Introductie: de betekenis van het legaliteitsbeginsel in de rechtsontwikkeling naar een eigentijds strafrecht, in: P.C. Bogert en T. Kooijmans (red.), Over de grens van het legaliteitsbeginsel, Deventer: Gouda Quint 2000, p. 1-34.

Mevis 2002

P.A.M. Mevis, Noodplan Schiphol: over het voordeel van meervoudig nadenken, Nederlands Juristenblad 2002 p. 265-267

Mevis 2006

P.A.M. Mevis, De ruimte voor het hoger beroep en voor wijziging van de regeling daarvan, Delikt en Delinkwent 2006, p. 1-16.

\section{Mevis, Reijntjes \& Wöretshofer 2001}

P.A.M. Mevis, J.M. Reijntjes, J. Wöretshofer, Rechtmatigheidstoetsing in het nieuwe millennium, in: C.H. Brants, P.A.M. Mevis en E. Prakken (red.), Legitieme strafvordering. Rechten van de mens als inspiratie in de 21ste eeuw, Utrecht: Intersentia Rechtswetenschappen 2001, p. 37-55.

Meyer-Goßner 1988

L. Meyer-Goßner, Hinweise zur Abfassung des Strafurteils aus Revisionsrechtlicher Sicht, Neue Zeitschrift für Strafrecht 1988, p. 529-537.

\section{Meyer-Goßner 1997}

L. Meyer-Goßner, Fortschritt durch Rückschritt um 100 Jahre, Deutsche Richter Zeitung 1997, p. 471-475.

Minkenhof/Reijntjes 2002

A. Minkenhof en J.M. Reijntjes, De Nederlandse strafvordering, Haarlem: Tjeenk Willink 2002.

Mintjes \& De Rooij 1989

G. Mintjes en H.J.I.M. de Rooij, Naar een nieuwe bewijsuitsluitingsgrond? Mogelijkheden voor de verdediging, Delikt en Delinkwent 1989, p. 860-872.

Modderman 1867

W. Modderman, De wettelijke bewijsleer in strafzaken, Utrecht: G.A. van Hoften 1867.

Modderman 1868

W. Modderman, Over wettelijke bewijsregelen; dupliek aan mr A.F. Jongstra. Nieuwe Bijdragen voor de regtsgeleerdheid en wetgeving, 1968, p. 505-544.

Mols 1991

G.P.M.F. Mols, Gemotiveerde verwerping van verweren, Advocatenblad 1991, p. 441-443.

Mols 1994

G.P.M.F. Mols, Over de kroongetuige in strafzaken, in: J.F. Bruinsma e.a. (red.), Precaire Waarden. Liber amicorum voor prof. mr. A.A.G. Peters, Arnhem: Gouda Quint 1994, p. 61-78.

Mols 2003

G.P.M.F. Mols, Getuigen in strafzaken, Deventer: Kluwer 2003.

Mols 2004

G.P.M.F. Mols, Politieambtenaar als bijzondere getuige, Nieuwsbrief Strafrecht 2004, p. 373-374.

Mols 2005

G.P.M.F. Mols, Van algemeen naar bijzonder. Over de zaak Scheper versus Nederland, Nieuwsbrief Strafrecht 2005, p. 1368-1370.

Momsen 1998

C. Momsen, Zur Zulässigkeit der strafprozessualen Sachrüge bei Angriffen gegen die Beweiswürdigung, Goltdammer's Archiv für Strafrecht 1998, p. 488-501.

Myjer 2001

E. Myjer, Geen Straatsburgs staartje aan kop-staartvonnis, NJCM-bulletin 2001, p. 227-231. 
Nack 1999

A. Nack, Strafprozessordnung - Kriminalistik - Beweisrecht; zum Beweiswert kriminaltechnischer Untersuchungsergebnisse, Kriminalistik: Zeitschrift für die gesamte Kriminalistische Wissenschaft und Praxis 1999, p. 32-39.

Nack 2001

A. Nack, Der Zeugenbeweis aus aussagepsychologischer und juristischer Sicht, StrafverteidigerForum 2001, p. 1-8.

Nack 2002

A. Nack, Revisibilität der Beweiswürdigung - Teil 1 en 2, Strafverteidiger 2002, p. 510-518 en 558-565.

Naeyé 1993

J. Naeyé, De opsporingsrisico's van een vereenvoudigde procedure voor de bekennende verdachte, in: M. Hildebrandt (red.), Een afzonderlijke procedure voor de bekennende verdachte?, Arnhem: Gouda Quint 1993, p. 45-57.

\section{Nederburgh 1919}

I.A. Nederburgh, Het aanhangig ontwerp strafvordering, Tijdschrift voor Strafrecht 1919, p. 281-332.

Nederlandse Vereniging voor Rechtspraak 2003

Nederlandse Vereniging voor Rechtspraak, Advies inzake het wetsvoorstel inzake aanpassing van de eisen te stellen aan de motivering van de bewezenverklaring bij een bekennende verdachte, $<$ http://www.verenigingvoorrechtspraak.nl/> advies nr. 248 d.d. 1 april 2003.

Nestler 2002

C. Nestler, Der richterzentrierte Strafproze $\beta$ und die Richtigkeit des Urteils; zur Notwendigkeit eines Wortprotokolls der Hauptverhandlung, in: C. Prittwitz e.a. (red.), Festschrift für Klaus Lüderssen zum 70. Geburtstag am 2. Mai 2002, Baden-Baden: Nomos 2002, p. 727-738.

Niemöller 1984

M. Niemöller, Die strafrichterliche Beweiswürdigung in der neueren Rechtsprechung des Bundesgerichtshofs, Strafverteidiger 1984, 431-442.

Nijboer 1978

J.F. Nijboer, 'De schijngestalte van de materiële waarheid', Nederlands Juristenblad 1978, p. 749-757.

Nijboer 1982

J.F. Nijboer, Algemene grondslagen van de bewijsbeslissing in het Nederlandse strafprocesrecht, Arnhem: Gouda Quint 1982.

\section{Nijboer 1987a}

J.F. Nijboer, Bewijsuitsluiting op grond van een verstrakte interpretatie van het negatief-wettelijk bewijsstelsel, Nederlands Juristenblad 1987, p. 1156-1159.

Nijboer $1987 \mathrm{~b}$

J.F. Nijboer, Enkele gedachten over concludentie en consistentie, Delikt en Delinkwent 1987, p. 832-839.

Nijboer 1987c

J.F. Nijboer, Enkele opmerkingen over de motivering van de bewezenverklaring in het schriftelijk vonnis in strafzaken, Rechtsgeleerd Magazijn Themis 1987, p. 120-142.

Nijboer 1990

J.F. Nijboer, Strafrechtelijk bewijs in de jaren '90: meer dan een papieren werkelijkheid?, Delikt en Delinkwent 1990, p. 138-155.

\section{Nijboer 1991}

J.F. Nijboer, Strafrechtelijk bewijs van een andere kant bekeken, Delikt en Delinkwent 1991, p. 332 344.

\section{Nijboer 1993}

J.F. Nijboer, Het streven naar de materiële waarheid in het strafproces, in: M. Hildebrandt e.a. (red.), Een afzonderlijke procedure voor de bekennende verdachte?, Arnhem: Gouda Quint 1993, p. 11-22. 


\section{Nijboer 1994}

J.F. Nijboer, Het blijft tobben, in: M. Hildebrandt, P.T.C. van Kampen en J.F. Nijboer (red.), Plea bargaining in Holland?, Arnhem: Gouda Quint 1994, p. 11-23.

Nijboer 1996

J.F. Nijboer, De toekomst van het strafrechtelijk bewijsrecht; een reactie op D.H.R.M. Garé's voorstel tot afschaffing van ons negatief-wettelijke stelsel, Delikt en Delinkwent 1996, p. 440-450.

Nijboer 1999a

J.F. Nijboer, Bewijs en bewijsrecht; een inleiding, Ars Aequi 1999, p. 16-25.

Nijboer 1999b

J.F. Nijboer, De waarde van het bewijs, in: J.F. Nijboer, De waarde van het bewijs, Deventer: Gouda Quint 1999, p. 1-30.

Nijboer 1999c

J.F. Nijboer, Hoe algemeen is het strafrechtelijke bewijsrecht, in J.F. Nijboer, De waarde van het bewijs, Deventer: Gouda Quint 1999, p. 31-75.

Nijboer 1999d

J.F. Nijboer, Enkele rechtsvergelijkende notities over verdachten en getuigen, in: J.F. Nijboer, De waarde van het bewijs, Deventer: Gouda Quint 1999, p. 91-113.

Nijboer 2000a

J.F. Nijboer, Strafrechtelijk bewijsrecht, Nijmegen: Ars Aequi Libri 2000.

Nijboer 2000b

J.F. Nijboer, De gedisciplineerdheid van de deskundige - het belang van de eisen van de professie in het deskundigenonderzoek en - bewijs, in: K. Boonen, A.C. 't Hart, en Th.A. de Roos (red.), Criminalistiek, forensische deskundigen en strafrechtspleging, Deventer: Gouda Quint 2000, p. 19-27.

Nijboer 2000c

J.F. Nijboer, De taken van de strafrechter, Deventer: Gouda Quint 2000.

Nijboer 2002

J.F. Nijboer, Het gekooide denken - over de rol van discipline binnen feitenonderzoek en bewijs in het recht, Leiden 2002.

Nijboer 2003

J.F. Nijboer, Forensische expertise - steeds opnieuw een uitdaging in de (straf)rechtspleging, Deventer: Kluwer 2003.

Nijboer 2004

J.F. Nijboer, Legaliteit en het strafrechtelijk bewijsrecht; uitholling van het wettelijk bewijsstelsel in strafzaken?, Ars Aequi 2004, p. 492-503.

Nijboer 2005

J.F. Nijboer, Openbaarheid en de afdoening van zaken vóór de zitting: transactie en (voorwaardelijk) sepot, in: M.Malsch en J.F. Nijboer (red.), De zichtbaarheid van het recht - openbaarheid van de strafrechtspleging, Deventer: Kluwer 2005.

Nijboer \& Jarigsma 2006

J.F. Nijboer en J.C. Jarigsma, De materiële waarheid in het (straf)procesrecht, in: Y.E. Schuurmans (red.), Bewijzen en beslissen; bijdragen aan het symposium, dat ter afscheid van prof. mr. W.D.H. Asser op 7 oktober 2005 aan de Universiteit Leiden werd gehouden, Deventer: Kluwer 2006, p. 23-30.

\section{Nijboer \& Sennef 1999}

J.F. Nijboer en A. Sennef, Justification, in: M. Malsch en J.F. Nijboer (red.) , Complex cases perspectives on the Netherlands criminal justice system, Amsterdam: Thela Thesis 1999, p. 11-26.

Nijboer \& Van Hoorn 1997

J.F. Nijboer en A.M. van Hoorn, Om de persoon van de getuige, Delikt en Delinkwent 1997, p. 563-580.

\section{Noordziek 1887}

J.J.F. Noordziek, Geschiedenis der beraadslagingen gevoerd in de Kamers der Staten-Generaal over het Ontwerp-Wetboek van strafvordering en over het vraagstuk der jury: zittingsjaar 1928-1929, Den Haag: 1887. 


\section{Paeffgen 1984}

H-U. Paeffgen, Ermessen und Kontrolle - Probleme einer Begriffsanleihe in bezug auf die Revisibilitat von Tatsachen, in: K. Wasserburg e.a. (red.), Wahrheit und Gerechtigkeit im Strafverfahren. Festgabe fur Karl Peters aus Anlass seines 80. Geburtstag, Heidelberg: Muller 1984, p. 61-92.

Pelser 1995

C.M. Pelser, De naam van het feit: over de kwalificatiebeslissing in strafzaken, Arnhem: Gouda Quint 1995.

Pelser 2002

C.M. Pelser, Motivering en openbaarheid, in: A. Beijer, C.H. Brants, L. van Lent en C.M. Pelser (red.), Openbare strafrechtspleging - Nederlandse strafrechtsdagen 2002, Deventer: Kluwer 2002, p. $45-65$.

\section{Pelz 1993}

C. Pelz, Die revisiongerichtliche Überprüfung der tatrichterlichen Beweiswürdigung, Neue Zeitischrift für Strafrecht 1993, p. 361-366.

\section{Peters 1972a}

A.A.G. Peters, Het rechtskarakter van het strafrecht (1972), in: Recht als kritische discussie; een selectie van het werk van A.A.G. Peters, Arnhem: Gouda Quint 1993, p. 15-34.

Peters 1972b

A.A.G. Peters, Illegale radiozender 'de Marconist' (1972), in: Recht als kritische discussie; een selectie van het werk van A.A.G. Peters, Arnhem: Gouda Quint 1993, p. 53-78.

\section{Peters 1986}

A.A.G. Peters 1986, Recht als kritische discussie (1986), in: Recht als kritische discussie; een selectie van het werk van A.A.G. Peters, Arnhem: Gouda Quint 1993, p. 209-238.

K. Peters 1985

K. Peters, Strafprozeß, Heidelberg: C.F. Müller Juristischer Verlag 1985.

\section{K. Peters 1988}

W. Küpers en K. Wasserburg (red.), Peters, Karl: Strafrechtspflege und Menschlichkeit-ausgewählte Schriften, Heidelberg: Müller, Juristischer Verlag 1988.

\section{Pfeiffer 2003}

G. Pfeiffer (red.), Karlsruher Kommentar zur Strafprozessordnung und zum Gerichtsverfassungsgesetz mit Einführungsgesetz, München: C.H. Beck 2003.

\section{Plantenga 1911}

B.P.J. Plantenga, Motiveering van strafvonnissen, Rechtsgeleerd Magazijn 1911, p. 318-335.

Polak 1927

E. Polak, De bewijskracht van het proces-verbaal van den opsporingsambtenaar, Tijdschrift voor Strafrecht 1927, p. 151-169.

\section{Pols 1882}

M.S. Pols, De wettelijke bewijsleer in strafzaken, Themis: regtskundig tijdschrift, p. 333-389.

\section{Pompe 1959}

W.P.J. Pompe, Het bewijs in strafzaken, Mededelingen van de Koninklijke Vlaamse Academie voor Wetenschappen, Letteren en Schone Kunsten van België 1959, nr. 4, p. 3-23.

\section{Posthumus 2005}

F. Posthumus, Evaluatie-onderzoek in de Schiedammer parkmoord, Amsterdam: aug. $2005<\mathrm{http}: / /$ www.om.nl/schiedammer_parkmoord/>.

Pradel 2000

J. Pradel, Criminal Evidence, in: J.F. Nijboer \& W.J.J.M. Sprangers (red.), Harmonisation in forensic expertise; an inquiry into the desirability of and opportunities for international standards, Amsterdam: Thela Thesis 2000, p. 411-429.

\section{Prakken 1989}

E. Prakken, Kan het zijn dat ik u ergens van ken? Over strafrechtelijk bewijs door herkenning, Nederlands Juristenblad 1989, p. 1405-1412. 


\section{Prakken 1996}

E. Prakken, Over kroongetuigen en deals met criminelen, Nederlands Juristenblad 1996, p. 16151621.

\section{Prakken 2003}

E. Prakken, De Raad voor de Rechtspraak: onafhankelijke verbetervoorstellen of onverbeterlijke afhankelijkheid van het ministerie?, Nederlands Juristenblad 2003, p. 834-835.

Prakken 2004

E. Prakken, Naar een cyclopisch (straf)recht, Nederlands Juristenblad 2004, p. 2338-2344.

Prakken \& Spronken 2001

E. Prakken en T. Spronken, Grondslagen van het recht op verdediging, in: C.H. Brants, P.A.M. Mevis en E. Prakken (red.), Legitieme strafvordering; Rechten van de mens als inspiratie in de $21^{\text {ste }}$ eeuw, Antwerpen/Groningen: Intersentia Rechtswetenschappen 2001, p. 57-74.

Prins 1892

A. Prins, Het begrip aanwijzing naar de leer van den Hoogen Raad, Amsterdam: Roeloffzen \& Hübner 1892.

\section{Promis eindrapport 2005}

Project motiveringsverbetering in strafvonnissen, Eindrapport d.d. 26 mei 2005.

Promis evaluatierapport 2005

Project motiveringsverbetering in strafvonnissen, Evaluatierapport d.d. 26 mei 2005.

Promis II projectplan 2006

Project motiveringsverbetering in strafvonnissen, Projectplan Promis II d.d. 2 oktober 2006.

\section{Rassin 1999}

E. Rassin, De rechter en de psycholoog: Betrouwbaarheidsbeoordelingen van getuigenverklaringen door gedragswetenschappers, Trema 1999, p. 302-306.

Rassin 2002

E. Rassin, De psycholoog en het deskundigenbewijs, in: P.J. van Koppen, D.J. Hessing, H.L.G.J. Merckelbach en H.F.M. Crombag (red.), Het recht van binnen; psychologie van het recht, Deventer: Kluwer 2002, p. 337-355.

\section{Rassin 2005}

E. Rassin, Tussen sofa en toga. Een inleiding in de rechtspsychologie, Den Haag: Boom Juridische uitgevers 2005.

Rassin Merckelbach \& Crombag 1997

E. Rassin, H. Merckelbach, H.F.M. Crombag, De Criteria Based Content Analysis (CBCA) als instrument om de geloofwaardigheid van getuigenverklaringen te bepalen. Een kritische notitie, Nederlands Juristenblad 1997, p. 1923-1929.

Rassin \& Van Koppen 2002

E. Rassin en P.J. van Koppen, Het verhoren van kinderen in zedenzaken, in: P.J. van Koppen, D.J. Hessing, H.L.G.J. Merckelbach en H.F.M. Crombag (red.), Het recht van binnen; psychologie van het recht, Deventer: Kluwer 2002, p. 507-530.

\section{Redactie Regtsgeleerd Bijblad 1839}

Redactie Regtsgeleerd Bijblad, Over het motiveren van Strafvonnissen, het Rechtsgeleerd Bijblad behoorende tot de Nieuwe bijdragen voor rechtsgeleerdheid en wetgeving, 1839, p. 294-304.

\section{Reijntjes 1980}

J.M. Reijntjes, Strafrechtelijk bewijs in wet en praktijk, Arnhem: Gouda Quint 1980.

Reijntjes 2003

J.M. Reintjes, Het aantonen van opzet - over de verhouding tussen vorm en materie in het strafrecht, in: M.S. Groenhuijsen en J.B.H.M. Simmelink (red.), Glijdende schalen. Liber amicorum J. de Hullu, Nijmegen: Wolf Legal Publishers 2003, p. 473-490.

Reijntjes 2006a

J.M. Reijntjes, Bewijs (suppl. augustus 2006), in: G.J.M. Corstens (red.), Handboek Strafzaken, Deventer: Gouda Quint z.j. 
Reijntjes 2006b

J.M. Reijntjes, Eigen wetenschap van de rechter; algemene bekendheid en ervaringsregels, Strafblad 2006, nr. 1, p. 46-58.

Reijntjes 2006c

J.M. Reijntjes, Minkenhof's Nederlandse strafvordering, Deventer: Kluwer 2006.

Reijntjes 2007

J.M. Reijntjes, Het hoger beroep beperkt, Strafblad 2007, p. 19-30.

Rieß 1978

P. Rieß, Zur Revisibilität der freien tatrichterlichen Überzeugung, Goltdammer's Archiv für Strafrecht 1978, p. 257-277.

\section{Rieß 1982}

P. Rieß, Über Aufhebungsgründe in Revisionsentscheidungen des Bundesgerichthofes, Neue Zeitschrift für Strafrecht 1982, p. 49-54.

Rieß 1999

P. Rieß, Gedanken zu Gegenwart und Zukunft der Revision in Strafsachen, in: U. Ebert e.a. (red.), Festschrift für Ernst-Walter Hanack zum 70. Geburtstag am 30. August 1999, Berlin: Walter de Gruyter 1999, p. 397-421.

\section{Röttgering 2006}

A. Röttgering, Schakelbewijs: een spooktrein in het bewijsrecht, Strafblad 2006, p. 36-42.

\section{Rozemond 1999a}

K. Rozemond, De dynamiek van het strafvorderlijk bewijsrecht; waarom het vooronderzoek beslissend is geworden, Justitiële Verkenningen 1999, afl. 9, p. 88-99.

\section{Rozemond 1999b}

K. Rozemond, De mythe van het de auditu-bewijs, Ars Aequi 1999, p. 144-150.

Rozemond 2002

K. Rozemond, Bewijsminima voor schriftelijk vastgelegde getuigenverklaringen in strafzaken, Nederlands Juristenblad 2002, p. 1930-1934.

\section{Rudolphi}

H-J. Rudolphi (red.), Systematischer Kommentar zur Strafprozessordnung und zum Gerichtsverfassungsgesetz, Neuwied: Lugterhand z.j.

Sander 2000

G.M. Sander, Zur Beweiswürdigung, vor allem bei Aussage gegen Aussage, Strafverteidiger 2000, p. $45-48$.

\section{Schäfer 1995}

G. Schäfer, Freie Beweiswürdigung und revisionsrechtliche Kontrolle, Strafverteidiger 1995, p. 147-157.

\section{Schäfer 2002}

G. Schäfer, Die Abgrenzung der Verfahrensrüge von der Sachrüge, in: E-W. Hanack e.a. (red.), Festschrift für Peter Rieß zum 70. Geburtstag am 4. Juni 2002, Berlin: Walter de Gruyter 2002, p. 477-490.

\section{Schlothauer 1992}

R. Schlothauer, Unvollständige und unzutreffende tatrichterliche Urteilsfeststellungen. Verteidigungsmöglichkeiten in der Revisions- und Tatsacheninstanz, Strafverteidiger 1992, p. 134-141.

Schlothauer 2000

R. Schlothauer, Das Revisionsrecht in der Krise, Strafverteidiger-Forum 2000, p. 289-295.

\section{Schmidt 1994}

A. Schmidt, Grundsätze der freien richterlichen Beweiswürdigung im Strafprozessrecht, Frankfurt am Main: Peter Lang 1994.

\section{Schmitt 1992}

B. Schmitt, Die richterliche Beweiswürdigung im Strafprozess: eine Studie zu Wesen und Funktion des strafprozessualen Grundsatzes der 'freien Beweiswürdigung' sowie zu den Möglichkeiten und Grenzen einer Revision in Strafsachen; zugleich ein Beitrag zum Verhältnis von Kriminalistik und staatlichen Strafrecht, Lübeck: Schmidt-Römhild, 1992. 
Schoon \& Van Koppen 2002

A. Schoon en P.J. van Koppen, Identificatie door honden, in: P.J. van Koppen, D.J. Hessing, H.L.G.J. Merckelbach en H.F.M. Crombag (red.), Het recht van binnen; de psychologie van het recht, Deventer: Kluwer 2002, p. 597-622.

Schröder \& Zank 1988

T. Schröder en H. Zank, Qualitative Anforderungen an die Beweiswürdigung im Strafverfahren, Neue Justiz 1988, p. 225-228.

Schulenburg 2002

J. von Schulenburg, Das Verbot der vorweggenommenen Beweiswürdigung im Strafprozeß, Berlin: Duncker \& Humblot, 2002.

Schum 1994

D.A. Schum, The evidential foundations of probabilistic reasoning, New York: John Wiley 1994.

\section{Schwaben 2002}

S. Schwaben, Die Freiheit der Beweiswürdigung im Blickwinkel der Rechtsprechung des Bundesgerichtshofs, Strafverteidiger-Forum 2002, p. 78-81.

Selznick \& Nonet 1978

$\mathrm{Ph}$. Selznick en $\mathrm{Ph}$. Nonet, Law and society in transition: toward responsive law, New York: Harper \& Row 1978.

Simmelink 1999

J.B.H.M. Simmelink, Bewijsrecht en bewijsmotivering, in: M.S. Groenhuijsen en G. Knigge (red.), Het onderzoek ter zitting. Eerste interimrapport onderzoeksproject Strafvordering, Groningen: 1999 , p. 397-354.

Simmelink 2006

J. Simmelink, Strafrecht, in: J.M. Barendrecht en M.W. de Hoon (red.), Verbetering van hoger beroep? Kosten en baten van voorstellen uit twaalf systemen van procesrecht, Den Haag: Boom Juridische uitgevers 2006, p. 118-136.

\section{Simons 1886}

D. Simons, Beknopte handleiding tot het wetboek van strafvordering, Haarlem: Erven F. Bohn 1886.

Simons 1898

D. Simons, Motiveering van strafvonnissen, Tijdschrift voor Strafrecht 1898, p. 323-354.

\section{Simons 1899}

D. Simons, Een paar vragen naar aanleiding van onze wettelijke bewijsleer, Tijdschrift voor Strafrecht 1899 , p. 252-317.

Simons 1925

D. Simons, Beknopte handleiding tot het wetboek van strafvordering, Haarlem: Erven F. Bohn 1925.

Simons 1926

D. Simons, Motiveering van strafvonnissen, Weekblad van het Recht 1926, nr. 11474, p. 1-2.

Simons 1928

D. Simons, Over: G.C. Bolten, Een rechterlijke dwaling? Medisch-forensische beschouwingen over eene belangrijke strafzaak, Rechtsgeleerd Magazijn 1928, p. 230-235.

\section{Simons 1926}

J.E. Simons, De redengevende feiten of omstandigheden van art. 359 Wetboek van Strafvordering, Weekblad van het Recht, nr. 11466, p. 8.

Sipkes 1926

O.W. Sipkes, De 'redengevende feiten of omstandigheden' van art. 359 Strafv., Weekblad van het Recht, nr. 11459, p. 8.

Sjerps \& Coster van Voorhout 2005

M.J. Sjerps en J.A. Coster van Voorhout, Het onzekere bewijs. Gebruik van statistiek en kansberekening in het strafrecht, Deventer: Kluwer 2005.

\section{Sommer 2002}

U. Sommer, Lebenserfahrung: Gedanken über ein Kriterium richterlicher Beweiswürdigung, in: E-W. Hanack e.w. (red.), Festschrift für Peter Rieß zum 70. Geburtstag am 4. Juni 2002, Berlin: Walter de Gruyter 2002, p. 585-610. 


\section{Spronken 2000}

T. Spronken, Anonieme getuigen, een 'continuing story', in: R.A. Lawson en E. Myjer (red.), 50 jaar Europees Verdrag voor de Rechten van de Mens 1950-2000, Leiden: NJCM 2000, p. 115-135.

Spronken 2001

T. Spronken, Verdediging. Een onderzoek naar de normering van het optreden van advocaten in strafzaken, Deventer: Gouda Quint 2001.

\section{Spronken 2003}

T. Spronken, A place of greater safety. Bespiegelingen over een Europees Statuut voor de strafrechtadvocaat, Deventer: Kluwer 2003.

\section{Stamhuis 1999}

Stamhuis, E.F., De onpartijdigheid en onbevangenheid van de rechter ter zitting, in: M.S. Groenhuijsen en G. Knigge (red.), Het onderzoek ter zitting. Eerste interimrapport onderzoeksproject Strafvordering 2001, Groningen: 1999, p. 145-177.

\section{Stamhuis 2006}

E.F. Stamhuis, 'Onderzoeksbijeenkomst of openbare vertoning; de recente wetgeving rondom de terechtzitting in perspectief geplaatst', in: J.B.J. van der Leij en J. Hielkema (red.), Herschikking van de zitting?, Deventer: Kluwer 2006.

\section{2}

G. Strate, Freie Beweiswürdigung und gebundene Beweiserhebung, in: E-W. Hanack e.a. (red.), Festschrift für Peter Rieß zum 70. Geburtstag am 4. Juni 2002, Berlin: Walter de Gruyter 2002, p. 611-620.

\section{Stolwijk 1976}

S.A.M. Stolwijk, Het onderzoek ter terechtzitting in strafzaken, Arnhem: Gouda Quint 1976.

Stolz 2003

G. Stolz, Die Abgrenzung zwischen Sach- und Verfahrensrüge bei Revisionsangriffen gegen die Beweiswürdigung, Juristische Schulung 2003, p. 71-76.

\section{Stuffken 1866}

N.G. Stuffken, Het wettelijk bewijs in strafzaken, Leiden: Engels 1866.

Taverne 1918

B.M. Taverne, De taak van den strafrechter, Zwolle: W.E.J. Tjeenk Willink, 1918.

\section{Taverne 1924}

B.M. Taverne, Iets over de plaats van aanwijzingen en rapporten van deskundigen in ons wettelijk bewijssysteem. Tijdschrift voor Strafrecht 1924, p. 295-326.

Taverne 1927

B.M. Taverne, Motiveering van strafvonnissen, Tijdschrift voor Strafrecht 1927, p. 210-263.

\section{Tripels 1882}

G. Tripels, Is wijziging van de regelen over het bewijs in strafzaken wenschelijk? Zoo ja, in hoever moet het wettelijk bewijs worden behouden?, Handelingen der Nederlandsche Juristen-vereeniging 1882, p. 142-166.

\section{Twining 1985}

W. Twining, Theories of Evidence: Bentham \& Wigmore, Stanford: Stanford University Press 1985.

\section{Uytwerf Sterling 1829}

J.J. Uytwerf Sterling c.s., Aanmerkingen op het ontwerp van het wetboek van strafvordering voor het Koninkrijk der Nederlanden, Amsterdam: Erven H. Gartman, 1829.

\section{Van Almelo, Cohen \& Wiewel 1992}

A.E. van Almelo, R.F. Cohen en P.G. Wiewel, Stroomlijning van het Nederlands strafproces - een overzicht, Nederlands Juristenblad 1992, p. 501-512.

\section{Van de Vrugt 1982}

M. van de Vrugt, Aengaende criminele saken; drie hoofdstukken uit de geschiedenis van het strafrecht, Deventer: Kluwer 1982.

Van de Bunt, Keijser \& Elffers 2004

H. van de Bunt, J. de Keijser en H. Elffers, Responsieve rechters, Rechtstreeks 2004, nr. 2, p. 6-33. 
Van der Kruijs 2000

P. van der Kruijs, De laatste (?) stuiptrek tegen de kroongetuige, Nederlands Juristenblad 2000 , p. $976-977$.

Van Dijck 1922

J.V. van Dijck, Reconstructie van strafbare feiten, Alphen aan den Rijn: Samson 1922.

Van Dijck 1927

J.V. van Dijck, Het de-auditu-arrest, Nederlands Juristenblad 1927, p. 49-54.

Van Dijk \& Croll 2003

D.H. van Dijk en R.S. Croll, Raad voor de rechtspraak spreekt niet met his master's voice, Nederlands Juristenblad 2003, p. 1863-1864.

Van Dorst 2004

A.J.A. van Dorst, Cassatie in strafzaken, Deventer: Kluwer 2004.

Van den Emster 2005

F.W.H. van den Emster, Reflectie op een rechterlijke dwaling, Trema 2005, p. 294-295.

Van Heusden 1840

J. van Heusden, Bijdrage tot beantwoording der vraag: moeten volgens het tegenwoordig regt in Nederland, de strafvonnissen, anders dan onder de hier telande voor 1 october 1838 bestaan hebbende wetten worden gemotiveerd, Nederlandsche jaarboeken voor regtsgeleerheid en wetgeving 1840 , p. $17-56$.

Van Kampen 1998

P.T.C. van Kampen, Expert evidence compared: rules and practices in the Dutch and American criminal justice system, Antwerpen/Groningen: Intersentia rechtswetenschappen 1998.

Van Koppen 2003a

P.J. van Koppen, De Schiedammer parkmoord: Een rechtspsychologische reconstructie, Nijmegen: Ars Aequi Libri 2003.

Van Koppen 2003b

P.J. van Koppen, Verankering van rechtspraak - over de wisselwerking tussen burger, politie, justitie en rechter, Deventer: Kluwer 2003.

Van Koppen 2004

P.J. van Koppen, Paradoxen van deskundigen; over de rol van experts in strafzaken, Deventer: Kluwer 2004.

Van Koppen \& Van der Horst 2006

P.J. van Koppen en E.M. van der Horst, De simpele logica van getuigenconfrontaties, Nederlands Juristenblad 2006, p. 788-795.

Van Koppen \& Wagenaar 2002

P.J. van Koppen en W.A. Wagenaar, Herkennen van gezichten, in: P.J. van Koppen, D.J. Hessing, H.L.G.J. Merckelbach en H.F.M. Crombag (red.), Het recht van binnen; psychologie van het recht, Deventer: Kluwer 2002, p. 543-572.

Van Maanen 1839

G.A.G. van Maanen, Beweegredenen bij de vonnissen op te geven; de feiten, dezelver qualificatie, en de schuld der beklaagden te onderscheiden, Nederlandsche jaarboeken voor regtsgeleerdheid en wetgeving 1839, p. 68-83.

\section{Van Oosten en Takens 2005}

G. van Oosten en R. Takens, Voeren van betrouwbaarheidsverweer wordt dankbaar werk, Advocatenblad 2005, p. 674-677.

Van Veen 1977

Th.W. van Veen, De witte raaf en verder, Nederlands Juristenblad 1977, p. 376-381.

Van Veen 1986

Th.W. van Veen, Stroomlijning strafprocesrecht. Kop- staartuitspraken legaliseren. Mondeling vonnis bevestigen. Cassatie, verwijzen, terugwijzen, Nederlands Juristenblad 1986, p. 993-997.

Van Woensel 2004

A.M. van Woensel, Sanctionering van onrechtmatig verkregen bewijsmateriaal, Delikt en Delinkwent 2004, p. 119-171. 
Van Woensel 2007

A.M. van Woensel, Stroomlijning: voortbouwen, afbouwen en doortimmeren, in: P.G. Wiewel en R.E. de Winter (red.), Stroomlijning van het hoger beroep in strafzaken, Nijmegen: Ars Aequi Libri 2007, p. 9-29.

Van Zeben 2005

P.D.J. van Zeben, Het desgevraagd horen van getuigen in strafzaken, Trema 2005, p. 93-107.

Van Zeben 2006

P.D.J. van Zeben, Het ondervragingsrecht in strafzaken: compensatie van handicaps, Trema 2006, p. 6-13.

Vegter 2005

P.C. Vegter, Strafprocessen niet of nauwelijks te volgen? - Iets over eisen aan de motivering van het strafvonnis in het bijzonder in verband met uitdrukkelijk onderbouwde standpunten, in: A.H.E.C. Jordaans, P.A.M. Mevis en J. Wöretshofer (red.), Praktisch Strafrecht. Liber amicorum Jan Reijntjes, Nijmegen: Wolf Legal Publishers 2005, p. 577-589.

Verburg 2005

J.J.I. Verburg, Kantelende werkelijkheid, Trema 2005, p. 296-297.

Von Feuerbach 1813

P.J.A. von Feuerbach, Betrachtungen über das Geschworenengericht, Landshut: 1813.

Von Savigny 1858

F.K. von Savigny, Über Schwurgerichte und Beweistheorie im Strafprozesse. (gedeeltelijke publicatie van Die Prinzipien in Beziehung auf eine neue Strafprozeßordnung), Goltdammers's Archiv für Strafrecht 1858, p. 469-487.

Von Schledorn 1997

C. von Schledorn, Die Darlegungs- und Beweiswürdigungspflicht des Tatrichters im Falle der Verurteilung, Regensburg: S. Roderer Verlag 1997.

Voorduin 1839-1840

J.C. Voorduin, Geschiedenis en Beginselen der Nederlandsche Wetboeken, volgens de beraadslagingen deswege gehouden bij de Tweede Kamer der Staten-Generaal uit oorspronkelijke, grootendeels onuitgegeven staatsstukken opgemaakt en aan den Koning opgedragen, VI deel Wetboek van Strafvordering, I deel art. 1-169 en II deel art. 170-466, Utrecht: Robert Natan 1839.

Waaldijk 1963

L.T. Waaldijk, Motivering van strafvonnissen, Nijmegen: Dekker \& Van de Vegt 1963.

\section{Wagenaar 1993}

W.A. Wagenaar, Een empirische vraag: zijn bekentenissen diagnostisch voor daderschap, in: $\mathrm{M}$. Hildebrandt e.a. (red.), Een afzonderlijke procedure voor de bekennende verdachte?, Arnhem: Gouda Quint 1993, p. 59-64.

\section{Wagenaar 1995}

W.A. Wagenaar, De diagnostische waarde van bewijsmiddelen, Mededelingen van de Afdeling Letterkunde, Nieuwe Reeks, 1995 Deel 58, no. 3.

\section{Wagenaar 2006}

W.A. Wagenaar, Vincent plast op de grond; nachtmerries in het Nederlands recht, Amsterdam: Bert Bakker 2006.

Wagenaar \& Crombag 2002

W.A. Wagenaar en H.F.M. Crombag, Ook rechters maken menselijke fouten, in: P.J. van Koppen, D.J. Hessing, H.L.G.J. Merckelbach en H.F.M. Crombag (red.), Het recht van binnen; de psychologie van het recht, Deventer: Kluwer 2002, p. 835-853.

\section{Wagner 1994}

H. Wagner, Die Beweiswürdigungspflicht im tatrichterlichen Urteil im Falle der Verurteilung, Zeitschrift fur die gesamte Strafrechtswissenschaft 1994, p. 259-302.

Walter 1979

G. Walter, Freie Beweiswuerdigung: eine Untersuchung zur Bedeutung, Bedingungen und Grenzen der freien richterlichen Überzeugung, Tübingen: Mohr, 1979. 


\section{Weidemann 2002}

J. Weidemann, Verfahrens- und Sachrüge gegen Prozeßurteile, in: G. Duttge e.a. (red.), Gedächtnisschrift für Ellen Schlüchter, Köln: Carl Heymanns Verlag 2002, p. 653-665.

Weiland 1826

J.A. Weiland, Bijdragen tot de wetenschap der strafrechtspleging, Delft: Wed. J. Allart 1826.

Weiler 2001

E. Weiler, Substantiierungsanforderungen an die Verfahrensrüge gemäss § 344 Abs. 2 Satz 2 StPO, in: A. Eser e.a. (red.), Strafverfahrensrecht in Theorie und Praxis - Festschrift für Lutz MeyerGossner zum 65. Geburtstag, München: C.H. Beck 2001, p. 571-593.

Wiersinga 1993

H.C. Wiersinga, Geheimzinnig of zinvol? Over de 'verkorte vonnissen' in het strafproces, in: M. Hildebrandt (red.), Een afzonderlijke procedure voor de bekennende verdachte, Arnhem: Gouda Quint 1993, p. 117-121.

Wiewel \& De Winter 2007

Wiewel P.G. \& R.E. de Winter, Stroomlijning van het hoger beroep in strafzaken, Nijmegen: Ars Aequi 2007.

\section{Willeumier 1882}

C.M.J. Willeumier, Is wijziging van de regelen over het bewijs in strafzaken wenschelijk? Zoo ja, in hoever moet het wettelijk bewijs worden behouden? Handelingen der Nederlandsche Juristenvereeniging 1882, p. 100-141.

\section{Zeelenberg 2005}

A.J. Zeelenberg, De vingerafdruk onder druk, Strafblad 2005, p. 42-62.

\section{Zijlstra 1926}

L.D. Zijlstra, De redengevende feiten en omstandigheden van art. 359 Wetb. van Strafv., Weekblad van het Recht, nr. 11471, p. 8. 



\section{Jurisprudentie}

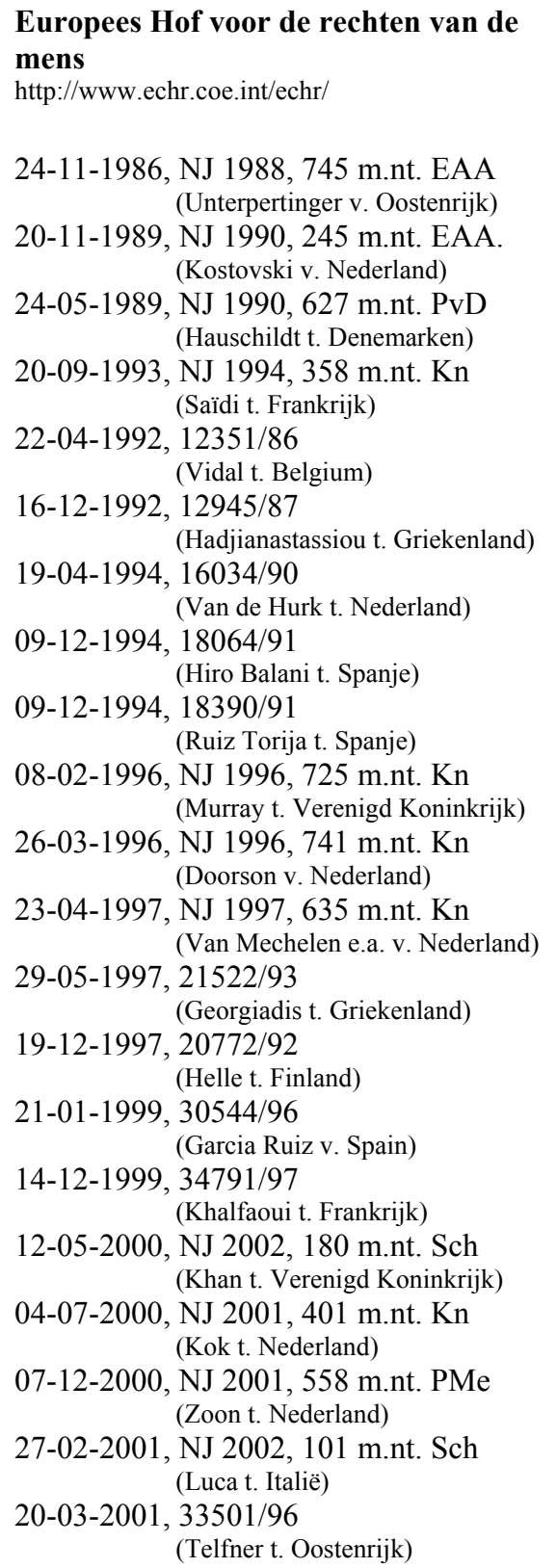

27-09-2001, 49684/99

(Hirvisaari t. Finland)

21-03-2002, 53478/99

(Sajtos t. Griekenland).

21-05-2002, 28856/95

(Jokela t. Finland)

02-07-2002, NJ 2003, 671

(S.N. t. Zweden)

05-11-2002, NJ 2004, 262

(Allan t. Verenigd Koninkrijk)

01-07-2003, 37801/97

(Suominen t. Finland)

27-01-2004, NJ 2004, 669 m.nt. Sch. (Verhoek t. Nederland)

30-11-2004, 26890/95 (Kukkola t. Finland)

05-04-2005, NJ 2005, 551 m.nt. Sch (Scheper t. Nederland).

06-09-2005, 65518/01 (Salov t. Oekraïne)

29-09-2005, 2507/02 (Kurti t. Griekenland).

10-11-2005, NJ 2006, 239 m.nt. Sch (Bocos-Cuesta t. Nederland)

Europese Commissie voor de rechten van de mens

http://www.echr.coe.int/echr/

$$
\begin{aligned}
25-02-1995, & 22922 / 93 \\
& \text { (Colak t. Nederland) } \\
14-01-1998, & 29202 / 95 \\
& \text { (Zoon t. Nederland) } \\
04-12-1998, & 29202 / 95 \\
& \text { (Zoon t. Nederland) }
\end{aligned}
$$

\section{Bundesgerichtshof}

http://www.recht.com/heymanns/start.xav?startb $\mathrm{k}=$ heymanns bgh ed bghrz en http://www.bundesgerichtshof.de/

28-11-1950, NJW 1951, 122 22-04-1952, BGHSt 2, 300. 09-02-1957, BGHSt 10, 208 28-06-1961, BGHSt 16, 166 01-08-1962, BGHSt 17, 382 
21-05-1969, BGHSt 23, 8

23-11-1969, BGHSt 23,187

07-06-1979, BGHSt 29, 18

17-10-1979, 3 StR 361/79

26-10-1983, BGHSt 32, 140

05-12-1984, BGHSt 33, 83

16-04-1985, BGHSt 33, 178

05-02-1986, BGHSt 34, 15

10-12-1986, BGHR StPO § 261 Beweiswürdigung, unzureichende 5

11-03-1987, BGHR StPO $§ 261$ Vermutung 1

22-09-1987, BGHR StPO § 250 Satz 1 Unmittelbarkeit 1

23-06-1988, BGHR StPO $§ 261$ Vermutung 4

04-11-1988, BGHSt 36, 1

24-11-1988, BGHR StPO § 261 Erfahrungssatz 4

17-12-1987, BGHSt 35, 164

31-03-1989, BGHSt 36, 159

06-04-1990, BGHR StPO § 261 Identifizierung 6

29-07-1991, 5 StR 278/91

13-08-1991, 5 StR 231/91

22-01-1992, BGHR StPO § 261 Aussageverhalten 12

03-09-1992, 1 StR 559/92

16-10-1992, StV 1993, 235

24-11-1992, BGHR StPO § 261

Vermutung 11

03-02-1993, 5 StR 715/92

14-04-1993, 3 StR 604/92

26-08-1993, BGHSt 39, 310

14-09-1993, 1 StR 450/93

20-06-1994, BGHR StPO § 261 Zeuge 17

03-03-1995, BGHR StPO § 267 Abs. 1 Satz 1 Beweisergebnis 8

09-05-1996, BGHR StPO § 244 Abs. 2 Aufdrängen 6

16-05-1995, BGHR StPO § 261 Beweiswürdigung, widerspruchliche 4

05-07-1995, BGHSt 41,153

02-08-1995, BGHSt 41, 206

05-12-1995, StV 1996, 214

20-06-1996, StV 96, 883

12-09-1996, BGHR BMG § 29

Beweiswürdigung 15

08-11-1996, BGHR StPO $§ 261$

Überzeugungsbildung 26

19-11-1996, StV 1998, 117
14-02-1997, BGHR StPO 261

Überzeugungsbildung 27

14-05-1997, 3 StR 193/97

03-06-1997, 4 StR 213/97

18-06-1997, BGHR StPO § 261

Beweiswürdigung 14

26-06-1997, 1 StR 212/97

05-11-1997, BGHR StGB $§ 176$ Abs 1 Beweiswürdigung 3

10-06-1998, BGHR StPO $§ 261$

Überzeugungsbildung 31

29-07-1998, BGHR StPO § 261

Beweiswürdigung 15

29-07-1998, BGHSt 44, 153

29-07-1998, NStZ 99, 421

17-11-1998, BGHR StPO § 261 Beweiswürdigung 17

15-09-1998, StV 1998, 635

31-03-1999, BGHR StPO § 261

Überzeugungsbildung 33

23-06-1999, NStZ-RR 99, 332

30-07-1999, BGHSt 45, 164

08-09-1999, BGHR StPO § 261

Erfahrungssatz 6

09-11-1999, StV 2000, 243

26-11-1999, 2 StR 461/99

19-01-2000, BGHR StPO § 261

Aussageverhalten 20

08-02-2000, 5 StR 310/99

17-05-2000, 3 StR 161/00

18-05-2000, 4 StR 647/99

23-05-2000, 1 StR 156/00

25-07-2000, 1 StR 169/00

25-07-2000, BGHSt 46, 93

21-09-2000, 1 StR 634/99

19-10-2000, 1 StR 439/00

19-10-2000, BGHR StPO § 261

Beweiswürdigung 23

06-12-2000, 2 StR 372/00

13-12-2000, 5 StR 540/00

17-05-2001, 4 StR 412/00

14-11-2001, 3 StR 276/01

27-03-2003, 3 StR 446/02

27-03-2003, BGHR StPO § 261

Sachverständiger 9

29-07-2003, 4 StR 253/03

04-03-2004, 3 StR 218/03 


\section{Hoge Raad}

http://www.rechtspraak.nl/

24-12-1838, Rechtsk. Bijblad 1839, p. $44-50$

19-06-1916, WvhR nr. 9980, p. 2 18-06-1923, WvhR nr. 11097, p. 3 02-02-1925, WvhR nr. 11342 , p. 2 20-12-1926, NJ 1927, 85 17-01-1927, NJ 1927, 189 11-04-1927, NJ 1927, 596 02-05-1927, NJ 1927, 768 09-01-1928, NJ 1928, 212 m.nt. vD 22-10-1928, NJ 1929, 1410 m.nt. T 14-10-1929, NJ 1929, 1552 25-11-1929, NJ 1930, 102 16-12-1929, NJ 1930, 313 23-12-1929, NJ 1930, 229 24-01-1930, NJ 1930, 118-119 19-10-1931, NJ 1932, 1290 16-11-1931, NJ 1932, 282 18-12-1933, NJ 1934, 324 14-01-1935, NJ 1935, 494 14-11-1935, NJ 1936, 102 18-11-1935, NJ 1936, 117 02-12-1935, NJ 1936, 136 27-11-1939, NJ 1940, 339 m.nt. T 17-06-1940, NJ 1940, 822 20-10-1941, NJ 1942, 59 m.nt. T 12-01-1942, NJ 1942, 373 21-03-1944, NJ 1944/45, 400 26-02-1946, NJ 1946, 168 26-02-1946, NJ 1946, 173 16-04-1946, NJ 1946, 328 08-11-1949, NJ 1950, 120 18-11-1952, NJ 1953, 64 20-12-1955, NJ 1956, 202 m.nt. BVAR 19-06-1956, NJ 1956, 516 12-06-1956, NJ 1956, 389 m.nt. WP 14-06-1960, NJ 1960, 597 14-06-1961, NJ 1962, 26 26-06-1962, NJ 1962, 470 m.nt. WP 16-03-1965, NJ 1965, 275 m.nt. B.V.A.R. 01-03-1966, NJ 1966, 391 m.nt. v.Berckel 18-06-1968, NJ 1969, 68 m.nt. Enschedé 17-10-1968, NJ 1968, 79

22-04-1969, NJ 1970, 125 m.nt. Enschedé 23-06-1970, NJ 1971, 7 08-06-1971, NJ 1972, 231 m. nt. ALM 29-06-1971, NJ 1971, 417 26-10-1971, NJ 1972, 194
07-12-1971, NJ 1972, 243

01-02-1972, NJ 1974, 450 m.nt. ThWvV 30-05-1972, NJ 1972, 381 30-05-1972, NJ 1972, 490 m.nt. CB 30-05-1972, NJ 1973, 456 10-10-1972, NJ 1973, 457 10-10-1972, NJ 1973, 458 m.nt. ALM 13-02-1973, NJ 1973, 139 03-04-1973, NJ 1973, 283 m.nt. ThWvV 12-06-1973, NJ 1973, 373 19-03-1974, NJ 1974, 241 m.nt. ThWvV 28-05-1974, NJ 1974, 331 m.nt. ThWvV 15-10-1974, NJ 1975, 189 29-10-1974, NJ 1975, 108 12-11-1974, NJ 1975, 41 m.nt. ThWvV 19-11-1974, NJ 1975, 118 m.nt. ThWvV 10-12-1974, NJ 1975, 165 07-01-1975, NJ 1975, 197 08-04-1975, NJ 1975, 281 m.nt. ThWvV 30-09-1975, NJ 1976, 70 m.nt. GEM 21-10-1975, NJ 1976, 178 18-05-1976, NJ 1976, 539 m.nt. ThWvV 01-06-1976, NJ 1977, 42 20-09-1976, NJ 1977, 257 14-12-1976, NJ 1977, 175 m.nt. ThWvV 21-12-1976, NJ 1977,162 m.nt. GEM 01-02-1977, NJ 1977, 230 m.nt. ThWvV 28-06-1977, NJ 1978, 437 03-01-1978, NJ 1978, 627 21-02-1978, NJ 1978, 663 18-04-1978, NJ 1978, 365 m.nt. ThWvV 06-06-1978, NJ 1979, 31 20-06-1978, NJ 1979, 41 m.nt. ThWvV 12-12-1978, NJ 1979, 142 m.nt. GEM 08-01-1980, NJ 1980, 201 15-01-1980, NJ 1980, 274 22-01-1980, NJ 1980, 293 05-02-1980, NJ 1980, 342. 09-09-1980, NJ 1981, 53 m.nt. GEM 21-10-1980, NJ 1981, 69 m.nt. GEM 17-02-1981, NJ 1981, 536 m.nt. GEM 07-04-1981, NJ 1981, 399 m.nt. ThWvV 04-05-1981, NJ 1982, 268 m.nt. ThWvV 03-11-1981, NJ 1982, 160 17-11-1981, NJ 1983, 84 m.nt. ThWvV 16-02-1982, NJ 1982, 405 m.nt. ThWvV 16-02-1982, NJ 1982, 411 02-03-1982, NJ 1982, 524 m.nt. ThWvV 18-05-1982, NJ 1983, 49 15-06-1982, NJ 1983, 106 
22-06-1982, NJ 1983, 90

28-09-1982, NJ 1983, 765

12-10-1982, NJ 1984, 23 m.nt. GEM

09-11-1982, NJ 1983, 268 m.nt. 'tH 04-01-1983, NJ 1983, 321 m.nt. ThWvV 18-01-1983, NJ 1983, 417

01-02-1983, NJ 1983, 402 m.nt. ThWvV 19-04-1983, NJ 1983, 574

11-10-1983, NJ 1984, 585 m.nt. GEM

29-11-1983, NJ 1984, 441

13-12-1983, NJ 1984, 653 m.nt. ALM

27-03-1984, NJ 1984, 685

29-05-1984, NJ 1985, 6 m.nt. ThWvV

12-06-1984, NJ 1985, 135 m.nt. ThWvV 26-06-1984, NJ 1984, 790 m.nt. GEM 23-10-1984, NJ 1985, 319

30-10-1984, NJ 1985, 320

27-11-1984, NJ 1985, 379 m.nt. GEM

19-02-1985, NJ 1985, 633

14-05-1985, NJ 1986, 9 m.nt. ThWvV

11-06-1985, NJ 1986, 59

25-06-1985, NJ 1986, 109 m.nt. ThWvV 25-09-1984, NJ 1985, 427 m.nt. ThWvV 01-07-1985, NJ 1986, 161 01-10-1985, NJ 1986, 629 29-10-1985, NJ 1986, 420 12-11-1985, NJ 1986, 409 26-11-1985, NJ 1986, 389 10-12-1985, NJ 1986, 426 10-12-1985, NJ 1986, 736 11-03-1986, NJ 1986, 718 18-03-1986, NJ 1986, 770 22-04-1986, NJ 1987, 44 06-05-1986, NJ 1986, 800 06-05-1986, NJ 1987, 60 m.nt. ThWvV 13-05-1986, NJ 1987, 81 10-06-1986, NJ 1987, 61 m.nt. C 04-11-1986, NJ 1987, 363 25-11-1986, NJ 1987, 687 09-12-1986, NJ 1987, 561 m.nt. ThWvV 16-12-1986, NJ 1987, 746 06-01-1987, NJ 1987, 916 27-01-1987, NJ 1987, 886 m.nt. ThWvV 17-02-1987, NJ 1987, 920 24-02-1987, NJ 1988, 540 03-03-1987, NJ 1987, 1007 10-03-1987, NJ 1988, 25 17-03-1987, NJ 1988, 28 31-03-1987, NJ 1987, 868 m.nt. ThWvV 19-05-1987, NJ 1988, 218
02-06-1987, NJ 1988, 178 22-09-1987, NJ 1988, 380 22-12-1987, NJ 1988, 756 26-04-1988, NJ 1988, 933 31-05-1988, NJ 1989, 210 19-09-1988, NJ 1989, 478 01-11-1988, NJ 1989, 574 m.nt. ALM 08-11-1988, NJ 1989, 657 m.nt. 'tH 20-12-1988, NJ 1989, 735 24-01-1989, NJ 1989, 600 28-02-1989, NJ 1989, 748 14-03-1989, NJ 1989, 747 m.nt. 'tH 25-04-1989, NJ 1989, 866 m.nt. 'tH 18-09-1989, NJ 1990, 166 15-05-1990, NJ 1991, 10 m.nt. ThWvV 26-06-1990, NJ 1991, 172 02-07-1990, NJ 1990, 692 m.nt. ThWvV 17-09-1990, NJ 1991, 12 09-10-1990, NJ 1991, 98 23-10-1990, NJ 1991, 171 m.nt. ThWvV 23-10-1990, NJ 1991, 328 04-06-1991, NJ 1991, 790 m.nt. ThWvV 11-06-1991, NJ 1991, 792 25-06-1991, NJ 1991, 808 m.nt. Sch 08-10-1991, NJ 1992, 156 13-11-1991, NJ 1991, 278 03-12-1991, NJ 1992, 251 m.nt. ThWvV 04-02-1992, NJ 1992, 530 m.nt. ThWvV 11-02-1992, NJ 1992, 516 18-02-1992, NJ 1993, 28 m.nt. Sch 12-05-1992, NJ 1992, 658 26-05-1992, NJ 1992, 676 m.nt. 'tH 30-06-1992, NJ 1993, 194 m.nt. Sch 08-07-1992, NJ 1993, 407 m.nt. ThWvV 14-09-1992, NJ 1993, 54 m.nt. ThWvV 22-09-1992, NJ 1993, 55 m.nt. ThWvV 29-09-1992, NJ 1993, 58 m.nt. Kn 17-11-1992, NJ 1993, 408 m.nt. ThWvV 16-03-1993, NJ 1993, 719 26-10-1993, NJ 1994, 100 01-02-1994, NJ 1994, 427 m.nt. C 15-03-1994, NJ 1994, 511 29-03-1994, NJ 1994, 577 m.nt. Sch 27-09-1994, NJ 1995, 65 18-10-1994, NJ 1995, 101 23-05-1995, NJ 1995, 683 m.nt. Sch 03-07-1995, NJ 1995, 734 26-09-1995, NJ 1996, 93 03-10-1995, NJ 1996, 109 12-12-1995, NJ 1996, 397 
12-12-1995, NJ 1996, 398 12-12-1995, NJ 1996, 399 23-01-1996, NJ 1996, 400 m.nt. 'tH 12-03-1996, NJ 1996, 511 m.nt. 'tH 12-03-1996, NJ 1996, 539 19-03-1996, NJ 1996, 540 m.nt. Sch 21-05-1996, NJ 1996, 611 04-06-1996, NJ 1996, 633 18-06-1996, NJ 1996, 750 25-06-1996, NJ 1996, 751 25-06-1996, NJ 1997, 106 m.nt. Sch 15-07-1996, NJ 1997, 107 m.nt. Sch 05-11-1996, NJ 1997, 138 01-07-1996, NJ 1996, 752 26-11-1996, NJ 1997, 210 17-12-1996, NJ 1997, 473 m.nt. Sch 29-04-1997, NJ 1997, 666 13-05-1997, NJ 1998, 318 m.nt. Sch 20-05-1997, NJ 1998, 22 m.nt. JR 03-06-1997, NJ 1997, 584 17-06-1997, NJ 1997, 735 17-06-1997, NJ 1997, 736 m.nt. JdH 09-12-1997, NJ 1998, 385 m.nt. JR 09-12-1997, NJ 1998, 855 27-01-1998, NJ 1998, 404 m.nt. JR 03-03-1998, NJ 1999, 59 17-03-1998, NJ 1998, 798 m.nt. JR 24-03-1998, NJ 1998, 536 24-03-1998, NJ 1998, 557 14-04-1998, NJ 1999, 73 23-06-1998, NJ 1998, 860 30-06-1998, NJ 1998, 799 m.nt. Sch 30-06-1998, NJ 1999, 60 m.nt. Kn 30-06-1998, NJ 1999, 88 m.nt. JR 29-09-1998, NJ 1999, 74 m.nt. Kn 06-10-1998, NJ 1998, 881 06-10-1998, NJ 1998, 912 20-10-1998, NJ 1999, 49 17-11-1998, NJ 1999, 152 12-01-1999, NJ 1999, 247 16-03-1999, NJ 1999, 369 16-03-1999, NJ 1999, 387 30-03-1999, NJ 1999, 451 m.nt. 'tH 06-04-1999, NJ 1999, 565 m.nt. Sch 20-04-1999, NJ 1999, 677 m.nt. 'tH 11-05-1999, NJ 1999, 526

18-05-1999, NJ 2000, 106 m.nt. Sch 06-07-1999, NJ 2000, 379 21-09-1999, NJ 1999, 786 21-09-1999, NJ 2000, 380 m.nt. Kn
12-10-1999, NJ 1999, 827

19-10-1999, NJ 2000, 109 m.nt. JdH 09-11-1999, NJ 2000, 71 30-11-1999, NJ 2000, 215 m.nt. JdH 11-01-2000, NJ 2000, 194 01-02-2000, NJ 2000, 264 11-04-2000, NJ 2000, 546 18-04-2000, NJ 2001, 352 m.nt. Kn 16-05-2000, NJ 2000, 510 13-06-2000, NJ 2000, 523 27-06-2000, NJ 2000, 503 27-06-2000, NJ 2000, 548 31-10-2000, NJ 2001, 238 m.nt. Sch 07-11-2000, NJ 2001, 35 21-11-2000, NJ 2001, 48 09-01-2001, LJN AA9480 09-01-2001, NJ 2001, 125 09-01-2001, NJ 2001, 141 30-01-2001, NJ 2001, 242 06-03-2001, NJ 2001, 295 20-03-2001, LJN AB0606 17-04-2001, NJ 2002, 107 m.nt. Sch 08-05-2001, NJ 2001, 479 29-05-2001, LJN AB1818 05-06-2001, NJ 2001, 500 19-06-2001, NJ 2001, 482 19-06-2001, NJ 2001, 521 30-10-2001, NJ 2002, 149 13-11-2001, NJ 2002, 220 20-11-2001, NJ 2003, 632 m.nt. PMe 18-12-2001, NJ 2002, 350 22-01-2002, LJN AD6244 28-01-2002, NJ 2003, 168 05-03-2002, LJN AD8883 16-03-2002, LJN AE0118 19-03-2002, NJ 2002, 567 26-03-2002, NJ 2002, 355 26-03-2002, NJ 2002, 356 26-03-2002, NJ 2004, 351 m.nt. De Jong 28-05-2002, LJN AE1490 28-05-2002, LJN AE1494 28-05-2002, LJN AE1511 28-05-2002, NJ 2003, 142 m.nt. Sch 04-06-2002, NJ 2002, 416 04-06-2002, NJ 2002, 603 m.nt. PMe 11-06-2002, NJ 2002, 459 25-06-2002, LJN AE1185 10-09-2002, NJ 2002, 474 10-09-2002, NJ 2002, 519 24-09-2002, NJ 2002, 570 
24-09-2002, NJ 2002, 629

29-10-2002, NJ 2003, 38

14-01-2003, NJ 2003, 288 m.nt. YB

25-02-2003, NJ 2003, 571

25-03-2003, NJ 2003, 552 m.nt. YB

25-03-2003, NJ 2003, 556

01-04-2003, NJ 2003, 553

08-04-2003, NJ 2003, 433

08-04-2003, NJ 2003, 443

08-04-2003, NJ 2003, 554

06-05-2003, NJ 2003, 710 m.nt. Sch

20-05-2003, NJ 2003, 672 m.nt. Sch 03-06-2003, LJN AF5087

24-06-2003, NJ 2003, 555

24-06-2003, NJ 2004, 165 m.nt. JR

01-07-2003, NJ 2003, 545

23-09-2003, NJ 2004, 166

02-12-2003, NJ 2004, 119

06-01-2004, NJ 2004, 200

10-02-2004, NJ 2004, 452 m.nt. Kn 30-03-2004, NJ 2004, 376 m.nt. YB 20-04-2004, NJ 2005, 241 m.nt. Kn 04-05-2004, NJ 2004, 480 01-06-2004, NJ 2004, 366 01-06-2004, NJ 2005, 252 m.nt. Kn 08-06-2004, NJ 2004, 413 28-09-2004, NJ 2004, 611 28-09-2004, NJ 2005, 93 m.nt. JR 26-10-2004, LJN AR2190 26-10-2004, NJ 2004, 690 02-11-2004, NJ 2005, 275 23-11-2004, LJN AR3280 14-12-2004, NJ 2005, 383 m.nt. YB 08-02-2005, NJ 2005, 514 m.nt. PMe 18-01-2005, NJ 2006, 12 22-02-2005, LJN AR5714 15-03-2005, LJN AR3260 15-03-2005, LJN AS4681. 05-04-2005, NJ 2005, 300. 24-05-2005, NJ 2005, 396. 24-05-2005, NJ 2006, 433 m.nt. PMe 06-09-2005, NJ 2006, 85 04-10-2005, LJN AT5759 22-11-2005, NJ 2006, 219 m.nt. Sch 06-12-2005, LJN AT5754 06-12-2005, NJ 2006, 162 24-01-2006, LJN AU6786 07-02-2006, LJN AU8912 28-02-2006, LJN AU9426 14-03-2006, LJN AU5496
14-03-2006, NJ 2006, 209

28-03-2006, LJN AV1620

11-04-2006, NJ 2006, 393 m.nt. YB 18-04-2006, LJN AU8913 18-04-2006, LJN AU9422 18-04-2006, LJN AV2377 18-04-2006, NJ 2006, 394 18-04-2006, NJ 2006, 395 18-04-2006, NJ 2006, 397 m.nt. YB 18-04-2006, NJ 2006, 645 m.nt. Sch 09-05-2006, LJN AV0316 16-05-2006, NJ 2007, 119 16-05-2006, LJN AU8917 16-05-2006, LJN AU8920 16-05-2006, LJN AV1581 16-05-2006, NJ 2007, 120 30-05-2006, LJN AV6203 06-06-2006, NJ 2006, 330 06-06-2006, LJN AW2475 06-06-2006, NJ 2006, 332 13-06-2006, LJN AV8527 13-06-2006, NJ 2006, 345 13-06-2006, NJ 2006. 371 13-06-2006, NJ 2007, 48 m.nt. YB 20-06-2006, LJN AW4479 20-06-2006, NJ 2006, 358 27-06-2006, LJN AW2473 04-07-2006, NJ 2006, 386 12-09-2006, LJN AX3862 12-09-2006, NbSr 2006, 393 26-09-2006, NJ 2006, 541 26-09-2006, NJ 2006, 542 03-10-2006, NJ 2006, 549 03-10-2006, NJ 2006, 550 07-11-2006, LJN AY6787 07-11-2006, NJ 2007, 108 m.nt. YB 14-11-2006, NJ 2006, 632 21-11-2006, NJ 2006, 649 28-11-2006, NJ 2007, 49 28-11-2006, NJ 2007, 122 28-11-2006, NJ 2007, 123 m.nt. JR 12-12-2006, LJN AZ2078 09-01-2007, LJN AZ2184 09-01-2007, NJ 2007, 53 16-01-2007, NJ 2007, 71 06-02-2007, NJ 2007, 112 13-02-2007, LJN AZ5473 20-02-2007, LJN AZ5717 15-05-2007, LJN BA0424 15-05-2007, LJN BA0425 


\section{Gerechtshoven}

http://www.rechtspraak.nl/

Amsterdam 07-10-2003, LJN AL7736

Arnhem 12-10-2005, LJN AU4229

Den Bosch 09-02-2004, LJN AO3222

Den Bosch 18-06-2004, LJN AP3706

Den Bosch 23-06-2004, LJN AP3589

Den Bosch 23-06-2004, LJN AP3696

Den Bosch 25-06-2004, LJN AQ4440

Den Haag 18-06-2004, LJN AP2846

Den Haag 21-06-2004, NJ 2004, 432

Den Haag 18-10-2005, LJN AU 4447

Leeuwarden 24-04-2002, LJN AE 1877

\section{Rechtbanken}

http://www.rechtspraak.nl/

Den Haag 24-03-2003, LJN AF6172

Rotterdam 31-12-2002, NJ 2003, 136

Rotterdam 27-03-2003, LJN AF6787

Rotterdam 24-01-2005, NJ 2005, 148 



\section{Dankwoord}

Mijn collega Taru Spronken schreef in het dankwoord bij haar proefschrift dat het een voorrecht is om de gelegenheid en tijd te krijgen om onderzoek te doen en te schrijven. Ik onderschrijf dat, maar moet tegelijkertijd erkennen dat er momenten waren waarop het schrijven van het proefschrift niet voelde als een voorrecht, maar eerder als een loden last. En met name degenen in mijn directe omgeving, Arjen, Sanne en Renske, hebben dat gemerkt. Ik dank met name hen voor het geduld dat ze hebben weten op te brengen en het feit dat ze - en dat geldt vooral voor jou, Arjen - mij zijn blijven steunen. Renske, in antwoord op jouw regelmatig terugkerende vraag 'Is dat boek nou nog niet af?', kan ik je nu zeggen: $\mathrm{Ja}$, het is af. Sanne, ik hoop dat het lezen van woorden als 'bewijsmotiveringsvoorschriften' op zevenjarige leeftijd geen blijvende schade tot gevolg heeft.

Daarnaast gaat bijzondere dank uit naar Alette, Harald, Hans en Yvonne. Alette's niet te stuiten dadendrang heeft zij deels geprojecteerd op mij en mijn proefschrift. Bij elk moment van dreigende zwakte was zij aanwezig om duidelijk te maken dat dat boek echt af moest. Harald vormde zoals gewoonlijk een rots in de branding; de rust zelve en aanwezig als je hem nodig hebt. Hans en Yvonne hebben ieder op hun eigen, zeer uiteenlopende wijze de noodzakelijke en niet altijd proefschriftgerelateerde 'mental coaching' voor hun rekening genomen. 



\section{Curriculum Vitae}

Wilma Dreissen is geboren op 24 september 1966 te Geleen. In 1984 behaalde zij haar VWO-diploma aan de Scholengemeenschap Sint Michiel te Geleen. Zij begon haar studie rechtsgeleerdheid in Nijmegen en zette deze vervolgens voort in Maastricht. In 1990 studeerde zij af. Onderbroken door een korte periode in de advocatuur bij het Advokaten Kollektief Rotterdam is zij telkens verbonden geweest aan een juridische faculteit (Utrecht: 1993-1994 en Maastricht: 1990-1992 en 1994-heden). Zij heeft onderwijsgerelateerde functies afgewisseld met specifieke onderzoeksfuncties. Sinds 1 september 2007 is zij als universitair docent verbonden aan de capaciteitsgroep Strafrecht \& Criminologie van de Universiteit Maastricht. 